Historic, Archive Document

Do not assume content reflects current scientific knowledge, policies, or practices. 


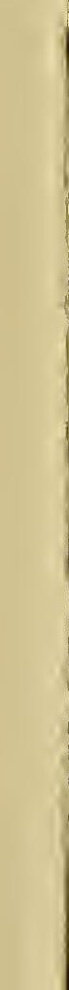


hexex

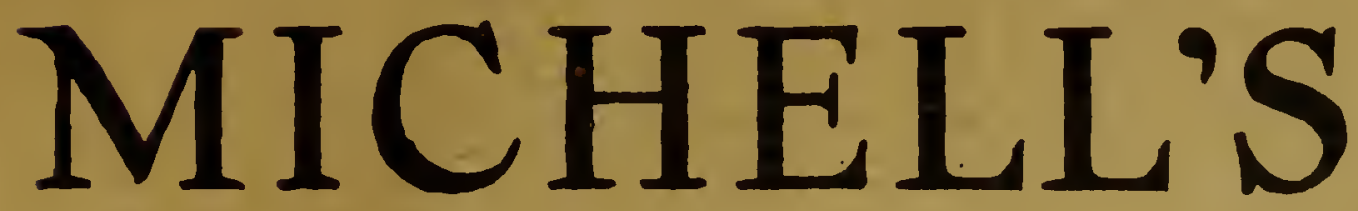

JANUARY TO JUNE (Inclusive)-1914

\section{WHOLESALE PRICE LIST OF}

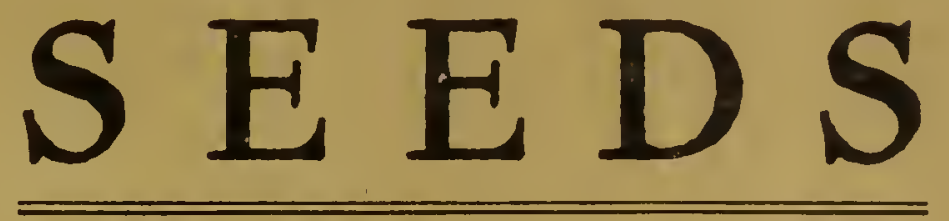

BULBS PLANTS GARDEN TOOLS FERTILIZERS INSECT DESTROYERS, Etc.

To be Disseminated Beginning January, 1914

THE NEW

SCARLET BEDDING GERANIUM

"Helen Michell"

For particulars see inside cover page and color plate

The New Scarlet Bedding Geranium "HELEN MICHELL"

\section{HENRY F. MICHELL CO.}

TELEPHONES

BELL-

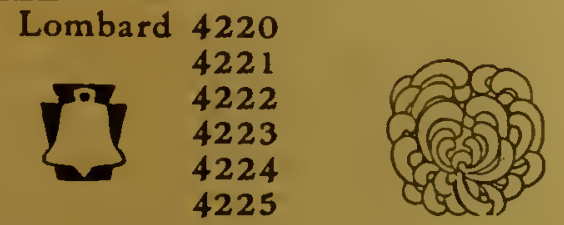

KEYSTONE-

Main 3600
518 Market Street, Philadelphia.

Warehouses, 509-511-513 Ludlow Street 


\section{New Scarlet Bedding Geranium "HELEN MICHELL" \\ (SEF COLOR PLATE OPPOSITE)}

(Name registered with S. A. F. \& O. H.)

(Cross-Seeding Jean Viaud $\dot{X}$ Alphonse Ricard)

\section{We offer $\$ 50.00$ in Gold}

For the Best 4-inch Pot (single plant) of this New Geranium in Bloom

TO BE COMPETED FOR AT THE

\section{American Sweet Pea Society's Show}

To be held the latter part of JUNE, 1914, in NEW YORK CITY

\author{
Full particulars as to date can be had from your
} Florist Club.Secretary.

This new Geranium is introduced by us as THE BEST COMMERCIAL NOVELTY, FOR 1914, and in order to popularize it the first year of its introduction, we are offering the above remarkable prize, hoping that every grower in the land will compete.

The competition is absolutely fair as no plants are disseminated until January, 1914, and no larger plants are then furnished than from $2 \frac{1}{4}$-inch pots. Every one knows how to grow a Geranium, and it can be carried to the Show, avoiding express charges, delays and damages.

\section{Additional Awards to be Made}

For the second best plant as above described, THE MICHELL GOLD MEDAL.

For the third best plant, THE MICHELL SILVER MEDAL.

The latter awards will be made to enable some who cannot win the First Prize, of having an opportunity of at least getting a reward for their effort.

This remarkable Geranium was exhibited Spring, 1913, at the National Flower Show, New York City, where it was pronounced the finest Geranium Novelty that was ever seen. In addition, it was awarded the only certificate of merit for new plants exhibited at the Show. This fact alone should insure its being a novelty of sterling worth.

\section{OUR FURTHER CLAIM}

for this novelty is, that it surpasses all other Scarlet Geraniums,

(1.) In brilliancy of color.

(2.) In size of bloom.

(3.) In number of clusters to the individual plant.
(4.) In vigor and strength.

(5.) In earliness of bloom.

(6.) In constancy of bloom.

(7.) In propagating quality no Geranium equals it.

(8.) In a wonderful ability to retain its brilliancy of color in the hotiest of weather.

\section{Each 25c; $\$ 2.50$ Dozen; $\$ 15.00$ per $100 ; \$ 125.00$ per 1000}

Single plants mailed free; for mailing dozen lots allow

$25 \mathrm{c}$ per doz. for postage, larger quantities sent by express.

6 supplied at dozen rate, 25 at 100 rate, 250 at 1000 rate.
Read what two of the greatest American Geranium growers have to say about "Helen Michell."

Philadelphia, June 15, 1912.

Gentlemen:

Relative to the new Geranium, "Helen Michell," which was shown to us a few days ago, would say that we consider this variety a GREAT IMPROVEMUNT MUCH LARGER than the Ricard variety, and the color is superb. It appeared UNUSUALLY FREE. We have known of this variety for the past two years and think it will be one of the grandest bedders in commerce.

RÖBERT CRAIG CO.

Gentlemen:

White Marsh, Md., June 10, 1912

We take pleasure in assuring you that we were very favorably impressed with exceptional value to the grower, and we are confident it will immediately find its place among the leading class of Geraniums. Respectfully yours, R. VINCENT, JR., SONS.

\section{BUSINESS TERMS}

We especially invite Charge Accounts. A charge account is more convenient than to remit for each order at the time it is sent us; you pay no more for your goods by reason of this accommodation. As to our responsibility, we refer you to Dun's or Bradstreet's Mercantile Agency.

When sending your first charge order, refer preferably to some one in either your own or our line of business with whom you have a charge account. This saves many a delay. When sending us your first order accompanied by remittance, we prefer cashier's check or money order, unless cash is sent. This frequently also saves delays.

\section{Net Cash Items}

Grain, Clover, Bird and Farm Seeds, also Fertilizers, are handled on very close margins and are sold with no cash discount.

\section{Discounts}

On bills for Flower, Vegetable Secds and Bullbs, a discount of $2 \%$ for payment 10 days from reccipt of bill may be deducted, if cash accompanies the order (lver roods are strictly net, as are also bills for goods supplied under special quotation unless otherwise agrced upon.

Henry F. Michell Company endeavor to send out only the very best quality of Seeds, Bulbs and Plants, but cannot guarantee results or crops. If customers do not accept goods on the above conditions, they can be returned to us within ten days. 


\section{The New Scarlet Bedding Geranium}

\section{"HELEN MICHELL"}

For Particulars See Opposite Cover Page

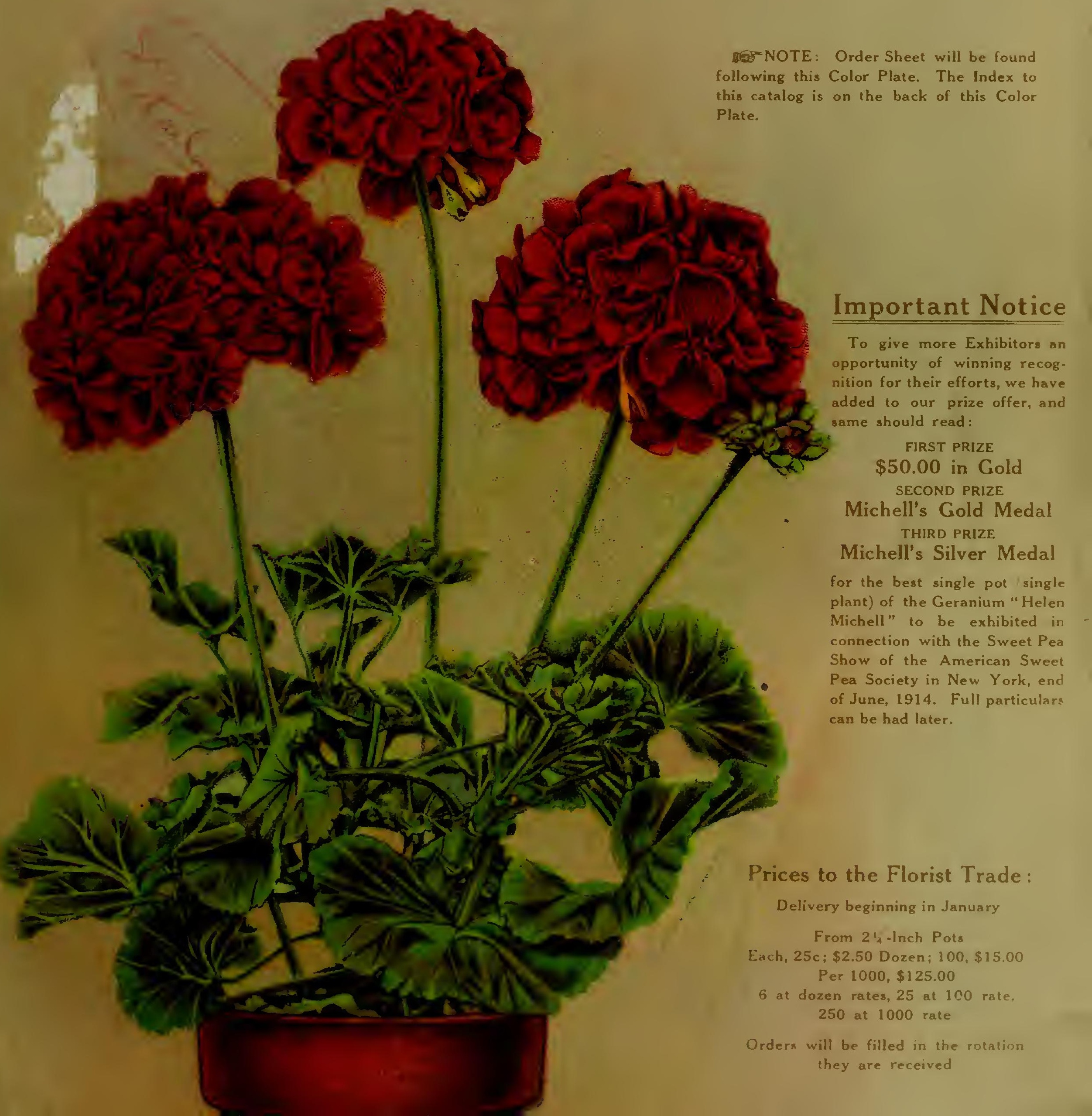




\section{Index to Contents of Michell's 1914 Wholesale Catalog}

(hexex. sick)

\begin{tabular}{|c|c|c|}
\hline SEEDS & PAGE & MISCELLANEOUS \\
\hline PAGE & Heliopsis..... & PAGE \\
\hline Clovers.... & Hemerocallis . . . . . . . & Acid Phosphate.... \\
\hline Farm Seeds..... & Heuchera. . . . . . . . . . . .70 & Animal Bone and Pot \\
\hline Flower Seeds. & Hibiscus . . . . . . . . & Ant Exterminator.... \\
\hline Grass Seeds. . . . . . . & Hollyhock.......... & Antipest........... \\
\hline Seeds for stores, etc.... & Honeysuckle. . . . . . . . & Aphine.......... \\
\hline Vegetable Seeds. ....... & $\begin{array}{l}\text { Hop Vine. . . . . . . . . . } \\
\text { Hydrangea }\end{array}$ & $\begin{array}{l}\text { Aphis Punk...... } \\
\text { Aprons. . . . . }\end{array}$ \\
\hline & Hy pericum ............ & Arsenate of Lead... \\
\hline PLANTS AND BULBS & Hyacinthus. . . . . . . . . 58 & Ashes.............. \\
\hline & $\ldots \ldots \ldots \ldots \ldots 71$ & Asparagus Fertilizer. \\
\hline chillea..... & Ipomea... & Asparagus Knives... \\
\hline chyranthes..... & Ismene. . . . . . . . . . . 58 & Asparagus Tape.... \\
\hline conitum ........ & 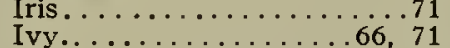 & Azalea Pots........ \\
\hline $\begin{array}{l}\text { ctaea............ } \\
\text { etheopappus. }\end{array}$ & & Barrels . . . . . . . . . . . . .79 \\
\hline 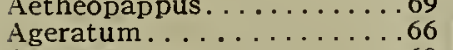 & Jasminum.............73 & Basic Slag. \\
\hline Agrostemma . . . . . . . . 69 & & Bellows........ \\
\hline Akebia............... & $\begin{array}{l}\text { Kalmia } \\
\text { Kudzu } \ldots \ldots \ldots \ldots \ldots \ldots \ldots 71\end{array}$ & Blood, Bone and Potas \\
\hline $\begin{array}{l}\text { Althernanthera } . \ldots \ldots \ldots \ldots \\
\text { Alyssum.............. }\end{array}$ & & Blood (Dried)......... \\
\hline Amyssum & Lantana. & Blood Flour....... \\
\hline 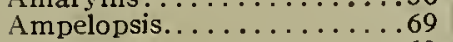 & Larkspur. & Bon Arbor . . . . . \\
\hline 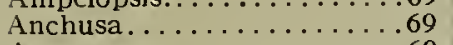 & Lathyrus. & e (Cracked) \\
\hline nemone...............69 & Liatris.... & Bone Flour...... \\
\hline Antirrhinum . . . . . . . 66 & Lilacs. . & Bone (Ground) \\
\hline quilegia . . . . . . . . . 69 & Lilies ...........64 64 & Bone Meal....... \\
\hline Arabis . . ............ & Lily of the Valley . . . . 64, 71 & Bonora........... \\
\hline A ristolochia...........6 69 & $\begin{array}{l}\text { Lobelia.... } \\
\text { Lupinus... }\end{array}$ & $\begin{array}{l}\text { Bordeaux Mixture } \ldots \ldots \ldots \ldots 88 \\
\text { Boro Wax......... } \ldots \ldots \text { 88 }\end{array}$ \\
\hline Armeria . . . . . . . . . . 69 69 & $\begin{array}{l}\text { Lupinus... } \\
\text { Lychnis... }\end{array}$ & Bouquet Wire............92 \\
\hline $\begin{array}{l} \\
\ldots \ldots \ldots \ldots \ldots \ldots \ldots 696\end{array}$ & Lythrum............... & Boxes ............. \\
\hline Asters..................69 & & Brooms........... \\
\hline Azalea............... 73 & Mexican Vine..... & 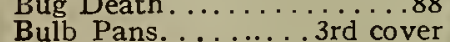 \\
\hline & Monarda............. & Button Bone............90 \\
\hline$\ldots \ldots \ldots \ldots, 70$ & Moon Vine........... & Cane Stak \\
\hline Berberis.............. 73 & & Carbolineu \\
\hline Bignonia................69 & Oenothera & Carnation \\
\hline conia.............. & Oxalis.... & 87 \\
\hline Boltonia : . & & Carnation Supports. \\
\hline Bouvardia. & Paeonias .... & Celery $\mathrm{Br}$ \\
\hline Boxwood... & Pachysandra..........71 & Celery Hiller.. \\
\hline$\ldots \ldots \ldots \ldots$ & Pancratium ......... & Celery Tape........ \\
\hline$\ldots \ldots \ldots .56-58$ & Pentstemon . . . . . . & Cemetery Vases..... \\
\hline$\ldots \ldots \ldots \ldots \ldots 58$ & ials . . . . . . .69-73 & Charcoal...... \\
\hline$\ldots \ldots \ldots \ldots$ & Philadelphus. . . . . . . 73 & Chrysanthemum Manure. . .90 \\
\hline hus.......... & Phlc & izer. .........90 \\
\hline nula............ & Physostegia & Cocoanut Fibre. . \\
\hline ons $\cdots \cdots \cdots{ }_{65}-57$ & Pinks......... & Copperas....... \\
\hline ons........ .65-66 & Platycodon... & Copper Solution \\
\hline$\ldots \ldots \ldots \ldots 60696$ & Plumbago... & per Stra \\
\hline themum . . $65-66-69-70$ & Poinsettia... & Corn Phosphate. \\
\hline $\begin{array}{l}\text { athemum . . 65-66-69-70 } \\
\text { on Vines. . . . . . .58 }\end{array}$ & Poppy... & Cotton Seed Meal... . \\
\hline 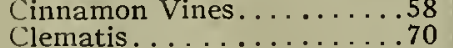 & $\begin{array}{l}\text { Primula } \\
\text { Privet. }\end{array}$ & Cow Ease.... \\
\hline 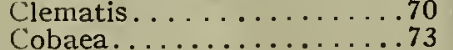 & $\begin{array}{l}\text { Privet.... } \\
\text { Pueraria. . }\end{array}$ & Cow Mar \\
\hline$\ldots \ldots \ldots \ldots \ldots \ldots 66$ & $\begin{array}{l}\text { Pueraria................ } \\
\text { Pyrethrum } . . \ldots \ldots \ldots\end{array}$ & Cultivato \\
\hline $\begin{array}{l}\text { Coleus... } \\
\text { Coreopsis. }\end{array}$ & Pyrethrum .......... & Cultive \\
\hline $\begin{array}{l}\ldots \ldots \ldots \ldots \ldots 70 \\
\ldots \ldots \ldots \ldots \ldots .58\end{array}$ & & Cut Flower Boxes.... \\
\hline Cycas. & 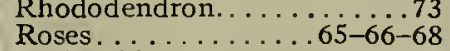 & Cyanide of Potassium . \\
\hline$\ldots \ldots \ldots$ & Rudbeckia .............. & .88 \\
\hline & & \\
\hline 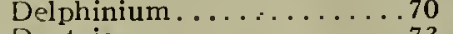 & Sago Palm & .88 \\
\hline & $.66-72$ & Dissolved B \\
\hline & $\ldots .72$ & Dowels.: : \\
\hline .70 & Schizophragma & \\
\hline & $\cdots 72$ & Evaporator.... \\
\hline .70 & 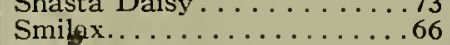 & Extension Pipes........ 81 \\
\hline & ggon...........66 & Farmogerm \\
\hline Edelweiss. . . . . . . . & $\ldots .73$ & ..3rd cover \\
\hline & & Fern Pans... \\
\hline .70 & $\ldots .36$ & Fertilizer Distributors. . \\
\hline & $\ldots \ldots \ldots \ldots 73$ & Fertilizers.... \\
\hline & $\ldots 66$ & $\begin{array}{l}\text { Fibre Saucers } \ldots \ldots \ldots \text { 3rd cover } \\
\text { Fibre Vases . . . }\end{array}$ \\
\hline $\begin{array}{l}.58 \\
.70\end{array}$ & & Fir Tree Oil Soap........88 \\
\hline$\ldots 73$ & & Fish Guano......... \\
\hline & Thalictrum........... & wer Boxes.......... \\
\hline & mopsis............... & Flower Pots.........3rd cover \\
\hline Gaillardia & & Flower Vases..... . \\
\hline & & migators......... \\
\hline es & .73 & Fungine................. \\
\hline inam......... & & Garden Line \\
\hline$\ldots \ldots \ldots \ldots \ldots \ldots 70$ & $\mathrm{Va}$ & .078 \\
\hline$\ldots \ldots \ldots 62.63$ & & Getz-ther \\
\hline &.. .73 & Glass Cle \\
\hline (Ornamental).. & .73 & Glass Cutters.... \\
\hline Gypso phila.............70 & Viola. . . . . . . . . . . . .73 & Glazing Points... \\
\hline & & $.78,87$ \\
\hline & Weigela... & Grafting Tool. \\
\hline $1 \mathrm{um} . . . \ldots$. & Wistaria.............. & Grape Dust. . \\
\hline $\begin{array}{l}\text { Helianthus. . . . . . . . . .70 } \\
\text { Helleborns. . . . . . . }\end{array}$ & & $\begin{array}{l}\text { Grass Catchers........ . 76 } \\
\text { Grass Hooks. }\end{array}$ \\
\hline & & \\
\hline
\end{tabular}

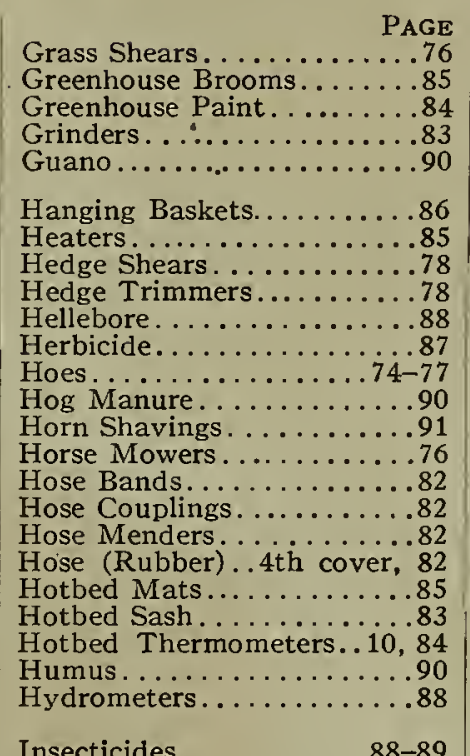

Insecticides . . . . . . . 88-89

Kainit ..............91

Kerosene Emulsion....... . .88

Knives. . . . . . . . . . . .

Labels...............886

Land Plaster............

Lawn Dressing

Lawn Mowers.....

Lawn Rakes....

Lawn Rollers.

Lawn Sand......

Lawn Trimmers....

Leaf Mould.

Leaf Racks.............

Limestone. .

Lime Sulphur.

Manure.

Manure Distributo

Mapes Fertilizer

Mastica Macrine........ 8

Mehler Handy Gardener. . . .83

Muriate of Potash.........

Nicofume. . . . . . . . . . . 89

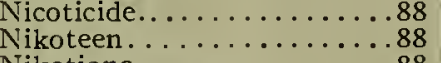

Nikotiana $\ldots \ldots \ldots \ldots \ldots 88$

Nozzles.......... $81-82-83$

Orchid Peat............87

Orchid Receptacles...3rd cover

Pans......................... cover

Paris Green . . . . . . . . . . . . .89

Peat...............8. 87

Pebbles.

Phosphate..............9.8

Plant Food...............

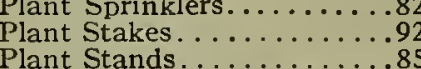

Plant Stands . . . . . . . . . . . 85

Plows.................

Posthole Digger. ..........

Pot Hangers ......... 3 rd cover

Pot Labels ................ cove

Pots.............3rd cover

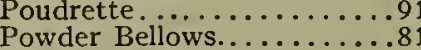

Powder Gun.

Protecting Cloth

Pruning Gloves

Pruning Saws.

Pumps.

Putty ..............

Putty Bulbs...........

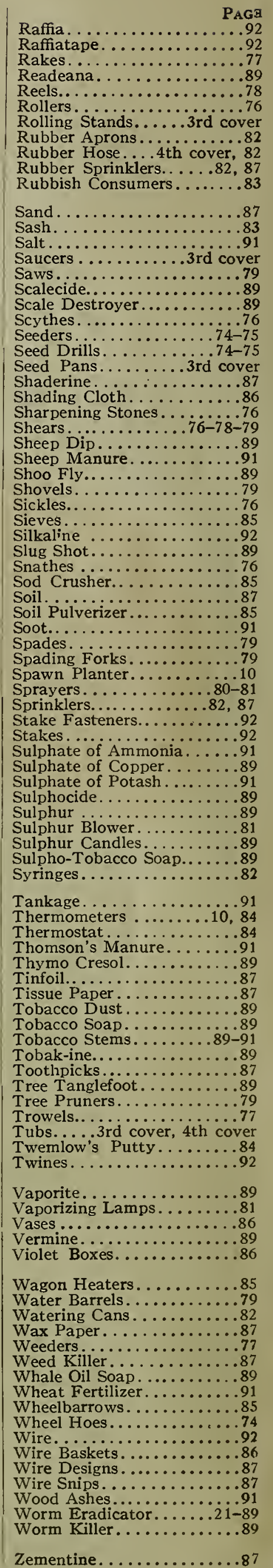




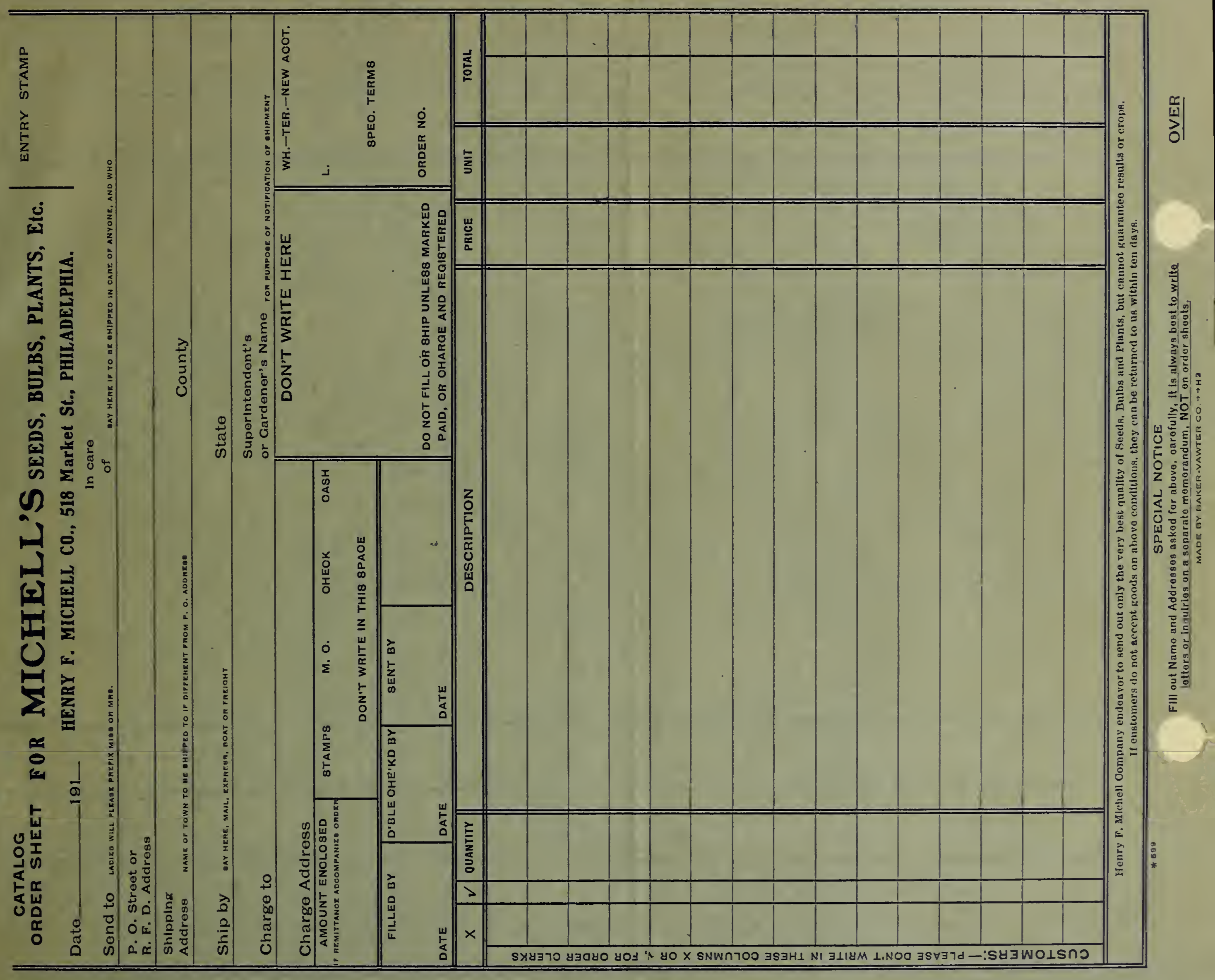




\section{Index to Contents of Michell's 1914 Wholesale Catalog}

(hexex. sick)

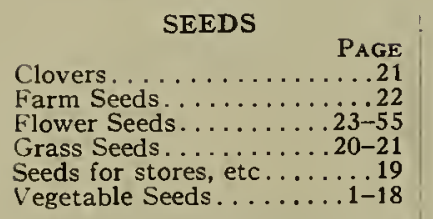

PLANTS AND BULBS

Abutilon. .

Achillea.....

Aconitum

Actaea.......

Ageratum.........

Agrostemm

Althernanthera

Alyssum....

Ampelopsis.

Anchusa. . .

Anemone......

Aquilegia

Arabis.

Aristolochia.

Armeria.

Asclepias.

Asters. .

Begonia.

Bellis.

Berberis. .

Bocconia.

Boltonia.

Bouvardia
Boxwood.

Buddleya. . .

Caladium. . .

Callas.........

Calycanthus.

Canna......

Carnation

Centaurea ...............
Chrysanthemum . $65-69-69$

Cinnamon Vines

Cobaea.....

Coleus......

Coreopsis

Dahlias

Deisy . . .

Deutzia..

Dianthus.

Dielytra

Doronicum

Echinops.

Edelweiss

Eupatorium

Fern Balls.

Ferns......
Forsythia.
Funkia...

Gaillardia.

Galega...

Gentiana.

Geranium.

Geum......

Gloxinia

Grasses (Omamental)

Helenium. . .

Heliotrope.

Helianthemum

Helleborıs.
Heliopsis.......

Heuchera.....

Hibiscus.

Hollyhock.

Honeysuckle.

Hydrangea

Hyacinthus.

66 Incarvillea

1smene.

1ris......

Jasminum.

Kalmia

Kudzu Vine

Lantana.

Larkspur

Lathyrus.

Lilacs. .

Lily of the Valley.

Lobelia.

Lupinus.

Lythrum.

Mexican Vine

Monarda.

Moon Vine.

Oenothera

Oxalis. .

Paeonias

Pachysandra

Pancratium.
Passion Vine.

Pentstemon

$\begin{aligned} .58 & \text { Perennials .... } \\ 69 & \text { Philadelphus } \\ .73 & \text { Phon }\end{aligned}$

.69 Philade

69 Physostegia

.57 Pinks..

Platycodon.

69 Plumbago

Poppy

8 Primula

\begin{tabular}{ll} 
& Privet.... \\
3 & Pueraria \\
\hline
\end{tabular}

66
70

Rhododendron

Rudbeckia.

70

70 Sago Palm

73 Salvia....

70 Schizophragma.

70 Sedum.

70 Shasta

Smilgx......

00 Spiraea.

70 Stachys.

70 Statice.

\begin{tabular}{l|l}
70 & Stevia..... \\
73 & Stokesia.
\end{tabular}

58 Sweet William

70
73
70

Tamarix

Thermopsis

70 Trillium

\begin{tabular}{l|l}
70 & Trollius. \\
66 & Tritoma. \\
70 & Tuberose
\end{tabular}

70

.70

.63 Veronica.

.58 Viburnum.

70 Vinca.
70 Viola.

70 Wallfower

66 Weigela.

70 Wistaria

$\begin{array}{ll}70 & \text { Yucca }\end{array}$
Page
70

.70
.70
.70

70 Acid Phosphate.........90-91

70 Ant Exterminator ..........88

71 Antipest.................88

71 Aphine .................

73 Arsenate of Lead.........8.

Asparagus Bunchers.........78

Asparagus Fertilizer.........78
Asparagus Knives........78

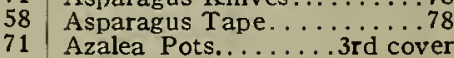

... 78

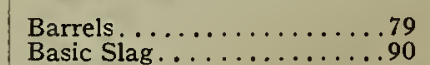

Bellows.

Black Lea

Blood, Bone and Potash.....90

Blood (Dried)

Blood Flour.

Bone (Cracked)

Bone Flour..

Bone (Ground)

Bonora

Bondeaux Mixture.

Boro Wax.......

Boxes.

Brooms......

Bug Death.

Button Bone...... 3rd cover

31,73

Cane Stakes

Carbolineum.

Carnation Dye ...........

Carnation Supports.

Celery Brushes.

Celery Hiller.

Cemetery Hooks.

Cemetery Vases.

Charcoal ....

73 Chrysanthemum Manure...990

72
72
Clay's Fertilizer............90

Copper Solution

Copper Strainer.

Cotton Seed Meal.

Cow Ease....

71 Cultivator

72 Cultivator Teeth

$65-66-68$
$6 \ldots 72$

Cut Flow

Dalmatian Powder....... 88

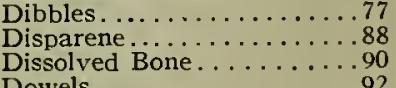

Dowels $\ldots . . . \ldots \ldots \ldots \ldots \ldots 92$

Evaporator

Extension Pipes.

Farmogerm

Fern Dish Liners. . . . 18-90

Fern Pans.........3rd cover

Fertilizer Distributors....74-75

Fibre Saucers...........

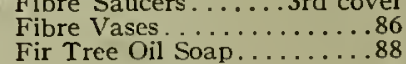

Fir Tree Oil Soap $\ldots \ldots \ldots \ldots .68$
Fish Guano.............

Fish Guano..............
Flower Boxes........
Flower Pots........

Flower Pots.........3rd cover
Flower Vases..........86

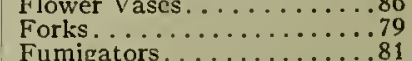

Fumigators

Garden Line............78

Garden Reels..............78

Getz-there Soap

Glass Cleaner.

Glazing Points.

Glove

3 Grafting Wax

3 Grafting Tool

Grape Dust.

Grass Catchers
Grass llooks.

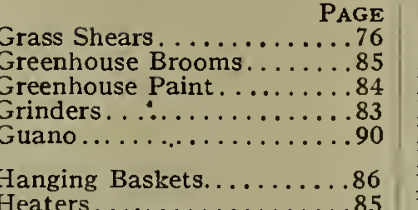

Heaters . ............... 85

Hedge Shears.

Hedge Trimmers

Herbicide.

Hoes.........

Horn Shavings

Horse Mands.

Hose Couplings............ 82

Hose Menders. . . . . . . . .

Hose (Rubber) ...4th cover, 8

Hotbed Sash

Hotbed Thermometers...10, 84

Humus.

Hydrometers.

Insecticides.

......... $88-89$

Vases..............88

Kainit .

Kerosene Emulsion

$\ldots 91$

Kil-O-Scale

Labels.

Land Plaster

Lawn Dressing

Lawn Mower Oil.

Lawn Rakes..

Lawn Rollers.

Lawn Sand.

Lawn Trimmers.

Leaf Mould .

Leaf Racks.

Lemon Oil insecticide.......79

Lime

Limestone........

Lopping Shears.

Manure

Manure Distributor

Mapes Fertilizer.

Mastica

Mastica $\ldots \ldots . . . \ldots \ldots \ldots .68$

Meliler Handy Gardener

Moss ................ 87

Nicofume.............89

Nicoticide.

Nikotiana

Nitrate of Soda............
Nozzles...........

Orchid Peat.

Orchid Recentacles...3rd cover

Pans.

Paper.........

Paris Greell Shakers...... 89

Peat....

Phosphate.

Plant Food

Plant Sprinklers

Plant Stakes.

Plant Tubs, 3rd cover, 4 th cover

Plows..........

Potato Manure

Pot Hangers...........3rd cover

Pot Labels .................

Pots....................... cover

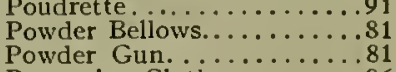

Protecting Clot

Pruning Saws....

Pruning Shears .

Pumps.

Putty Bulbs

Pyrox.

\begin{tabular}{l|l} 
GE & \\
76 & $R$ \\
85 & $R$ \\
84 & $R$ \\
83 & $R$ \\
90 & $R$ \\
86 & $R$ \\
85 & $R$ \\
78 & $R$ \\
78 & $R$ \\
88 & $R$
\end{tabular}

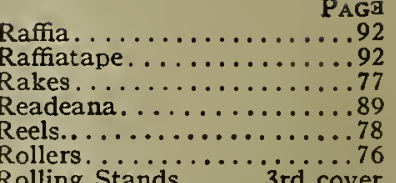

Rollers. ..................76

Rubber Aprons.........82

Rubber Hose......th cover, 82

Rubbish Consumer.....82.87

Sand $\ldots \ldots \ldots \ldots \ldots \ldots, \ldots 7$

Sash ................... 83 


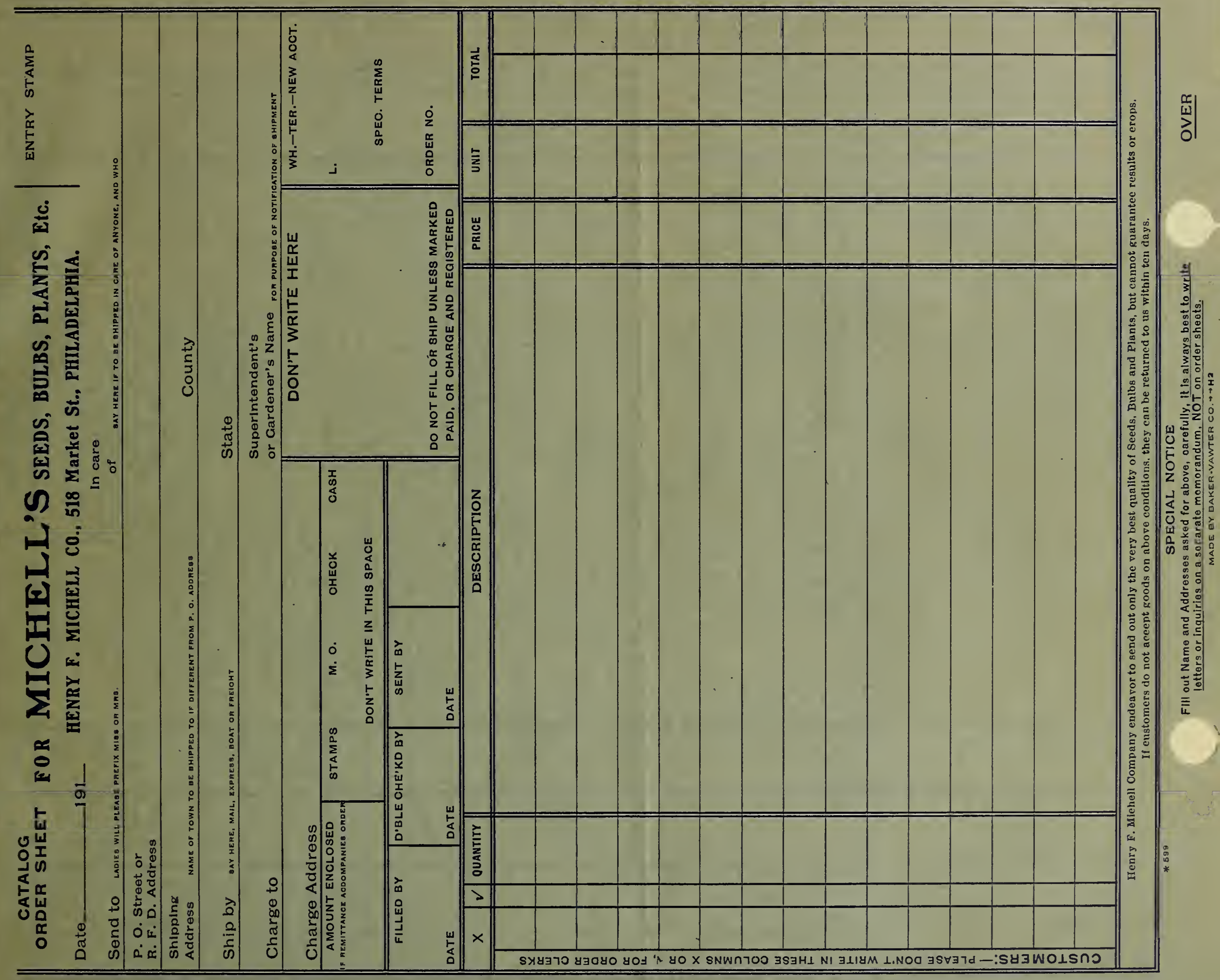




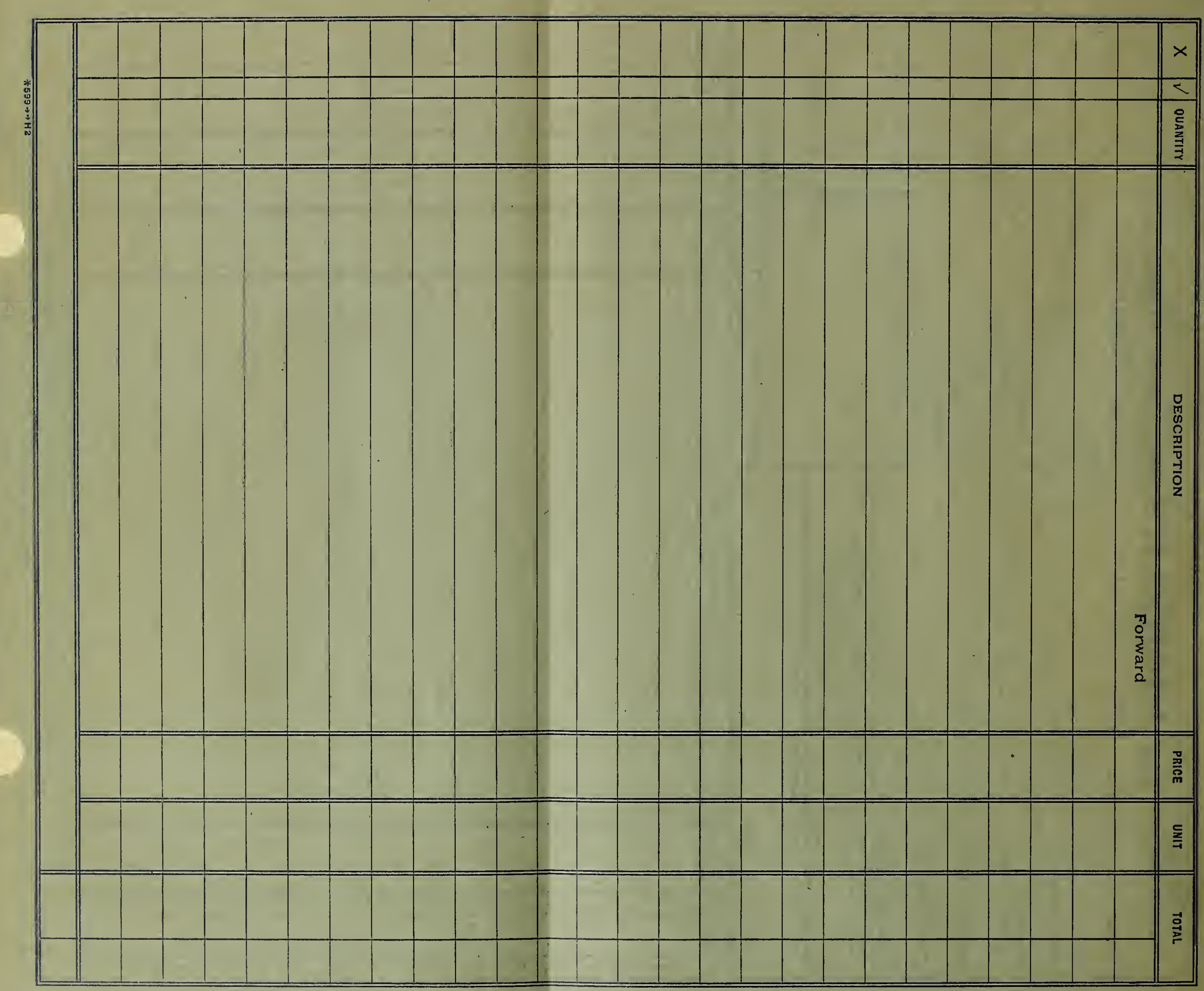




\section{Michell's Vegetable Specialties for 1914}

\section{Wax Bean}

Sure Crop Stringless. A variety which seems to always produce a good yield, regardless of conditions. The pods are long, slender and very brittle and we would consider it among the best, if not the best Wax Bean on the market to-day. The pods are rich golden yellow, produced in abundance, are practically rustproof. The seed may be planted very early, earlier than most other Wax Beans. The originator, a man who has produced more good varieties of beans than any other, in late years has been improving this strain, until he thinks it good enough now for any one to plant. 20c. per pt. (postpaid 28c.), per qt. 40c. (postpaid 56c.), \$I.50 per 4 qts., per pk. \$2.50, \$9.00 per bu.

\section{New Cabbage "Copenhagen Market"}

The earliest strictly round head variety in cultivation, all heads of which are ready for cutting at one time if necessary, which to market gardeners is a most important point, as it gives them an opportunity of using their ground for other purposes needed. The loose leaves around a very solid head, which is almost ballshaped, are light green and rather small. The heads frequently weigh as much as Io lbs. It combines the most excellent qualities of Danish Ball Head, except that it is almost as early as the Jersey Wakefield and has a fine-grained white interior. Ioc. per $1 / 2$ oz., per oz. 20c., 70c. per $1 / 4$ lb., lb. $\$ 2.50$

\section{Celery}

New York. This is a large growing, self blanching variety, earlier than White Plume and fully 6 inches taller. It is in reality a cross between White Plume and Golden Self Blanching. The stalks are of an enormous size, very heavy and never pithy, and is recommended as one of the finest Celery for the market gardener, offered in recent years. 8c. pkt., 20c. oz., $1 / 4 \mathrm{lb} .60 \mathrm{c}$., $\$ 2.25$ per $1 \mathrm{~b}$

\section{Sugar Corn "Early Giant Wonder"}

A true sugar corn, combining the earliness of the hybrid kinds with the sweetness of the later varieties. The ears are large, well shaped and the kernels in rather even rows, so that it may readily be eaten from the cob. It is lusciously sweet and a variety that will recommend itself instantly to any one who likes a delicious sugar corn. 3oc. per qt. (postpaid 50c.), 4 qts. $\$ \mathbf{I} .00$ \$1.75 peck, bu. \$7.00.

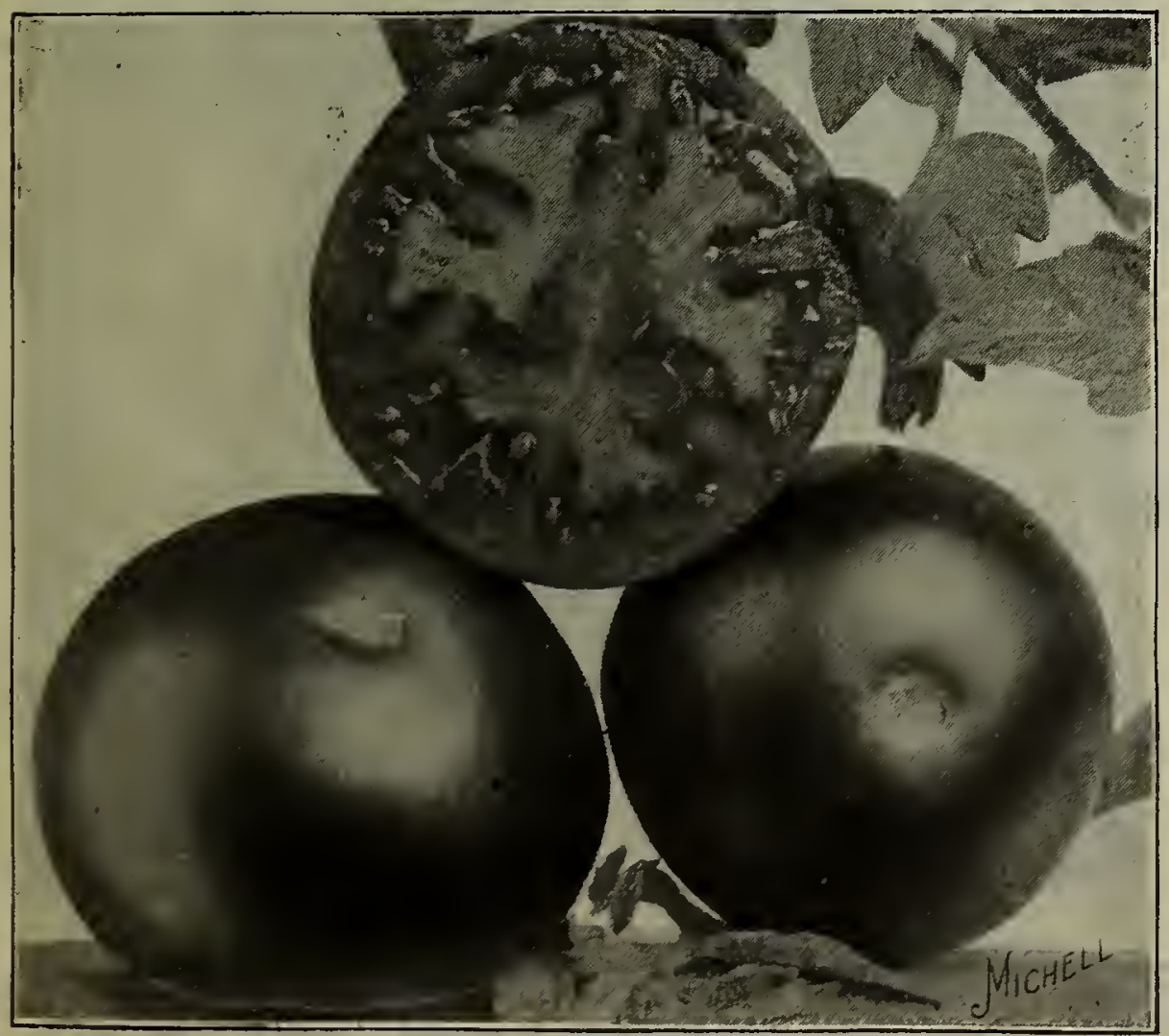

Michell's Crackerjack Tomato

\section{Pole Lima Bean}

Mich e 11's Evergreen. A variety which had its origin in Philadelphia. This remarkable pole lima e $q$ u a $1 \mathrm{~s}$ the earliest for earliness, is far more productive than any other and retains at all times a b e a $u t$ if $u l$ green color. Pods contain on the average 5 to 6 beans. The pods hang in clusters, 6 to 8 in a bunch, which makes the $m$ very easy to gather. All who grow $1 \mathrm{im} \mathrm{as}$ should $h$ a ve this valuable variety in the home or market garden. 20c. per pt. (28c. p os tpaid), qt $40 \mathrm{c}$ (56c. postp a i d), \$1.50 per 4 qts., pk. $\$ 2.50, \quad \$ 10.00$ per bu.

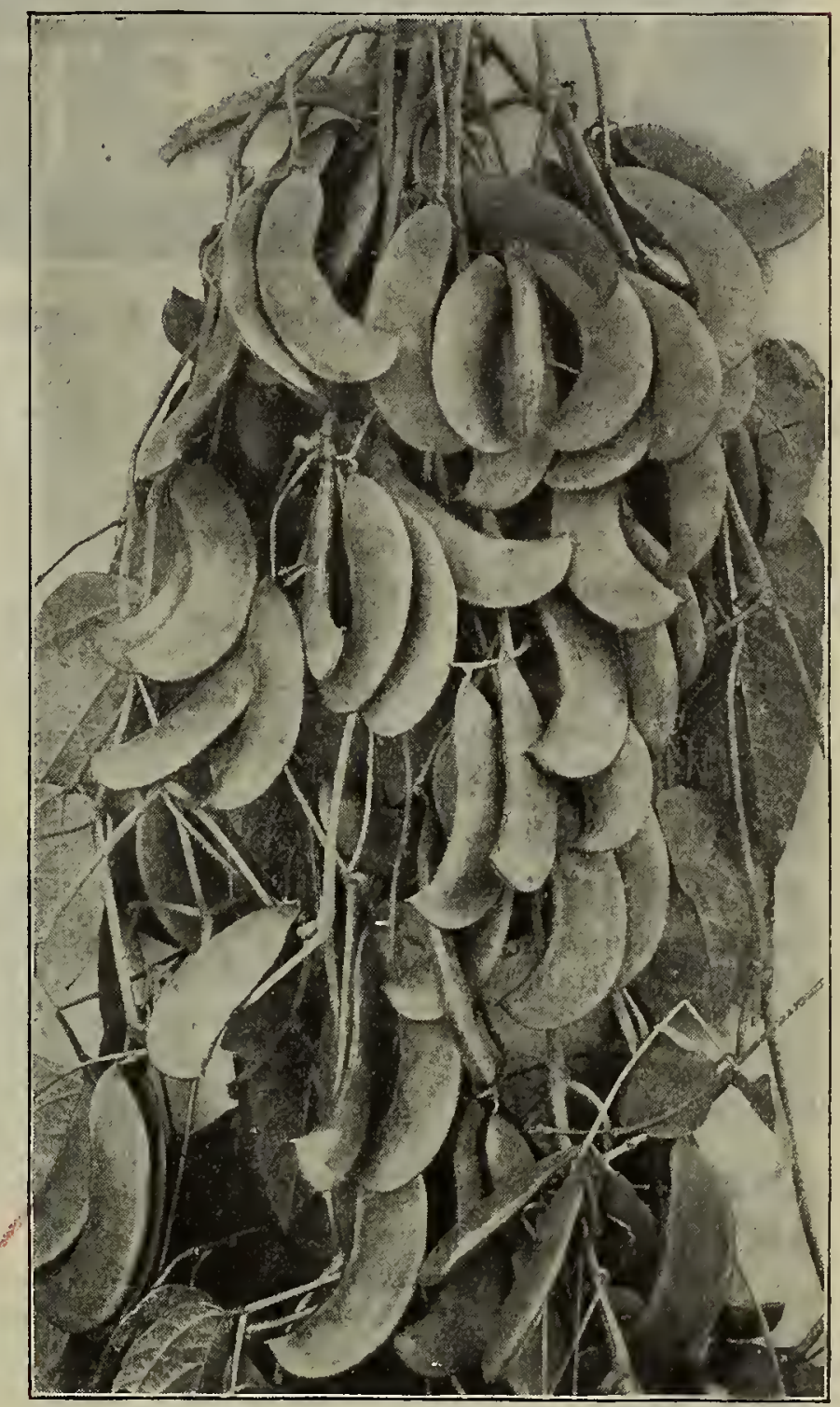

Michell's Evergreen Pole Lima

\section{Lettuce}

Summer Queen. There are but few varieties of lettuce that can be depended upon to mature to perfection during the excessively hot months. When we state that "Summer Queen" is the most reliable variety for this purpose we claim an absolute fact. It constitutes the best midsummer crop for the market gardener. The heads are enormous, very solid, of a light green color and are much superior to any other variety that "can be cropped at that time. It will stay longer without going to seed than any others. Oz. 25 c., 75 c. per $1 / 4$ lb., 1b. $\$ 2.50$

\section{Garden Pea}

The Harvester. We tested this out at our trial grounds last year, and although the season was unfavorable, it did remarkably well, yielding a heavy crop of large pods, filled with luscious peas. In quantity of production it compares favorably with the extra early kinds and rivals such sorts as Gradus and Laxton for flavor and eating qualities. It grows about i 8 inches high. $25 \mathrm{c}$ per pint (postpaid 33c.), 45c. per quart (postpaid 60c.), $\$$ I.75 for 4 quarts, per peck $\$ 3.25$, \$I 2.00 per bushel.

\section{Two Good Tomatoes}

\section{Cracker Jack. One of the earliest Tomatoes grown and a con-} tinuous bearer until frost, the latter being one of its chief chatacteristics, most early tomatoes having finished by the middle of September. The fruit is medium sized, brilliant red, very smooth and solid, with remarkably few seeds. Grows principally in clusters of from 5 to to tomatoes, which are invariably uniform in shape. 7 c. pkt., $1 / 2$ Oz. I 5 c., 3Oc. Oz., I/4 1b. \$I.oo.

Red Rock. Certainly well named, being almost as solid as a stone. The fruit is very large and somewhat longish in shape; a heavy cropper. Color, light red. For canning or market purposes this will be found better than any other. $25 \mathrm{c}$. 0z., $1 / 4 \mathrm{lb}$. $85 \mathrm{c}$., $\$ 3.00$ per $1 \mathrm{~b}$. 


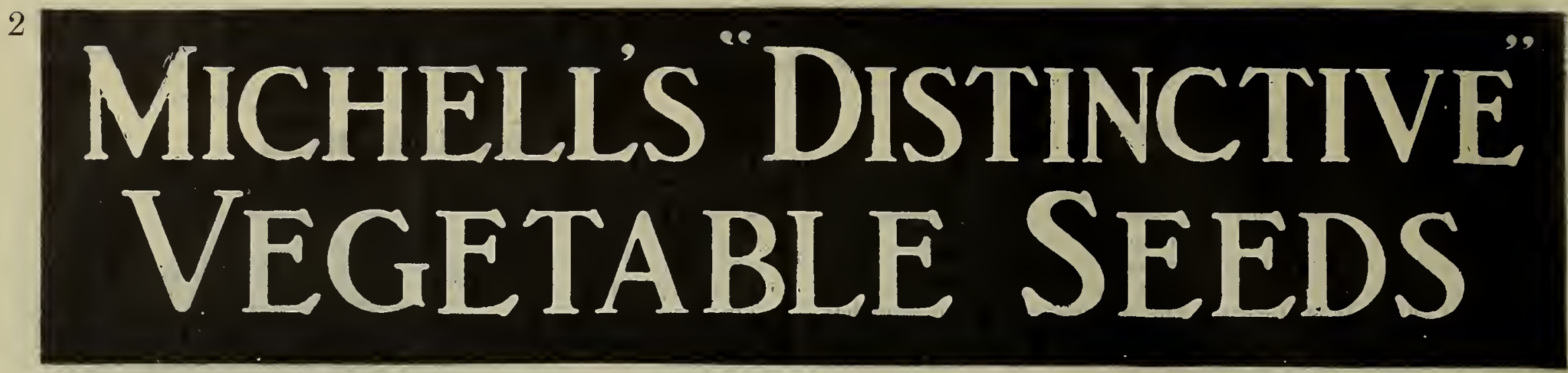

\section{Grown Especially for Market Gardeners' Trade}

The trucker and commercial grower are realizing more than ever that they must be extremely careful in the selection of seeds, not only for the purpose of procuring carefully grown strains, but also that the variety he chooses is that which is the most salable in his market. Both of these features have been given our utmost attention in the make-up of our list, and market gardeners can absolutely rely upon "Michell's Seeds." Varieties especially suited to the Market Gardener and trucker are marked with an asterisk (*).

\section{ASPARAGUS}

*Barr's Mammoth. A favorite in the markets of Philadelphia; big, tender, green stalks. Oz. 5c., I 5c. r/4 lb., 1b. 40c., $\$ \mathrm{I} .75$

$\begin{array}{llll}\text { per } 5 \text { lbs. } & \text { Oz. } & 1 / 4 \mathrm{Lb} . & \mathrm{Lb} . \\ \text { Columbian } & \text { Mammoth White } & (5 \mathrm{lbs} . \\ \$ 2.00) & \$ 0.05 & \$ 0.15 & \$ 0.50\end{array}$ Conover's Colossal, Giant White Variety

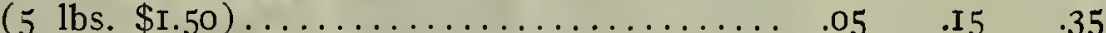

Giant d'Argenteuil, French White sort.......

Palmetto or Eclipse (5 lbs. $\$ \mathrm{I} .75) \ldots \ldots \ldots \ldots . .05$.I 5 .40

ASPARAGUS ROOTS 2 year old Roots 3 year old Root

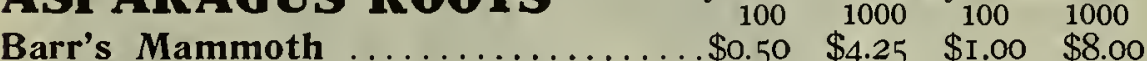

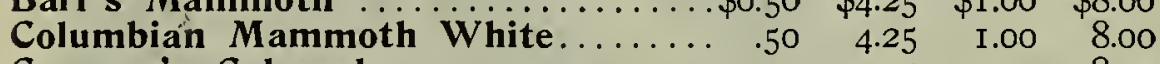

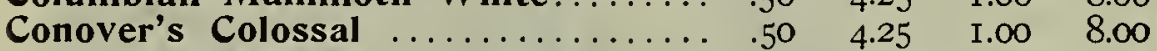

Giant d'Argenteuil ................ .6o 4.25 I.00 8.00

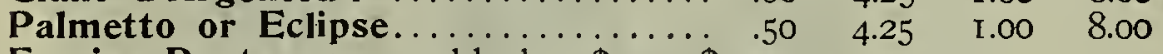

Forcing Roots. 5 yrs. old, doz. \$1.50, \$9.00 per Ioo.

ANISE. Used for Flavoring..........\$0.07 $\begin{array}{ccc}1 / 4 \mathrm{Lb} . & \mathrm{Lb} . \\ \$ 0.25 & \$ 0.90\end{array}$

ARTICHOKE. Large Green Globe Secd. $\quad .25 \quad \begin{array}{lll}.75 & 2.75\end{array}$ " Green Globe Plants. \$1.00 doz., 100 \$7.00.

“ Jerusalem Roots. Ioc. qt., peck 6oc., $\$ 2.25 \mathrm{bu}$.

BALM. $\quad$ T/2 oz. IOc., 20c. per oz.

For flavoring and food for bees....\$0.07 \$0.25

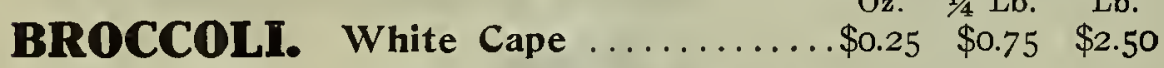

$\begin{array}{lllll}\text { BRUSSELS SPROUTS. Matchless. . } & .15 & .50 & \text { I.75 }\end{array}$

\section{TABLE BEETS}

*Michell's Improved Crimson Globe. The leading sort for the market garden, our strain is renowned and used exclusively by many growers, splendid for early sowing and general crop; almost round in shape and of rich deep color. Ioc. per oz., I $/ 4$ lb. 35c., \$I.I 5 per lb., 5 lbs. $\$ 5.25$.

Crosby's Egyptian. Very early, roundish flat, very tender; for sowing under glass it is an ideal sort. IOc. Oz., I/4 lb. 35c., \$I.I5 per lb., 5 lbs. $\$ 5.25$

*Lentz Extra Early Turnip. For early spring and late summer sowing; the flesh is finely grained and very sweet. 8c. oz., 1/4 lb. 20c., 70c. 1b., $\$ 3.25$ for 5 lbs.

Bastian's Half Long. This is a true blood variety, sown for a winter crop exclusively. It makes handsome roots. Ioc. oz., I/4 lb. 30c., \$I.00 per lb., 5 lbs. $\$ 4.00$.

Arlington Favorite. Rich blood red, turnip-shaped. Oz. Ioc., 30c. $1 / 4$ lb., lb. $\$ 1.10, \$ 5.00$ per 5 lbs.

Bassano. This is the principal butter beet; white and rose colored; flat shaped. Oz. 8c., 25c. 1/4 1b., 1b. 85c., \$4.00 per 5 lbs.

Bastian's Early Turnip. Very similar to Lentz, but a somewhat larger root. IOc. Oz., $1 / 4$ lb. $25 \mathrm{c}$., $85 \mathrm{c}$. 1b., 5 lbs. $\$ 3.75$

Detroit. Rich deep red, a splendid winter beet, turnip shaped. IOc. 0z., $1 / 4$ lb. 35 c., \$I.I5 lb., 5 lbs. $\$ 5.25$

Eclipse. Very small; round, splendid for forcing. Oz. 8c., 25 c. $1 / 4$ lb., lb. 85 c., $\$ 4.00$ per 5 lbs.

\section{TABLE BEETS-Continued}

Edmands. Blood red, turnip shaped, fine for summer. 8c. oz., $1 / 4$ lb. 25 c., 85 c. 1 b., 5 lbs. $\$ 4.00$.

Improved Long Blood. Large root, rich color, for winter use. 8c. 0z., $1 / 4$ lb. 25 c., 85 c. 1b., 5 lbs. $\$ 4.00$.

\section{CATTLE BEETS OR MANGEL WURZEL}

1/4 Lb. Lb. 5 Lbs.

Imperial White Sugar.......................

Lane's Improved White Sugar...........

Mammoth Long Red.................... .I2 .40 I.75

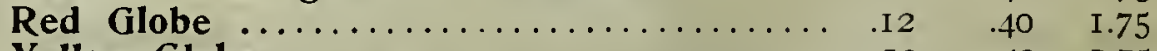

Yellow Globe ...................... I2 $\quad .40 \quad 1.75$

If Mangel Wurzel is wanted by mail add $8 \mathrm{c}$. per $1 \mathrm{~b}$. for postage.

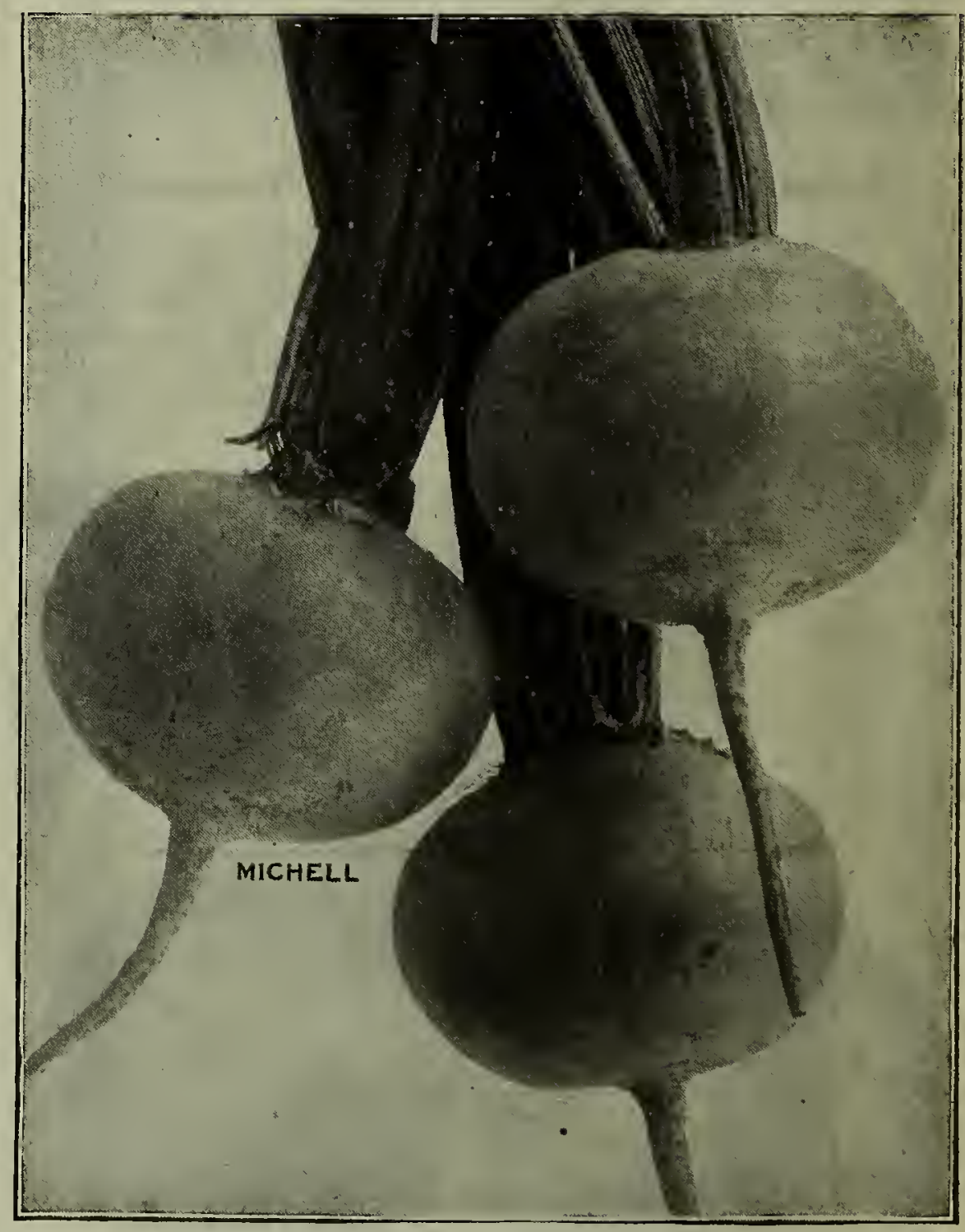

Crimson Globe Beet

SDFCTAT NOTTCF All Vegetable Seeds Nor listed In our Wholesale Catalogue which may be found in the Retail List, are subject to the following discounts from Retail Prices, vlz.: Packets $33 \frac{1}{3}$ per cent.; ounces, pints and quarts, 25 per cent.; novelties, 20 per cent. 


\section{BEANS (Crop Very Short, Order Early)}

Varieties Marked * Especially Suited to Market Gardeners' Needs

\section{Dwarf Green Varieties}

Plant I qt. to Ioo ft. of drill, or 12 to I5 qts. per acre.

Stringless Green Pod. While this is possibly not the longest bean, it is undoubtedly the most tender; absolutely stringless. The market will demand it constantly after it has been better introduced; round podded. Qt. 30c., \$1.00 per 4 qts., peck \$1.75, \$7.00 bush.

* Black Valentine. This is the big cropper for the market gardener, very early, round podded, also a most suitable variety for planting under glass. 25c. qt., 4 qts. 90c., \$1.50 per peck, bush. $\$ 6.00$.

* Mammoth Stringless Green Pod (Giant Valcntine). An improved Valentine, combining the excellent qualities of it and the Stringless Green Pod. 30c. qt., 4 qts. \$1 .00, \$1.55 peck, bush. \$6.20.

*Red Valentine (Ex. Early). For first and last planting this round podded variety is a tremendous yielder. 25c. qt., 4 qts. 90c., \$I.50 per peck, bush. $\$ 6.00$.

*Extra Early Refugee. Extremely early fleshy round podded sort, good for early and last planting. 30c. qt., 4 qts. \$1.00, \$I.60 per pk., bu. $\$ 6.40$.

Best of All. 25c. qt., 4 qts. $85 \mathrm{c}$., $\$ 1.50$ per peck, bush. \$6.0o.

Boston Navy or Pea. 20c. qt., 4 qts. 70c., \$1.25 per peck, bush. $\$ 5.00$.

Broad Windsor (Shelling). 25c. qt., 4 qts. $85 \mathrm{c}$., $\$ 1.50$ per peck, bush. \$6.25.

Dwarf Horticultural (for shelling). 30c. qt., 4 qts. \$I.00. \$1.75 per peck, bush. \$7.00.

Early Long Yellow ( 6 weeks). 20c. qt., 4 qts. $70 c$. \$1.25 per peck, bush. \$5.00.

Early Mohawk (6 weeks). 20c. qt., 4 qts. 70c., $\$ 1.25$ peck, bush. $\$ 5.00$

Longfellow. 25c. qt., 4 qts. $85 \mathrm{c}$, $\$ 1.50$ peck, bush. $\$ 6.00$.

Sion House (forcing). 50c. qt., 4 qts. \$1.50, \$2.75 per peck.

Triumph of Frames (for forcing). 35c. qt., 4 qts. \$I.40, \$2.15 per peck.

White Kidney or Royal Dwarf. 20c. qt., 4 qts. $60 c ., \$ 1.15$ per peck, bush. \$4.60.

White Marrowfat (used shelled). 20c. qt., 4 qts. 65 c., \$1.25 per peck, bush. $\$ 5.00$.

\section{Dwarf Wax or Yellow Pod}

Plant same quantity, per given space, as recommended for Dwarf Green Beans.

*Michell's Improved Dwarf Golden Wax (Rust Proof). The beautiful round podded, golden yellow beans are very prolific, will pick more to the acre than any other similar variety. 30c. qt., 4 qts. \$1.00. \$1.75 peck, bush. \$7.00.

* Currie's Rust Proof Golden Wax. A tremendous yielder of long, golden yellow, flat pods. 25c. qt., 4 qts. 90c., \$1.75 peck, bush. \$7.00.

*Wardwell's Wax. The favorite flat-podded market gardener's bean, very long and slender. 30c. qt., 4 qts. \$I.Io, \$1.8o peck, bush. \$7.20.

Black or German Wax. 30c. qt., 4 qts. \$1.00, \$1.75 per peck, bush. \$7.00.

Stringless White Wax. 30c. qt., 4 qts. \$1.10, \$2.00 per peck, bush. $\$ 8.00$.

Round Pod Kidney Wax. 30c. qt., 4 qts. \$1.10, \$2.00 per peck, bu'sh. \$8.00.

Sure Crop Stringless Wax. (Neri.) Very early. perfectly stringless. 40c. qt., 4 qts. \$1.50, \$2.50 per peck, bush. \$9.0o.

Valentine Wax. (Round Pod.) 30c. qt., 4 qts. \$1.00, \$1.8j per peck, bush. \$7.20.

Davis' White Wax. 25c. qt., 4 qts. 90c., $\$ 1.75$ per peck, bu. \$7.00.

\section{Lima Beans (Pole Varieties)}

One qt. will plant 100 hills; I2 to I5 qts. wiil plant an acre.

*Michell's Evergreen. The earliest pole linia. Originated in Philadelphia, it is remarkably productive. When shelled/it is a ready seller, as it retains it s beautiful green color even when in the dey, state. Pods average 5 to 6 beans and are produced in clusters of 6 to 8 pods, which renders them easy of gathering. 40c. qt., 4 qts. \$1.50, peck \$2.50, \$10.00 per bush. Carpenteria. A variety similar to the above, but with a shorter pod, containing, as a rule. 3 to 4 beans of a green color, which is retained even when dried, very early. Qt. 30c., \$1.00 per 4 qts., peck \$I.75, \$7.00 per bush.

*Dreer's Improved (Potato, or Challenger). A round-seeded, thick-podded bean, very popular in many sections on account of its earliness. $25 \mathrm{c}$. qt., 4 qts. 90c., \$1.75 per peck, bush. \$7.00.

*King of the Garden. A medium-sized bean in large pods with 3 to 5 beans, very vigorous, being continuously in bloom and bearing. $25 \mathrm{c}$. qt., 4 qts. 90c., \$1.75 peck, bush, \$7.00.

* Michell's Selected Large Jersey Lima. This is a very fine selection of the popular Jersey Lima, grown especially for our trade, and please those who want a very large bean. $30 c$. qt., 4 qts. \$1.00, \$1.75 per peck, bush. \$7.00.

* Shotwell's Improved. This is a cross between Dreer's pole and Extra Early Jersey, combining earliness and sweetness. $25 \mathrm{c}$. qt., 4 qts. 93c., $\$ 1.75$ peck, bush. \$7.00.

Extra Early Jersey. Very prolific, mediumsized bean, planted extensively by market gardeners. 30c. qt., 4 qts. \$1.00, \$1.75 pk., bu. \$7.00.

Ford's Mammoth Podded. A gigantic pod which fills the measure well; pods contain 4 to 5 beans. 30c. qt., 4 qts. \$r.00, \$I.75 pk., bu. 7.cJ.

\section{Lima Beans (Bush Varieties)}

*Fordhook. A thick, luscious bean of wonderful producing qualities, very early and continuing to bear right up to frost time. The plant is upright in growth and bears its clusters far above the ground, so they can easily be gathered. $45 \mathrm{c}$. qt., 4 qts. \$1.60, \$3.00 per peck, bush. \$12.00.

Burpee's Improved. The large bean, very thick, sweet and produced in profusion; a favorite on account of its tenderness and far superior to the old variety. $40 \mathrm{c}$. qt., 4 qts. $\$ 1.40$, peck $\$ 2.65$, $\$ 10.00$ bushel.

Burpee's Bush (Old Variety'). The true largeseeded dwarf lima. 30c. qt., 4 qts. \$I.0o, \$I.80 peck, bush. \$7.20.

Dreer's (or Kummerle). A small, thick, roundseeded bean, very late. 30c. qt., 4 qts. \$I.Io, $\$ 2.00$ peck, bush. \$8.0o.

Henderson's. The earliest bush lima, but producing very small flat seed, which though are of excellent flavor, being much in demand. qt., 4 qts. 90c., \$1.70 peck, bush. \$6.75.

New Wonder. A variety very similar to B
$25 \mathrm{c}$. qt., 4 qts. $90 \mathrm{c}$., $\$ 1.75$ peck, bush. $\$ 7.00$.

\section{Pole Beans (Not Lima)}

Early Golden Cluster Wax. Handsome long yellow, flat pod ideal for pickling; a great producer; very tender. 4 qts. \$I.I 5, \$2.20 peck, bush. \$8.75.

Horticultural. Extensively used for shelling, also when green, highly colored red, very prolific and $p$

market. Qt. 25c., 90c. 4 qts., peck \$I.75, \$7.00 bus.

on the list of every market gardener. It is long, round, green pods, and 4 qts., peck \$1.70, \$6.75 bush.

Lazy Wife's. Green pod. 30c. qt., 4 qts. \$1.Io, \$I.85 per bush. $\$ 7.25$

Scarlet Runner. peck, bush. $\$ 7.20$. 


\section{${ }^{4}$ Michell's Cabbage Seed (choice Long Island Grown)}

\section{Varieties Marked * are Especially Suited for Market Gardeners}

Pennsylvania is known to produce some of the best cabbage grown in this country and when the seed which is used is produced from a selected strain, it is one of the most profitable crops the trucker can bring to the market. We have realized this important factor and we can truthfully say that no strain of cabbage seed is superior to Michell's.

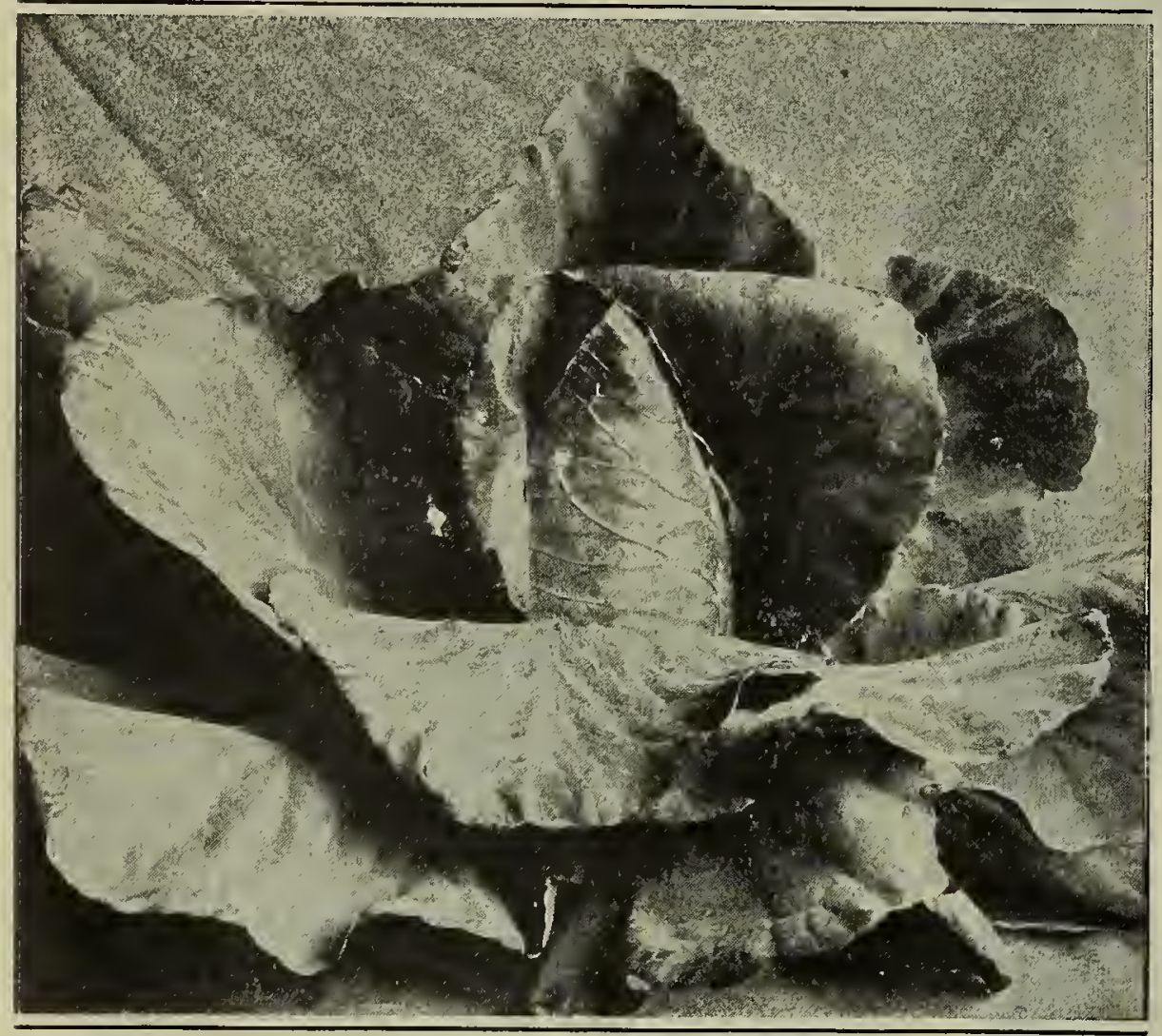

Michell's Early Jersey Wakefield Cabbage

\section{EARIY VARIETIES}

*Improved Early Jersey Wakefield. The most popular first crop variety, having pointed heads with few outer leaves and which sells readily. Perhaps of no other variety are as many varying strains offered as of this one. We are positive that those who grow ours will be well pleased with the result.

Private Strain (extra selected). Oz. 25 c., 85c. I/4 1b., 1b. \$3.00.

Usual Strain. Oz. 20c., 70c. 1/4 1b., 1b. \$2.50.

* Large Charleston Wakefield. Similar to the above but with heads almost twice as large and more blunt at the point; matures a week later than the above. 20c. oz., $1 / 4$ lb. $70 \mathrm{c}$., $\$ 2.50 \mathrm{lb}$

Early Winnigstadt. A variety similar to Wakefield, but not quite as compact header; it is very early, following the former variety in maturing. Oz. I5c., 50c. $1 / 4 \mathrm{lb}$., 1b. $\$ 2.00$.

All Head. The largest of the early cabbages, being roundish flat and very solid. Oz, 25c., $75 \mathrm{c}$. $1 / 4 \mathrm{lb}$., 1b. \$3.0o.

Early Flat Dutch. Very compact grower with a medium size, roundish flat head, which is always solid. Oz. I5c., 6oc. $1 / 4 \mathrm{lb}$., lb. $\$ 2.00$

\section{SECOND EARLY VARIETIES}

Henderson's Early Summer. Enormous solid heads, roundish flat, one of the best midsummer varieties and is a ready seller. Oz. 20c, 70c. $1 / 4$ lb., lb. $\$ 2.50$.

Succession. Very popular with the market gardener, producing enormous uniform heads and matures a few days later than Early Summer. Oz. 20c., 70c. 1/4 1b., 1b. $\$ 2.50$.

Early Drumhead. Very large flat head with few outer leaves, it follows in maturing the Large Charleston Wakefield. Oz. 20c, 6oc. $\mathrm{I} / 4 \mathrm{lb}$., $1 \mathrm{~b} . \$ 2.25$.

\section{LATE OR WINTER VARIETIES}

*Improved Late Flat Dutch. A specialty with us in a strain that cannot be duplicated elsewhere; our grower selects the heads with infinite care and the testimonials we receive from our customers on this variety are the best proof of its quality. It makes enormous solid heads of the finest type, extremely uniform, ideal for sauer kraut and winter keeping. Oz. 20c. 65 c. $1 / 4$ lb., lb. $\$ 2.25$.

\section{LATE OR WINTER VARIETIES-Continued}

*Michell's Improved Danish Ball Head. One of the best winter cabbages grown to-day; in weight the individual heads exceed any other variety, and where cabbages are sold by weight this is the sort that will bring in the most money. Particularly desirable because it succeeds under most trying conditions. Round, solid, well-formed heads. Oz. 20c., 70c. 1/4 lb., 1b. $\$ 2.50$.

Large Late Drumhead. Very large, with roundish heads which are very solid, excellent winter keeper. Oz. $15 \mathrm{c}$, 50c. $1 / 4 \mathrm{lb}$, lb. $\$ 2.00$.

All Seasons ( $V$ andergaw). Beautiful heads which are suitable for midsummer and winter use, very large, round and solid. Oz. 20c., 6oc. $1 / 4$ lb., 1b. $\$ 2.25$.

*Volga. While growing it appears undesirable, but when prepared for market there are few other cabbages that excel it in weight and solidity; cut open, the interior is almost pure white: heads perfectly round, almost ball shaped. A special feature, which recommends it to the market gardener, is that it is almost worm-proof. Oz. 20c., 70c. 1/4 lb., 1b. $\$ 2.50$.

*Perfection Drumhead Savoy. The great favorite of the German populace; finding a ready sale in most any market. This variety grows very large and has no waste to it; heads almost round with beautifully curled leaves. $\mathrm{Oz} .20 \mathrm{c}, 1 / 4 \mathrm{lb}$. $60 \mathrm{c}$., 1b. $\$ 2.25$

*Red Dutch Drumhead. A specialty with all Europeans, and a limited quantity of this is a profitable crop. The head is of medium size, very solid and almost round; every bit of it can be used. I5c. Oz., I/4 lb. 50c., $\$ 1.75 \mathrm{lb}$.

\section{CABBAGE PLANTS}

Per 100 Per 1000

Early Varieties from hotbeds, ready May Ist.......\$0.35 \$3.00 Early Varieties from cold frame, ready in April..... .6555 .50

Late Varieties ready in July................. .30 2.50 Special price on larger quantities.

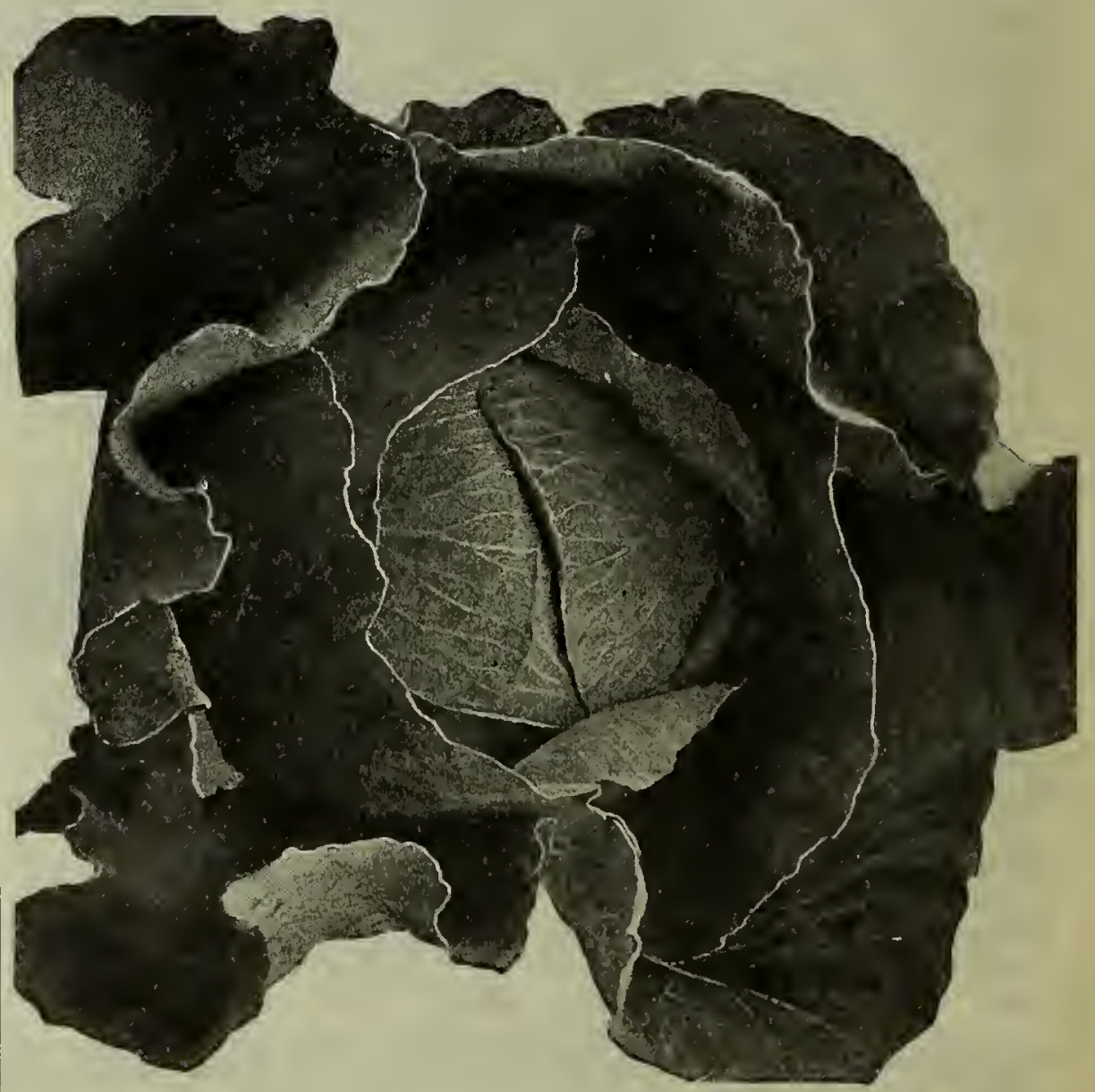

All Seasons Cabbage 


\section{Michell's Selected Carrot Seed}

Harvested from pure stock and selected roots. 3 to 4 Ibs. will sow an acre.

NOTE-Prices of all vegetable seeds in this catalog include postage, unless otherwise ncted. SHOP BY MAIL.

*Chantenay Half Long. Very similar to Rubicon but a trifle longer, much used for sowing under glass and in hotbeds; a splendid carrot for bunching, and used extensively in the New York market gardening district. Oz. IOc., 30c. I/4 lb., lb. \$I.IO.

*Danver's Half Long. The heaviest yielding carrot we know of, ideal for general crop and winter keeping, stumpp rooted, of fine orange color and medium long. Our strain is a reselection by a carrot specialist. IOc. Oz., I/4 lb. $30 \mathrm{c}$., $\$ 1.00 \mathrm{lb}$.

Early Half Long Scarlet. Grows from 5 to 6 inches long, of a rich scarlet orange color. point rooted; an intermediate sort between Scarlet Horn and Long Orange, can be sown under glass for early use. Oz. IOc., 30c. I/4 1b., lb. \$I.00.

Early Scarlet Horn. A very early outdoor variety, of fine color, stump rooted and desirable for bunching. Oz. IOc., 30c. I/4 1b., 1b. \$I.0O.

French Forcing or Early Short Horn. Very small round root, one of the earliest varieties to mature either outdoors or under glass. Oz. IOc., 30c. I/4 lb., 1b. $\$$ I.0o.

Guerande or 0 xheart. A short stump rooted sort, which can be readily grown on stiff hard soils, where other varieties would not succeed so well, grows about 3 inches long and is of rich orange color. Oz. I oc., 30c. I/4 lb., lb. $\$ 1.00$.

* Long Orange (Improzed). The longest table carrot, frequently ro inches long, of deep orange color. Its yield is enormous and of uniform shape; for stock feeding it is extensively used. 8c. Oz., I/4 1b. 25c., 85c. $1 \mathrm{~b}$.

Red Surrey. Very long, similar to Long Orange. 8c. oz., $1 / 4 \mathrm{lb}$. 25c., $85 \mathrm{c}$. lb.

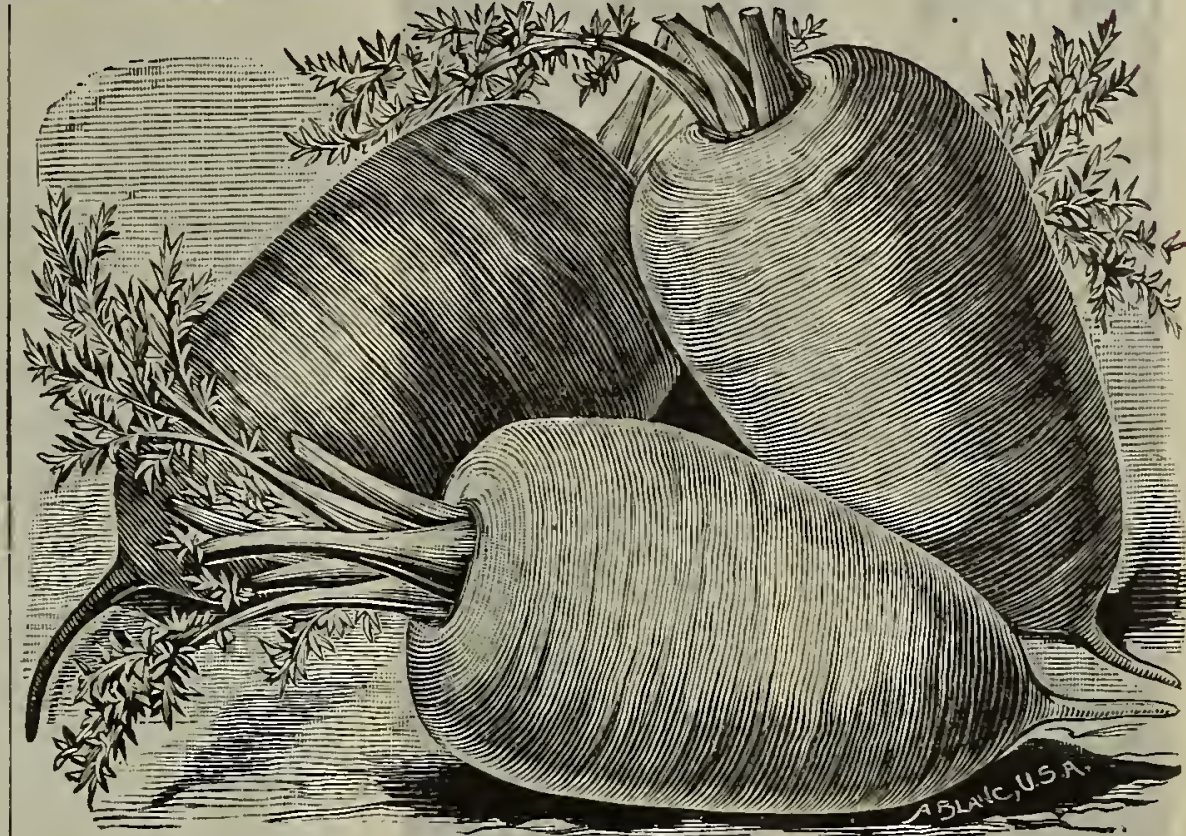

Danver's Carrot

*Rubicon Half Long. The leading market gardeners' variety, one of the earliest and frequently used for forcing and sowing in hotbeds; in form it resembles the Danver's, but is considerably shorter in length, rich orange color, stumpp rooted. Oz. IOc., 30c. $1 / 4$ lb., lb. \$I.Io.

White Belgian. Used for stock feeding only, very long white root, also good for soiling when turned under. Oz. 8c., $20 c$. $\mathrm{I} / 4$ lb., lb. 6oc.

\section{Michell's Pedigreed Cauliflower Seed One ounce of seed will produce about 3,000 plants.}

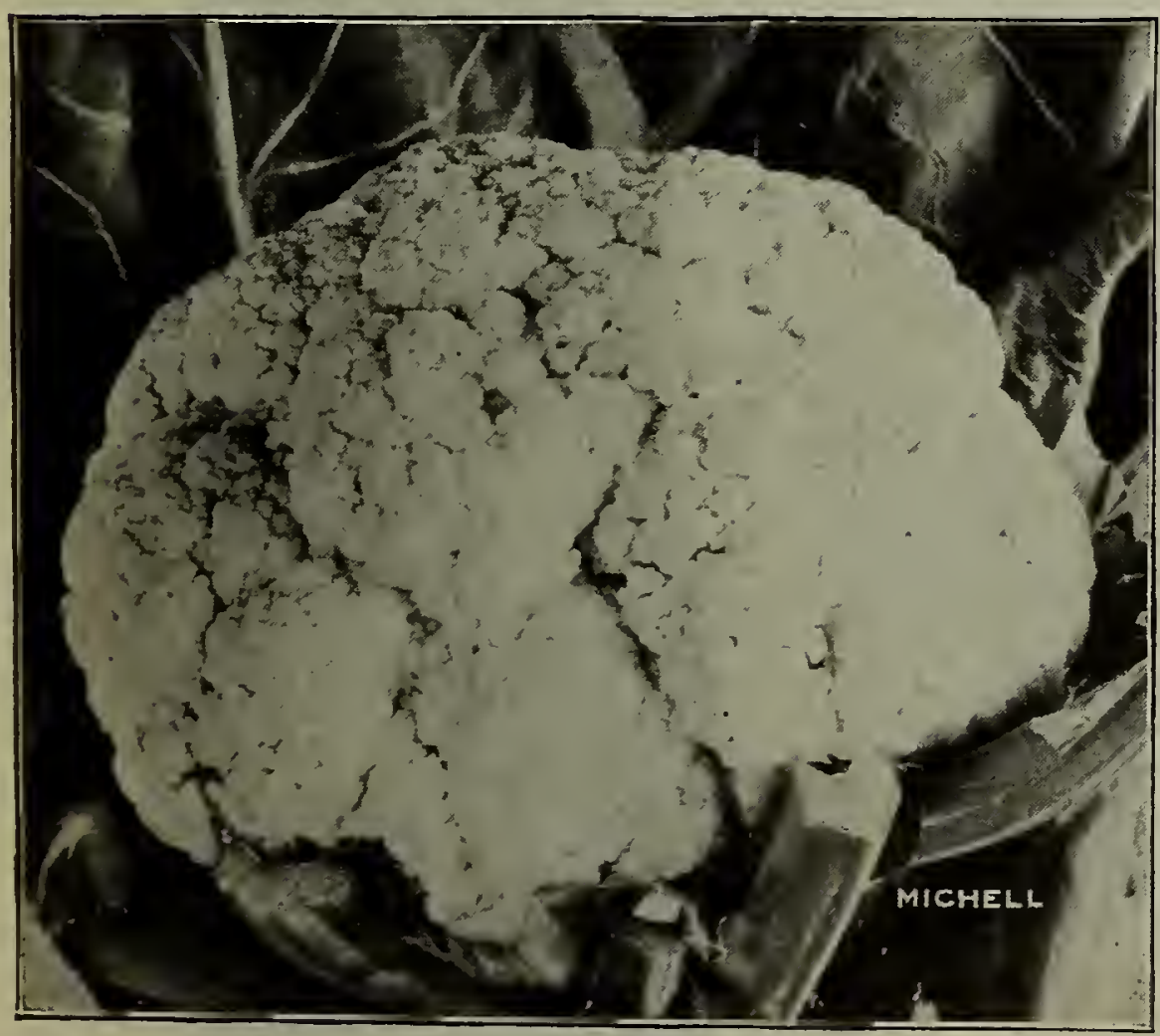

Snowstorm Cauliflower

Algiers. Large heads; late; for outdoors. Pkt. 7c., 20c. $1 / 4$ oz., oz. 6oc., $\$ 2.00$ per $1 / 4 \mathrm{lb}$.

*Danish Giant. A variety which is especially recommended for midsunmer use, because it will stand more drought and heat than any other sort. The heads are very large, snowy white, and well protected by a liberal growth of foliage; a sure header and therefore just the sort for the market gardener. Large pkt. 20c., 80c. 1/4 oz., oz. $\$ 3.00$, \$10.00 per $1 / 4 \mathrm{lb}$.
*Early Snowball. Perhaps one of the best known varieties and therefore used extensively; the heads are quite large and can be successfully grown even under adverse weather conditions. The head is very white. Large pkt. I5c., trade pkt. 40c., 60c. $1 / 4$ oz., oz. $\$ 2.00, \$ 7.00$ per $1 / 4 \mathrm{lb}$.

Half Early Paris. Small heads for frame or outdoor planting. Pkt. 7c., I5c. $1 / 4$ oz., Oz. 50c., $\$ 1.50$ per $1 / 4 \mathrm{lb}$.

Matador. One of the best forcing varieties, makes medium size solid pure white heads; the foliage is ample for folding over the heads as they mature; it is also suitable for outdoor culture in early spring. Large pkt. $15 \mathrm{c}$., $60 \mathrm{c}$. $1 / 4 \mathrm{Oz}$., per $\mathrm{Oz}$ $\$ 2.00, \$ 7.00$ per $1 / 4 \mathrm{lb}$.

*Michell's Earliest Snowstorm. Colossal heads of the purest white, averaging often ro inches in diameter, particularly desirable for its extreme earliness, though it may be used to equal advantage either under glass or outdoors. This cauliflower seed we sell to the most critical market gardeners who would refuse to use any other. (Large pkt. I7c.) Trade pkt. 40c., \$I.25 per I/4 Oz., OZ. \$4.00, \$I 4.00 per $1 / 4 \mathrm{lb}$.

Selected Erfurt (Michell's Special Strain). Selected for its earliness and is particularly suitable for growing under glass, though it does very well outdoors as an early spring crop. Of dwarf growth with short foliage; medium sized heads, but mature very quickly. Large pkt. I5c., $40 \mathrm{c}$. per trade pkt., 6 ac. $1 / 4$ oz., oz. $\$ 2.00, \$ 7.00$ per $1 / 4 \cdot 1 \mathrm{~b}$.

Veitch's Autumn Giant. Very large; late. Pkt. 7c., roc. $1 / 4$ oz oz. 30c., $\$ 1.00$ per $1 / 4 \mathrm{lb}$.

\section{CAULIFLOWER PLANTS}

Hotbed Grown

Doz. $\quad 100 \quad 1000$

Pot Grown

CARAWAY. $\begin{array}{ccc}.45 & 3.50 & 32.5 \\ \text { Oz. } 1 / 4 \mathrm{lb} & \text { Lb. }\end{array}$

CARDO0N. Broad Ribbed

CATNIP. (Pkt. 7c.) ... 


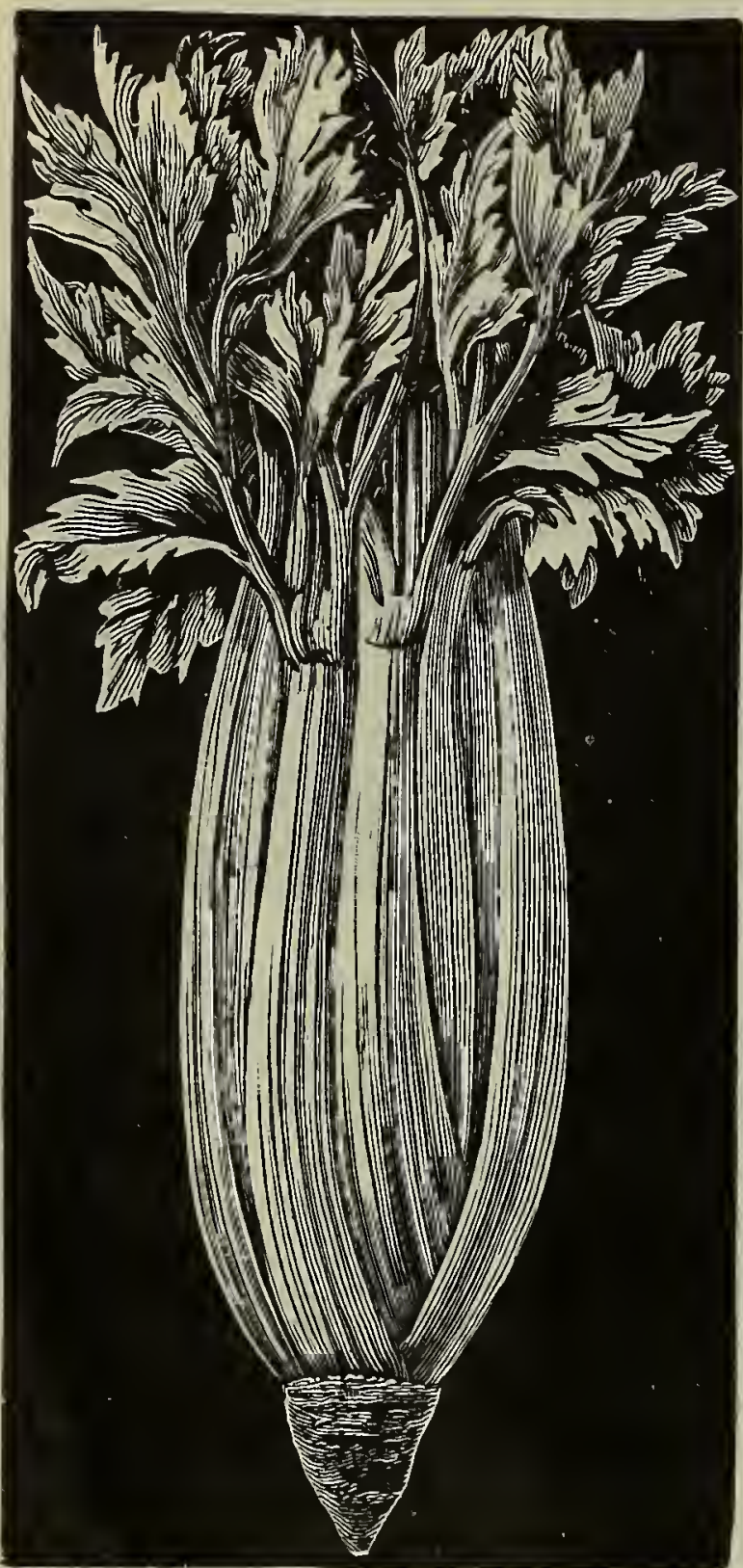

Michell's Improved White Plume

Special Prices will be quoted on celery plants in large lots.

\section{CELERY}

* Michell's Improved White Plume (Private Stock). One of the earliest of celeries, and grown in enormous quantity by all the leading truckers. Our strain of this is unusually fine. Many of our customers engage their requirements a year ahead, so as to be sure and procure it from us before our stock is exhausted. Oz. $25 \mathrm{c}$., 75c. $1 / 4$ lb., 1b. $\$ 2.50$.

White Plume (Usual Strain). Oz. 20c., 6oc. 1/4 lb., lb. $\$ 2.00$.

*Golden Self Blanching (French Grown Seed, Vilmorin Stock). The leading variety for Thanksgiving market; enormous stalks of golden yellow, requiring almost no artificial blanching; grown in enormous quantities by all who specialize in celery. Our stock is the best in the world and absolutely true. This strain is very scarce this year; $1 / 4$ Oz. 40c., 7Oc. $1 / 2$ Oz., $\$$ I.40 per Oz., I/4 lb. $\$ 5.50$.

*New Columbia. A popular variety with the truck gardener, especially in the Chicago market; of medium height, but very solid and heavy; three. stalks make a massive bunch; splendid winter variety, keeping well. 40c. oz., $1 / 4 \mathrm{lb}$. $\$ \mathrm{I} .50$, $\$ 5.50 \mathrm{lb}$.

*Giant Pascal. Ideal for the trucker, keeping longer than any other sort, of splendid appearance and exceedingly tall, three features which recommend it to the man who grows for profit; blanches pure white. Oz. I 5c., 40c. I/4 lb., 1b. \$1.50.

*Michell's Far Superior. The best mid-winter variety, very tall and with a large full heart; no waste; sells on sight. Oz. I 5c., 50c. I/4 lb., lb. \$I.50.

*Winter Queen. A medium tall solid variety, keeps well through the winter; very full and large heart. Oz. 20c., 6oc. 1/4 lb., lb. $\$ 2.25 . \quad$ Oz. 1/4 Lb. Lb.

Early Snowdrift. An Improved White Plume............\$0.25 $\$ 0.85 \quad \$ 2.75$

Dwarf Golden Heart. A Christmas celery............... . I5 $.40 \quad$ I.35

Pink Plume. Rose-colored stalks....................... . I $5.50 \quad$ I.75

Magnificent. Semi-late, brittle variety, white stalks...........25 $\quad .75 \quad 2.50$

Winter King. For late winter use..................25 $\quad .75 \quad 2.50$

*New York. A self-blanching va-

riety, being a cross between Giant Pascal and White Plume. It is crisp, brittle and a fine variety for the market gardener, coming ahead of White Plume and is much larger. Pkt. 8c. 20c. oz., $\mathrm{r} / 4$ lb. 6oc., $\$ 2.25$ per lb.

Celeriac. Giant Smooth Prague. I 5c. oz., I/4 lb. 50c., lb. \$1.85.

Flavoring Celery. Not for sowing. $8 \mathrm{c} .1 / 4 \mathrm{lb} ., 1 \mathrm{~b}, 25 \mathrm{c}$.

\section{CELERY PLANTS}

Leading Varieties. Early and late. 40c. per roo, per I000 $\$ 3.25$.

\section{CUCUMBER}

*Arlington Improved White Spine. The best sort for growing under glass and general outdoor crop for market, producing fruits which are always uniform; deep green, very smooth and rounded at the end. It is not always the largest cucumber which is wanted by the market gardener, because the produce man is limited as to the price he can get. Oz. IOc., 30c. I/4 lb., lb. \$1.00.

*Davis' Perfect. Very similar in form to the above; a heavy crop can always be depended upon whether grown under glass or outcloors. As a rule it bears three or four specimens in a cluster of even larger size than the White Spined; of rich deep green color. IOc. oz., I/4 1b. 25c., 85c. 1b.

* Jersey Pickle, or Green Prolific. A staple variety with many of the larger market gardeners, it is short and thick and used principally for pickling. Oz. 8c., $20 c .1 / 4$ lb., lb. $70 \mathrm{c}$.

Cool and Crisp

Cumberland

Emerald

Evergreen

White Spined (Lsual Strain)

Japanese Climbing

Long Green Turkey

Small Gherkin or Burr.

\begin{tabular}{rrr}
\multicolumn{1}{c}{ Oz. } & $1 / 4 \mathrm{Lb}$. & \multicolumn{1}{c}{ Lb. } \\
\$0.08 & $\$ 0.20$ & $\$ 0.75$ \\
.08 & .20 & .75 \\
.08 & .25 & .85 \\
.08 & .25 & .85 \\
.08 & .25 & .85 \\
.08 & .85 \\
.10 & .30 & 1.00 \\
.08 & .20 & .75 \\
.10 & .30 & 1.00
\end{tabular}

ENGLISH FORCING CUCUMBERS

Lockie's Perfection, Sion House, Telegraph, Tender and True. The above

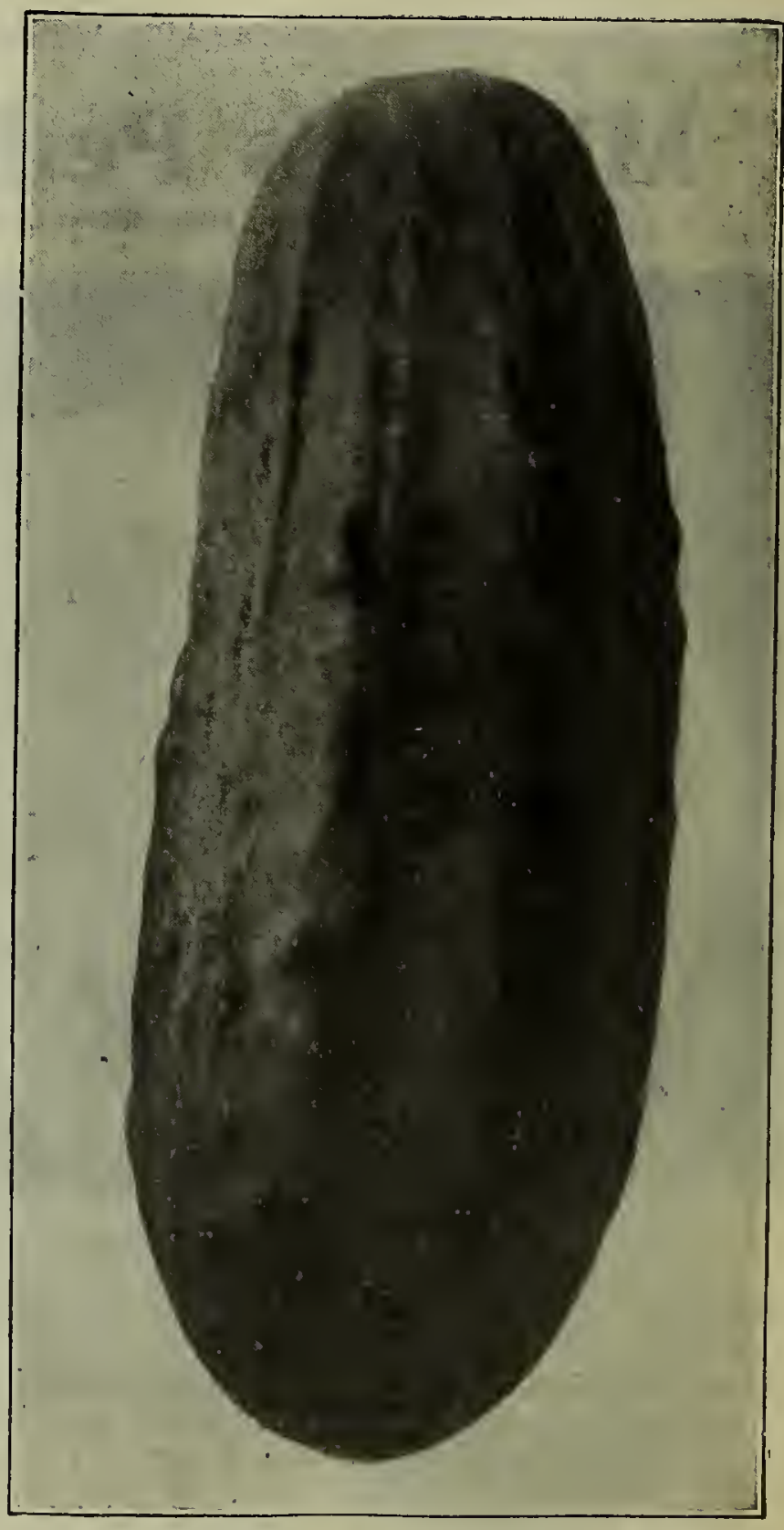

Davis Perfect Cucumber varieties $20 \mathrm{c}$. each, per pkt. of 12 sceds. 
Varieties Marked * are Especially Suited for Market Gardeners' Use

NOTE. If Corn is wanted by mail add Ioc. per quart for postage. irrespective of zone or distance, as the rate on seeds is uniform.

\section{EARLY VARIETIES}

*Early Giant Wonder. It is the earliest of the true sugar corns and produces fine, large, regular-grained ears. 30c. qt., 4 qts. \$1.00, \$1.75 per peck, bush. \$7.00.

Early Champion. Large ears, well-shaped and exceedingly sweet. 20c. per qt., 4 qts. 6oc., \$I.Io per peck, bu. \$4.40.

*Ideal. One of the biggest yielders among the first earlies, and for this reason it is often preferred by market gardeners. Notwithstanding its earliness, the ears are quite large and our grower pays more attention to reselecting this variety than any other sort. 20c. qt., 4 qts. 70c., \$I.25 pk., bu. \$5.00.

*Stabler's Extra Early. A very popular sort among the truckers; as the ear when ready for market is very attractive and is a ready seller. 20c. qt., 4 qts. 60c., \$1.ro pk., bu. \$4.40.

*Kendel's Early Giant. Very cylindrical ears, which are large deep-grained and very sweet. 20c. qt., 4 qts. 70c., \$1.I 5 pk., bu. \$4.50.

Golden Bantam. The sweetest corn grown and while the ears are small it is the color actually which prevents it from being a favorite in the market. If the trucker will persist in introducing it, his customers will continue to ask for it; color, a beautiful golden yellow. 25c. qt., 4 qts. 90c., \$I.60 peck, bu. $\$ 6.25$.

Golden Rod. Similar to Golden Bantam with larger ears and lighter color and not quite so early. 25 c. qt., 4 qts. 90c., \$1.60 peck, bush. $\$ 6.25$.

Metropolitan. An extra early sort following Crosby's but with larger ears; very sweet and a great producer. Qt. 20c., 6oc. for 4 qts., peck, \$I.Io, \$4.40 per bushel.

Adam's Extra Early. Pure white, mediumsized ears. I5c. qt., 4 qts. 50c., 85 c. peck, bu. $\$ 3.40$.

Aristocrat. Finely shaped ears with even rows of kernels, very sweet and attractive. Qt. 20c., 4 qts. 70c., \$1.25 peck, bush. \$5.00.

Crosby's Extra Early. Medium-sized, very early and sweet, divarf grower, but very productive. 20c. qt., 4 qts. 60c., \$̦r.To per peck, bu. \$4.40.

Early Evergreen. Like "Stowell's" in appearance and quality, but much earlier. Qt. 20c., 70c. per 4 qts., peck \$I.I 5, \$4.50 bush.

Early Mammoth. Really a second early variety, producing enormous ears on a mammoth stalk. Qt. 20c., 70c. per 4 qts. peck \$I.Io, \$4.40 bushel.

First of All. A quick growing variety with good shaped ears, with pure white kernels, in the dry state it turns pink and reddish. 20c. qt., 4 qts. $60 c$., \$1.Io per peck, bush. \$4.00.

Peep o'Day. The earliest corn in existence, but produces very small ears; especially adapted for growing under glass. Qt. 20c., 6oc. per 4 qts., peck $\$$ I.I5, $\$ 4.50$ per bu.

Premo. One of the real good extra early large-eared varieties. Qt., 25c., 4 qts. 70c., \$I.30 peck, bush. \$5.20.

\section{MEDIUM AND LATE VARIETIES}

*Eastwick. A new rariety that will become a great favorite. The hull when the corn is eaten remains on the cob, which is a valuable feature; it is of medium size and exceptionally sweet. 30c. qt., 4 qts. \$I.IO, \$2.00 per peck, bushel $\$ 8.00$.

*Michell's Delicious. Any market gardener selecting this variety as his standard for a mid-season planting will not be disappointed. Not only does it produce handsome ears in large quantity, but its flavor is excellent, and once tasted it is demanded again. Medium late. Qt. 30c., \$1.1o per 4 qts., peck \$2.00. $\$ 8.00$ per bu.

Stowell's Evergreen. This old favorite cannot be superseded by any; it has the shape, size and quality in such abundant measure that the grower not only likes to plant it, but the consumer demands it. . Qt. 20c., 6oc. per 4 qts., \$1.00 per peck, bush. \$4.00.

*Country Gentleman. A large late variety, where the deep kernels are set very irregularly on the cob. It is undoubtedly one of the sweetest late corns grown, which alone recommends it. Qt. 20c., 70c. per 4 qts. peck \$I.25, \$5.00 per bu.

Little Gem or Shoe=Peg ( $N_{c}$ Plus Ultra). Very similar to the above, having the same merits. Qt. 20c., 70c. per 4 qts., peçk \$1.25. $\$ 5.00$ per bu.

Black Mexican. Medium-sized ears, black and white kernel, very sweet; late. Qt. $20 \mathrm{c}$. 6oc. per 4 qts., peck \$I.Io, $\$ 4.40$ bu.

Late Mammoth. The latest maturing and the largest of all sweet corn, gigantic ears produced in quantity. The stalks often grow 8 to 9 feet high. Qt. 20c., 6oc. per 4 qts. peck \$I.IO, \$4.25 per bu.

\section{Sugar Corn on Ears}

We can supply the following varieties in selected, well-shaped ears; bought in this manner one can make a careful reselection of grains or ears:

Crosby's, Country Gentleman, Stowell's Evergreen, Late Mammoth, Kendel's and Stabler's. 7c. each, doz. 75c., \$5.00 per too.

POP CORN (on Ears) For seeding or popping.

White Rice... Lb. $10 \mathrm{Lbs}$ Golden Queen \$.08 $\$ 0.65$

\section{FIELD CORN}

Grown especially for seed purposes, shelled from selected ears, carefully tipped and butted. Sugat Cor Chester Co. Mammoth

Cloud's Early Yellow Dent.

Early Yellow Canada or Flint

Golden Beauty Improved.

Hickory King. White

Leaming Early Dent. Selected strain...

Pedigree Strain (in

$\begin{array}{lll}\text { Qt. } & \text { Pk. } & \text { Bu. } \\ \text { \$o.I } & \$ 0.55 & \$ 2.00\end{array}$

. $10 \quad .60$

$\begin{array}{lll}10 & .55 & 2.00\end{array}$

$\begin{array}{lll}.10 & .55 & 2.00\end{array}$

IO $\quad .55 \quad 2.00$

crates, $\$ 3.75$, 5 bushels for $\$ 17.50)$.

I oo Day Early Bristol.

Red Cob Ensilage. IVhite.

Eureka Ensilage. Yellow.

Virginia Ensilage. White.

When ordering Field Corn in I bushel lots and for each 2 bushel seamless bag. (These are returnable for credit.) 


\section{CHERVIL}

Fow market gardeners realize that they can have a steady income during the winter from supplying fresh greens to the hotel trade. Chervil is a flavoring green which is used in dressing lettuce and while it is but little known a single introduction will work up considerable demand.

Double Curled. Oz. roc., 30c. $1 / 4$ lb., 1b. \$r.00.

CHICORY. Large Rooted. 8c. oz., $1 / 4$ lb. 20c., 7oc. lb. Witloof. IOc. OZ., T/4 lb. $35 \mathrm{c}$., $\$ \mathrm{I} .25 \mathrm{lb}$.

CORIANDER. For flavoring. 7 c. oz., $1 / 4$ 1b. 20c., 5oc. $1 \mathrm{~b}$.

\section{CORN SALAD}

On account of the German populace in and near Philadelphia, this is much in demand and constitutes a profitable crop, bringing in money at a time of the year when vegetables are either exhausted or have not yet matured.

Large Seeded. Oz. 5c., I5c. T/4 lb., lb. 45c., \$2.00 per 5 lbs.

CHIVES. Strong clumps. 75c. doz., roo $\$ 5.00$. Seed, pkt. Ioc.

\section{WATER CRESS}

A profitable side crop on any place where there is a stream of water, once established it remains for years, seeding itself. Prefers a running stream, not too deep; a money-maker in the spring, without any bother.

True Erfurt. Oz. $25 \mathrm{c} ., 85 \mathrm{c}$. I/4 lb., 1b. \$3.00.

GARDEN CRESS. Extra Curled or Pepper Grass. 5c. Oz., I/4 1b. I5c., 35c. 1b.

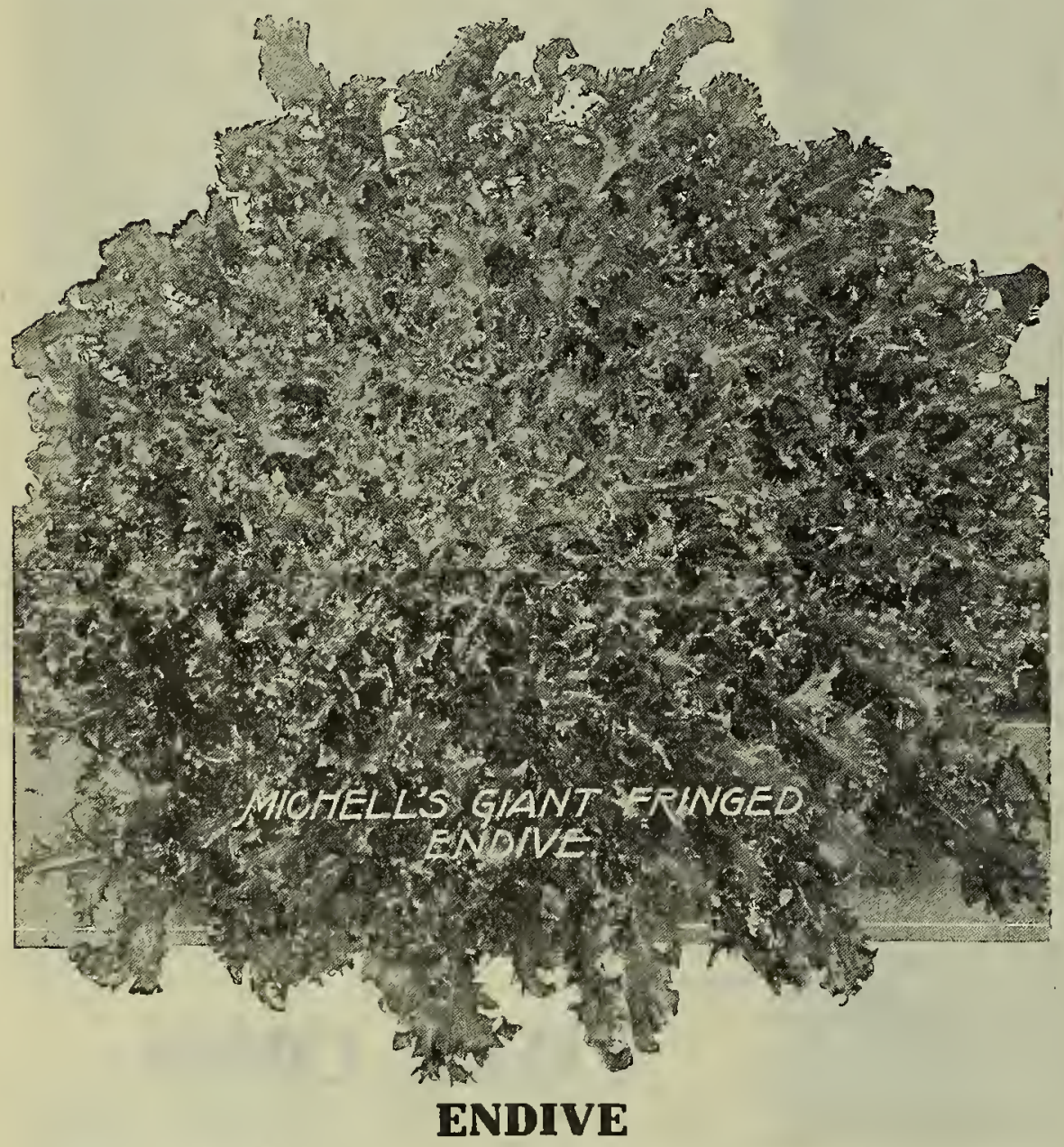

Giant Fringed. One of the largest and most curley varieties, very tender when properly blanched. This is another crop that brings in returns during the dull season. Properly cared for it can be kept all winter and marketed.as required. Oz. I5c., 5oc. $1 / 4$ lb., lb. \$r.50.

Broad Leaved Batavian. This variety has large broad, ribbed leaves, which blanch almost pure white and which sells readily, especially to the French and Italian people. Oz. Ioc., 35c. I/4 lb., lb. \$1.25.

Improved Green Curled

White Curled. Self Blanching............... . $\begin{array}{r}.35 \\ \text { I.25 }\end{array}$

FENNEL. An aromatic herb......... $.07 \quad .20 \quad .65$

GARLIC. ….....25c. 1b. (5 lbs. \$r.00)

HOP VINES. Strong plants. $75 \mathrm{c}$. doz., per roo $\$ 6.00$. Seed pkt. 8c.

\section{LEEK}

*Giant Carentan. Enormously 1 a r ge very thick, long stalk with. plenty of edible heart. I5c. oz., $\mathrm{T} / 4 \mathrm{lb}$. 50c., \$1.75 lb.

*Large Mussell= burg. Slightly longer tha $n$ the Carentan, but not so thick at the base. I5c. Oz., I/4 lb. 50c., \$1.75 lb.

London Flag. Oz. I5c., 45C. I/4 lb., lb. $\$ 1.50$.

\section{LAVENDER}

(Herb). I5c. Oz., I/4 1b. 35c., $\$ 1.001 \mathrm{~b}$.

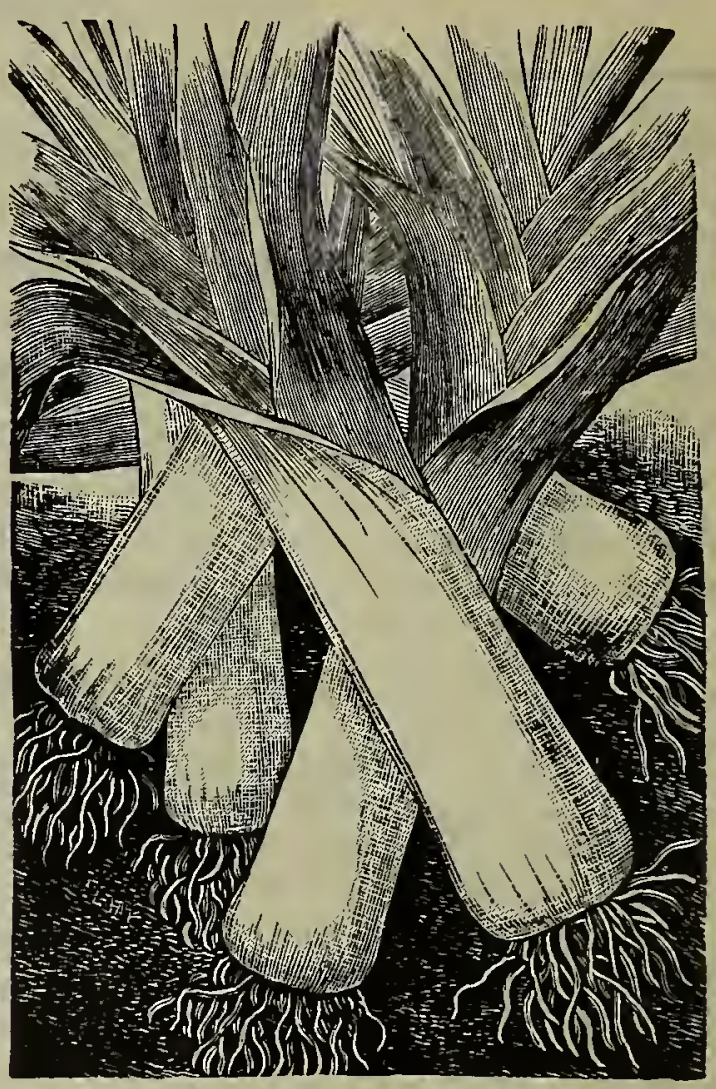

Giant Carentan Leek

\section{DANDELION}

This is not the common weed known under that name, but one which is especially cultivated as a spring green, being grown in frames for this purpose. We handle only the true French Grown Seed, yfich is the only kind that should be used.

Thick Leaved, or Cabbaging. Oz. $25 \mathrm{c}$., $85 \mathrm{c}$. per $\mathrm{I} / 4$ lb., 1b. $\$ 3.00$.

\section{DILI}

Used as a flavoring for pickles laid in brine, there is a lively demand for it in all sections where cucumbers are put up in this way. Oz. 5c., I5c. $1 / 4$ lb., lb. 5oc.

\section{EGG PLANT}

*Black Beauty. The earliest, largest and finest colored fruit, extensively grown in New Jersey as the leading market variety. Our strain of seed is carefully selected from the best ripe specimens. Oz. 30c., \$I.ro I/4 lb., lb. \$4.25.

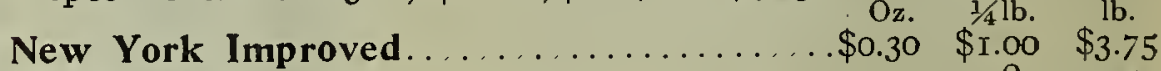

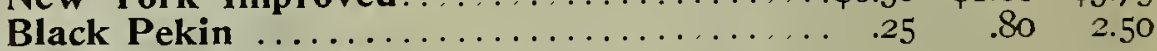

Early Long Purple..................... .15 .55 2.ro

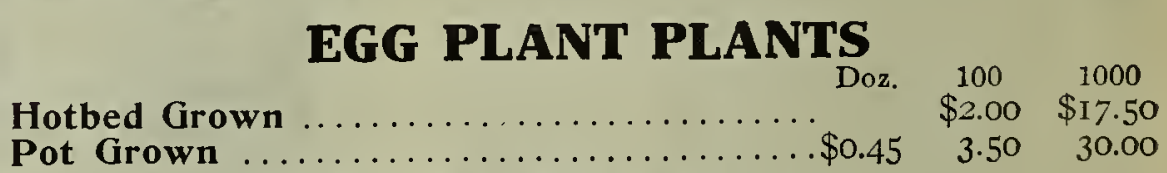

\section{HORSE RADISH ROOTS}

Maliner Kren, 6oc. per I00, per I000 $\$ 5.25$.

Common Variety. 40c. per I00, per I000 $\$ 3.75$.

\section{KALE OR BORECOLE}

New Imperial, or Long Standing. Very curly and of fine dark green color, stands about 15 inches high and is a tremendous cropper. Oz. 7c., 20c. 1/4 1b., 1b. 6oc. (5 lbs. \$2.50).

Dwarf Green Curled Scotch. A semi-dwarf variety which stands the severest winters extremely well, of rich green color and finely curled. 7c. Oz., $1 / 4$ lb. 20c., 6oc. $1 \mathrm{~b}$.

Dwarf Green German. 7c. OZ., I/4 1b. 20c., 50c. lb.

Sea Kale. Pkt. 8c., 20c. per oz.

\section{KOHL RABI}

This should be grown by market gardeners, especially those who have the patronage of German people; growers should be careful to market young roots only, as then only are they tender and delicious; can be successfully grown in frames.

White Vienna Oz. 1/4lb. lb.

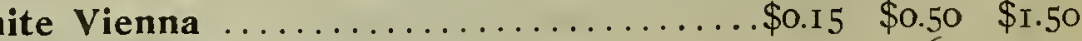

Earliest White Erfurt..................20 $\quad .65 \quad 2.25$

Purple Vienna ...................... . 50 . 50 


\section{Michell's Choice Lettuce Seed}

Grown from carefully selected heads and strains of seed. Especially for market gardeners' trade.

VARIETIES. marked * are especially suited to market gardeners' needs.

SPECIAL NOTE-Seeds offered on this page mailed postpaid at prices named. SHOP BY MAIL.

1 oz. Seed

prod ue es

about 2,500

plants.
All Heart. Fine for spring and summer, large loose heads with a solid heart. 20c. 0z., 1/4 lb. 60c., lb. \$I.75

* Big Boston (Selected Stock). Qne of the best varieties for forcing under glass, but is equally satisfactory planted outdoors, large solid heads. Oz. I2c., 35c. I/4 Ib., 1b. \$I.25.

Black Seeded Simpson. Ideal for midsummer; large, loose leaved curly heads. Ioc. oz., $1 / 4$ lb. 30c., $\$$ I.oo per lb.

Boston Market. Splendid forcer and for spring use outdoors, small solid heads. Oz. Ioc., 30c. I/4 lb., lb. \$1.00.

Cabbage Head Giant. Monster head lettuce for summer. $20 \mathrm{c}$. oz., 1/4 lb. 6oc., \$2.25 lb.

Early Cabbage, or White Butter. Very large heads, excellent for early spring or summer use. IOc. Oz., I/4 lb. 30c., $\$ \mathrm{I} .00 \mathrm{lb}$.

* May King. If sown under sash and cropped outdoors this has proven to be the earliest lettuce in existence. I5c. oz., $1 / 4 \mathrm{lb}$. $40 \mathrm{c}$, \$I.25 Ib.

*Michell's All=Right. For the first crop in hotbeds or outdoors in spring. A very large solid head with a rich green color. It requires less of these to fill a barrel than any other lettuce we know of, fine also for an autumn crop. Oz. 20c., 6oc. $1 / 4 \mathrm{lb}$, lb. $\$ 2.00$

* Michell's Number One. Ideal for autumn use, a sure header, immensely large. Oz. I5c., 40c. I/4 lb., lb. \$I.50.

* Michell's Summer Queen. There are but few varieties of lettuce that can be depended upon to mature to perfection during the excessively hot months. When we state that "Summer Queen" is the most reliable variety for this purpose we claim an absolute fact. It constitutes the best midsummer crop for the market gardener. The heads are enormous, very solid, of a light green color and are much superior to any other variety that can be cropped at that time. It will stay longer without going to seed than any others, thus being all profit and no loss to the grower. Oz. 25c., 75c. per $\mathrm{t} / 4$ lb., Ib. $\$ 2.50$.

Sensation. Large solid heads for summer or sowing under sash in spring. I5c. oz., I/4 lb. $35 \mathrm{c} ., \$ 1.25 \mathrm{lb}$

*Spotted Dutch Butter (Private Strain). A very early lettuce, may also be used as a second crop; its appearance, if nothing else, sells it. The outer leaves are slightly tinged with brown on the edges, towards the centre they are light green, with a golden yellow heart. Oz. I5c., 50c. I/4 1b., 1b. \$1.75.

Spotted Dutch Butter (Regular Strain). Oz. IOc., 35 c. I/4 Ib., lb. \$1.25.

Tennisball (Black Secded). One of the earliest for under glass or outcloors, makes small, compact heads. Ioc. Oz., I/4 lb. 30c. $\$ \mathrm{I} .00 \mathrm{lb}$.

Unrivaled. Similar to Big Boston. I5c. oz., I/4 lb., 35c., \$1.25 per lb.

\section{Lettuce Summet Queen}

Dayy's Improved Big Boston. This strain had its origin in France, near Paris, where it is probably grown more than any other sort. For a number of years a certain market gardener in the ricinity of New York had a monopoly on this variety, but after careful inquiry we have located the source of supply and are pleased to offer this most excellent lettuce in our catalogue for the first time. It is superior in every way to the usual strain of the Big Boston variety. The heads are larger almost twice the size, more solid and of a better flavor. The grower would only allot us a very limited amount, so the stock is quite scarce for this season. We advise early ordering. 30c. per $0 z$, per $1 / 4 \mathrm{lb}$. $\$ 1.00, \$ 3.50$ per $\mathrm{lb}$

Emperor Forcing. The finest variety for greenhouse or hotbeds. IOc. Oz., I/4 lb. $35 \mathrm{c}$., $\$ 1.25 \mathrm{lb}$.

Hanson Improved. Crisp, curly heads, very solid, for summer use only. IOc. Oz., I/4 lb. 30c., \$I.Io lb.

* Mammoth Salamander. Splendid for midsummer, will resist heat and drought, always making a large solid head. Oz. I 5c., 35c. $1 / 4$ lb., lb. \$1.25.
Wonderful, or New York. Splendid midsummer and late autumn sort, large curled leaf; heads. I5c. oz., I/4 lb. $40 \mathrm{c}$., $\$ \mathrm{I} .25 \mathrm{lb}$.

\section{LOOSE OR CURLED LEAVED VARIETIES}

Early Curled Simpson. Very much like the Black Seeded Simpson, but is much earlier. IOc. Oz., $1 / 4 \mathrm{lb} .30 \mathrm{c}$., $\$ \mathrm{I} .00 \mathrm{lb}$.

Grand Rapids (Special Strain). A variety used by many for forcing under glass, it is loose-leaved; very fine and brittle Oz. IOc., 30c. $1 / 4$ 1b., lb. \$1.Io.

Silesian. Ideal for a cutting lettuce, very early and lasts a long while, does not head. IOc. Oz., I/4 lb. 30c., \$I.00 lb.

\section{COS ROMAINE OR CELERY LETTUCE}

Kingsholm Cos. Tall upright growth, fine heads, this sells readily to hotel trade, must be tied to blanch. IOc, oz., $1 / 4 \mathrm{lb}$. 30c., \$I.IO $\mathrm{lb}$

Trianon Self Folding. Similar to the Kingsholm, but does not require tying to blanch. Oz. IOc., 30c. I/4 lb., lb. \$I.IO.

\section{LETTUCE PLANTS}

Leading Heading Varieties. Per $10035 \mathrm{c}$., \$2.85 per I000 


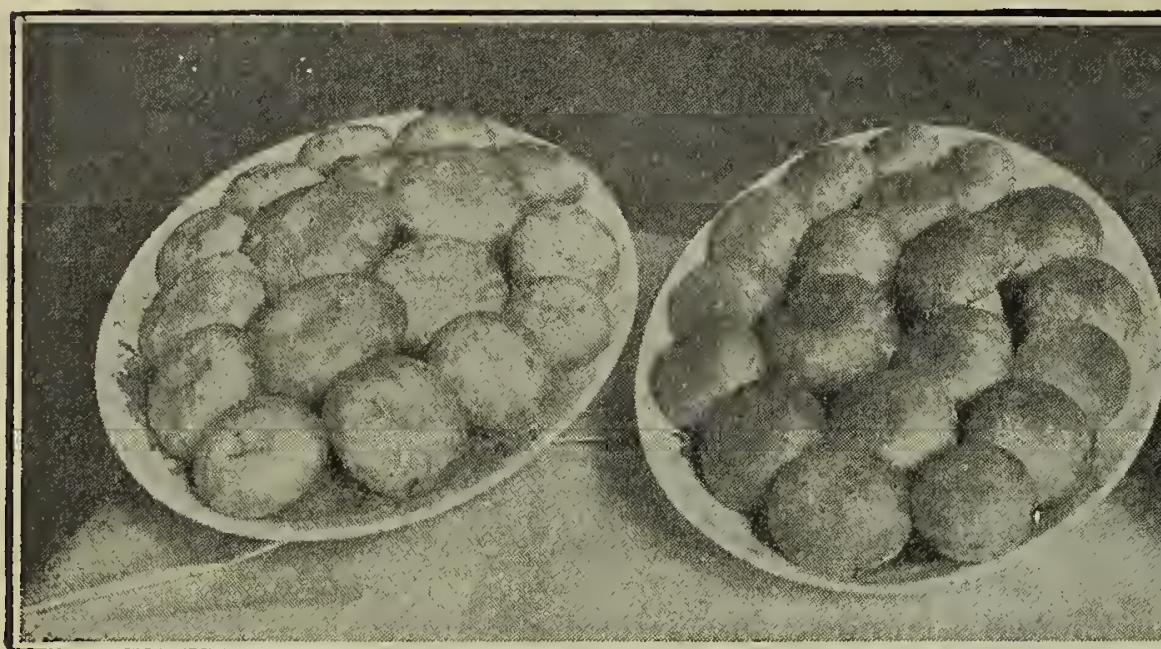

\section{BRANDYWINE PURE CULTURE SPAWN}

This type produces heavy, short-stemmed mushrooms of uniform size. The bricks are inoculated with Pure Spawn culture in the same manner as the "Lambert" strain. While this brand is comparatively new, it bids fair to become very popular in a short while; the bricks are larger than other brands. $25 \mathrm{c}$. brick (postpaid 35c.), 5 bricks \$I.I5, I2 bricks \$2.I5, \$4.00 per 25, 100 bricks $\$ 15.00$

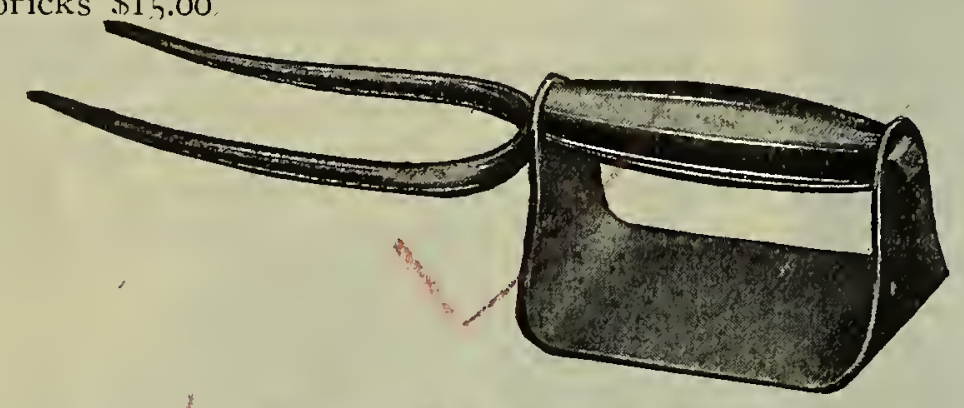

SPAWN PLANTER

An ingenious device for planting mushroom spawn. Opens the trench and closes it. 75c. each.

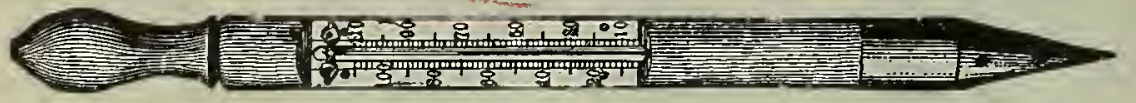

THERMOMETERS FOR MUSHROOM BEDS

\section{Iron Point}

Brass Point

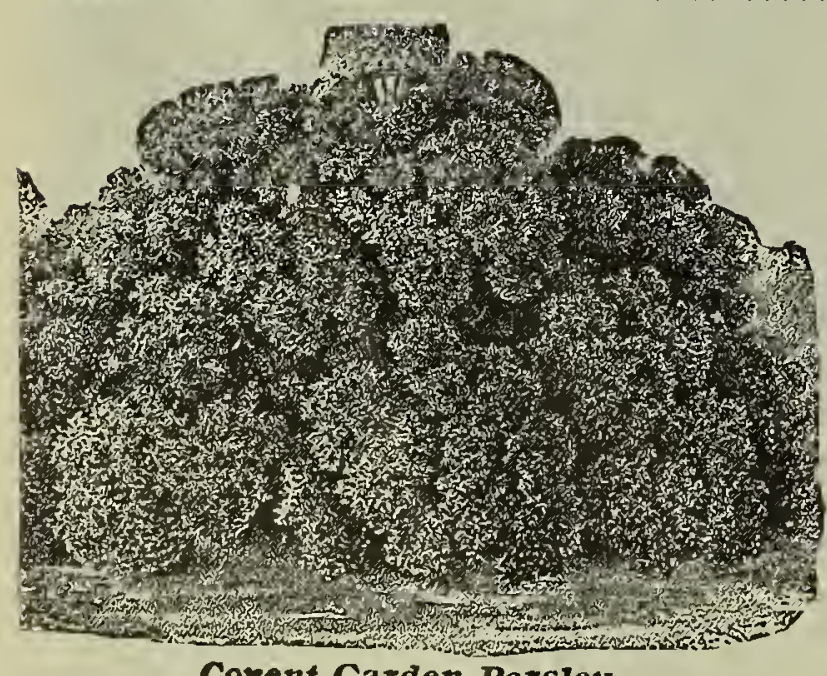

\$0.90 each

\section{PARSLEY}

*Covent Garden or Double Curled. This is the best variety for the market gardener, as it produces in$t$ e 11 s e ly curled leaves of good size of a rich green color, with 1 o $11 \mathrm{~g}$ st e m s, wh i ch makes it easy to bunch. Oz. IOC 25c. $\mathrm{T} / 4$ lb., lb. 9oc. (5 1bs. \$3.75).

*Champion Moss Curled. Densely curled, light green, long stemmed. Oz. 8c., 25c. I/4 1b, 1b. 9oc.

Hamburg or Rooted. I favorite among the foreign people who cook the root (crop very short). Oz. IOc., 25c. $1 / 4 \mathrm{lb}$., lb. $90 \mathrm{c}$.

*Summer Green. This variety retains its color better than any other in hot weather, also remains without going to seed for a long while. The leaf is very light green; not very curly. Oz. IOc., 25c. $1 / 4$ lb., 1b. 9oc.

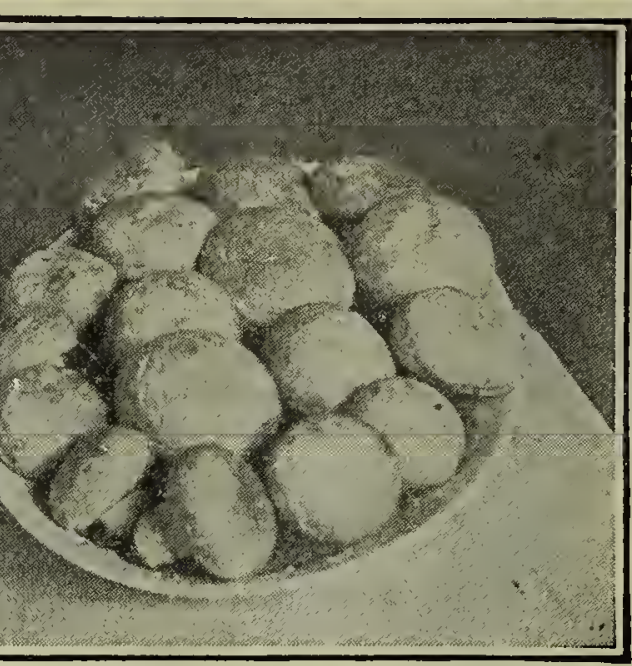

\section{MUSHROOM SPAWN}

We make a specialty of this very important article, handling all the tried and proven strains. From July to March we receive frequent shipments of new spawn, thus insuring our customers of getting first class quality. Descriptive pa m phlet on Mushroom Culture "Free," ask for a copy.

\section{LAMBERT'S PURE CULTURE SPAWN}

This type produces larger mushrooms than the English, coming into bearing somewhat earlier, and continuing for a longer time. Standard No. 8 Cream White. For use from April to October. Standard No. 9 Pure White. For use from October to April. Prices of Pure Culture Spawn. Standard Bricks.

Per brick, about $\mathrm{I} / 2 \mathrm{z}$ lbs. $\$ 0.20 \mid 25$ Bricks .......... $\$ 3.25$ Per brick, postpaid...... . .30 50 " $\ldots \ldots \ldots \ldots \ldots 6.60$ 5 bricks ............. .90 100 " I2 " $\ldots \ldots \ldots \ldots \ldots \ldots \ldots \ldots \ldots \ldots \ldots$ I.80 1000 " Direct No. 8 Cream White. For use from April to October.

Direct No. 9 Pure White Type. For use from October to April. Prices of Pure Culture Spawn. Direct Bricks.

Per brick ............ \$0.25 25 Bricks ........ \$4.00

Per brick, postpaid ..... . .35 50 " $\ldots \ldots \ldots \ldots .7 .50$

5
bricks. $\ldots \ldots \ldots \ldots \ldots$

\section{MICHELL'S ENGLISH MUSHROOM SPAWN}

I5c. per brick (25c. postpaid); per doz., \$I.40; 25 lbs., \$I.60; $\$ 6.00$ per I00 lbs.; per IO00 $1 \mathrm{bs} ., \$ 55.00$.

\section{OKRA OR GUMBO}

*Perkin's Long Pod. A very dwarf prolific variety, the pods are long and dark green.
Oz. 7 c., I 5 c. $1 / 4$ lb., $1 \mathrm{~b} .45 \mathrm{c}$.

Dwarf Green. Exceedingly productive, dark green pods, this variety grows somewhat taller than the Perkin's. Oz. 7c., I5c. I/4 lb., 1b. $40 \mathrm{c}$.

White Velvet, or Creole. Pods very smooth and white. $\mathrm{Oz}$ 7c., I5c. I/4 lb., 1b. 4 Oc.

\section{PARSNIP}

*Sugar, or Hollow Crown. Very thick, broad shouldered variety, pure white roots of large size. Oz. 8c., I5c. I// lb., 1b. 50c. (5 lbs. \$2.25).

Guernsey or Student. Slightly shorter with a broader top or shoulder than the above. Oz. 8c., I5c. $1 / 4$ lb., 1b. $50 c$.

\section{MINT}

20c. per pkt. (3 pkts. 50c.).

Mint Plants. 75c. doz., $\$ 5.00$ per Ioo.

\section{MUSTARD}

White or Yellow. 5c. oz., I/4

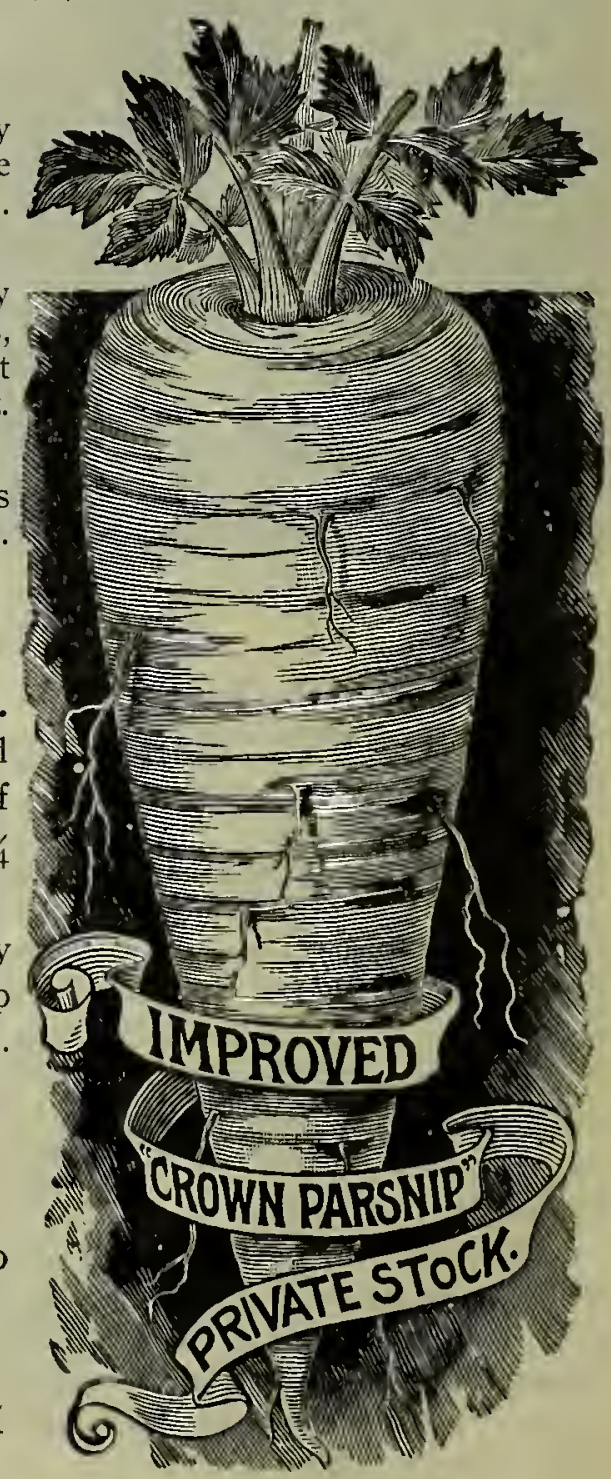




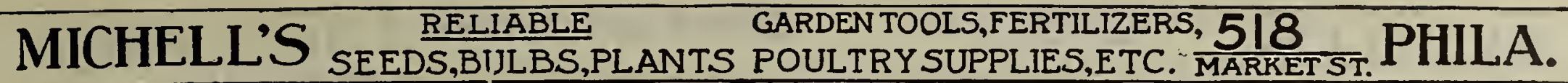

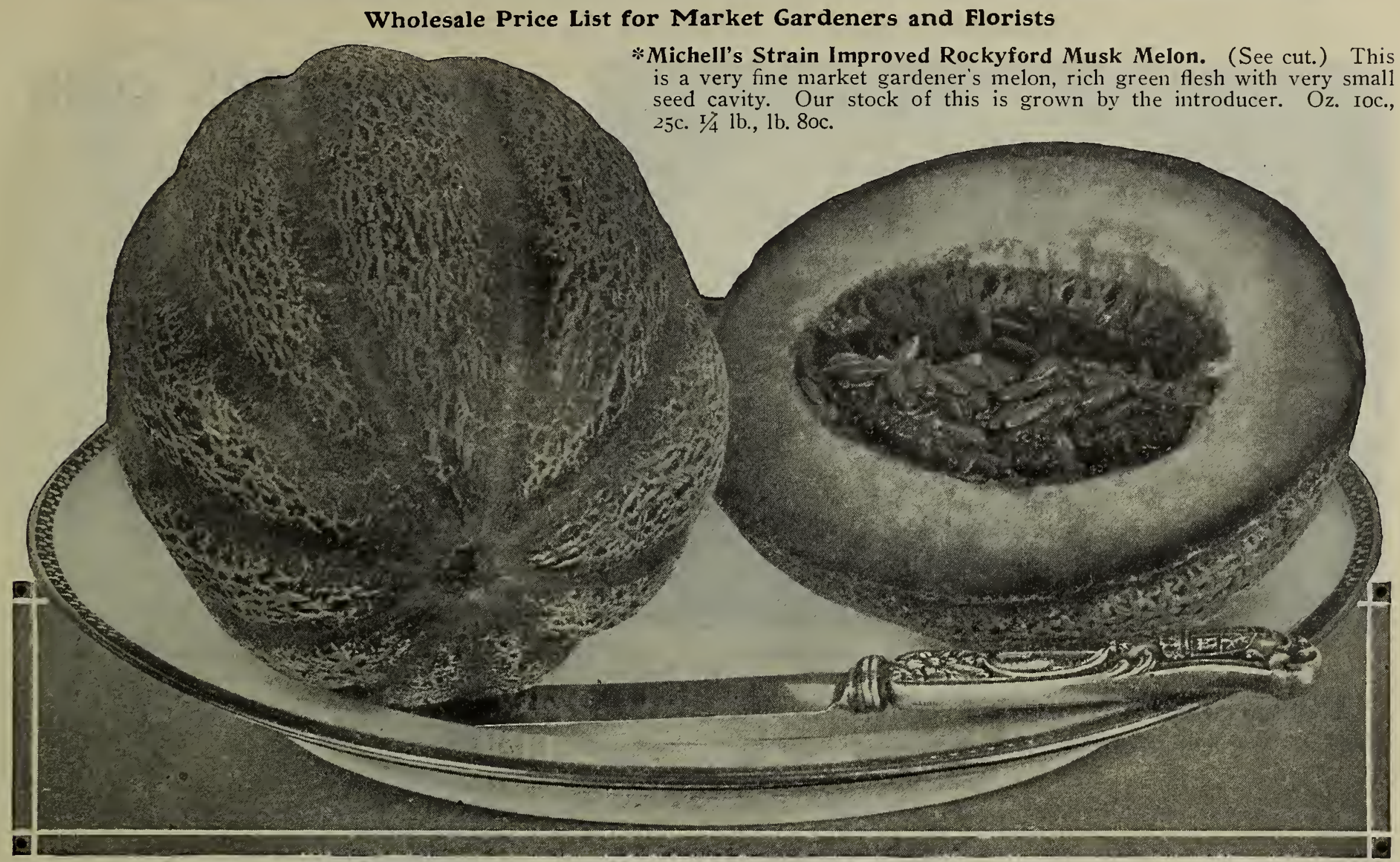

\section{MUSK MELON Or CANTELOUPE}

*Fordhook. An improved Emerald Gem, salmon-orange flesh large flat fruit. Oz. IOc., 30c. $1 / 4$ lb., lb. \$I.0O.

* Burrel Gem. In shape similar to Rockyford, but with rich orange meat, an excellent shipper, an ideal melon for the market gardener. Oz. IOc., 30c. 1/4 lb., lb. \$1.00.

Michell's Delicious. Very large with silver grey smooth skin, flesh deep salmon; fine for hotel trade. (Pkt. IOc.) 40c. oz. $1 / 4$ lb. \$1.00, \$3.75 per $1 \mathrm{~b}$.

*Emerald Gem. A leading variety with rich salmon flesh, very sweet and prolific. IOc. Oz., $1 / 4 \mathrm{lb}$. 30c., $\$ 1.00 \mathrm{lb}$

Extra Early Hackensack. "Of Turk's Cap form, being very early, netted and deeply ribbed, flesh light green. Oz. 7c., $20 \mathrm{c}$ $\mathrm{T} / 4 \mathrm{lb} ., 1 \mathrm{~b} .7 \mathrm{oc}$

*Jenny Lind. Small but very early, planted for the first picking, green flesh. Oz. 7c., 25c. 1/4 lb., lb. $85 \mathrm{c}$.

Golden Jenny (Netted Gem). Very prolific, resembling someWhat the Fordhook variety. Oz. 7c., 20c. $1 / 4$ lb., 1b. 7oc.

Defender. Salmon flesh. 8c. oz., $1 / 4$ lb. $25 \mathrm{c} ., 85 \mathrm{c}$. lb.

Eden Gem. An improved Jenny Lind. 8c. oz., I/4 1b. 25 c., 85 c. 1b. Hoodoo. Orange flesh, very fine. $8 \mathrm{c}$. oz., $1 / 4 \mathrm{lb} .25 \mathrm{c} ., 85 \mathrm{c}$. lb.

Golden West. The finest orange-fleshed melon grown, -very large. 20c. oz., $1 / 4$ lb., 65 c., $\$ 2.50$ per $1 \mathrm{~b}$.

\section{WATER MELON}

*Tom Watson. A very dark green fruit, frequently 2 feet long and $\mathrm{I} 2$ inches in diameter. The very dark green rind is a contrast to the bright scarlet flesh which, by the way, is of splendid texture and flavor. Nothing can touch it in the melon line for shipping qualities, the rind being tough it will resist plenty of abuse. IOc. oz., $1 / 4$ lb. 25c., $85 \mathrm{c}$. per $1 \mathrm{~b}$.

*Halbert Honey. An ideal melon. The long fruits with blunt ends are very large and weigh often $50 \mathrm{lbs}$.; the rind is very thin, dark green while the flesh is a rich crimson. $7 \mathrm{c}$. per oz., $\mathrm{I} / 4 \mathrm{lb}$. 20c., 70c. per $1 \mathrm{~b}$.

* Kleckley Sweets. Not a shipping variety, as the rind sets too close to the ripe fluffy, rich red meat. The melons average about 20 inches long and ripen quite early. $7 \mathrm{c}$. per oz., $1 / 4 \mathrm{lb}$. 20c., 70c. per $1 \mathrm{~b}$.

\section{WATER MELON-(Continued)}

Black Boulder. A mammoth melon with very dark green, almost black rind. The skin is a delicious mass of rich, red, crisp meat; a great producer. 7c. per oz., $1 / 4$ lb. 20c., 65c. per lb.

*Dixie. One of the old-time favorites, roundish-long in shape. The skin is dark green, mottled light; the flesh is very sweet and ripens close to the rind. $7 \mathrm{c}$. per oz., $1 / 4 \mathrm{lb}$. 20c., 6oc. per $1 \mathrm{~b}$.

Cuban Queen. Very similar in description to Dixie, except the melon is of manmoth size; it is very solid and good for shipping. $7 \mathrm{c}$. per oz. I/4 lb. 20c., 6oc. lb.

* Mountain Sweet. Early and very large, oblong shape, rind dark green; flesh red, solid and sweet. $7 \mathrm{c}$. per oz., $\mathrm{T} / 4 \mathrm{lb}$. $15 \mathrm{c}$., 50c. per lb.

Sweet Hearr. Handsome oval shape, very large, green and mottled, solid, meaty and sweet. $7 \mathrm{c}$. per oz., $1 / 4 \mathrm{lb}$. 20c., $60 \mathrm{c}$. per $1 b$.

Florida Favorite. Large oblong fruit with striped skin: flesh is brilliant pink, of most delicious flavor. $7 \mathrm{c}$. per oz., 1/4 1b. 20c., 6oc. per lb.

Dark Icing. Large in size, very sweet and luscious. 7c. per oz., $\mathrm{I} / \mathrm{lb}$ lb, 20c.,6oc per lb.

Light Icing. Flesh bright red, outside color very light green, round in shape. $7 \mathrm{c}$. per oz., $1 / 4$ lb. 20c., 6oc. per $1 \mathrm{~b}$.

\section{PRESERVING CITRON OR MELON}

Red Seeded. 7c. per oz., I/4 lb. 20c., 6oc. per $1 \mathrm{~b}$.

\section{POTATOES (Northern Grown)}

We can also supply all other sorts.

Beauty of Hebron

Early Rose (Maine Grown)

Michell's "Beats them All" (Ex. Early).

State of Maine

Irish Cobbler

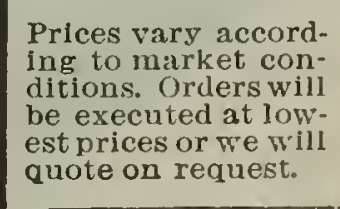

SWEET POTATO PLANTS (Keady in May)

Yellow and Red Nansemond. 30c. per I00, per $1000 \$ 2.50$

Special price in large lots. 


\section{MICHELL'S $\frac{\text { RELIABLE }}{\text { SEES,BULBS,PLANTS PARDENTOOLS,FERTILIZERS, } 518}$ POULTRYPLIES,ETC. MARKET ST. PHILA.}

Wholesale Price List for Florists and Market Gardeners

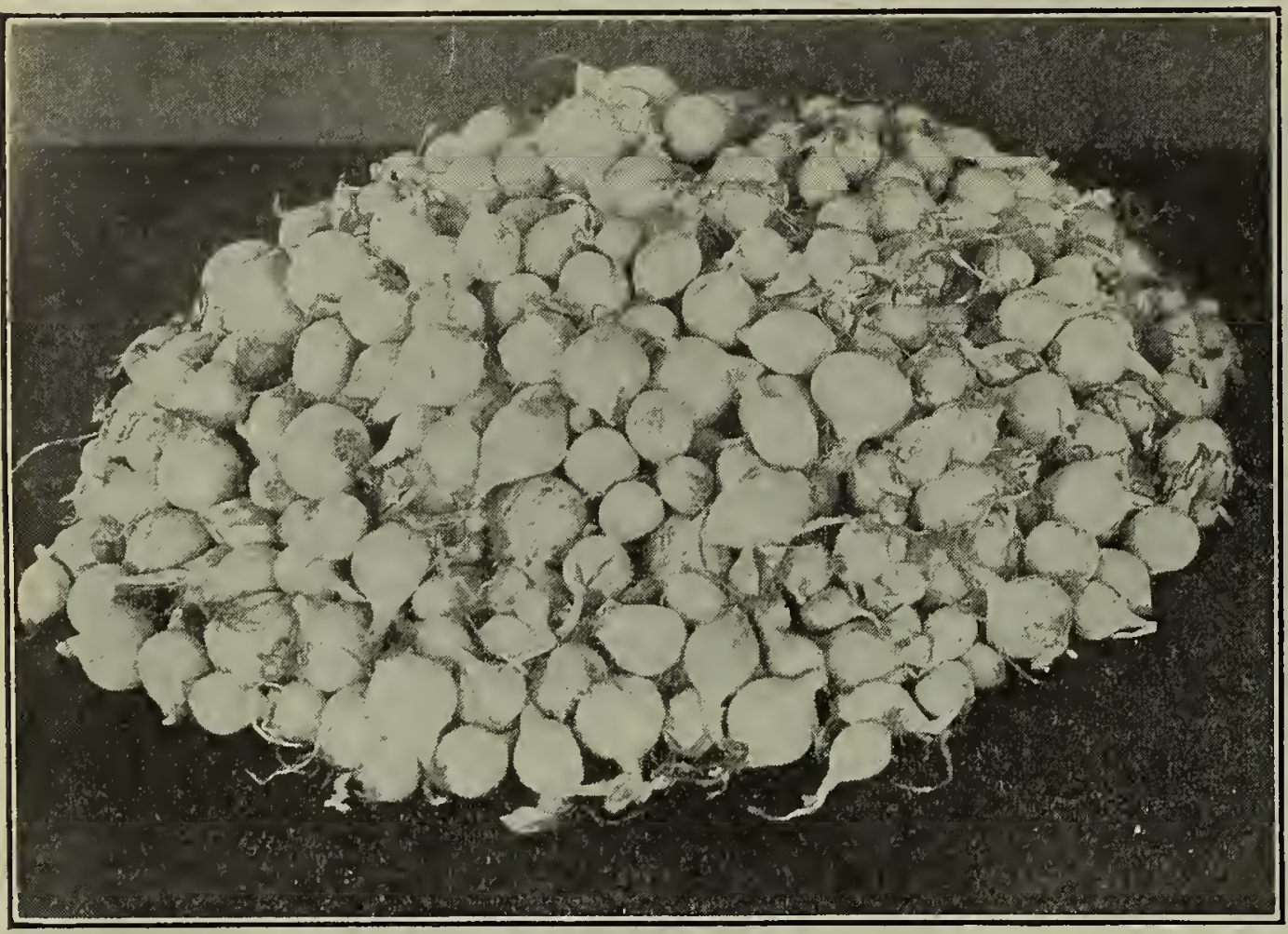

Choice Onion Sets alwaya find a ready markei

HOME GROWN ONION SETS, Etc.

Shipped on Local Orders about March 10th, unless otherwise requested.

Yellow

White

Red

White Multiplier

Potato Onion

Shallots

Tree or Top. (Can be supplied in Sept. and Oct.)

Garlic Sets. Per 1b. 25c., Io lbs. for $\$ 2.00$.

\begin{tabular}{|c|c|c|}
\hline \multicolumn{2}{|c|}{ Ouart ${ }^{4}$} & \\
\hline & & \\
\hline 0.1 & $\$ 0.50$ & $\begin{array}{c}\text { Prices vary } \\
\text { constantly. }\end{array}$ \\
\hline .15 & .50 & Orders will \\
\hline .20 & .70 & be executed \\
\hline .20 & .70 & quotat i on s \\
\hline & .90 & $\begin{array}{l}\text { or spectal } \\
\text { prices will }\end{array}$ \\
\hline & & $\begin{array}{l}\text { bequoted on } \\
\text { request. }\end{array}$ \\
\hline
\end{tabular}

PRICES ON ONION SETS ARE SUBJECT TO CHANGE

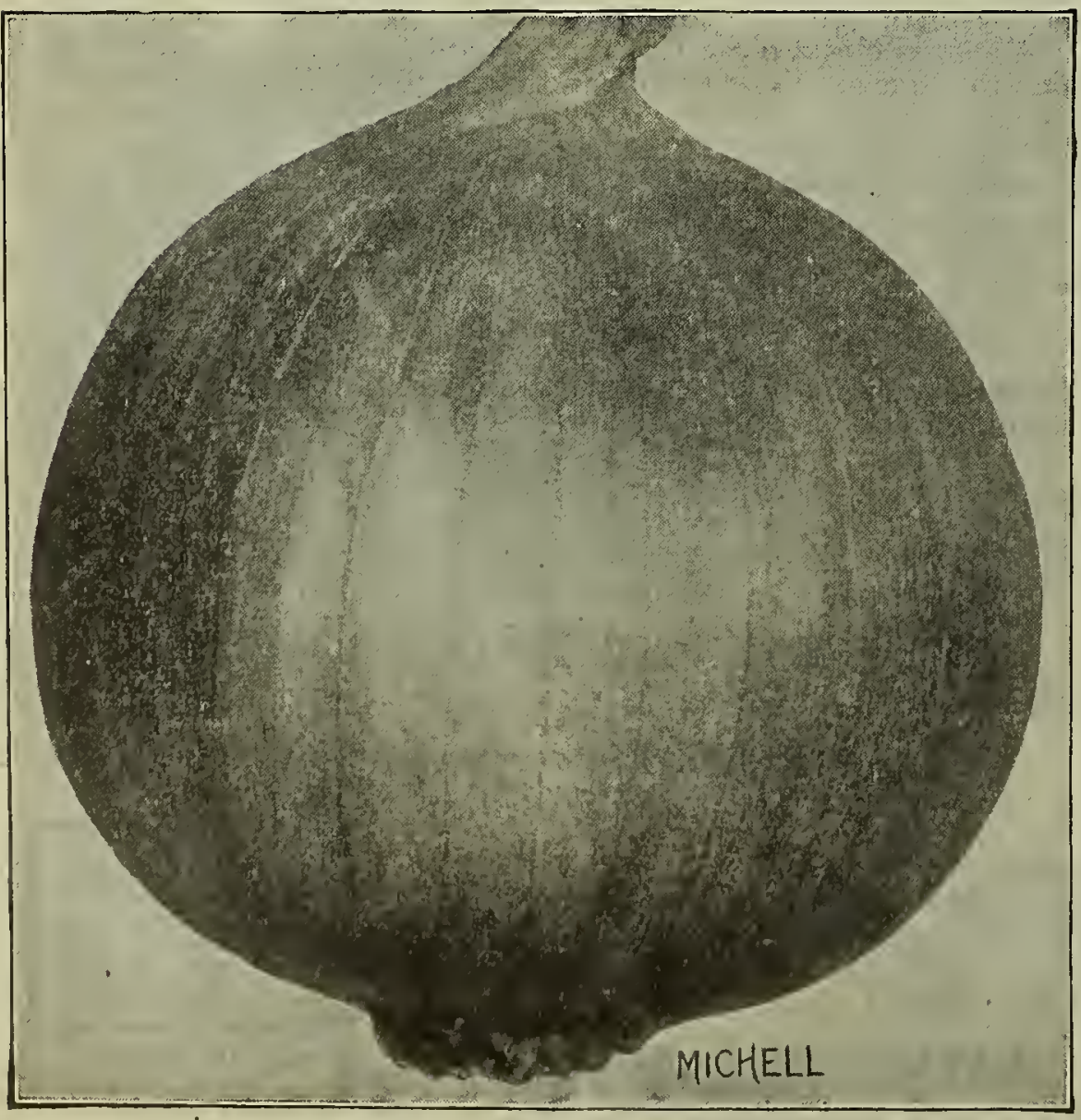

Prizetaker Onion

\section{CHOICE ONION SEED}

Ailsa Craig. The largest of all onions often weighing three lbs. and over, each. In England it is the foremost variety and will be seen there on exhibition during all vegetable shows. It is globe-shaped, slightly pointed at the top and base; the color is a beautiful straw yellow. To obtain best results sow seed in the hotbed and later transplant where it is to grow; in planting place 4 to 6 inches apart and thus procure gigantic specimens. $25 \mathrm{c}$. oz., I $/ 4$ lb. 75 c., 1b. $\$ 2.50$.

*Prizetaker. This mammoth yellow variety if sown thinly produces full size onions in one season from seed, rivaling with the Bermuda varieties for size and flavor, often weighing 3 lbs. and more. Oz. I5c., 50c. per $1 / 4$ lb., \$I.75 per lb., 5 lbs. \$8.oo.

*Danver's Yellow Globe. This almost round in shape onion is extensively sown by the private and market gardener on account of its good keeping qualities. It is a dark straw color and always produces a good crop, growing to large size. Oz. I2c. 40c. $1 / 4$ lb., lb. \$I.40 (5 lbs. \$6.50)

Southport Yellow Globe. Similar to the Danvers. except larger in size, more like the Prizetaker. This is probably one of the most uniform growing varieties, every bulb being almost perfectly round and of the same size; light colored skin. Oz. I2c., 40c. 1/4 lb., lb. \$I.40.

* Yellow Strasburg (or Dutch). A dark straw color skinned sort, aln.ost flat in shape but a large onion. Its fine keeping qualities is what recommends itself to the home as well as the market gardener. For a yellow sort it is rather mildly flavored; for growing sets more of this variety is sold than any other; one of the best winter keepers. Oz. IOc., $35 \mathrm{c}$. $1 / 41 \mathrm{~b}$., 1b. \$I.25 ( 5 lbs. \$5.75).

Large Red Wethersfield. A flat large growing variety. This class are excellent winter keepers, being flavored much like the yellow sorts; full size onions can be grown from the seed in one season. Oz. I 5c., 40c. 1/4 lb., lb. \$I.25.

*White or Silver Skin. The standard white onion for market or home use, it is of very mild flavor, semi-globe shaped and is very uniform in growth and size. 20c. per oz., $1 / 4 \mathrm{lb}$. 6oc., $\$ 2.25$ per lb. ( 5 lbs. \$10.50).

* Southport White Globe. A beautiful type of an almost round onion, growing to enormous size. 20c. oz.. $\mathrm{x} / \mathrm{4} \mathrm{lb}$. $70 \mathrm{c}$., $\$ 2.50 \mathrm{lb}$.

Southport Red Globe. Form and style of this are the same as of Southport Yellow Globe. Oz. I2c., 40c. 1/4 1b., 1b. \$1.50.

White Barletta. Extra early small round variety used principally for pickling. Oz. I5c. 50c. $1 / 4$ lb., 1b. $\$$ I. 75 .

Bermuda White. An early variety growing an immense globeshaped bulb, producing (if when transplanted about 4 inches apart) gigantic onions. Oz. 20c., 60c. $1 / 4$ 1b., 1b. $\$ 2.35$

Bermuda Red. Similar in every way except color to the aforegoing variety. Oz. 20c., 6oc. $1 / 4$ 1b., 1b. $\$ 2.35$.

\section{PUMPKIN}

* Large Tours or Mammoth. The liggest pumpkin in cultivation, producing fruits that often weigh $200 \mathrm{lbs}$. When fully ripened it is of a golden orange. Oz. 8c., $\mathrm{T} / 4 \mathrm{lb}$. $25 \mathrm{c}$. 8oc. $1 \mathrm{~b}$.

Tennessee Sweet Potato. An oblong-shaped, medium-sized fruit with a very light buff yellow skin, for pies it is delicious. 7c. Oz., $1 / 4$ lb. 20 c., 7oc. $1 \mathrm{~b}$.

* Large Cheese. A very large, flat, ribbed fruit, of a beautiful buff yellow color. 7c. Oz., I/4 1b. 20c., 6oc. lb.

Japanese Pie. A crook-necked variety, deep green striped clarker, which turns to a rich golden yellow. Per oz. 7 c., 2oc. I/4 lb., 1b. $70 \mathrm{c}$

Winter Luxury. Of very round and symmetrical shape. The skin is a russet yellow, while the flesh golden orange when ripe. Oz. IOc., 20c. $1 / 4$ lb., 1b. 70c.

Cashaw or Golden Crook Neck. A very meaty sort; suitable for pie or stock feeding purposes; flesh golden yellow and very tender. Per 0z. 7c., 20c. I/4 1b., 1b. 65c.

Connecticut or Common Field. Flesh coarse and suitable only for stock feeding; color light yellow. 4c. per oz., $\pi / 4 \mathrm{lb}$. IOc., 3oc. per $1 \mathrm{~b} ., 5$ lbs. $\$$ I.2O. 


\section{Michell's Choice Garden Peas grown Especially tor

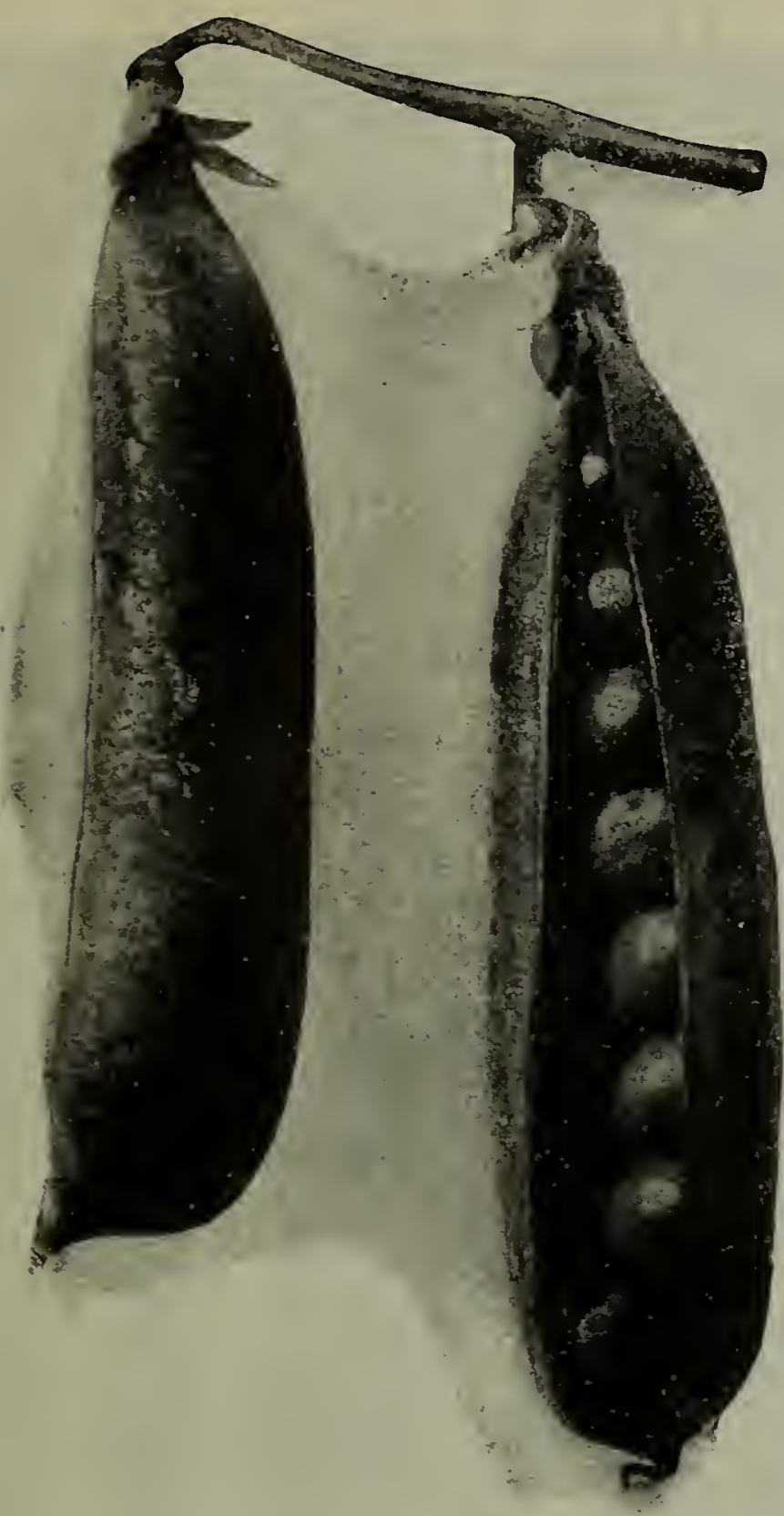

NOTE. If peas are desired by mail please add I5c. per qt. for postage, regardless of zone or distance.

VARIETIES marked $(*)$ are especially recommended for market gardeners use.

\section{EXTRA EARLY VARIETIES}

Alaska. Smooth seeded, very early, height $2 \frac{1}{2} 2$ feet. 25 c. qt., 4 qts. 90c., $\$$ I.60 peck, bush. \$6.25.

Ameer. A very large podded early pea, following the Alaska. It is a heary cropper. 30c. qt., 4 qts. \$1.00, \$1.75 peck, bush. \$7.00.

American Wonder. The earliest wrinkled dwarf variety, exceedingly sweet; height, Io to I 2 inches. 30c. qt., 4 qts. \$I.IO, \$I.85 peck, bush. \$7.25.

Bountiful. The pods are very large and well filled; it is very early, a good cropper. 30c. qt., 4 qts. $\$ 1.00, \$ 1.85$ peck, bush. $\$ 7.25$.

Dandy Extra Early. These are a selection of the Eureka; smooth seeded, very prolific. 30c. qt., 4 qts. \$I.IO, \$I.75 peck, bush. \$7.00.

Early June. A green-seeded, smooth pea, desirable for first planting, an improvement on Alaska; height, $2 \frac{1}{2}$ feet. 25 c. qt., 4 qts. 9oc., $\$$ I.6o peck, bush. $\$ 6.25$.

Early Morn. One of the earliest of wrinkled peas, earlier and better it is claimed than Gradus or Thos. Laxton. The pods are large and well filled, matures in 60 days and is very prolific. 30c. qt., 4 qts. \$I.Io, \$2.00 peck, bush. $\$ 8.00$.

Eureka. A great producer and extremely early, smooth-seeded; height, 24 inches. 25 c. qt., 4 qts. $90 c ., \$ 1.60$ peck, bush. $\$ 6.25$.

Gradus, or Prosperity. Exceedingly luscious, wrinkled and a producer of gigantic pods and peas; height, 36 inches. 40c. qt., 4 qts. \$1.25, \$2.25 peck, bush. \$9.00.

Harvester. A great producer under trying conditions. I 8 inches high, rery sweet, wrinkled. Qt. 45 c., \$I.75 for 4 qts., pk. \$3.25, \$1 2.00 per bushel.

Laxtonian. An extra early marrowfat type, growing 12 inches high, very prolific. 30c. qt., 4 qts. \$I.IO, \$I.90 pk., bu. \$7.50.

Little Marvel. Dwarf wrinkled variety, very sweet and prolific, I5 to I 8 inches high. 35 c. qt., 4 qts. \$I. I $0, \$ 2.00$ pk., bu. \$8.00.

McLean's Little Gem (or Premium Gem). Similar to American Wonder, but a heavier producer, wrinkled seed; height, I8 inches. 30c. qt., 4 qts. $95 \mathrm{c}$., $\$ 1.75$ peck, bush. \$7.00.

Michell's Special Extra Early. Extremely early, lusciously sweet and very tender; a grand yielder; height, 24 inches. 40c. qt., 4 qts. \$1.40, \$2.25 peck, bush. $\$ 9.00$.

Nott's Excelsior. One of the leading varieties for the market garden. Height, I5 inches. 30c. qt., 4 qts. \$1.00, \$1.85 peck, bush. \$7.25.

Saxonia. One of the earliest peas, producing pods $3 \frac{\mathrm{T} / 2}{2}$ inches long. The rines grow about 2 feet high and are very vigorous. 30c. qt., 4 qts. \$I.00, \$I.75 peck, bush. \$7.00.

Sutton's Excelsior. It is dwarf, growing about I6 inches and makes a long, broad pod, well filled. 30c. qt., 4 qts. \$I.IO, \$2.00 peck, bush. \$7.75.

Thos. Laxton. On a par with Gradus in quality, heavy producer. 40c. qt., 4 qts. \$I.35, \$2.25 peck, bush. \$9.00.

\section{GENERAL OR LATER CROP VARIETIES}

Black Eye Marrowfat. Excellent where a large crop is desired; height, 4 feet. 20c. qt., 4 qts. 75 c., \$I.35 per peck, buish. \$5.00.

Champion of England. A rery tall, rank grower, but a wonderful yielder of delicious quality peas; seed wrinkled; height, 5 feet, 30c. qt., 4 qts. 90c., \$1.60 peck, bush. $\$ 6.25$.

Dwarf Champion. Possesses most all the good qualities of the famous Champion of England, and having the further advantage of being dwarf: a very delicious pea, which should be planted largely: height, 2 feet. 30c. qt., 4 qts., \$1.00, \$1.75 peck, bush. $\$ 6.75$.

Fillbasket. Market gardeners and those desiring a large crop should plant this variety; quality very good; height, 30 inches. 25c. qt., 4 qts. 90c., \$1.75 peck, bush. \$7.00.

Stratagem (Improied). Immense pods, containing an abundance of good, large, tender peas: seed wrinkled; height, 20 inches. 3oc. qt., 4 qts. \$I.IO, \$I.85 peck, bush. \$7.25.

\section{SUGAR OR EDIBLE POD VARIETIES}

This type produces large, well-filled pods. The latter are cooked with the peas intact. They are very tender and exceedingly sweet.

Dwarf Sugar. Gray seed; height, 2 feet. 30c. qt., 4 qts. \$I.Io, $\$ 2.00$ peck, bush. $\$ 8.00$.

Melting Sugar. White seed; height, 4 feet. 35c. qt., 4 qts. \$I.25, $\$ 2.25$ peck, bush. $\$ 9.00$.

\section{SECOND EARLY VARIETIES}

Alderman. A very large pod filled with luscious peas; plants grow 3 feet high and are very prolific. 30c. qt., 4 qts. \$I.00, \$I.75 peck, bush. \$7.00.

Bliss Abundance. Large pods containing six and even more peas of a delicious flavor. 25c. qt., 4 qts. $85 \mathrm{c}$., \$1.6o peck, bush. $\$ 6.25$.

Daisy, or Dwarf Telephone. One of the best medium early sorts, bearing heary pods in the greatest abundance. 30c. qt., 4 qts. \$I.00, \$1.75 peck, bush. $\$ 7.00$.

Heroine. A fine, wrinkled variety; height, 2 feet; a great cropper. 30c. qt., 4 qts. \$I.00, \$I.75 peck, bush. \$7.00.

Long Island Mammoth. Largely in use among market gardeners; it yields handsome, large peas. 30c. qt., 4 qts. 95c., \$I.75 peck, bush. \$6.75.

Pride of the Market. An excellent dwarf variety for early summer use: pods containing as many as nine peas. 30c. qt. 4 qts. \$1.00, \$1.75 peck, bush. \$7.00.

Potlatch. A grand variety similar to Daisy, very sweet. Q 30c., \$I.Io for 4 qts., pk. \$2.00, $\$ 8.00$ per bushel.

Quite Content. An improved Alderman, very large pods, containing often 9 to Io peas, is very prolific, yielding for a long while 5 to 6 feet high. Qt. 35 c., \$1.20 per 4 qts., pk. $\$ 2.00, \$ 8.00$ bu.

Telephone (Tall). The finest late wrinkled pea grown; exceedingly sweet; an abundant producer; height $3 \frac{1}{2}$ feet. $30 \mathrm{c}$. qt. 4 qts. \$1.00, \$1.75 per peck, bush. \$6.75.

White Marrowfat. Used for cooking with meats; height, 3 feet. 20c. qt., 4 qts. 75 c., $\$ 1.35$ per peck, bush. $\$ 5.00$. 


\section{MICHELL'S SEEDS,BULBS,PLANTS POULTRY SUPPLIES,ETC. $\frac{\text { RELIABLE }}{\text { MARET ST. }}$ PHILA.'}

Wholesale Price List for Market Gardeners and Florists

\section{PEPPER Chotco Seed, New Jerwey Grown}

*Cayenne. A long red variety, very hot and used principally for bunching with pot herbs. I5c. Oz., I/4 lb. 50c., \$1.75 lb.

Celestial. A Chinese variety bearing roundish upright pods of various colors on one bush. 20c. oz., 1/4 lb. 6oc., $\$ 2.00 \mathrm{lb}$.

* Chinese Giant. This is a real monster pepper, perfectly sweet, the fruit is green turning to bright scarlet, matures very late, a very shy seeder. One of the best for market. $35 \mathrm{c}$. oz., $1 / 4 \mathrm{lb}$. $\$ 1.25, \$ 4.50$ per $1 \mathrm{~b}$.

Ruby Giant (New). Very large; adapted for stuffing; mild flavor. 30c. oz., $1 / 4$ lb., \$I.Io, \$4.00 per lb.

Golden Dawn. A large yellow variety, shaped like the Chinese Giant, very sweet. 20c. oz., I/4 1b. 60c., \$2.00 1b.

Hot Bull Nose. This variety is identical, except flavor, with the Sweet sort bearing the same name. 20c. oz., 1/4 lb. 65c., \$2.25 lb.

Large Sweet Spanish. A variety rivaling with Chinese Giant, is, however, not as large. Color and shape very similar, also late in maturing. 20c. oz., $1 / 4 \mathrm{lb}$. 6oc., $\$ 2$ oo $1 \mathrm{~b}$.

Neapolitan. This variety is an excellent one, grows in long shape and somewhat narrow; it stands upright on the bushes. The fruit is sweet and bright red; a very early sort. 20c. oz., T/4 1b. 7oc., $\$ 2.501 \mathrm{~b}$.

New Apple Pepper. A variety of novel appearance, having the form of an apple standing upright on the plant; first green it afterwards turns a brilliant red, very mild in flavor. For prolificness nothing can surpass it, beginning very early it continues to bear until killed by frost; about 3 inches in diameter. Choice seed grown at our Evergreen Seed Gardens (limited supply). 8c. per pkt. (2 pkts. 15c.).

Red Cherry. A small upright growing sort; very hot in flavor. 20c. Oz., $1 / 4$ lb. 60c., $\$ 2.00 \mathrm{lb}$.

Ruby King. A large red variety resembling Bull Nose. 20c. oz., $1 / 4$ lb. 6oc., $\$ 2.25 \mathrm{lb}$.

Small Chili. Used principally for seasoning and making sauce; the small, narrow, red pods are very hot. 20c. oz., $1 / 4 \quad 1 b$. $60 c$., $\$ 2.00 \mathrm{lb}$.

* Large Bell or Bull Nose. The standard f epper for market; a great producer. The large fruits are green, but later turn a vivid scarlet. 20c. oz., I/4 lb. 60c., $\$ 200 \mathrm{lb}$

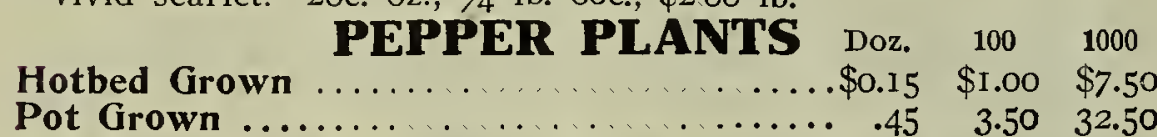

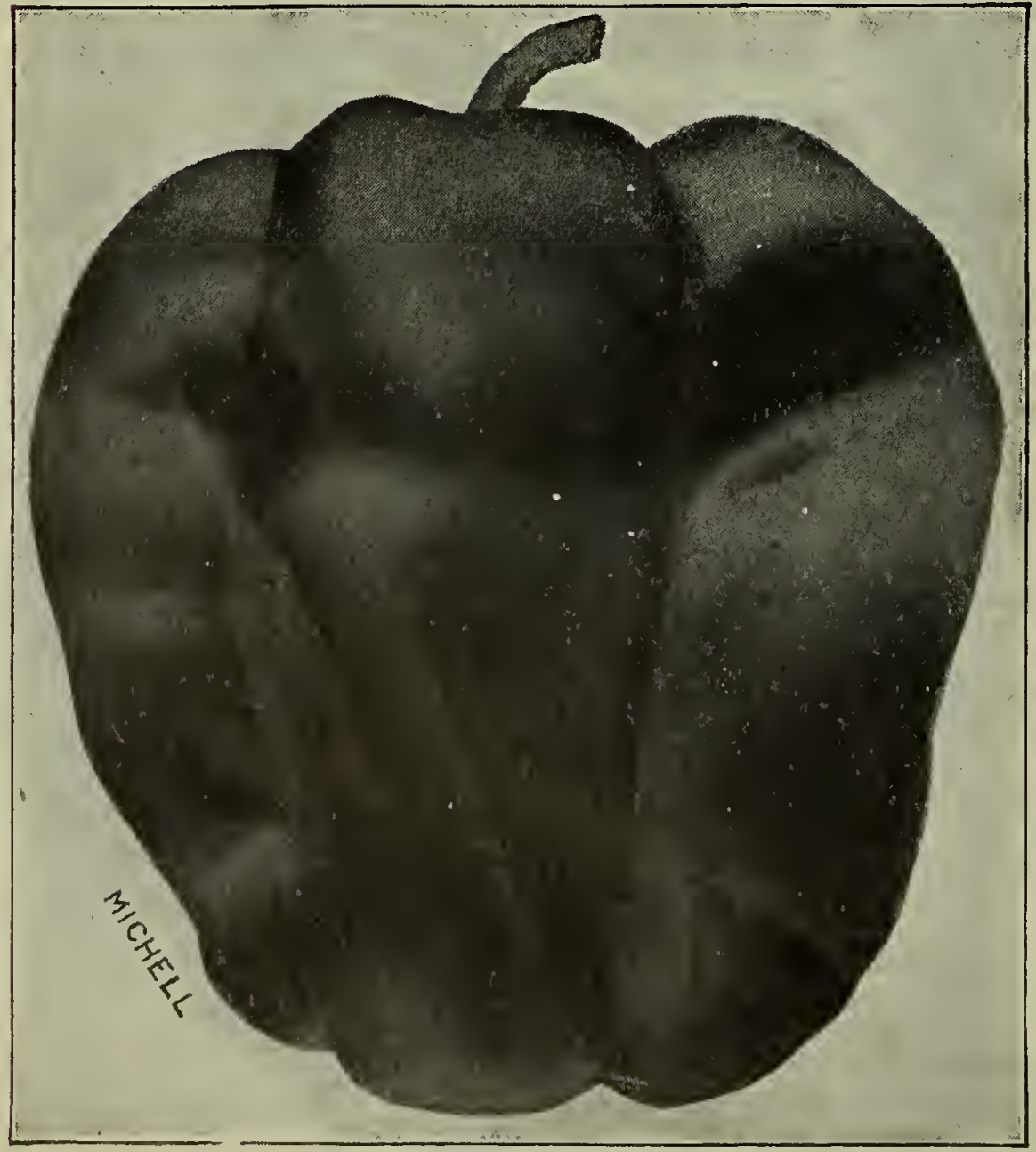

Chinese Giant Pepper

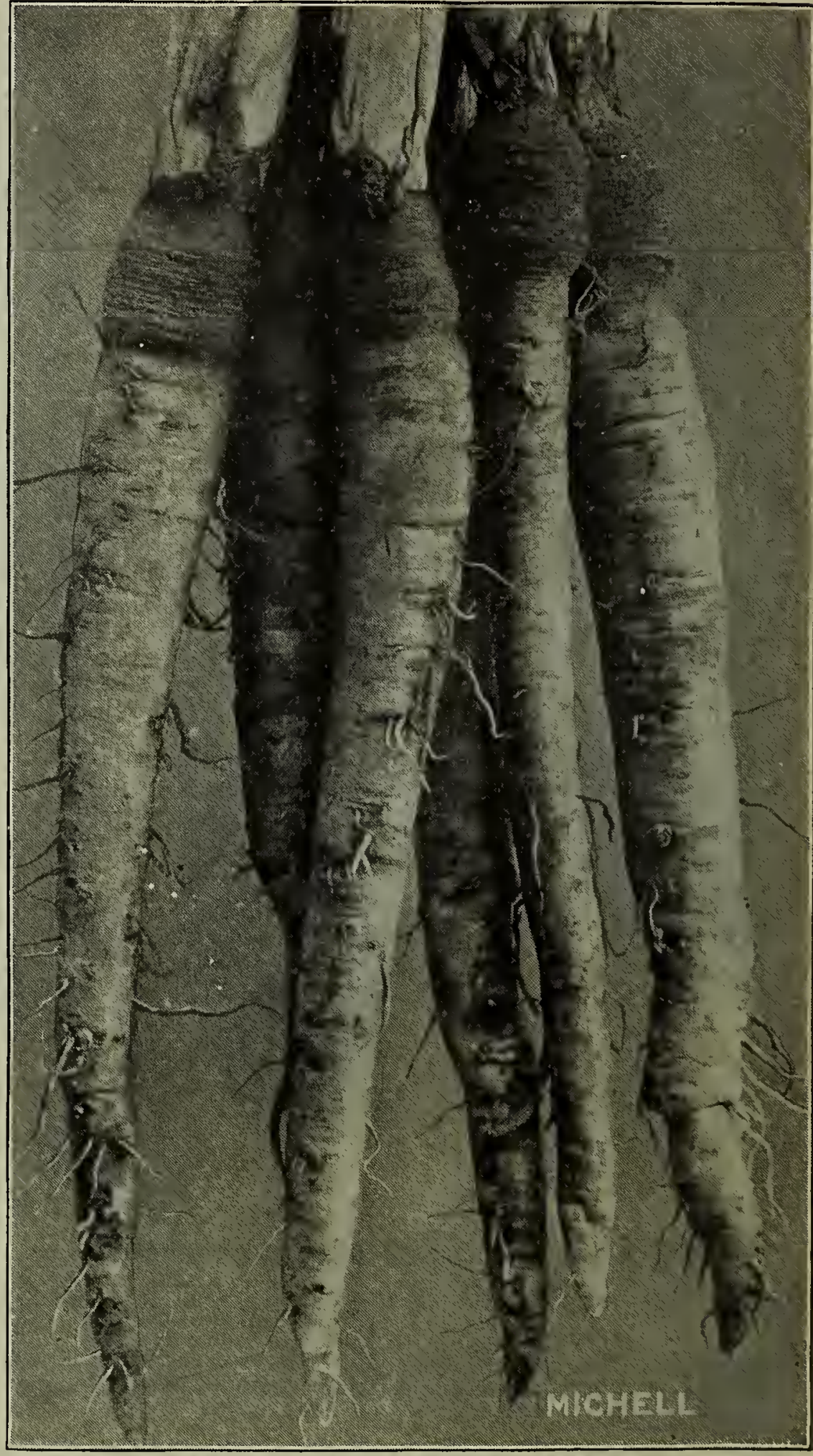

Mammoth Sandwich Island Salsify

SALSIFY (Oyster Plant)

Long White. The favorite market variety, somewhat thinner than the Sandwich Island variety. Oz. 7c., 25c. 1/4 1b., 1b. 9oc. * Mammoth Sandwich Island. This variety is of enormous size, twice as large as the ordinary French; pure white, very tender and delicious. Oz. toc., 3oc. 1/4 lb., 1b. \$r.to.

\section{A LETTER FROM GEORGIA \\ IIICKOX, GA.}

Seeds arrived O.K. Thanks for your courteous handling of my order. A prospective customer I had in mind for you: bought elsecolicre, his seeds arrized at the time yours did, so we are off in a race for supremacy. Michell's seeds ar already, at the start, far in the lead. H. J. McGEE.

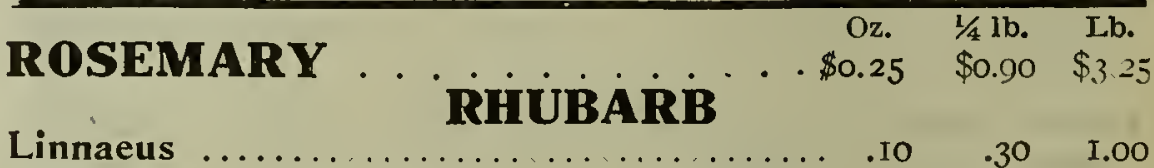

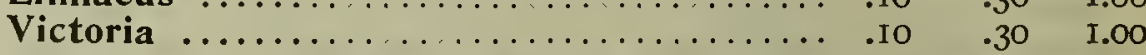
RHUBARB ROOTS Doz. $100 \quad 1000$

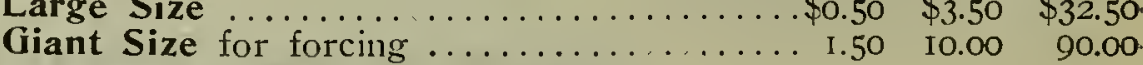
SORREL. French Broad Leaved, oz. I 2c., 25c. 1/4 1b., 1b. \$0.80. 


\section{MICHELL'S SEEDS,BULBS,PLANTS PORDENTRYOLS,FERTILIZERS, 518 RELIES,ETC. MARKET ST. PHILA.}

\section{RADISH}

\section{EARLY SORTS}

Brightest Scarlet, Half Long. Entirely distinct, being a vivid scarlet color, tipped with white. 7c. oz., I/4 lb. I5c., 5oc. lb.

* Cardinal or Scarlet Globe. The very best forcing variety, is of globular shape and brilliant cardinal red color. 7c. oz., $1 / 4 \mathrm{lb}$. 20c., 65 c. $1 \mathrm{~b}$.

* Cardinal Globe (Improved Strain). This popular radish will be welcomed readily in an improved form, the color and shape are perfect. The leading variety for the market gardener and one of which we sell in very large quantities. The seed of this is harvested from transplanted roots, which have been especially selected as to color and shape. IOc. oz., I/4 lb. 30c.,\$I.00 lb.

Crimson Giant. Turnip shaped; very large and tender. Oz. $7 c$., 20c. $1 / 4$ lb., lb. $70 \mathrm{c}$.

*Early French Breakfast. Oblong shape, rapid grower, of a beautiful scarlet color, tipped white. Oz. 7 c., 20c. I/4 lb., lb. $60 \mathrm{c}$.

*Fireball. Turnip shaped; brilliant scarlet color, crisp and tender; useful only as a forcing variety or for early spring sowing. $7 \mathrm{c}$. oz., $1 / 4$ lb. 20c., 6oc. $1 \mathrm{~b}$.

*Icicle. A magnificent white variety of fine taste, grows $3 \frac{T}{2}$ to 4 in. long in 22 days. Also suitable for summer. Oz. 7 c., 20c. $\mathrm{I} / 4$ lb., lb. $60 \mathrm{c}$.

*Long Scarlet Short Top or Salmon. The standard variety: long bright scarlet with small short top. Oz. 7 c., I5c. $1 / 4 \mathrm{lb}$., 1b. $50 \mathrm{c}$.

*Round Red Forcing or Button. Very quick in maturing, very short top. 7c. 0z., I/4 lb. 20c., 6oc. lb.

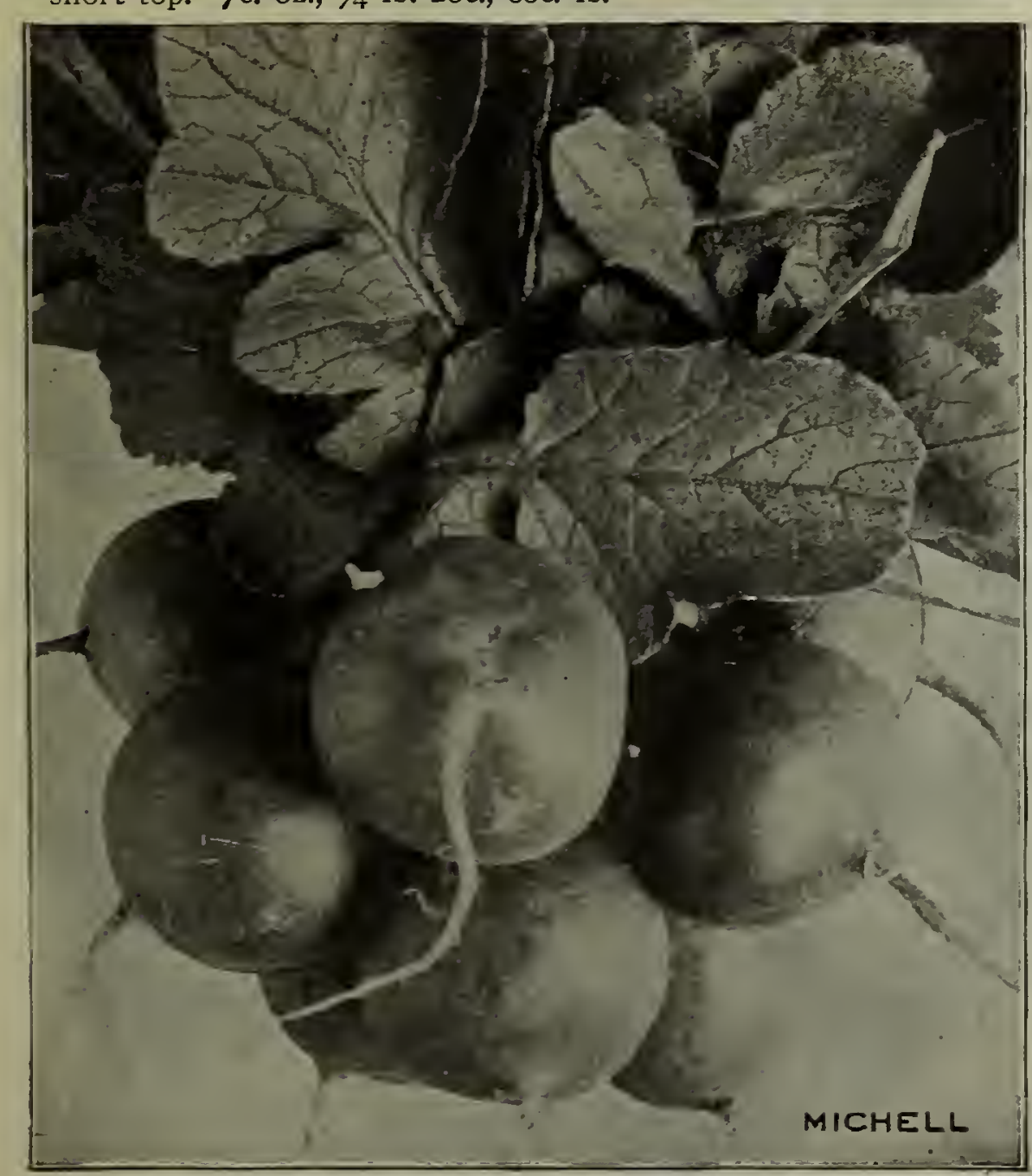

Michell's Private Stock Cardinal Globe Radish

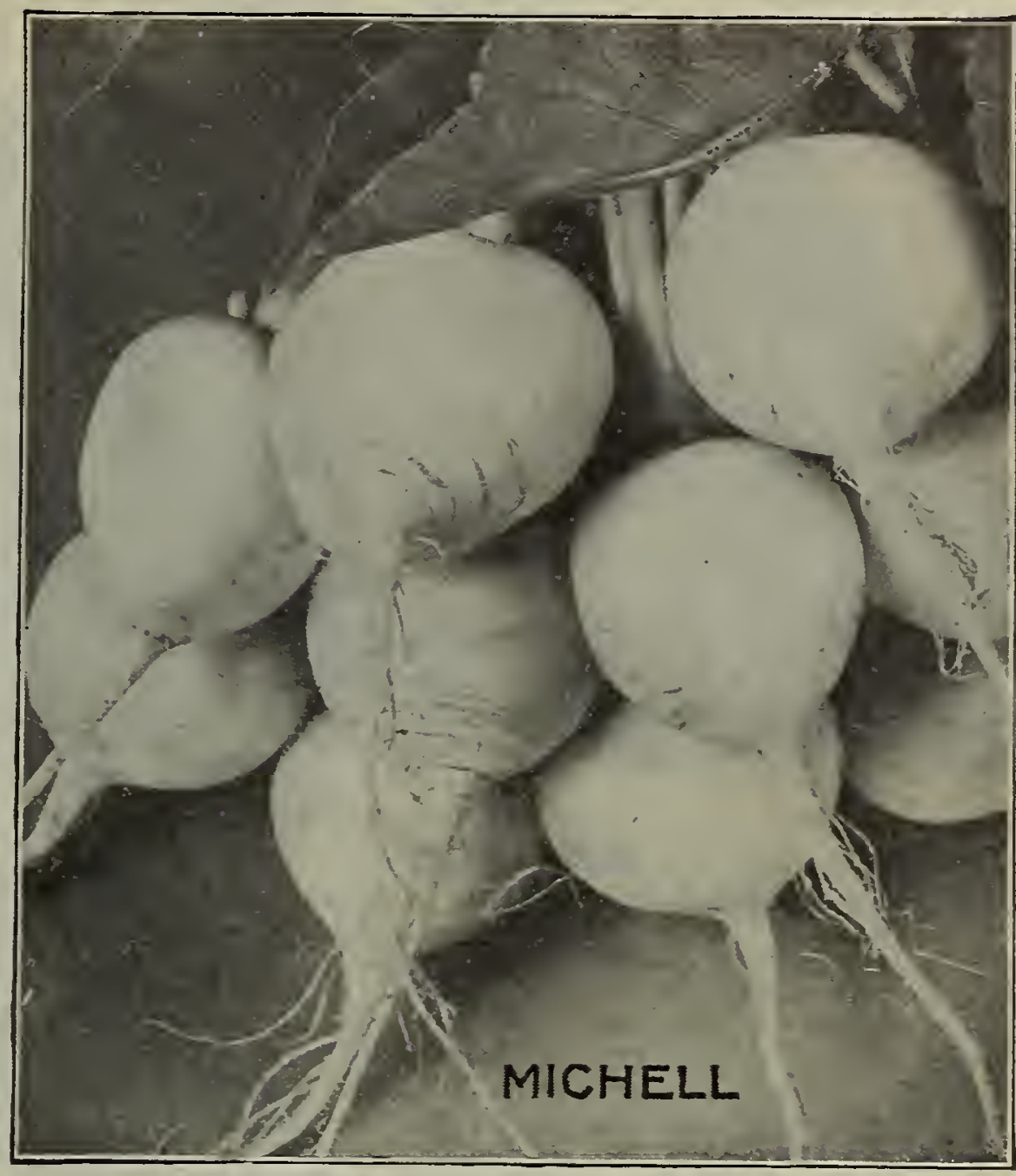

Felton's Stock White Box Radish.

\section{EARLY SORTS-Continued}

Round White Forcing or Turnip. An excellent small solid variety. 7c. oz., I/4 lb. 20c., 6oc. lb.

*White Box, Felton's. (Private stock.) A selection of the old reliable White Box radish, more perfect in form, producing shorter tops, and does not have a tendency to grow long in shape. $7 \mathrm{c}$. Oz., $1 / 4 \mathrm{lb}$. $20 \mathrm{c} ., 6 \mathrm{oc}$. $\mathrm{lb}$.

White Box, Philadelphia Grown. Perfectly round, smooth skin, pure white. 7 c. oz., I/4 lb. I5c., 5oc. lb.

\section{SUMMER SORTS}

*Beckert's Chartier (Long). Color bright salmon scarlet, shading to white as it approaches maturity; it is very crisp and tender. Oz. 7c., 20c. 1/4 lb., 1b. 6oc.

Golden Olive Shaped Yellow. An improvement on the old Yellow Globe sort. This is an ideal summer radish and is of exceptional quality, very mild. Oz. 7 c., I5c. 1/4 lb., 1b. $50 c$.

Large White Summer Turnip. Very large root of uniform round shape. Oz. 7 c., I5c. $1 / 4$ lb., lb. $45 \mathrm{c}$.

Long White Lady Finger. A fine white. crisp and mild variety. Oz. 7 c., I 5 c. $1 / 4$ lb., lb. 5oc.

*White Strasburg. Oblong of a pure white color, and mild flavor. This is one of the standard half long varieties for the market gardener. Oz. 7c., I5c. 1/4 1b., 1b. 5oc.

\section{WINTER VARIETIES}

$\because$ California White Winter. Grows 8 to to inches long. One of the best for winter. Oz. 7c., 20c. 1/4 lb., 1b. 6ac.

*Celestial or White Chinese. Large size. Pure white, excellent keeper. Oz. 7c., 20c. T/4 lb., 1b. 70c.

*Half Long Black. A great improvement on the old Long Spanish Radish. Oz. 7c., 20c. 1/4 1b., 1b. 6oc.

Long Black Spanish. A favorite among winter sorts, Oz, 7c., IJc. I/4 lb., 1b. 45 c.

Round Black Spanish. Like the above, except in form. Oz. 7 c., I5c:, I/4 lb., lb. $45 \mathrm{c}$.

China Rose. Bright rose color; flesh firm. One of the best for winter use. Half long in shape with a scarlet blunt tip. Fine variety for market gardeners. $7 \mathrm{c}$. oz., $1 / 4 \mathrm{lb}$. 20c., $60 \mathrm{c}$. lb. 


\section{MICHELL'S SEEDS,BULBS,PLANTS POULNTRY SUPPLIES,ETC. MARKETST. PHILA.}

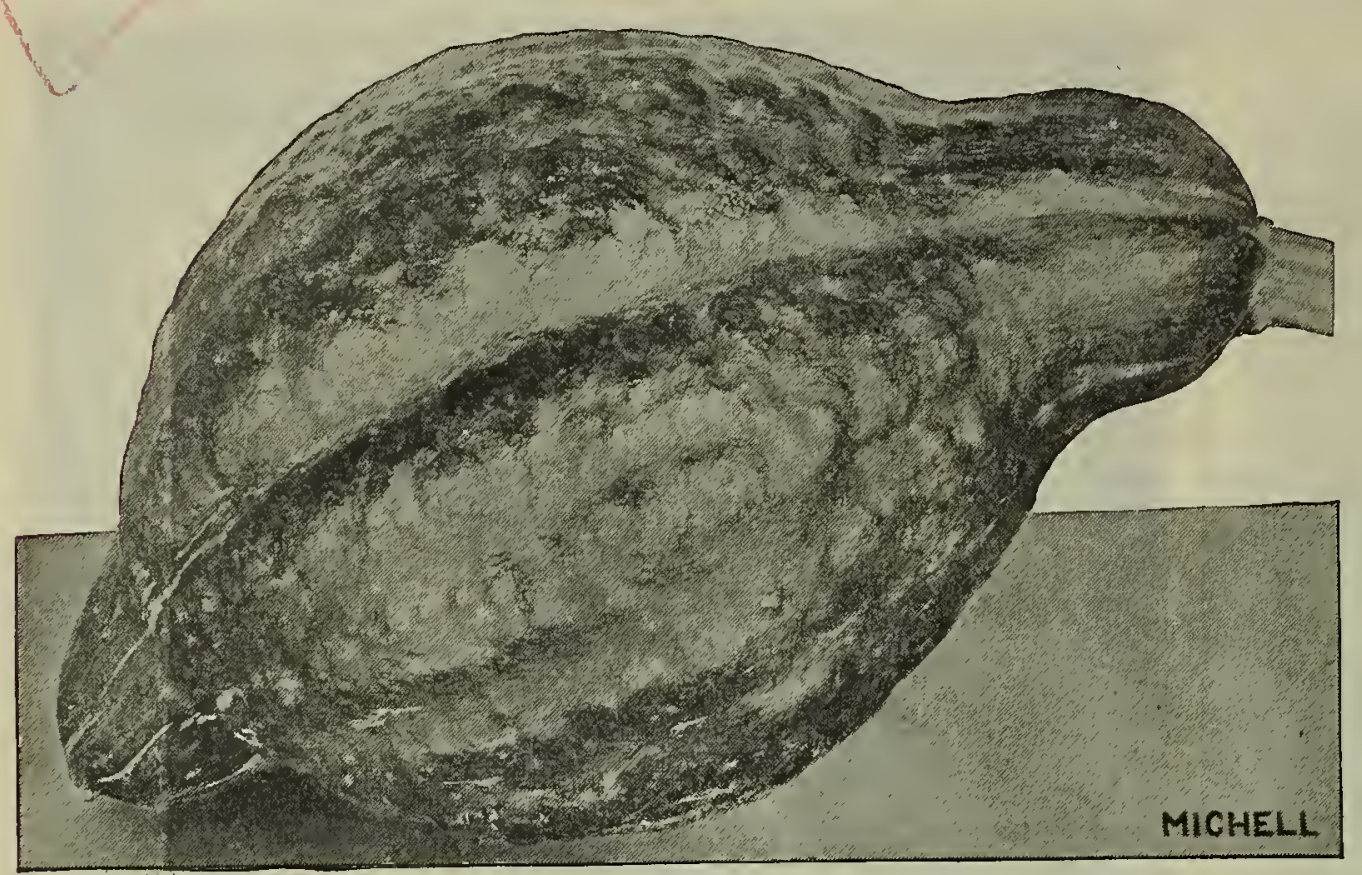

Golden Hubbard Squash

\section{SPINACH}

Bloomsdale Round=Seeded Savoy (Improved Strain.) The hardiest Savoy leaved variety; curled and crimped, thick, fleshy leaves; the best for early spring and fall sowing. 8c. $x / 4 \mathrm{lb}$., lb. 20 c., \$1.25 per peck (Io lbs.), bushel (40 lbs.) \$5.00.

Long Season. A cross between the old reliable Bloomsdale and the Victoria. It produces tremendously large plants and leaves which are strong and robust. It will resist heat better without shooting to seed than any variety yet introduced. The leaves are somewhat curled, and are tender. Color, a beautiful dark green. IOc. $1 / 4$ 1b., 1b. $25 \mathrm{c}$., $\$$ I.6o per peck (Io lbs.), bushel (40 lbs.) \$6.00

New Zealand. This variety endures heat and drought; excellent for summer use; the leaves are small and thick. It is an enormous yielder, growing upright, one sowing can be picked from the entire summer, a very distinct variety. This variety is not used much by market gardeners, but if once introduced by them would find a ready sale; it insures a supply of spinach all season regardless of heat. 20c. $1 / 4$ lb., 1b. 60c. ( $\$ 5.00$ per Io lbs.).

Victoria Long Standing. This thick-leaved variety is distinguished by the exceedingly dark green color, and also for its long-standing qualities and crinkled foliage, especially valuable for summer use, resisting the heat to a remarkable degree. 8c. $1 / 4$ 1b., lb. 20c., $\$ 1.25$ per peck (Io lbs.), bushel (40 lbs.) $\$ 5.00$

Garden Giant (New). A last year's introduction of ours; it produces an enormous plant and leaf and is especially desirable where quantity is wanted. It is suitable for either spring or fall, though not a winter spinach; very dwarf. 25c. 1b., \$1.00 per 5 lbs, , Io lbs. $\$ 2.00$.

\section{SWISS CHARD}

To our knowledge no market gardener has ever attempted to grow this for profit, and yet we find that among our general customers there is a great demand for it, and we honestly believe that if properly introduced it could be made one of the most profitable of garden products. It will bring in twice as much money per acre as spinach and can be cut all summer, as it does not go to seed. Oz. 1/4 lb. Lb. 5 Lbs.

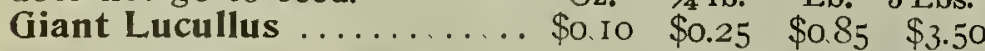

SAFFRON

SAGE $\$ 0$ o7 $\$ 20 \%$ \$o 60

SAGE PLANTS 75c doz.; i $00 \$ 5.00$

SAVORY (Summer)

SVEET BASIL

SWEET MARJORAM (American)

SWEET MARJORAM (Imported)

THYME (Broad Leaved)

TOBACCO SEED. Havan vania. Each, $7 c$. per pkt.
Wholesale Price List for Market Gardeners: and Florists

\section{SQUASH SUMMER VARIETIES}

Golden Custard. A flat scalloped type, like the White Bush; the skin is of a light yellow color, which is very thin, leaving plenty of meat in the centre; a bush or compact growing kind. Oz. 7c., 20c. $1 / 4$ lb., lb. $60 \mathrm{c}$.

* Mammoth White Bush. Of round scalloped form with an ivory white skin. This variety has an abundance of meat of very fine flavor. It is one of the earliest to mature and is very prolific, bearing continually until killed by frost. Comes in market earlier than any other. Oz. 7c., 20c. 1/4 1b., 1b. 6oc.

Yellow Summer Crook Neck. Shaped like a club with a bent neck. The skin is very rough and warted, of an orange yellow color. Much preferred by the cook on account of its very dry meat when boiled. This is a running variety. Oz. 7 c., I 5 c. I/4 1b., Ib. $55 \mathrm{c}$.

FALL AND WINTER VARIETIES (Running Sorts)

*Delicious. Well named, as it has the finest flavor of any squash, of oblong shape with a deep green skin and thin rind, with a seed cavity so small that it almost meets in the centre. One of the best winter keepers; grown extensively for market; when matured it weighs from 5 to Io lbs. and is in its prime during the early winter. Oz. 7c., 25c. r/4 lb., 1b. 85 c.

*Golden Hubbard. Used extensively for pie, and served as a vegetable; it is very dry and delicious. The outside is a deep orange red, while the flesh is very tender. An ideal winter market squash. Oz. 7c., 25c. 1/4 lb., lb. 65c.

Boston Marrow. Shaped similar to Hubbard, golden orange; fine for canning for winter use; cooked as a vegetable or in pie. Oz. 7 c., 20 c. $1 / 4$ 1b., 1b. $60 c$.

Vegetable Marrow. A long greenish white variety; fine for cooking; very sweet and tender. This is the favorite squash with the English people. Market gardeners will find a ready demand for this sort. Oz. 7c., 20c. $1 / 4$ lb., lb. 7oc.

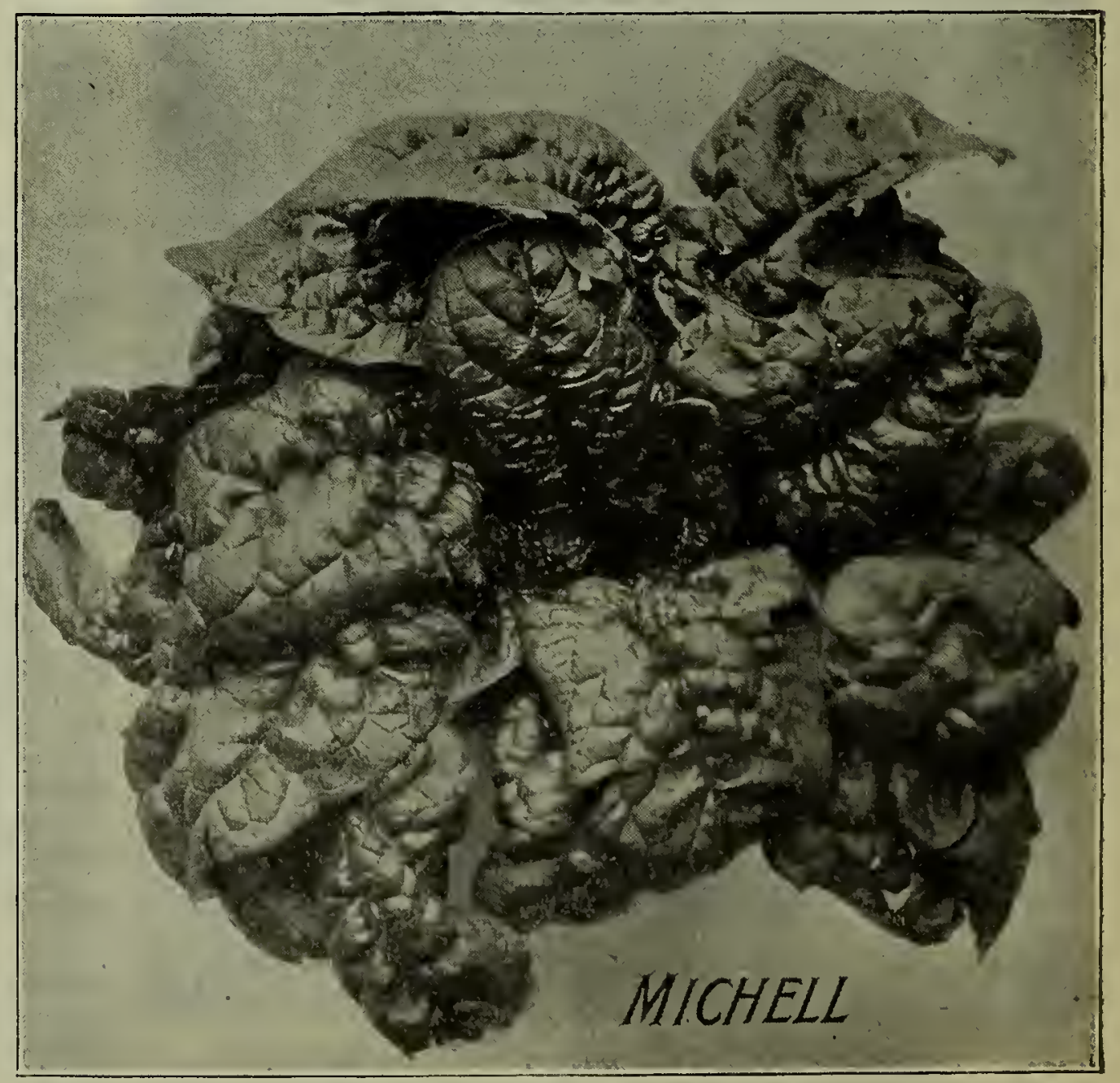

Long Season Spinach 


\section{Michell's Choice Tomato Seed}

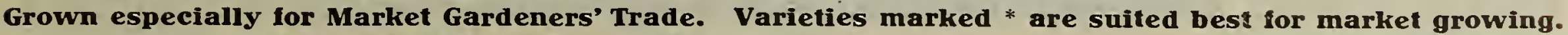

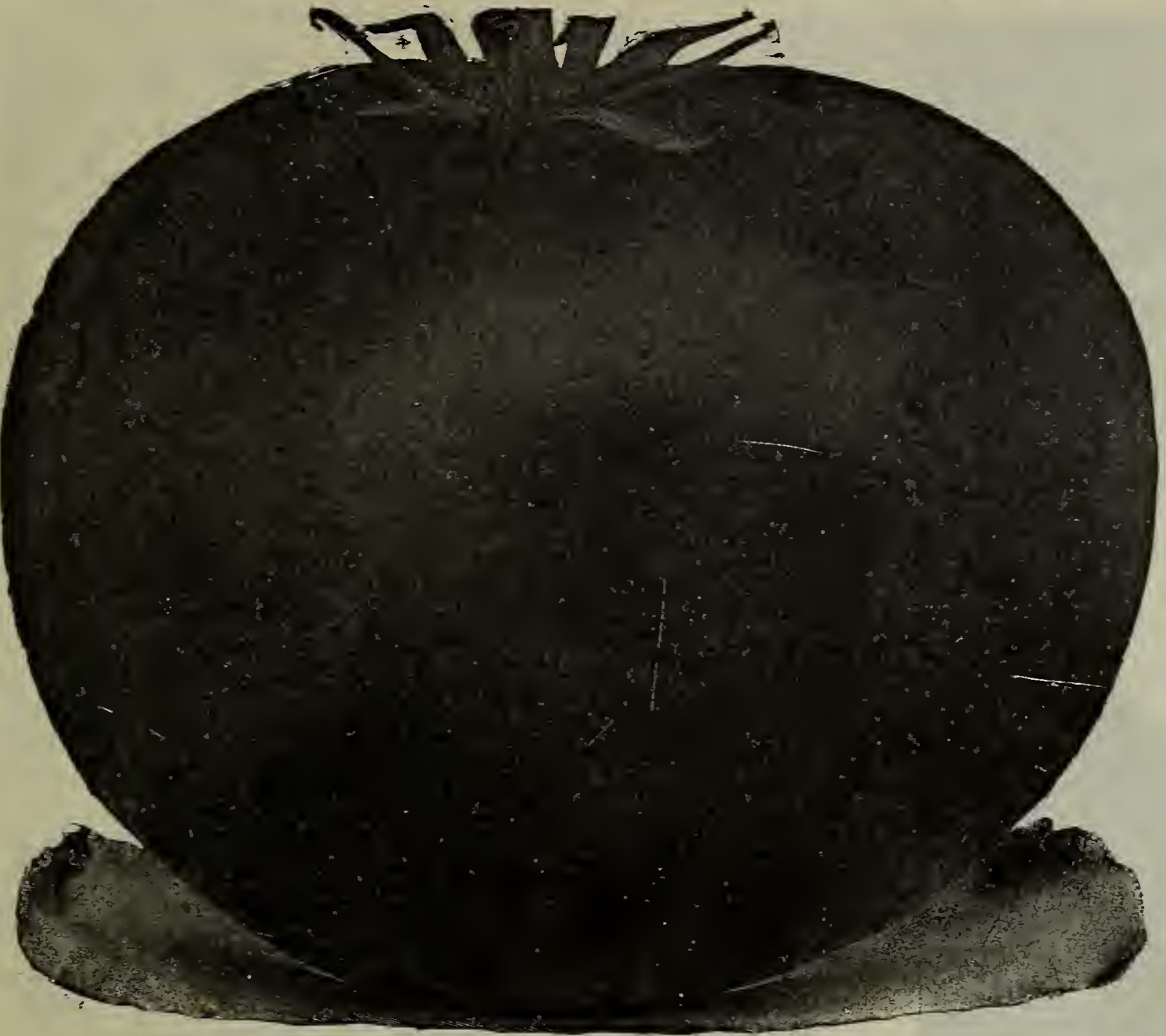

Michell's Private Stock Stone Tomato

\section{Early Varieties}

*Michell's Crackerjack. Its "distinctive" qualities are so numerous that space will not permit us to describe all. Here are some:

Two weeks earlier than any other sort tried in our gardens. A continuous early bearer, producing fruits right up till frost time. The most abundant tomato we know, absolutely smooth fruit; never cracks, except when overripe. All fruit is of even size, and every fruit can be used. Grows in clusters from 5 to Io perfect tomatoes, of a brilliant rich scarlet. The firm flesh makes it an ideal shipper. $7 \mathrm{c}$. pkt., I/2 Oz. I 5c., 30c. Oz., I/4 lb. \$I, \$3.75 lb.

$*$ Michell's Very First. Frequently the tomatoes will weigh fourtéen to sixteen ounces each. It is a heary producer of handsome fruits which are all well shaped and of a bright red color, in our trials we have found it to be the very first to ripen. Pkt. 7c.; 20c. per $1 / 2$ Oz.: Oz. 40c., $\$ 1.35$ per $1 / 4$ lb.. 1b. $\$ 5.00$.

*Earliana (Spark's). The most prolific early tomato ever produced. Grows in clusters; medium in size; solid and most desirable. IOc. per $1 / 2$ oz., oz. 20c., 6oc. I/4 lb., lb. $\$ 2.25$.

*Bonny Best. One of the best and most prolific of early tomatoes. The size is not so large but it is rery solid and evenly formed. Color a beautiful bright red. Pkt. 7C., I3c. $1 / 2 \mathrm{oz}$., oz. $25 \mathrm{c} ., 75 \mathrm{c}$. per $\mathrm{T} / \mathrm{l} \mathrm{lb}$., lb. \$2.75.

*Early Jewel (Chalk's). A favorite variety with the market gardener. Color, a bright red; solid and a good shipper. Pkt. 7 c., I3c. per $1 / 2$ oz., oz. 25 c., 75 c. per $1 / 4 \mathrm{lb}$., 1b. \$2.50.

June Pink. One of the recent introductions in tomatoes. In habit it is very much like Earliana, but a beatiful pink color instead of red. $1 / 2$ oz. IOc., Oz. 20c., 6oc. per $1 / 4$ lb., 1b. $\$ 2.25$.

Beauty. One of the largest bright red tomatoes, solid and meaty, quite early. Oz. Ijc., joc. per I/4 lb., lb. \$I.j5

\section{Forcing Varieties}

While especially adapted for growing under glass during the winter, they succeed outdoors quite well, and have one especially valuable feature, being extremely early.

Stirling Castle. A firm. medium fruit, with few seeds; very productive and of uniform shade, color rich red. Pkt. $7 \mathrm{c}$.; I $5 \mathrm{C}$ $1 / 2$ oz., oz. 30c., \$1.00 per I/4 lb., 1b. \$3.50.

\section{Forcing Varieties-Continued}

Michell's Crackerjack. See opposite column.

Sutton's Best of All. Grown from original stock. The fruit is medium sized, and of an intense red color, containing but few seeds, it is produced in clusters of from three to six fruits. Pkt. 7c., 20c. 1/2 oz., Oz. 35 c., \$I.25 per $1 / 4 \mathrm{lb}$.

Frogmore. Grows in large clusters and especially fine variety, very uniform and prolific, of deep red color. Pkt. $7 \mathrm{c}$., I 5 c. $1 / 2$ oz., oz. 25 c.. 85 c. $1 / 4$ lb., lb. $\$ 3.25$

Comet. A cluster averages six tomatoes of medium size of the brightest red, ripening up to the stem. Continues in bearing for a long while. 7 c. pkt., $1 / 2$ uz. 20c., 35c. Oz., $1 / 4$ 1b. \$1.00, \$4.00 1b.

Sutton's Eclipse. A very smooth fruit, borne singly on plants which produce little foliage, a good point in a forcing tomato, vermilion red color; original packets $40 \mathrm{c}$.

\section{Later and General Crop Varieties}

Michell's Improved Globe. One of the largest and heaviest tomatoes on our list, the shape is rather oblong so that for slicing it cuts more from a fruit than any other variety : absolutely smooth, never cracks and colors right to the stem. Pkt. 7C., I IC. per I/z Oz., Oz. 30c, \$I.00 per I/4 lb., 1b. $\$ 3.75$

*Livingston's Gilobe. Especially adapted to slicing; very solid; color a handsome red, and a great producer; one of the best general crop varieties. IOc. $1 / 2 \mathrm{Oz}$, oz. $20 c ., 60 \mathrm{c}$. $1 / 4$ lb., 1b. $\$ 2.25$

*Stone (Michell's Private Stock). A very careful selection of the old favorite Stone. The fruits are larger, more even, and produced in greater abundance. One of the best tomatoes on the market. I5c. 1/2 Oz., Oz. 25c., 75c. I/4 1b., 1b. \$2.50.

Greater Baltimore. An excellent variety for canning or market use, very large and solid, of rich red color, uniform in size. 7c. pkt., I/2 oz. I 5 c., 25c. Oz., I/4 lb. 75 c., $\$ 2.75$ per lb.

Dwarf Giant. A dwarf type of true Ponderosa, very meaty and of gigantic size, rich purple crimson, fine shipper. Pkt. $7 \mathrm{c}$., I5c. 1/2 oz., oz. 30c., \$I.00 per 1/4 lb., 1b. \$3.75.

Stone. (Usual Strain.) Ioc. 1/2 oz., oz. 20c., 6oc. I/t 1b., 1b. $\$ 2.00$. $*$ Red Rock. One of the most solid varieties, medium size and of a brilliant red color, a fine one for the market garden: medium early. 7 c. pkt., I 5 c. I/2 oz., oz. 25 c., 85c. I/4 lb., lb. \$3.00.

* Ponderosa. The largest tomato in existence; a beautiful red color; heavy producer, and of even form. 7 c. pkt., $1 / 2 \mathrm{Oz}$. I $5 \mathrm{c}$., oz. 25 c., 9oc. $1 / 4$ lb., 1b. $\$ 3.25$.

Dwarf Champion. A distinct type, the plant looks like a miniature tree; very dwarf and compact: color of fruit bright red and very solid. IOc, $1 / 2$ oz., Oz. 20c. 60c. I/4 1b., 1b. $\$ 2.00$

:Dwarf Stone. A compact growing plant, yielding a large crop of medium-sized solid tomatoes. Color, bright red. The plant is very distinct. IOc. $1 / 2$ oz., Oz. 20c., 65 c. $1 / 4$ lb., 1b. $\$ 2.50$.

Golden Queen. Large yellow. IOc. $1 / 2$ Oz., Oz. 20c., $70 \mathrm{c}$

1b. $\$ 2.25$.

Matchless. Large red fruit, general crop. IOc. $1 / 2$ OZ.. OZ. $20 \mathrm{C}$. 6oc. $1 / 4$ 1b., 1b. $\$ 2.25$.

\section{Small Fruited Varieties}

\section{Highly desirable for preserving, almost free from}

Red Cherry.

Yellow Pear or Plum.

SO.IO So. 20 So. 60

Strawberry or Husk.

Red Peach of peach form and color... $10 \quad .10 \quad .20 \quad .60$

Tomato Plants (Ready in April) Doz. 100

Hotbed=Grown. Leading sorts........... \$0.15 \$1.00

Pot=Grown Crackerjack

Pot=Grown. Extra strong stock; leading sor 


\section{Wholesale Price List for Florists and Market Gardeners}

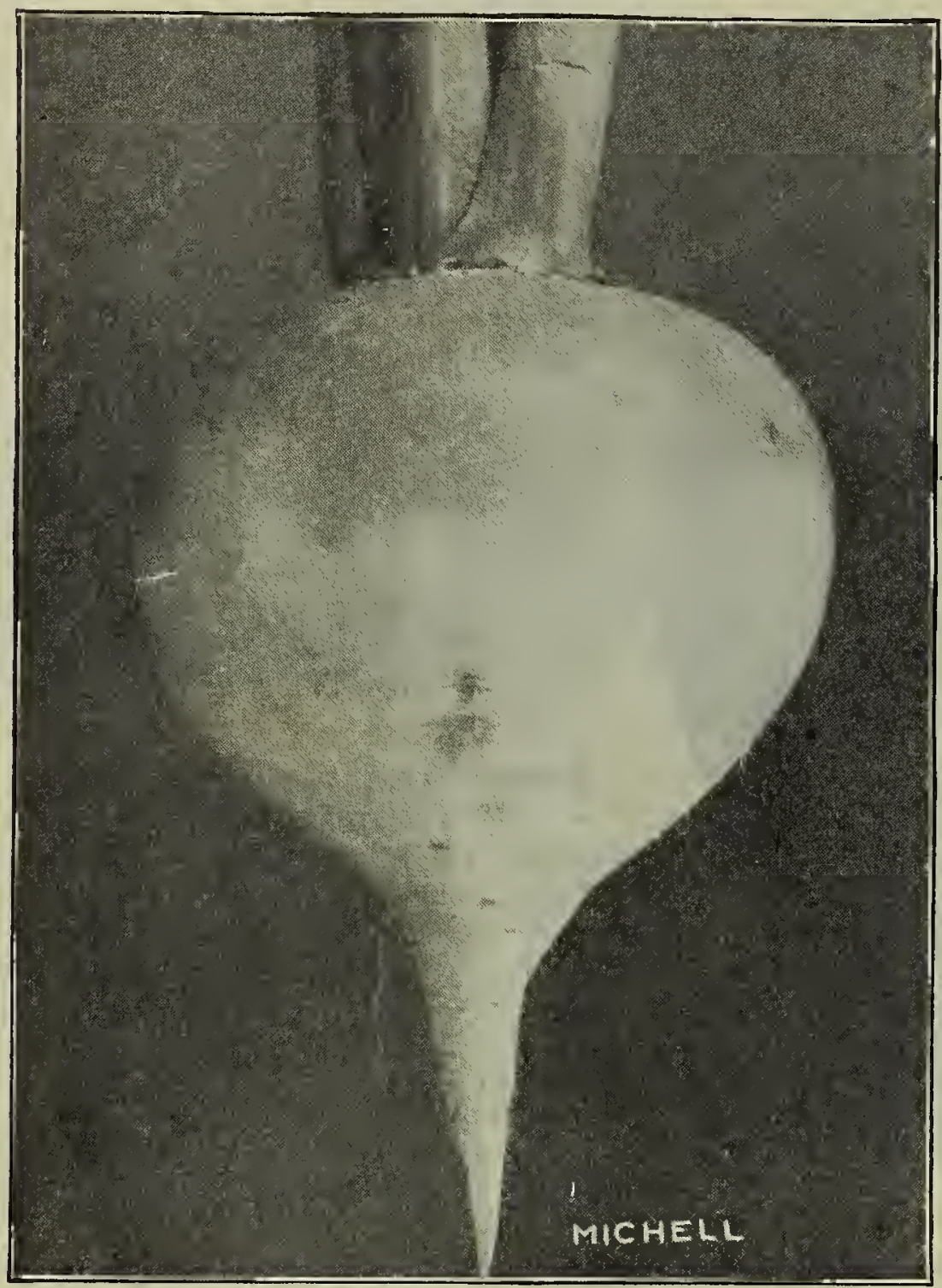

Private Strain Improved Purple Top White Globe Turnip

\section{TURNIP}

Aberdeen. A flat yellow variety, a good winter keeper. Oz. 5c., I5c. $1 / 4 \mathrm{lb}, \mathrm{lb} .45 \mathrm{c}$.

Cow Horn. A long white variety used for soiling and stock feeding. Oz. 7c., I5c. I/4 ib., 1b. 5oc.

Early Purple Top Munich. A flat variety, very early, white flesh. Oz. 7c., I5c. I/4 lb., 1b. 50c.

Early White Flat Dutch. A good variety for early spring sowing, matures quickly. Oz. 5c., I5c. $1 / 4$ lb., 1b. 40 .

*Early Purple Top Flat. The most popular variety in cultivation, a large yielder, well flavored. Oz. 5c., I5c. I/4 lb., lb. 45c.

*Purple Top White Globe. A large perfect shaped sort, the skin is purple at top and white at bottom, very sweet. Oz. 7c., I5c. $1 / 4$ lb., lb. 5 oc., 5 lbs. $\$ 2.25$.

*Purple Top White Globe. (Private stock.) This is a careful selection of the above variety, especially adapted for market gardens. Oz. IOc., 20c. T/4 lb., lb. 70c., 5 lbs. $\$ 3.00$.

Robertson's Golden Ball. A globular-shaped sort, with deep yellow flesh. Oz. 5c., I5c. 1/4 1b., 1b. 40c.

Snowball. A pure white globe variety, very early. Oz. 7c., I5c. $\mathrm{T} / 4 \mathrm{lb}, 1 \mathrm{~b} .45 \mathrm{c}$.

White Egg. A small egg-shaped variety, good for early sowing. $\mathrm{Oz}, 5 \mathrm{c}$., I5c. $1 / 4$ lb., lb. 45c.

White Milan. A handsome flat sort, grand for very early use, sweet and tender. Oz. 7c., 20c. 1/4 1b., 1b. 7oc.

* Yellow Globe or Amber. Shaped like the Purple Top Globe, but the color is like that of a Yellow Ruta Baga. Oz. 5 c., I5c. $1 / 4$ lb., 1b. $40 \mathrm{c}$.

\section{RUTA BAGA}

*Private Stock Purple Top Yellow. This is the perfect ideal Ruta Baga. Top is purple, the bottom yellow. It brings a high price when sold in the market on account of its shape. Oz. IOc., 20c. $1 / 4$ lb., lb. 75 c., 5 lbs. $\$ 3.25$.

Improved Purple Top Yellow. This variety is the same color as the above, except the shape is more oblong. It is very desirable for table use and stock feeding. Oz. 5c., I5c. I/4 lb., lb. $40 \mathrm{c}, 5$ lbs. $\$ 1.75$.

\section{WORMWOOD}

A medicinal herb of great value. Perfectly hardy with slight protection. I5c. oz., T/4 lb. $50 \mathrm{c}$.

\section{FARMOGERM \\ THE.WONDER FUL FERTILIZER FOR LEGUMINOUS CROPS}

\section{PEAS, BEANS AND OTHER LEGUMINOUS FARM CROPS WILL GROW MORE ABUNDANTLY}

if the soil is properly sweetened with lime and worked to a good seed bed and the seed inoculated with Farmogerm high-bred bacteria. Without bacteria, of the proper variety, in sufficient amounts (and in an active nitrogen-gathering condition) it is impossible to successfully grow alfalfa or other legume crop.

The great Fertilizer Value of Legumes depends entirely upon Inoculation with Farmogerm. 1000 to 2000 Pounds of Nitrates to the acre can be deposited in little sacks or nodules on the roots of the legumes, which will be immediately available for any following crop. Legumes embrace all of the various types of clovers, peas, beans and such other plants that have blossoms similar in shape and form as the above named. This type of plant has the ability of taking from the air vast quantities of free nitrogen, which exists there and which is not absorbed by other plants than those which belong to the legume family. This nitrogen is taken (breathed so to say) through the stems of the plant and deposited at the roots in little sacks or nodules, where it becomes immediately available as plant food in the form of nitrates. The application of Farmogerm to the seed of these legumes when planting practically trebles the nitrogen-gathering power and for this reason we urge all planters to use it on all such occasions. Please note that Farmogerm is not applicable to any other class of plant through inoculation, except as noted below; succeeding crops, though, following on ground where Farmogerm was used, derive tremendous benefits, as many plants that are not legumes require quantities of nitrates as plant food.

\section{FARMOGERM SAVES THE COST OF ALL EXPENSIVE NITRATE FERTILIZERS}

FARMOGERM can be had for any of the following crops in either $\mathrm{T} / 4$ acre, I and 5 acre bottles. Each crop requires a different culture or bacteria and one cannot be used for the other (except where noted):

$\begin{array}{llll}\text { Alfalfa or Lucerne } & \text { Canada Peas } & \text { Garden Peas } \\ \text { Alsike } & \text { Cow Peas } & \text { Peanuts } \\ \text { Burr Clover } & \text { Garden Beans (Pole and } & \text { Red Clover } \\ \text { Crimson Clover } & \text { Bush) } & & \text { Sweet Peas }\end{array}$

No. 2 for Alfalfa or Lucerne. No. 4 for Soja Beans

No. 3 for Vetch or Canada and Cow Peas in mixture.

\section{Soja Beans}

Vetches

White Clover

No. 5 for Garden Peas, Garden Beans (Pole and Bush) and Sweet Peas.
No. $\mathbf{r}$ for Red, White,
on and Alsike Clover.

\section{GARDEN OR $1 / 4$ ACRE SIZE, 50c.}

\section{ACRE SIZE, $\$ 2.00$.}

\section{ACRE SIZE, $\$ 9.00$}

Complete Book on Farmogerm and Inoculations FREE. Always state for what crop Farmogerm is desired when ordering. 


\section{Michell's Seeds and Specialties for Florists' Store Sales}
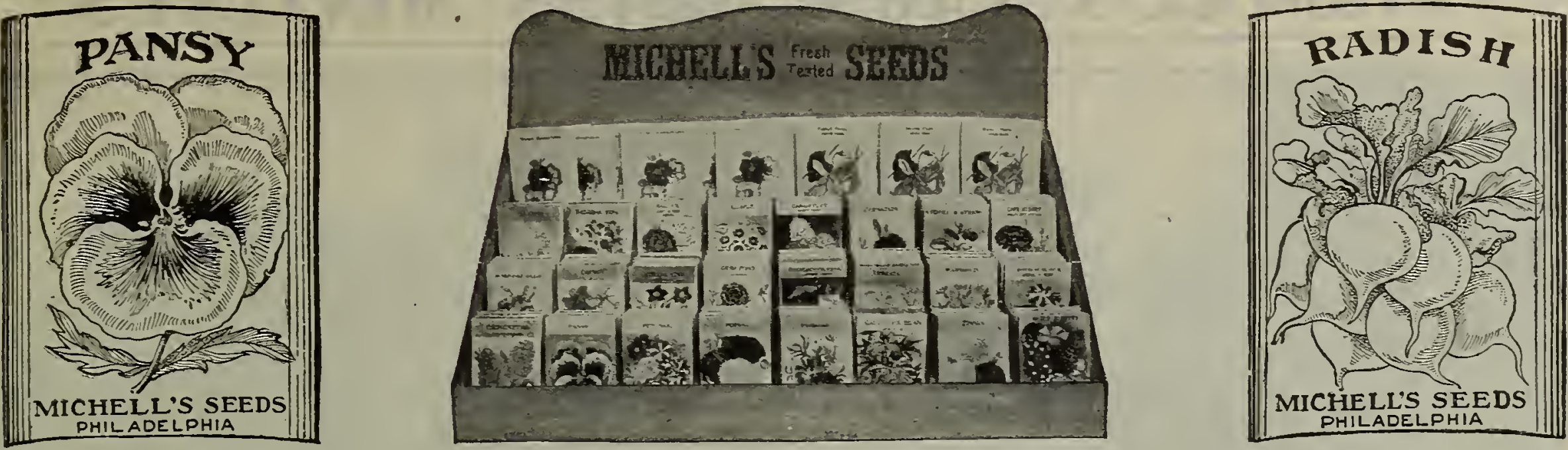

Florists and other merchants with stores may reap a good profit by selling seeds in packets during planting season. No knowledge of the seed business required, because the packets being lithographed are attractively arranged in a special display cabinet, which is loaned. Our packets of seed must not be compared with those often sold at Ic. and 2c. per packet. which are unreliable. Nichell's Seeds as sent out in these packets are the same quality as sold by us over our own counters. If the display cabinets are properly placed, the goods sell themselves, and frequently bring you trade for other things.

List of Vegetable Seeds-nustrated Packets

\section{Beets}

Beans

Beans (pole

lima)

Beans (bush

lima

Cabbage, early

Cabbage, Tate

Carrots, early

Carrots, late

Cucumber

Celery

TERMS ON SEEDS IN PACKETS LISTED ABOVE

Where customers in ordering do not specify just how many of each is desired, we select assortments containing 50 , 100 , I 50 and 200 packets in large variety such as will sell readily in cities and suburbs. IVe reserve the right where seeds are shipped on consignment to modify the quantity in accordance with customers' sales record the previous year. The cabinet when filled with these gayly colored packages is an ornament to the fanciest store.

Prices (regardless of quantity) on Illustrated Packets of Flower and Vegetable Seeds consigned, returnable only when in good, clean condition July Ist, \$2.50 per Ioo packets.

On outright sale, not returnable, $\$ 2.00$ per 100 packets, per I000 packets $\$ 18.00 ; 250$ packets at the I000 rate.

Special Note: All seeds, other than listed above, or in different size packages, are sold outright only, and if purchased cannot be accepted for credit if returned.

Cabinets for displaying seeds are supplied at $\$$ I.00 each. These are returnable for credit if in good order, either on consignment or on outright purchases. Display signs free.

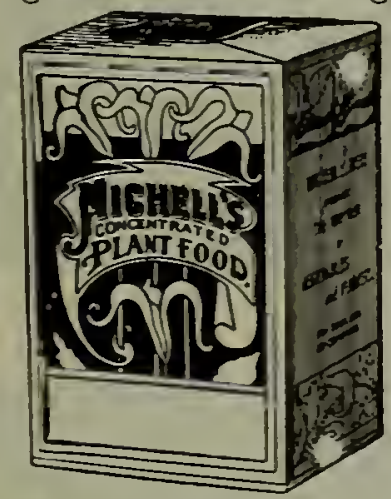

\section{Fertilizers,}

\section{Insect Destroyers}

Michell's Plant Food. \$1.00 per doz. packages: per I00, \$8.00. (Retails I5c.) Bowker's Plant Food. Small, \$1.35 per doz. pkgs.; per 100, \$10.50. Large, \$2.25 per doz. pkgs.; per I00, \$16.00.

Bone Meal. 3-lb. boxes (retails for I 5c.) I2c. each, \$I.30 doz., \$1o.0o I00. Bone Meal. 5-1b. boxes (retails for 25c.) 20c. each, \$2.25 doz., \$I 8.00 Ioo Bone Meal. Io-lb. boxes (retails for 40c.) 32c. each, \$3.75 doz., \$30.00 100,

Sulpho=Tobacco Soap. 3-oz. boxes (retail for IOc.), 85 c. per doz.; per IOO, \$6.I5. $1 / 2-1 b$ boxes (retail for $20 \mathrm{c}$.), $\$_{1.70}$ per doz: per I0O, \$I 2.50

Lemon Oil, Insecticide. $1 / 2$-pt. cans (retail for $25 \mathrm{c}$.), doz., $\$ 2.40$; Si 8.00 per IOO.

Aphine. 1/4-pt. cans (retails at 25c. each), 20c. each; per doz., $\$ 2.30 ; \$ 19.00$ per 100.
List of Flower Seeds-Illustrated Packets

\section{Ageratum \\ Castor Oil Bean| Hyacinth Bean | Poppy}

Antirrhinum

Alyssum

Aster

Balloon Vine

Balsam

Balsam Apple

Calendula

California

Poppy

Calliopsis

Candytuft

Canary Bird

Vine

Carnation

\begin{tabular}{l|l} 
Celosia & Larkspur \\
Chrysanthe- & Lobelia \\
mum & Marigold \\
Cobaea & Mignonette \\
Cornflower & Moonflower \\
Cosmos & Morning Glory \\
Cypress Vine & Nasturtium, \\
Flower Seeds, & dwarf \\
in mixture & Nasturtium, \\
Forget-Me-Not & tall \\
Four Oclock & Pansy \\
Gaillardia & Petunia \\
Gourds & Phlox \\
Hollyhocks & Pinks
\end{tabular}

Portulaca

Scarlet Sage

Straw Flowers

Stocks

Sunflower

Sweet Pea

Sweet William

Thunbergia

Verbena

Vild Cucumber

Zinnia

No Flower Seeds consigned except those described above.

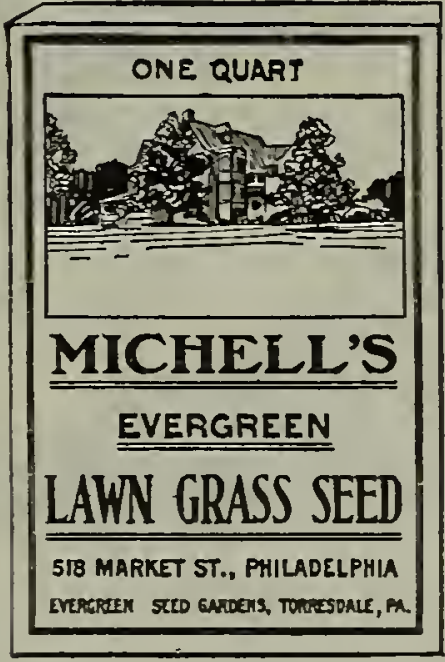

\section{Michell's "Renowned" Grass Seeds}

Grass Seed is one of our main specialties, and our trade in this article alone is approaching the million pound mark annually. It is known from the Atlantic to the Pacific and, when offered requires no introduction.

\section{Consigned Price Outright Sale Price}

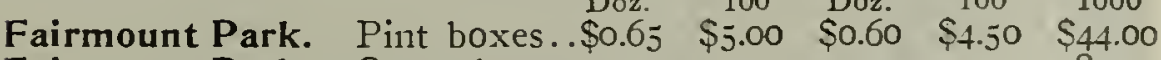
Fairmount Park. Quart boxes. I.25 $\begin{array}{lllll}\text { I0.00 } & \text { I.20 } & 9.00 & 87.50\end{array}$ Michell's “Evergreen" Din. 100

Michell's "Evergreen." Quarts.....2.2.00 15.00 Michell's "Evergreen." 2 quarts.... 3.50 27.50 Michell's "Evergreen." 4 quarts.... $\$ .50 \quad 40.00$

Michell's "Shaded Lawn." Pints... I.20 9.50 Michell's "Shaded Lawn." Quarts. 2.00 I6.00 Michell's "Shaded Lawn." 2 quarts 3.6028 .00 Michell's "Shaded Lawn." 4 quarts 6.00 45.00

These

Grass Mixtures are not White Clover. Consigned, 30c. per dozen packets, $\$ 2.50$ per 100 packets; on Outright Sale, $\$ 2.00$ per 100 packets for any quantity. I/4-lb. pkgs., \$I.50 per doz., \$I 2.00 per I00.

Under no circumstances do we consign Insecticides; Fertilizers, Michell's "Evergreen" Grass Seed, "Shaded Lawn" Grass Seed o Basis only. 


\section{MICHELLS GRASS SEEDS $\frac{518}{\text { manktisis PHILA }}$}

\section{MICHELL'S LAWN GRASS MIXTURES}

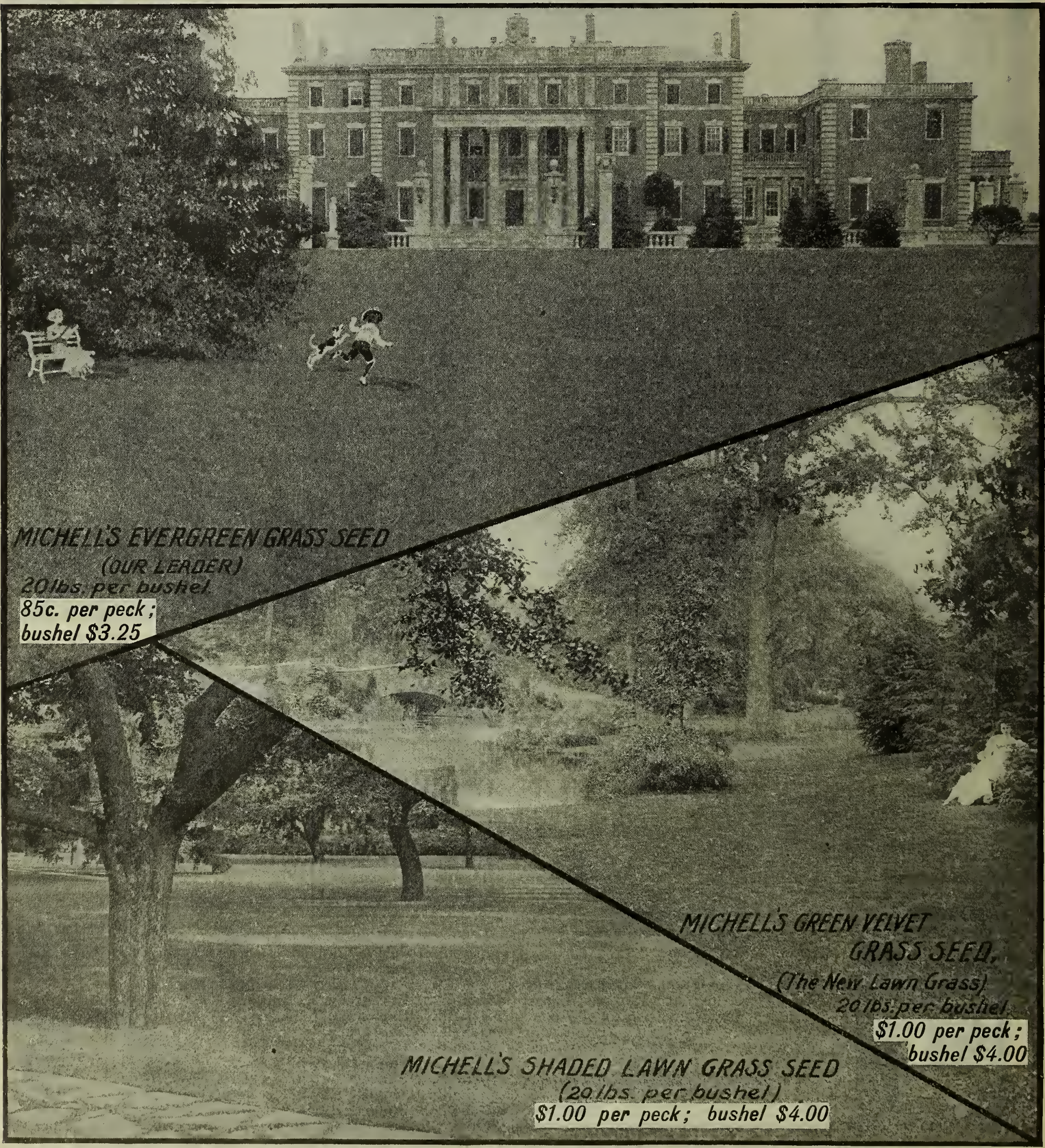

CLIMAX LAWN SAND HILLS WEEDS BUT NOT THE GRASS.

We have absolute confidence in recommending this article for what it is suggested, viz.: to kill weeds in the lawn. Panuphlet glving detalled Information with thorough instructions for use, mailed upon application. A ready seller. Florists with stores will flnd this profitable to handle. 3\% lbs., 30c.; 60c. per 7 lbs.; 14 lbs., $\$ 1.00 ; \$ 1.60$ per 28 lbs.; 56 lbs., $\$ 2.80 ; \$ 4.80$ per 112 lbs.; 560 lbs.. $\$ 20.00$. 


\section{MICHELL'S RECLEANED GRASS AND CLOVER SEEDS}

Grasses and Clovers represent a very large volume of our business. Last year it aggregated nearly 500,000 lbs. Vve buy direct from the cleaners and growers and are invariably able to save our customers considerable money in this line. Our stock of native and foreign grown grasses are subjected to the most critical purity and germination tests by the U. S. Dept. of Agriculture prior to being offered for sale by us.

\section{GRASS SEED MIXTURES}

Michell's “Top Notch" Lawn Seed. (25 lbs. per bu.) This is the very best grass mixture that can be put together. Per peck, \$I.75; \$6.25 per bushel. 1 Qt. 4 Qt. Peck Bu. 5 Bu.

Michell's Green Velvet Lawn Seed

(20 lbs. per bu.) ................ \$0.20 \$0.6o \$1.00 \$4.00 \$19.00

Michell's Evergreen Lawn Seed $\begin{array}{llllll}(20 \text { lbs. per bu. }) \ldots \ldots \ldots \ldots \ldots \ldots \ldots & .20 & .50 & .85 & 3.25 & 15.75\end{array}$

Michell's Shaded Lawn Seed (20

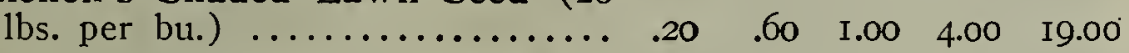

Fairmount Park Lawn Seed (I5

lbs. per bu.) ..................

Evergreen Grass, with no clover

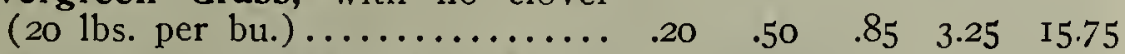

Special Sod Grass Mixture (I5

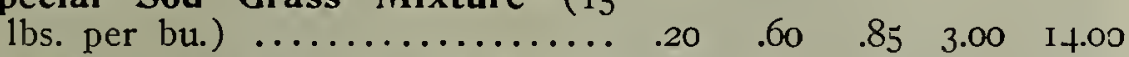

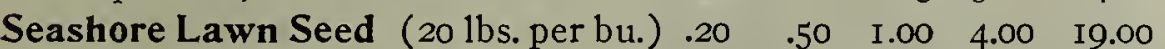

Lawn Tennis Grass Seed (20 lbs.

$\begin{array}{lllllll}\text { per bu. }) \ldots \ldots \ldots \ldots \ldots \ldots \ldots \ldots & .20 & .50 & .85 & 3.25 & 15.75\end{array}$

Golf Course Grass Seed ( ${ }_{5}$ lbs.

per bu.) ......................

Terrace or Embankment Lawn

Seed (20 lbs. per bu.)...........

Southern States Lawn Seed (I5

lbs. per bu.) …...............

Putting Greens Grass Seed Michell's Formula (20-lb. bu.)...

Permanent Pasture Grass Seed ( I 5 lbs. per bu.) …............ . . $5 \quad .40 \quad .60 \quad 2.25 \quad$ II.00

Hay Field Mixture (I 5 lbs. per bur)

These mixtures are fully described in our General Retail Seed Catalogue.

GRASS SEED IN PACKAGES FOR COUNTER TRADE

The following prices are on outright sale basis, for price on consigned basis for Fairmount Park Mixture see page 19.

Fairmount Park. Pint boxes .......... Per doz. Per 100 Per 1000 Fairmount Park. Quart boxes ................20 $94.00 \quad 87.50$ Evergreen. Pint boxes ..................... $1.20 \quad 9.50 \quad 90.00$ Evergreen. Quart boxes $\ldots \ldots \ldots \ldots \ldots \ldots \ldots . \ldots 2.00$ I 5.00 I 140.00

Shaded Lawn. Pint boxes $\ldots . \ldots \ldots \ldots \ldots \ldots$ I.20 $9.50 \quad 90.00$ Shaded Lawn. Quart boxes .............. 2.00 I6.00

RECLEANED WHITE DUTCH OR LAWN CLOVER

For sowing in lawns to encourage grass growing this is highly valuable. Sow Io to I $2 \mathrm{lbs}$. per acre. We handle the choicest grade only. 40 c. per lb.; 5 lbs., $\$ 1.80 ; \$ 3.50$ per Io lbs.; per I0o lbs., \$30.00.

\section{CARTER'S WORM-ERADICATING FERTILIZER}

This is used extensively by the leading golf clubs on putting greens. It positively destroys worms of all kinds that are a detriment to good greens.

Put up in $100 \mathrm{lb}$. bags only. Price: $\$ 4.00$; $1000 \mathrm{lbs} ., \$ 36.00$; $\$ 69.00$ per ton of 2000 lbs. Special price f. o. b. Boston.

\section{GRASSES IN SEPARATE VARIETIES}

Prices Subject to Market Changes

We handle the best recleaned grass seeds in separate varieties. Some persons like to do their own mixing or prefer to sow only one kind of grass; we make no charge for mixing. Lbs.

Lb. Bushel $100 \mathrm{lbs}$

Bermuda Grass

I4 Blue Grass (Kentucky). Extra Fancy.

3 to 5 bu. per acre (55c. per peck)...

10.00

\begin{tabular}{llllll} 
& Crested Dogstail. $31 / 2$ to 4 bu. per acre.. & .40 & 6.50 & 30.00 \\
\hline .75 & 24.00
\end{tabular}

24 English Rye (Pacey's Fancy Perennial Rye), fine for lawns. 3 bu. per acre.

I4 Fine Leaved or Slender Fescue........

32 Herd or Red Top. Fancy recleaned.......

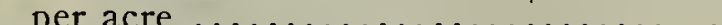

2 Hard Fescue. 30 lbs. per acre..

I8 Italian Rye. 50 lbs. per acre.

22 Meadow Fescue. English Blue Grass...

I2 Orchard. 40 lbs. per acre.

I4 Red or Creeping Fescue.

I4 Rhode Island Bent. $40 \mathrm{lbs}$. per acre

I2 Sheep's Fescue. 40 lbs. per acre...

Sweet Vernal (Perennial). (5 lbs. \$2.25) 3 lbs. per acre with other grass.......

Sweet Vernal (Annual). (5 lbs., 8oc.) 3 lbs. per acre with other grass........

Io Tall Meadow Oat (French Rye Grass)

I5 Various Leaved Fescue..

I4 Wood Meadow. 30 lbs. per acre...

\section{$\begin{array}{lll}.12 & 2.25 & 8.00\end{array}$}

$\begin{array}{llr}40 & 5.00 & 32.00\end{array}$

$\begin{array}{lll}30 & 9.00 \quad 27.50\end{array}$

$\begin{array}{lll}\text { I8 } & \text { I.5O } & \text { I } 2.50\end{array}$

$\begin{array}{lll}.18 & 1.50 & 12.50 \\ .25 & 2.60 & 20.00\end{array}$

$\begin{array}{llr}.12 & 1.75 & 8.00\end{array}$

I $5 \quad 2.50 \quad$ II .00

$.20 \quad 2.10 \quad 14.50$

$\begin{array}{lll}.25 & 3.25 & 20.00\end{array}$

$\begin{array}{lll}.40 & 4.55 & 30.00 \\ 25 & 2.75 & 21.00\end{array}$

$.50 \quad 40.00$

$.20 \quad$ I 4.00

$\begin{array}{lll}.22 & 2.00 \quad \mathrm{I} 7.50\end{array}$

$\begin{array}{lll}.15 & & \\ .30 & 4.00 & 25.00\end{array}$

$\begin{array}{lll}.40 & 4.75 & 32.00\end{array}$

RECLEANED CLOVERS (Prices Subject to Change)

Alfalfa or Lucerne. The most valuable forage crop on the American farm to-day. It is sown during May, August and September, although it can be sown at other times with a possible chance of doing well. Our Special Circular on Alfalfa is free for the asking. Sow not less than $1 / 2$ bushel (30 lbs.) per acre, preferably with no other crop. Price per $1 \mathrm{~b} ., 25 \mathrm{c}$ Write for price on larger quantities, as it changes constantly. Alsike or Swedish Clover (Trifolium Hybridum). It grows from I to 2 feet high, is sown early in the spring or late summer and early autumn. It is as nutritious as red clover. Sow Io to 15 lbs. per acre alone or 8 lbs. per acre with timothy. Price, 25c. 1b. Price on larger quantity on application.

Bokhara Clover (Melilotus Alba). Extensively used as a bee food and for soiling (green manure). It grows from 3 to 5 feet high, according to soil and location. Sow I5 lbs. per acre in early spring alone, or Io lbs. per acre with other crops. Price, 3oc. per lb., Io lbs. $\$ 2.50$.

Crimson Clover (Trifolium Incarnatum). Delaware Grown Seed. This is used principally for soiling or green manuring, for which purposes it is highly valuable. Sow any time from April to October, the earlier the better, 20 lbs. to the acre Price, I5c. per 1b. Larger quantity prices on application.

Red Clover, Medium (Trifolium pratense). Height from I 8 inches to $2^{T} / 2$ feet. Sow early in the spring or in late summerJuly and August; if alone $20 \mathrm{lbs}$. per acre; if with other crops Io lbs. per acre. Price, 25c. 1b.; larger quantity, price on application.

Mammoth Red Clover (Trifolium Pratense Perenne). This differs from the "Medium," being of a ranker growth. It ripens somewhat later and is more hardy, lasting several seasons longer than the medium red clover. Sow in early spring or in July and August, using 20 lbs. per acr

lb.; larger quantity, prices on application.
White Dutch or Lawn Clover (Trifolimn Repens). For mixing with lawn grass it helps establish a quick, permanent tur Apply Io to I2 lbs. per acre if sown alone or 5 lbs. if old turf. Prices: 1/4 lb. I3c., 40c. 1b., 5 lbs., \$1.80, $\$ 3.50$ lbs., bu. (6o lbs.) \$18.00, \$30.00 per $100 \mathrm{lbs}$. 


\section{MICHELL'S HIGH GRADE FARM SEEDS Prices snbject to Market Changes}

ALFALFA. Choice recleaned seed, sow not less than $1 / 2$ bu. per acre in May, August or September. 25c. 1b. Write for price on larger quantities, as, it changes constantly.

BUCKWHEAT, Japanese. Sow from June Ist to July I5th, one bushel per acre, splendid for poultry food. Qt. I5c., 5oc. per peck, bushel (48 lbs.) \$I.50.

BUCKWHEAT, Silver Hull. Fine for poor ground. Qt. I5c., 5oc. per peck, bushel (48 1bs.) \$I.50.

BARLEY, Beardless Spring. For either hay or grain. Sow broadcast, either $I=/ 2$ to 2 bushels per acre, from May 15 th to July. Peck 50c., \$I.50 bu.

Primus (Sruedish). \$I.00 peck, bush. \$3.25.

BEANS, SOJA OR SOY. Drill $3 / 4$ bushel per acre during May. Hollybrook (Early). Ito Sans (Early). Wilson (Early).

Mammoth Yellow (Late). Soja Bean prices on application.

BROOM CORN, Evergreen. The tops are made into brooms. Sow in May ten pounds per acre in drills. 6oc. peck, bu. \$2.25. CLOVERS. See page 2 I.

COTTON SEED. Attractive and ornamental as a garden plant; grown in the South for a crop. Lb. 20c., 75c for 5 lbs.

FLAX. A very useful farm plant, which can be employed profitably in many directions. Sow a bushel to the acre from May I5th to June I 5 th. If desired for the fibre, sow $\mathrm{I} / 2$ to 2 bushels per acre. Lb. IOc., \$I.I5 per peck, bu. $\$ 4.00$.

CANADA FIELD PEAS. Used principally for green food, or hay for stock and for plowing under to add nitrogen to the soil. Alone, sow 3 bushels per acre; with oats, use $I / 2$ bushel of peas and $I \frac{I}{2}$ bushel oats, broadcast. Peck 65c., $\$ 2.50$ bush.

COW PEAS. A very inexpensive but effective soil regenerator, and indispensable to the farmer. Sow from May Ist to July Ist, 2 bushels per acre, broadcast, or I bushel per acre in drills. It can also be used as green food for grazing in the field, or cut and stored as hay. Florists will find this of value to plow under, as it is better than fertilizer for such plants as carnations, etc., to be set out in the field.

Black Eye. The right sort for fodder.

Whippoorwill. Fine for plowing under.

Wonderful, or Unknown. Good for fodder.

New Era. For soil regenerating.

\section{SEED OATS}

Swedish, or Washington. Sow from April till June, 3 bushels to the acre; good for straw or grain. Peck 4 Oc., $\$$ I.5O bu. Canadian Cluster. An enormous yielder. Peck $45 \mathrm{c}$., $\$$ I.50 bu. Storm King. One of the best, $5 \mathrm{ft}$. high. 6oc. peck, bush. \$2.00. Ligowo II. Swedish, pedigreed. Peck $65 \mathrm{c}$., $\$ 2.50$ bushel.

Welcome. A very popular sort. 35c. peck, bushel \$I.20.

Virginia Gray Winter, or Turf. Principally grown in the South. 40c. peck, bushel \$I.20.
KAFFIR CORN. Sow in June and July, Io lbs. per acre in drills; grain used for feeding poultry, fodder for stock. $40 \mathrm{Oc}$. peck., bushel \$I.5O.

\section{MILLET}

A handy emergency crop for all farmers. Can be sown as late as July I5th. Used as green manure or green food for stock.

Pearl (Pencillaria spicata). Sow Io lbs. per acre. I2c. 1b., Io lbs. \$I.Io.

Tennessee, German or Golden. A heavy cropper, must be sown early. Sow I bushel, broadcast, to the acre.

Hungarian. Of dwarf but very quick growth. Sow I bushel per acre. Price for millets on application.

Japanese Barnyard. Enormously productive. Sow I2 lbs. per acre, broadcast. Ioc. 1 b., Io lbs. 80c., $\$ 7.00$ per IOo lbs.

SPRING RYE. Good for both straw and grain; sow II/2 bushels broadcast per acre. 5oc. peck, bushel \$I.75.

WINTER RYE, Thousandfold. A splendid winter crop; sow $\mathrm{I} / 2$ bushel per acre as late as November. 40c. peck, bu. \$I.35. DWARF ESSEX RAPE. A green food for sheep and hogs. Sow 6 lbs. per acre broadcast or in drills, from April till October. Ioc. per lb., Io lbs. 90c., $\$ 7.00$ per Ioo $\mathrm{lbs}$.

SUGAR CANE Or SOR= G HUM, Ea r ly Amber. Ideal cattle food either in green or cured state. Seed is used for poultry feed. Sow 25 lbs. per acre in drills. Peck 6oc., \$2.25 bushel.

SUNFLOWER, Mam m ot h Russian. Splendid food for poultry; sow Io qts. per acre in drills. 55c. pk., bu. $\$$ r.75.

SPELTZ or EMMER. Used for feeding hogs and poultry; sow 2 bushels per acre, broadcast, after April Ist. 50c. peck, bushel \$I.75.

TIMOTHY. See page 2 I.

TEOSINTE (Reana Luxuri= ans). A forage used extensively on very poor ground. Sow in May and June, 5 to $6 \mathrm{lbs}$. per acre in drills. $75 \mathrm{c}$. 1b., 5 lbs. $\$ 3.50$.

VETCHES, Sand, Hairy or Winter (Vicia Villosa). A fine cover crop for winter and plowing under for green manure; sow I bushel per acre with winter rye in August or September. I5c. lb., bushel (6o lbs.). Price on application.

VETCHES, Spring (Vicia Satic'a). Sow I bushel per acre, broadcast, in May or June. Ioc. lb., Io 1 bs. 75 c., $\$ 3.25$ per bushel (6o lbs.), I00 lbs. $\$ 5.00$.

SPRING WHEAT, Saskatchewan Fife. Used principally.where winter wheat has failed or for green food. Sow $I^{1 / 2}$ to 2 bushels per acre, broadcast, in April or May. 6oc. peck, \$2.25 bushel.

In ordering Farm Seeds always allow 22c. for every twobushel Seamless Bag used. These are returnable for credit or refund at the price charged. 


\section{MICHELL'S "DISTINCTIVE” "FLOWER SEEDS 23}

\section{NOVELTIES and SPECIALTIES in

For General List of Flower Seeds, see pages 29 to 55

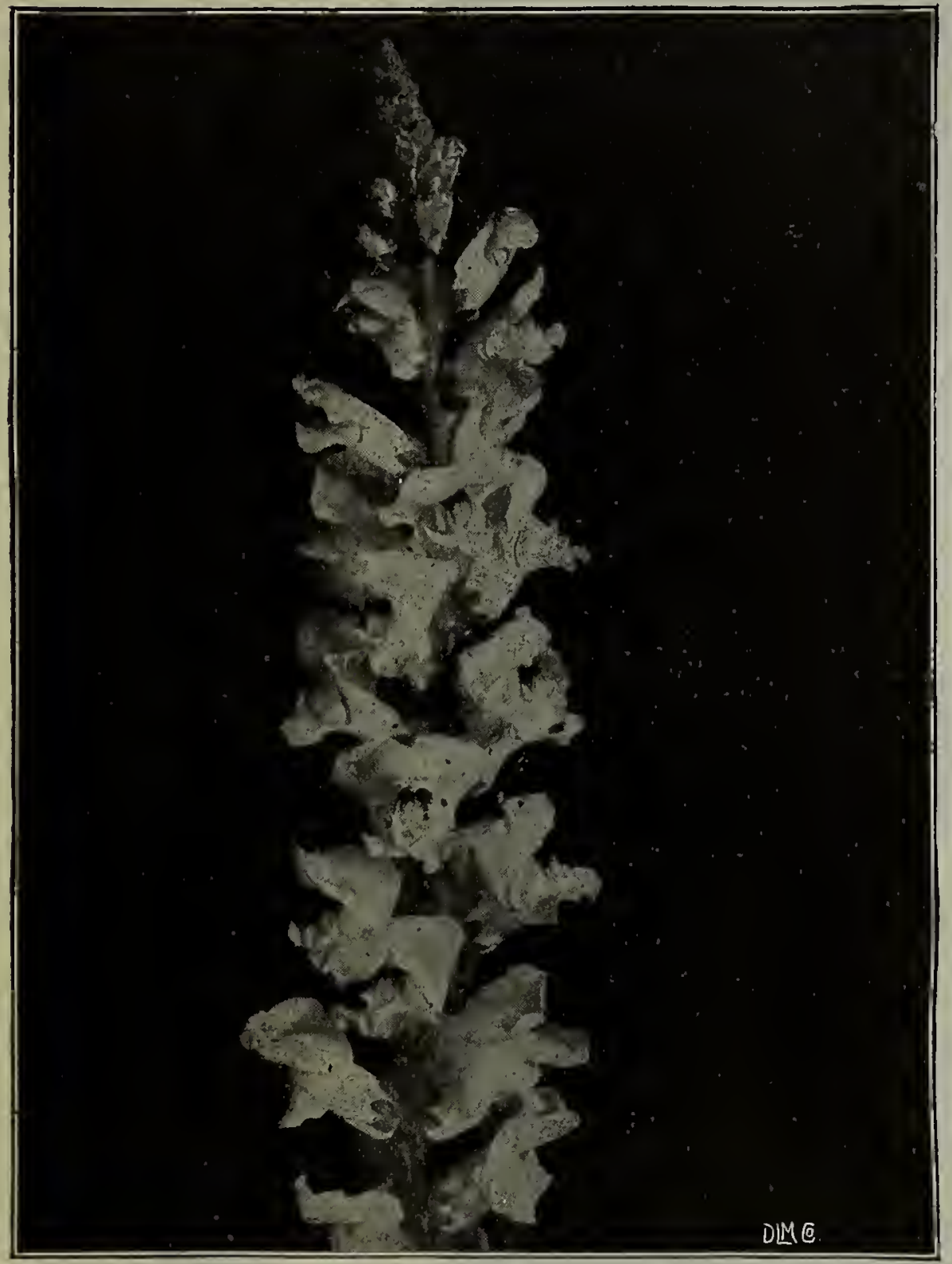

Michell's Giant Snapdragon

\section{NEW GIANT SNAPDRAGON}

\section{Michell's Salmon Pink}

A valuable addition to this popular florist's flower; the plants grow to a height of 2 to 3 feet and produce extra long spikes of flowers; color, a delicate salmon pink. Trade pkt. 30c., \$2.25 per $\mathbf{o z}$.

\section{Giant Double White Antirrhinum} (Snapdragon)

Flowers large and pure white; out of the mouth-like aperture between the upper and lower lips emerge abnormal petals, which give a double beard-like aspect to the blooms. Trade pkt. 30c., $\$ 2.50$ per oz.

\section{Asparagus Hatcheri}

A New Type of Asparagus Plumosus

Of dense and symmetrical growth; dainty fern-like fronds set close together along the stalks, making a full and heavy string; its large fronds and lasting qualities make it valuable for decorative use. As specimen pot plants or for quickly producing beautiful sprays its value is not easily over-estimated. Per IOO seeds $\$ 1.00, \$ 3.00$ per 250 seeds, 500 seeds $\$ 3.25, \$ 6.00$ per 1000 seeds.

We are headquarters for Asparadus Plumosus Nanus. See page 31 .

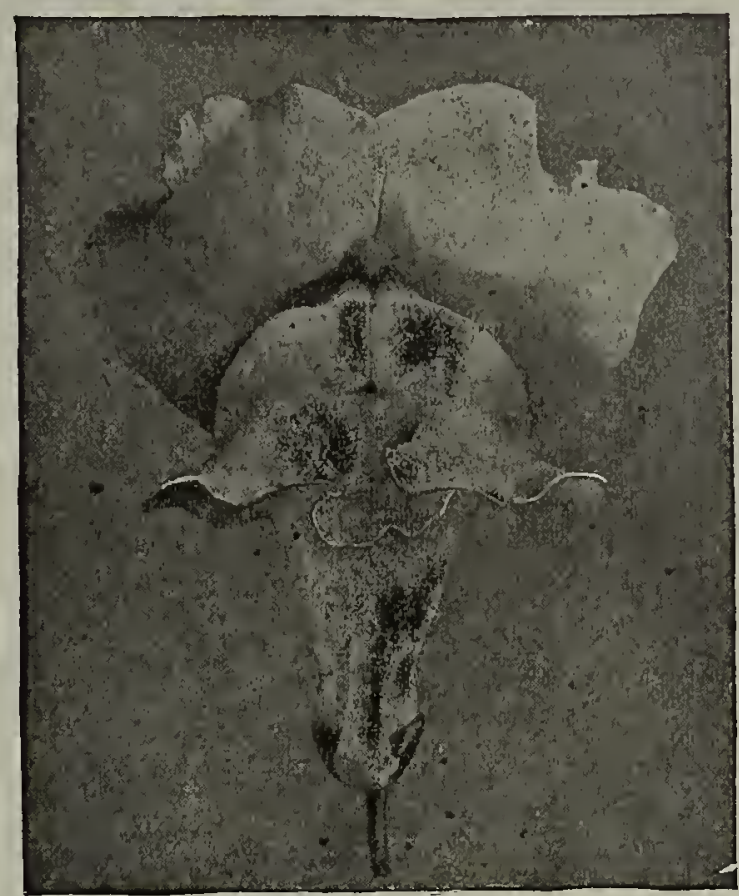

Antirrhinum-Venus

NEW GIANT ANTIRRHINUM

(Snapdragon)

Venus

A new color in the Giant Flowering Snapdragons; a lovely shell pink on white ground, set off by a pure white throat. The long stalks are thickly studded with large flowers of the finest form. This splendid new sort will undoubtedly become one of the most valued. Trade pkt. 30c., \$I.75 per oz.

See page 30 for other varieties of Antirrhinums.

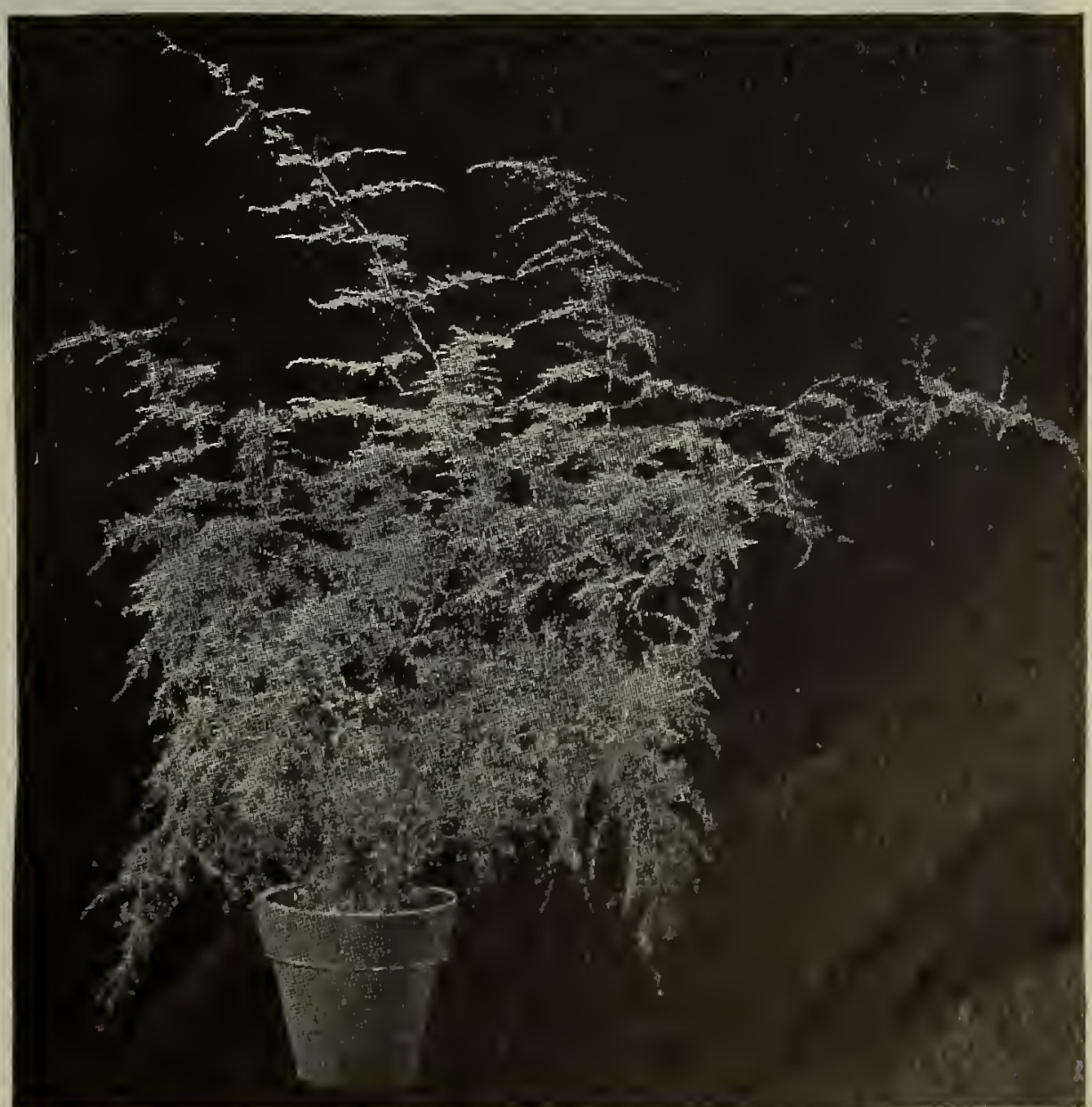

Asparagus Hatcheri 


\section{A PAGE OF VALUABLE ASTERS}

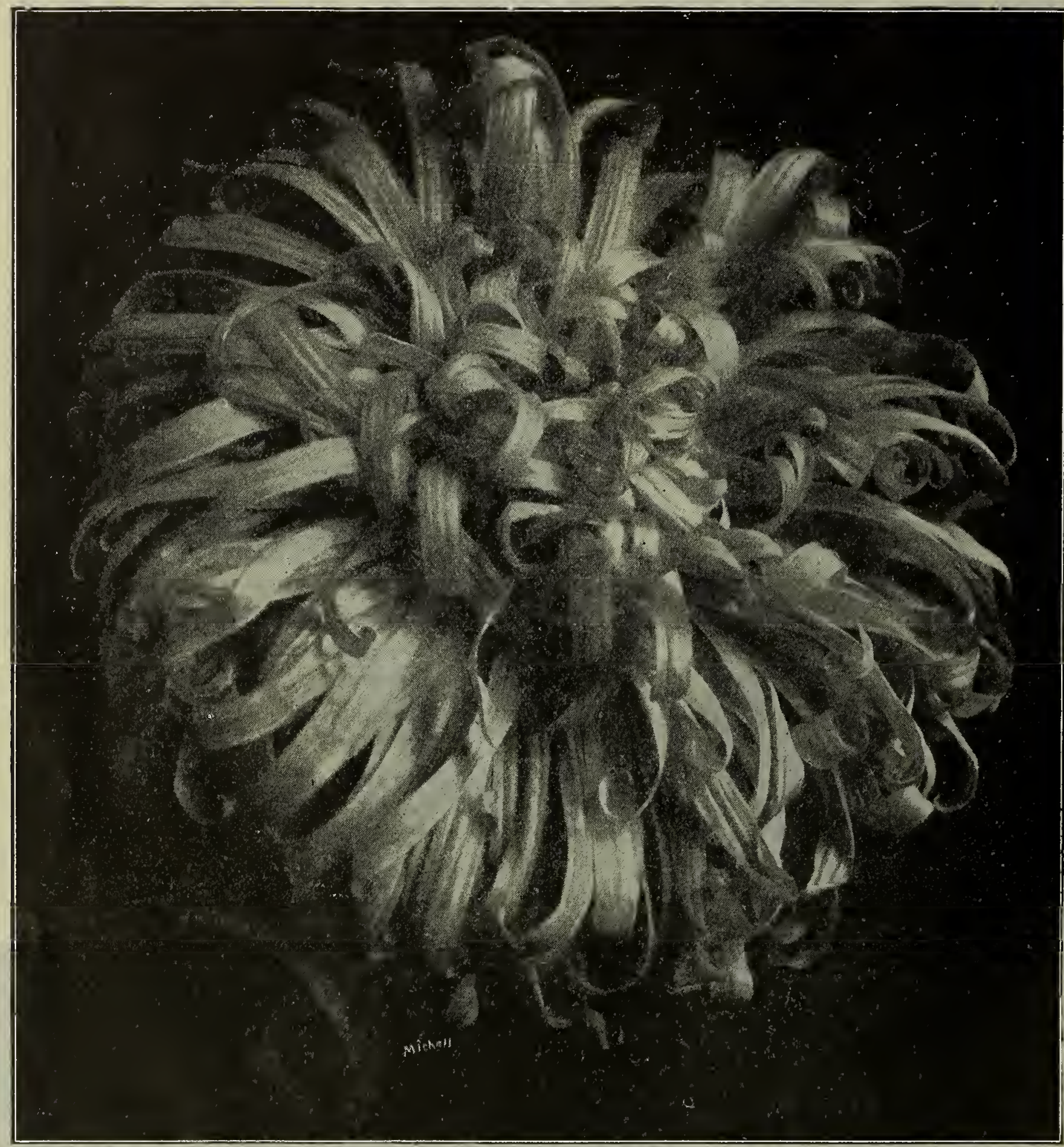

New Astermum
Aster-Vick's Enchantress Pink

A new variety of vigorous, up right, branching habit, with a great profusion of long, strong stems; the beautiful, large double flowers have the delicate pink shade of the Pink Enchantress Carnation. The broad, flat petals give a pleasing soft effect. Per pkt. 20c., 35c. per 2 pkts., 6 pkts. \$1.0o.

\section{Aster-}

\section{Vick's White King}

This new variety will attract the attention of every one who is acquainted with the Violet King. The flow = ers are large, full centered, and pure white; of the same type as Violet King ; plants of branching habit; stems long, I6 to 20 inches; a profuse bloomer. Per pkt. 20c., 35c. per 2 pkts., 6 pkts. \$1.oo.

\section{Aster-New Crego}

One of the finest varieties of Asters, and has rapidly come into popular favor. The flowers are gigantic in size, often 5 inches across, with long, stout stems averaging I5 inches in length. The twisted and curled petals give the flower the appearance of a huge, flat Chrysanthemum. Trade

\begin{tabular}{|c|c|}
\hline White .... & $\$$ pkt. \\
\hline Shell Pink & .40 \\
\hline Rose Pink. & .40 \\
\hline Purple .... & .40 \\
\hline Mixed . & .40 \\
\hline
\end{tabular}

\section{Aster-}

\section{Peerless Pink}

A valuable variety of the late-branching type, although coming into bloom a little earlier; bears a profusion of large, double flowers, of a rich, shell pink color, very similar in shade to the Mary Semple variety. Trade pkt. 50c., $\$ 2.50$ per oz.

\section{New Astermum}

\section{A Glorified Aster-A Splendid New Type}

A new Aster originating in the State of Illinois; a mid-season variety. The plant grows straight up with strong sturdy stems, starting near the base and reaching from 18 to 24 inches, and owing to the symmetry of the plant they may be set more closely than other varieties. Each plant yields from ten to fifteen blooms, large and double, which last a long while after being cut. We offered this variety last season for the first time and have received numerous reports from our customers of the entire satisfaction which it gave.

White

Trade pkt. Oz

Pink $\$ 0.50 \$ 3.00$

Lavender

$.50 \quad 3.00$

Mixed

$50 \quad 3.00$

$.50 \quad 3.00$

\section{Aster-Lady Roosevelt}

One of the finest recent introductions; flowers of marvelous beauty resemble incurved Chrysanthemums; color, a gorgeous pink; stems 30 to 36 inches long; season late. Per trade pki. 50c., $\$ 4.00$ per oz.

\section{Aster-Pink Beauty}

An excellent variety of the Chrysanthemum-flowered type; of strong, upright growth, and producing an abundance of immense, double flowers; inner petals incurved, outer reflexed; color, a soft, delicate blush pink. Trade pkt. 40c., \$2.50 per oz.

Henry F. Michell Co.

Gallitzin, Pa., June I3, I9I3

Dear Sirs:-Dr. S-, of Chester Springs, our county, grew the finest Asters we saw last season, and says he got the seed from you: please send us at once by mail a nice assortment of the finest kinds. Yours truly,

W. H. W. 


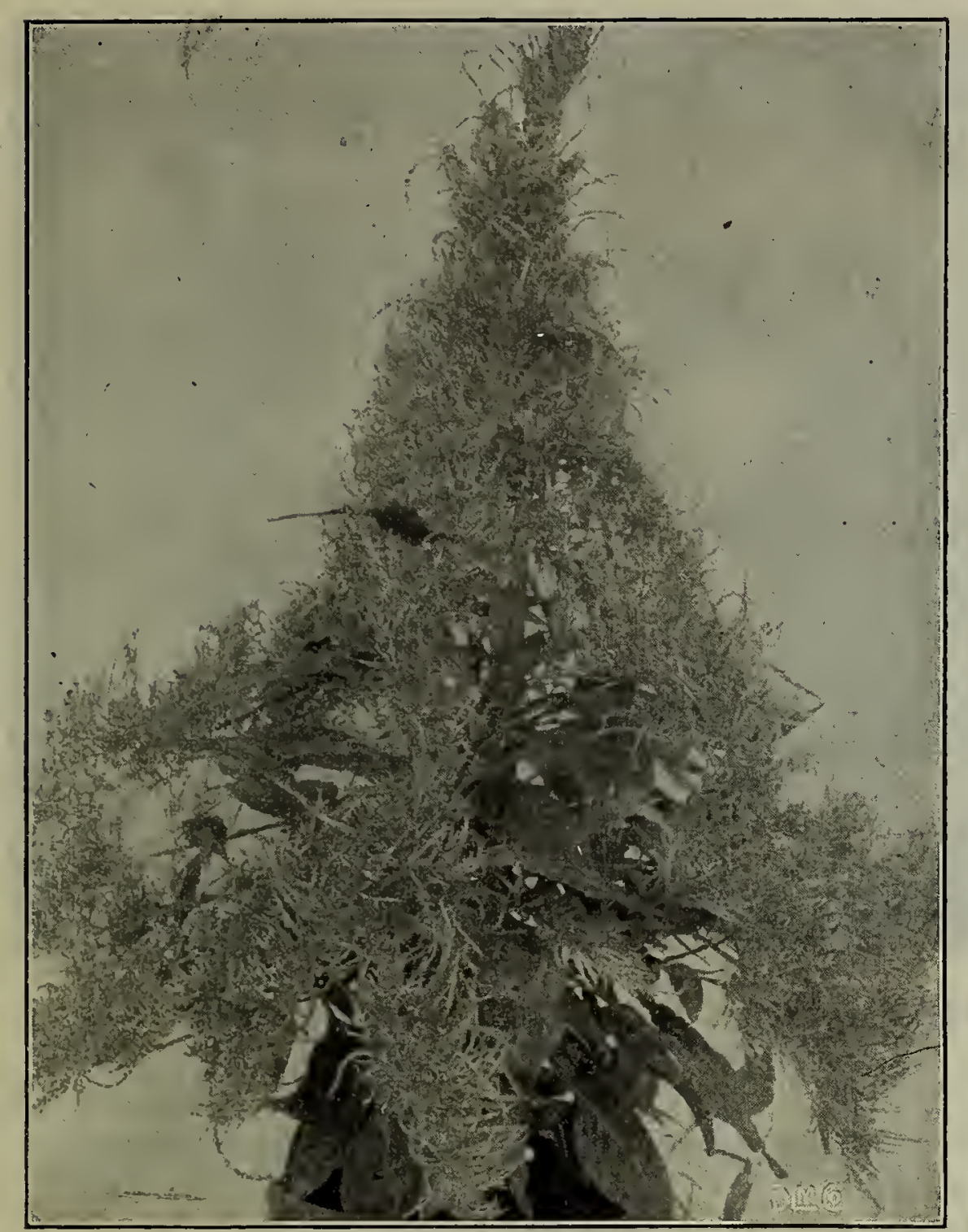

Celosia-Pride of Castle Gould

\section{OSTRICH PLUMED CELOSIA Pride of Castle Gould}

A distinct type of Celosia Plumosa and of great value, both as a pot plant and for bedding. Plants are of pyramidal growth, about 2 to 3 feet high; immense flower heads, closely resembling ostrich plumes; colors are blood red, carmine, yellow, orange, golden, orange scarlet, etc., in mixture. Per trade pkt., 3Oc.

\section{THE CARDINAL CLIMBER \\ (Ipomoea Quamoclit Hybrida)}

A distinct and valuable novelty; the result of a cross between Ipomoea Quamoclit or Cypress Vine and Ipomoea Coccinea. A very rapid grower and free bloomer; leaves dark green and deeply laciniated; bears a great profusion of fiery, cardinal red flowers which are about $1 \frac{1}{2}$ inches in diameter. Per pkt. I5c. ; 4Oc. per 2 pkts.

\section{NEW GIANT FLOWERED CENTAUREAS}

New varieties highly recommended for florists' use; excellent for cutting. The flowers are produced on long, stout stems, and last for a long time after being cut.

The Bride. Pure white............................... Trade Pkt.

The Bridegroom. Purplish mauve.........................

Honeymoon. Golden yellow..........................

\section{NEW GIANT COSMOS-WHITE LADY}

A selection from the Lady Lenox variety; flowers of immense size; pure white; petals broad and overlap each other. Per trade pkt. 30c., \$I.00 per oz.

\section{CYCLAMEN-“MRS. BUCKSTON"}

A new variety with beautifully frilled and waved flowers, which are of large size, often measuring $2^{\mathrm{T}} / 2$ to 3 inches across, and are produced in great abundance; color, delicate salmon. Per original pkt., $75 \mathrm{c}$.

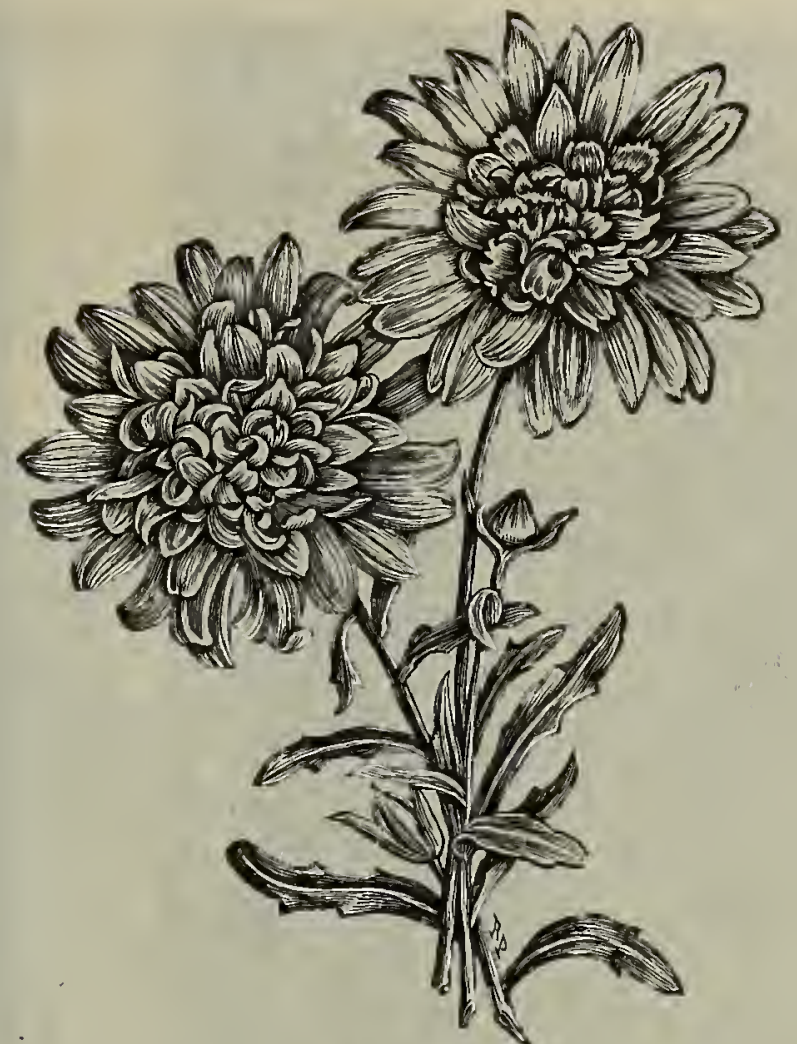

Dimorphotheca Aurantiaca Hybrida Fl. pleno

NEW DOUBLE AFRICAN DAISY

(Dimorphotheca Aurantiaca Hybrida Fl. pleno)

A new addition to this popular flower recently introduced; produces an abundance of double and semi=double flower's in many rich and varied shades, ranging from white to light and dark yellow, and from salmon rose to orange. Per pkt., 20c.; 55c. per 3 pkts.

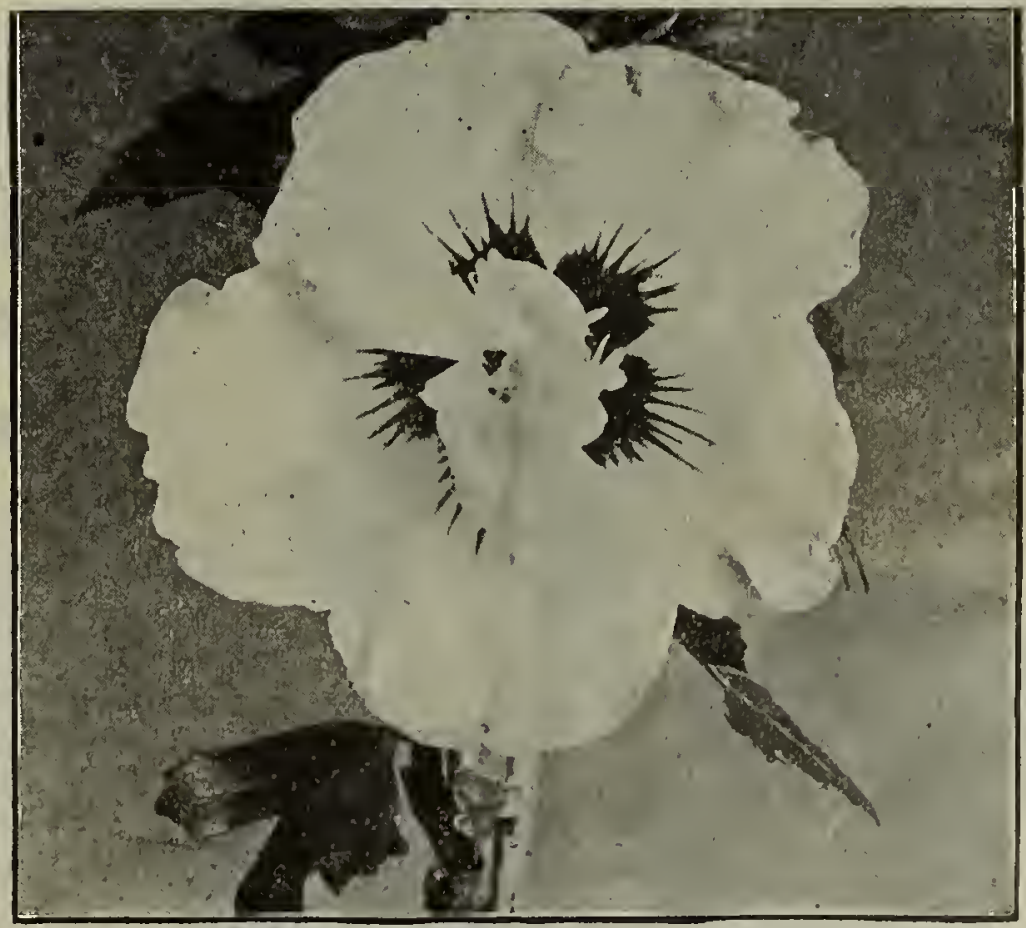

New Giant Hibiscus

\section{NEW GIANT HIBISCUS Mallow Marvels}

One of the most attractive perennials, flowering the second season from seed; grows to the height of 5 feet, bearing gigantic single flowers, 7 inches in diameter in many shades of red, pink, purple and white. The flowers resemble an open bell, face forward, and show their attractive yellow piston in the centre; blooms from July until frost. Per trade pkt., 30c.; $75 \mathrm{C}$ per oz. 


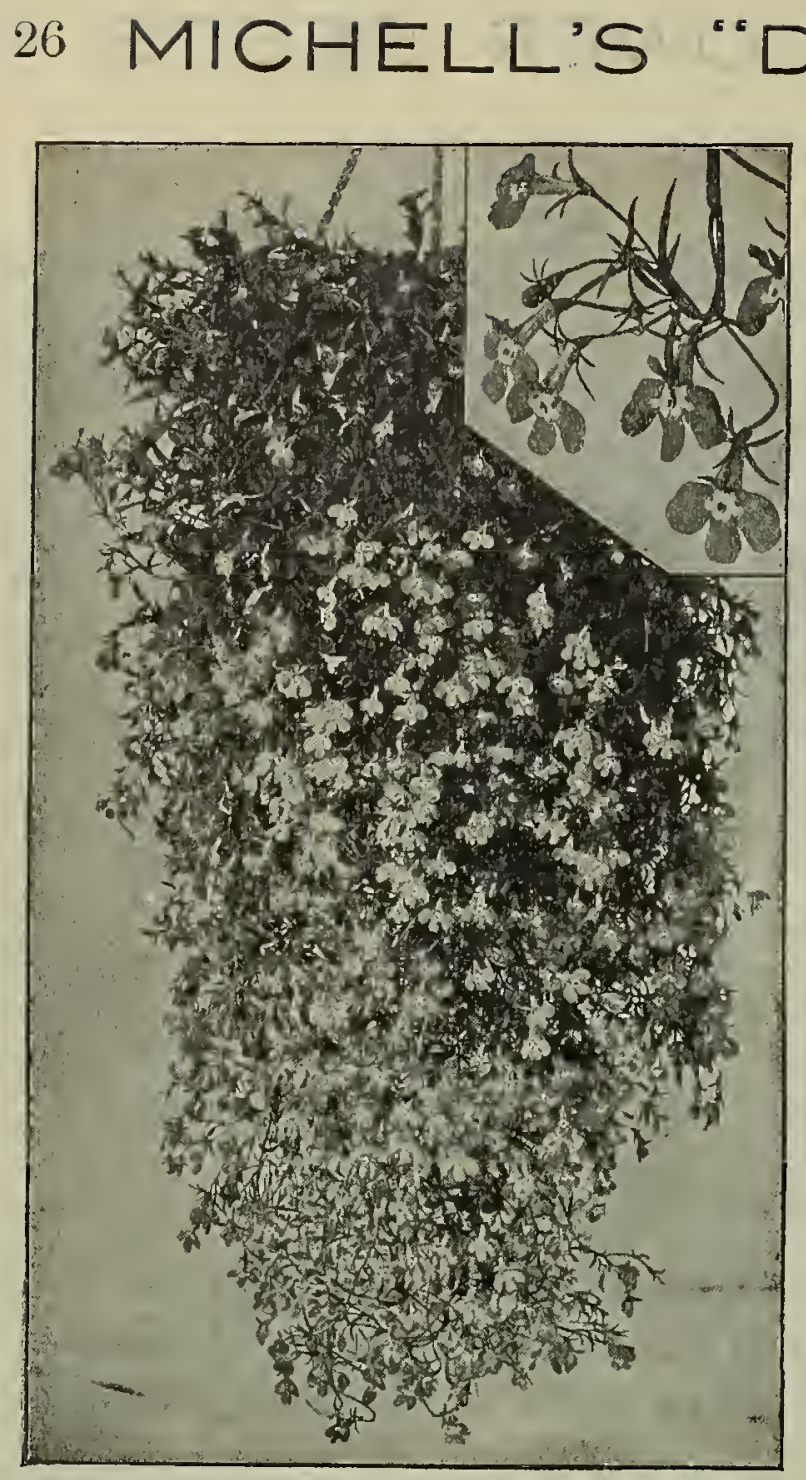

\section{Lobelia Hybrida-Sapphixe LOBELIA HYBRIDA ss Sapphire"}

This new trailing variety is of remarkably strong growth; the flowers are unusually large for a Lobelia, measuring three=quarter inch across, and are thickly set on the long, graceful sprays of foliage; color of flowers intense deep blue with large and clearly defined white eye. A well-grown plant covered with these lovely blue oculate flowers makes a splendid sight.

Per pkt. I5c.; 40c. per 3 pkts.

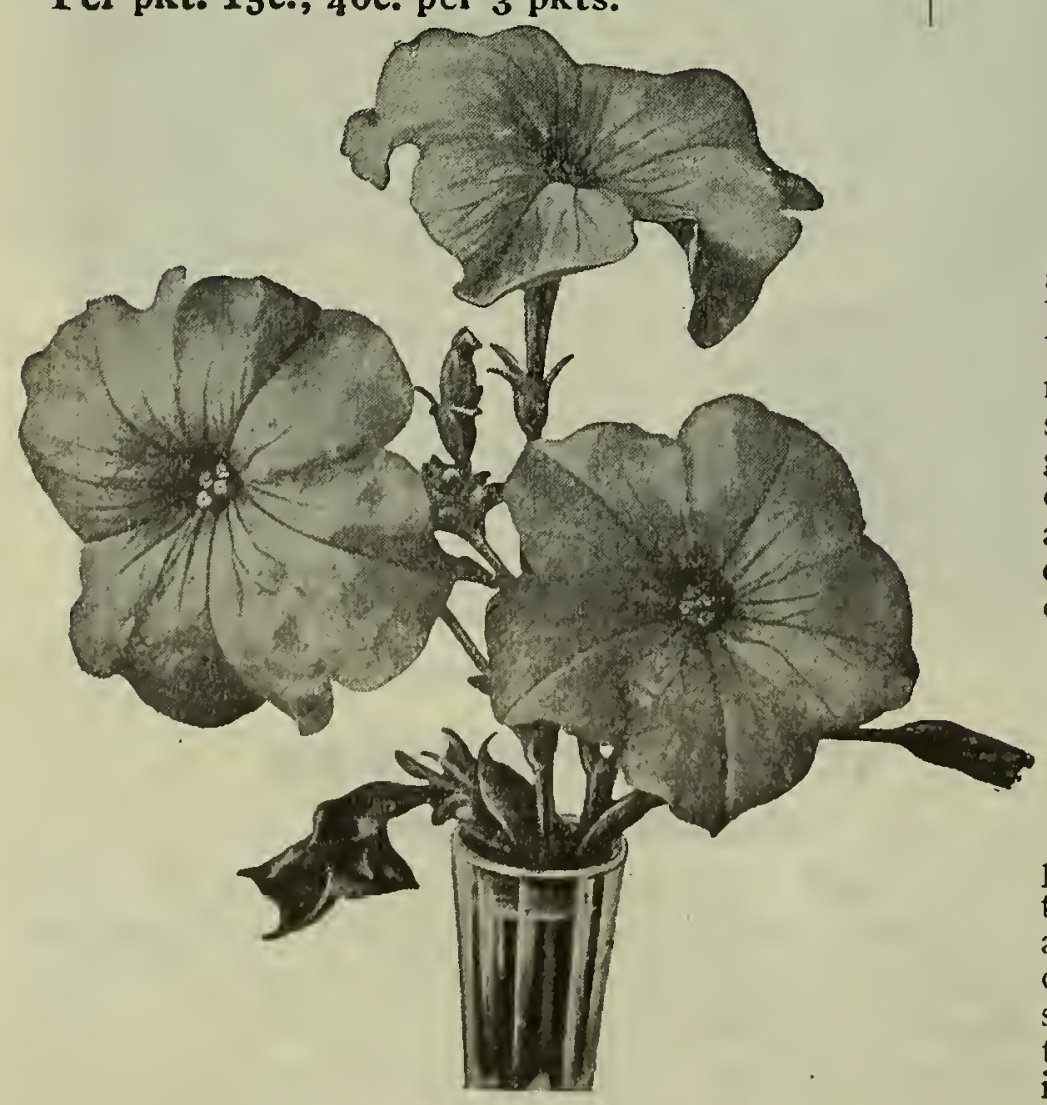

Petunia Hybrida-Undine
STINCTIVE" FLOWER SEEDS

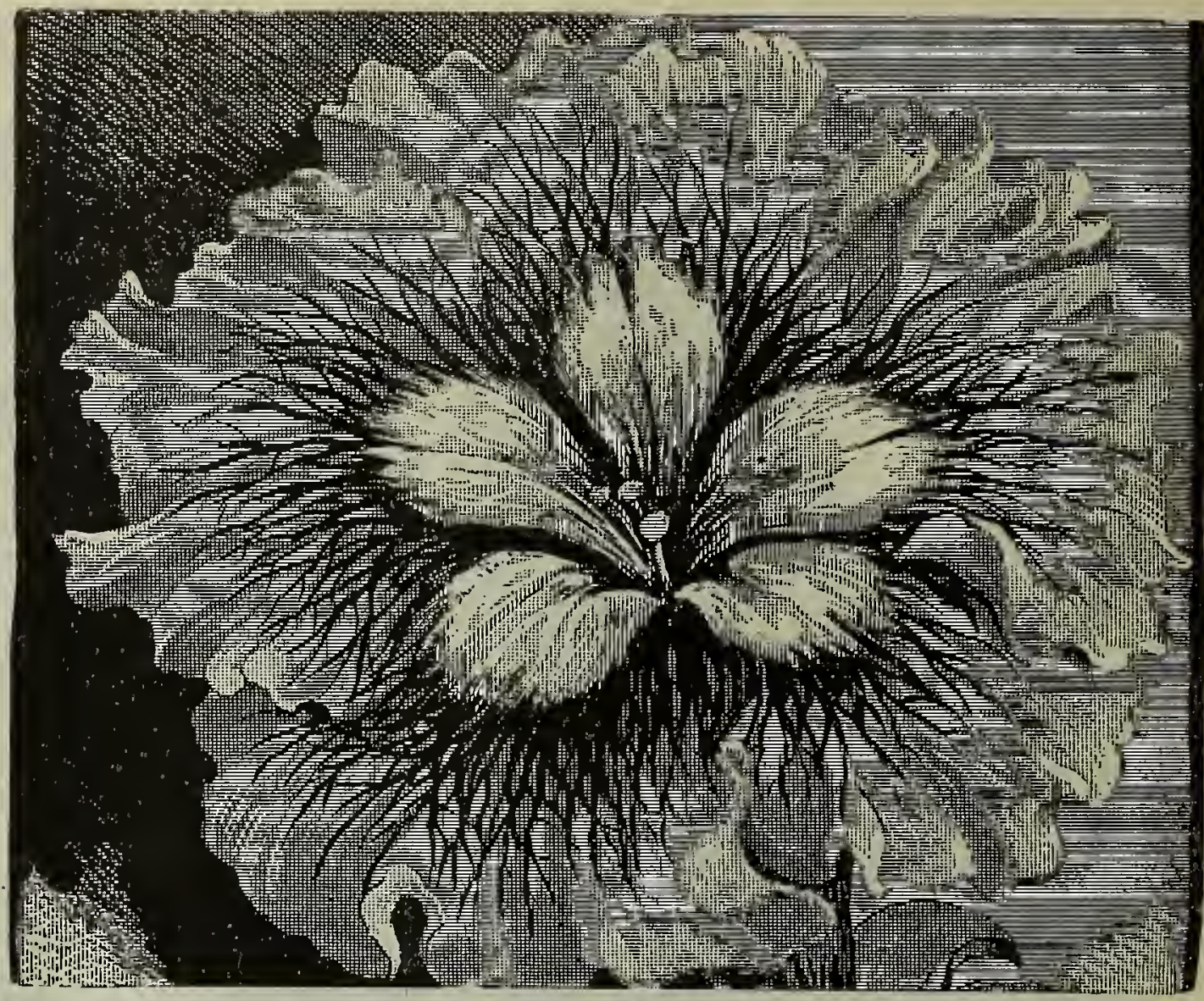

Petunia-Michell's Monstrosus

NEW LARGE FLOWERING PETUNIA Michell's Monstrosus

A great acquisition to the list of Large Flowering Petunias, surpassing the well=known Giants of California. The flowers are extremely large, quite a number of which are elegantly fringed; the colorings, markings, veinings, blotches, etc., are superb; many of them having deep throats of various shades.

Per $1 / 2$ trade pkt. 6oc.; $\$$ I.0o per trade pkt.

\section{GIANT EVENING PRIMROSE}

\section{Denothera "America"}

Flowers extra large; snow white when opening in the evening, changing in the morning to a delicate pink.

Per trade pkt., $40 \mathrm{c}$.

\section{PENTSTEMON \\ Large Flowering White (Pentstemon Hartwegi Albus)}

The plants of this fine new variety attain a height of about $2 \mathrm{I} / 2$ feet; they branch freely from the base, develop a brilliant green foliage and throw up numerous flower spikes, all thickly studded with large open=throated gloxinia=like blooms one to one and one-half inches across; the buds at first are of a creamy color, but change to a clear white when opening. It blooms early and continues for a long time.

Per pkt. 20c.; 55c. per 3 pkts.

\section{NEW BLUE PETUNIA "Undine"}

A new light blue Petunia of incomparable beauty and luxuriance, and therefore very valuable as a pot plant, as well as for garden beds; also excellent for window boxes, etc. The surpassing charm of this variety lies in the particular azure color which merges to the lilac margin.

Per pkt. 20c.; 55c. per 3 pkts.

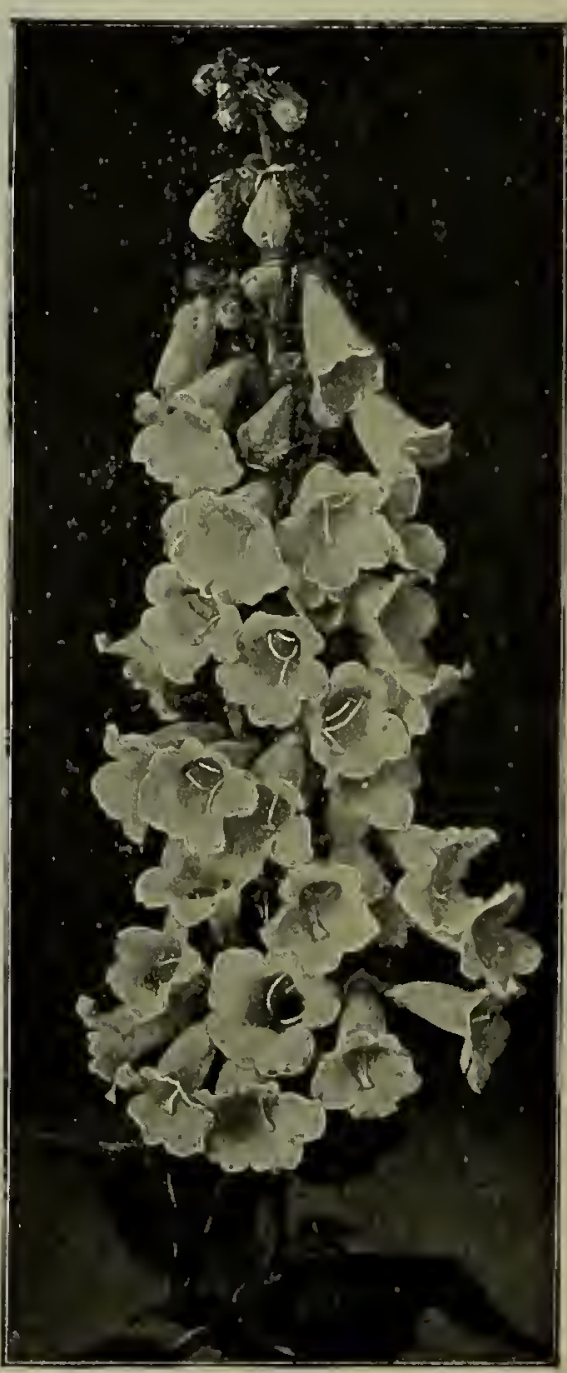

Pentstemon Hartwegi Albus 


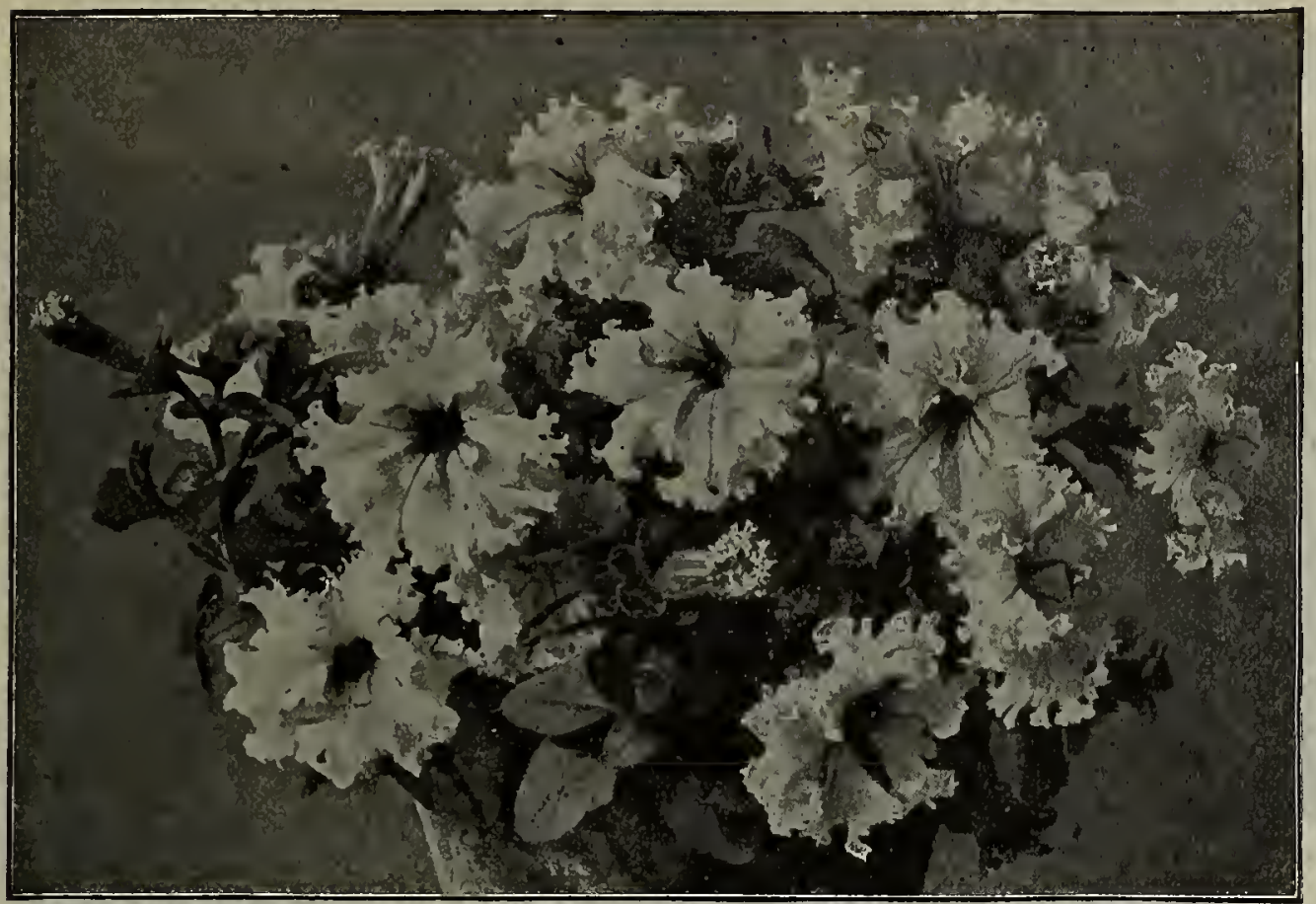

\section{PRIMULA OBCONICA GRANDIFLORA "Crispa"}

An entirely new form of this splendid plant, the edges of each flower being fringed and creased; fully developed flower clusters have, therefore, a double appearance, and an elegance which cannot readily be duplicated; the flowers are of extra large size; color, from delicate apple blossom pink to deep pink. Per pkt., 20c. ; 55c. per 3 pkts.

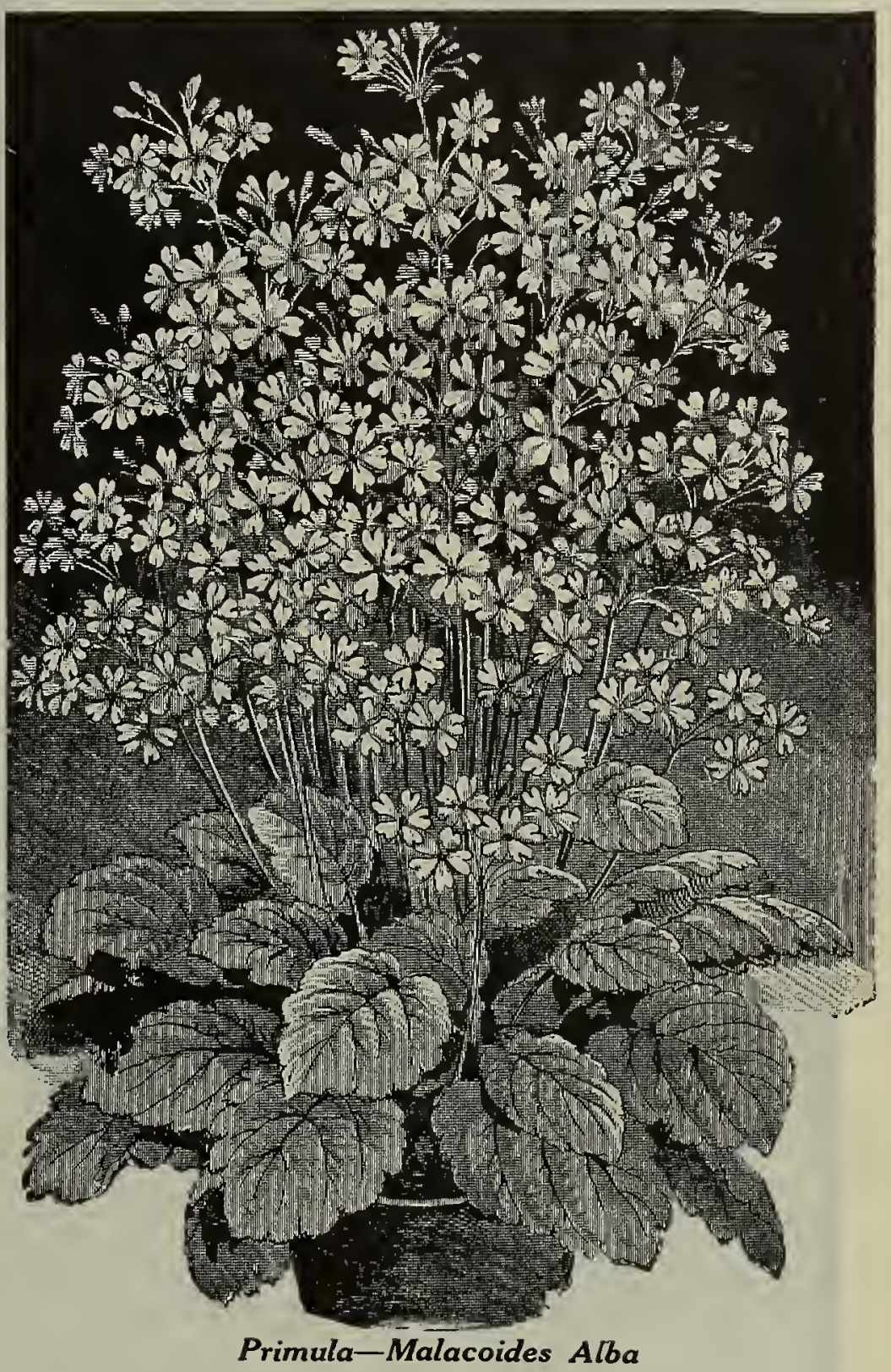

\section{PRIMULA "MALACOIDES"}

This new and pretty variety introduced from China two years ago has proved to be one of the freest-flowering species for pots and is, in consequence, already widely cultivated. The seedlings bloom in four to five months after sowing; resembles Primula Forbesi but its growth is much more sturdy, and the flowers which are borne in whorls on long stems are much larger; color, a pretty light lilac. Per trade plit., 50c.

\section{PRIMULA-MALACOIDES ALBA}

This new variety produces pure white flowers; it is equally as handsome as the lilac type form described above, and will, no doubt, soon achieve a similar share of popular favor. Per pkt., 20c.; 55c. per 3 pkts.

Schizanthus-Bridal Vel

\section{SCHIZANTHUS-BRIDAL VEIL}

A new variety selected from the hybrids of Schizanthus Wisetonensis. Plants grow about 16 inches high, are compactly formed and literally covered with glistening snowy white blossoms, which present a striking contrast with the bright green of the finely laciniated foliage. Excellent as a pot plant. Per pkt., 25 c. ; 65c. per 3 pkts.

\section{NEW SALVIA (Scarlet Sage)}

Michell's "Scarlet Glow"

A new variety of great merit; an improvement on the wellknown and popular $Z$ urich; larger flowers and more free blooming than any other variety; plants of dwarf habit, branch freely, and are covered with flowers of the most brilliant fiery scarlet; blooms very early and continues until frost. Per trade pkt., 50c.; $\$ 1.00$ per $1 / 4$ oz.; per oz., $\$ 3.50$. 
King White A "perfect" white Spencer form, size, and substance to all others of this color; flowers are of good substance, standards of immense size, bold expanded form and ex= quisitely waved. An extremely vigorous grower; very floriferous, and gives a large proportion of four-flowered sprays. It received an Award of Merit from the National Sweet Pea Society of England, July, I9I2; also Certificate of Merit at the Sweet Pea Show in Philadelphia, June 26, I9I3.

Original pkts. (I5 seeds) ............... \$0.12 Original pkts. ( 30 seeds)

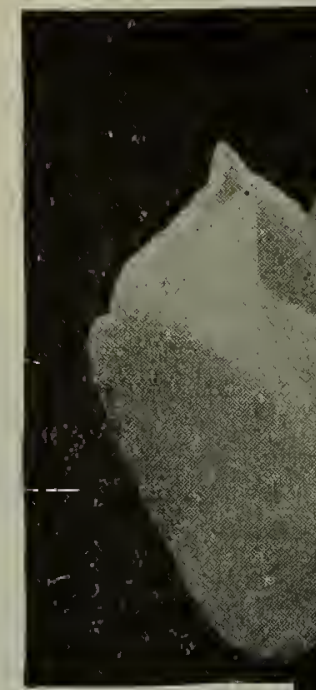

IIuminator The most charming color colors, yet seen in Sweet Peas, and very difficult to describe. The blooms, which are carried on

long, stout stems, have a ground color of a warm salmon orange overlaid with rich bright cerise pink. The flowers are of great substance; standard bold, expanded and attractively waved.

Original pkts. (I2 seeds).\$0.12 Original pkts. (25 seeds). $\$ 0.20$ Wedy WoOd This new variety is appropriately named, as Wedgwood blue. The flowers, which are produced in great profusion, are borne mostly in "fours," well placed on long, stout stems. Of finest Spencer form; the standard and wings are well waved. Original pkts. (12 seeds).\$0.12 Original pkts. (25 seeds).\$0.20 Empress Eucenie This beautiful novelty was awarded a Empress Lugene Certificate of Merit by the American Sweet Pea Society, June 29, 19II, but owing to its shy seeding character was not introduced until this season. The color is a delicate tone of light gray, flaked with light lavender. The flowers are of large size, beautifully waved and crimped. A vigorous grower and. free bloomer with a large proportion of four=flowered sprays.

Original pkts. ( 15 seeds).\$0.I2 Original pkts. (30 seeds). $\$ 0.20$

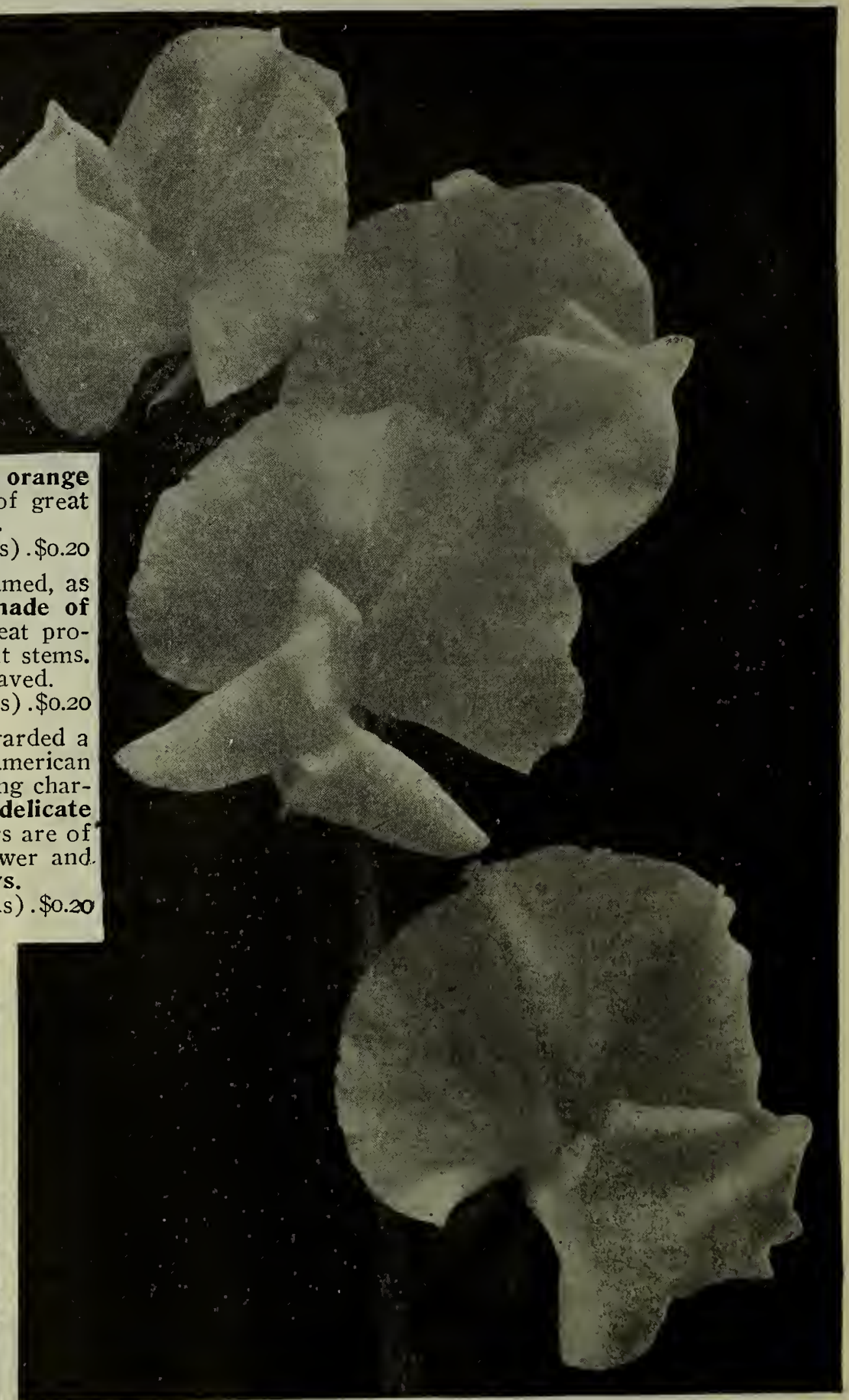

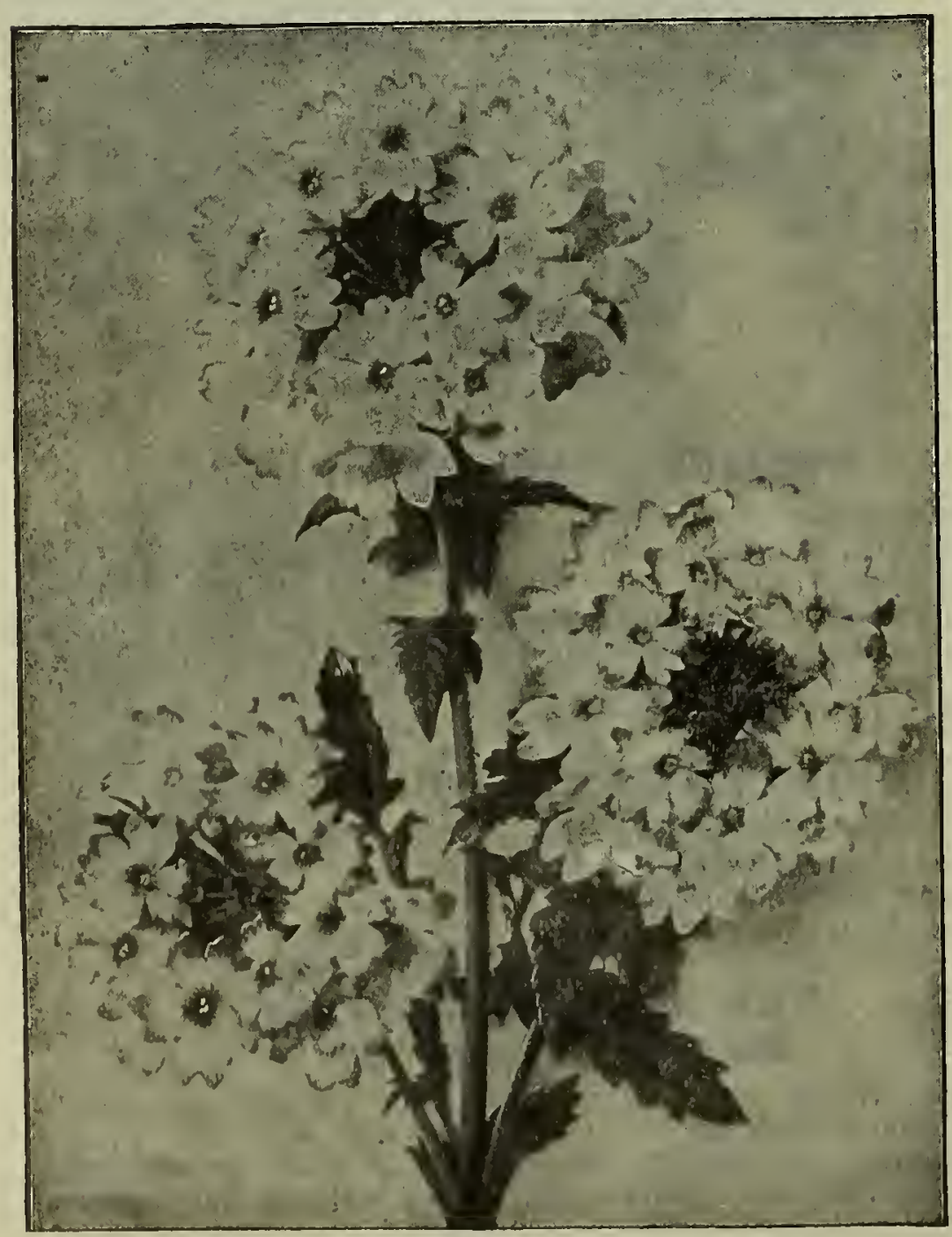

Verbena Hybrida Compacta, Dornroschen
An Average Spray of KING WHITE-Reproduced from a Photograph

\section{Verbena Hybrida Compacta "Dornröschen"}

A new variety of dwarf compact growth, especially valuable for planting for low groups or for borders. Bears a great profusion of large flowers; color, white with a soft carmine rose edge, giving to the plant a particularly nice aspect. Per pkt. 20c.; 55c. per 3 pkts.

\section{Verbena-"Helen Willmott"}

After many years of constant selection, sced of this Verbena has at 'ast been saved in sufficient quantity to be offered for sale A large percentage of the flowers are of the true "Helen Willmott" color, 2 pretty bright salmon rose, with white eye. Per pkt. 20c.; 55c. per 3 pkts. 


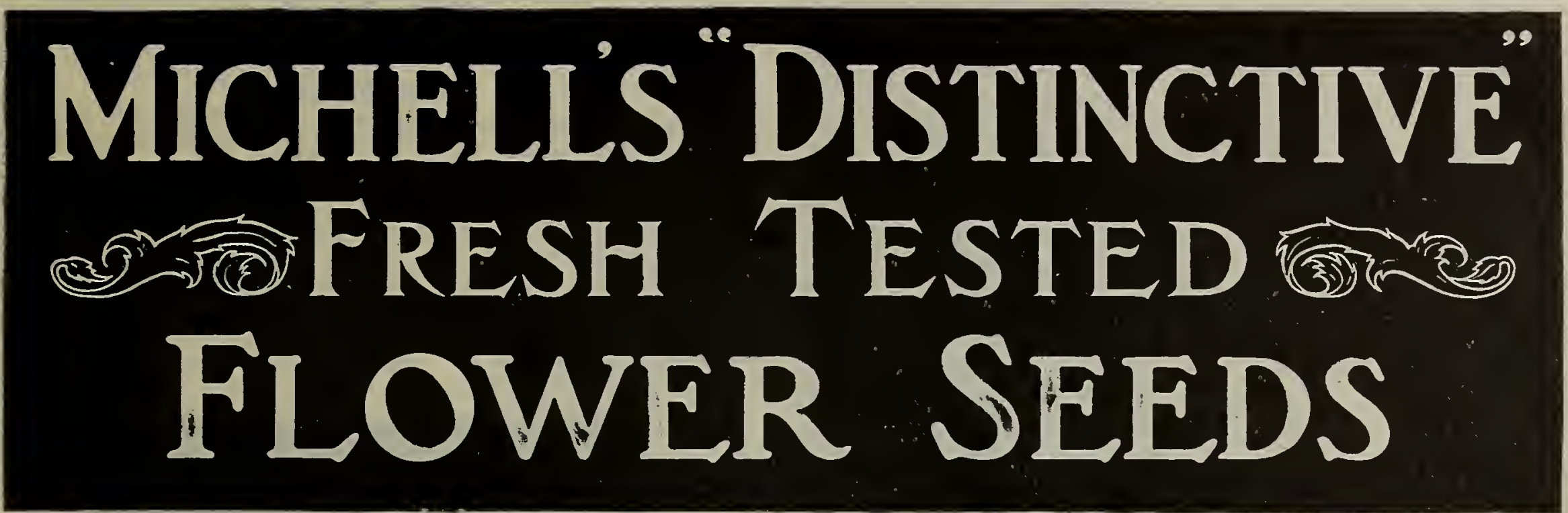

"Distinctive" Strains of Flower Seeds for the florist is one of the most important branches of our business; we constantly aim to secure for the florist only the most improved strains such as must give perfect satisfaction. Our wonderfully increased trade is our best proof for this claim.

For full description see our Retail Catalogue, a copy of which will be mailed free upon application.

Note-Half trade packets are only supplied where listed; where smaller quantities are wanted than that listed, retail packets may be ordered at a discount of $33 \mathrm{I} / 3$ per cent. from our retail catalogue prices.

\section{Abutilon (Flowering Maple)}

Used extensively for ornamental bedding. Trade Pkt. Is Choicest Mixed

\section{Achillea}

Perennial, flowering continuously all summer. 20 Ptarmica, fl. pl. "The Pearl." Double White . . .25

\section{Aconitum (Monk's Hood)}

Tall growing bushy perennial, flowering in July.

25 Napellus, Blue.

\section{Acroclinium (Everlasting)}

33 Single Mixed

\section{Adlumia (Allegheny Vine)}

A perennial vine with fern-like foliage.

37 Cirrhosa.

\section{Adonis}

42 Vernalis $(O x E y e)$. Hardy perennial; yellow.... .IO

\section{Ageratum (Floss Fower)}

Used for bedding and grown extensively by florists in pots for spring sales.

50 Blue Perfection. The most popular sort of all

Dark blue, height I2 ins, compact showy plant.

6I Little Blue Star. Dainty little plant; very dwarf. 54 Imperial Dwarf Blue. Height, 8 inches...

56 " “ " White. Height, 8 inches.

58 Cope's Pet. Blue; compact dwarf plant.

62 Princess Victoria Louise. Blue, white centre.

60 Grandiflorum Album. Tall, pure white.

\section{Agrostemma (Mullein Pink)}

66 Coronaria. Hardy perennial, with glaucus foliage, and deep crimson flowers..........
Alyssum

II Little Gem. Our strain of this popular sort is quite distinct, very dwarf, compact and absolutely true from seed............. I/4 lb., \$I.50 74 Little Dorritt. Even more compact than Little Gem and desirable for a pot plant...............

73 Sweet (Alyssum Benthami). The well-known fragrant white.................. Per lb., \$I.50 j2 Saxatile Campactum. Perennial; golden yellow.
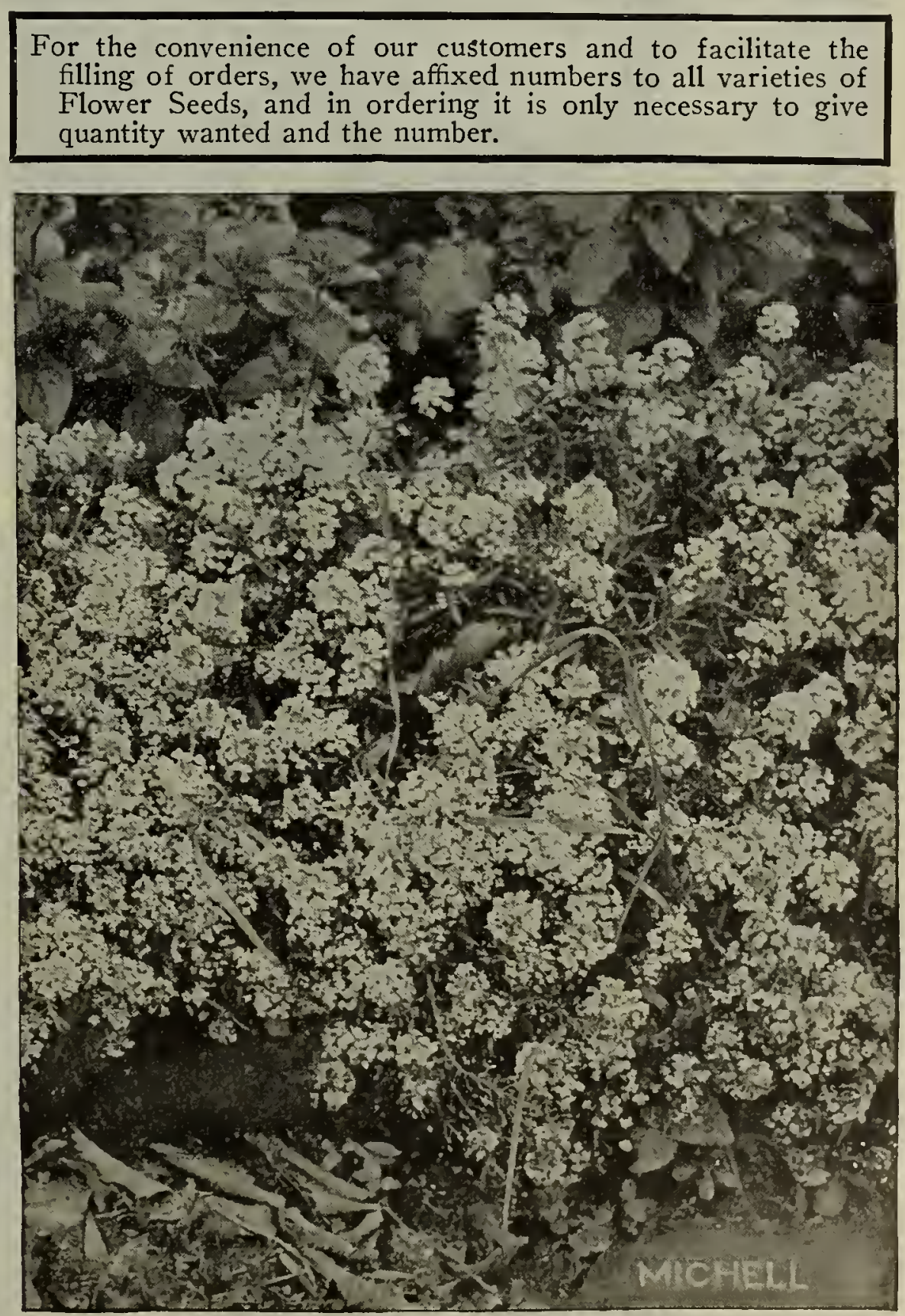

Alyssum-Little Gem

\section{Amaranthus}

Fine ornamental foliage plants.

80 Caudatus (Love-Lies-Bleeding).

86 Sunrise. Brilliant carmine

88 Tricolor Splendens (Josepli's Coat). Various col-

go Mixed l...... 


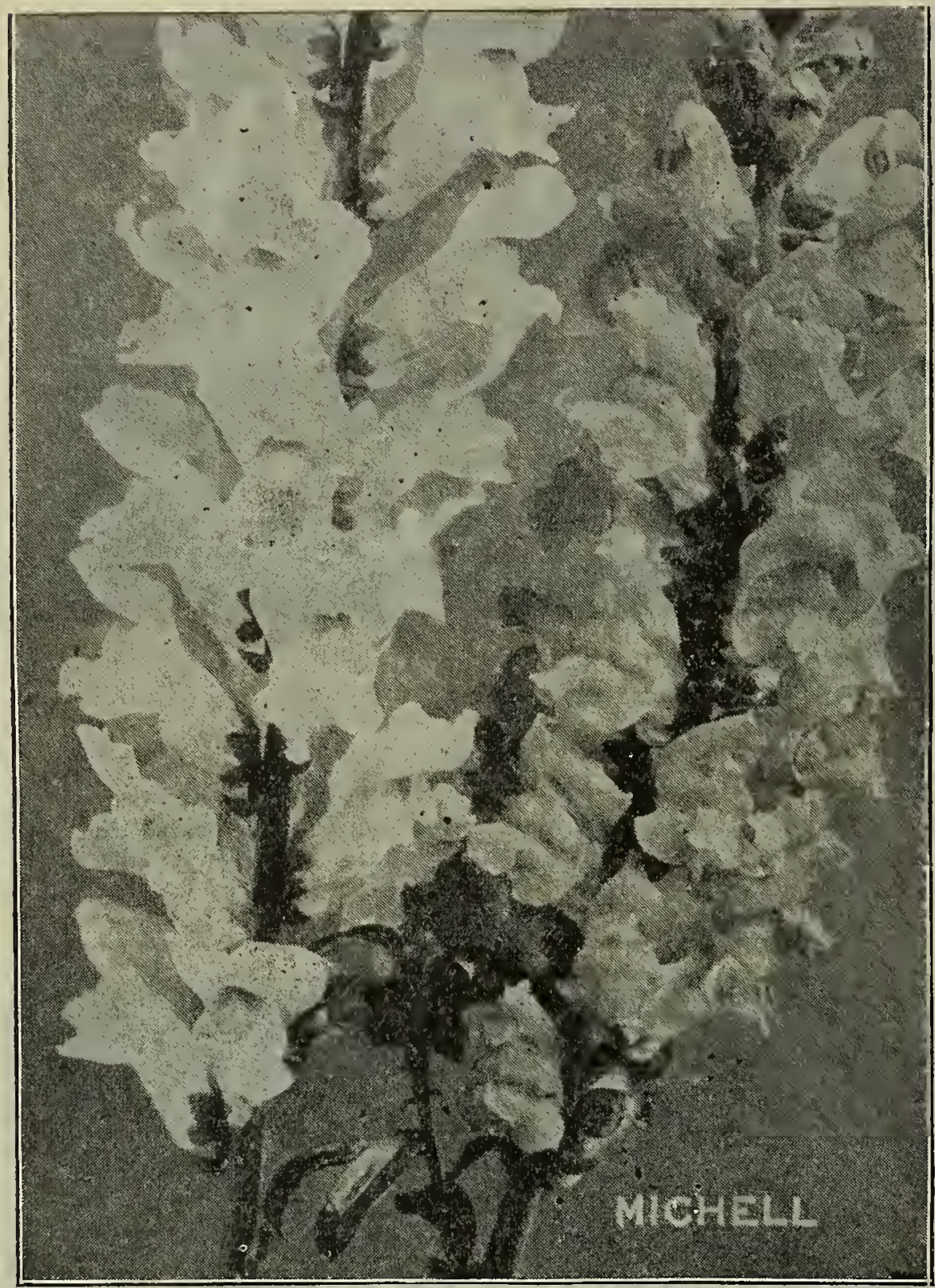

Giant Snapdragon (Antirrhinum)

\section{Antirrhinum (Snapdragon)}

\section{Michell's Giant Strain}

This "distinctive" strain is grown by many leading florists as a profitable cut flower during winter; spikes 2 to 3 feet tall with fully one-third a compact mass of giant flowers; colors clear and delicate.

I27 Michell's Giant Salmon Pink. A valuable Trade addition to this popular flower; extra long Pkt. Oz. spikes of flowers of a delicate salmon pink color.\$0.30 $\$ 2.25$

Iog Silver Pink $(N e w)$. An extra fine variety;

long spikes and a very profuse bloomer. Original pkts., \$I.00; $\$ 2.50$ per 3 pkts.

I 3 Giant Pink

I 4 " Scarlet

I2I “ Striped

II5 “ White

II6 “ Yellow

II7 “ Mixed

I25 “ Double White $\left(\hat{N} e z^{\prime}\right)$. Flowers large

I26 “V and double; color, pure white.... color, shell pink on white ground, with pure white throat

\section{Antirrhinum, Various Sorts}

I22 Tall Mixed. Regular strain; 2 feet........... . . I I Semi=Dwarf Daphne. Pink, I 8 inches........ .20 IIO " " Defiance. Fiery scarlet........... .20 II9 " "Golden Queen. Yellow............ . I5

120 " Queen of the North. White...... .I5

I 8 " Mixed $\ldots \ldots \ldots \ldots \ldots \ldots \ldots \ldots \ldots$. I

II 2 Tom Thumb Mixed. I2 inches.

\section{Ampelopsis}

Trade Pkt. Oz

Ioo Veitchi (Japanese Ivy). (Per 1b., \$1.50).......\$0.Io \$0.I5

\section{Anchusa}

I02 Italica, "Dropmore Variety." Perennial ; branch-

ing plant, 4 feet; light blue flowers........... .30 $\quad$ I.25

\section{Anemone (Windflower)}

Hardy perennial; excellent for cutting

105 Coronaria Mixed. The French Anemone....... . I5 50 I07 St. Brigid. The Irish Anemone............ .30 I.25

\section{Anthemis (Hardy Marguerite)}

I08 Tinctoria Kelwayi. Daisy-like bright yellow flowers; perennial ..................... . . .30

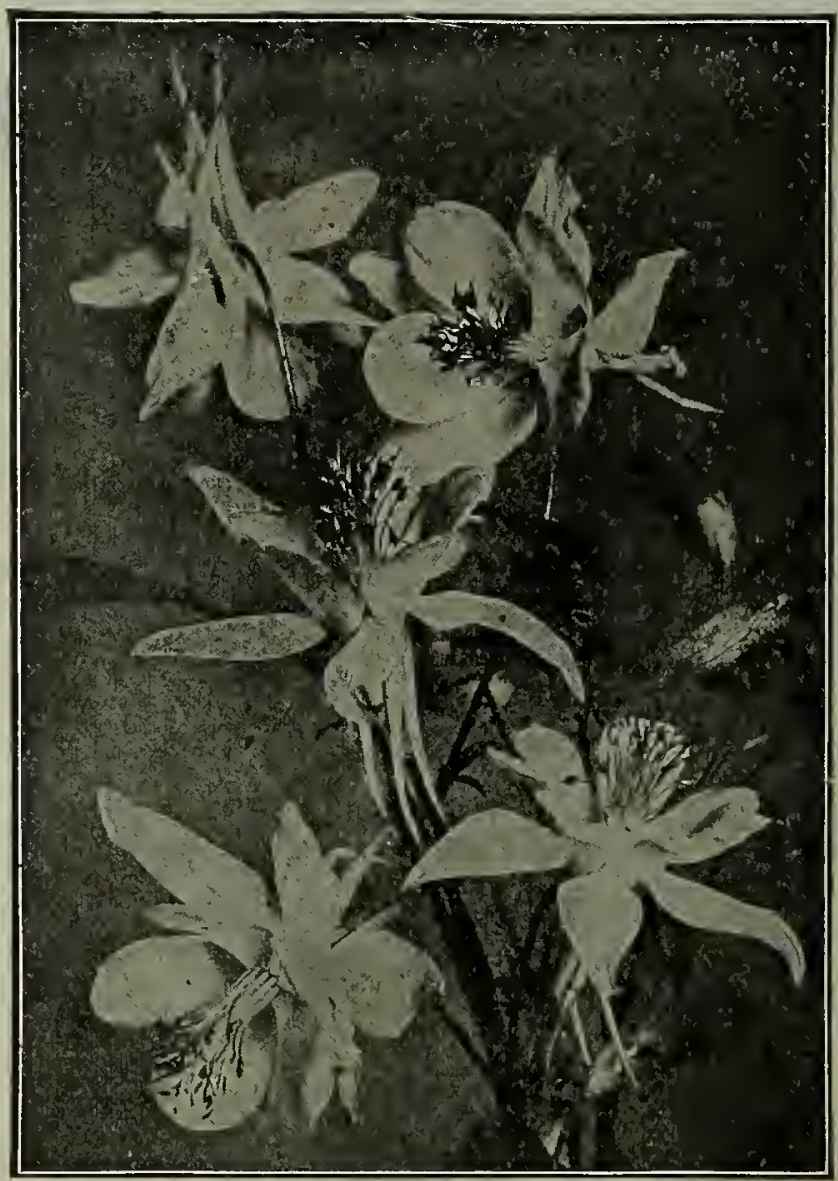

Aquilegia-Long Spurred

\section{Aquilegia (Columbine)}

These early flowering perennials are a valuable cut flower and the demand for same is constantly on the increase.

I39 Long Spurred Hybrids. A splendid Trade Pkt. Oz. I29 Canadensis. Scarlet and yellow.............20 I.00 I30 Chrysantha. Yellow .................... .20 I.00 I3I "Alba. Pure white................ I 28 Californica Hybrida. Mixed colors............ .20 2000 I32 Coerulea. Blue and white.................30 I.50 I 40 Flabellata Nana Alba: Dwarf white.................. I36 Glandulosa Vera. Lavender and white............ .30

I33 Haylodgensis Delicatissima. Delicate pink.... .40

I37 Nivea Grandiflora. Pure white.............. . .

I38 Rose Queen. Deep rose .................. .40

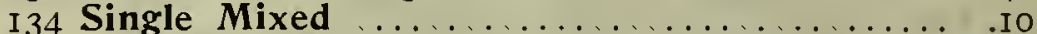

I35 Double Mixed ........................ . .

\section{Arabis (Rock Cress)}

I44 Alpina. Perennial; dwarf edging plant; flowers pure white ..........................

Arctotis (African Daisy)

I50 Grandis. Splendid annual for cutting; bluish

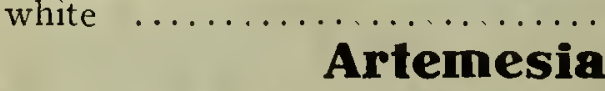

I52 Saccorum Viridis (Summer Fir). A new annual foliage plant. Per pkt. I5c.

ARUNDO. See Grasses, page 40 


\section{MICHELLS FLOWER SEEDS $\frac{518}{\text { MaRki ST PHILA. }} 31$}

\section{ASPARAGUS PLUMOSUS NANUS}

We are Headquarters for the true Northern Greenhouse Grown Strain.

Our seeds are absolutely fresh and of high germination; our greatly increased sales each season proves beyond a doubt the superiority of our stock.

I60 Greenhouse Grown Seed

I00 seeds....\$0.50| 5,000 seeds... \$I 5.00 I,000 seeds... 3.25 I0,000 seeds... 29.00 25.000 seeds.....\$70.00

I6I Lathhouse Grown Seed

\begin{tabular}{ll|l} 
I 00 seeds.... $\$ 0.35$ & 5,000 seeds... $\$ 12.00$
\end{tabular} $\mathrm{I}, 000$ seeds $\ldots .2 .50$ I $2.0,000$ seeds $\ldots 23.00$ 25,000 seeds. .... \$50.00

\section{I5 ASPARAGUS HATCHERII}

New Type of Plumosus

100 seeds.....\$1.00 500 seeds......\$3.25

250 seeds.... 2.00| I,000 seeds.... 6.00

\section{ASPARAGUS SPRENGERI}

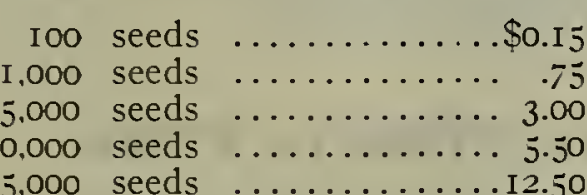

ASPERULA

I65 Odorata (Sweet Woodruff). Suitable for hardy bordeis: very dwarf; white. Trade pkt. I5c. oz. 6oc.

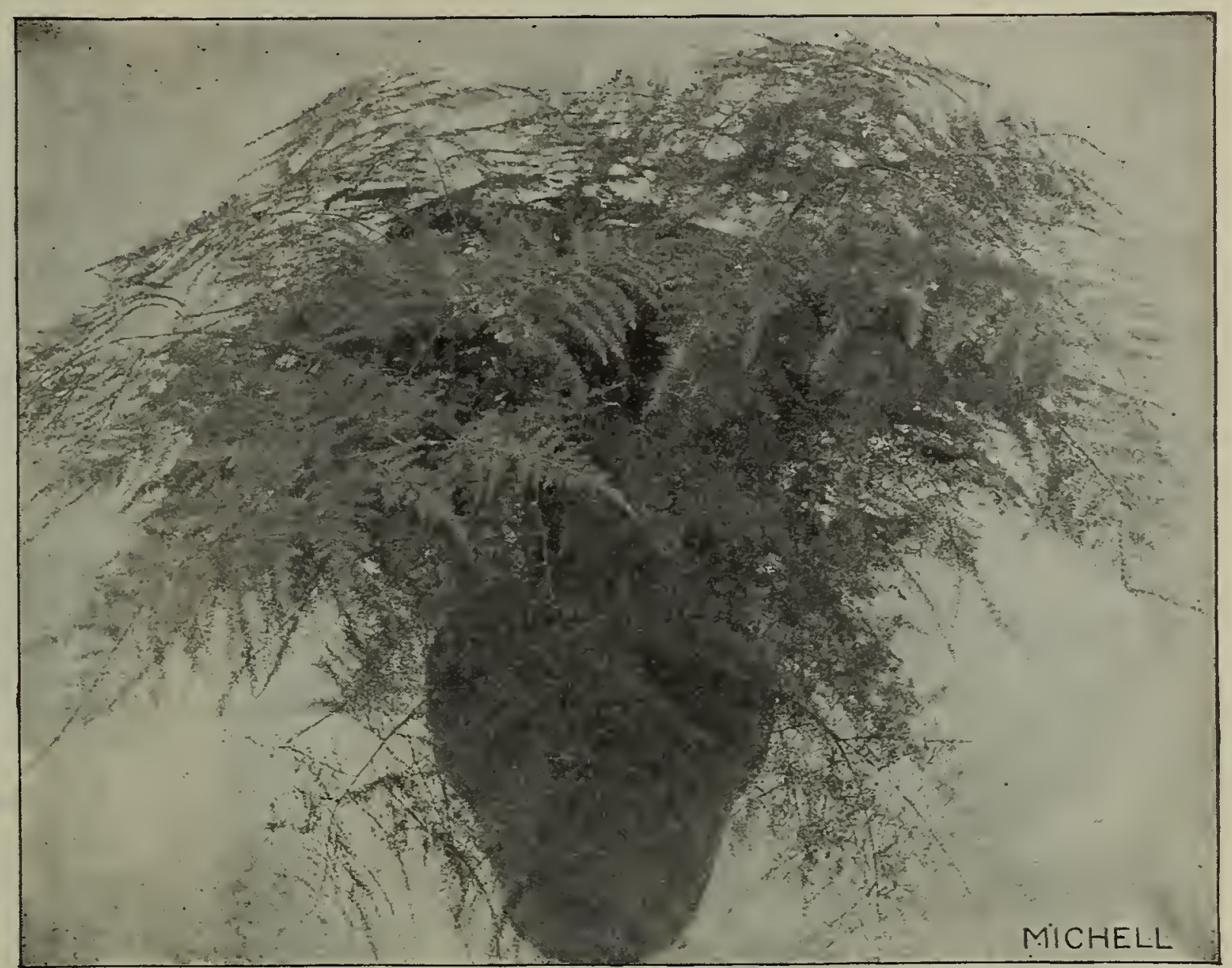

Asparagus Plumosus Nanus

Dear Sirs:

Out of the 5000 Asparagus Ptumosus Nanus Seeds received from you we have just potted up 4,738 plants and there are some still coming up.

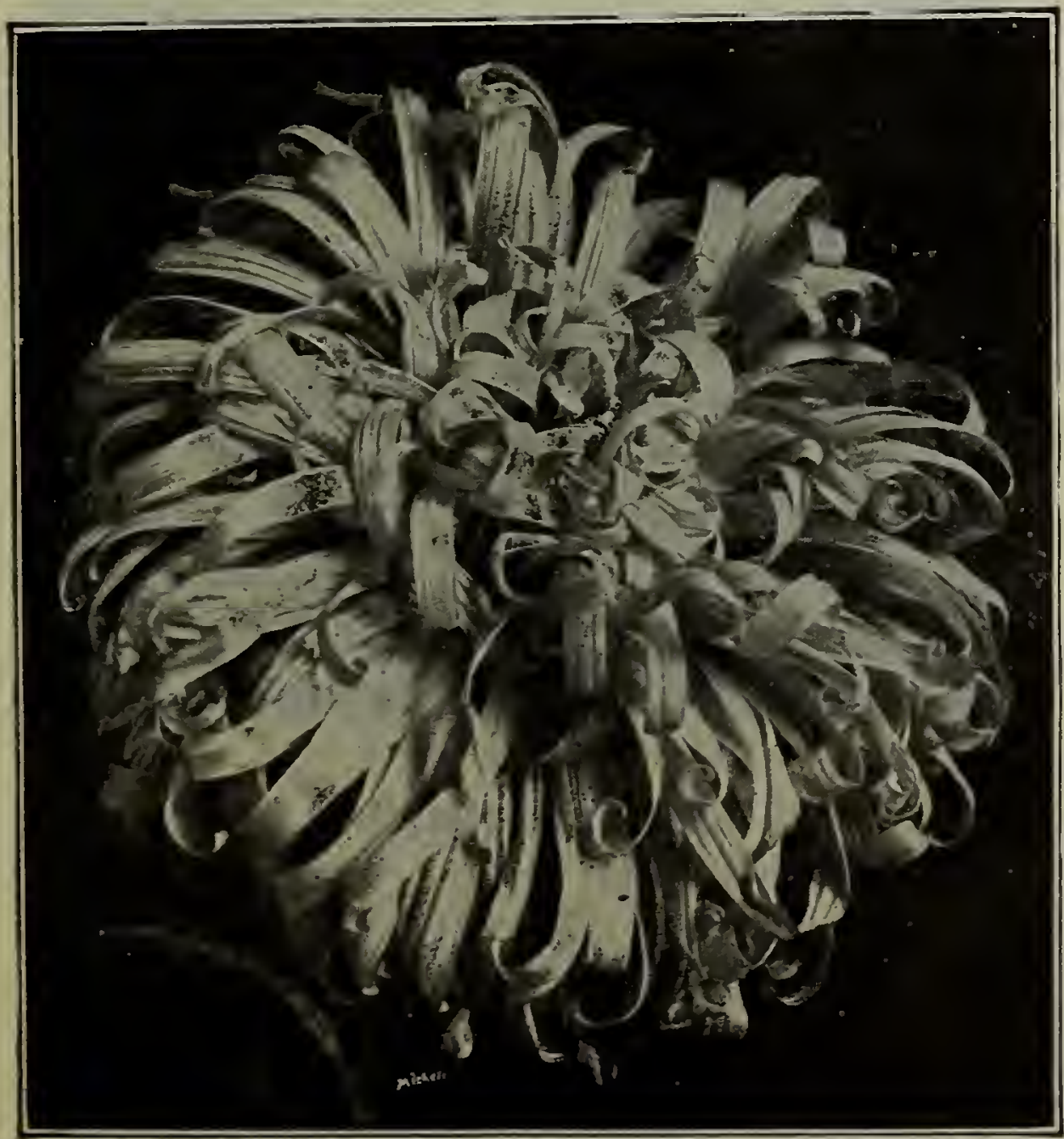

Crego Aster
Dear Sirs:

Out of 5,000 Asparagus Plumosus Nanus Seeds received

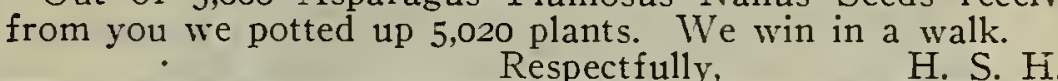

\section{MICHELL'S "DISTINCTIVE" ASTERS}

We wish to emphasize the fact that our Asters are grown for us by specialists, and in many cases under our own superision.

Michell's “Distinctive" Quality is nowhere more prominent than with our Asters, and we can recommend them with the utmost confidence to produce the very best results.

\section{ASTER NEW CREGO}

One of the finest varieties of Asters and has rapidly come into popular favor. Flowers are gigantic in size, often 5 inches across and with long, stout stems averaging I $_{5}$ inches in length. The twisted and curled petals give the flower the appearance of a huge, flat Chrysanthemum.

I99 White........ Trade Pkt. Oz. $\begin{aligned} & \text { Oz. } \\ & \$ 1.75 \\ & 201\end{aligned}$ I98 Shell Pink.... .40 1.75 203 Mixed .......... 202 Rose Pink.... 40 I.75

\section{ASTER, EARLY WONDER}

The earliest variety in cultivation, coming into bloom several days before "Queen of the Market.' Flowers are large, very double, similar to "Comet" type and are carried erect on long stems.

228 White....... Trade Pkt. Oz. $\$ 2.00 \mid 227$ Pink........ Trade Pkt. $\$ 2.00$

ASTER, QUEEN OF THE MARKET

\section{(Extra Early)}

The standard-bearer of the early flowering sorts Our strain has been re-selected for its earliness and will prove of exceptional quality 279 White

277 Blush Pink

274 Rose Pink

276 Light Blue

275 Dark Blue

278 Crimson

280 Choice Mixed 


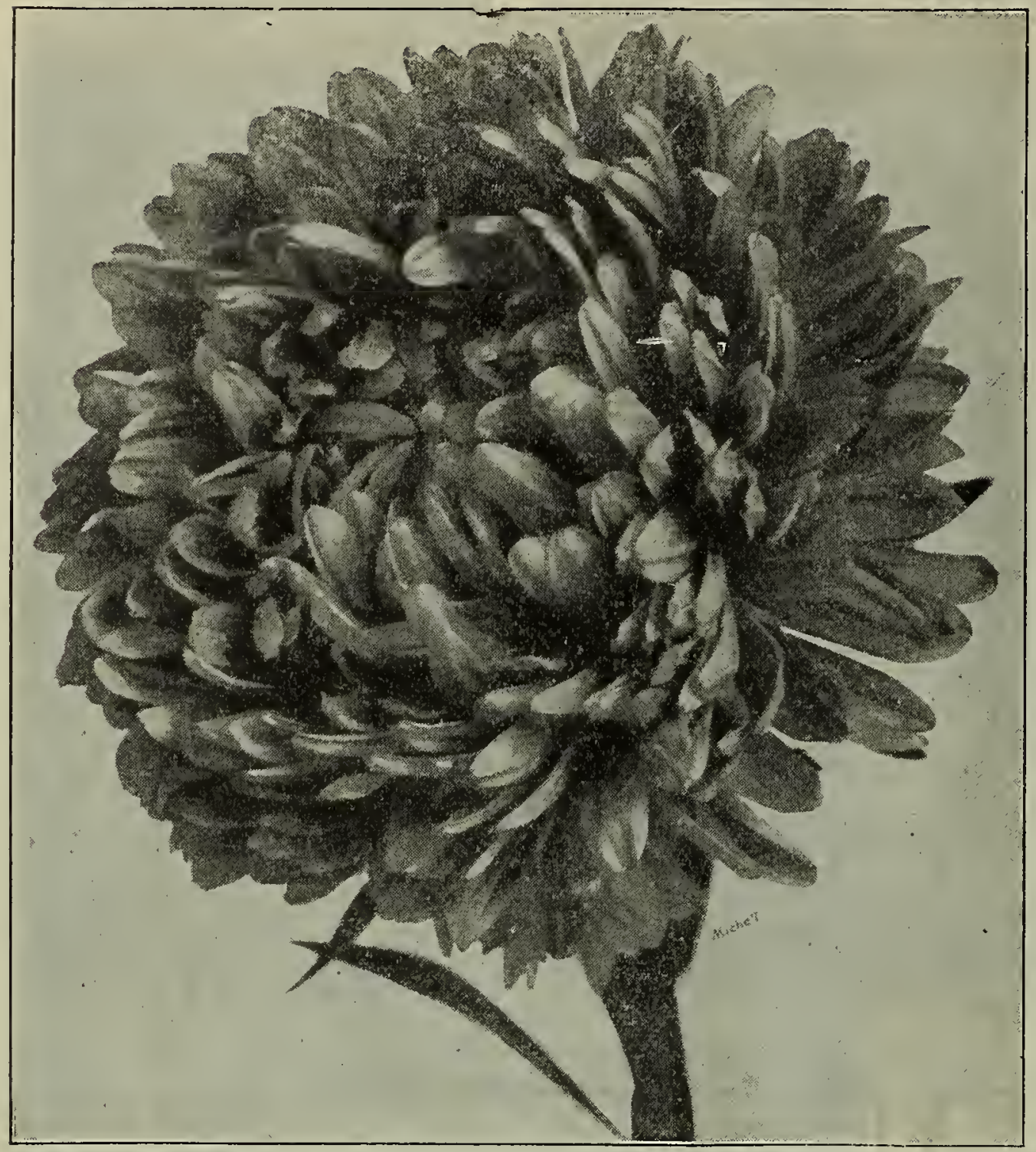

FLOWER SEEDS

\section{Aster, Truffaut's Prize (Paeony Flowered)}

Flowers are of incurved form, fairly large and are carried erect on straight stems. Fine for cutting or pots.

304 White

Trade Pkt. Oz

302 Pink

$\$ 0.30 \$ I .50$

30I Light Blue ...................... 30 I.50

303 Purple Violet .................

300 Crimson $\ldots \ldots \ldots \ldots \ldots \ldots \ldots \ldots \ldots . .30 \quad 1.50$

305 Choice Mixed ............................

\section{Aster, Giant Comet}

Long narrow petals which curve at the ends give this flower the appearance of a Japanese Chrysanthemum. Plants branch freely and produce their flowers on long stems.

\begin{tabular}{|c|c|c|}
\hline & (1) & \\
\hline I94 White ......... &.$\$ 0.30$ & $\$ 1.75$ \\
\hline I92 Peach Blossom & .30 & 1.75 \\
\hline I93 Pink and White & .30 & 1.7 \\
\hline Igo Light Blue ..... & .30 & 1.7 \\
\hline I 89 Dark Blue ...... & .30 & I.75 \\
\hline I9I Crimson ...... & .30 & 1.75 \\
\hline I95 Choice Mixed & .30 & I. 5 \\
\hline
\end{tabular}

\section{Aster, Victoria Prize}

A flat, solid, deep flower produced in masses on a compact, fairly dwarf plant. Good for pots.

$$
324 \text { White } \ldots \ldots \ldots \ldots \ldots \ldots \ldots \ldots \ldots . \ldots 0.30 \$ 2.25
$$

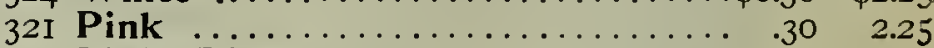

320 Light Blue ........................ . 2.25

322 Purple $\ldots \ldots \ldots \ldots \ldots \ldots \ldots \ldots \ldots . .30 \quad 2.25$

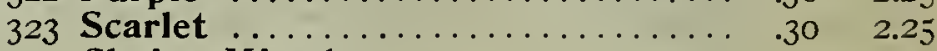

325 Choice Mixed .................. .30 2.00

Aster-Michell's Improved Semple's Branching

\section{Michell's Improved Semple's Branching Aster}

What we offer is an Improved Strain of this grand Aster, secured after many years of careful selection of our stock seed, and should not be compared to what is usually offered as the Semple's Branching.

257 Lavender

259 Shell Pink

262 White

258 Rose Pink

260 Purple

26I Crimson

263 Choice Mixed

Trade Plt. Oz.

$\$ 0.30 \$ 1.00$

$.30 \quad 1.00$

$\begin{array}{rr}.30 & 1.00 \\ .30 & 1.00 \\ .30 & 1.00\end{array}$

$.30 \quad 1.00$

$.30 \quad 1.00$

$.30 \quad 1.00$

$.30 \quad 1.00$

\section{Astermum}

\section{A Glorified Aster-A Splendid New Type}

The plants grow straight up with long, sturdy stems from I8 to 24 inches in length. For illustration and further description see Novelties, page 23 .

Trade Pkt. Oz. \$0.50 $\$ 3.00$ I 72 White

I I I Pink

I 70 Lavender I73 Mixed

\section{FIRST PRIZE FOR MICHELL'S ASTERS}

\section{Mr. HENRY F. MrCHell,} Dear Sir:-Last Spring 1 purchased some Aster seed from you, which were the best I ever saw ; the fiowers were large and plenty of them. We were asked to send some or them to the Bucks County Fair. They were arranged in a large bouquet and were awarded First Prize for the best display of Asters. Every flower in the bunch was raised from Michell's seed: they are good enough for me. Respectfilly yours,

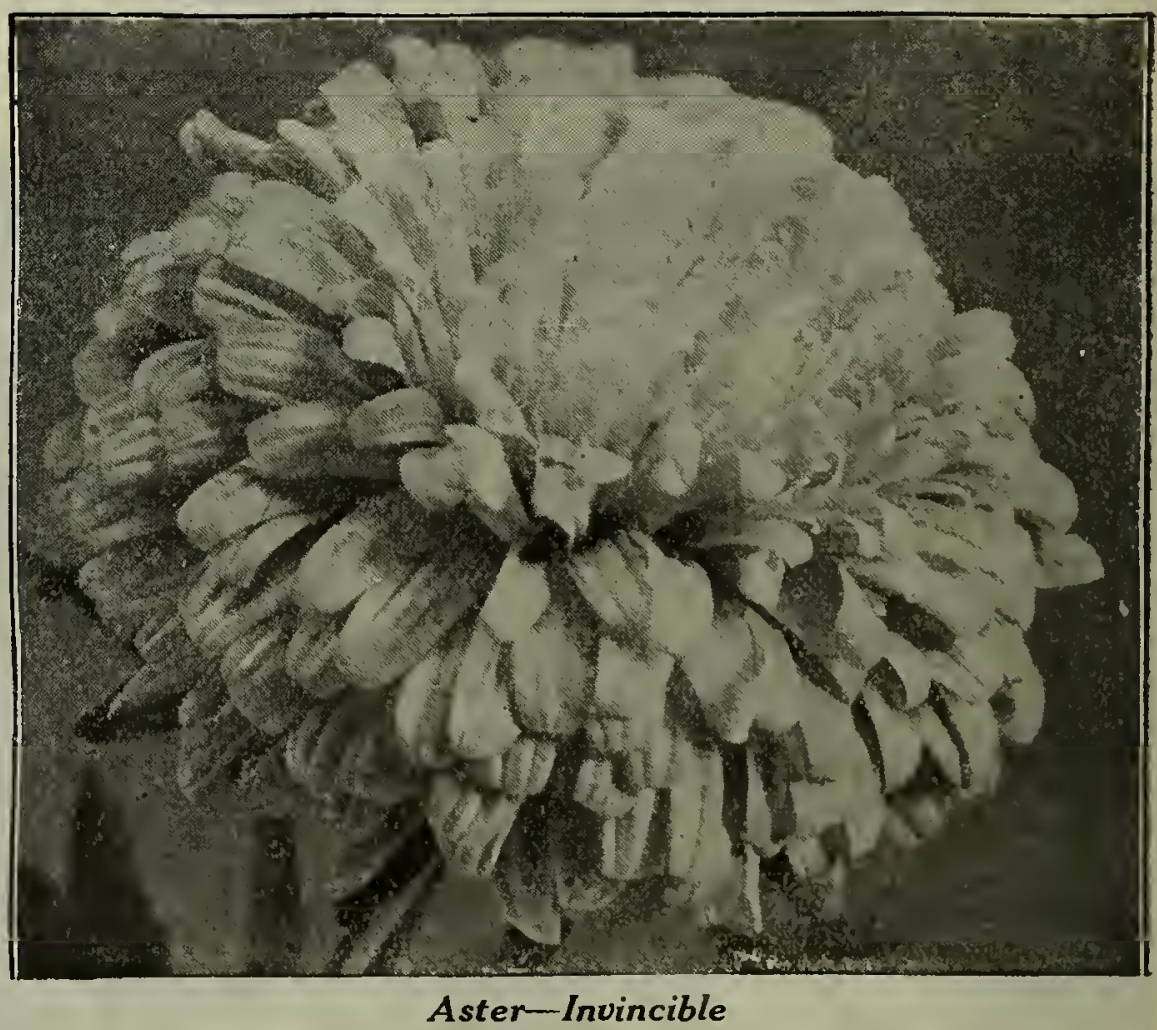

\section{Aster, Invincible}

A splendid Aster to fill in between the early sorts and the late ones. It is, so to say, a mid-summer Aster. Flowers are.very large, perfectly double and come on long, stout stems often two feet in length. Plants are of branching habit; one of the best florists' Asters 235 Blue........\$0.30 \$1.50 | 238 Rose Pink....\$0.30 \$1.50

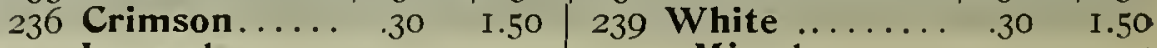
\begin{tabular}{lll|llll}
237 Lavender..... & .30 & I.50 & 239A Mixed ...... & .30 & I.25
\end{tabular} 


\section{MICHELL'S "DISTINCTIVE" FLOWER SEEDS}

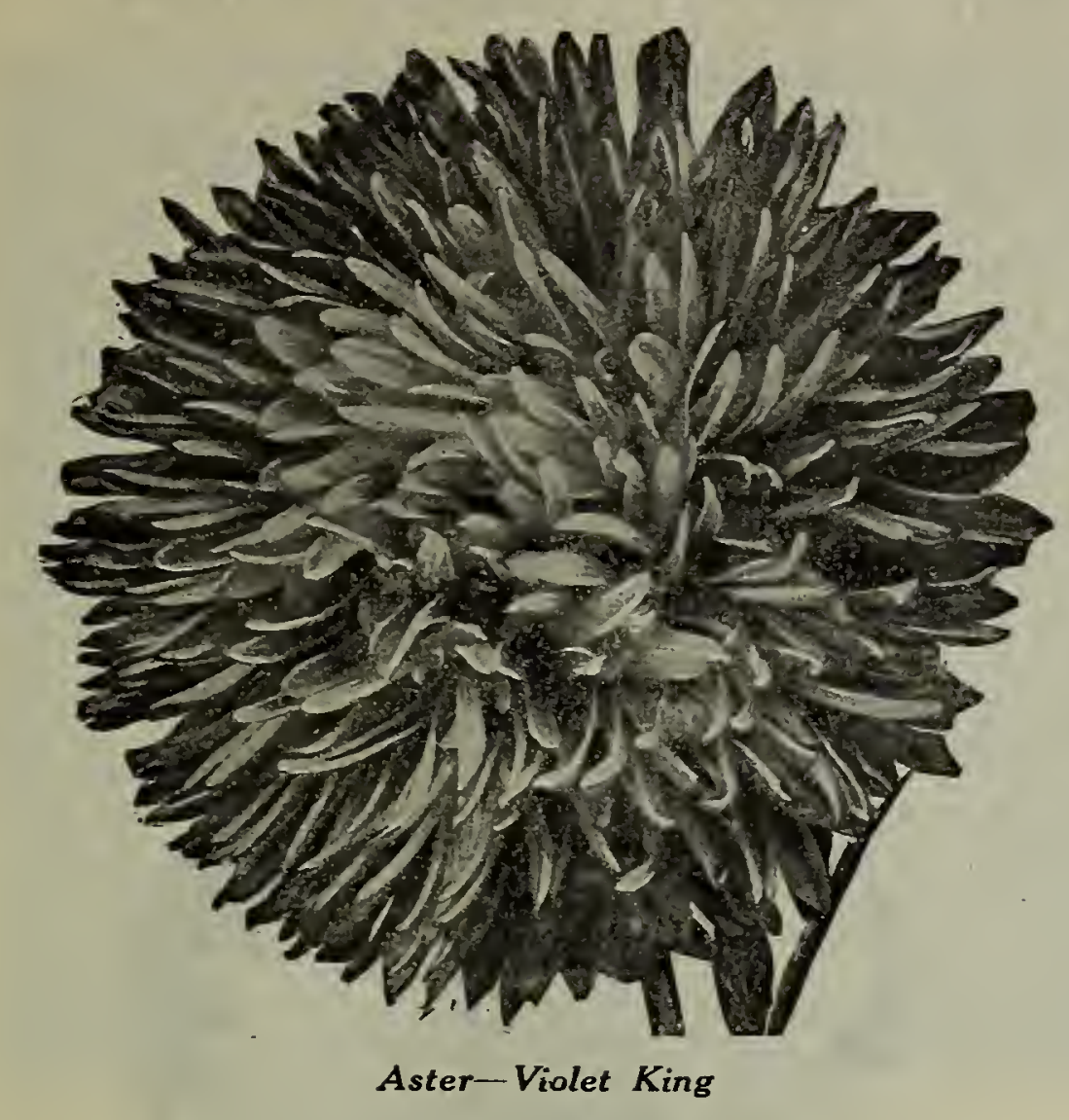

King Asters

Habit of growth similar to the Branching Aster; in form the flower is distinct; petals resemble the quilled varieties, but are larger and broader, those in the centre being curled and incurved. 3I7 Vick's White King (New'). The flowers are large, full centred and pure white and of the same type as Violet King; plants of upright habit; stems long. Per pkt. 20c., 35c. per 2 pkts.

282 Rose King. Plants of branching habit, with stems frequently 2 feet in length; flowers large, double, and of a deep rose color............\$0.40 \$r.50

316 Violet King. A distinct color, large double flowers of a pleasing shade of soft violet......... 40 .40 1.25

\section{Asters of the Daybreak Type}

The Daybreak class forms strong plants of symmetrical growth; flowers large, perfectly double and carried on long erect stems.

2jo Michell's Purity (White Daybreak). Our strain of this variety is a re-selection and a great improvement; color, pure glistening white....... \$0.30 \$2.50

205 Pink Daybreak. Large, double and of a delicate

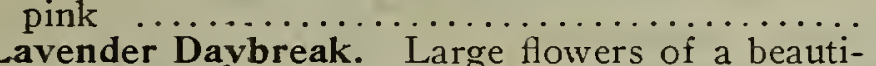
ful shade of lavender......................

253 Lemon Drop (Yellow Daybreak). Flowers perfect in form and of a decided yellow color....

284 Salmon King (Salmon Daybreak). A splendid addition to the Daybreak class; the color is

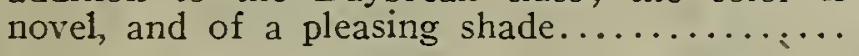

\section{Asters-Various Sorts}

266 Peerless Pink. A valuable variety of the late branching type, although coming into bloom a little earlier; bears a profusion of large, double flowers of a rich shell pink color, very similar in shade to the Mary Semple variety..........

229 Electric. A new and distinct variety, growing about 18 inches high, long wiry stems: flowers large; petals long, thread-like and quilled; color, snowy white.

312 Vick's Enchantress Pink ( $($ icw). Flowers large and double; color, a delicate shade of pink. Per pkt. 20c.. 3jc. per 2 pkts.

251 Lady Roosevelt. One of the finest recent introductions; flowers resemble incurving Chrysanthemums, the color a gorgeous pink, of marvelous beauty; stems 40 inches long are nothing umusual, 30 inches long are common; season late

\section{Asters-Various Sorts-Continued}

252 Lavender Gem. An excellent variety of "Comet" Trade form, with large perfectly double flowers, color Pkt. lavender .............................. \$2.50 268 Pink Beauty. Of the Chrysanthemum Flowered type; immense flowers; color, blush pink..... .40 2.50 I 80 China or German Mixed. This mixture contains

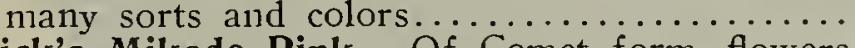

308 Vick's Mikado Pink. Of Comet form, flowers larger and more perfectly double, averaging 5

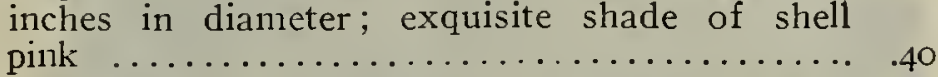

PERENNIAL ASTER (Michaelmas Daisy)

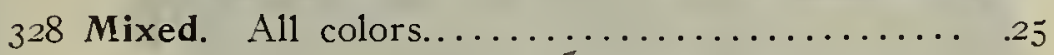
1.00

\section{Auricula (Primula Auricula)}

4To Choice Mixed. Hardy perennial with flowers of many beautiful colors..................40 4.00

Avena (See Grasses, Page 40)

Gentlemen:-

Hammonton, N. J

The Asters we are sending you are grown from your seeds, and we think they are extra fine. Yours truly, IV. \& N.

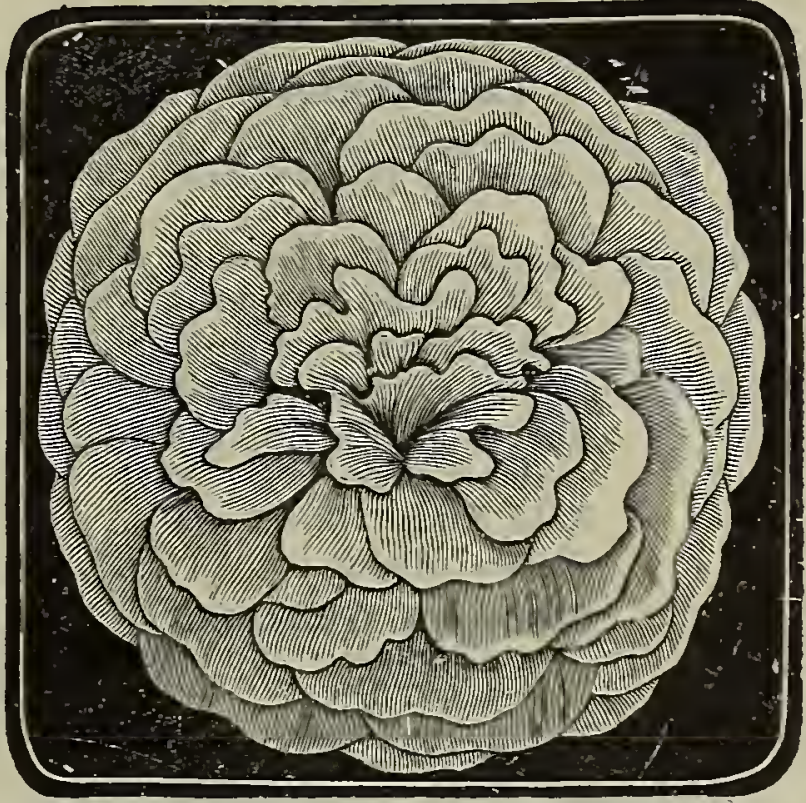

Balsam-White Perfection

Balsam (Lady Slipper) Trade Pkt. Oz.

425 Camellia Flowered Pink.............. \$0.20 \$0.60 426 " " Prince Bismarck. R i ch

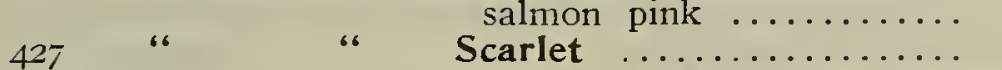

White Perfection............ .25 1.00

43I " " " Choice Mixed............. . I5 $\quad .40$

432 Fine Mixed ........................ .

\section{Balsam Apple}

440 Momordica Balsamina $\ldots \ldots \ldots \ldots \ldots \ldots \ldots$.

Baptisia (Faise Indigo)

442 Australis. Tall, showy plants with deep blue flowers; perennial.

\section{Bartonia}

443 Aurea. Dwarf edging plant; yellow flowers.

\section{Beans (Flowering and Running)}

444 Butterfly. Pink and white on same flower.

$$
\text { (1/4 lb. 25c.) }
$$

445 Scarlet Runner. (Pint i5c., 30c. per qt.)

$.504 .00 \quad 46$ White Runner. (Pint i 5 c., 30c. per qt.) 


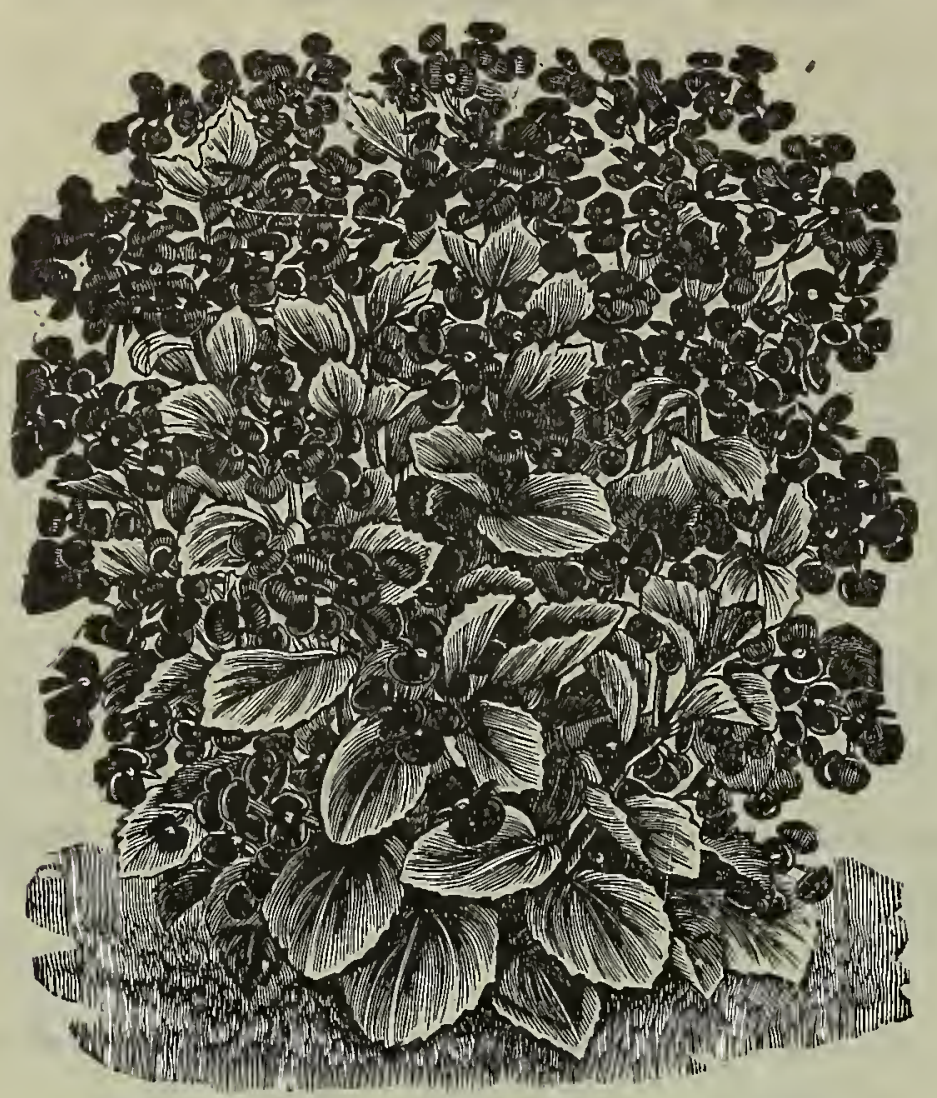

Begonia, Vermon

\section{BEGONIAS}

As a bedding plant there is nothing more satisfactory and result-giving. Seeds sown in January make splendid flowering plants in May.

47 I Semperflorens Vernon. The most popular of all; orang.e crimson flowers...\$0.25 \$2.50

455 “ Anna Regina. Deep rose ..... .50

459 " " Erfordia. Soft delicate pink... .30

463 "Queen of Carpet 'B e d d e r s.

473 " $\quad$ Dulu King. Blood red ........

467 " Choice Mixed ................ BEGONIA GRACILIS

This type produces very compact little plants that are literally covered with flowers; an easy seller. Trade Pkt.

460 Gracilis Prima Donna. Rose, shading to carmine. $\$ 0.50$

458 " Rosea. Pink ......................

457 " Luminosa. Fiery dark scarlet ........ . .40

456 " Alba. Pure white $\ldots \ldots \ldots \ldots \ldots \ldots \ldots .30$

BEGONIA REX HYBRIDS

464 Ornamental leaves, in self-color and variegation. . .50

BEGONIAS, TUBEROUS ROOTED

These are easily raised from seed; produce enormous flowers and grow best in partial shade.

469 Single Mixed

Trade Pkt. Oz.

46 I International Prize. Single; enormous flowers;

extra fine. Original pkt. I7c.

470 Double Mixed. Original pkt. I7c.

BOLTONIA (Falso Chamomile)

48I Latisquama. Perennial; aster-like flowers; pink-

ish lavender $\ldots \ldots \ldots \ldots \ldots \ldots \ldots \ldots \ldots \ldots . .25$ I.OO

BRACHYCOME (Swan River Dalsy)

485 Iberidifolia. Compact growing annual; small

blue flowers $\ldots \ldots \ldots \ldots \ldots \ldots \ldots \ldots \ldots \ldots \ldots \ldots$
BRIZA (See Grasses) page 40.

BROMUS (See Grasses) page 40.

\section{BROWALLIA}

500 Elata Coerulea. Blue .....................

502 Speciosa Major. Most desirable variety as a pot plant; large flowers, rich blue ...............25

\section{CALCEOLARIA}

A most decorative pot plant, which finds ready sale if well grown. The strains we offer are the best in the world. 5I 5 Hybrida Grandiflora, Choice Mixed ........\$0.60 \$1.00 516 " " Compacta. Dwarf, mixed .60 I.00 5I7 James' Superb Strain. Superfine, mixed ..... .60 .60 5 I9 Sutton's Perfection. In original packages, $75 \mathrm{c}$. 5 I8 Rugosa Mixed. A small flowering sort used for

bedding out .............................

Raised extensively as a pot plant for bedding. Trade Pkt. Oz. 526 Meteor. Orange, striped deep golden ......... \$O.IO \$0.15 527 Orange King. Rich dark orange ............ .I0 .I5 528 Prince of Orange. Dark orange striped.......... . . 525 Grandiflora. Large golden yellow ........... .ro .I 529 Sulphurea. Sulphur yellow .............. .10 .15 530 Mixed

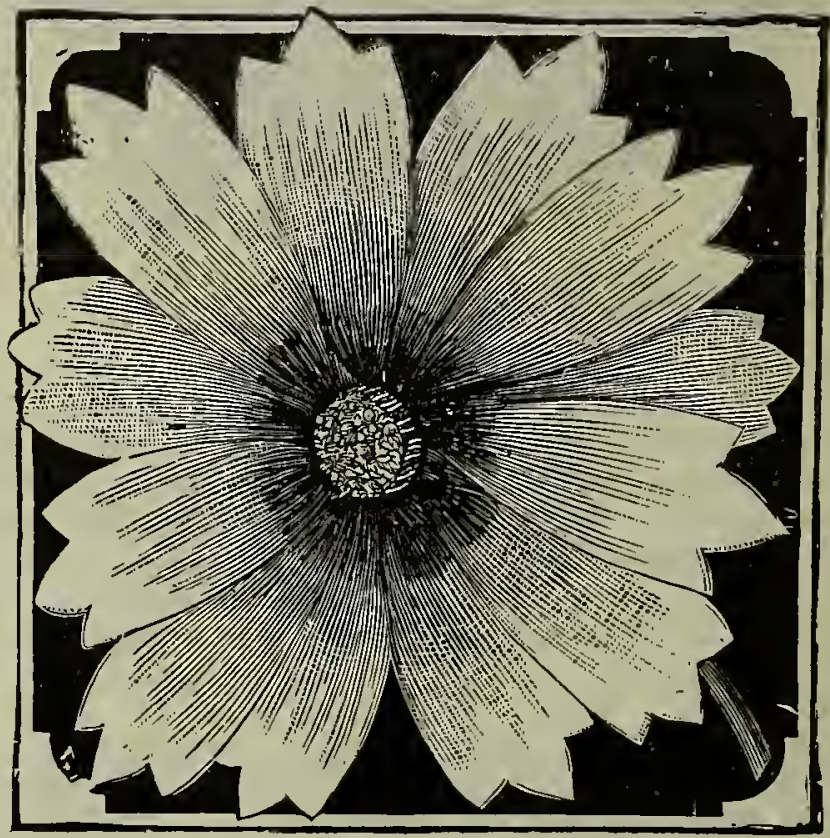

Calliopsis-Golden Wave

\section{CALIIOPSIS (Coreopsis)}

ANNUAL VARIETIES Trade Pkt. Oz.

535 Golden Wave (Drummondi). Large golden

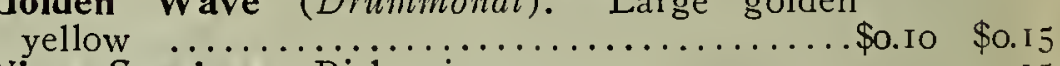
536 Nigra Speciosa. Rich crimson maroon ........ . . ${ }_{11}$ 537 Choice Mixed ....................... .I0 .I

PERENNIAL VARIETIES

Splendid flowers for cutting during the whole summer. 540 Lanceolata Grandiflora. Large golden yellow.. . . 0 54I California Sunbeams. Large flowers, yellow and brown $\ldots \ldots \ldots \ldots \ldots \ldots \ldots \ldots \ldots \ldots, 20$

CAMPANULA (Belliower) (Perennial)

The taller sorts are splendid for cut flowers and most decorative; as a border plant they are indispensable. Trade Pkt. Oz. 538 Carpatica Blue. Dwarf, 6 inches............ \$0.10 \$0.50 539 " White. Dwarf, 6 inches........... . . .50

547 Persicifolia Grandiflora, Blue. Grows 3 to $4 \mathrm{ft}$. high and produces large bell-shaped flowers along the whole stem..................... .25 2.00

548 Persicifolia Grandiflora, White $\ldots \ldots \ldots \ldots \ldots .25 \quad 2.00$

549 Pyramidalis (Chimncy Bell). 6 feet. Blue and white mixed $\ldots \ldots \ldots \ldots \ldots \ldots \ldots \ldots \ldots \ldots \ldots$. I5 .60

CAMPANULA MEDIA (Canterbury Bell) (Biennial) 543 Single Blue ......................... .

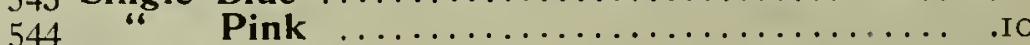

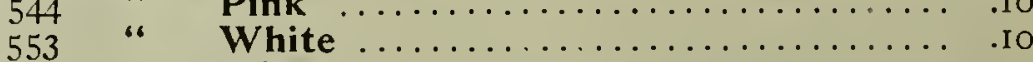

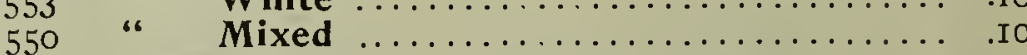

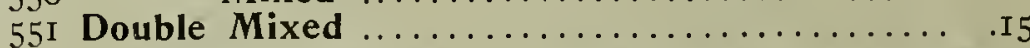

CAMPANULA CAL YCANTHEMA (Cup and Saucer)

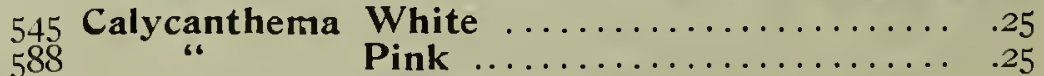

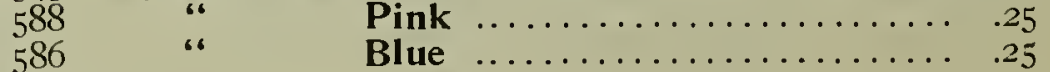
546 " Mixed $\ldots \ldots \ldots \ldots \ldots \ldots \ldots \ldots . .20$ 


\section{MICHELL'S "DISTINCTIVE” FLOWER SEEDS}

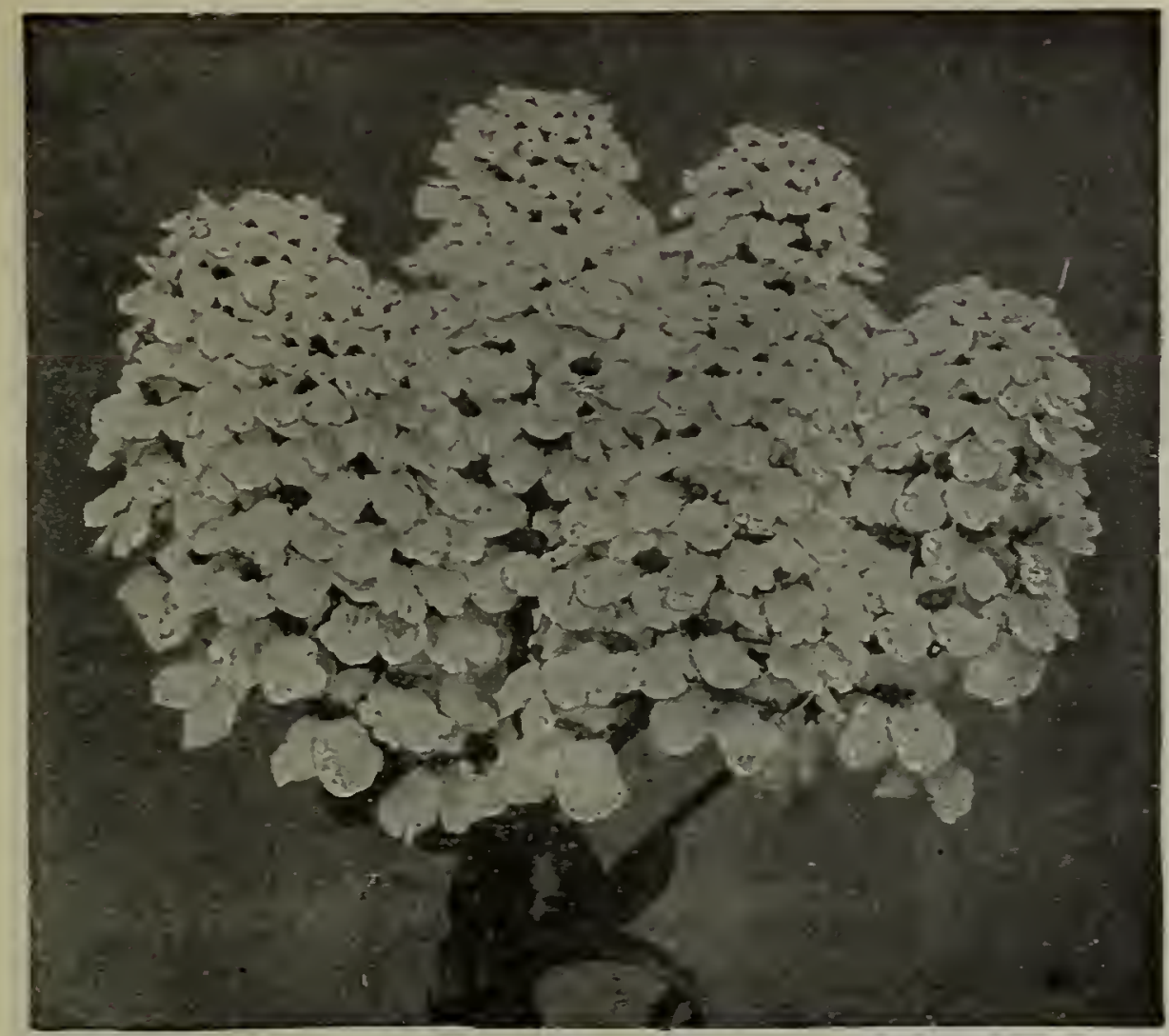

Candytuft-Michell's Giant

Candy tuft (Iberis)

56I Michell's Giant White. The largest of Trode all. Inmense spikes of pure white flow- Pkt. ers .................... (Lb. \$3.00) \$o.Is 562 Empress. Flat heads of white flowers.

566 Pink

(Lb. \$2.00) .I0

560 Crimson

559 Carmine

568 Purple

$5 \pi 4$ White Rocket....................... 6oc.)

564 Little Prince. Very dwarf, white...... . Io

576 Mixed. All colors ............ (Lb. $75 \mathrm{c}$.)

570 Sempervirens. Perennial; fine for edging borders: white ..................... 25

\section{Canary Bird Flower}

$5 \vdots \vdots$ Tropaeolum Canariense. Yellow........ ..

\section{Canna}

59- Mixed. Dwari French....... (Lb. \$1.00)

\section{Carnation}

600 Early Vienna Mixed.................

602 Finest German Mixed.......... (I/32 oz. \$I.50)

6ro Choice Mixed ........................ 40

604 Marguerite Excelsior, Mixed. Extra large flowers $\quad .30$

605 "“ Pink

606 " $607 \quad$ White

608 " " Yellow

609 " Choice

\section{Celosia}

Cristata or Cockscomb Varieties

6і; Giant Empress. Bright crimson, dark foliage.

6Ig Glasgow Prize. Dark crimson..

630 Aurea. Yellow

625 Sutton's Prize. Dwart scarlet (Orig. pkt. 40c.)

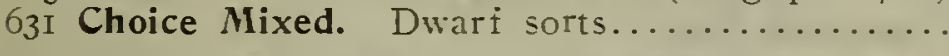

\section{Plumosa or Feathered Varieties}

622 Pride of Castle Gould (Neii). Large flower heads; color, blood red. carmine. yellow, orange

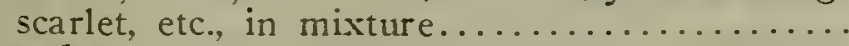
$62+$ Scarlet

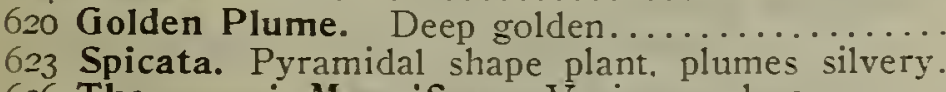

626 Thompsoni Magnifica. Various colors...

627 Thompson's Superb.

633 Choice Mixed
Oz. $\quad 1 / 4$ lb.

$\$ 0.35 \$ 1.00$

.20

.25

.15

.25

.15

.10

.30

2.00

.20

.10

rade Pht. Oz. $\begin{array}{lc} & \\ \$ 0.25 & \$ 1.50\end{array}$

\section{I.50}

I.OO

I.00

I.0O

I.00

I.00

.20 .60

\section{(63)}

$.25 \quad$ I.00

$.20 \quad 1.00$

$.25 \quad 1.00$

.15

.60

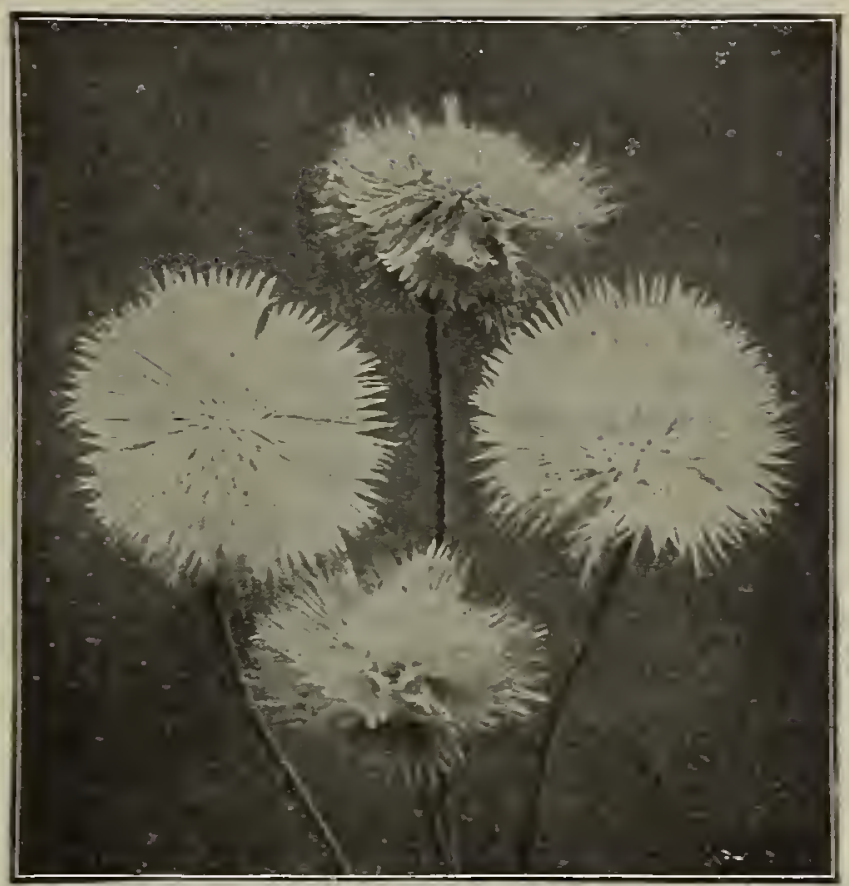

Centaurea Imperialis-New Giant Cornflower

\section{Centaurea}

Centaurea Cyanus (Cornflower) Trade Pkt. Oz.

638 Emperor William. Deep blue... (I/4 lb. 5oc.) \$়o.Io \$o.I5 644 Double Blue. Splendid for forcing........... .I5 60

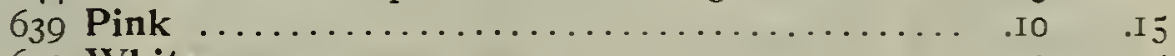

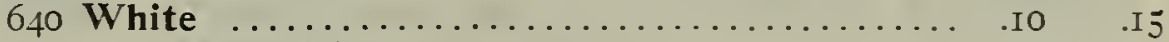

64I Choice Mixed .................. (I/4 lb. 40c.) Io .I5

$6+2$ Double Mixed .................................

Centaurea Imperialis (Giant Cornflower)

645 Deep Rose .................................. 60

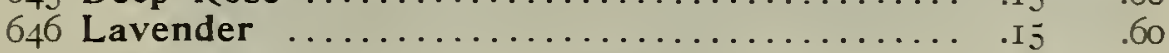

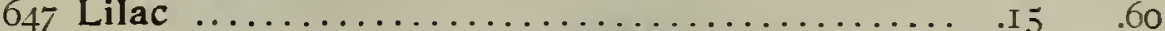

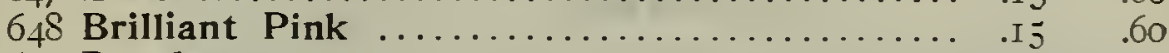

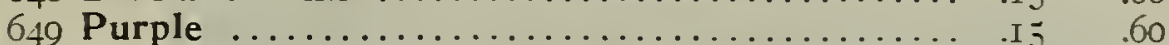

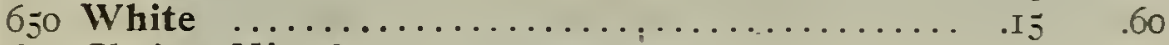

65 I Choice Mixed ..............................

\section{New Giant Flowered Centaureas}

Magnificent flowers of brilliant colors; excellent for cutting.

643 The Bride. Pure white...................30

652 The Bridegroom. Purplish mawe..................

659 Honeymoon. Golden yellow...................... 30

White Leaved Centaureas (Dusty Miller)

635 Candidissima. Broad cut silvery gray foliage.

636 Gymnocarpa. Silvery fine cut leares, bedding plant................. ( I000 seeds, I jc.)

\section{Various Centaureas}

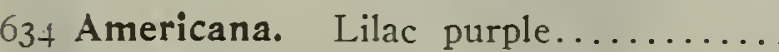

658 Pulcherrimus ( $\left(\backslash\right.$ e $\left.w^{\prime}\right)$. A perennial variety; flow-

ers resemble in appearance the Giant Corn-

flower: are of large size, and of a delicate

pink color. Per pkt. 20c., 5jc. per 3 pkts.

655 Montana. Perennial, blue

657 " Alba. Perennial, white

Centrosema (Butterny Pea)

660 Grandiflora. Rosy violet to purple..

Cerastium (snowin summer

662 Tomentosum. Dwarf, white leared edging plant; flowers white: perennial. 


\section{Chrysanthemum}

Annual Varieties Trade Pkt. Oz.

669 Helios. Large golden yellow.........\$0.Io \$0.25 680 White Star. Fern-like foliage, flowers white $\ldots \ldots \ldots \ldots \ldots \ldots \ldots \ldots \ldots \ldots \ldots \ldots$. I5 $\quad .50$ 670 Inodorum Snowball. Large double white $\ldots \ldots \ldots \ldots \ldots \ldots \ldots \ldots \ldots$. $15 \quad .50$

677 Segetum Grandiflorum. Golden yellow .ro $\quad .25$ 68 I Single Mixed ................... . I0 .I5 683 Double Mixed ...................... .10

\section{Perennial Varieties}

666 Comtesse de Chambord. Yellow Paris Daisy

667 Frutescens Grandiflorum. White Paris Daisy

67r Shasta Daisy "Ailaska.", Pure white.. 673 King Edward VII. Extra large; pure white $\ldots \ldots \ldots \ldots \ldots \ldots \ldots \ldots \ldots . .20$ 675 Princess Henry. Large flowered white .20 685 Japanese Hybrids. Large flowered,

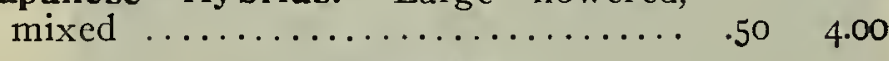

\section{Clarkia}

708 Single Mixed 709 Double Mixed

\section{Clematis}

7ro Flammula. Feathery white flowers... 7I 2 Jackman's Large Flowering. Mixed. jr 4 Paniculata. White star-shaped flowers. .I 5

\section{Cleome (Giant Spider Plant)}

720 Pungens. Rose-colored flowers........ . I5 $\quad$.50

\section{Cobea Scandens (Cup and Saucer Vine)}

A graceful vine of which millions are sold annually by florists as pot plants. Seeds should be placed edgewise to insure good germination. Trade Pkt. Oz. 725 Purple ....................... \$o.10 \$o.40 726 White $\ldots \ldots \ldots \ldots \ldots \ldots \ldots \ldots \ldots \ldots, .25 \quad .75$

COIX LACHRYMAE. See Grasses, page 40

\section{Coleus}

735 Large Leaved. Choicest mixed....... .50 2.50 CONVOLVULUS (Morning Glory). Seenext page.

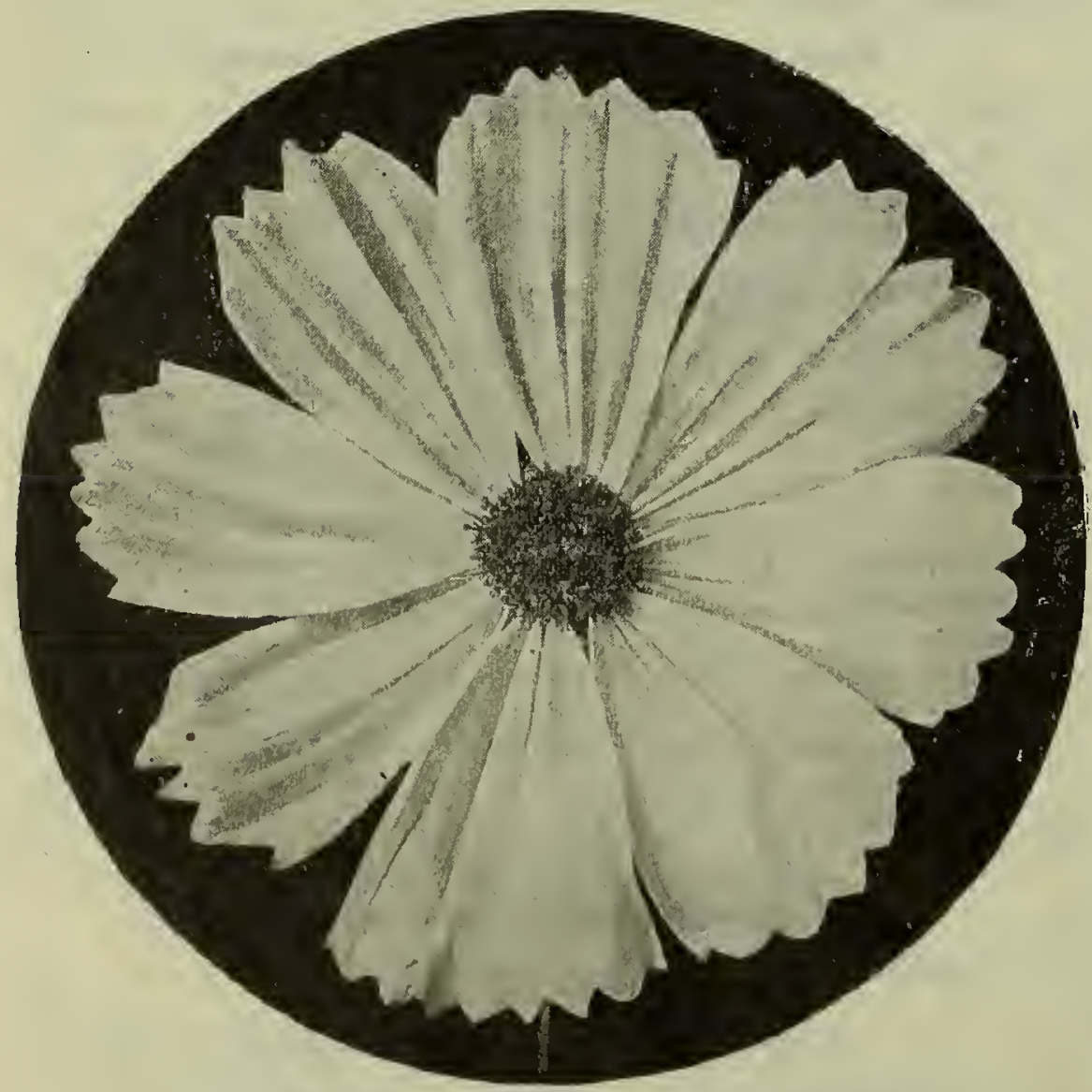

Photograph of Single Flower (Actual Size) Michell's GRut Fluwering Cosmos

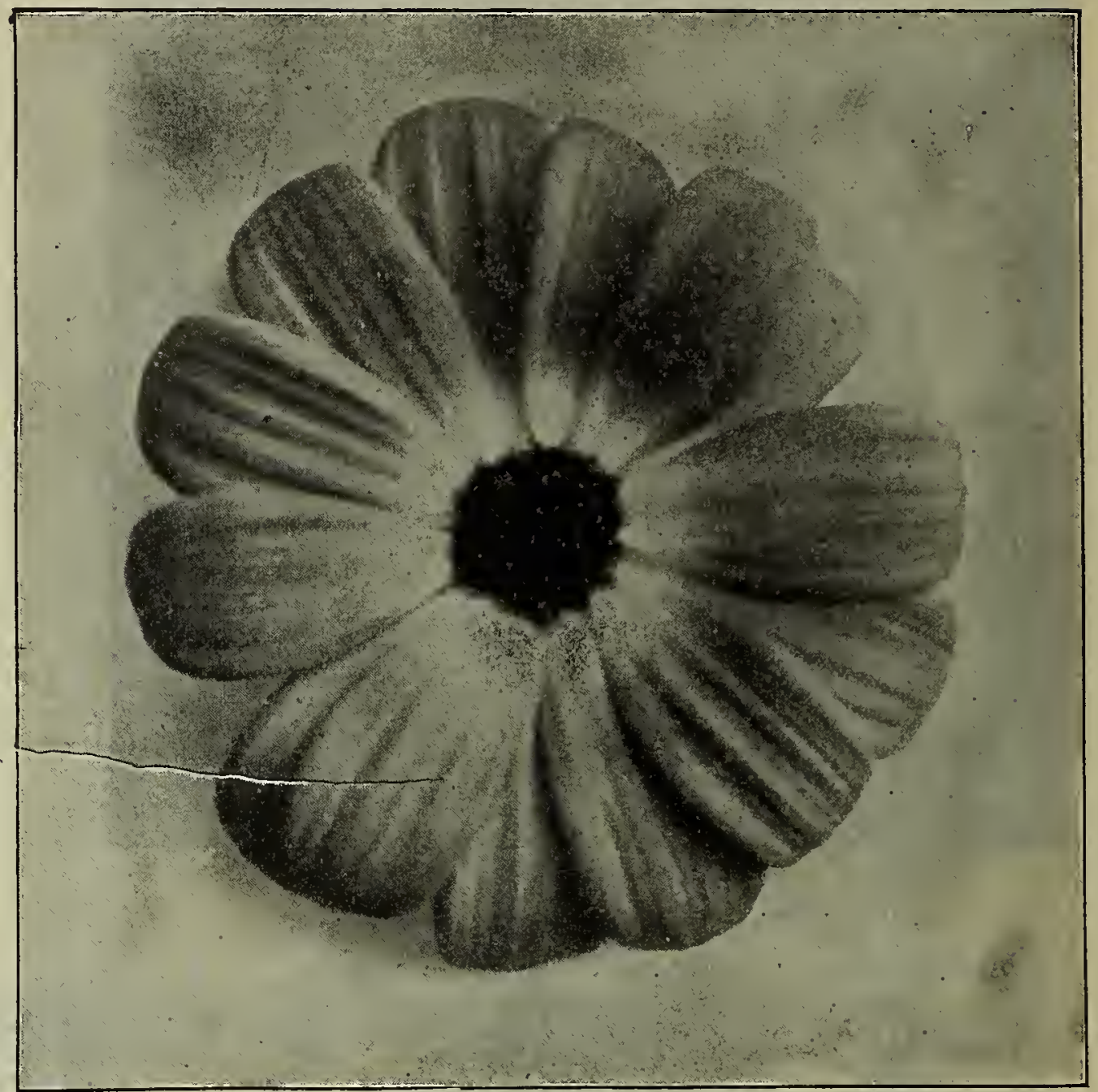

Cineraria-Michell's Grandiflora Prize

\section{Michell's "Distinctive" Cinerarias}

Our improved strains have been acclaimed wonderful; immense trusses of the largest flowers. $1 / 2$ Trade Trade 69I Dwarf Grandiflora Prize. Mixed colors...... \$0.60 \$1.00 693 Medium Tall “" “" 699 James' Giant Strain. Mixed colors...............60 707 Sutton's Superb. Mixed colors (Orig. pkt. 6oc.)

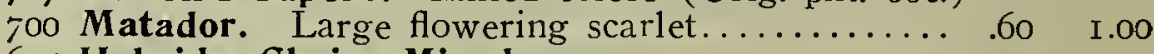
695 Hybrida, Choice Mixed .................. . .30 $\quad .50$ 702 Radiata Hybrida. Small star-like flowers.... .60 r.00 703 Sutton's Stellata. Star-shaped. (Orig. pkt. 6oc.)

705 Stellata Hybrida. Mixed colors.............. .60 1.00

\section{Cineraria (Dusty Miller) Trade Plst. $\mathrm{O}$.}

70r Maritima Candidissima. White leaved, used

for bedding...$\ldots \ldots \ldots \ldots \ldots \ldots \ldots \ldots \ldots$. $\$ 0.10$. $\$ 0.20$

\section{Cosmos}

\section{Michell's Large Early Flowering}

This new Early Flowering Strain begins blooming very early and produces flowers of large size. Trade Pkt. Oz.

75I Large Early Flowering, Crimson .......... \$0.15 \$0.50 752 " “ “

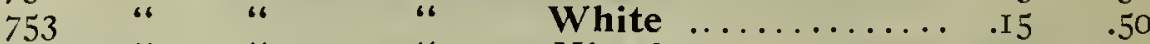

754 “ “ “ “ Mixed $\ldots \ldots \ldots \ldots \ldots$. 55 . 50

755 Dawn. Dwarf early; white, tinged pink.......... .I5 .50

\section{Giant or Lato Cosmos}

759 Giant Flowering Pink................. .ro ${ }_{.30}$

76 1 " "

763 " "

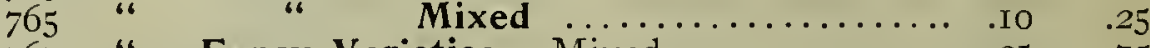

767 “ Fancy Varieties. Mixed...............25 . .75

768 “ Flowering Klondyke. Yellow ......... .

769 “ “ Flowering KIondyke.

77 flowers : color beautiful shell pink............ . I5 .40

773 Giant Flowering White Lady. Similar to Lady Lenox, excepting that the flowers are pure white $\ldots \ldots \ldots \ldots \ldots \ldots \ldots \ldots \ldots \ldots . . .30$ 


\section{MICHELL'S "DISTINCTIVE”"}

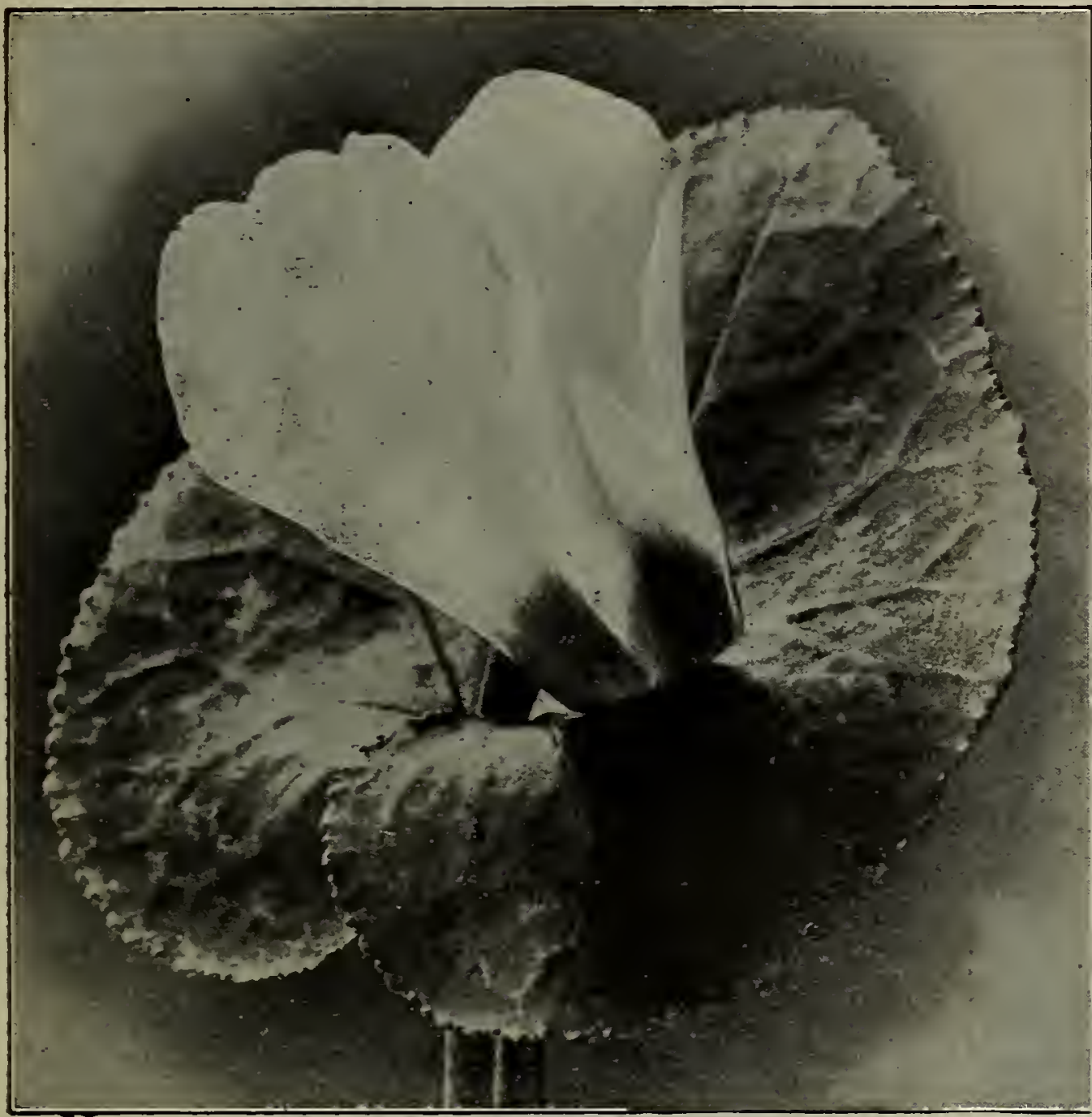

Michell's Fancy Giant Cyclamen

\section{Cyclamen}

Of this important florist's flower we now offer two distinct strains, both unchallenged in their class as "distinctively superior."

\section{Michell's "Distinctive" Giant}

This is the English strain, grown for us exclusively by a grower of world-renown, whose sole output is handled by us, consequently our quality cannot be duplicated. Flowers are gigantic; colors clear and superb; specimen plants are a thing of beauty and always win first prize at exhibitions.

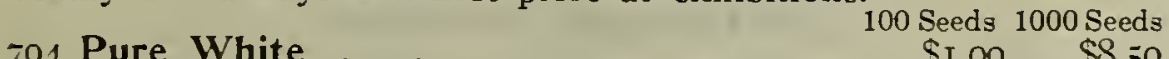
796 Soft Pink ......................... $1.00 \quad 8.50$ 792 White with Red Base................ I.00 8.50 790 Brilliant Crimson $\ldots \ldots \ldots \ldots \ldots \ldots \ldots \ldots \ldots$ 1.00 8.50 j98 Salmon Pink ....................... I.00 8.50 799 Mixed. A splendid assortment of colors.... $.90 \quad 8.00$

\section{Michell's Giganteum Cyclamen (Continental Strain)}

Again this is grown for us exclusively by a specialist, but on the Continent, and the distinction between the former and this strain is, that the Giganteum strain produces comparatively smaller flowers but twice and three times the number of flowers at one time, also that it flowers much earlier. German growers invariably prefer this strain, as it is the strain of the Fatherland.

-80 Album. White 100 Seeds 1000 Seeds

$\ldots \ldots \ldots \ldots \ldots \ldots \ldots \ldots \ldots \ldots \ldots \ldots \ldots \ldots+.75$

782 Roseum. Pink $\ldots \ldots \ldots \ldots \ldots \ldots \ldots \ldots \ldots \ldots \ldots \ldots \ldots \ldots \ldots \ldots \ldots \ldots$
784 Rubrum. Red $\ldots \ldots \ldots \ldots \ldots \ldots$

786 White with Red Eye......................... 75

-88 Mixed Colors ....................... 60

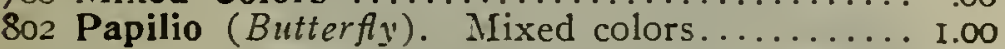

\section{Cyclamen, Sutton's Giant}

Mixed Colors. A celebrated strain. Original pkts., \$o.j5. 804 Cyclamen, Persicum

Mixed. The common type Trade Pkt. Os. $\$ 0.30 \$ 2.00$

\section{Convolvulus (Morning Glory)} Major or Tall Varieties

Trade Pkt. Oz.

740 Japanese Imperial. Mixed (1b. \$1.25). \$O.IO \$o.rj

$74 \mathrm{I}$ " $\quad$ Fringed. Mixed

742 Mixed (1b. \$2) $\ldots \ldots \ldots \ldots$. .10 .20

744 Double Flowering. Mixed colors...... . .

Minor or Dwarf Varieties

746 Tricolor. Blue .............. (1b. 5oc.)

748 Mixed ................... (lb. 40c.)

Cuphea (Cigar Plant)

775 Platycentra. Scarlet .............. .25 3.50

Cyperus (Umbrella Plant)

810 Alternifolius ....................40 1.50

Cypress Vine (Ipomoea Quamoclit)

8 i 5 Scarlet $\ldots \ldots \ldots \ldots \ldots \ldots \ldots \ldots \ldots \ldots$.ro . $_{20}$

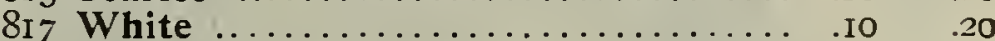

819 Mixed $\ldots \ldots \ldots \ldots \ldots \ldots \ldots \ldots \ldots \ldots \ldots \ldots$.IO

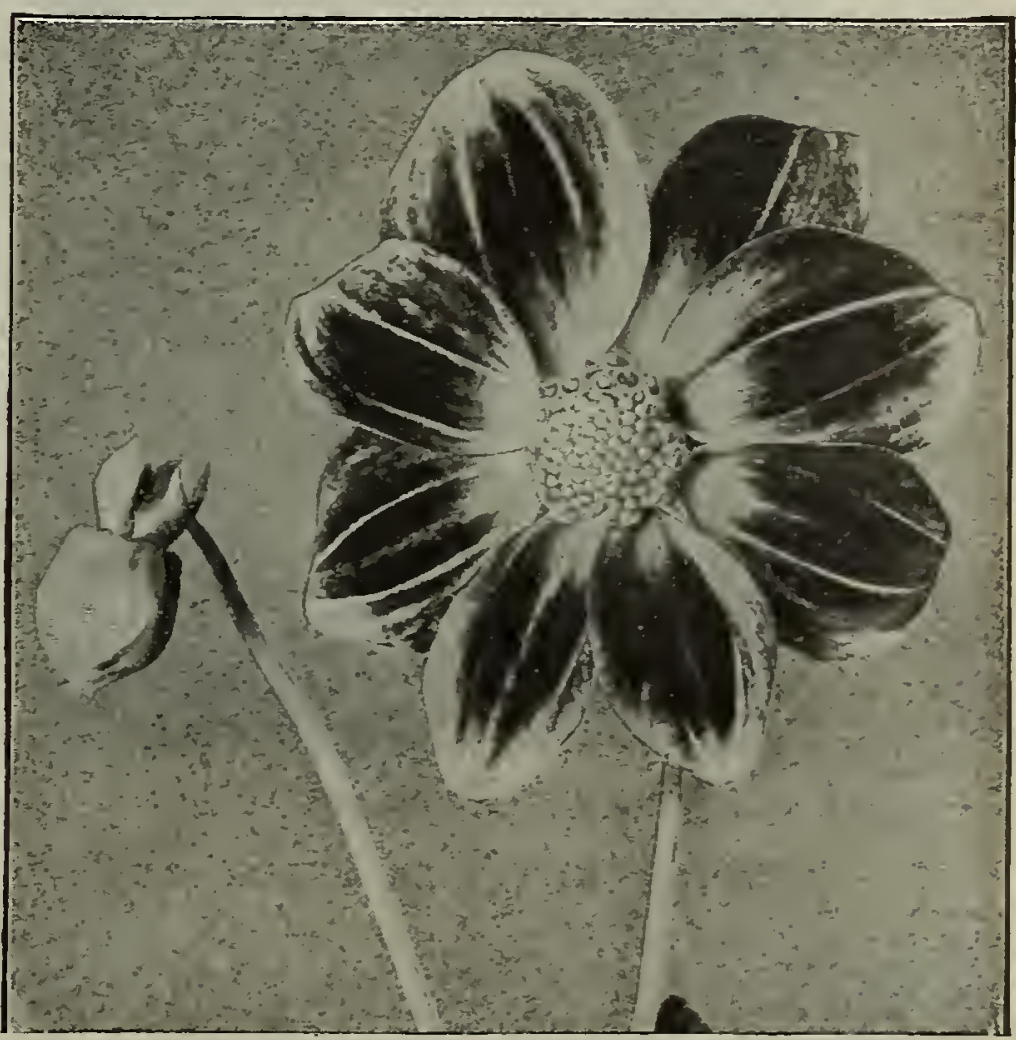

Twentieth Century Dahlia

\section{Dahlia}

Both the Double and Single Dahlias can be easily grown from seed, and will produce blooming plants the first summer if the seed is sown before May.

827 Double Cactus. All colors mixed........... Trade Pkt. Oz. 829 "Large Flowering. Show type, mixed.. .25 I.00 832 Single Century. Mixed from named sorts. (Pkt. I 5c.) 833 Collarette. Flowers of various colors, with a collar of small petals around the centre...... .25 I.00 835 "Giant Perfection. Mixed............. 847 “ Twentieth Century. (Pkt. IOc.).

Daisy, English Double (Bellis Perennis) 856 Monstrosa, Pink. ( $1 / 8$ oz. \$1.00) ........... .50

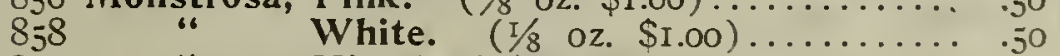

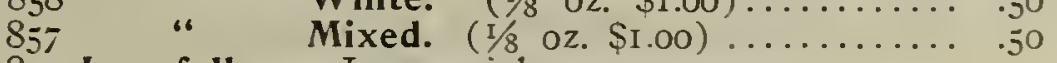
859 Longfellow. Large pink...................... 2.00 860 Snowball. Large white ................ .30 2.00 855 Giant Red. Various shades of red............ $50 \quad 2.00$ 86I Double Mixed

\section{Datura (Trumpet Flower)}

864 Cornucopia. White, marbled purple......... .10 .30 866 Double Golden ........................... . I0 .25

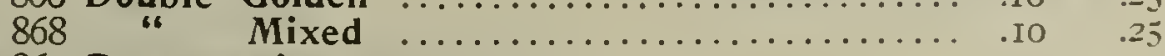
862 Brugmansia.

\section{0} . is 


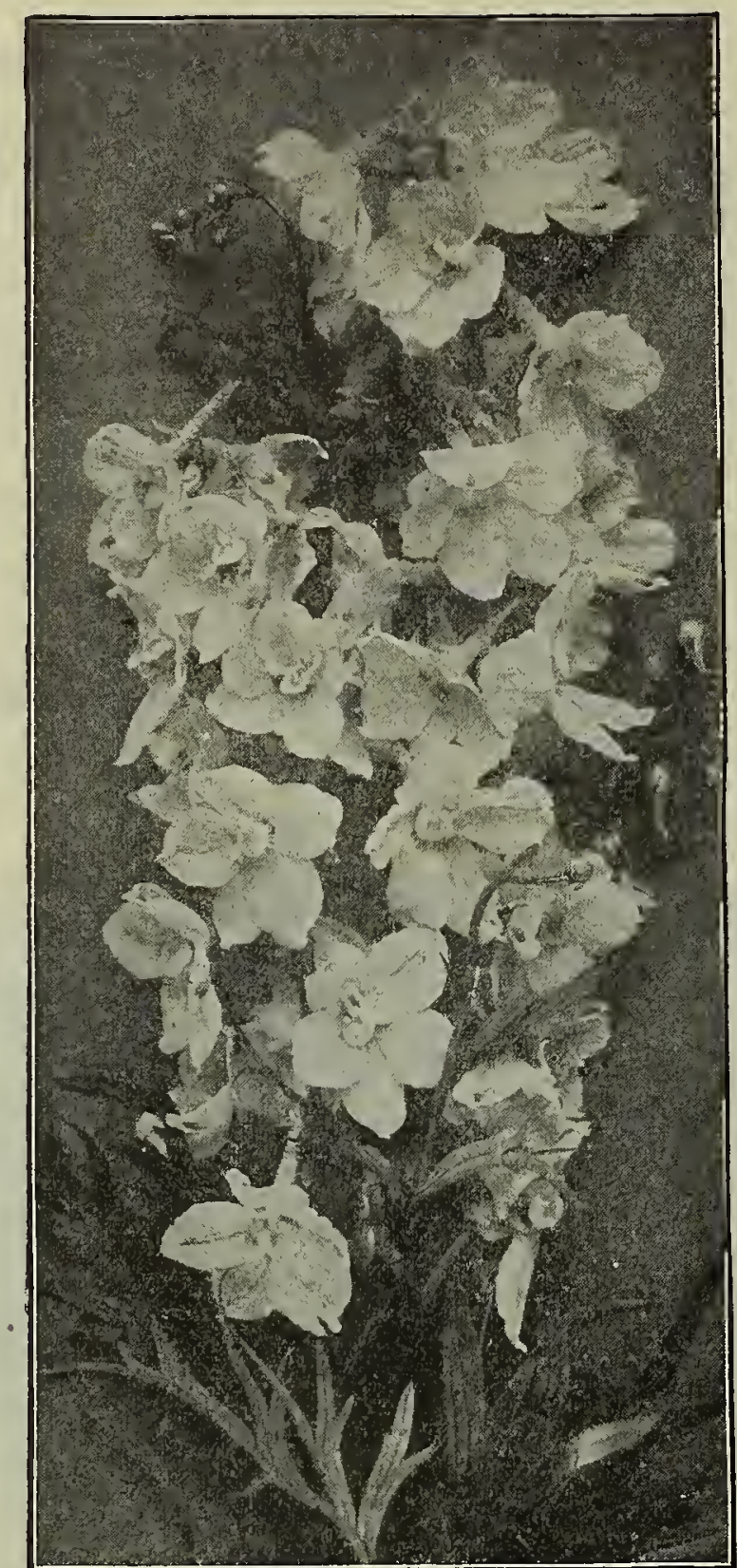

Delphinium-Kelway's Giant

\section{Delphinium (Perennial Larkspur)}

878 Kelway's Giant. Enormous spikes with flowers Prad. of many shades of blue............... \$0.40 $\$ 2.00$

87 I Bella Donna. Light turquoise blue......... $.50 \quad 2.50$

872 Burbank's Hybrids. Splendid assortment of colors; large flowers...................40

884 Amos Perry. Rosy mauve, flushed sky blue... .40

885 Duke of Connaught. Oxford blue, white eye.. .40

877 Formosum. Deep blue .................... . 5

880 " Coelestinum. Sky blue .......... .25

875 Chinense Grandiflorum. Dwarf, flowers blue.. .I

874 " " Album. White ......... I0

873 Cashmerianum. Large, dark blue...........40

876 Elatum (Bee Larkspur). Blue..............20

886 Mme. Violet Geslin. Clear blue, white eye... .40

879 Nudicaule. Scarlet ......................40

887 Portia. Cornflower blue, dark centre........40

888 Queen Wilhelmina. Soft lavender-blue, flushed

with rose, white eye......................

889 Rembrandt. Bright sky-blue, inner petals rosy

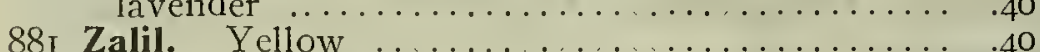

883 Hybridum, Mixed. All shades.............. .

For ANNUAL LARKSPUR See Page 42

Digitalis (Foxglove)

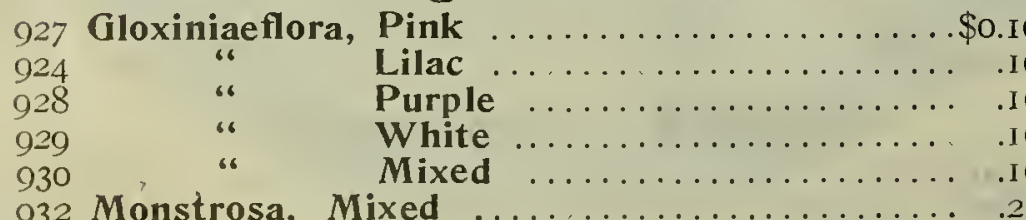

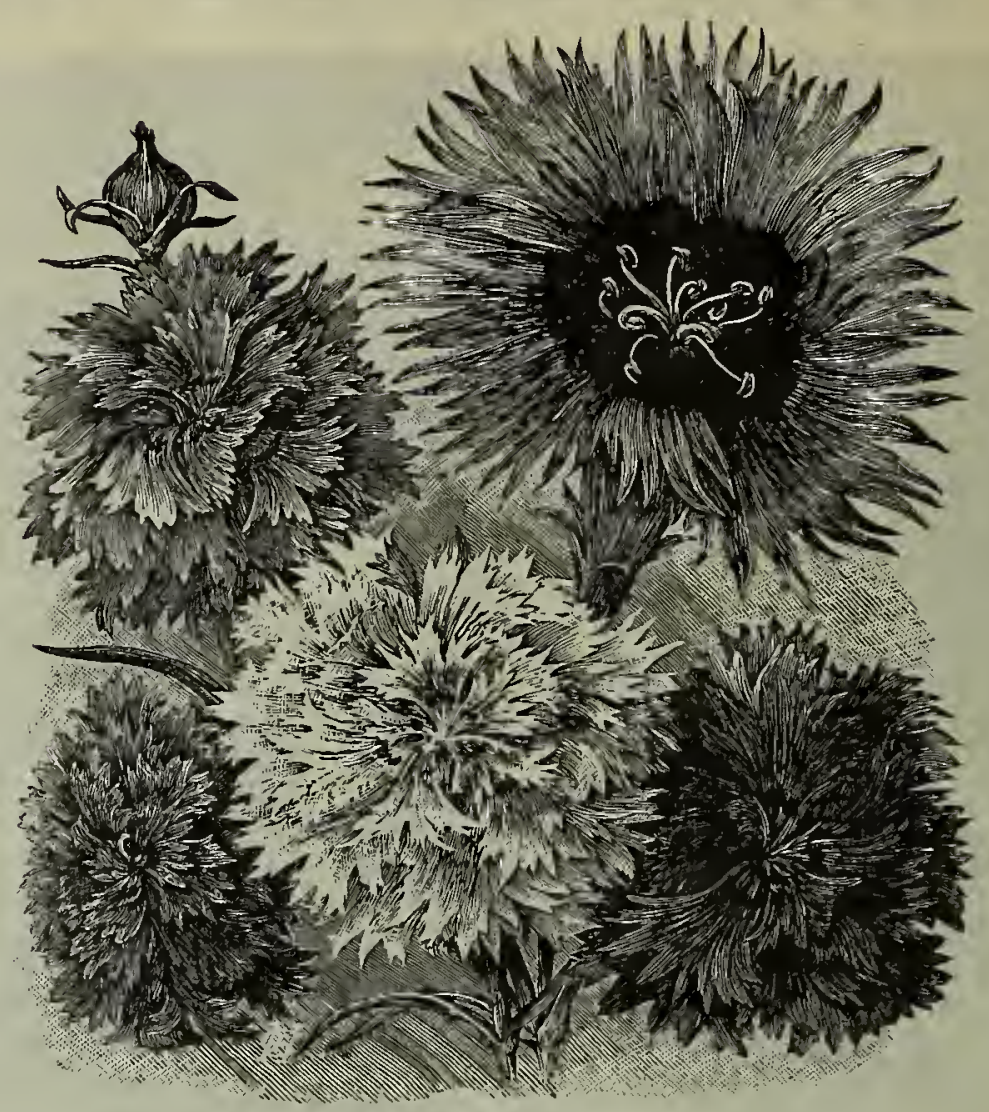

Dianthus (Annual Pink)

Dianthus (Pinks)

Double Annual Sorts Trade pkt. Oz.

890 China or India Pinks. Mixed............. \$0.10 \$0.25

892 Fireball. Fiery scarlet.................... . $5 \ldots \ldots$

894 Fringed. Large, mixed colors................. .15 $\quad .50$

896 Japan Pink. Choice mixed................ .15 .50

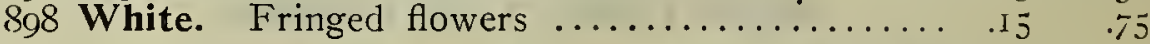

\section{Dianthus-Single Annual Sorts}

gog Japan Pink. Mixed colors ............... I5 to

9I I Nobilis (Japan Royal). Mixed......................... .50

9 I5 Salmon Queen. Brilliant salmon color......... .I .6o $^{2}$

\section{Dianthus-Hardy Garden Sorts}

919 Clove Scented. Double mixed........... .30 2.00 917 Dwarf Erfurt. Fragrant; double; mixed colors .50 2.50 920 Latifolius Atrococcineus (Everblooming $H y$ -

brid Sweet William). Double red.......... .20 $\quad .50$ 92I Pheasant's Eye. Single fringed flowers; mixed . I0 .50 923 Double Scotch. Choice colors, mixed.......... .30 1.50

\section{Dictamnus (Gas Plant)}

925 Fraxinella. Perennial; purple red flowers..... . . 0 .25

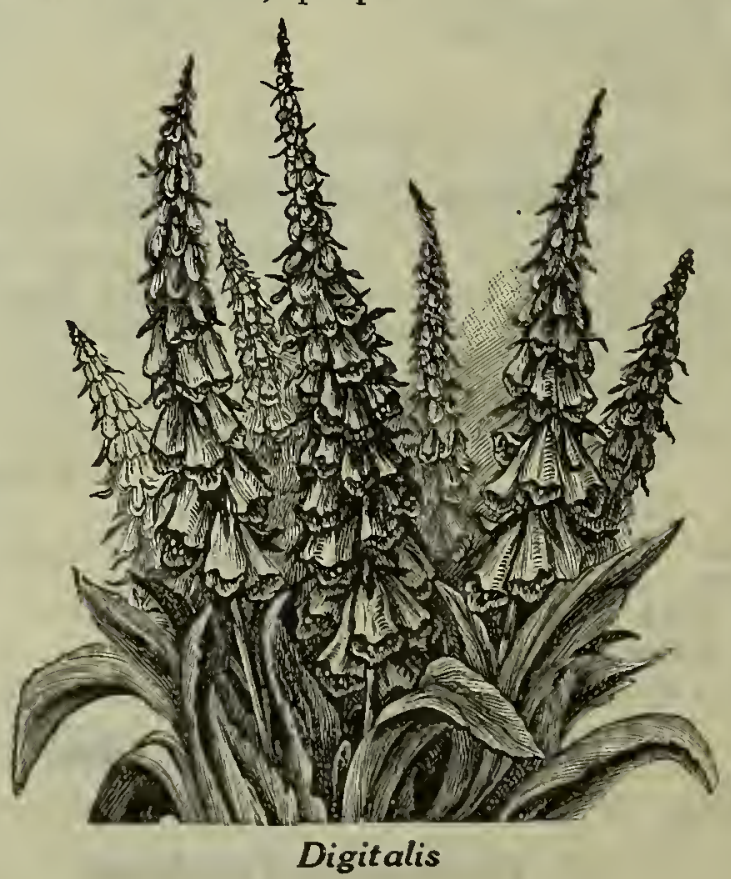




\section{MICHELL'S “DISTINCTIVE”" FLOWER SEEDS}

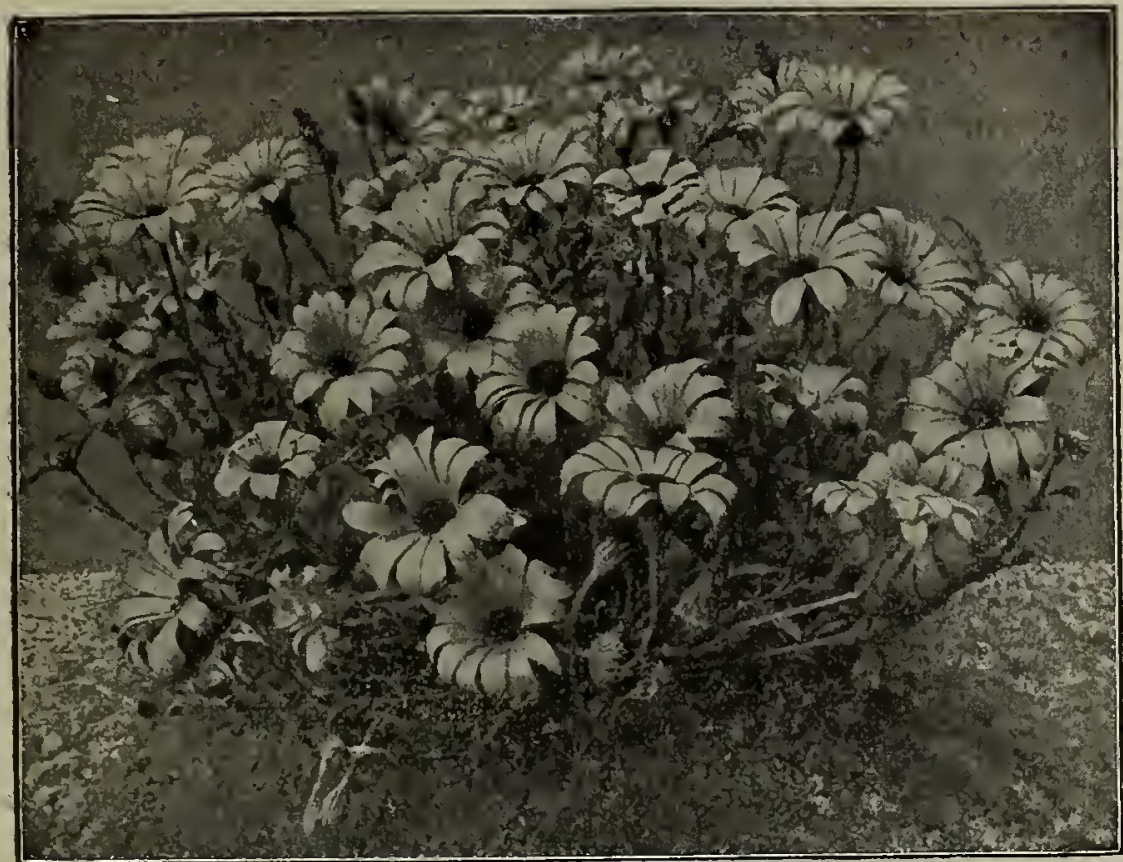

Dimorphotheca-Aurantiaca Hybrida

\section{Dimorphotheca}

926 Aurantiaca (African Orange Daisy).. The golden Trade orange daisy-like flowers are splendid for cut- Pkt. ting and especially adapted for forcing.......\$0.30 \$1.00

93I Aurantiaca Hybrida. A splendid mixture of colors and shades ..........................

938 Aurantiaca Hybrida, fl. pl. Double and semition and full description see Novelties, page 25. Per pkt. 20c., 55c. per 3 pkts.

\section{Dolichos (Hyacinth Bean)}

934 Darkness. Purple violet ( $1 / 4$ lb. 25c.) .........

935 Daylight. Pure white $(\mathrm{r} / 4$ lb. 25c.) $\ldots \ldots \ldots \ldots$

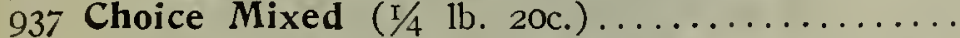

\section{Dracena}

942 Indivisa. Our seeds are picked for plumpness. Narrow green leaves; the popular sort for bedding or vases ................ ( $1 / 4$ 1b. $\$ 1.00)$

940 Australis. Broad leaves ................ .15

Echinocystis (wild Cucumber vine)

945 Lobata

............................. Io

\section{Edelweiss}

950 Gnaphalium Leontopodium. The popular Alpine .30

\section{Eschscholtzia (California Poppy)}

\section{I Californica. Yellow ................. .10}

952 Burbank's Crimson. Large; deep crimson..... .20

955 Golden West. Large golden yellow........... ..

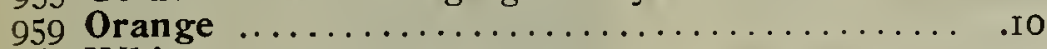

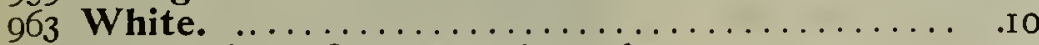

957 Mandarin. Orange and scarlet............. .IO

961 Rose Cardinal. Carmine rose.............. ro

965 Choice Mixed ........................ .

EULALIA (See Grasses) page 40

\section{Eupatorium}

A fine perennial, and useful for cutting.

975 Fraseri. White flowers

\section{Ferns for Greenhouses}

We make a specialty of greenhouse ferns and furnish absolutely fresh spores to insure prompt germination. The following varieties can be relied upon to come true to name: Trade Pkt. 985 Adiantum (Maiden Hair). Mixed..............\$0.30

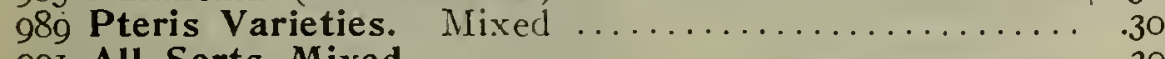
991 All Sorts Mixed Adiantum Cuneatum Aspidium Tensimense Cyrtomium Falcatum Lomaria Gibba

Lygodium Scandens

Pteris Adiantioides

"Alba Lineata Each variety, per Trade Package, 3oc.

\section{Euphorbia}

980 Heterophylla (Mcxican Firc Plant). Ornamen-Pkt. $\quad \mathbf{z}$. tal foliage plant, red flower bracts......... \$o.15 \$0.50 982 Variegata (Snow on the Mountain). Variegated

foliage and white flower bracts............. . IO .Is

\section{Feverfew (Matricaria)}

995 Double White. Fine for cut flowers........ . . ' ${ }_{2} 25$

\section{Freesia}

1005 New Hybrids Mixed. A valuable novelty, 100 1,000 flowering within 8 months from time of sow-Seeds Seed ing; various colors ..................\$0.35 $\$ 2.50$

\section{Fuchsia}

ror5 Mixed. Best single and double............. $30 \quad 2.25$

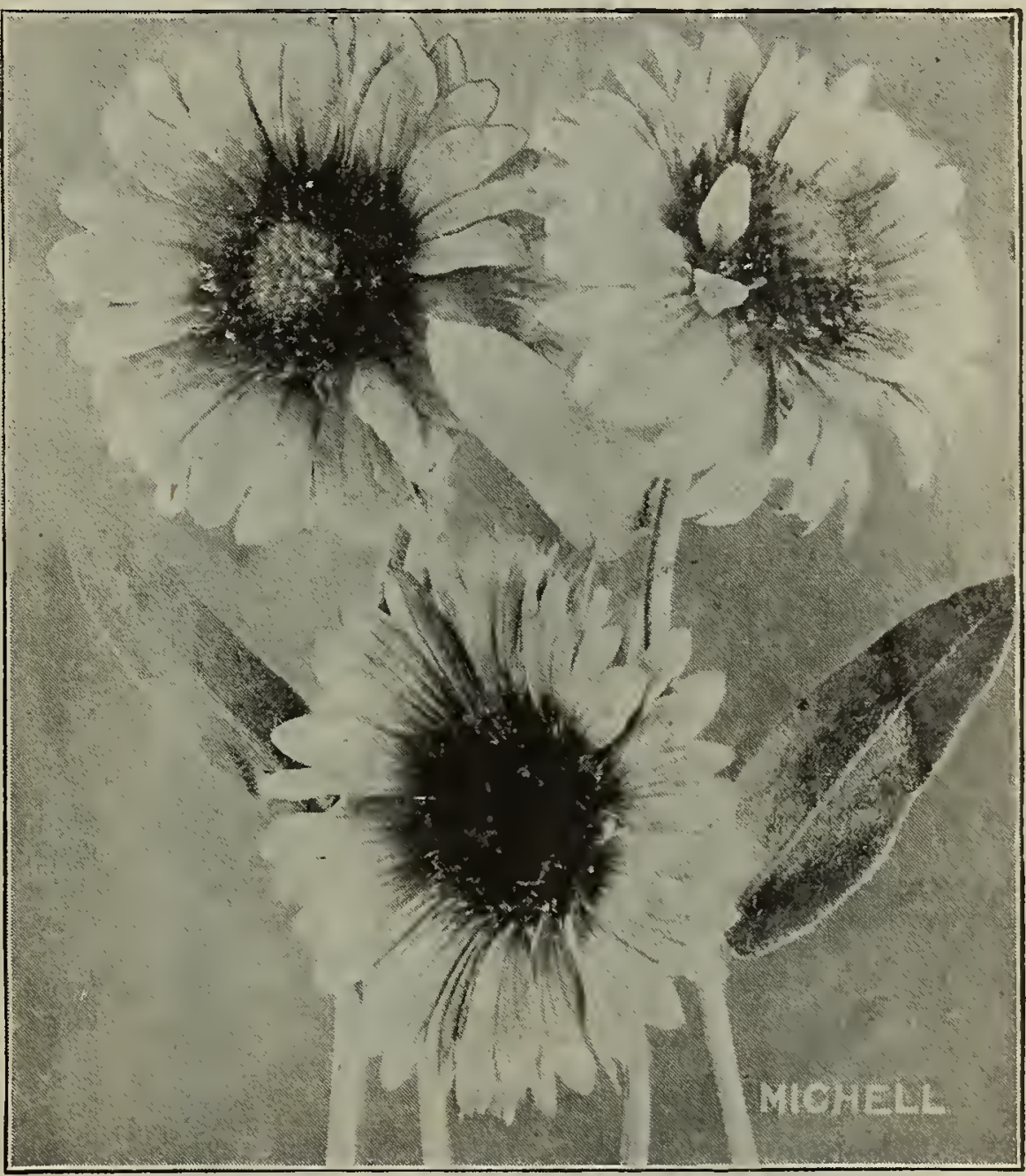

Useful for cutting, or for the mixed border. Trade Plt. Oz. I028 Picta. Single mixed .................. \$0.10 \$0.15 Lorenziana. Double mixed ............

\section{Gaillardia-Perennial Varieties}

These occasionally flower the first year from seed. Gigantic attractive flowers appear during the whole season; fine for cutting or borders.

IO2I Sanguinea. Blood red

1020 Grandiflora Compacta.

1022 "“ Superba. Mixed .............

I030 Sulphurea Oculata. Sulphur yellow, maroon

eye $\ldots . . . . . . . . . . .$.

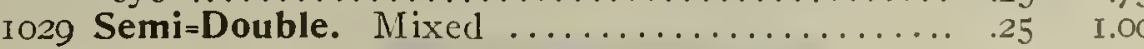

Gentiana (Blue Gentian)

I035 Acaulis. Hardy perennial; blue flowers..... .15 . 5

\section{Geranium}

r040 Apple Scented. Per 100 seeds, 20c.; \$I.50 per rooo seeds.

I042 Pelargonium (Lady Washington). Per 100 seeds, $7 \vec{s} \mathrm{c}$.

ro44 Zonale, Mixed. ...................... . 


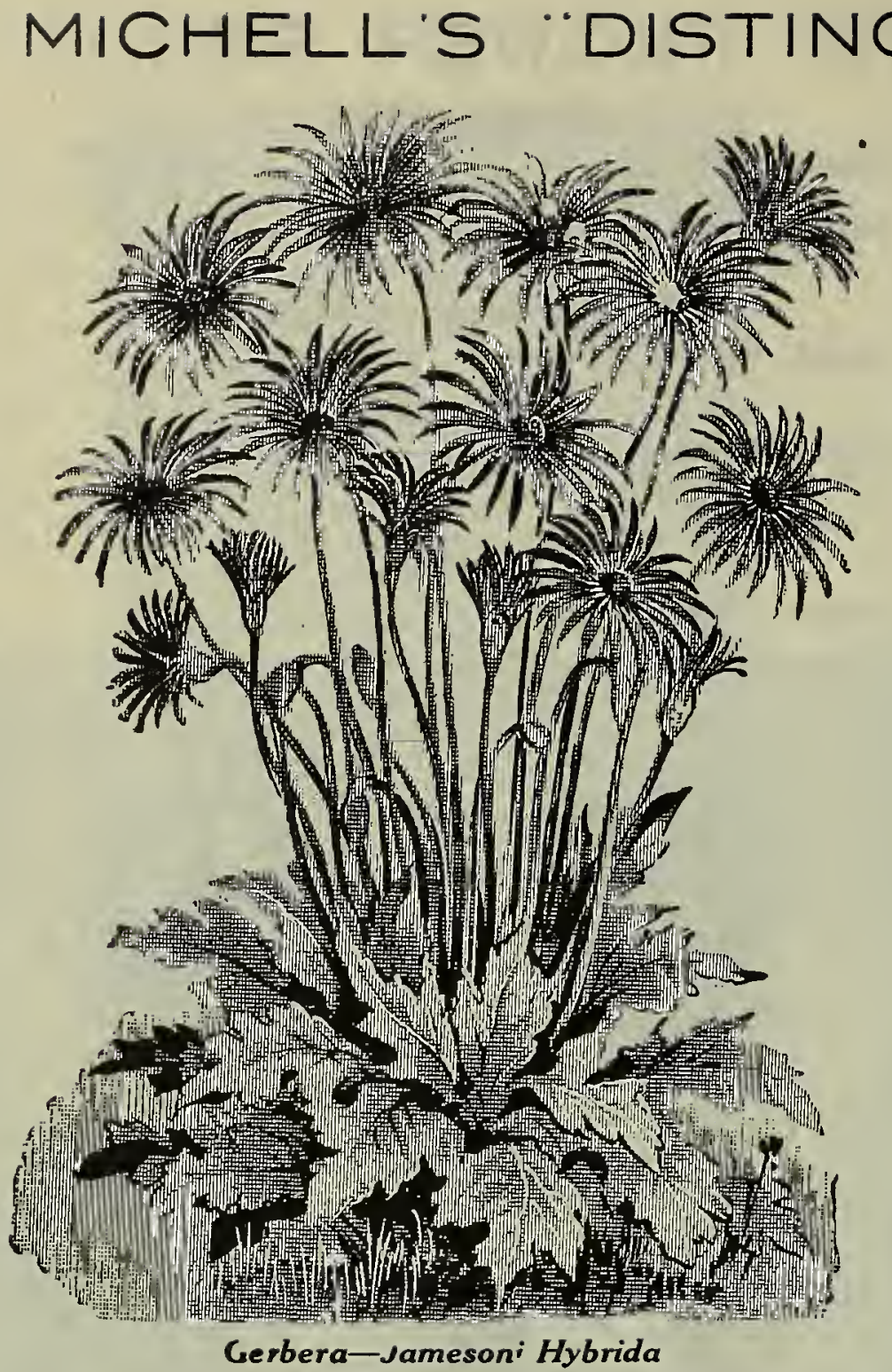

Gerbera (I ransvaal Daisy)

This is strictly a greenhouse perennial and will no doubt become a popular cut flower when the grower makes a closer acquaintance. Place seeds on edge and let fuzzy part protrude. I049 Jamesoni Gigantea. Immense scarlet flowers. Per Ioo seeds, $75 \mathrm{c}$

I047 Jamesoni Hybrida. One of the best recent introductions. These hybrids produce every possible shade of colors. Per 100 seeds, $75 \mathrm{c}$.

\section{Geum} dark crimson flowers, perennial..........\$0.20 \$0.75

\section{Gloxinia}

Perfect flowers and shapely plants are the result of carefully saved seeds from specimens only. That is just what we are offering.

1055 Hybrida Grandiflora, Choicest Mixed. Trade Pkt. Oz. ( I/2 trade pkt., 60c.)................\$1.00

\section{Godetia (Satin Flower)}

I06o Gloriosa. Blood red I062 Choice Mixed

\section{Golden Rod}

I065 Solidago Canadensis. Perennial; golden yellow .ı .40

Gomphrena (Globe Amaranth)

rozo Nana Compacta. Dwarf red...

I0:2 Mixed. All colors.

Gourd (ornamental)

3075 Calabash, or Dipper. Very useful

I077 Egg=Shaped. White

I079 Hercules Club. Club-shaped; 4 feet long

1081 Luffa (Dish Rag or Bonnet Gourd) ...

ro83 Orange=Shaped (Mock Orange)

i 085 Pear=Shaped. Striped; very showy.

108- Serpent. Striped like a serpent. 5 teet long......

I080 Sugar Trough. Used as water holders...........

I09I Mixed. In a great variety.
FLOWER SEEDS

Grasses (ornamental)

\section{Annual Varieties Trade $\mathrm{P}_{\mathrm{k} i}$. $\mathrm{O}_{2}$.}

4 I 5 Avena Sterilis (Animated Oats) ......... \$0.10 \$0.15 490 Briza Maxima (Quaking Grass).............. .io .I 495 Bromus Brizaeformis................... . I0 .I

730 Coix Lachrymae (Job's Tears)................. 10

I 66 Hordeum Jubatum (Squirrel Tail Grass)...... . . . $\quad .20$

I640 Pennisetum Longistylum ................. . . $\quad .25$

Grasses-Perennial Varieties

I55 Arundo Donax (Great Reed) ............... .I5 $\quad .40$

970 Eulalia Japonica ....................... . . $\quad .30$

I IOo Gynerium Argenteum (Pampas Grass).......... . .

I642 Pennisetum Ruppelianum (Purple Fountain Grass ) .............................. .10 .25

2005 Stipa Pennata (Feather Grass) .............. .10 .25

\section{Grevillea (Silk oak)}

1095 Robusta. An ornamental foliage plant, grown extensively for vase work and very easily grown from seed......................... GYNERIUM. (See Grasses above.)

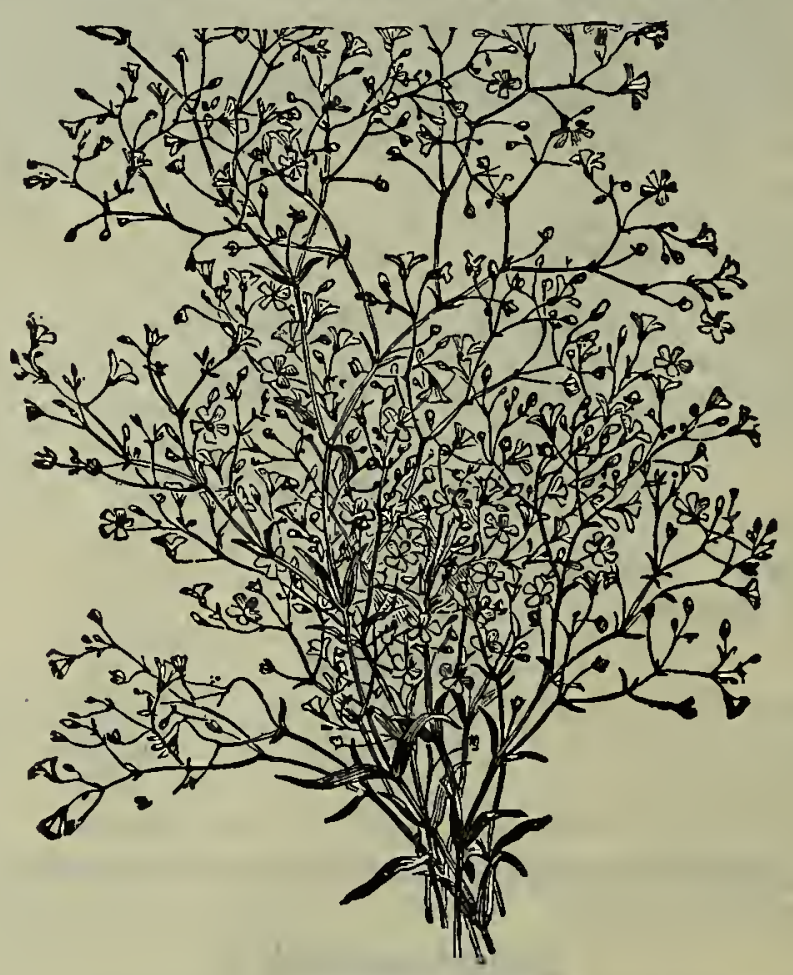

Gypsophila Paniculata

Gypsophila (Baby's Breath) Trade Pkt. Oz,

II03 Elegans Alba Grandiflora. Hardy annual variety: flowers pure white................. \$o.10 \$0.20 I 105 Paniculata. Perennial; graceful sprays of white

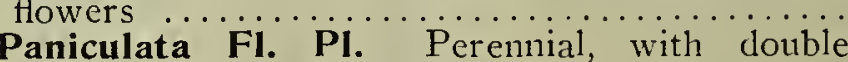
IO $\quad .25$ 1106 Paniculata Fi. PI. Perent
white flowers. Per pkt. $15 \mathrm{c}$.

\section{Helenium}

i 108 Autumnale Superbum. Perennial; golden yel-

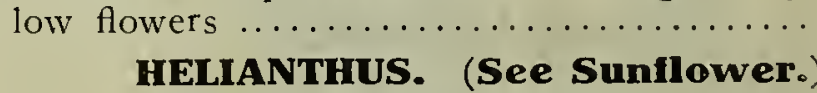

\section{Helichrysum. (straw nower)}

II Io Monstrosum. Double mixed $\ldots \ldots \ldots \ldots \ldots$. . . . 30

Heliopsis (orange Sunflower)

III2 Pitcheriana. Perennial; deep golden yellow flowers $\ldots \ldots \ldots \ldots \ldots \ldots \ldots \ldots \ldots \ldots \ldots \ldots \ldots \ldots \ldots$.10 .30

Media, Pa., Aug. Io, I9I2. Dear Sirs:-Enclosed find order and remittance. My experience with your seeds is, that almost every seed germinates; I get the finest plants and blooms from your seeds of any I have ever tried. Very truly yours, 

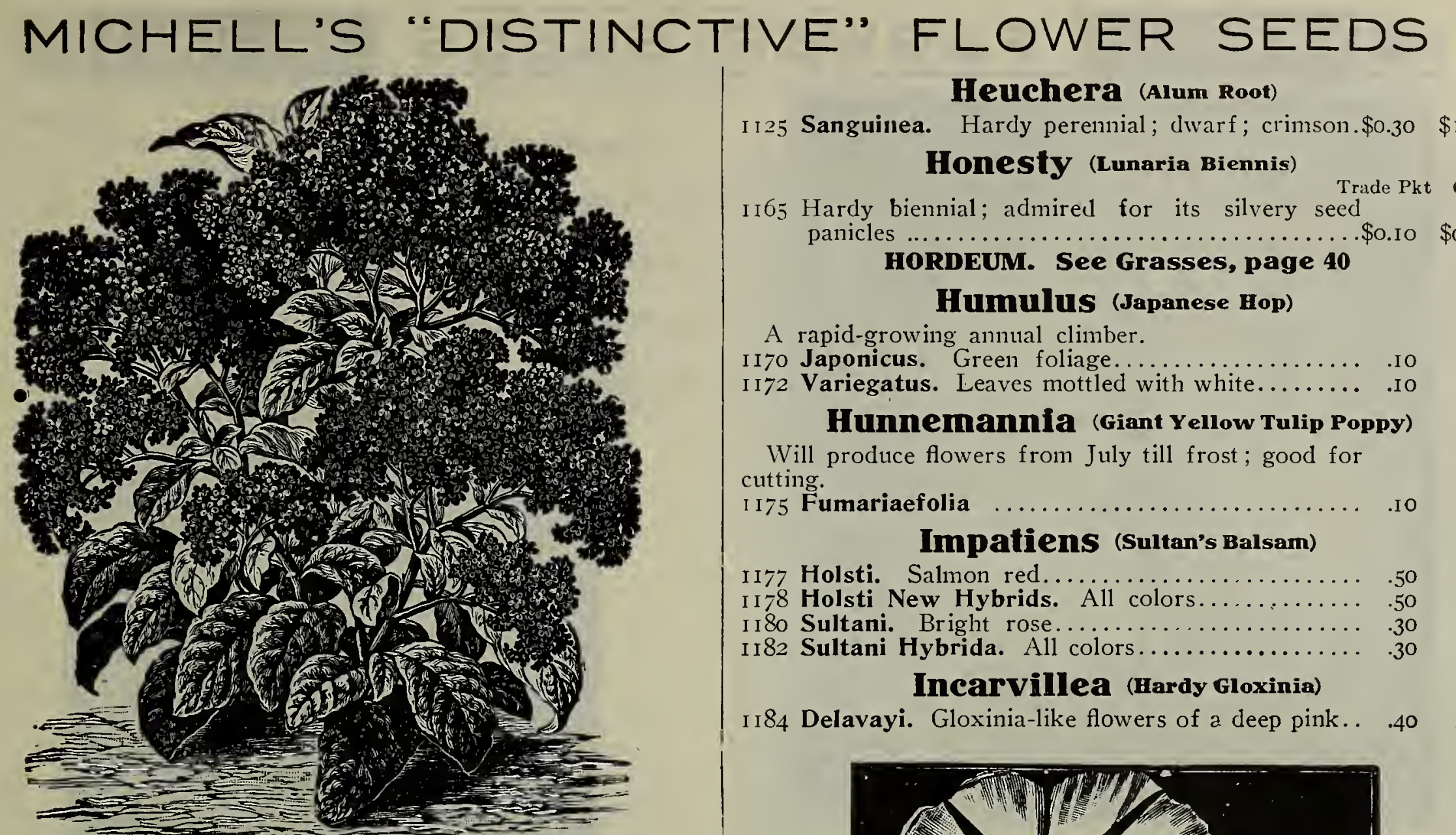

Heliotrope, Lemoine's Giant

\section{Heliotrope}

III Lemoine's Giant Hybrids. Immense flowers \$0.40

III7 Regal. Dwarf large flowering............. $40 \quad 2.00$

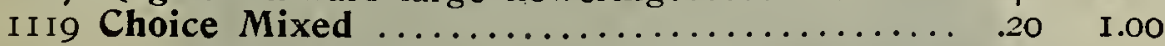

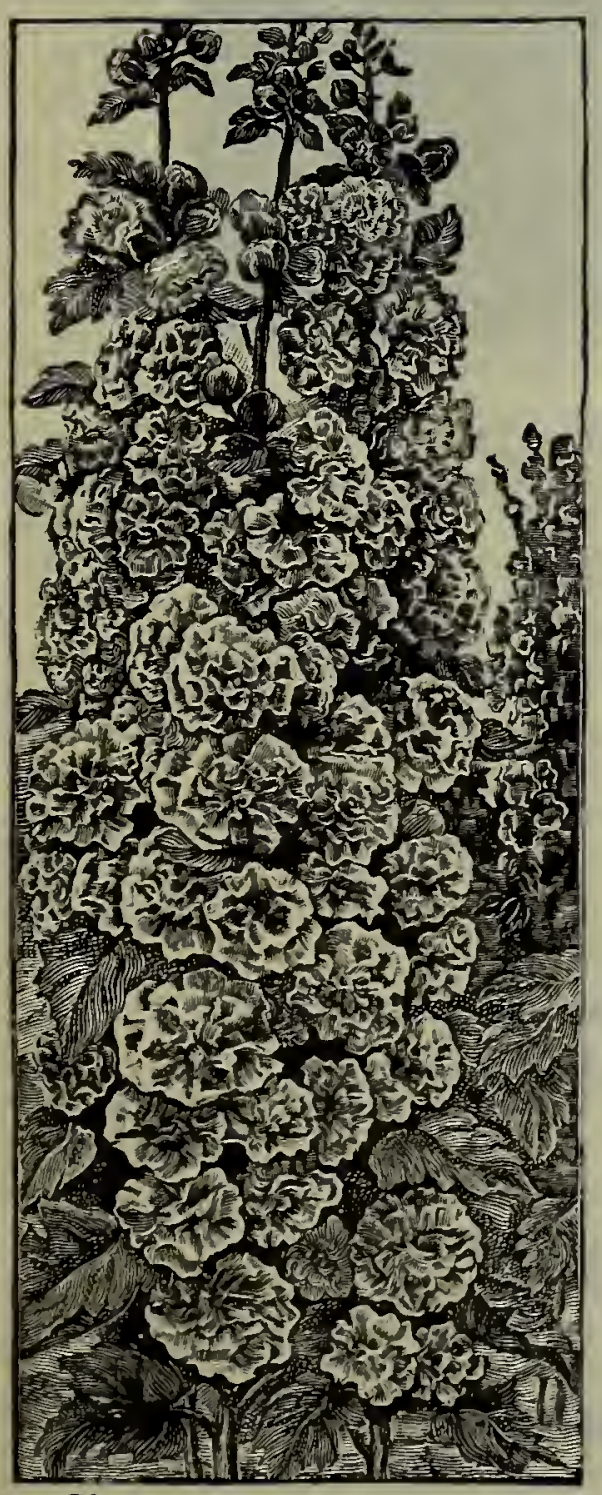

Chater's Double Hollyhock
Hibiscus (Marshmallow)

II33 New Gi a nt.

(Mallow Mar

vel.) Immense

flowers in

shades of red, pink, purple and white...

I 30 C r i m s o n

Eye. White

with crimson centre

I 132 Golden Bowl.

Yellow with

maroon cen-

Pre 1 us t i ris.

Pink. ......

II3I Moscheutos.

Large pink

flowers $\cdots .$. .I

Chater's Double Selected

I 49 Pink

II 50 Maroon ..... $\quad .25 \quad .65$

I I 5I Red ............

I I 53 Salmon .... $\quad .25 \quad .65$

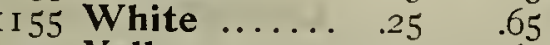

I 57 Yellow $\ldots \ldots$. $25 \quad .65$

159 Choice Mixed .20 .60

HOLLYHOCK-other Sorts

I 160 Single Mixed .I 5 .50

I 48 Single Hybrid

Everbloom=

ing. Flowers

the first year

I 47 Double Hybrid

Everb $100 \mathrm{~m}=$

ing. Flowers

the first year

I 46 Fringed Alle= gheny ......

\section{Heuchera (Alum Root)}

I 25 Sanguinea. Hardy perennial; dwarf; crimson. \$0.30 \$1.75 Honesty (Lunaria Biennis)

65 Hardy biennial; admired Pkt Oz. panicles ........................... \$o.1o \$0.30 HORDEUM. See Grasses, page 40

\section{Humulus (Japanese Hop)}

A rapid-growing annual climber.

I I7o Japonicus. Green foliage............... . Io

I 72 Variegatus. Leaves mottled with white........ .I

Hunnemannia (Giant Yellow Tulip Poppy)

Will produce flowers from July till frost; good for cutting.

I 75 Fumariaefolia

.10

.30

\section{Impatiens (Sultan's Balsam)}

II 77 Holsti. Salmon red...................... .50

I 78 Holsti New Hybrids. All colors............. .50

I 80 Sultani. Bright rose................... .30

I 82 Sultani Hybrida. All colors.............. .30

\section{Incarvillea (Hardy Gloxinia)}

I 84 Delavayi. Gloxinia-like flowers of a deep pink.. .40 I.50

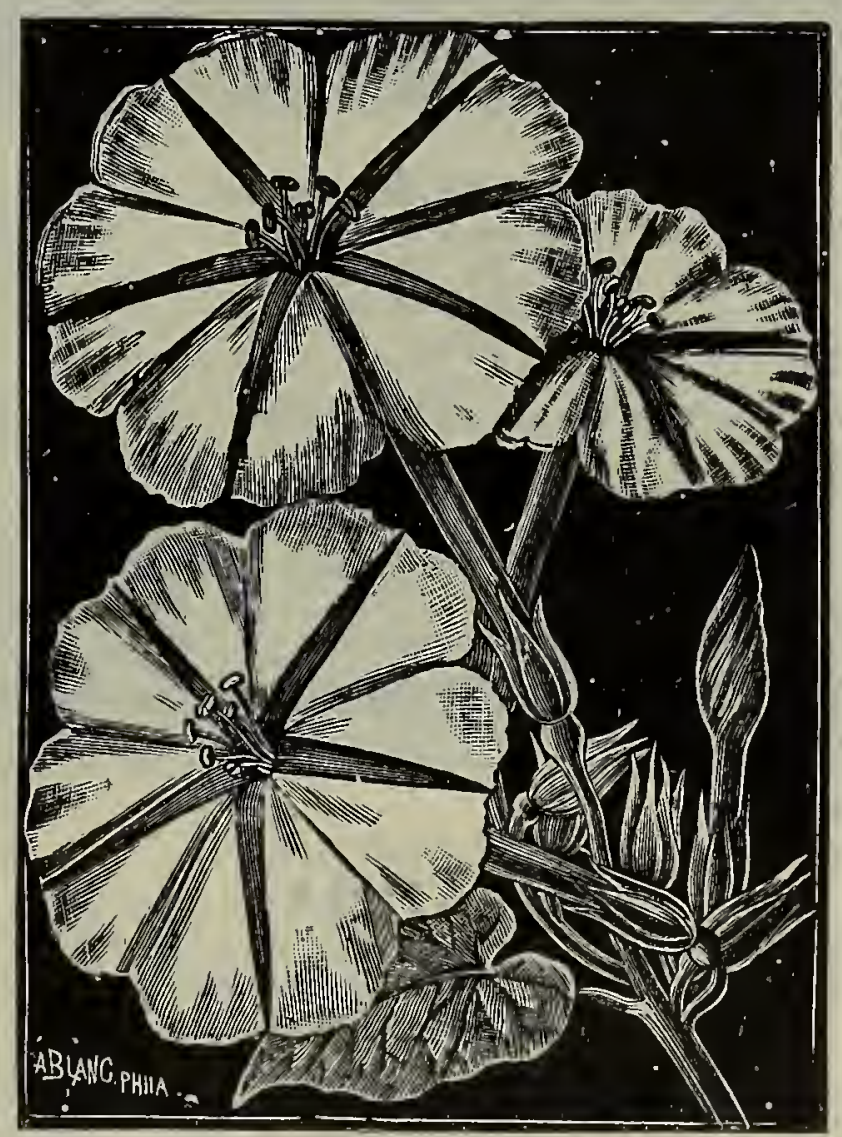

Moonflower (Ipomoea Noctitlora)

\section{Ipomoea}

II 89 Noctiflora (Moon Flower). Lb \$450 $\$ 15$ Trade Pkt. Oz. II85 Grandiflora Superba. Blue. edged white...... .I I I87 Heavenly Blue (Rubra Cocrulea) .............. . I5 .40 I I9I Setosa (Brasilian Morning Glory). Pink. . I 93 Mixed

\section{Iris (Flowering Flag)}

II94 Kaempferi (Japancsc Iris). Mixed colors

\section{Kenilworth Ivy}

I 95 Linaria Cymbalaria. Flowers violet. .

Kochia (Summer Cypress, or Mexican Fire Bush) I 98 Trichophylla. A very popular annual.

\section{Lantana}

A valuable plant for bedding, pot culture I 200 Dwarf Compact Mixed. I 20 I Choice Mixed 


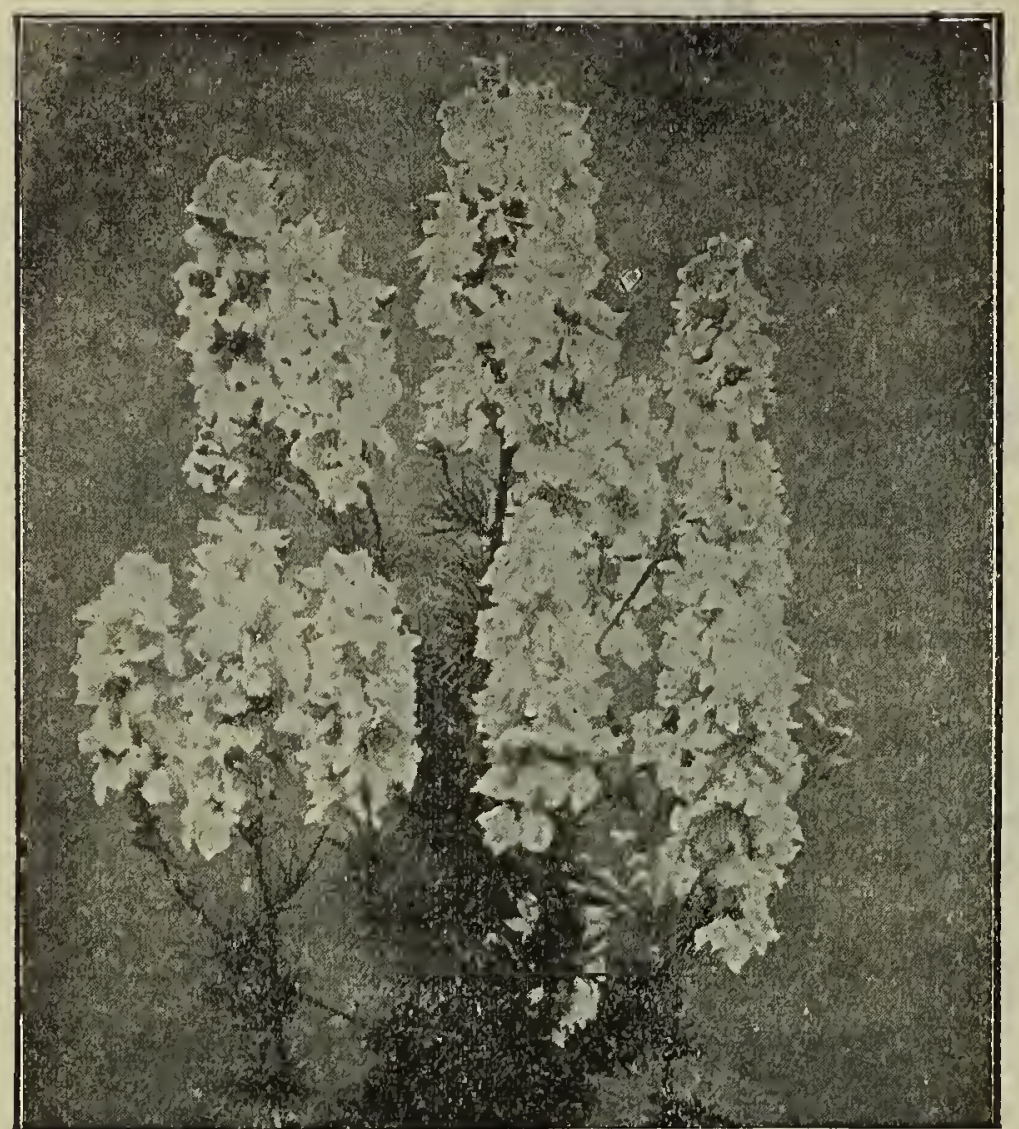

Larkspur, Double Tall Stock Flowered

LARKSPUR (Annual) Tradepkt. Oz.

I202 Tall Stock Flowered Dark Blue ...........\$0.10 \$0.30

I203 “ “ “ "

1206 " " " "

I209 " " " "

1207 " " " " Mixed ..............

I222 Giant Hyacinth Flowered Shell Pink......... . IO .25

I223 “ “ “ “ “

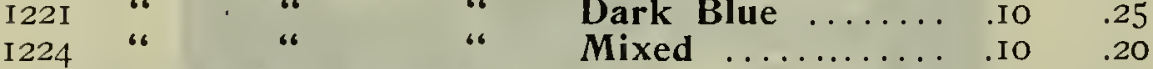

I 226 Queen of the Pinks. Splendid for cutting or

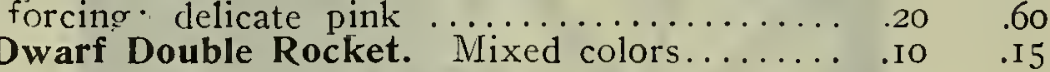

LATHYRUS LATIFOLIUS (Perennial Pea)

I2 Io Crimson $\ldots \ldots \ldots \ldots \ldots \ldots$. IO

I2I 2 Pink Beauty. Bright pink ............. .Io

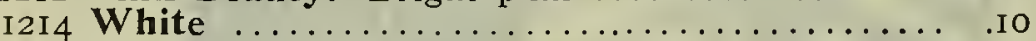

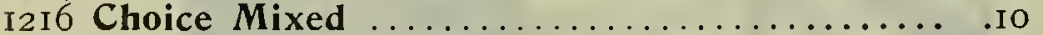

\section{LAVATERA}

I2 8 Splendens Rosea. A splendid annual for cutting and decorative work; pink flowers ...... . I5

\section{LOBELIA}

No list of bedding plants is complete without Lobelia, and what we offer in this line are all gems. Seed should be sown early.

I239 Crystal Palace Compacta. This is the leading dwarf variety, having dark blue flowers carried erect

I235 Barnard's Perpetual. Dwarf; blue with white

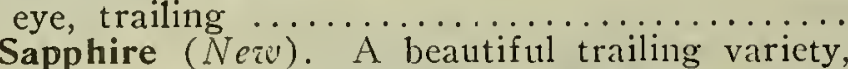

I254 Sapphire (Nea). Alue with white eye. Per plit. I 5c.

I24I Crystal Palace Speciosa. The best trailing sort for baskets and vases; deep blue..........
Double Flowering. Deep blue; holds its flower longer than any other sort.

245 Emperor William. Dwarf, light bl

I 249 Gracilis. Light blue, trailing

I255 White Gem. Pure white; dwarf

I257 Choice Mixed

\section{LOBELIA-PERENNIAL VARIETIES}

I237 Cardinalis (The Cardinal Flower). Stately plants with spikes of cardinal red flowers...

$.40 \quad 3.00$

Read Pages 23 to 28 for Valuable Novelties in Flower Seeds.
LAVENDER

Trade pkt. Oz.

I220 Lavendula Vera (True). Fragrant blue flowers.\$o.ı $\$ 0.50$ LIATRIS (Blazing Star)

I227 Pycnostachia. Perennial; deep rose flowers... .40 3.00 LILY OF THE VALLEY

I 225 Convalaria Majalis

$$
\text { LINUM }
$$

I230 Grandiflorum Rubrum (Scarlet Flax)........ . . . . 5 LOPHOSPERMUM

I 260 Scandens. For hanging baskets, vases, etc....

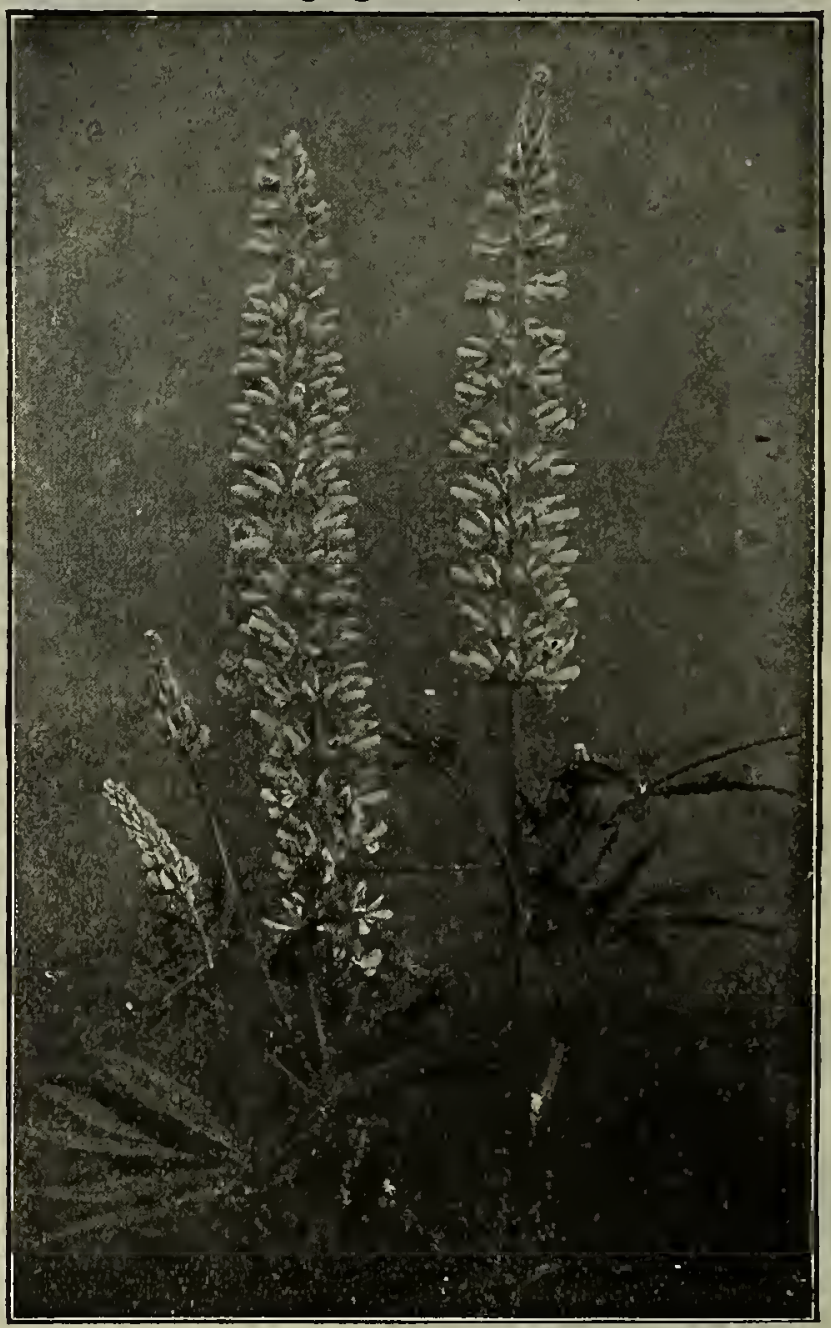

I upinus-Annual

LUPINUS (Annual)

This is one of the most popular forcing annuals. Six weeks from day of germination will produce the flower; very showy and keep well after cutting. An easy seller. Trade pkt. Oz. I 268 Michell's Pink Beauty. This is by far the best; color a most pleasing delicate salmon pink. This may be grown in single spikes or

branching; both are good.................\$o.1o \$o.30 I265 Blue

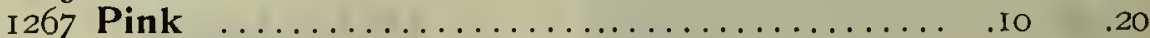

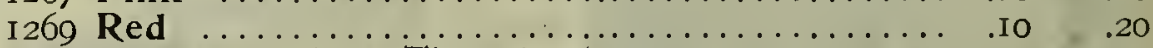

I27I Scarlet, White Tipped ................ . I0 ${ }_{.20}$

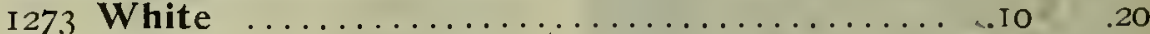

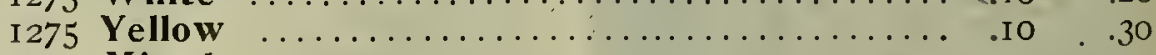

I277 Mixed

\section{LUPINUS-PERENNIAL VARIETIES}

Showy plants for semi-shady spots.

I 278 Polyphyllus Roseus. Soft pink .......... .30 1.00

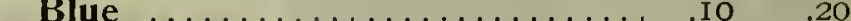

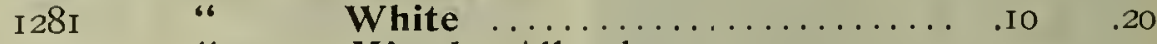

I279 “ Mixed. All colors ............ . Io .I5

\section{LYCHNIS}

I285 Chalcedonica. Perennial; scarlet; 2 feet....... . I0 .25 I286 Flos Cuculi. Bright red, fringed flowers........ .25 I.50 I 287 Haageana Hybrida. Mixed, 8 inches.......... . I5 I.00

\section{LYTHRUM}

I 288 Roseum Superbum. Stately spikes of pink flowers, 3 feet, August ................. .io 


\section{MICHELLS FLOWER SEEDS $\frac{518}{\text { makrti ST PHILA. }}$}

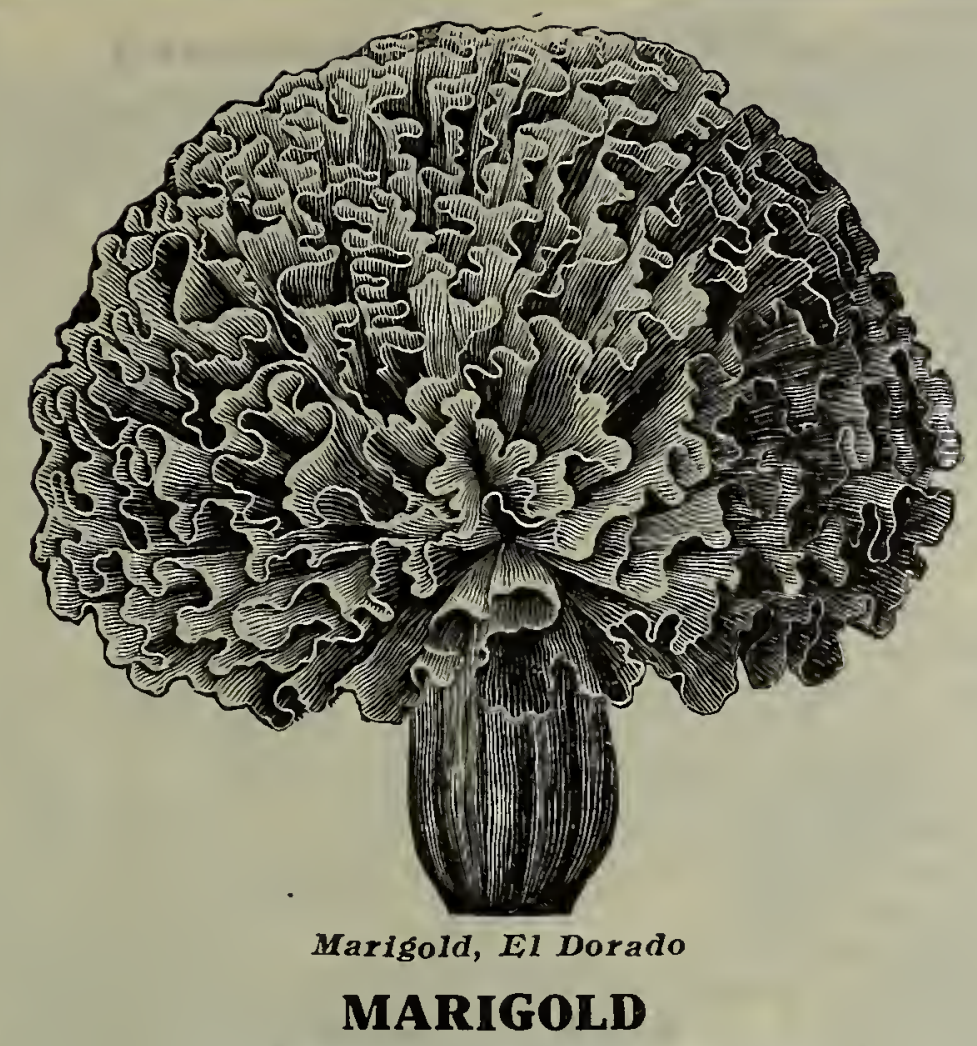

DWARF FRENCH VARIETIES Trade pkt. Oz.

290 Double Pulchra. Yellow and brown........\$0.10 \$0.20

I 294 Gold Striped. Double .................. . .25

I 302 Legion of Honneur. (Little Brownie). Single,

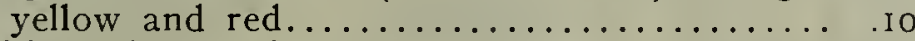
I306 Liliput (The Miniature Marigold). Mixed.... . I5 I 292 Dwarf French Mixed ................... Io

MARIGOLD-AFRICAN VARIETIES

I 206 El Dorado. Tall growing sort, double orange.. .Io

I307 Orange Prince. Rich orange yellow, double.. . I5

I303 Lemon Queen. Clear lemon yellow, double.. . .

I 308 Pride of the Garden. Golden yellow, dwarf... . I5

I300 Tall Double Mixed.................. . I0

MARVEL OF PERU (Fonr O'clocks)

1315 Mixed .................... (1/4 1b. 15c.)

MATRICARIA See Feverfew.

MATTHIOLA

I3I8 Bicornis (Evening Scented Stock). Purplish

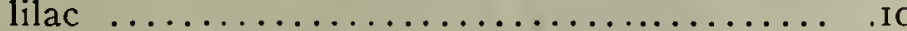

MAURANDIA

A splendid flowering plant for vases, baskets, etc.

I 320 Barclayana. Purple ..................\$0.20 \$1.25

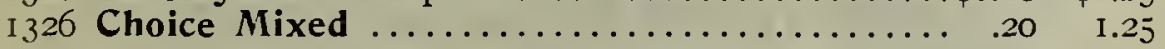

\section{MESEMBRY ANTHEMUM}

I 330 Cordifolium Variegatum. Pink flowers...... .25

I33I Crystallinum (Ice Plant). White flowers........ .I0

I332 Tricolor (Wax Plant). Various colors.......... .10

\section{MIMULUS}

I370 Moschatus (Musk Plant). Yellow flowers.... .25

1372 " Compacta. Fine for pots........ .

1374 Tigrinus (Monkey Flower). Mixed.............

\section{MINA}

1380 Lobata. A rapid growing climber..

\section{MONARDA (Bergamot)}

I382 Didyma. Perennial; large heads of deep red flowers .............

MOON FLOWER See Ipomoea. MORNING GLORY See Convolvulus. MUSA

I 385 Ensete (Abyssinian Bunana). foc. per 25 seeds. I 00 seeds $\$ 1.00$

Philadelphis, PA., June 26th, 1912

Gentlemen :

We purchased 58 Varicties of Flower Seeds from you this spring, and not one variety failed with us.

Yours truly, \&E \& YOST.

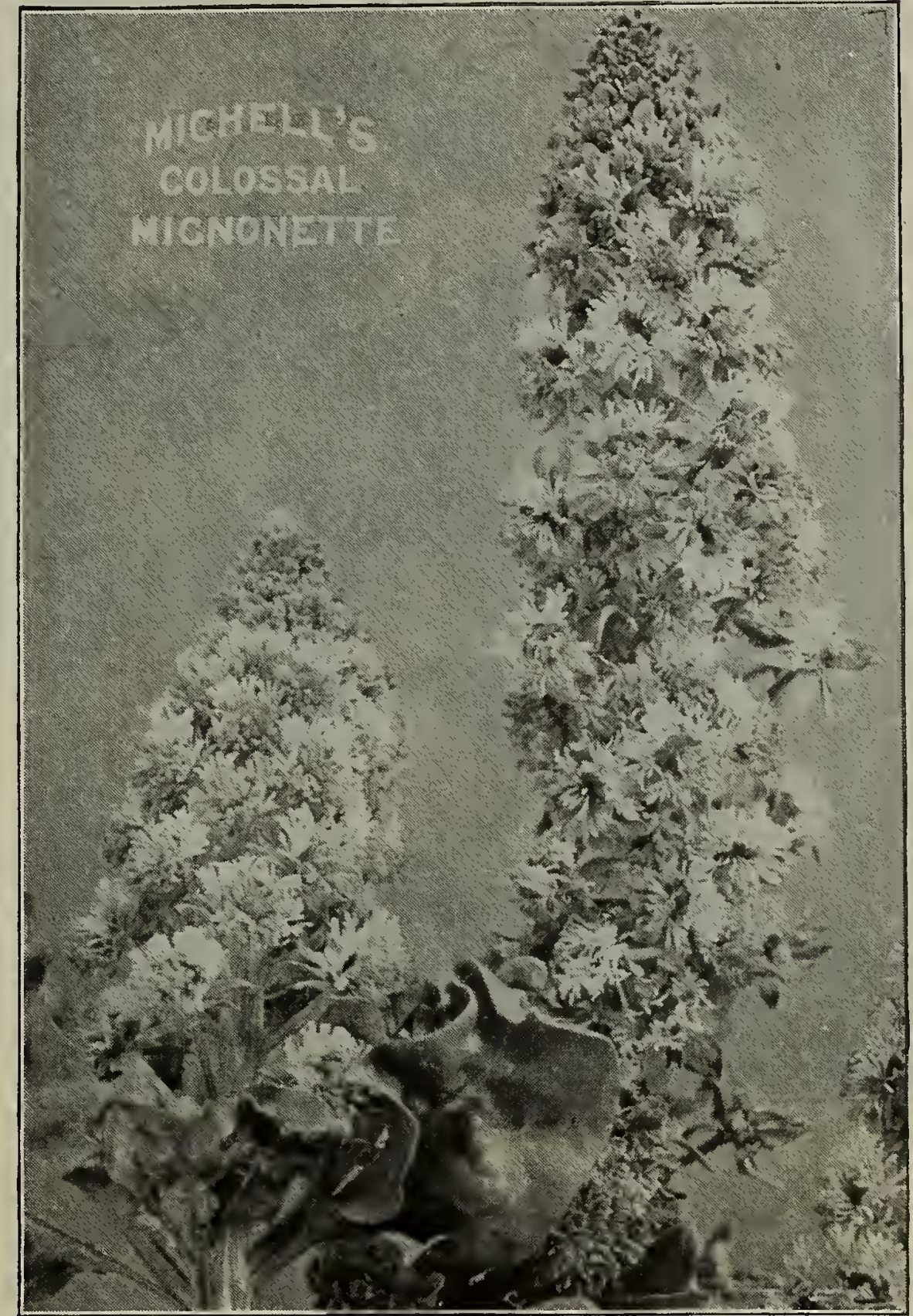

\section{MIGNONETTE}

$\underset{\text { prade }}{\text { prt. }} \mathrm{Oz}$

356 Michell's Colossal. One of the finest sorts for forcing. Colossal spikes from 18 to 24 inches high, with massive flowers.............40 4.00 I354 Hoehl's Giant Flowering. Grown by a specialist; seeds saved from specimen plants. cialist; seeds saved from specimen plants . . .
1340 Allen's Defiance. Large spikes.. ( $1 / 4$ lb. \$1.25) 1355 Machet. Improved and selected....(1/4 1b. 75c.) .10 .25 1 349 Golden Machet. Yellow ................ . . .30 I 352 Goliath. Giant spikes .................. I5 .50 I363 Sutton's Giant. Fine, large reddish buff. Original packets, 30.

I357 Miles' Spiral. Good for outdoor..(1/4 1b. 50c.) .Io .I I359 Parson's White. Almost white.............. . . .20 I 365 Sweet Scented. The old-fashioned (1b., 5oc.)

\section{MYOSOTIS (Forget-Me-Not)}

I39I Alpestris Victoria. Bright blue; the best for bedding; dwarf and compact.............. I 406 Ruth Fischer (New). Flowers large, and of true Forget-Me-Not blue.............

I 395 Eliza Fanrober. Halustris. Heavy, robust plants, deep biuc.

I 403 Grandiflora Alba. White

I 400 " Rosea. Pink

1405 Royal Blue. Erect growing; blue.

I 407 Choice Mixed

I 393 Dissitiflora (Percinial). Deep bluc 


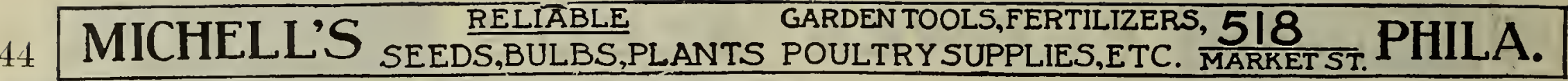

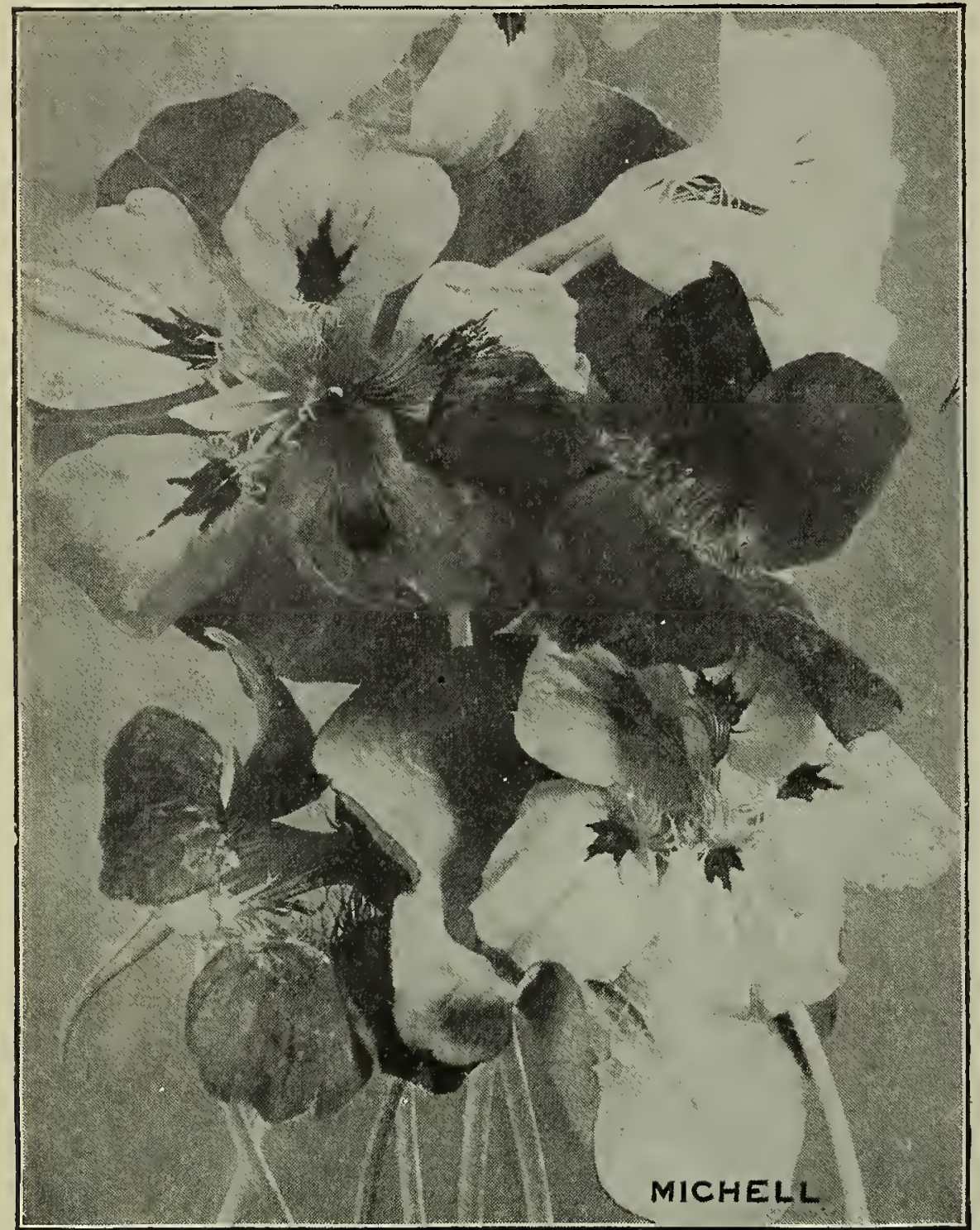

Michell's Fancy Giant Nasturtiums

\section{NASTURTIUMS DWARF OR TOM THUMB VARIETIES}

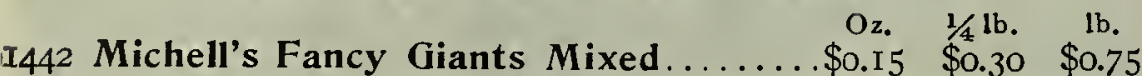

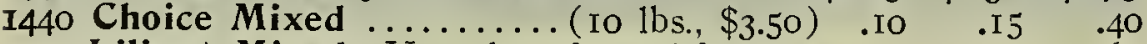

I445 Liliput Mixed. Very dwarf, good for pots $\quad$.10 $\quad .20 \quad .60$

I446 Queen of Tom Thumb Mixed. Silver

variegated foliage, very showy .........

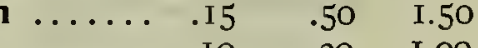

I 443 Ivy Leaved Mixed ....................

I4I7 David Burpee Spencer. Plänts compact. leaves wavy and ruffled; flowers deep

I4Io Aurora. Bright orange ..................

1412 Beauty. Red and yellow .............. .IO

I4I3 Bronze. Burnished bronze color $\ldots \ldots \ldots$ plant

1416 Cloth of Gold. Scarlet, yellow foliage.

I4I5 Crystal Palace Gem. Sulphur yellow,

${ }_{141} 8$ Empress of India. ' Deep crimson, dark

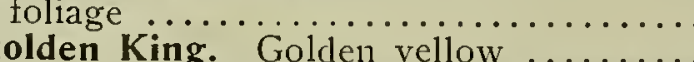

$\$ 422$ Golden Queen. Yellow flowers and foliage $\ldots \ldots \ldots \ldots \ldots \ldots \ldots \ldots \ldots \ldots$.

I 423 King of Tom Thumbs. Dark scarlet...
i 424 King Theodore. Dark foliage, flowers almost black

I 426 Lady Bird. Yellow and red ................

I 428 Pearl. White ..................... .

1430 Pink

I 429 Prince Henry. Cream, spotted and tipped

1432 Scarlet

I434 Spotted. Orange, spotted crimson .....

I436 Vesuvius. Salmon pink, dark leaved .

I438 Yellow

\section{NASTURTIUMS-Continued CLIMBING OR TRAILING VARIETIES}

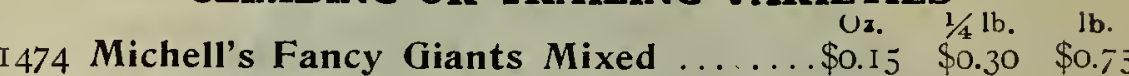

I 472 Choice Mixed ........... (Io lbs., \$3.00) .I0 .I $^{2} .35$

r 475 Queen of Talls, Mixed. Mottled foliage .IO $\quad .25 \quad .75$

I47 I Hybrids of Madame Gunther, Mixed.

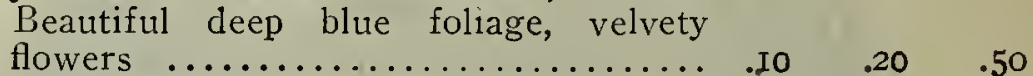

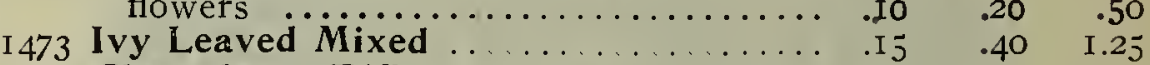

I450 Chameleon. Different colors on the same

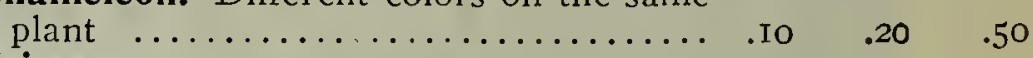

I 452 Crimson $\ldots \ldots \ldots \ldots \ldots \ldots \ldots \ldots \ldots$. Io $\quad .20 \quad .50$

I453 Hemisphaericum. Orange salmon and scarlet $\ldots \ldots \ldots \ldots \ldots \ldots \ldots \ldots \ldots \ldots \ldots \ldots$. I0 $\quad .20 \quad .50$

I 456 Jupiter. Iellow crinkled, very fine..... . . 10 .20

I 458 King Theodore. Dark foliage, flowers almost black ..................... . . 20 . 50

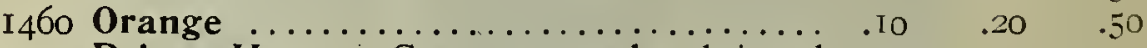

I459 Prince Henry. Cream, spotted and tipped red $\ldots \ldots \ldots \ldots \ldots \ldots \ldots \ldots \ldots \ldots \ldots$. 10 .20 .50

I46I Pearl. Creamy white .............. . I0 $.20 \quad .50$

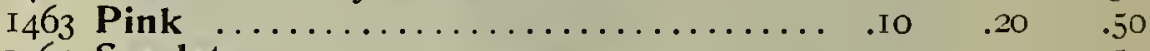

I 462 Scarlet ....................... . . $\quad .20 \quad .50$

I466 Vesuvius. Salmon pink, dark leaved.... . . .

I 470 Yellow Striped Scarlet ............. . . $\quad .20 \quad .50$

\section{LOBB'S CLIMBING}

I480 Asa Gray. Yellowish white .......... . . 10 .20 .60

I 482 Brilliant. Glowing scarlet ............

I 484 Giant of Battles. Yellow, with carmine . Io $\quad .20 \quad .60$

I 486 Golden Queen. Golden yellow .........

I 488 Roi des Noirs. Dark garnet red ........

I489 Rudolph Virchow. Fine ruby rose..... . . 0 . 20 .60

I490 Spitfire. Brilliant scarlet ............ . .

I 492 Choice Mixed. Lobb's varieties ........ . . . . . . .50

NEMOPHILA (Love Grove) Trade Pkt. Oz.

I500 Mixed. Free flowering annual ............ \$0.10 \$o.I5

NICOTIANA (Ornamental Tobacco)

I505 Affinis. Large white fragrant flowers.......... . . I0 ${ }_{.20}$ 1506 “ Hybrida. All colors .................. I 508 Sanderae. Flowers carmine red ............. 15 I509 Sylvestris. Pure white, fragrant .......... . . $\quad .25$

\section{NIEREMBERGIA}

I5I3 Frutescens. White, tinted with lilac........... .I5

NIGELLA (Love in a Mist)

I5I5 Damascena. Double mixed $\ldots \ldots \ldots \ldots \ldots \ldots$. Io .I5 I5 I7 Miss Jekyll. Beautiful clear blue ..........

\section{OENOTHERA (Evening Primrose)}

I523 America (New). Flowers extra large; snow white when opening in the evening, changing in the morning to a delicate pink ......... .40 I525 Mixed. Annual varieties ................. .IO .15

\section{PAEONY}

I534 Mixed. Double and semi-double $\ldots \ldots \ldots \ldots \ldots .25 \quad 1.00$

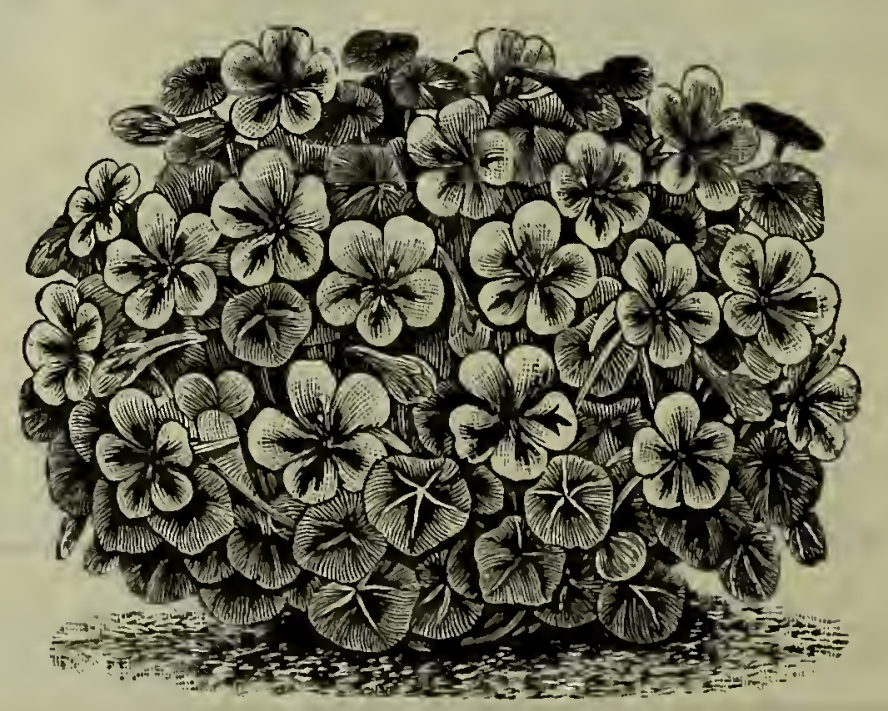

Dwarf or Tom Thumb Nasturtiums 


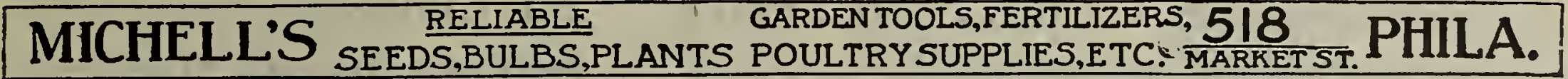

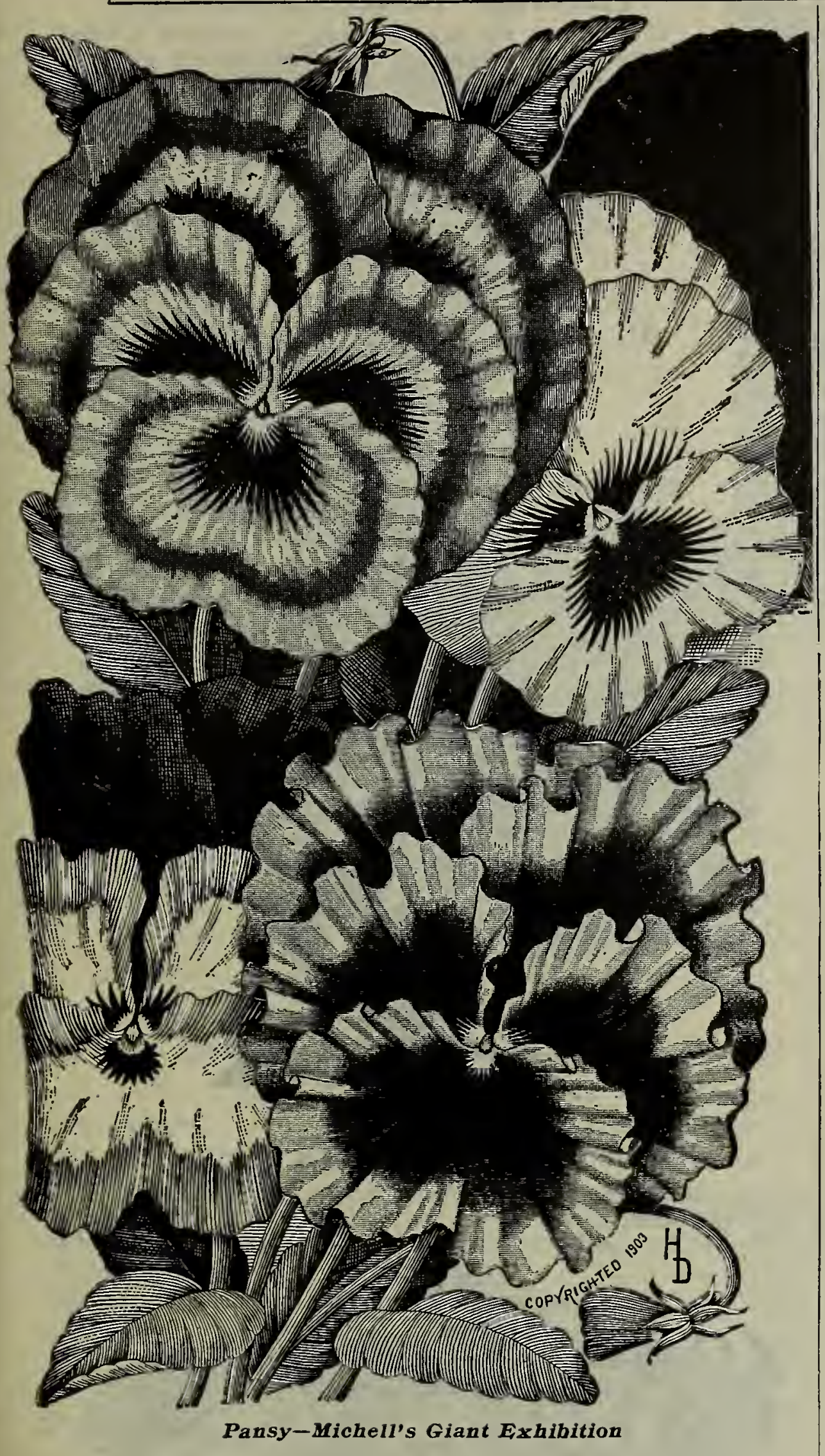

\section{PANSIES}

Note-Please do not compare our Giant Prize Pansies with the ordinary Giant Trimardeau; the seed we offer will produce flowers of much heavier texture.

\section{GIANT SORTS IN SEPARATE COLORS}

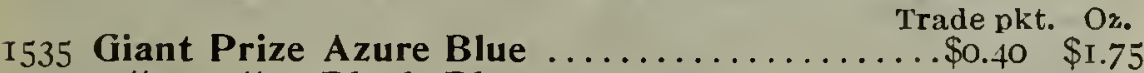
I537 “ " Black Blue ...................40

I539 “ “ "Emperor William. Blue ........40

I 54I “ “

I543 " “ King of the Blacks ............40 I.75

I545 “ “

I549 " " Peacock. Blue, claret and white.. .40 2.50

I55I “ “ Snow Queen. Pure white ...... .40 I.75

I553 “ " “ Striped and Mottled ............40

I557 “ " "White with Eye ............ .40 1.75

I559 “ " " Pure Yellow ...................4.

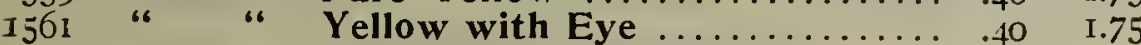

PANSIES-Continued

\section{REGULAR SORTS IN SEPARATE COLORS}

I565 Belgian Striped

Trade pkt. Oz.

I567 Emperor William. Ultramarine blue ...........25

I 569 Faust, or King of the Blacks $\ldots \ldots \ldots \ldots \ldots \ldots .25$ I.00

I57 G Gold Margined. Purple, golden edge ..........25

I573 Havana Brown ..........

I575 Lord Beaconsfield. Purple violet $\ldots \ldots \ldots \ldots \ldots .25$ I.00

I577 Mahogany Colored $\ldots \ldots \ldots \ldots \ldots \ldots \ldots \ldots \ldots .25$ I.00

I579 Silver Edged. Purple, silver edge ............25. .00

I58I Snow Queen. Pure white $\ldots \ldots \ldots \ldots \ldots \ldots \ldots . .25$ I.oo

r583 White with Eye $\ldots \ldots \ldots \ldots \ldots \ldots \ldots \ldots \ldots . .25 \quad$ I.00

I585 Yellow Gem. Pure yellow .................

I587 Yellow with Eye $\ldots \ldots \ldots \ldots \ldots \ldots \ldots \ldots \ldots .25 \quad$ I.00

\section{PANSIES IN MIXTURE}

I595 Michell's Giant Exhibition Mixed. A giant strain which we have secured from the leading Pansy specialists in Germany, England and France. For size of bloom, heary texture and varied shades and colors, with their distinct markings, this strain cannot be excelled. 30c. per $1 / 2$ trade pkt., trade pkt. 50c., 75c. per 1/8 oz., per oz. \$5.00.

I608 Triumph of the Giants Mixed. A very robust grower, producing on long stems flowers of immense size and of unusual substance; the petals being very broad and overlapping each other make the flowers appear almost double; many beautiful, rich and rare shades. 6oc. per $r / 2$ trade pkt., trade pkt. \$I.oo, \$I.75 per $1 / 4$ oz., per oz., \$6.oo.

I597 Bugnot, Odier and Cassier. Superb mixture..\$0.50 \$4.00 I599 Giant Trimardeau. Very large flowering...

I 600 Mad. Perret. Blooms very early; fragrant; especially rich in red shades.

I60I Masterpiece (Frilled Pansy). Flowers beau-

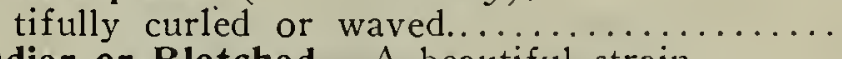

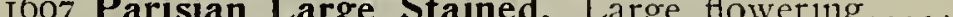
I609 Finest English Mixed. Large flowering...... . .25 $\quad .75$ I6r I Very Fine Mixed

\section{PASSIFLORA (Passion Flower)}

1630 Mixed

PENNISETUM (See Grasses, page 40)

\section{PENTSTEMON}

I644 Sensation. Annual variety; mixed colors..... .30 $\quad$. .75

I645 Mixed. Hardy perennial ................ . Io ${ }_{.20}$

I643 Barbatus Torreyi. Perennial, scarlet ........ .

I646 Digitalis. Perennial, white ................

PERILLA

I650 Nankinensis. Dark purple foliage plant....... .. .

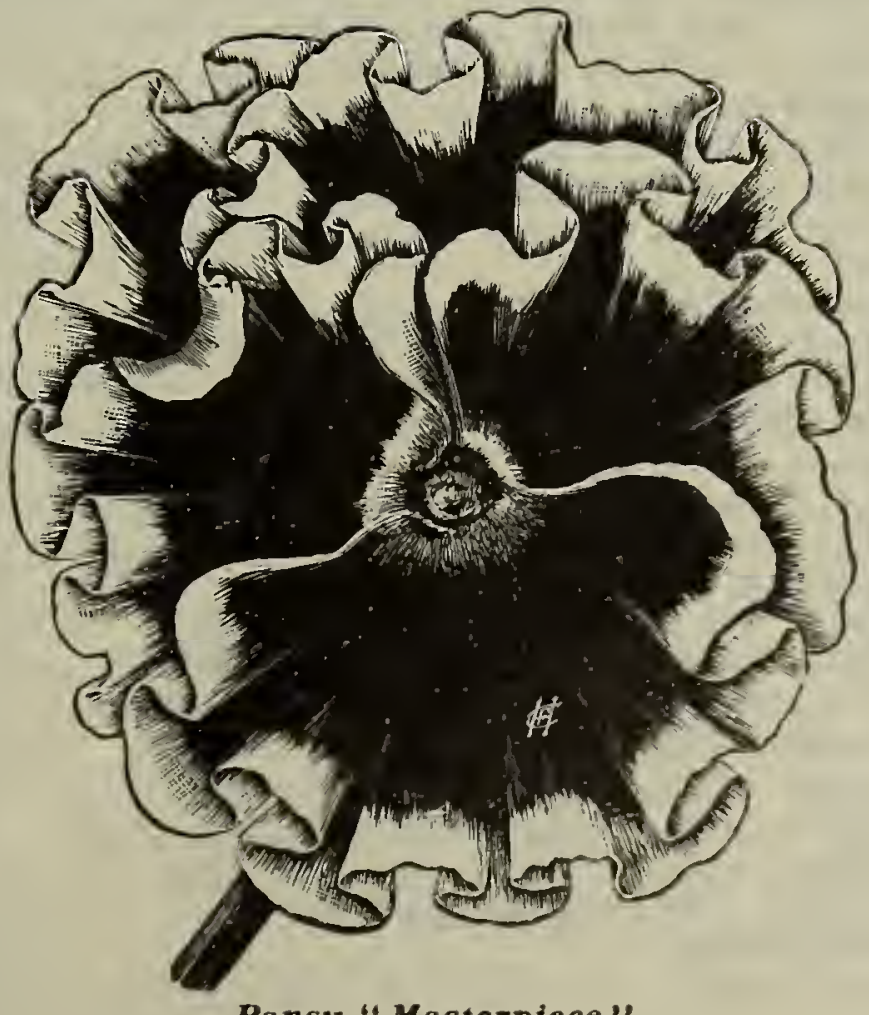




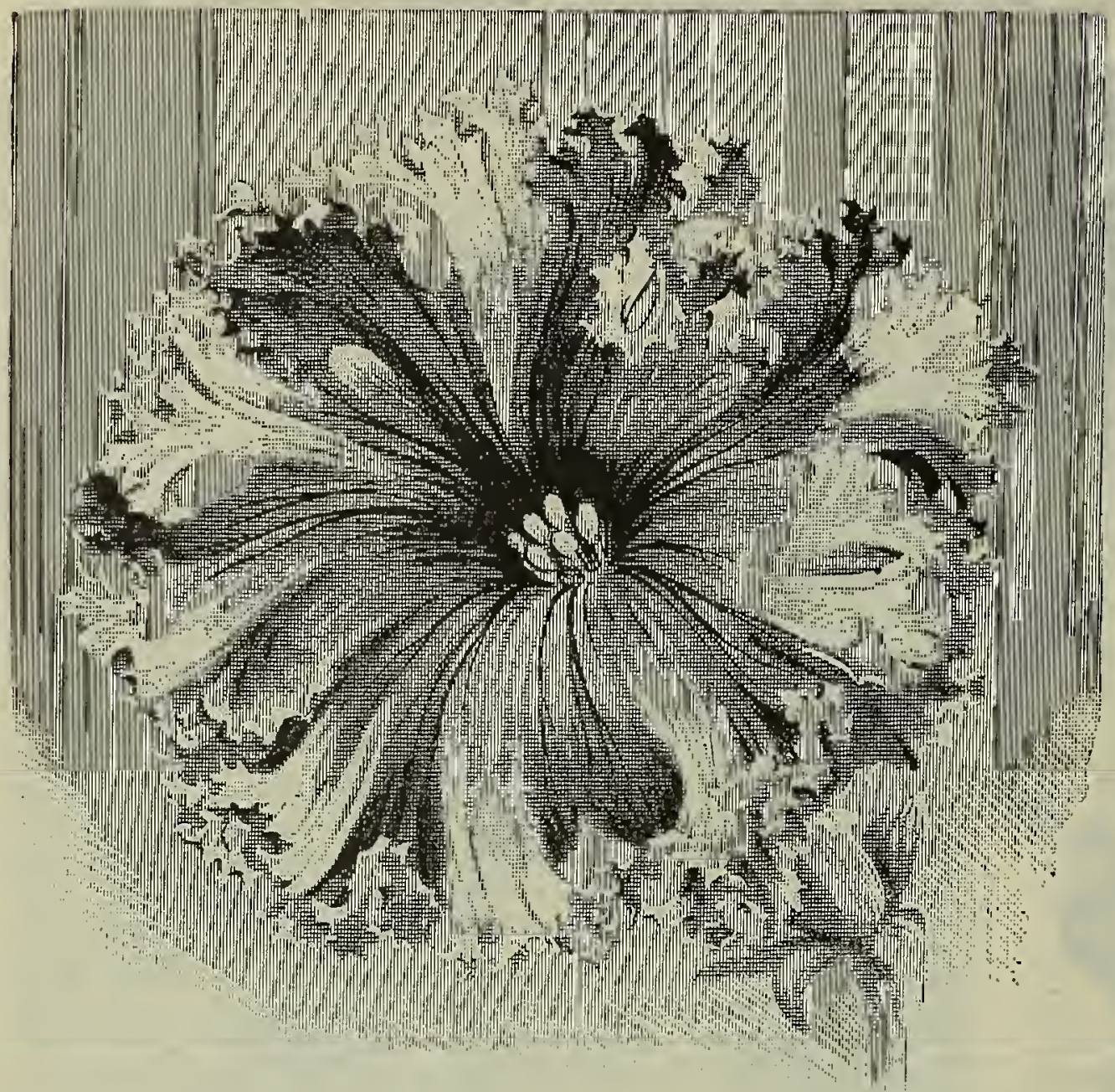

\section{PETUNIA-Double Flowering}

One of our specialties; seeds will produce a large percentage of double flowers. The weaker seedlings should receive great care, as they produce the finest double flowers.

I661 Double Hybridized and Fringed Mixed. Superb colors and of mammoth size. Per 500 seeds, 75c.; $\$ 1.50$ per 1000 seeds.

I659 Double Fringed White. Extra large. Per I/2 trade pkt., 60c.; \$1.00, per trade pkt.

Petunia-Grandiflora Fringed

\section{PETUNIA}

We call attention to our Large Flowering strains of Petunias, which, for size and brilliancy of coloring, cannot be surpassed.

\section{Single Flowering}

$\begin{array}{ccc}1 / 2 \text { Trade } & \text { Trade } \\ \text { Pkt. } & \text { Pkt. } & \\ & & \end{array}$

1657 California Giants. Strong, robust plants immense flowers of bright and desirable colors ( $1 / 16$ oz., \$2.25) ...........\$0.30 \$0.50

1665 Grandiflora Fringed. Each petal of these giant flowers is delicately fringed; all colors ( I/16 oz., $\$ 2.00) \ldots \ldots \ldots \ldots \ldots \ldots$

I666 Monstrosus (Michell's). Large flowering; a large number of the flowers are finely fringed; all colors mixed......... ruffled and frilled at edges.............

1664 Dwarf Large Flowering Fringed (New). Large flowers of many colors. Per pkt.

I667 Hender's English Strain. Oriģ. pkt. 40c. I663 Dwarf Inimitable. Of dwarf, compact habit; striped and blotched ............

1668 Rosy Morn. Brilliant pink with white

1662 Enchantress. Dwarf, flowers of many

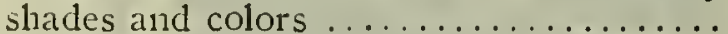

I67 I Snowball. Dwarf, pure white........... I673 Star. A beautiful variety; crimson maroon flowers, each having a distinct five-pointed white star ...............

I655 Adonis. Deef pink, white throat........

16,2 Pepita. Fringed flowers of a rich deep scarlet, with a white border............

$167+$ Undine (Neal). Azure blue with lilac

margin. Per pkt. $20 \mathrm{c}$.

1675 Choice Mixed

1677 Fine Mixed

$.60 \quad 1.00$

$30 \quad .50$

$30 \quad .50 \quad \$ 1.25$

$.30 \quad .50 \quad 1.75$

30

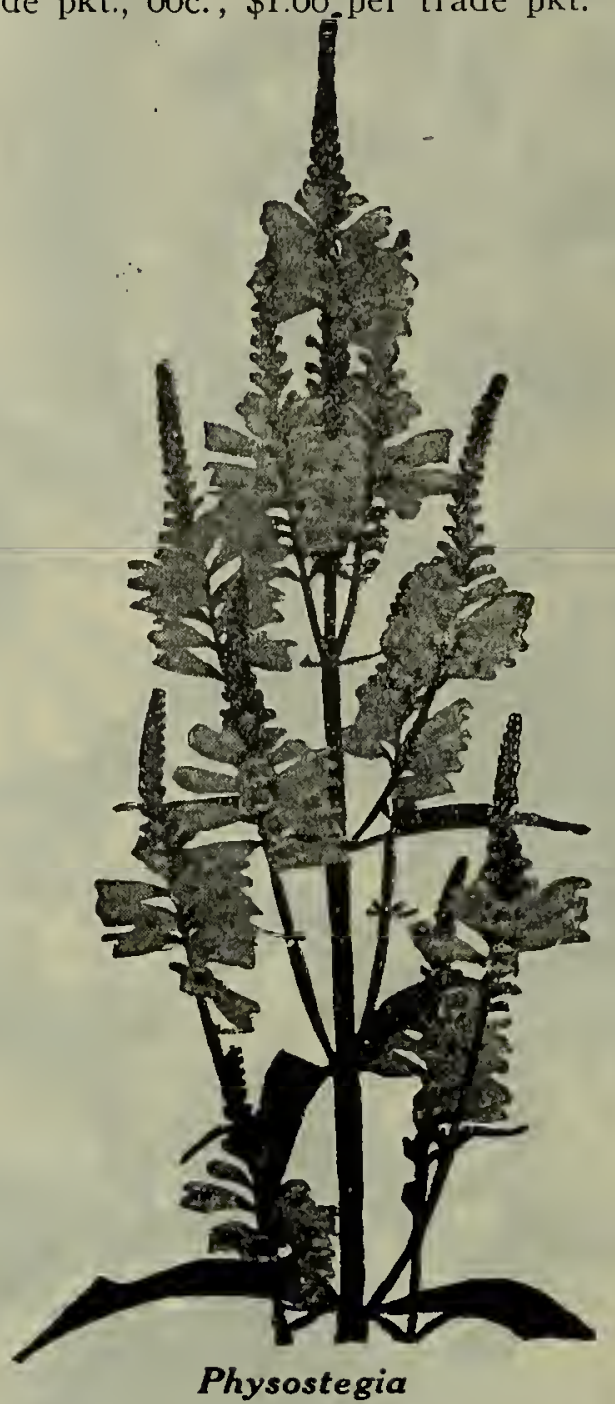

PHYSOSTEGIA

Perennial, bearing delicate tubular flowers. Trade Pkt. Oz.

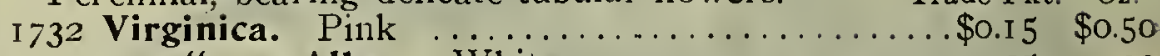
I 733 " Alba. White.................

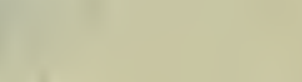

$30 \quad .50 \quad 2.00$
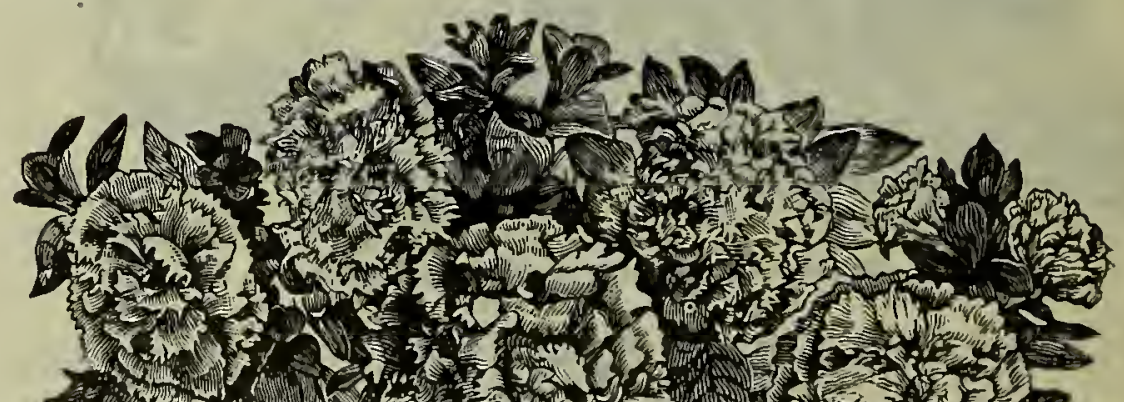

(2) 5$)^{2}$

C.

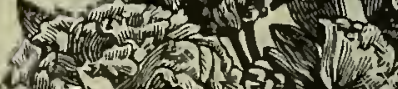

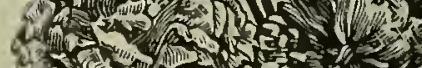

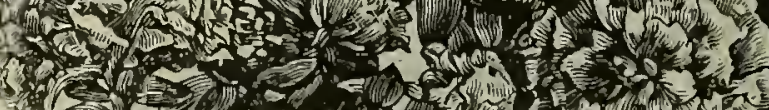

$\begin{array}{rrr}30 & .50 & 2.00 \\ .30 & 1.25\end{array}$

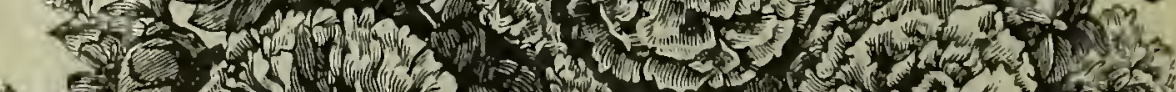

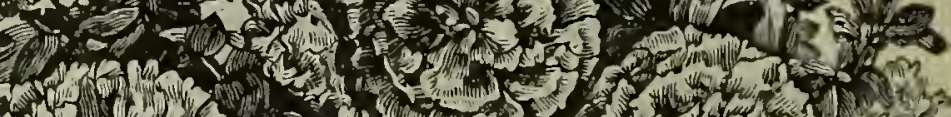

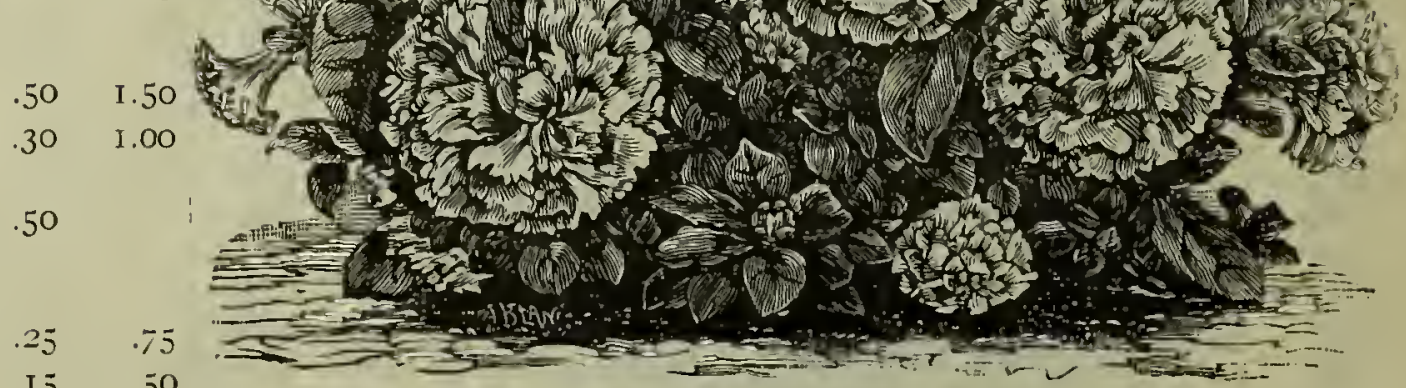

Double Fringed Fetunia 


\section{MICHELLS FLOWER SEEDS $\frac{518}{\text { mankisis PHIILA. }}$}

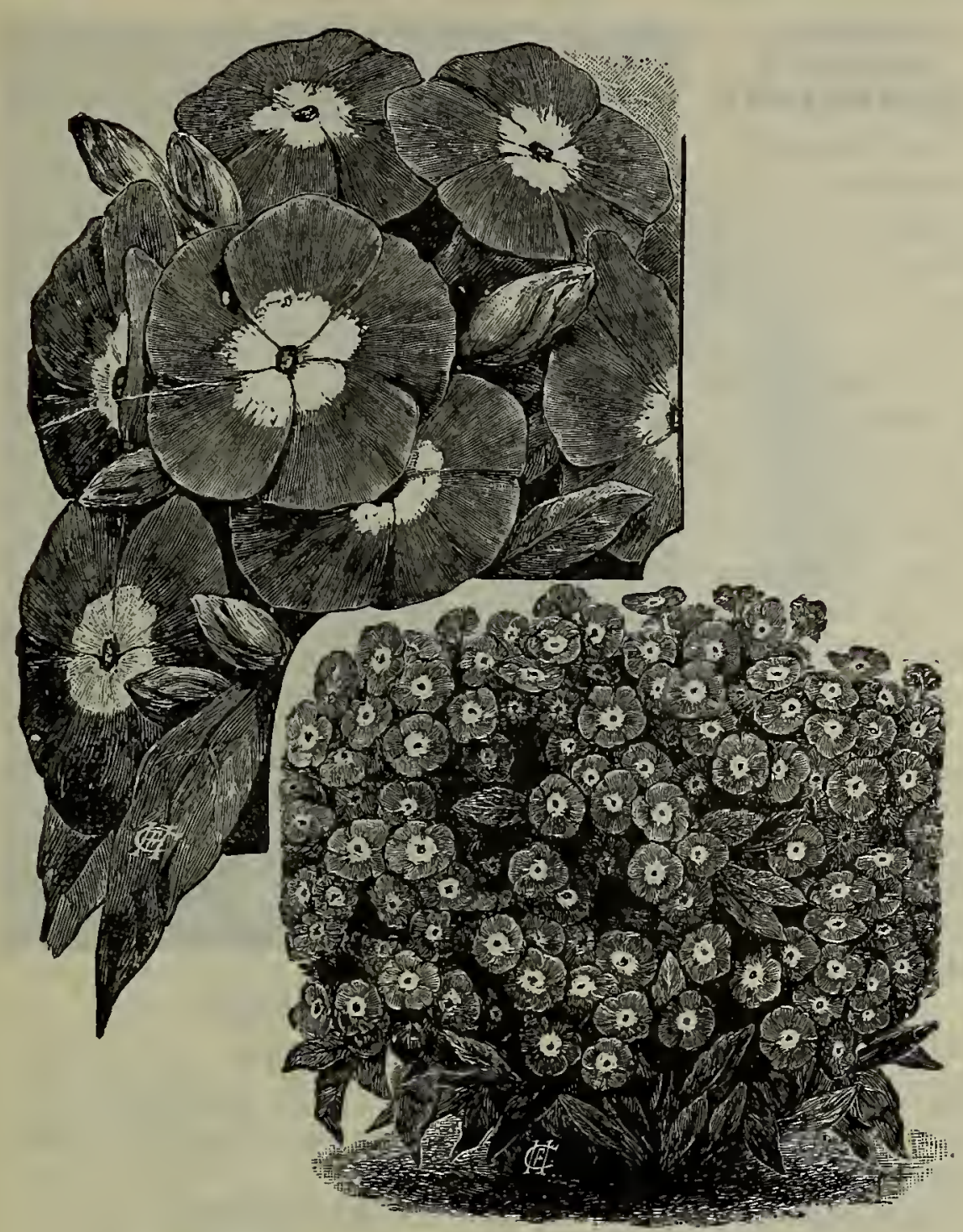

Phlox Drummondii, Dwarf “ Cecily" Strain

\section{PHLOX DRUMMONDII DWARF OR COMPACT VARIETIES}

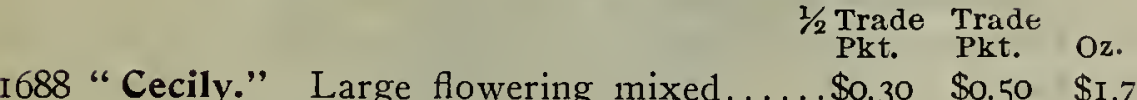

I690 Crimson with White Eye ............25 .40 2.00

I692 Deep Scarlet .......................25 .40 2.00

I693 Fair Maid. Soft pink ............. .25 .40 2.07

I694 Fireball. Brilliant scarlet ............25 . .40 1.75

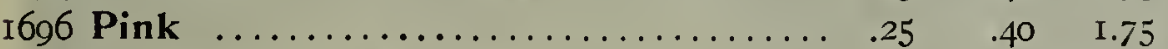

I700 Snowball. Pure white $\ldots \ldots \ldots \ldots \ldots \ldots .25 \quad .40 \quad 1.75$

I702 Violet with White Eye $\ldots \ldots \ldots \ldots \ldots . .25 \quad .40 \quad 2.00$

I704 Choicest Mixed ...................25 .25 .40

PHLOX-GRANDIFLORA VARIETIES Trade pkt. Oz.

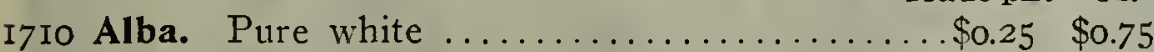

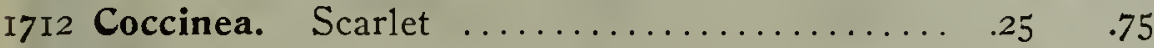

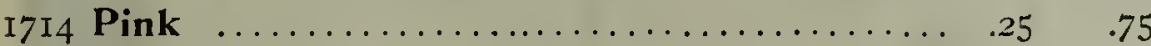

I716 Stellata Splendens. Scarlet, with white eye... $.25 \quad .75$

I720 Choicest Mixed .................... .20

\section{PHLOX-VARIOUS SORTS}

I722 Fine Mixed

I723 Double Mixed

I729 Star of Quedlinburg. Mixed

I725 Hardy (Decussata). Choice mixed ......... .25

PLATYCODON (Chinese Bell Flower)

I735 Grandiflorum, Blue. Perennial

1736

White. Perennial

I737 Japonicus F1. Pl. Double blue

POLYANTHUS (Primala Elatior)

1738 Gold Laced. Very showy

I740 Double Mixed

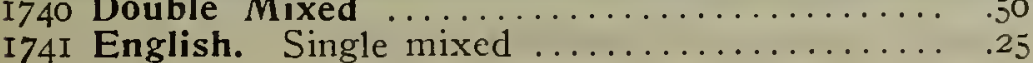

2.25

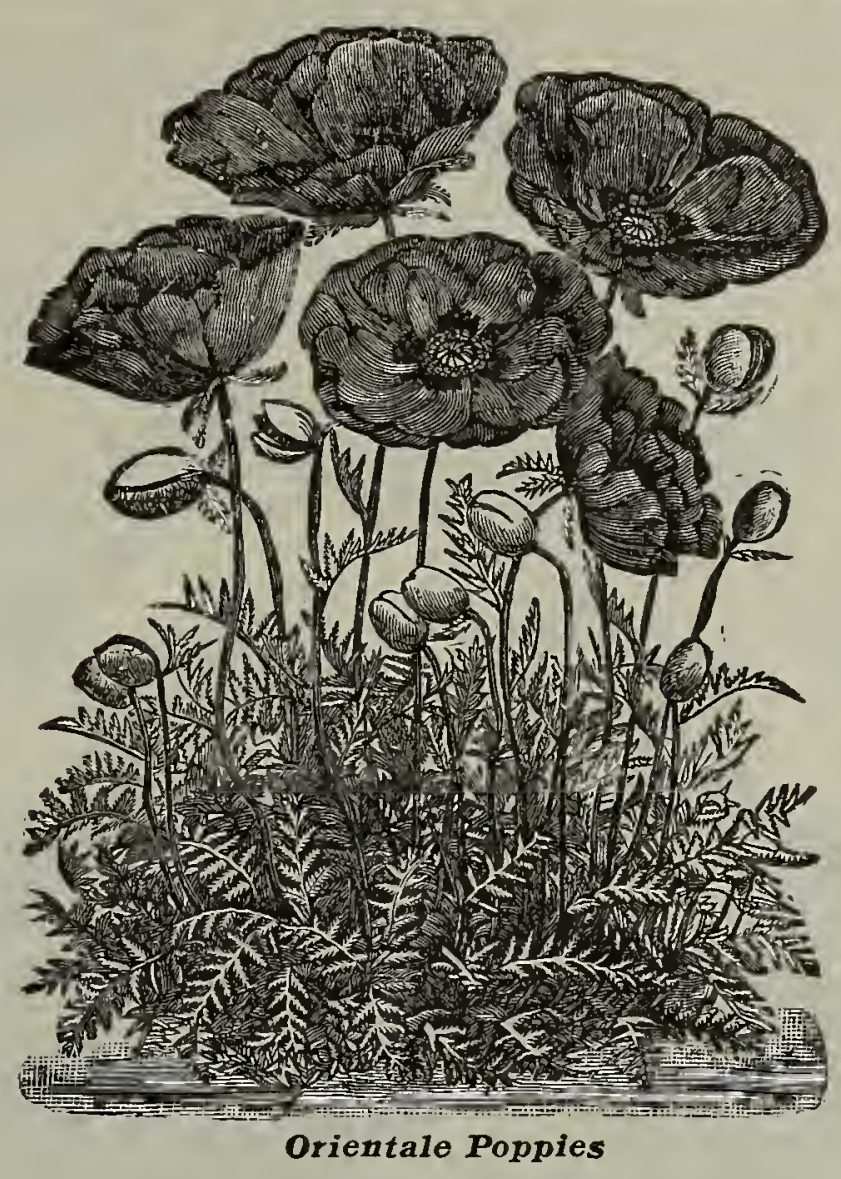

POPPY

DOUBLE ANNUAL VARIETIES

Trade pkt. Oz.

I743 Carnation Flowered. Mixed (I/4 1b. 25c.).... \$0.10

I 745 Crimson King. Crimson $\ldots \ldots \ldots \ldots \ldots \ldots \ldots$ \$0.10 ${ }_{\text {.I }}$

I747 Fairy Blush. White, fringed pink ......... .Io .I5

I75 I Mikado (Striped Japanese) ............... . Io .I5

I753 Paeony Flowered, White $\ldots \ldots \ldots \ldots \ldots \ldots$. Io .I

I755 " "

I752 " "

I757 " " Mixed (I/4 1b. 25c.) $\ldots \ldots$.

I759 Shirley. Mixed colors $\ldots \ldots \ldots \ldots \ldots \ldots \ldots$. Io .I

POPPY - SINGLE ANNUAL VARIETIES

I773 Shirley. Large flowers of many beautiful

colors and shades $(\mathrm{I} / 4 \mathrm{lb}$. $50 \mathrm{c}.) \ldots \ldots \ldots \ldots$. Io $\quad .20$

I764 Admiral ( $N e w)$ ). Pure white with scarlet edge .10 .30

I767 King Edward. Deep scarlet ..............30 1.00

I765 Danebrog. Scarlet with white spot ........... .Io .I5

I 769 Maid of the Mist. White, fringed............ Io 20

I77I Miss Sherwood. Chamois rose ............ . Io ${ }_{2} 25$

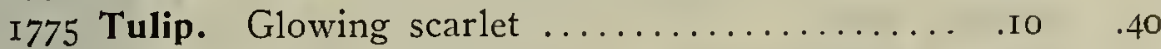

I777 Umbrosum. Rich vermilion ............. Io . I5

\section{POPPY - PERENNIAL VARIETIES}

1782 Giant Scarlet

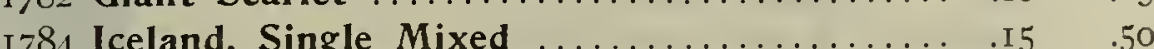

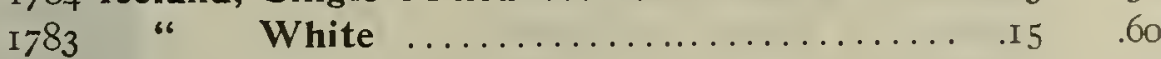

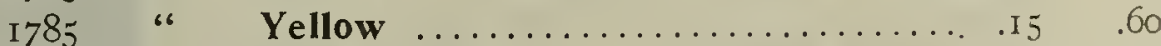

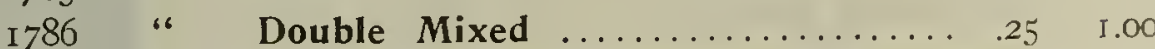

I787 Orientale. Deep, scarlet ................ .20 . 50

179I " Mrs. Perry. Rich salmon pink.... .30 I.50

I 789 " $\quad$ Parkmanni. Deep crimson .........30 .30

I792 " " Psyche. Delicate rosy blush ...... .30 2.00

I793 " " Trilby. Brilliant red ............. $30 \quad 2.00$

I788 “ Hybrids. Nixed colors ...........

\section{PORTULACA}

I795 Double. Large flowering, mixed

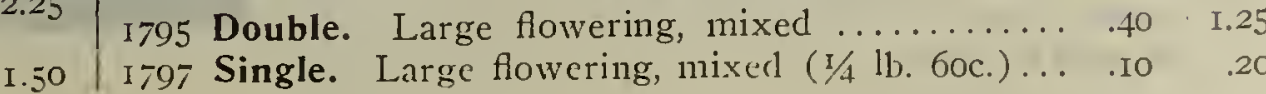




\section{MICHELLS FLOWER SEEDS 518 PHIIIA,}

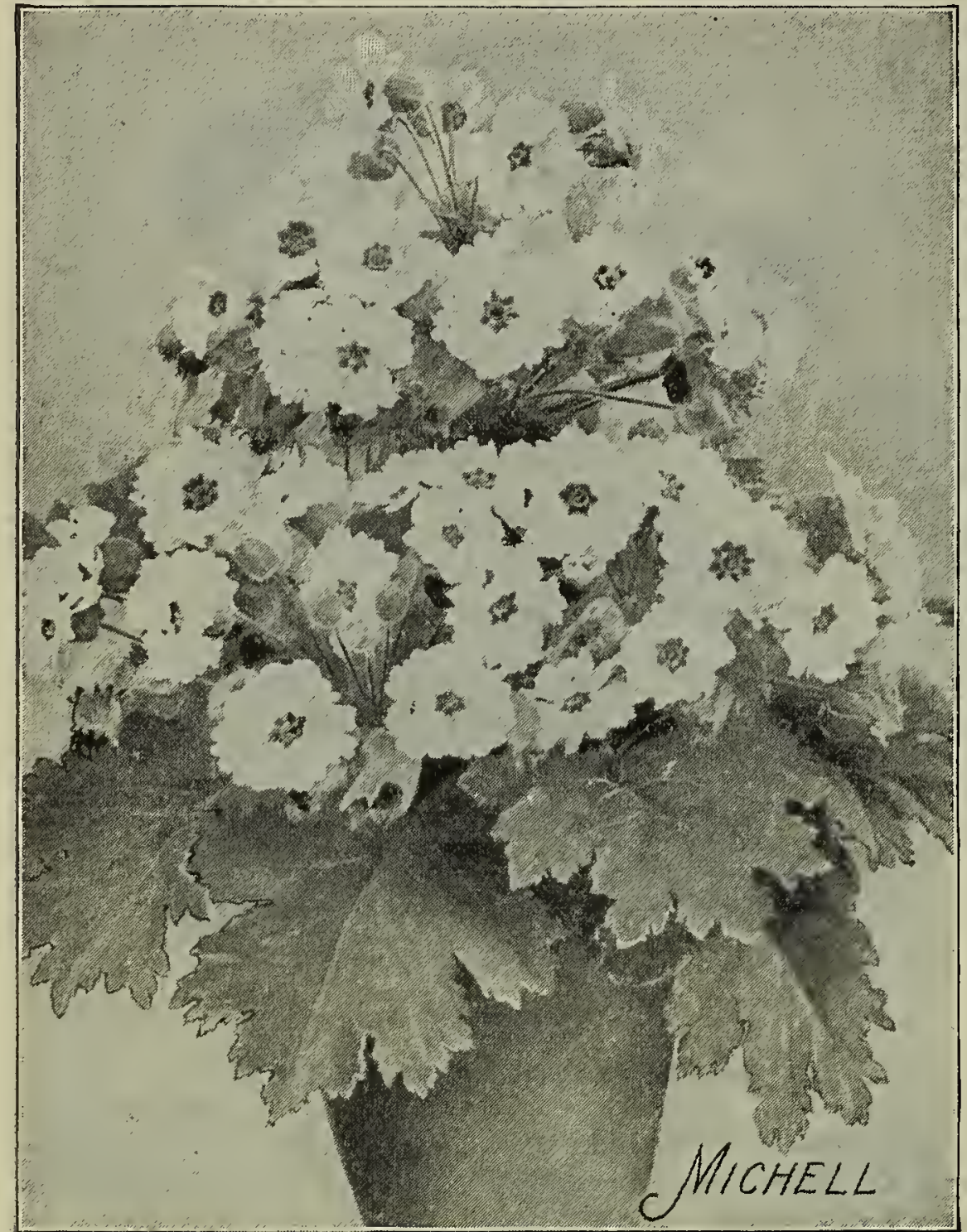

Michell's Prize Chinese Primula

\section{MICHELL'S "DISTINCTIVE" PRIMROSES} PRIMULA CHINENSIS

It is with no little amount of pride we offer this superb strain, grown for us exclusively by one of the best specialists in Europe. The plants are compact, individual and clusters of flowers immense, colors superb and mostly fringed petals. If you grow Primulas remember Michell's "Distinctive" Quality is the best. I8I9 Michell's Prize Mixture. An Oz. pkt. pkt. even blending of all colors...\$2.00 $\$ 0.60$ \$1.00 I 805 Alba Magnifica. White..... 2.50 .60 I.00 1806 Chiswick Red. Bright red.... $2.50 \quad .60 \quad 1.00$ I808 Duchess. Large, white with zone of rosy carmine; yellow

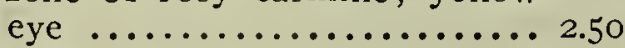

I 807 Holborn Blue ............. 2.50

I809 Kermesina Splendens. Crimson 2.50

I8I I Rosy Morn. Pink ......... 2.50

I8I3 Sutton's Stellata (Star Primrose). Distinct st $\mathrm{r}$ a in of pyramidal growth and loose branches of flowers. Original pkts., 6oc.

1815 Fern Leaved Mixed.......... I.50

\section{PRIMULA OBCONICA GIGANTEA}

A great improvement over the old type; flowers much larger and produced in greater abundance. These are splendid pot plants and stay in bloom the entire winter.

I83I Lilacina. Pale lilac Trade pkt.

1826 Rosea. Pink

1827 Kermesina. Deep crimson ............. 50

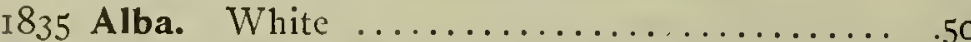
1829 Hybrida Mixed

\section{PRIMULA OBCONICA GRANDIFLORA}

I 828 Grandiflora Compacta. Dwarf compact growing plants ; flowers rosy lilac. Trade pkt. $50 \mathrm{c}$.

I830 Grandiflora F i m b r i a t a. Fringed flowers; mixed colors. Trade pkt. 5oc.

I837 Vesuvius. (New). Deep crimson. Trade plkt. 5oc.

I833 C r i s p a (New). L a rge flowers, which are crisped or curled; color, from apple blossom pink to rose. Per pkt. 20c., 55 c. per 3 pkts.

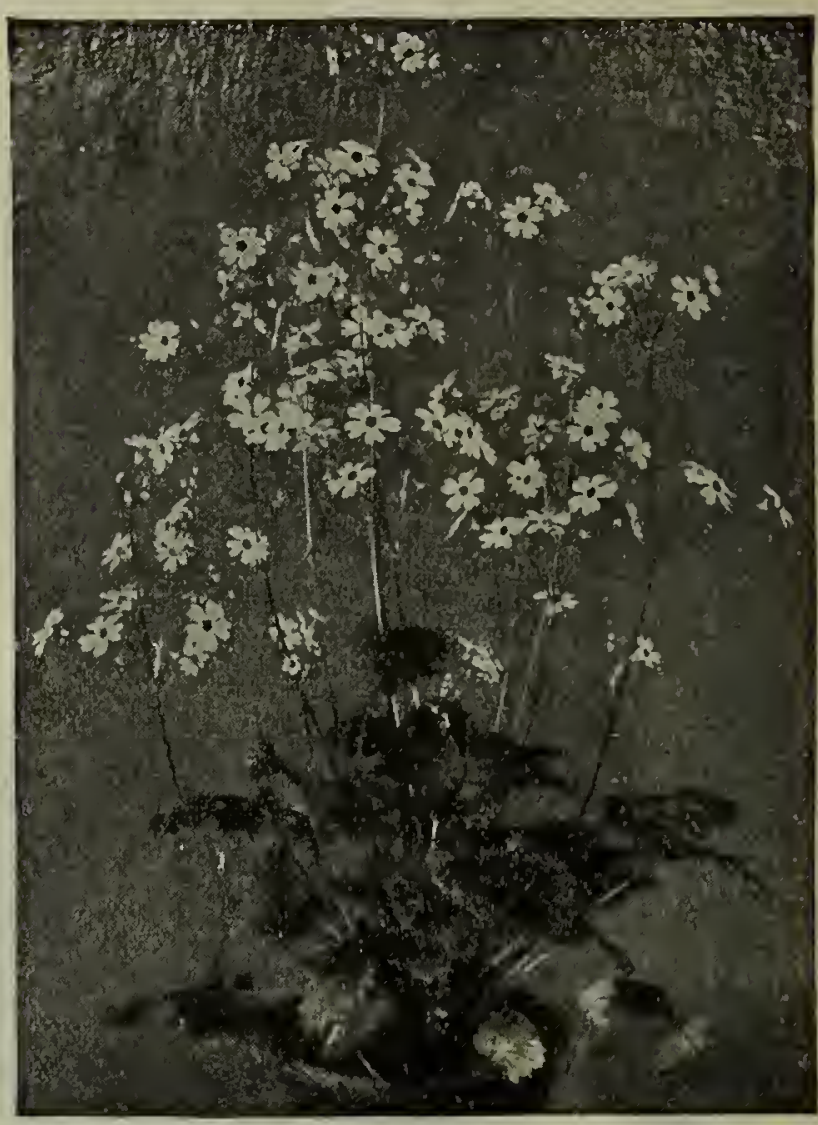

Primula Malacoides

PRIMULA, VARIOUS SORTS

Trade pkt

I8+2 Malacoides (New). Resembles Primula Forbesi, but the flowers are much larger; color, light lilac....... \$0.50

I 843 Malacoides Alba. Pure white.......... (Pkt., 20c.)

I845 Kewensis (Verbena Scented Yellow Primrose). Of strong, vigorous growth; numerous spikes, I2 to I8 inches long; large yellow flowers... (I/I6 oz., \$I.50) .50 I839 Buttercup. Yellow ............. (I/32 oz., \$1.00) .50 I840 Cortusoides Sieboldii ..................... .50 I844 Forbesi (Baby Primrose)........... ( $1 / 8$ oz., \$1.oo) $\quad .50$ I846 Veris (Cowslip). Mixed................ Oz., 75c.) .I I848 Vulgaris (English Yellow Primrose)....(Oz., \$1.25) .30

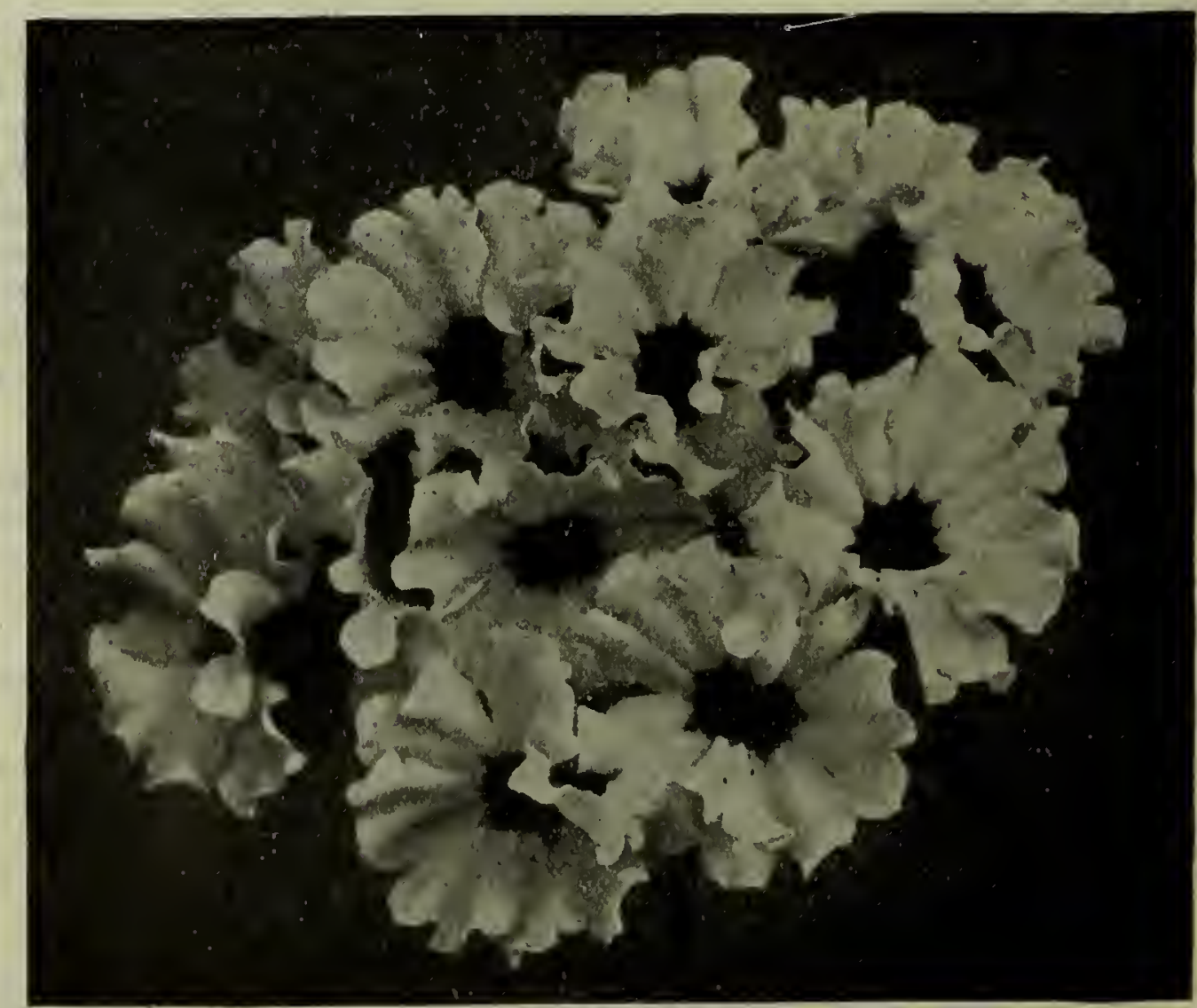

Primuly Obconica Grandifora-Crispa 


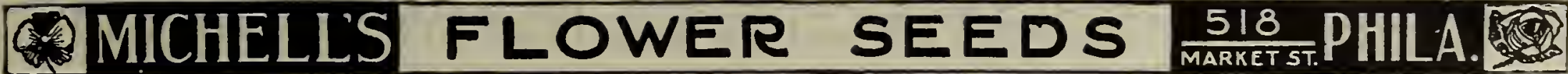

PUERARIA (Kndza Vine) Trade Pkt. Oz.

I855 Thunbergiana. Perennial climber; rosy purple

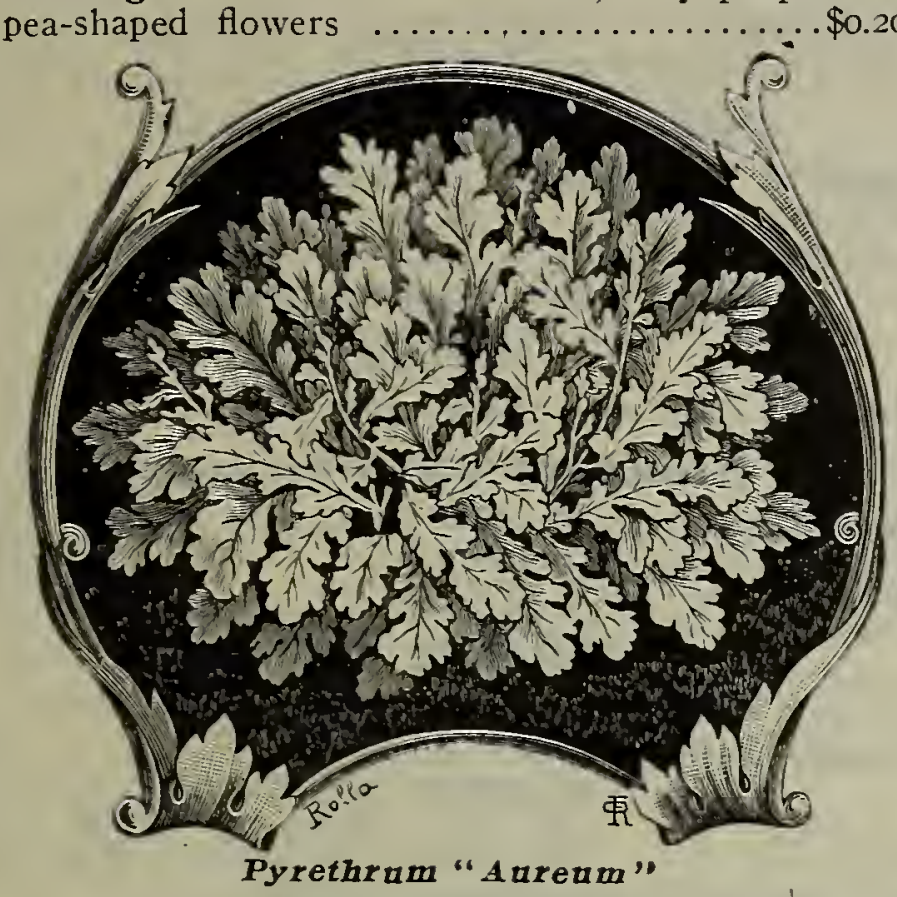

\section{PYRETHRUM FOLIAGE SORTS FOR BEDDING}

I860 Aureum (Golden Feather). Yellow foliage....\$o.io \$0.25

I864 Selaginoides. Yellow fern-like foliage ....... .I5 .50

PYRETHRUM-FLOWERING SORTS (Perennial)

I862 Roseum. Pink .....................20 I.50

I866 Uliginosum (Giant White Daisy) $\ldots \ldots \ldots \ldots \ldots . .25 \quad$ r.25

I 868 Hybridum. Single mixed................. I5 I.50

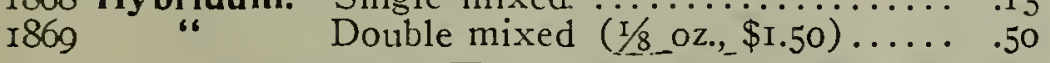

RHODANTHE (Everlanting Flower)

I875 Mixed. Hardy annual ................ .I

.50

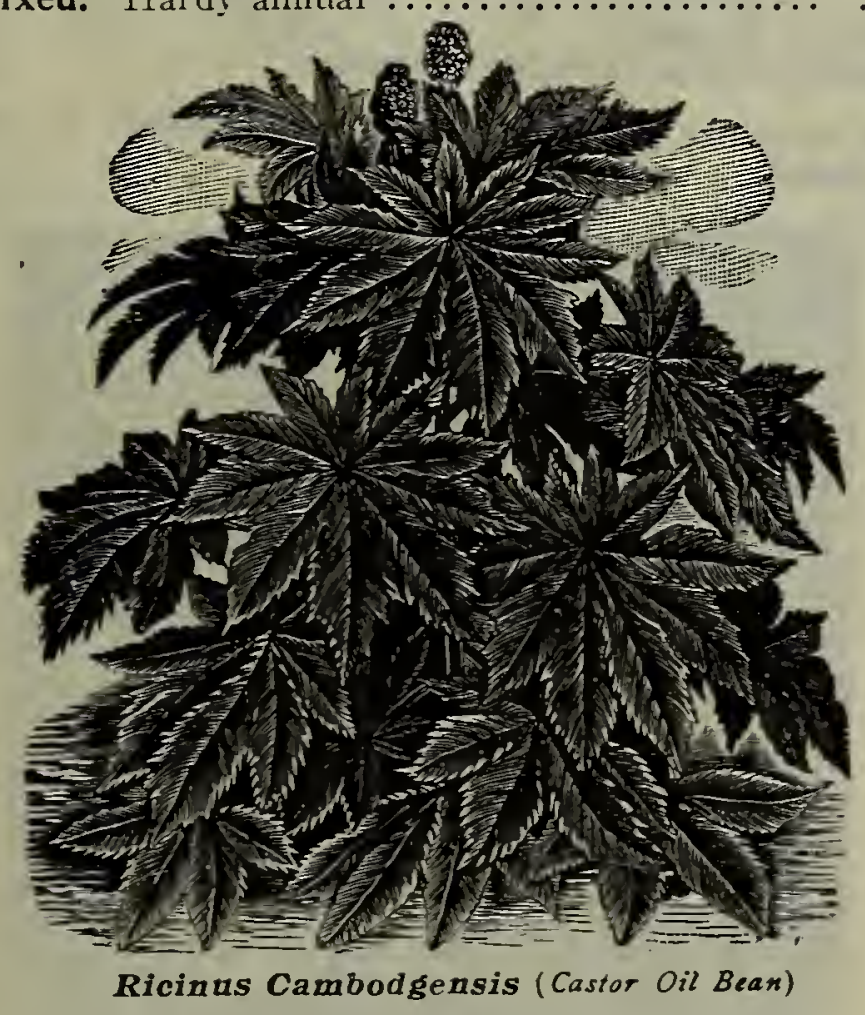

RICINUS (Castor oll Bean)

There is alway's a good demand for these plants.

I885 Michell's Giant. A new hybrid of gigantic size; stems and stalks covered with Oz. $1 / 1 / \mathrm{lb}$

I880 Borboniensis. Green foliage; 15 feet... . I0

I882 Cambodgensis. Bronzy maroon; 5 feet .Io

I884 Gibsoni. Dark red; 5 feet ............ IO

I886 Philippiensis. Dark foliage; to feet.... .Io

I888 Sanguineus. Blood-red stalks; 8 feet... . . IO

I890 Zanzibariensis. Large; various colors; I2 feet ......................... .Io

I\&gI Mixed. Ail sorts ....................... .
RUDBECKIA (Cone Flower) Trade Pkt. Oz. I900 Bicolor Superba. Yellow flowers, brown centre.\$0.10 \$o.30 I902 Newmani. Hardy perennial, yellow ......... .30 I.oo 1904 Purpurea (Giant Purple Cone Flower). Hardy

perennial; reddish purple flowers .......... . I5 .75

SAINTPAULIA (Atrican Violet)

I9Io Ionantha. Similar to violets in color and form.

Per pkt. 20c

\section{SALPIGLOSSIS}

Very showy annuals; excellent for cutting.

I9I2 Grandiflora, Black, Yellow Veined...........25 I.25

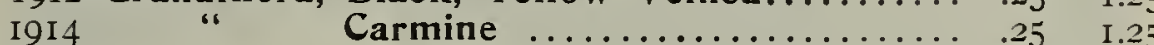

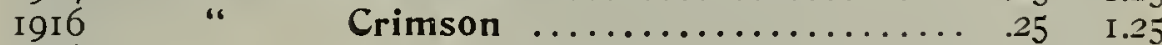

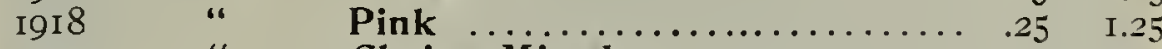

1920 " Choice Mixed ..................20

I922 " Emperor. Choice mixed ........ .30 I.00

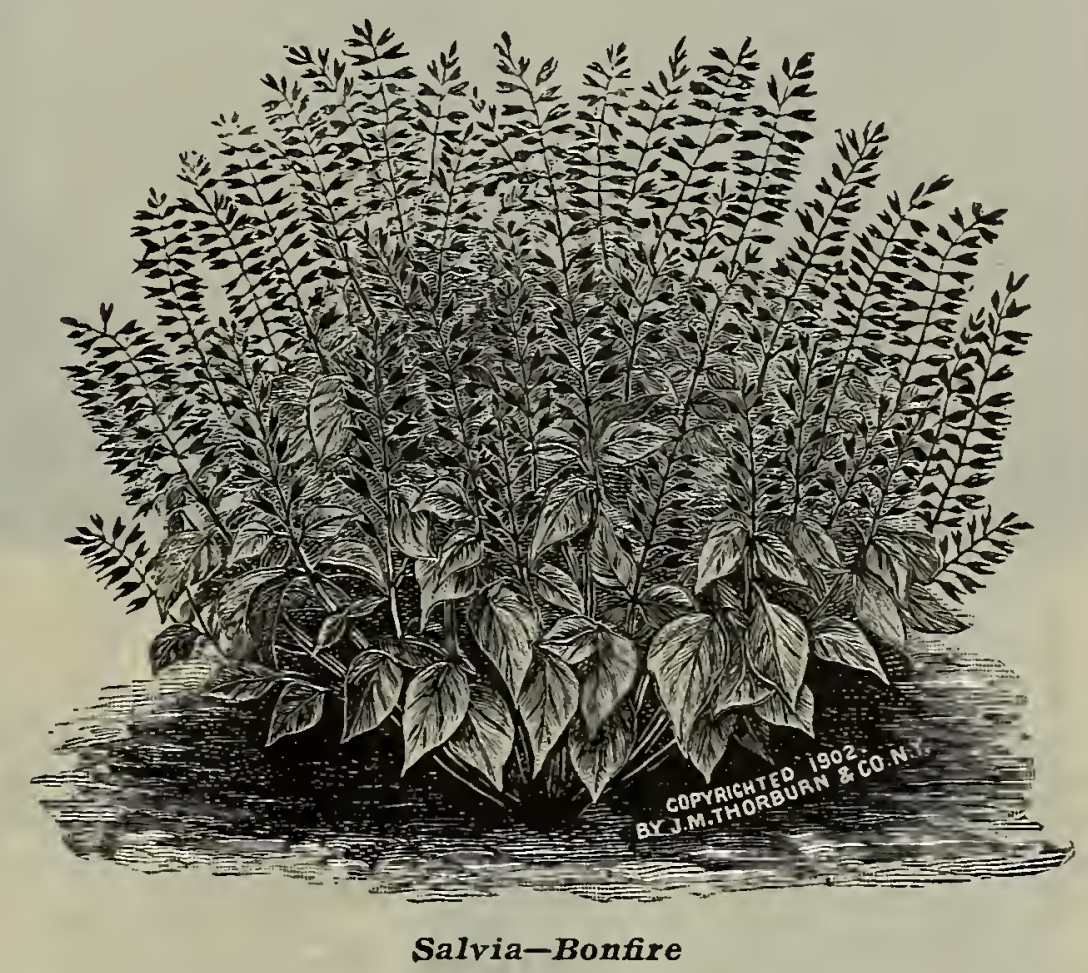

SALVIA (Floworing Sage)

Much of the Salvia we offer this year has been saved from specimen plants grown at our own grounds at Torresdale, $\mathrm{Pa}$., under our own supervision. Seeds are plump, strong in germination and must give superior satisfaction. $\quad 1 / 2$ Trade Trade r94 Michell's Scarlet Glow (New). An im- Pkt. Pkt. provement on the Zurich; plants dwarf and compact; early flowering, with a mass of brilliant scarlet flowers ......\$0.30 \$0.50 \$3.50 I930 Bonfire. Medium dwarf, scarlet. This is one of the best varieties $\ldots \ldots \ldots \ldots \ldots . .25 \quad$.40 2.00 I928 Ball of Fire. Intensely scarlet, medium dwarf

I946 Zurich. Quite dwarf, intense scarlet flowers, much earlier than other sorts..

1944 Splendens. The popular sort, scarlet.. I937 King of Carpets. Plants are only I8 inches high and produces flowers right from bottom; color bright scarlet..

I93I Compacta Alba (New). Dwarf; flowers pure white. Per pkt. $25 \mathrm{c}$.

I940 Patens. Blue

I927 Azurea Grandiflora. Perennial, sky blue

\section{SANVITALIA}

I947 Procumbens Fl. PI. Dwarf annual for edgings, vases or baskets; double yellow flowers 


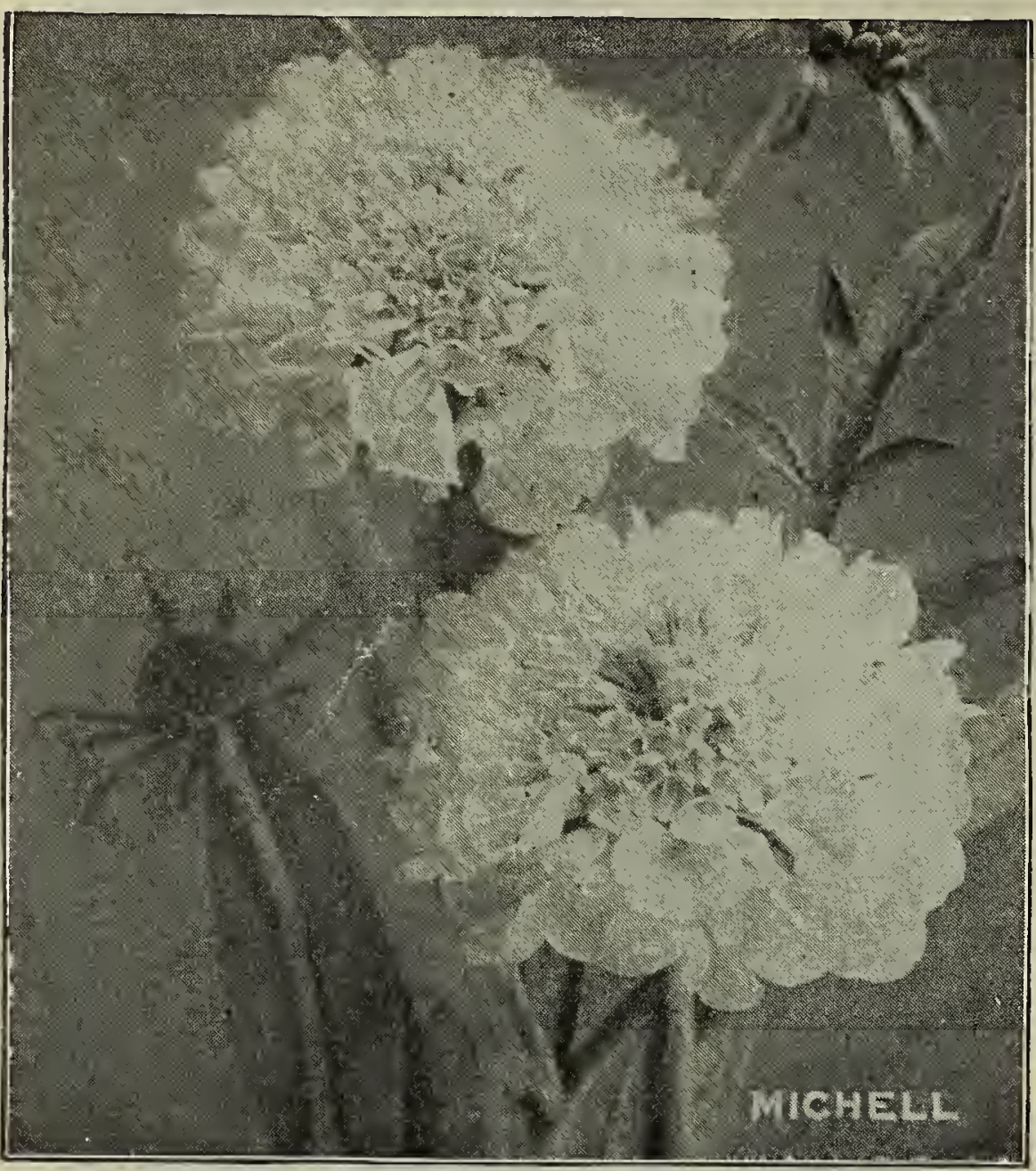

Scabiosa, Grandiflora

\section{Scabiosa (Mourning Bride)}

Trade Pkt. Oz. I95 I Grandiflora or Tall, Azure Fairy. Light blue..\$0.I5 \$0.75 I953 “" “" Fiery Scarlet .......... . . 5 " 1954 " " " " 1955 " " " $"$ " King of the Blacks. Deep

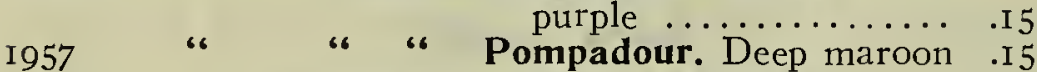

I959 “ “ “ “ “

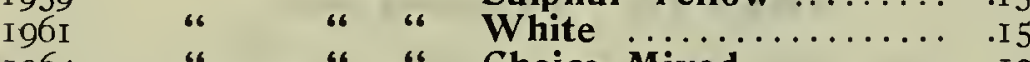

I964 " " " Choice Mixed ........... . .

I962 Dwarf Double Mixed $\ldots \ldots \ldots \ldots \ldots \ldots \ldots \ldots$. Io

I966 Othello. Dark purple .................... .15

I950 Caucasica. Perennial; lilac .................. .30

I948 Alba. White $\ldots \ldots \ldots \ldots \ldots \ldots \ldots \ldots . .40$

I965 Japonica. Perennial; lavender blue ........... .30

\section{Schizanthus (Butterfly Flower)}

I968 Grahami Niveus. Pure white............... .40 I 970 Hybridus Grandiflorus. Dwarf, mixed..............

I97I Wisetonensis. Various colors ................. Albus "Bridal Veil" ( $N e w)$.
Large, snowy white flowers.

I972 Mixed. All colors ....................... .10

\section{Sensitive Plant (Mimosa)}

1975 Pudica. Flowers pinkish white............ .Io SHASTA DAISY (See Chrysanthemum)

\section{Shamrock}

I978 True Irish

\section{Silene}

I980 Bonetti Dwarf Pink. Flowers bright pink..... . . 1982 Dwarf Golden Leaved. Pink flowers........... . Io I984 Double Dwarf White ................... .

Smilax (Myrsiphyllum Asparagoides)

I985 A desirable greenhouse climber of great value for floral decorations. Trade pkt. Ioc., 30c. oz., I/4 lb. \$I .00, $\$ 3.00 \mathrm{lb}$.

SNAPDRAGON (See Antirrhinum)
FLOWER SEEDS

Solanum

Trade Pkt. Oz.

I990 Capsicastrum (Jerusalem Cherry). Scarlet

berries ............................. \$0.10 \$0.25

I99I Fra Diavolo. Of dwarf, compact growth; leaves

and fruit smaller than above............... .25 I.00

Statice (Everlasting Flower)

I993 Latifolia. 'Perennial variety; large, deep blue

flowers $\ldots \ldots \ldots \ldots \ldots \ldots \ldots \ldots \ldots \ldots \ldots \ldots . .20 \quad .75$

I995 Suworowi. Annual variety; flowers pink..... .I5 .50

STIPA (See Grasses, page 40)

\section{Stevia}

2000 Serrata. Fragrant white flowers............. .15 $\quad .75$

\section{Stokesia (Corntlower Aster)}

2055 Cyanea. A hardy perennial; each plant bearing

20 to 30 lavender-blue flowers..............20 - .75

2057 Cyanea Alba. Pure white..........................

\section{Sunflower (Hellanthus)}

\section{Annual Varieties} 2070 Cucumerifolius. $\begin{gathered}\text { Single yellow } \ldots \ldots \ldots \ldots \ldots \\ \text { Purpureus }(\text { New }) . \text { Large flow }\end{gathered}$

urpureus (New). Large flow
ers in a series of shades from pink to purple. Per pkt. I $5 \mathrm{C}$.

2072 Cut=and=Come=Again. Single yellow ........ . . $\quad .30$

2074 Double Globe. Rich yellow................. .I0 .I

2076 Dwarf Double. Deep yellow................... .I0 .I

2068 Chrysanthemum Flowered. Immense double

yellow flowers. ....................... .I

2080 Oscar Wilde. Yellow, with black centre........ .I0 .I5

2082 Perkeo. Dwarf yellow, black centre..............

2084 Polar Star. White, with black centre.......... .I5 .60

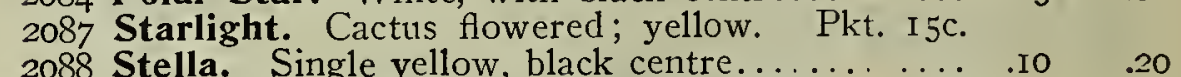

2086 Russian. Large yellow, single ............... 05

\section{Sunflower-Perennial Varieties}

2078 Golden Bouquet. Perennial; yellow......... .20 1.00 2079 Choice Mixed. Single flowering...............30 $\quad 1.25$

Read carefully pages 23 to 28 for valuable Novelties in Flower Seed.

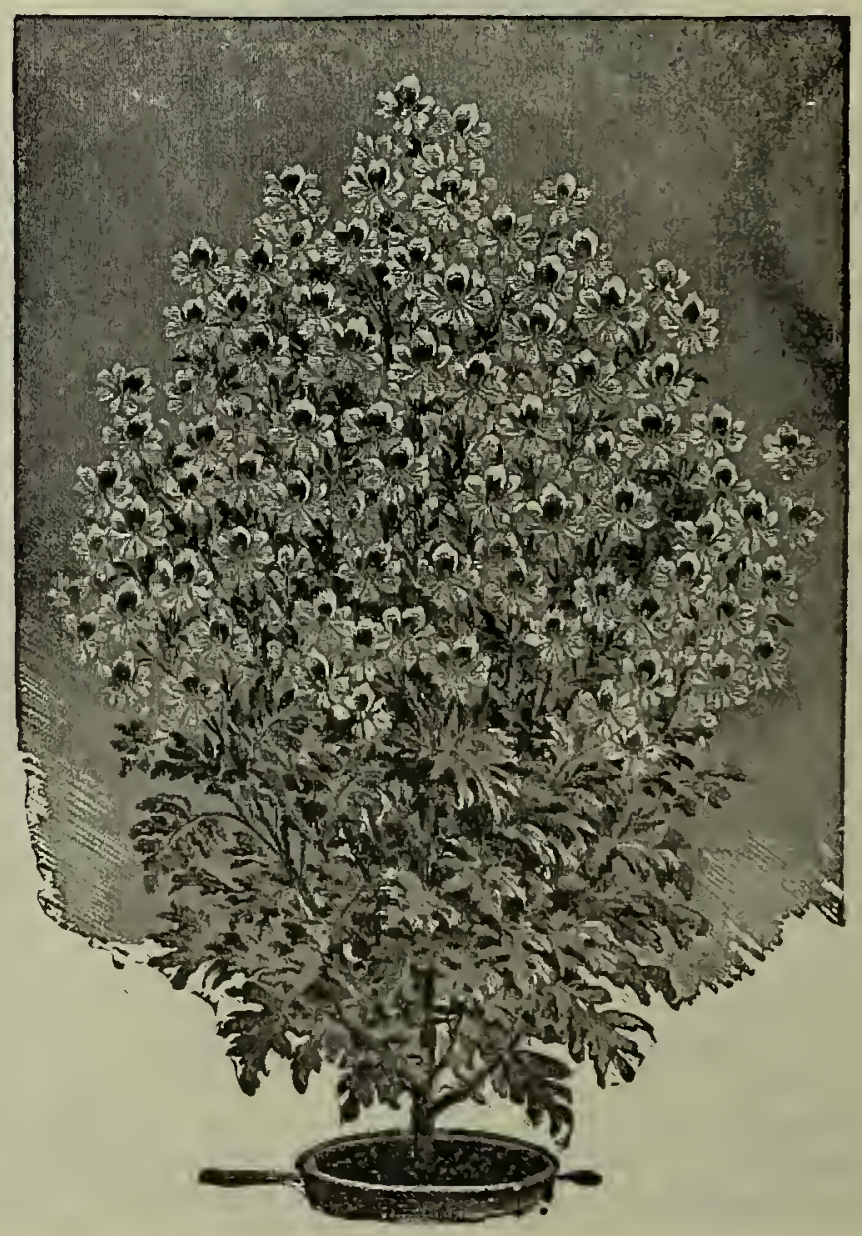

Schizanthus-Wisetonensis 


\section{MICHELL'S " DISTINCTIVE" STOCKS}

For Easter and Decoration Day, Stocks are invaluable and are the most profitable flowers to raise, provided you sow the right strains. For years we have made a specialty of supplying "distinctive" strains and have built up a reputation bar none. Our stocks are easily distinguished by their superior quality. strong germination, and a remarkably small percentage of single flowers. For Decoration Day, sow January ist to February 2oth.

\section{MICHELL'S FLOWER MARKET STOCK}

A branching stock of remarkable vigor of growth and size of bloom; produces its flowers evenly distributed over the stem and very early. A single plant can readily produce from Io to Is separate flower branches equally perfect. The type is of Cut-and-Come-Again, but much superior to what is usually known by that name. Our assortment of colors should satisfy the most critical grower.

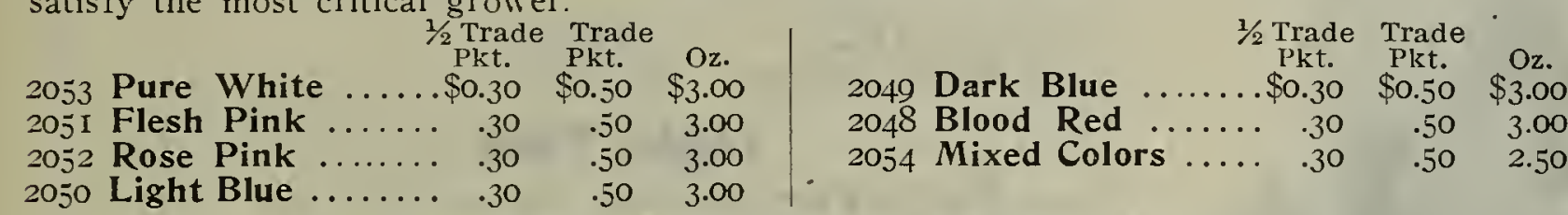
2050 Light Blue $\ldots \ldots \ldots . .30 \quad .50 \quad 3.00$

\section{MICHELL'S "DISTINCTIVE" COLUMN STOCK}

Produces plants composed of one gigantic spike dressed with immense perfect double flowers. Plants can be set as close as 6 inches, allowing double the quantity of plants to a bench.

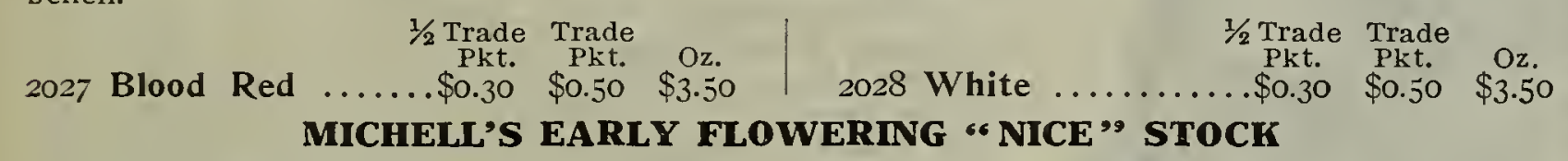

A branching stock of a different habit, less robust in growth but branches are literally covered with blooms which appear earlier than in any other strain. The colors are very distinct, so much so that they are not reproduced in any other strain. The seed we offer comes direct from the originator, a thing of which we pride ourselves. $1 / 2$ Trade Trade 2035 Beauty of Nice. Charming delicate pink, the most popular of all ...\$0.30 $\$ 0.50 \quad \begin{aligned} & \text { Pzt. } \\ & \text { Pkt. }\end{aligned}$ 2038 Queen Alexandra. Delicate lavender.......................30 $.50 \quad 2.50$

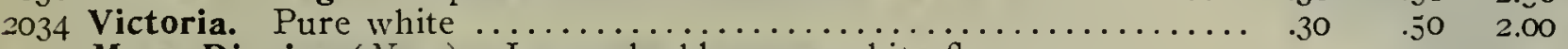
204 I Mme. Rivoire $(N e w)$. Large double, pure white flowers.......... 2029 Abundance. Dwarf, spreading habit; color carmine-rose.......... $\quad .30 \quad \begin{array}{rl}.50 & 3.00\end{array}$ 2040 La Brilliante $(\mathrm{New})$. Double, large flowers; rich brilliant crimson $\quad .30 \quad \begin{array}{llll}.50 & 3.00\end{array}$

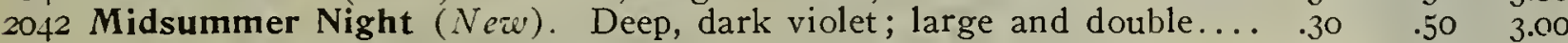

\section{LARGE FLOWERING DWARF TEN WEEK STOCKS}

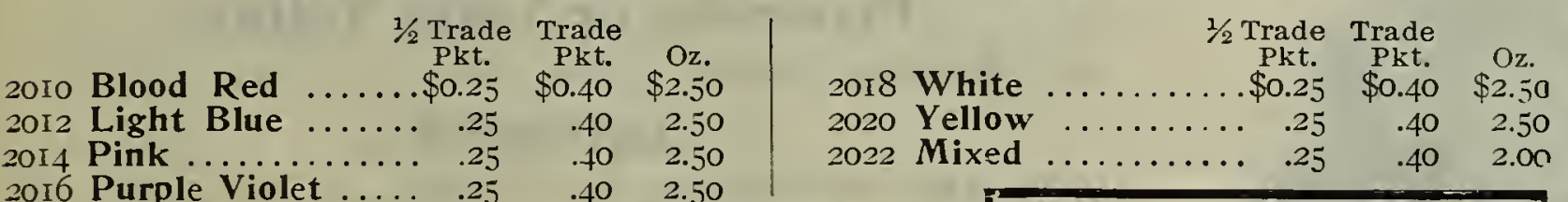

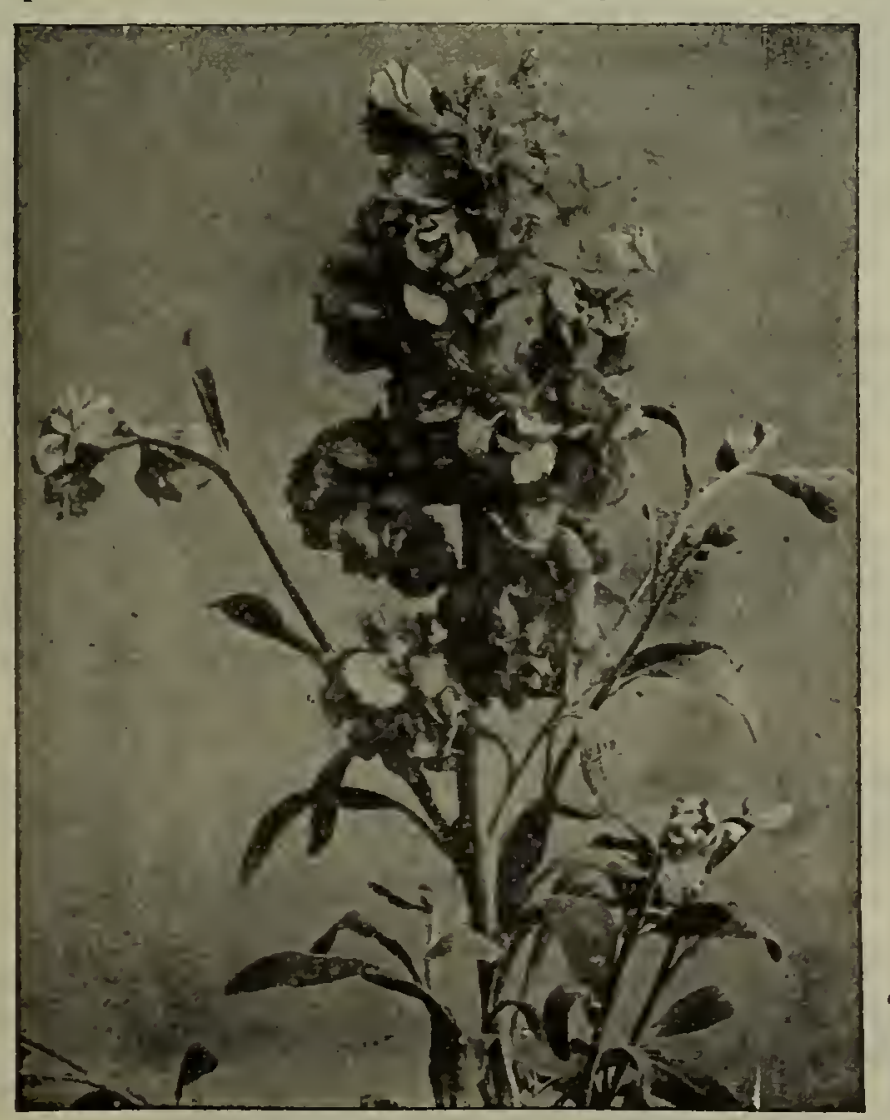

Beauty of Nire Stock
Overbrook, Pa., Mar. 23, igi2. Gentlemen:

I am cutting the finest Stocks Beauty of Nice I ever saw : 95 per cent double flowers. M. DALY.

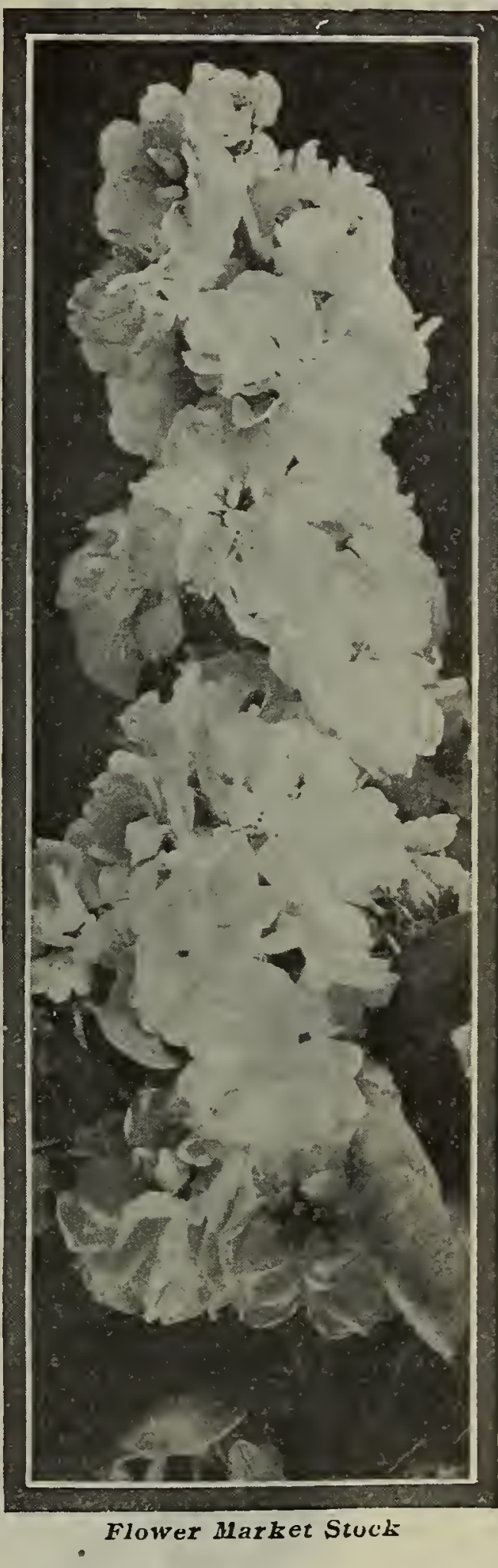

STOCKS-Various Sorts $\begin{array}{ll}1 / 2 \text { Trade } & \text { Trade } \\ \text { Pkt. Pkt. Oz. }\end{array}$ 2025 Wallflower Leaved. Choice mixed....\$0.25 \$0.40 \$2.50 2037 Brompton, or Winter. Mixed. $.30 \quad .50 \quad 2.50$ 2043 Princess Alice (Cut-and-Come-Again). Of branching habit; pure white; excellent for cutting...

$.30 \quad .50 \quad 2.50$ 203I New Pyramidal Stock, "Bismarck." A splendid sort for cutting; immense pure white flowers are regularly lined along a colossal spike, often 30 inches in length, with many side shoots......

2045 New Winter Stock, "White Lady." The plants throw up a massive central spike, which branches freely in candelabra fashion; flowers large, double and of lustrous snowy white. Per pkt. 20c.

2047 Virginian. Mixed
$.30 \quad .50 \quad 3.00$ 


\section{MICHELL'S “DISTINCTIVE” FLOWER SEEDS Spencer or Orchid-Flowered Sweet Peas}

The characteristics of this new type are: (I) Enormous flowers with wavy petals. (2) Invariably four flowers to the stem. (3) Stems averaging I2 to I5 inches in length. (4) Plant, foliage, stem and flower of extraordinarily robust health. Every variety listed here is of tried value, those of commercial preference are prefixed with $*$.

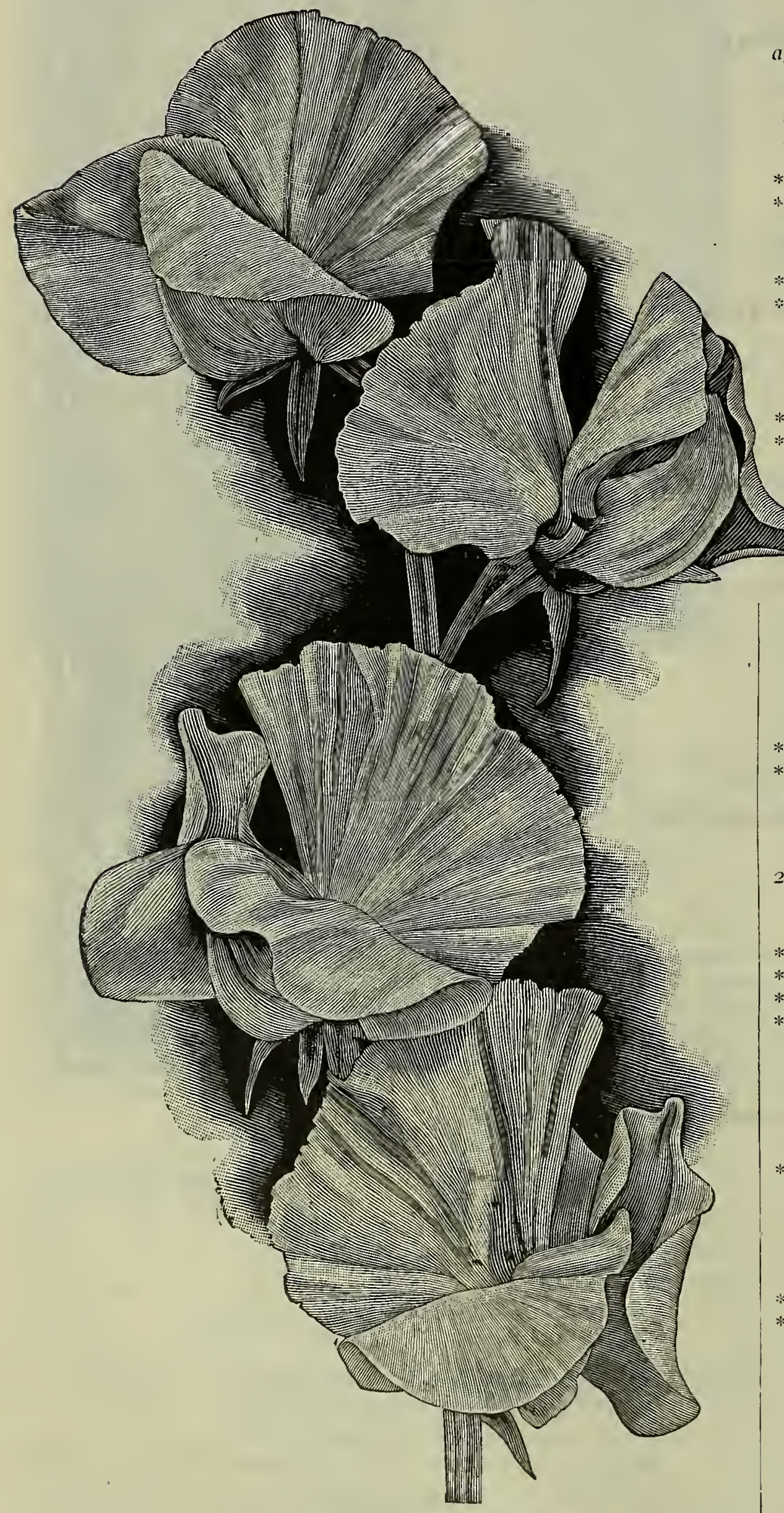

New Spencer Sweet Pea

\section{Superb "Spencer" Mixture}

Blended from only the Giant Waved Spencer varieties, including a number of new hybrids of exquisite colors and shades; we are sure this mixture will give absolute satisfaction.

Per oz. I5c., 40c. per 1/4 lb., per 1b., \$1.35.
If Sweet Peas are wanted by mail, add Sc. per lb. for post-

White

Oz. $\quad 1 / 4 \mathrm{lb} . \quad \mathbf{L b}$.

2I48 Etta Dyke. Pure white........... \$0.I5 \$0.50 \$I.75 2201 Mrs. Sankey Spencer. Black seeded,

pure white .................... .I $\quad .50 \quad 1.50$

*2216 Nora Unwin. Extra large white.........

2255 White Spencer. Clear white......... $.25 \quad .85 \quad 3.00$

\section{Light Pink}

2I I2 Blanche Ferry Spencer. Pink and white $\quad .25 \quad 75 \quad 2.50$

2I35 Countess Spencer. Soft rose pink..... . . 5 .50 $\quad$ I.75

2I43 Duplex Spencer. Large; beautiful

cream pink ..............................

2I 44 Elfrida Pearson. Light pink, margined

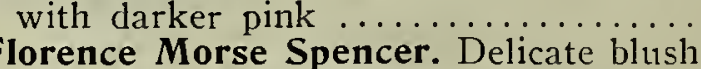

$.40 \quad I .25 \quad 4.25$

2I 52 Gladys Unwin. Delicate pink.......... . . $\quad .30$ I0 .00

2I 57 Helen Lewis. Orange pink........... .20 $\quad .60 \quad 2.00$

2187 Lovely Spencer. Deep pink, shad-

ing to blush.................

2198 Mrs. Hugh Dickson. Salmon pink

on cream ground................ .I 5 .50 1.75

2199 Mrs. Routzahn Spencer. Buff

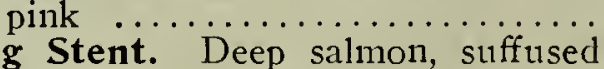

2246 Stirling Stent. Deep salmon, suffused

with orange $\ldots \ldots \ldots \ldots \ldots \ldots \ldots \ldots .40 \quad$ I. $40 \quad 5.00$

2249 W. T. Hutchins. Apricot pink....... .20 60 .60 2.00

\section{Deep Pink or Rose}

2099 Apple Blossom Spencer. Deep pink... .20 216i Geo. Herbert. Rose pink............. .I5

2189 Marie Corelli. Rich rose crimson..... .25

Primrose or Light Yellow

2224 Primrose Spencer. Light yellow...... . .25 $\quad .75$

\section{Lavender}

2I00 Asta Ohn Spencer. Rich lavender.... .25 2I 55 Flora Norton Spencer. Light lavender.

*2147 Florence Nightingale. Large; lavender .25

2I 53 Frank Dolby. Mauve lavender........ .I

2188 Margaret Madison. Light lavender or azure blue ...................... 60

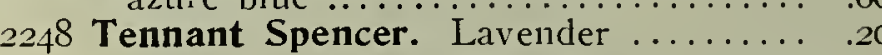

\section{Blue and Purple}

*2124 Captain of the Blues Spencer. Standard purple, wings blue ............... 2164 Irish Belle. Rich lilac flushed pink.... . .40

\section{Scarlet}

2I60 George Stark. Bright scarlet......... .I *2169 King Edward Spencer. Bright crimson .20 2229 Queen Alexandra. Bright scarlet..... .25

2254 Vermilion Brilliant. Intense scarlet.... I.25

\section{Maroon}

2108 Black Knight Spencer. Deep maroon. . . 20 $\quad .60 \quad 2.25$ 2219 Othello Spencer. Deep marcon...... .20 $\quad .60 \quad 2.25$

\section{Striped and Flaked}

2097 America Spencer. Red flakes on white Around ..................................

2I03 Aurora Spencer. White flaked salmon.
2145 Ethel Roosevelt. Large; soft primrose, flaked with crimson ................20 2123 Charm. White, suffused blush pink....
2215 Mrs. W. J. Unwin. White, flaked with orange scarlet
$.20 \quad .60 \quad 2.25$

.60 2.00

$.60 \quad 2.25$

$60 \quad 2.00$

$40 \quad 1.50$ 


\section{MICHELL'S "DISTINCTIVE" FLOWER SEEDS 53 Michell's Standard Sweet Peas}

\section{Separate Colors}

The varieties we offer below have been selected from a large list and embrace only the very best large flowering sorts. Varieties marked * are the most desirable for florists.

For the convenience of our customers, we have arranged the different varieties according to color.

If a anted by mail, add 8 cents per $1 b$. for postage.

\section{White}

2106 Blanche Burpee. Large; pure white...\$0.0 $\begin{array}{cccc}\text { Oz. } & \text { 1/4b. } & \text { Lb. } \\ \text { \$o.20 } & \text { \$o.6o }\end{array}$

*21 36 Dorothy Eckford. Extra large; white. .07 .20 .60

$*_{21} 50$ Emily Henderson. Pure white....... . . 75 .20 60

\section{Primrose and Yellow}

*2162 Hon. Mrs. E. Kenyon. Primrose yellow .io $\quad .25 \quad .75$

\section{Rose and Pink}

*21 ro Blanche Ferry. Pink and white...... .07

$*_{21} 66$ Katharine Tracy. Brilliant pink......... . .

*21 86 Lovely. Soft shell pink.............

*2222 Prima Donna. Lovely soft pink...... .07

*2226 Prince of Wales. Rose crimson......... .I0

\section{Orange}

*2194 Miss Willmott. Deep orange pink... .. .

\section{Crimson and Scarlet}

*2168 King Edward VII. Crimson scarlet.... .0 2228 Queen Alexandra. Large scarlet...... . .

2242 Salopian. Scarlet

\section{Lavender}

*2134 Countess of Radnor. Pale lavender... .0

2I5I Flora Norton. Delicate lavender....... .IO

*2170 Lady Grisel Hamilton. Pale lavender. .IO

\section{Blue and Purple}

2I42 Duke of Westminster. Standard clear purple, wings violet ............... 2 iz8 Lord Nelson. Rich nary bilue..................

*22I 4 Navy Blue. Deep violet blue......... .07

\section{Maroon}

2105 Black Knight. Maroon ............. .10

*2218 0thello. Very dark maroon ............. .

\section{Striped and Mottled}

2095 America. Blood red, striped on white. .0;

\section{Sweet Peas in Mixture}

2258 Michell's Magnificent. Great care has been taken in making up this mixture, selecting the large flowering, long stemmed varieties, a large percentage of which are of the lighter colors and shades

2260 Michell's Gilt Edge. Eckford's large flowering; represents almost every color and shade in sweet peas....... 2292 Cupid or Dwarf Varieties. Mixed colors

For Spencer or Orchid Flowered Sweet Peas, see page 52

.60

.60

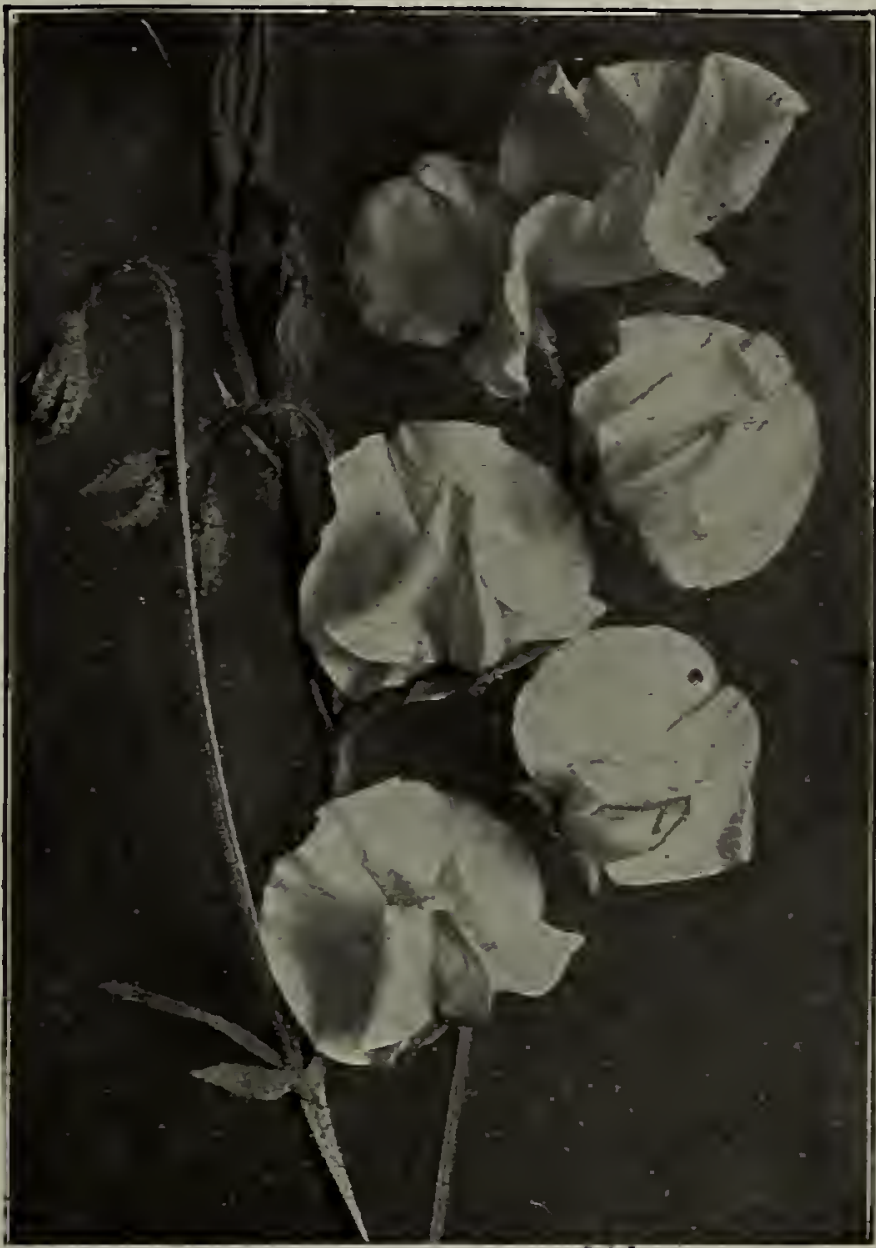

Winter Flowering Sweet Peas

\section{Michell's Christmas or Winter Flowering} Sweet Peas

\section{Especially Adapted For Forcing}

If wanted by mail, add $8 \mathrm{cts}$. per lb. for postage.

This seed has been grown from originator's stock, and can be depended upon for excellent results.

2245 Michell's Snowdrift. Pure white; black

seeded; extra early; large flowers on $\mathrm{Oz}$. 1/4lb. Lb.

long stems $\ldots \ldots \ldots \ldots \ldots \ldots \ldots \ldots \ldots \ldots .25$ \$0.75 $\$ 2.00$

2II4 Blanche Ferry (Extra Early). Pink and

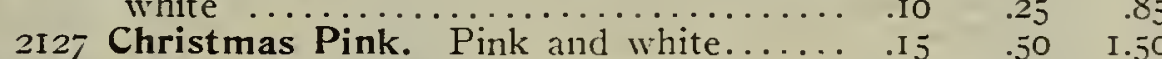

2129 " White ................. .15 .50 1.50

2126 " Meteor. Scarlet

2I 46 Earliest of All. Pink and white....... I0 .25 .75

2174 Le Marquis. Large dark blue........... .15 .50 1.50

2202 Mont Blanc. Early; pure white....... .10 $.25 \quad .85$

2203 Mrs. Alex. Wallace. Lavender.......... I5 .50 I.50

2206 Mrs. Chas. H. Totty. Lavender.......... .15 .50 1.50

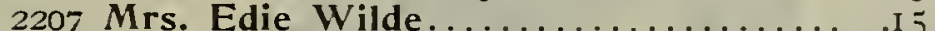

2209 Mrs. F. J. Delansky. Daybreak pink... .I 5 .50 I.50

2210 Mrs. Geo. Lewis. Pure white.......... .1 5 .50 I.50

2213 Mrs. William Sim. Salmon pink......... .1 50

22 I I Mrs. W. W. Smalley. Satin pink....... .I 5.50 I.50

2264 Mixed. Winter flowering ............ .15 .50 1.50

\section{Zvolanek's Christmas or Winter Flowering} Sweet Peas

2127A Christmas Pink. Pink and white.

$\begin{array}{ll}\text { 2129A “ } & \text { White (Florence } \\ \text { 2126A } & \text { Meteor. Scarlet }\end{array}$

2I74A Le Marquis. Dark blue

2203A Mrs. Alex. Wallace. Lavender.

2206A Mrs. Chas. H. Totty. Lavender

22IoA Mrs. Geo. Lewis. Pure white.

2213A Mrs. William Sim. Salmon pink.

22I IA Mrs. W. W. Smalley. Satin pink.

2253A Wallacea. Lavender

2257 A Watchung. Pure white

2264A Mixed. Vinter flowering 


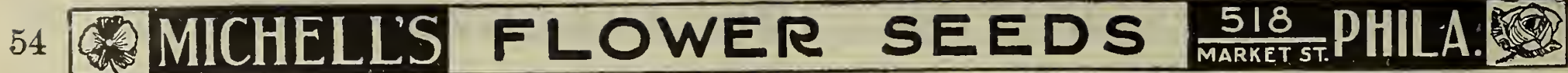

SWEET ROCKET (Hesperis) Tradepkt. Oz. 2300 Mixed. Perennial; purple and white.........\$o.Io \$o.I5 SWEET SULTAN (Centaurea Moschatus)

2305 Mixed. Fragrant $\ldots \ldots \ldots \ldots \ldots \ldots \ldots \ldots \ldots$.ro . I5

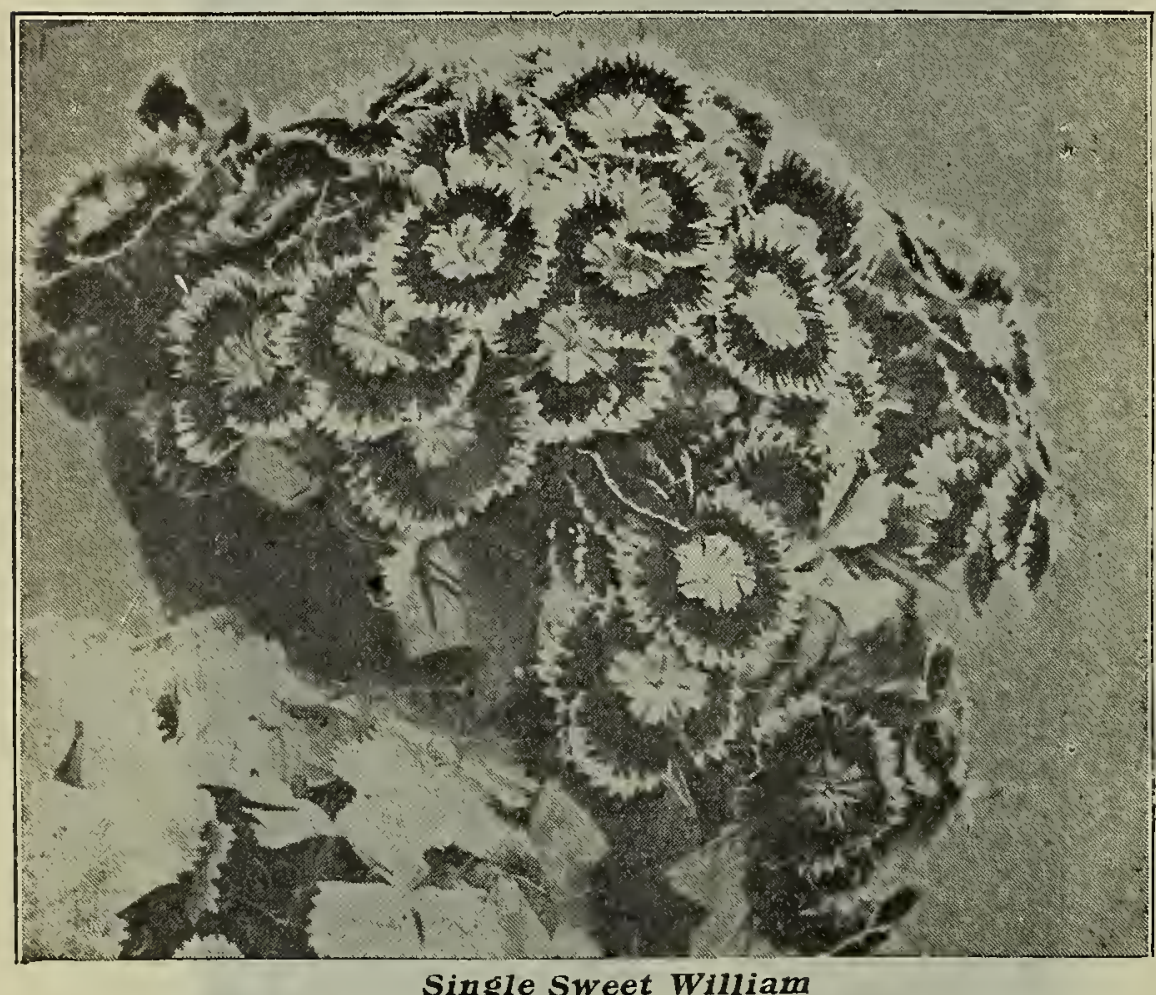

SWEET WILLIAM (Dianthus Barbatns)

Trade pkt. Oz. 2306 Single Crimson ..................... \$o.ro \$o.30 2307 " Red with white eye................ . . ${ }^{30}$ 2308 " Velvety Maroon ................... . I0 $\quad .30$ 2309 "Violet with white eye.............. . $23 I I$ " White ...................... . 23 I2 Single Mixed. All colors. $1 / 4 \mathrm{lb} .60 \mathrm{c} . \ldots \ldots \ldots$.IO 23I3 Pink Beauty. Large flowers of salmon pink.. .30 2315 Scarlet Beauty. Intense, rich deep scarlet..... .40 23ro Auricula Flowered. Single mixed........... . I0 $23 r_{4}$ Double Mixed. All colors.................. . 5

\section{TAGETES}

2320 Golden Ring. Single, brown and yellow...... .15 THUNBERGIA (Black-Eyed Susan)

2326 Alata. Buff, dark eye................... .I5

2325 Alba 0culata. White, dark eye............. .I5

2327 Aurantiaca. Orange, dark eye................ .15

2328 Mixed TORENIA

2337 Fournieri Grandiflora. Blue ............ .30

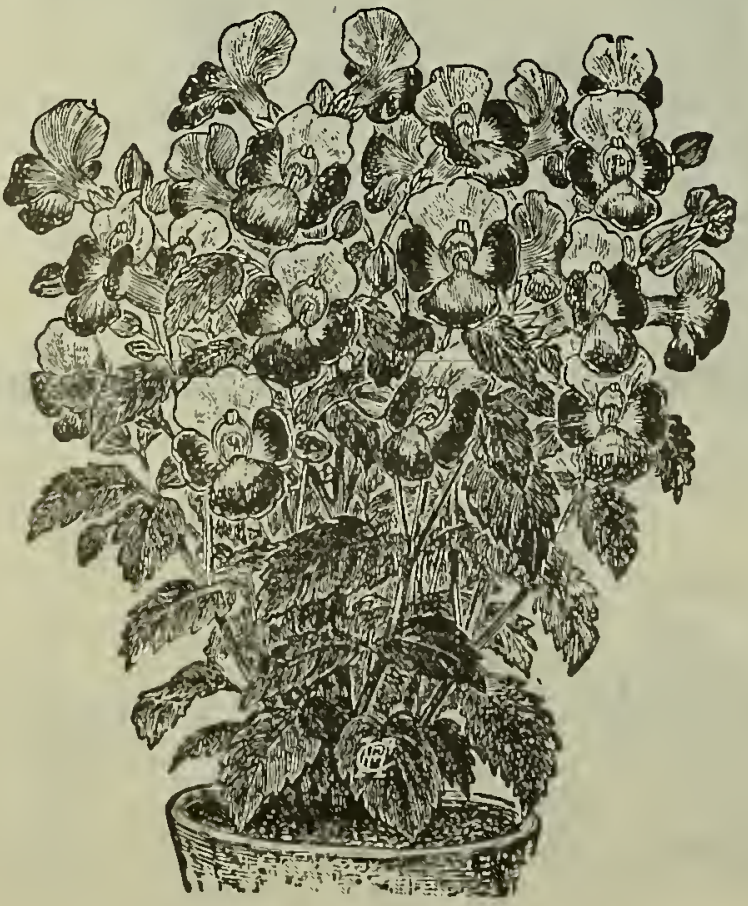

Torenia, Fournieri Grandiflora
TRITOMA (Red Hot Poker Plant) Tradepkt $\mathrm{Oz}$ 2345 Uvaria Grandiflora. Orange scarlet......... \$0.I5 \$0.60

VALERIANA (Garden Heliotropo)

2348 Officinalis. Perennial; rose pink flowers.......30 $\quad$ I.50 2350 Mixed. Perennial; fragrant .............. . . $\quad .20$

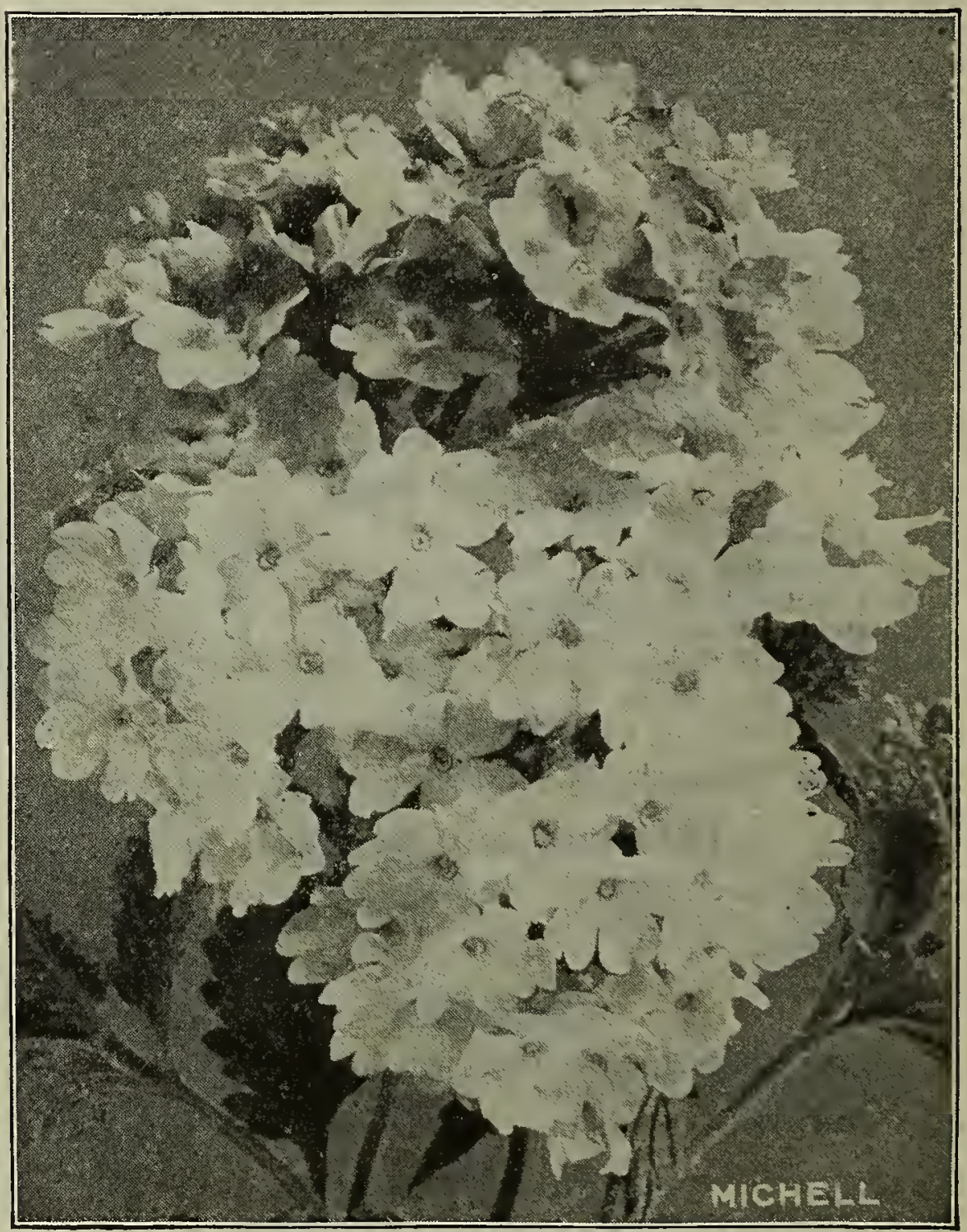

Michell's Mammoth Fancy Verbena

\section{MICHELL'S VERBENAS}

Our Mammoth Fancy Strain of this popular bedding plant cannot be excelled for its free floworing qualities, large slzo and purity of colors.

2355 Michell's Mammoth Fancy Blue........... Trade pkt. 0 Oz, 2357 “ “ “ “ Pink ............30

2359 “ “ “ “

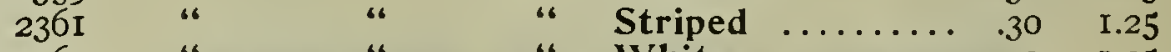

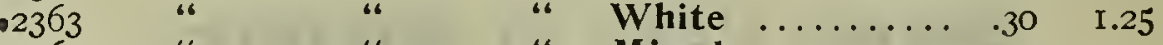

2365 " " " "

2367 New Giant Flowered Mixed. A new variety of large size with extra large, white eyes...50 2.50

2368 Helen Willmott (Nezv). Large flowers of a bright salmon rose, with white eye. Per pkt., 20c.

2354 Hybrida Compacta "Dornröschen" (Nezv). A dwarf compact-growing variety; flowers white, with a soft carmine rose edge. Per pkt., 20c.

2366 Mammoth Choice Mixed................25 .75

2369 Fine Mixed ............................. .20 .60

237 I Lemon Scented (Aloysia Citriodora)......... .30 r.60

\section{VERONICA (Speedwell)}

A showy, hardy perennial border plant.

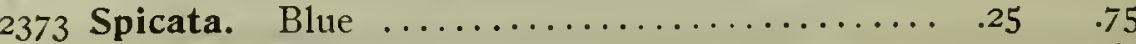
2374 Virginica. White...................25 1.60 


\section{MICHELLS FLOWER SEEDS $\frac{518}{\text { Makret Pit PHILA. }}$}

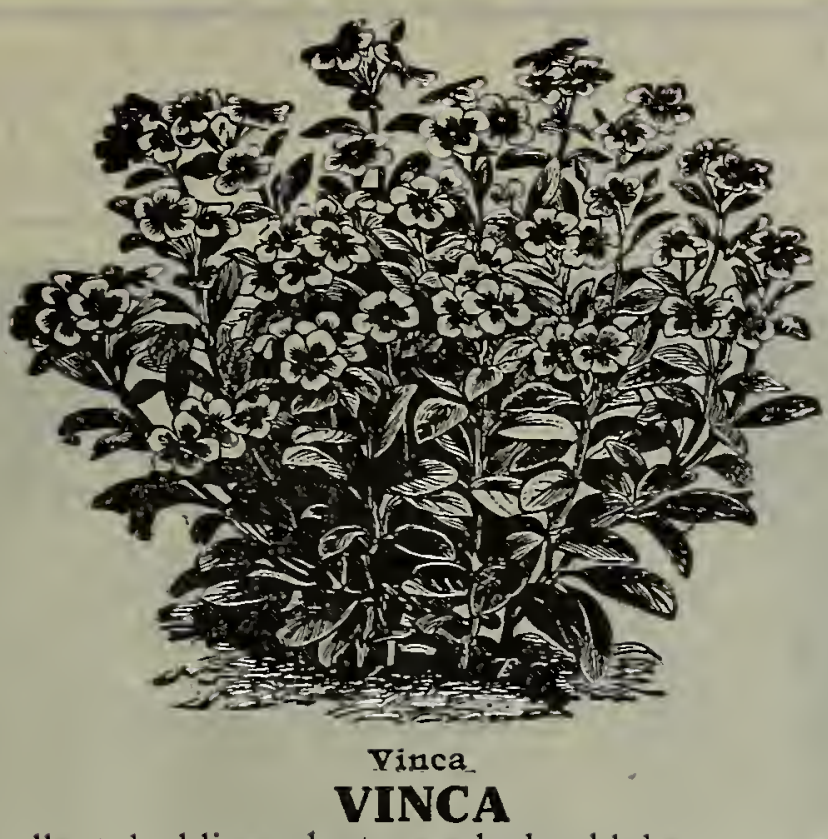

An excellent bedding plant; seed should be sown early. 2375 Alba. White, with rose centre trade pkt. 2376 Alba Pura. Pure white............... I5 2377 Rosea. Pink

2378 Mixed

VIOLA CORNUTA (Turted Panses)

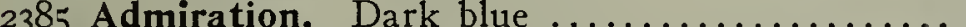

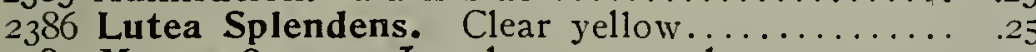
2384 Mauve Queen. Lovely mauve color..............25

2387 Perfection. Light blue

2388 White Perfection. Pure white................ .25 2389 G. Wermig (New). Of the identical color of

the "Princess of Wales" Violet. Per pkt. I5c.'

\section{VIOLET (Sweet scented)}

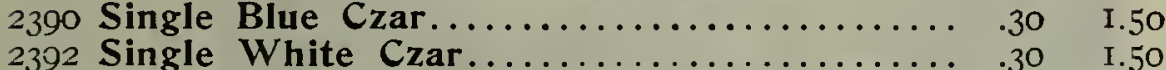
2394 Single Mixed $\ldots \ldots \ldots \ldots \ldots \ldots \ldots \ldots \ldots \ldots \ldots . .30$

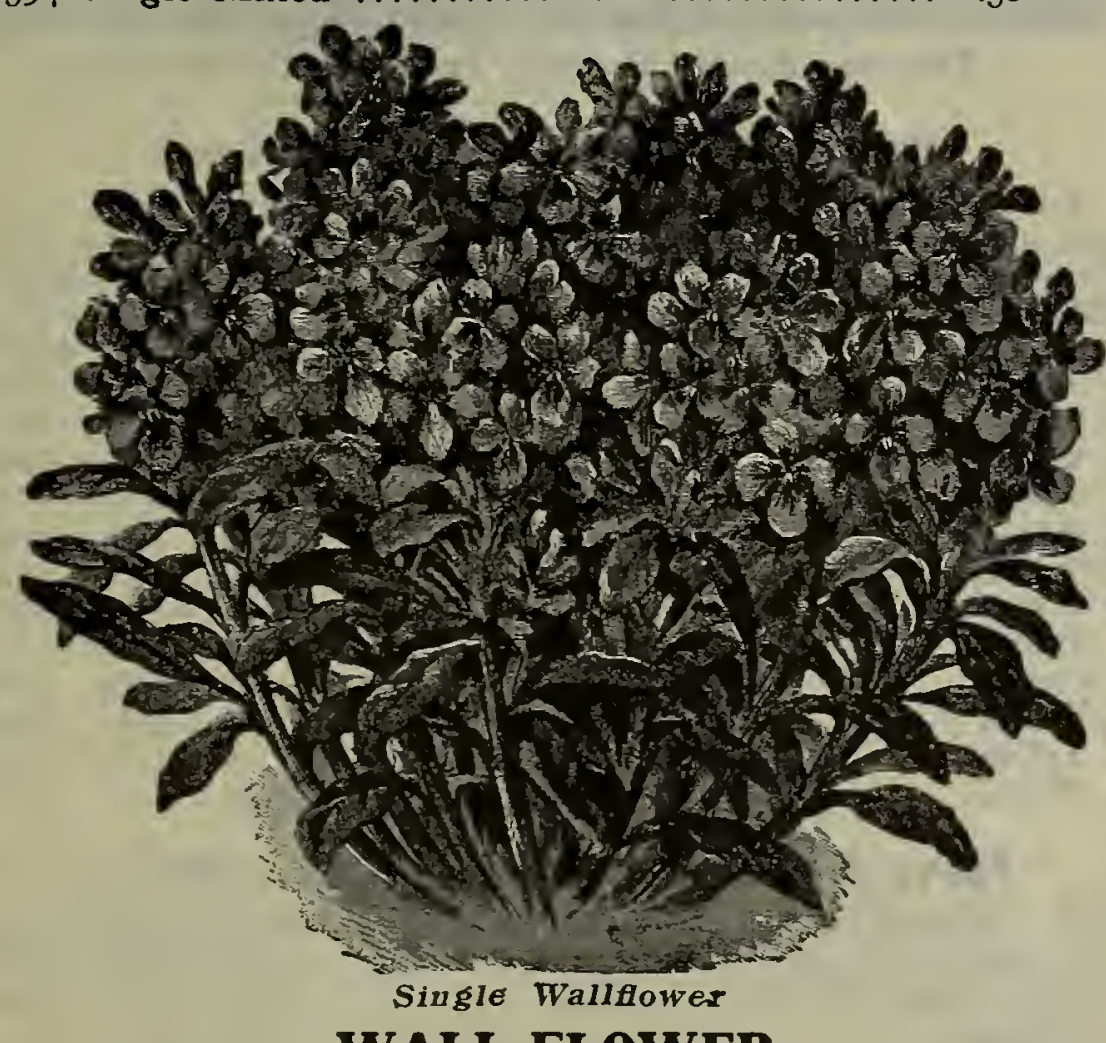

WALL FLOWER

2400 Double Brown ............... (1/4 oz. 75c.) .40 2402 Double Yellow ................. (1/4 oz. 75c.) .40

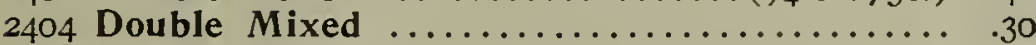
2408 Single Mixed ......................... .10

Paris Extra Early. Single flowering; blooms the first year from seed. 2407 Blood Red

2409 Yellow

2406 Mixed.

XERANTHEMUM (Everlasting Flowor)

2420 Double Mixed. Annual, for winter bouquets... .Io

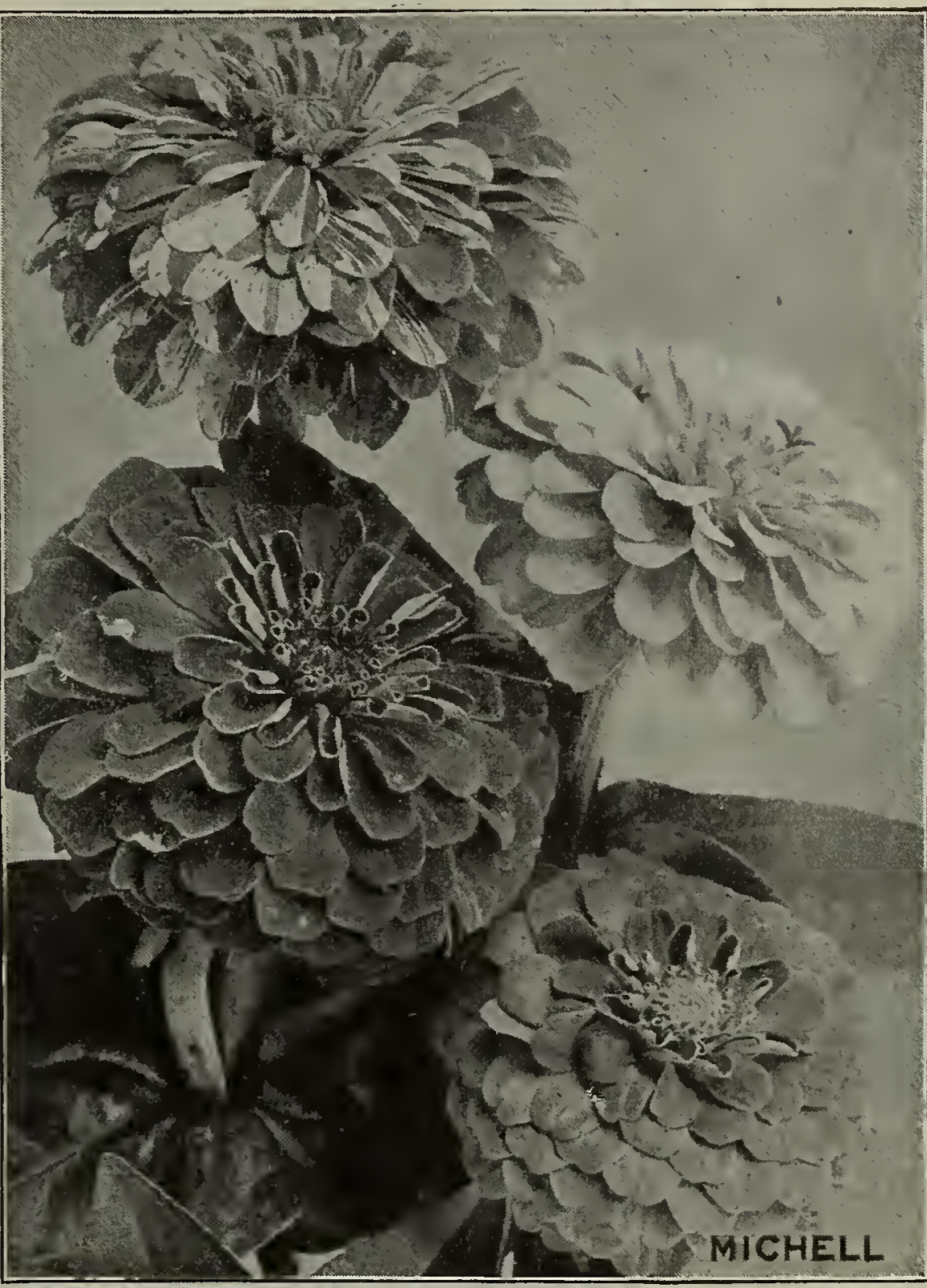

New Giant Robusta Zinnias

MICHELL'S " DISTINCTIVE" ZINNIAS

We claim perfection in form, size and color for our strain of Zinnas, as those who grow them will attest. Trade pkt. Oz. 2440 Tall Double Crimson..........................

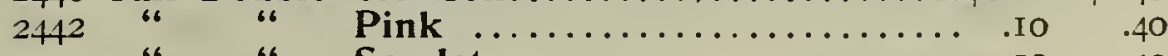
2443 " "

2444 " " " White

2446 " " " Yellow.

2448 " " " Mixed

2430 Dwarf Double Jacqueminot, Crimson......... I0

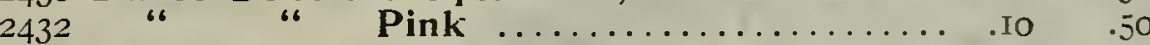

2433 " " $"$ Salmon Rose ............ .10 .50

2434 " " " White .......................

2435 “ “ “ $\quad$ \carlet $\ldots \ldots \ldots \ldots \ldots \ldots \ldots \ldots$.

2436 “ “ 2438 Mixed ................. 50

\section{ROBUSTA OR GIANT ZINNIAS}

Flowers of immense size and perfectly double.

2470 Scarlet

2473 White

2468 Golden Yellow

2466 Crimson

2467 Flesh Color

2469 Purple

247 I Sulphur Yellow

2472 Violet

2454 Choicest Mixed. Trade pkt. 20c.,60c. per oz.

VARIOUS ZINNIAS

2453 Red Riding Hood. Miniature flowe

2450 Curled and Crested. Double mixed...

2458 Zebra, or Striped. Double.

MIXED OR WILD FLOWER GARDEN SEEDS

A mixture containing nearly I0o varietie
and interesting flowers. (Per 1 b. $\$ 1.00$ ) 


\section{${ }^{56} \quad$ Michell's Summer Flowering Bulbs, Etc., for Florists}

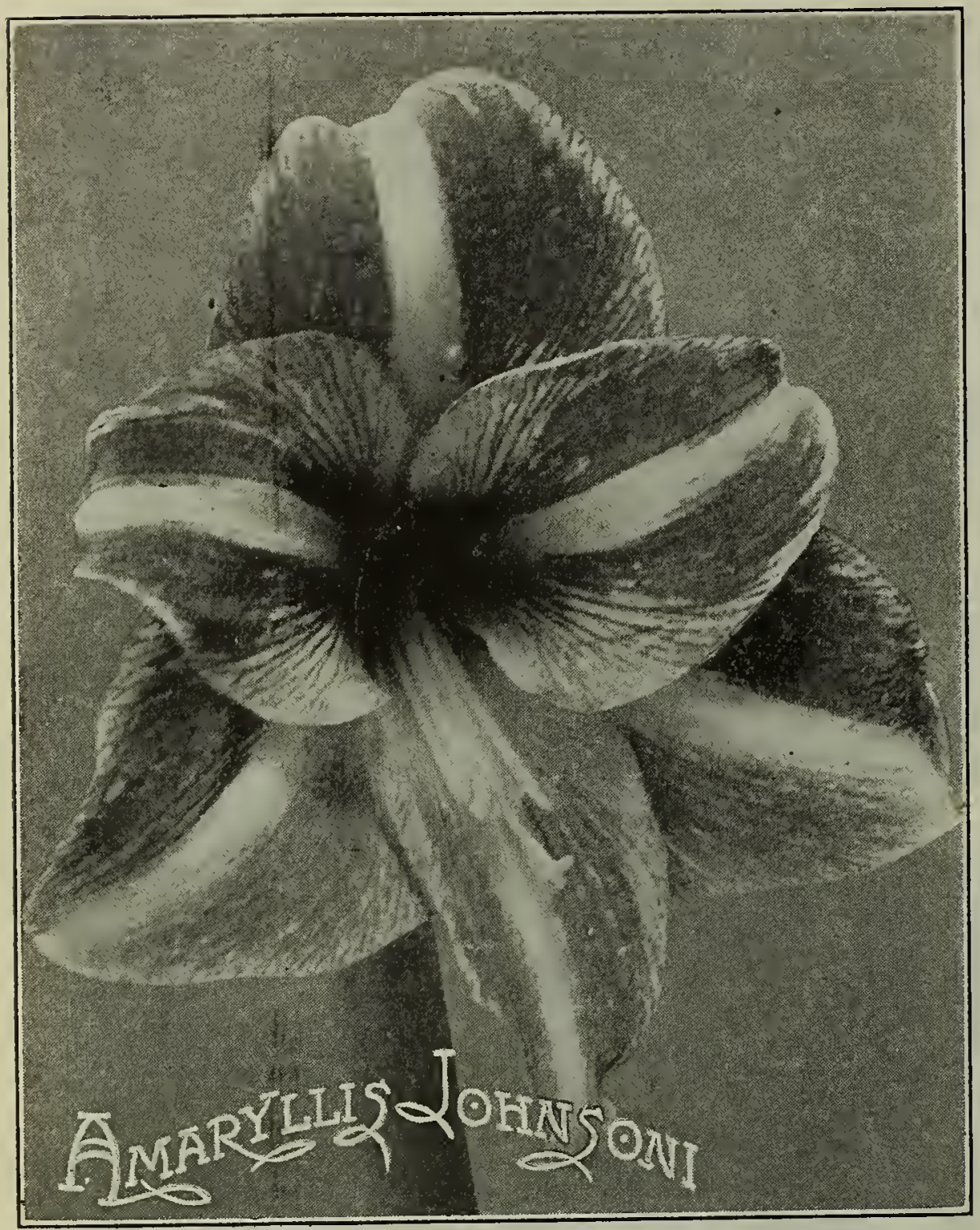

\section{Amaryllis Bulbs}

Belladonna. Pink, IOc. each............... \$0.85 $\$ 6.00$ Hybrids of Vittata. Choice mixture, 35c. each..... $3.50 \quad 25.00$ Johnsoni. Red and white, large bulbs, 25c. each..... 2.50 19.00 Formosissima (Jacobcan Lily). Red, large bulbs.... $75 \quad .75$ Treatea Alba (Zephyranthes). (Extra large bulbs.) $.45 \quad 3.25$ Rosea

$\begin{array}{lll}\text { (Extra large bulbs.) } & .45 & 3.25\end{array}$

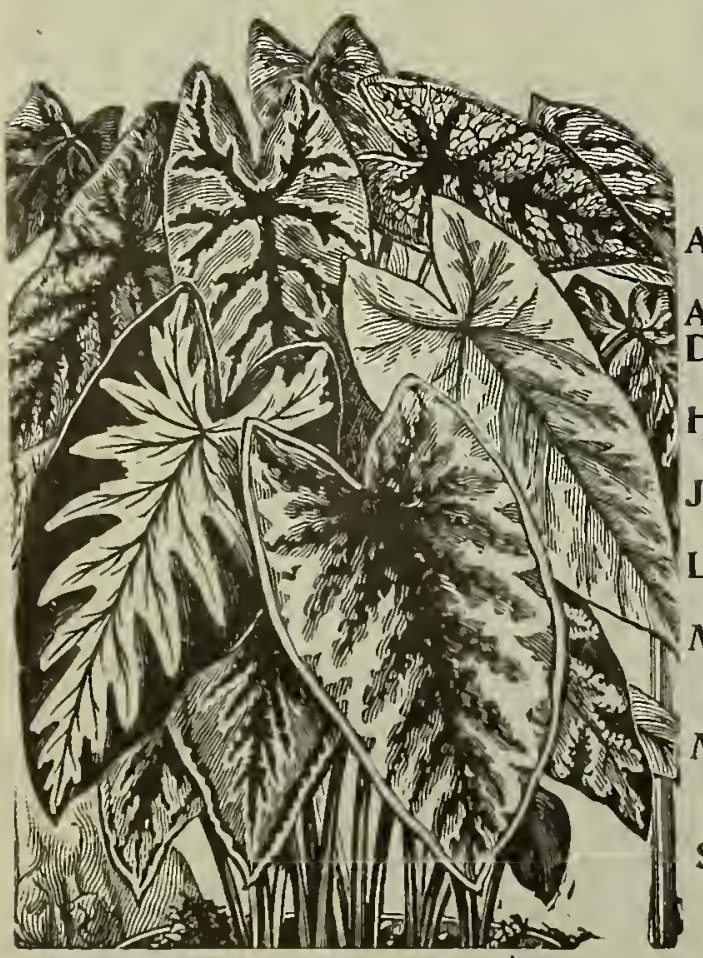

Fancy Leaved Caladium Bulbs

(Ready in March)

Aguape. One of the grandest. Vivid red, transparent. Alfred Mame. Velvety red. Dr. Augusto de Castro. Red, white and green.

Hermione. Rosy-red, ribs bright red, green border. John Peed. Glowing red cenA narrow green border. 'Automne. Creamy-white, Marie Carola (New) en green, spotted red, suffused yellow.

Marmoratum (Alocasia Puezli). Glaucous green, with white spots.

Stephen Girard. Green, marbled white, red ribs.

Triguara. Entirely red, with bronze reflections, ribs brilliant red. White Flag. White.

The above named rare sorts, 20c. each, doz. \$2.00, Ioo \$14.00.

Mixed Varieties. I 5c. each, doz. \$1.65, \$I I.00 per 100.
NOTE. We guarantee the safe arrival of all bulbs shipped during the winter months if sent by Express. Freight and Boat Shipments of bulbs are very risky during cold weather and can be forwarded this way at customer's risk only.

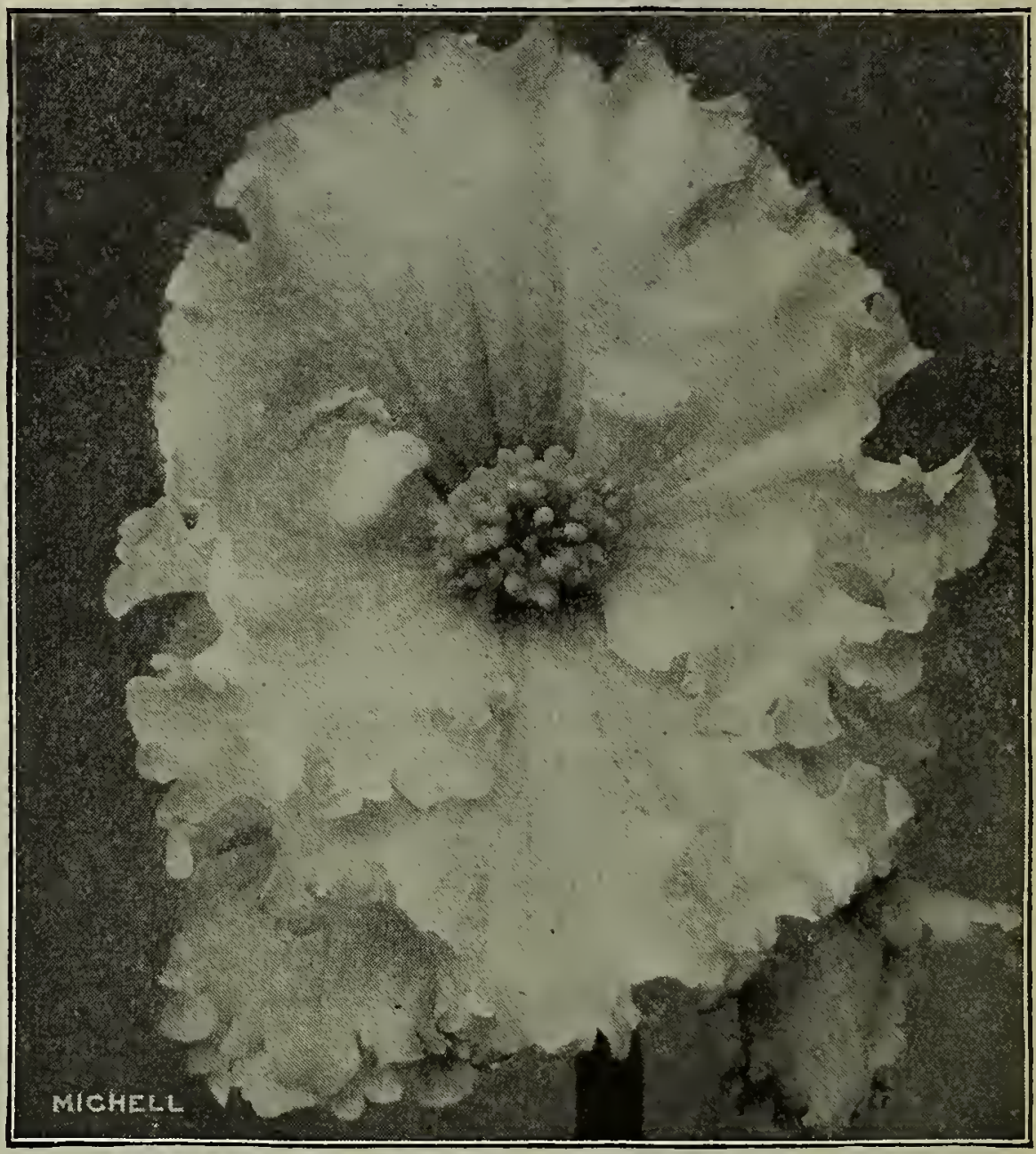

Tuberous' Rooted Begonia, Frilled or Crispa Type

\section{Begonia Bulbs-(Tuberous Rooted)}

Very choicest giant flowering type. Extra large bulbs. The past year we made some extensive trials of strains of tuberous rooted Begonias and are convinced that ours cannot be surpassed.

\begin{tabular}{|c|c|c|c|}
\hline SINGLE & Doz. & 100 & 1000 \\
\hline Orange &.$\$ 0.40$ & $\$ 2.50$ & $\$ 22.00$ \\
\hline Scarlet & . .40 & 2.50 & 22.00 \\
\hline Pink . & .40 & 2.50 & 22.00 \\
\hline White & .40 & 2.50 & 22.00 \\
\hline Yellow & .40 & 2.50 & 22.00 \\
\hline Mixed & .30 & 2.25 & 20.00 \\
\hline DOUBLE & Doz. & 100 & 1000 \\
\hline Crimson &.$\$ 0.65$ & $\$ 4.00$ & $\$ 35.00$ \\
\hline Scarlet & .65 & 4.00 & 35.00 \\
\hline Pink . & .65 & 4.00 & 35.00 \\
\hline White & .65 & 4.00 & 35.00 \\
\hline Yellow & .65 & 4.00 & 35.00 \\
\hline Mixed & .50 & 3.75 & 33.00 \\
\hline
\end{tabular}

New Frilled Begonia (See Cut Above)

A beautiful crested type, producing very large single flowers The above cut, which was reproduced from an actual bloom, will convey some idea of its beauty. Doz. $100 \quad 1000$

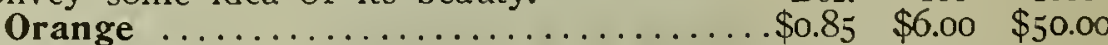
Scarlet $\ldots \ldots \ldots \ldots \ldots \ldots \ldots \ldots \ldots \ldots \ldots, \quad 85 \quad 6.00 \quad 50.00$

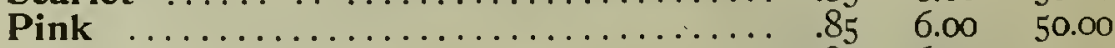
White $\ldots \ldots \ldots \ldots \ldots \ldots \ldots \ldots \ldots \ldots \ldots, 85 \quad 6.00 \quad 50.00$ Yellow $\ldots \ldots \ldots \ldots \ldots \ldots \ldots \ldots \ldots \ldots \ldots \ldots$. $85 \quad 6.00 \quad 50.00$

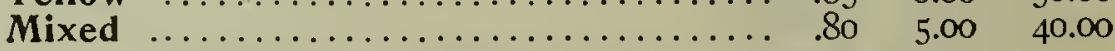

\section{Named Tuberous Begonias}

Lafayette. Brilliant crimson, double...... \$0.15 $\$ 1.50$ \$10.00 Graf Zeppelin. Double; vermilion scarlet .12 $1.25 \quad 9.00$ Bertini. Brilliant vermilion, single........ . ro $\quad$ x.00 $\quad 7.50$ Cardinal. Rich cardinal red............ .20 $1.75 \quad 12.50$ 


\section{MICHELL'S (Home Grown) Thrifty CANNA ROOTS}

Our Roots are crtra strong, with plenty of cyes, are clean and absolutely true to name. They will be found far superior to the cheap southern-grown stock which cannot be relied upon for trueness to name. Our Cannas are all true to name. When ordering please state if immediate shipment is desired; also if we shall send via express or freight. This stock is grown by ourselves at Evergreen Seed Gardens on especially prepared soil and is in extra fine shape.

\section{Newer Varieties of Special Merit}

Brilliant. Pure golden yellow with tongues of fiery red. $75 \mathrm{c}$. doz., per $100 \$ 5.00$, $\$ 40.00$ per 1000 .

Comte de Sachs. Clear crimson scarlet, carried well above the foliage; a fine sort. 75c. doz., per $100 \$ 4.00, \$ 32.50$ per 1000 .

Gladio=Flora. Petals short and rounded, overlapping each other; a new form; color, crimson, changing to deep rose, with an uneven edge of gold to each petal. Height, $3^{\mathrm{I} / 2}$ feet. $\$ \mathbf{I} .50 \mathrm{doz}$, per 100 $\$ 10.00, \$ 90.00$ per 1000 .

Halley's Comet. Blazing scarlet, with a yellow throat, margined yellow. \$1.50 doz., \$I0.00 per I00, \$90.00 per I000.

Minnehaha. Wavy petals of immense size form a fantastic flower which is resplendent in colors only known to orchids; seashell pink, deepening to gold and cream, with a centre of peach blow. 3 feet; foliage green. \$I.00 doz., \$6.00 per Ioo, $\$ 50.00$ per io00.

Mrs. Alfred F. Conard. Salmon pink; very fine, large truss and flowers. \$2.25 doz., per I00 \$16.00, \$150.00 per I000.

Pink Beauty of Hungaria. An especially fine salmon pink. claimed to be an improvement on Mrs. Alfred F. Conard: heavy, massive green foliage and gigantic flower truss. 3 feet. $\$ 2.50$ doz., per I0o \$16.00, \$1 50.00 per I000.

Rosea Gigantea. Rich rose pink, a monster flower, an advance both in color and size. To appreciate the beauty of this novelty one must see it; words, no matter how eloquent, cannot do it justice. It is a coming winner. Height, $3^{1 / 2}$ feet; foliage green. \$1.25 doz., per I0o $\$ 8.50$, \$80.00 per Iooo.

Venus. Gay rose pink, with a mottled border of creamy yellow; green foliage. 60c. doz., $\$ 4.00$ per I00, $\$ 37.50$ per 1000 .

Wawa. Fine pink, growing 3 feet high. $85 \mathrm{c}$. doz., $\$ 6.00$ per roo, $\$ 50.00$ per I000.

\section{Crimson and Red Shades}

Alphonse Bouvier. Deep crimson, green Doz. foliage, 4 feet .....................\$0.50

Black Prince. Dark crimson, green foliage.. .60

Brandywine. Scarlet red, green foliage..... .60

Chas. Henderson. Fine crimson.......... .50

Comte de Sachs. Clear crimson scarlet..... .75

Crimson Bedder. Crimson, green foliage.... .50

Egandale. Bright cherry red, bronze foliage.. .60

Express. Scarlet crimson $\ldots \ldots \ldots \ldots \ldots \ldots \ldots$
President Meyer. Carmine red, bronze foliage,

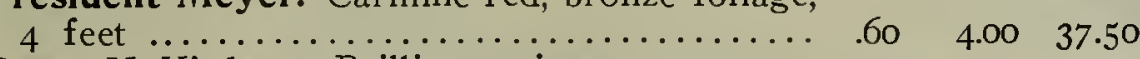

Pres. McKinley. Brilliant crimson.......... .50 $3.00 \quad 27.50$

Wm. Saunders. Bright scarlet............ I.00 $6.00 \quad 50.00$

\section{Orange Scarlet Shades}

King Humbert. Bronze foliage, orange red,

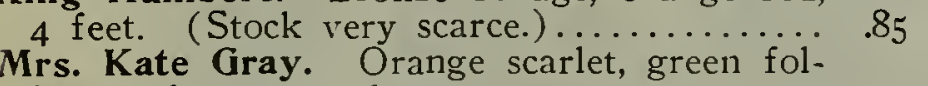
iage, 4 feet; very showy................ .50 $3.00 \quad 2 \% .50$

\section{Pink Shades}

Hiawatha. Rosy pink, variegated foliage..... $6 \begin{array}{llll}60 & 3.50 & 32.50\end{array}$ Mad. Berat. Brilliant rose pink, very fine.... .6o $3.00 \quad 27.50$ Minnehaha. Seashell pink, deepening to gold, peach blow centre................. I.0o

Pink Beauty of Hungaria. Soft salmon

rose, 3 feet. ....................... 2.50 I6.00 I 50.00 Wawa. Extra fine pink, 3 feet................. $85 \quad 6.00 \quad 50.00$

Venus. Rosy pink, bordered yellow......... .60 $4.00 \quad 37.50$

Rosea Gigantea. Rich rose pink.......... I.25 $8.50 \quad 80.00$

Mrs. Alfred F. Conard. Soft salmon pink... 2.25

I6.00 I 50.00

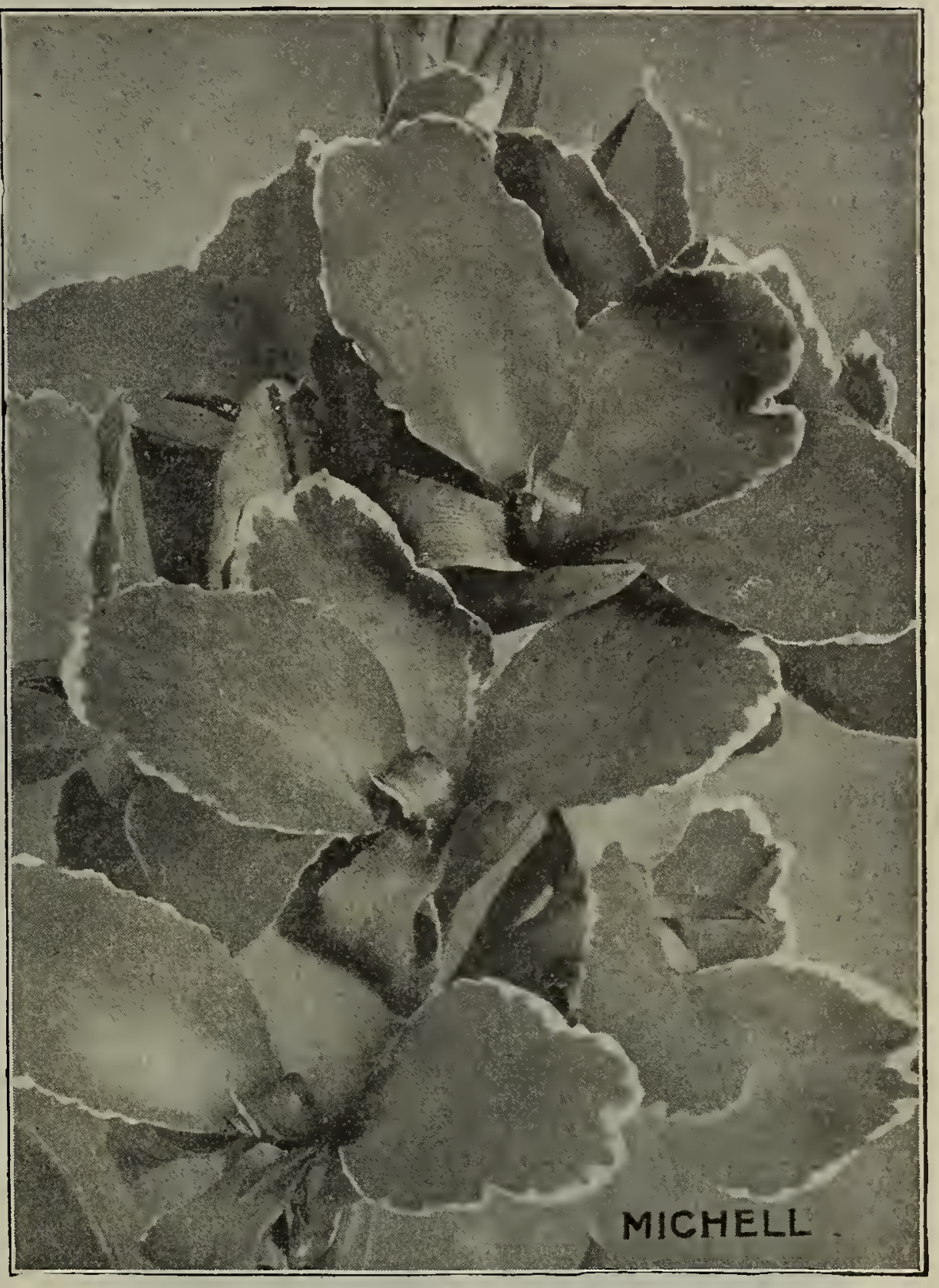

Gladiolflora

Scarlet Edged Yellow Varieties

Gladio Flora. Crimson, changing to rose, Doz. 1001000

each petal edged gold................. \$I.50 \$Io.00 \$90.00

Halley's Comet. Blazing scarlet, with a yel-

low throat, edged yellow............... I.50 I0.00

Italia. Scarlet, broadly edged yellow, 6 feet... 50 .5 3.2530 .00

Mme. Crozy. Scarlet, bordered golden....... $.50 \quad 2.75 \quad 25.00$

Niagara. Rich crimson, edged gold......... .60 $4.00 \quad 37.50$

Queen Charlotte. Crimson, with wide gold

border, 3 feet ....................... 6o 3.2530 .00

\section{Brilliant. Pure Spotted Varieties}

Brilliant. Pure golden yellow, striped red... $\quad .75 \quad 5.00 \quad 40.00$

Florence Vaughan. Yellow, spotted red, 4 ft. $.40 \quad 2.75 \quad 25.00$

Gladiator. Yellow, spotted red..............6 $30 \quad 3.50 \quad 32.50$

\section{Yellow Varieties}

Alsace. Pale sulphur, changing to cream..... $.50 \quad 2.75 \quad 25.00$

Austria. Deep golden yellow, 6 feet........... $.50 \quad 3.25 \quad 30.00$

Gustave Gumpper $(N e \tau)$. Rich yellow; very

fine, 4 feet Wichard Wallace. The finest commercial

light yellow canna, 4 feet............... .60 $3: 2530.00$

\section{Foliage Cannas}

Black Beauty (Improved). A foliage variety,

bronzy purple leaves, 6 feet high...........

Musa Folia. A broad green foliage variety,

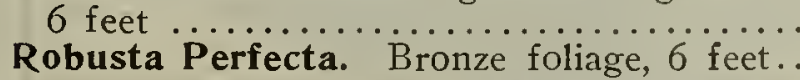

\section{Mixtures}

Dwarf French Mixed.
Tall Sorts Mixed....... 


\section{${ }^{58}$ Michell's Summer Flowering Bulbs, etc., for Florists}

\section{Caladium, Esculentum Bulbs}

Mammoth. II to $I 2$ in. cir. \begin{tabular}{cccc} 
Doz. & 100 & 1000 \\
\hline 1.35 & $\$ 10.00$ & $\$ 92.50$
\end{tabular}

First Size. 9 to I I in. " $\ldots .85 \quad 6.00 \quad 52.50$

Second " 7 to 9 in. " .. $50 \quad 3.50 \quad 30.00$

Third " 5 to 7 in. " .. $30 \quad 30 \quad 2.00 \quad 16.00$

\section{Callas}

Spotted Foliage. White flower........ $\$ 0.60 \quad \begin{array}{cc}100 \\ \$ 4.00\end{array}$

Black ....................... . $85 \quad 6.00$

Elliottiana. Yellow .......e each 20c. 2.00 I 5.00

\section{Cinnamon Vine}

Extra Strong Tubers. 40c. per doz.; per IOO, \$3.00.

\section{Cycas Revoluta}

Strong Healthy Stems. (Ready in March.) 25 lbs., $\$ 2.25 ; \$ 8.50$ per I00 lbs., 300 lbs. for $\$ 24.00$.

\section{Hyacinthus}

Candicans. White flowering; very desirable for planting in borders. Doz. 35c., \$2.50 per roo.

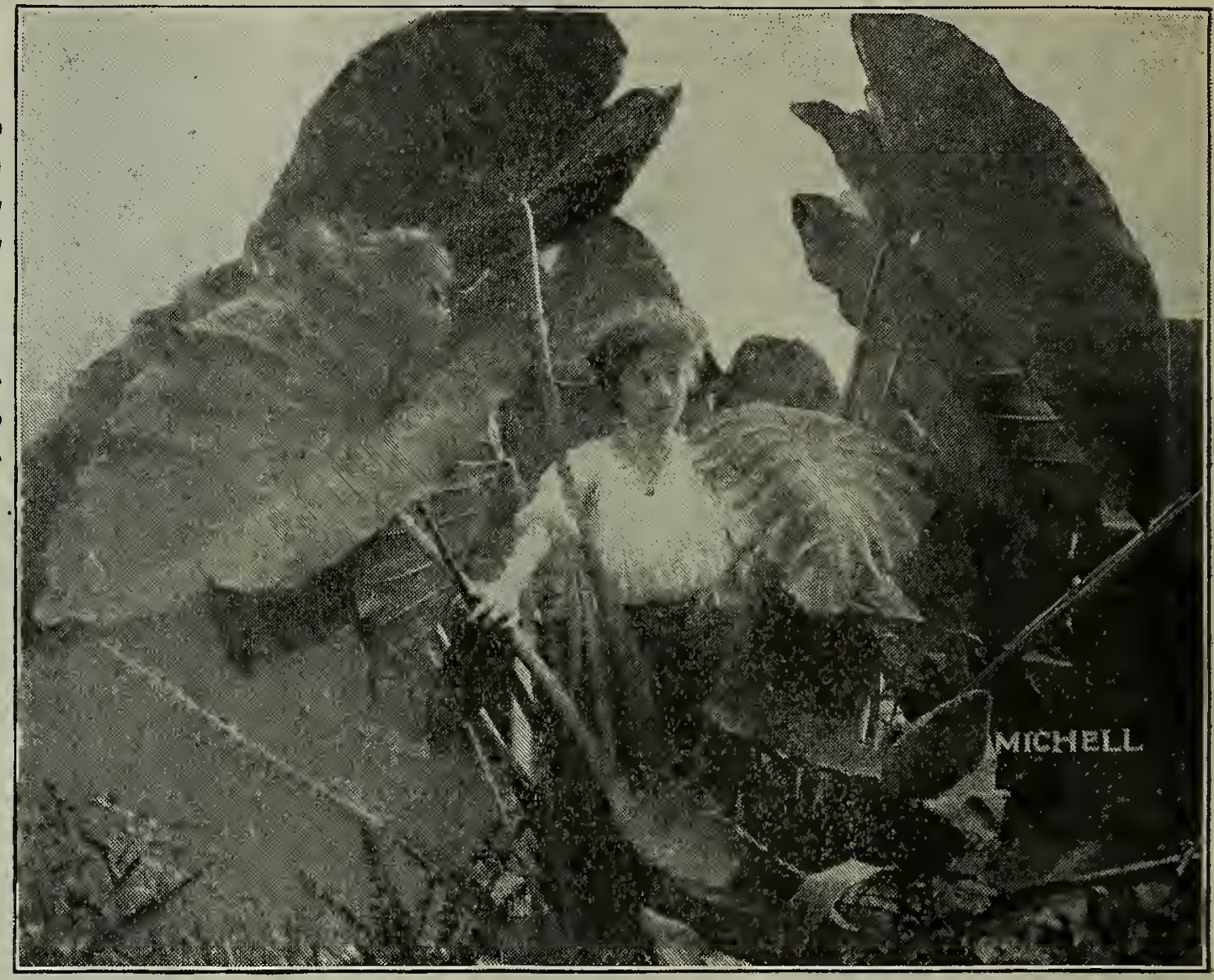

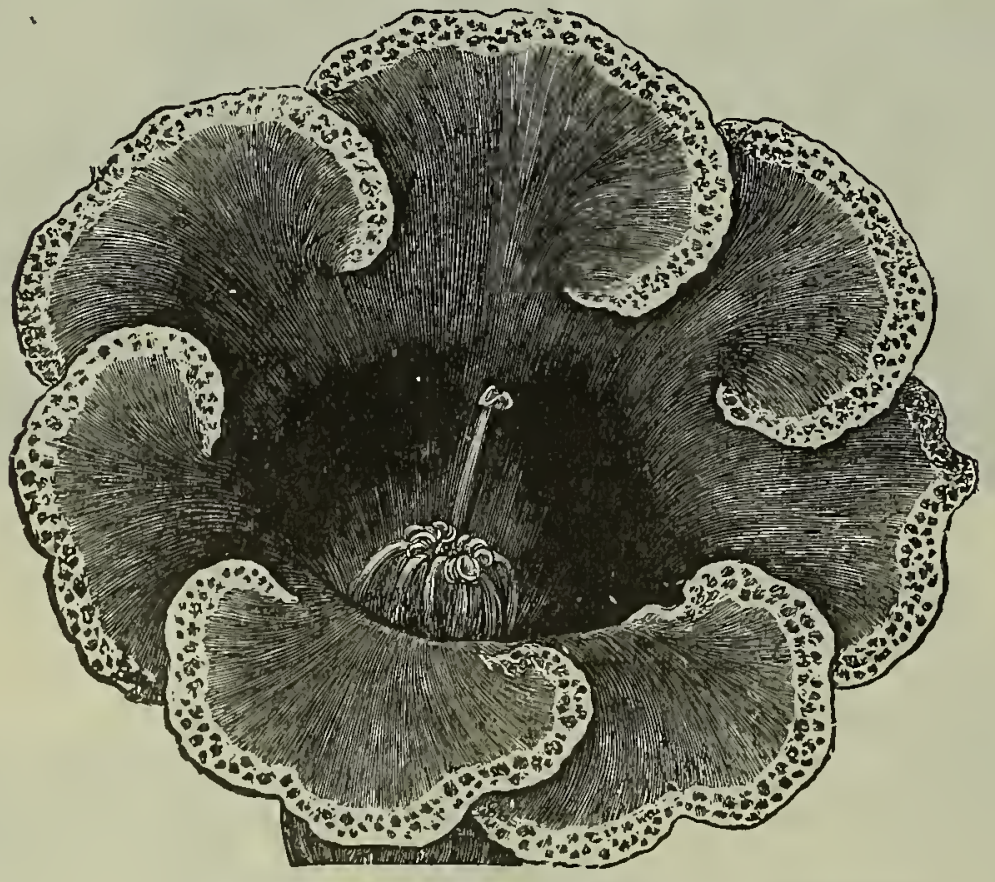

Gloxinias Bulbs Giant Flowering Strain

$\begin{array}{llll}\text { Doz. } & 100 & 1000\end{array}$

$\$ 0.60 \quad \$ 3.25 \quad \$ 30.00$

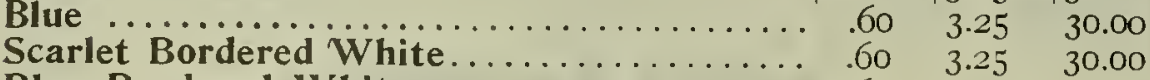

Blue Bordered White.................. .60 $3.25 \quad 30.00$

White Spotted Scarlet.................60 $3.25 \quad 30.00$

White ..........................6 .60 $3.25 \quad 30.00$

Choicest Mixed .....................50 $3.00 \quad 27.50$

Waterloo. Deep purple, bordered carmine... I.25 9.00

Meteor. Carmine, edged white............ I.25 9.00

Graf Zeppelin. Carmine, fringed......... I.25 9.00

Nixe. White, bordered blue............ I.00 7.50

Marienthaler Kind. Deep crimson, bordered

$1.00 \quad 7.50$

For full description of all bulbs and plants offered in this book, consult our Retail Catalog. Mailed free.

6 Bulbs of any one variety at dozen rates; 25 at 100 rates; 250 at 1000 rates.

\section{Ismene Calathina (Pancratium Lily)}

One of the choicest of our summer flowering bulbs, blooming profusely during the entire season, flowers a beautiful waxy white and deliciously fragrant. Bulbs are not hardy and should be removed to the house in October. These sell readily as a bulb or flower, and for summer funeral work are equal to lilies. Giant bulbs Ioc. each, per doz. 90c., $\$ 6.50$ per IOO (see opposite cut).

\section{Japanese Fern}

Balls (Dormant)

A very attractive novelty. Finds a ready sale when in foliage.

Large size. .

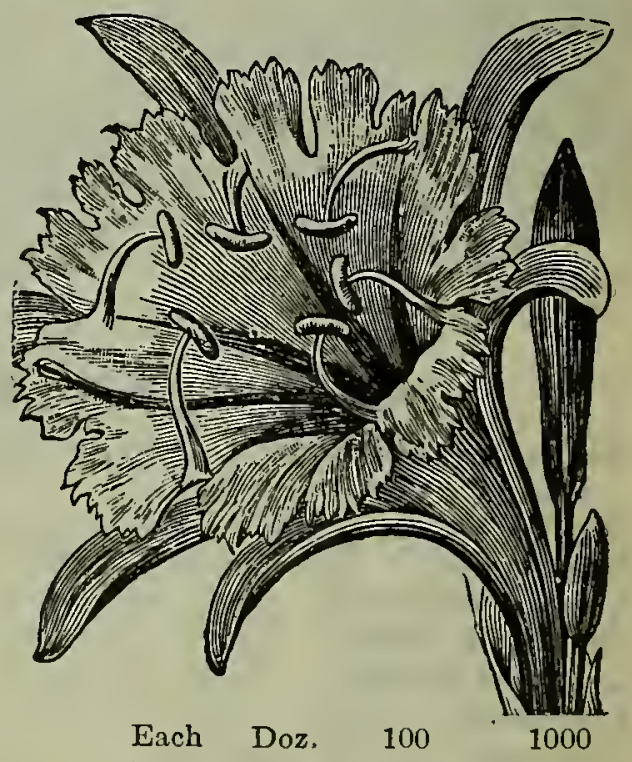

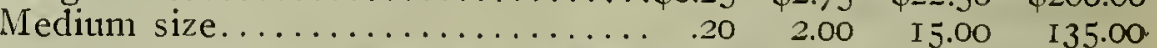

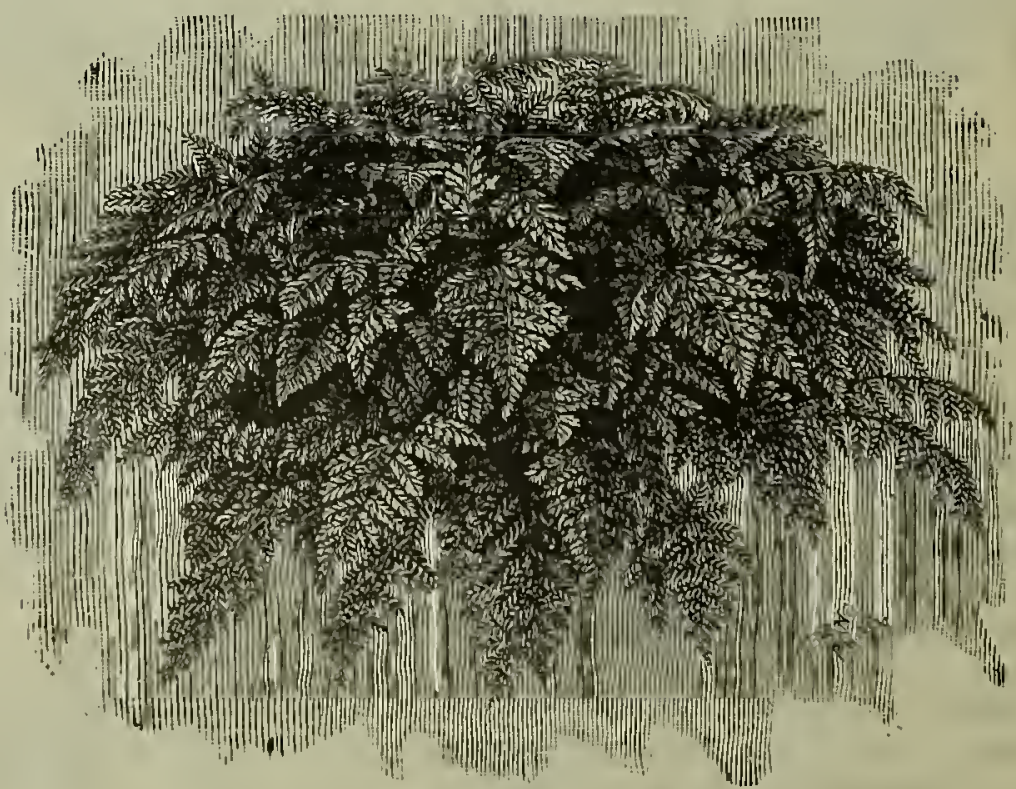

Japanese Fern Ball (in foliage) 


\section{Michell's Superb Dahlias (strong Roots)}

Our trade among Florists for high-class Dahlias for cut flowers has increased to such proportions that we made extensive preparations for further increase of business in this line. We send out only strong, field-grown roots, which will make heavy plants. If you require anything in this line, you will find our prices right for the quality supplied. We do not handle small divided roots, such as are usually handled in the mail order trade. As the season advances our stock of roots in certain varieties becomes exhausted. In such cases we will send out (unless instructed to the contrary) beginning in May, sturdy plants. These invariably give splendid satisfaction. These varieties have been selected from a long list, on account of their

being especially suitable for cut-flower purposes.

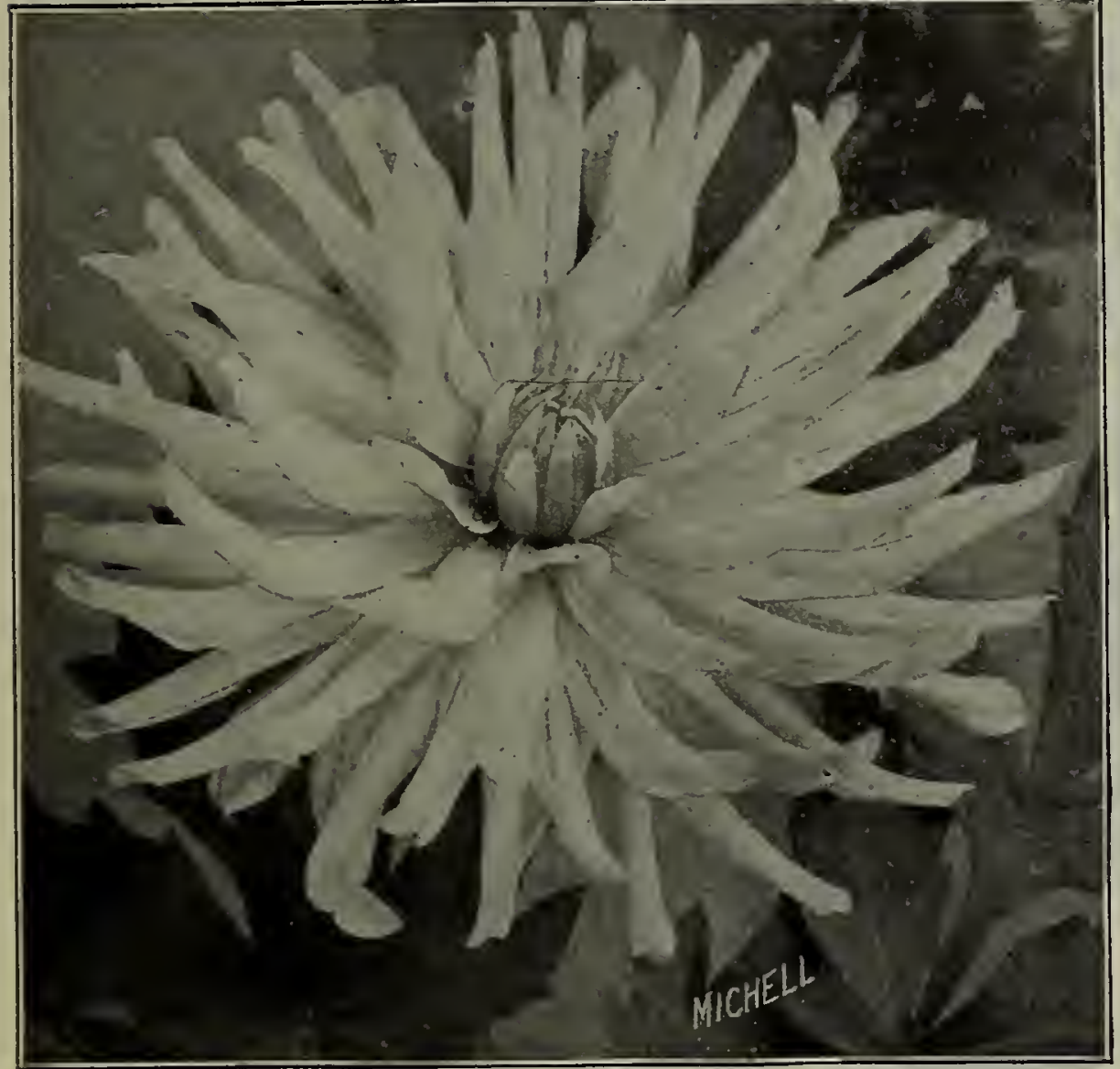

\section{Cactus Dahlia Pink Pearl CACTUS VARIETIES}

Alpha. White, spotted and flushed pink.....\$I.I5 Amos Perry. Rich bright scarlet.......... I.I5 Atlanta. Large, bright rich red........... I.I5 Britannia. Deep salmon.................. I.I5

Burbank. Brilliant dazzling scarlet......... I.I 5

Clara J. Stredwick. Salmon flush, shaded

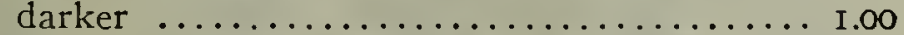

Cocatoo. Lemon yellow, shaded rose, with pure white centre petals; sometimes entirely yellow and white..................... I 5

Comet. Silvery rose, speckled and splashed

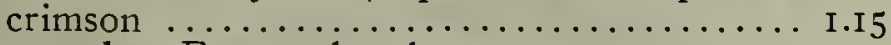
Comrade. Fawn colored................... I.00

Country Girl. Deep golden yellow, shaded sal-

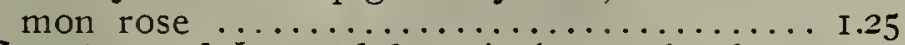

Countess of Lounsdale. Amber and salmon

pink ............................. I

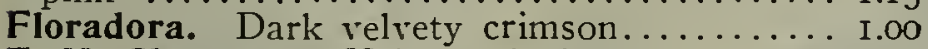
F. H. Chapman. Yellow, shaded deep orange I.I5 F. A. Wellesley. Bright crimson........... I.I5 Galliard. Scarlet crimson.................. I.oo General Buller. Velvety maroon tipped white I.Is H. F. Robertson. Pure deep yellow......... I.I5 Island Queen. Soft lavender pink........... I.oO J. B. Briant. Golden yellow, changing to

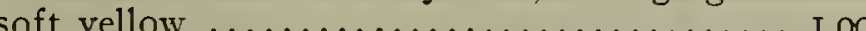

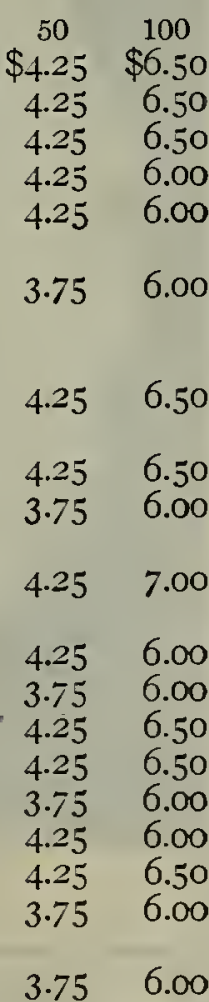

Special Note.-On account of the low prices we have made on Dahlias no order for less than 6 of a kind will be supplied at dozen rates quoted in this catalogue. Such orders will be priced from our retail list at a discount of $20 \%$ from retail prices; 25 Dahlias of a variety in this catalogue will be priced at the 50 rate, and not less than 100 of a kind will be supplied at the Ioo rate quoted in this catalogue; 75 will be priced at the pro rata rate for 50 .
J. H. Jackson. Deep rich maroon Doz. $50 \quad 100$

Keynes White. Fine pure white............ I.I5 $4.25 \quad 6.50$

Kriemhielde. Pink, white centre................ I. $4.25 \quad 6.50$

Leuchtfeuer. Bright blood red............. I.I5 4.256 .00

Libelle. A distinct shade of purple.......... I.35 $\quad 5.25 \quad 7.50$

Lovely. Violet rose, shaded white............... $2.00 \quad 6.25$ ro.oo

Mabel Tullock. Soft rosy pink............ I.00 3.756 .00

Mary Farnsworth. Pure yellow, tipped white I.I5 $4.25 \quad 6.00$

Mary Service. Yellow and salmon, suffused

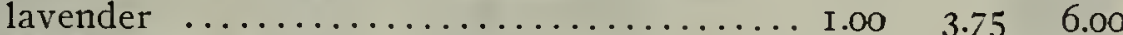

Master Carl. Bright amber................ $1.35 \quad 5.25 \quad 8.00$

Mrs. De Luca. Golden yellow, tipped orange I.I5 $4.25 \quad 6.50$

Mrs. Edward Mawley. Pale lemon yellow. I.I5 $4.25 \quad 6.00$

Mrs. H. J. Jones. Red, striped white........ I.25 $4.25 \quad 7.00$

Mrs. James P. Mace. Light pink............ 1.00 $3.75 \quad 6.00$

$\begin{array}{lllll}\text { Mrs. Freeman Thomas. Clear yellow, shaded } & & \\ & & & \end{array}$

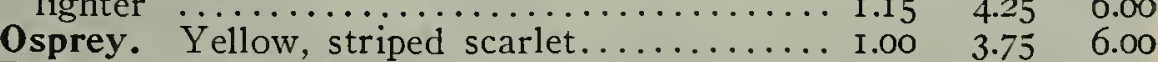

Prince of Yellows. Rich canary yellow........ $1.00 \quad 3.75 \quad 6.00$

Princess. Clear rose pink................ I.00 $3.75 \quad 6.00$

Queen Alexandra. Soft salmon, suffused pink $1.00 \quad 3.75 \quad 6.00$

Rene Cayeux. Rich blood red........... 2.75 I0.00 I6.50

Roland von Berlin. Bright scarlet......... I.25 $4.25 \quad 7.00$

Rosine. A pleasing shade of pink............. I.I5 $4.25 \quad 6.50$

Ruth Forbes. Clear pink............... I.35 $5.25 \quad 8.00$

Siegfried. Rich creamy white............ I.I5 $4.25 \quad 6.00$

Spotless Queen. Pure white................ I.I5 $4.25 \quad 6.00$

Standard Bearer. Bright scarlet.................. I.00 $3.75 \quad 6.00$

Strahlen Krone. Intense cardinal red........ I.I5 $4.25 \quad 6.00$

T. A. Havemeyer. Deep yellow, changing to

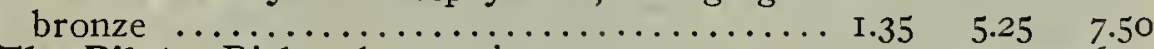

The Pilot. Rich velvety crimson............ I.00 $3.75 \quad 6.00$

Thuringia. Fiery red................... 1.00 $3.75 \quad 6.00$

Uncle Tom. Very dark maroon............. I.I5 4.256 .00

Victor v. Scheffel. Deep rose pink.......... I.I5 $4.25 \quad 6.00$

Volker. Clear canary yellow................ I.I5 $4.25 \quad 6.00$

Winsome. Clear ivory white............... $1.00 \quad 3.75 \quad 6.00$

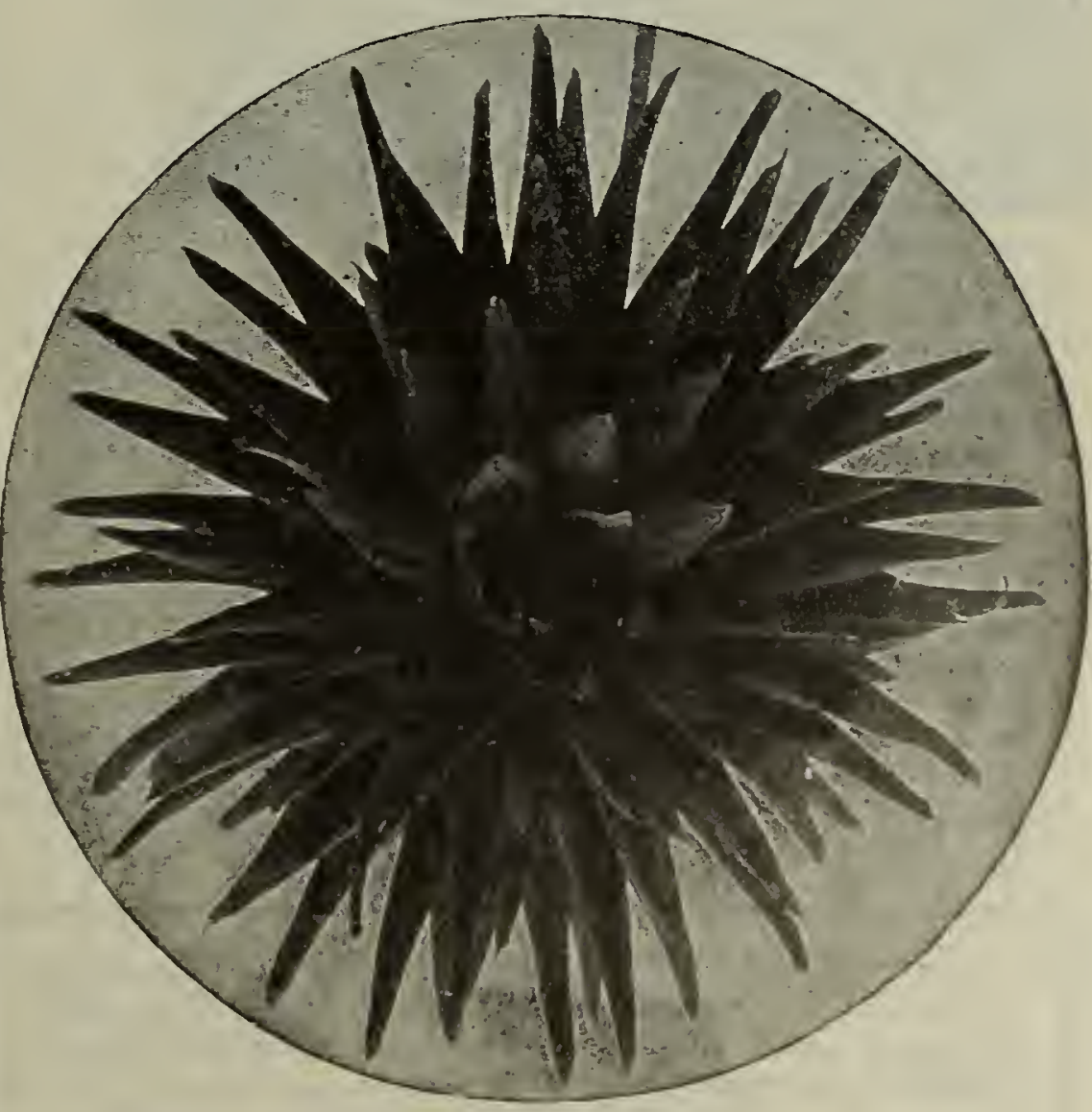

Cactus Dahlia J. H. Jackson 


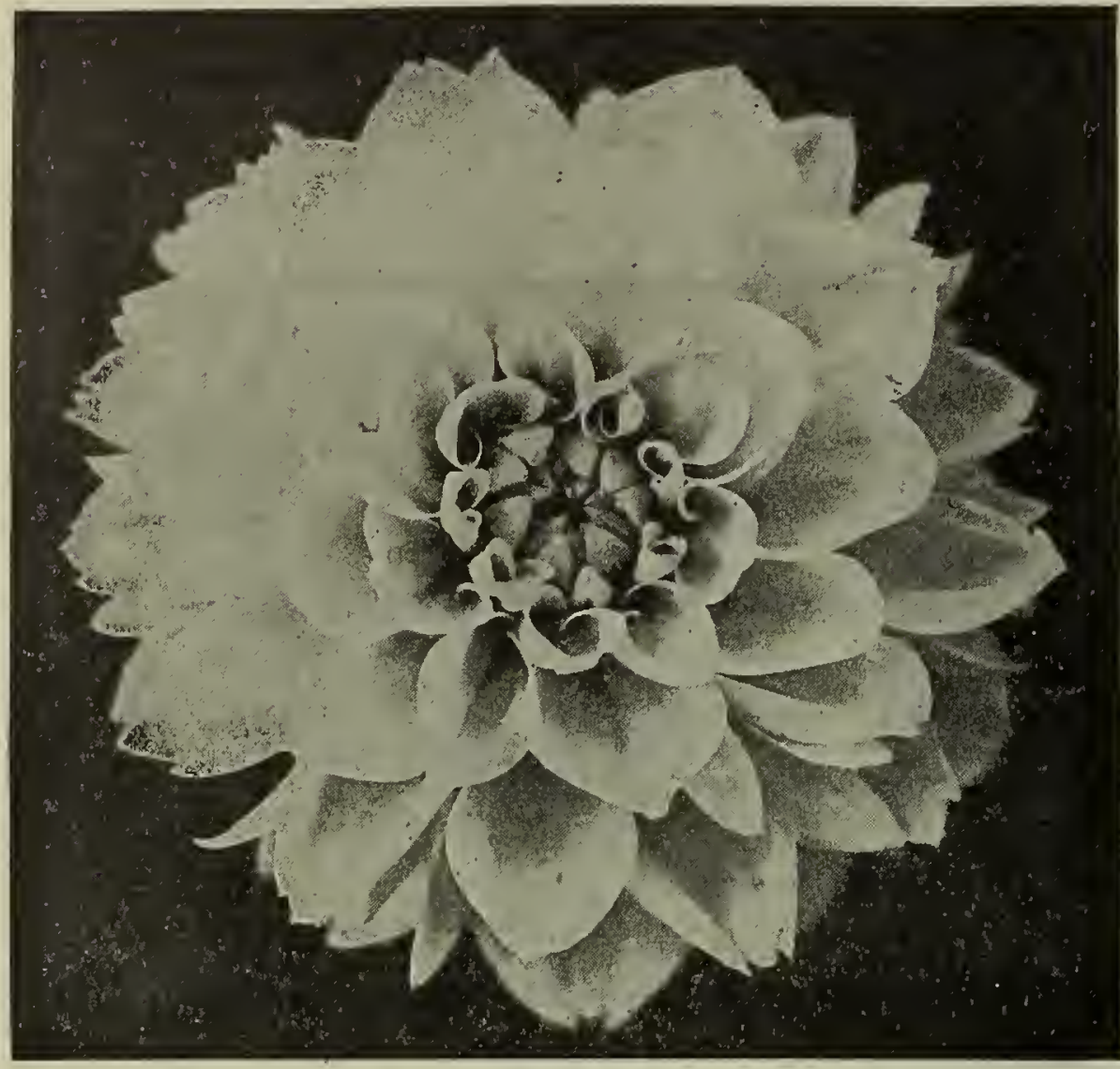

Show or Double Dahlia Dorothy Peacock

\section{Decorative Varieties}

Admiral Dewey. Brilliant purple.

Augusta Nonin. Clear scarlet. .

Beauty of Brentwood. Plum, striped maroon

Black Beauty. Dark velvety maroon......... I.IO

C. W. Bruton. Canary yellow............. I.IO

Catharine Duer. Crimson scarlet........... I.IO

Claribel. Bright purple.

Delice. Brilliant pink.

Denver. Yellow, shaded red.

Dr. Gates. Exquisite pink.

Eureka. Clear rose.

Flora. Pure white.

Frank L. Bassett. Bright purple.

Henry Patrick. Pure white...

Jack Rose. Rich crimson. .

Jumbo. Deep scarlet..

Kaiserin Augusta Victoria. Pure white...... . I.50

La France. Rose pink.................. I.IO

Lyndhurst. Bright scarlet............... I.IO

Mad. Van den Dael. Shell pink.

Maid of Kent. Red, tipped white.

Marchioness of Bute.

Miss Minnie McCullough. Yellow, shaded

bronze
Miss Nellie Stewart. White, shaded pink.............. IO

Mrs. Chas. Turner. Canary yellow......... I.IO

Mrs. Winters. Pure white.............. I.IO

Orange King. Rich orange.

Salmon Queen. Soft salmon.

Souvenir de Gustave Doazon. Red......... I.50

Sylvia. White, shaded pink.............. I.IO

Wm. Agnew. Scarlet................. I.IO

Yellow Colosse. Clear yellow................ I.50 5.25

Zulu. Maroon

I.10

$\begin{array}{rr}\$ 3.25 & 9.00 \\ 3.50 & 6.00\end{array}$

3.75

3.50

3.75

3.50

6.25

3.50
3.75

3.75

3.75

3.75
3.75

3.75
3.50

$3 \cdot 50$
4.50

4.50

3.75

3.75
5.00

3.50

3.50

3.50

3.75

3.75

3.50

3.50
3.50

3.50

5.25

3.75

3.50

$\begin{array}{ll}4.50 & 8.50\end{array}$

$\begin{array}{ll}5.25 & 9.00\end{array}$

3.50

(EXTRA STRONG ROOTS)

Order Dahlia Roots Early. Each season some customers are disappointed by not being able to get roots This is caused by waiting too long before placing their orders. Stock of some sorts is frequently exhausted as early as March. Orders for Dahlia roots received of a variety, which stock is exhausted, will be filled in strong, thrifty plants about May Ist, unless advised to the contrary. Dahlia plants give splendid satisfaction.

\section{Double or Show Varieties} Agent. Soft pink..................\$1.10 \$3.75 \$6.50

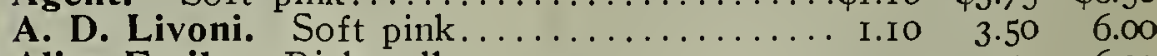
Alice Emily. Rich yellow............... I.Io $3.50 \quad 6.00$ Arabella. Pale primrose................ I.IO $3.50 \quad 6.00$ Beauty. Snow white.................... $3.50 \quad 6.00$ Camellia Alba. Dwarf, pure white......... I.Io 3.506 .50 Carol. White, tinted pink................ I.Io $3.75 \quad 6.50$ Chas. Lanier. Amber, shaded buff........... $2.00 \quad 6.25$ I I.00 Dorothy Peacock. Pink, white centre...... $2.75 \quad 8.75$ I5.00

Frank Smith. Purple and red............ I.75 $6.00 \quad$ I 2.00 Jamaica. Purple, shaded maroon.............. I.IO $3.50 \quad 6.00$ James Vick. Rich plum................. I.IO $3.75 \quad 6.50$ Lemon Beauty...................... I.IO $3.75 \quad 6.50$ Miss Dodd. Yellow.................... I.IO $3.50 \quad 6.00$ Mrs. Langtry. Cream, peach and purple...... I.IO $3.75 \quad 6.50$ Paul's Scarlet. Light scarlet.............. I.IO $3.50 \quad 6.00$ Queen of Yellows. Clear yellow............. I.IO $3.50 \quad 6.00$ Queen Victoria. Deep yellow............... I.Io $3.75 \quad 6.50$ Red Hussar. Scarlet crimson............. I.IO $3.50 \quad 6.00$ White Swan. Snow white............... I.Io $3.75 \quad 7.00$

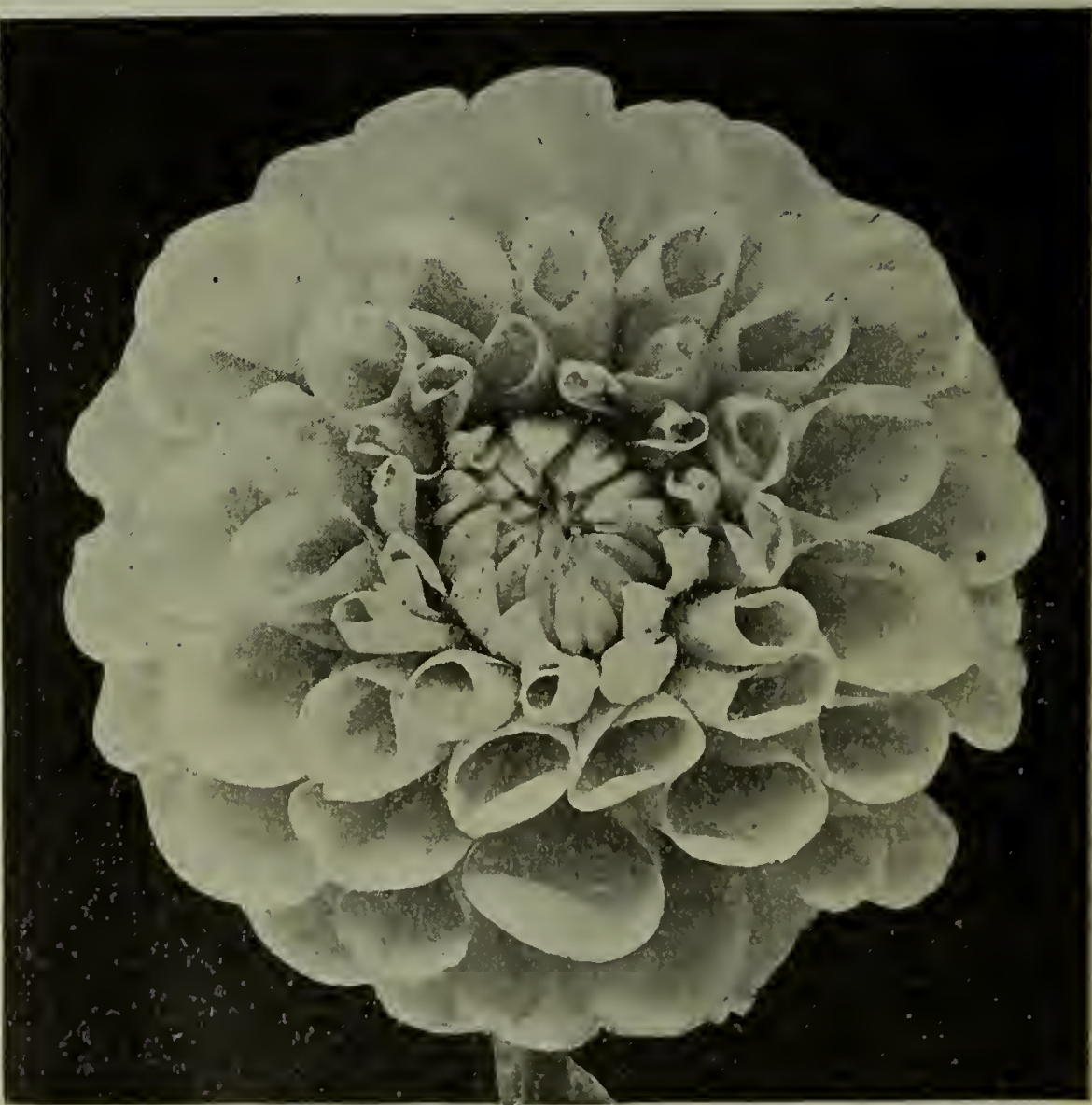

Show Dahlia Red Hussar

Special Note.-On account of the low prices we make on Dahlias, no orders for less than 6 of a kind will be supplied at dozen rates quoted in this catalogue. Such orders will be priced from our retail list at a discount of 20 per cent. from retail prices. 25 Dahlias of a variety in this catalogue will be priced at the 50 rate. Not less than I oo of a kind will be supplied at the IOo rate, quoted in this catalogue. 75 will be priced at the pro rata rate for 50 .
Our retail catalogue contains a long list of standard and newer Dahlias. A copy will be sent on request. Our special catalogue on Dahlias, Cannas and Gladiolus will also be found of interest. 


\section{Michell's Superb Dahlias for Florists (Extra Strong Roots)}

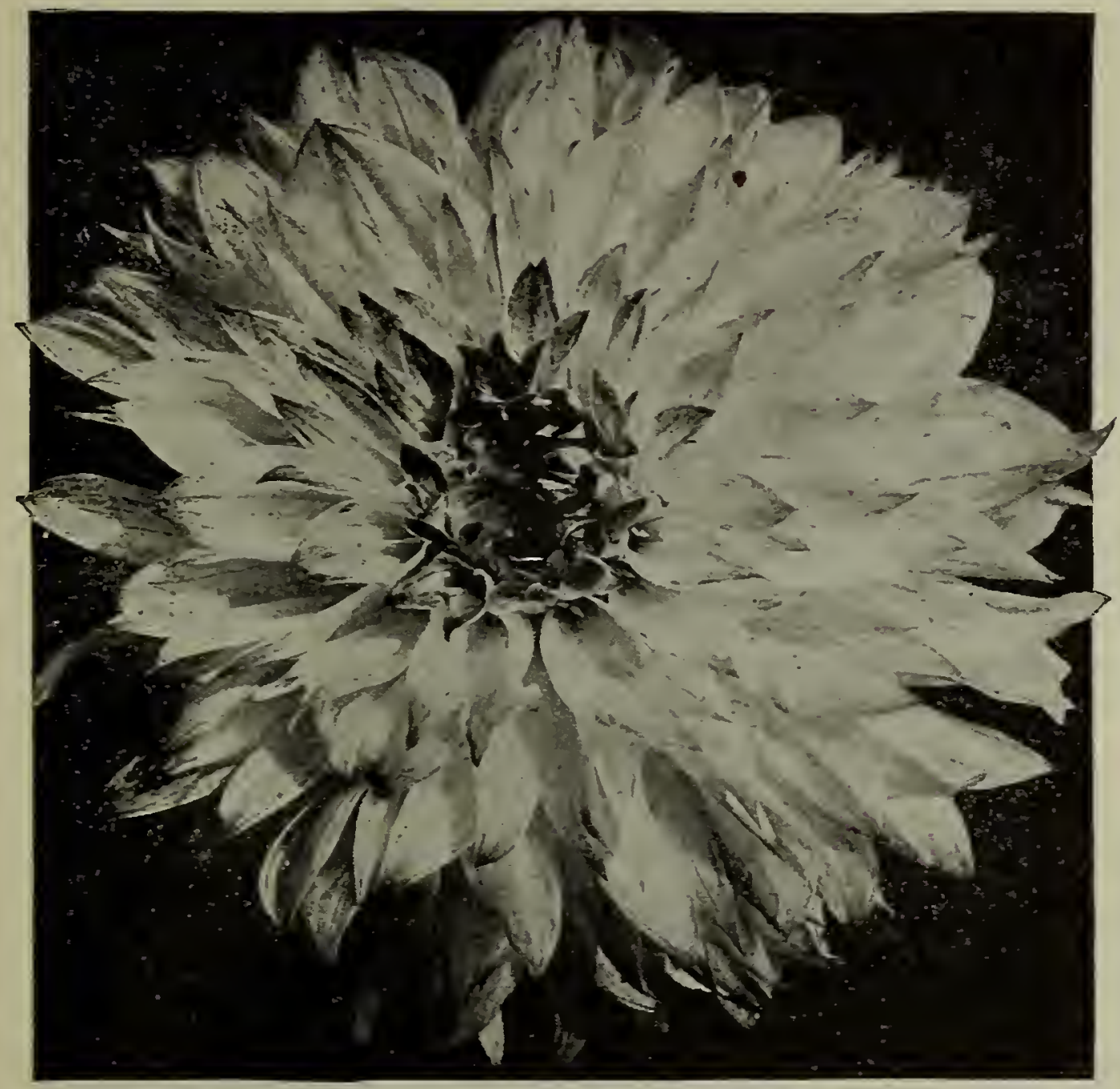

Dahlia Delice (See page 60)

\section{Paeony Flowered Dahlias}

Germania Doz. Herzog Heinrich. Beautiful light red.....................

King Leopold. Creamy white and yellow............. I.50

Paul Kruger. Striped, white and red.............. I.50

Queen Emma. Rich pink....................... I.Io

Queen Wilhelmina. Finest pure white.

\section{Fancy Dahlias}

Elois. Blush pink, shaded white................. Io

Frank Goodman. Rich purple, tipped white........... I.Io

Keystone. Pink, striped crimson................. 1.io

Lucy Fawcett. Yellow, spotted rose............. I.50

Mrs. Stancombe. Light yellow, suffused amber....... I.10 3.50

Progress. Soft rose, spotted crimson.................

Penelope. White, flaked lavender................... I. 3.75

Uncertainty. Varies from white, marbled blush and

\section{Single and Century Dahlias}

\section{Amy Barrilet. Rich garnet.......................}

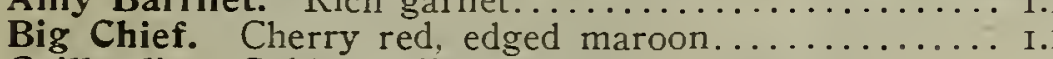

Gaillardia. Golden yellow..................... I.Io

Gorgeous. Fiery scarlet............................ I.

Jack. Brilliant scarlet......................

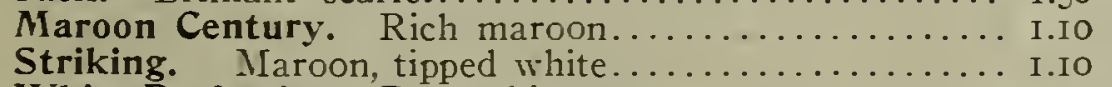

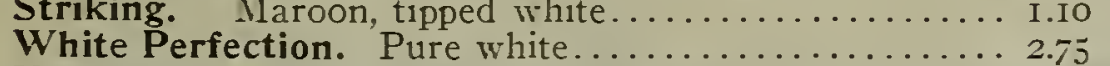

Yellow Century. Buttercup yellow................... I.Io

Twentieth Century, Rosy crimson and white........ I.00
Variegated Liszt. Dark red, shaded bronze........ I.Io

$3.75 \quad 7.00$

\section{Pompon Dahlias}

Alewine. White, Doz. $50 \quad 100$

Allie Maurey. Light pink, tipped-

deeper pink ................ I.IO $3.75 \quad 7.00$

Fairy Queen. Sulphur yellow, edged

peach .................... 1.10 $3.75 \quad 7.00$

Indian Chief. Crimson........... I.Io $3.75 \quad 7.00$

La Petite Jean. Rich crimson..... I.IO $3.75 \quad 7.00$

Philip Freud. Orange salmon...... I.IO $3.75 \quad 7.00$

Snowclad. Pure white............ 1.10 3.75 7.00

Splendens Imbricata. Bright red... I.IO $3.75 \quad 7.00$

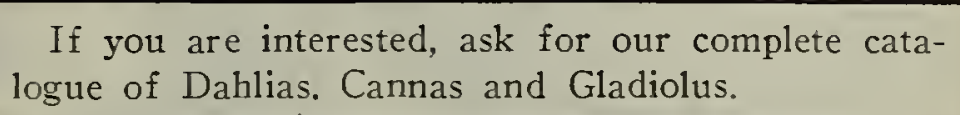

logue of Dahlias. Cannas and Gladiolus.

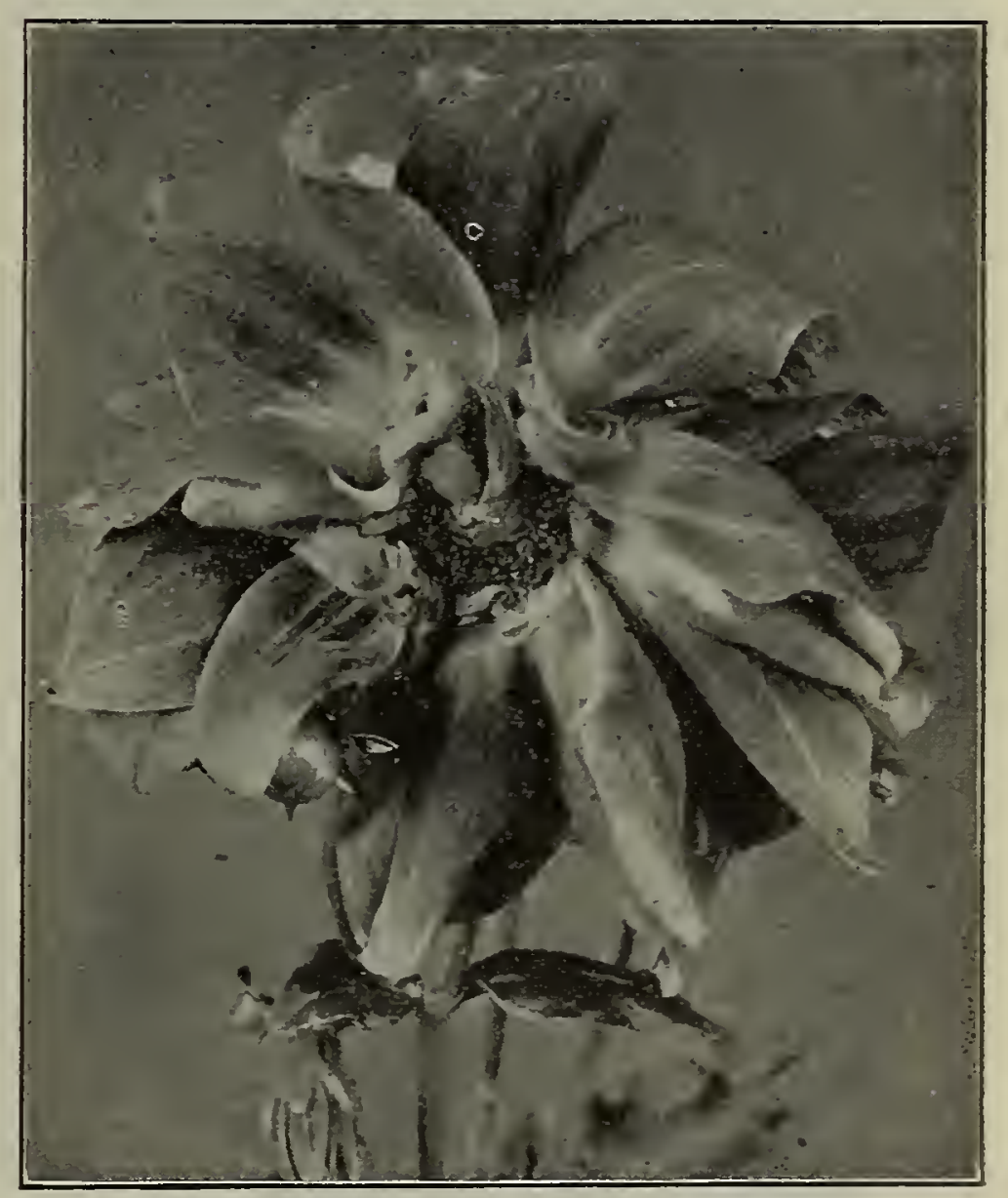

Paeony Flowered Dahlia

\section{Dahlias}

Mixed and to Color (Our Selection)

SPECIAL NOTE. On account of the low prices we made on Dahlias, no orders for less than 6 of a kind will be supplied at the dozen rates quoted in this catalogue. Such orders will be priced from our retail list at a discount of 20 per cent. from retail prices. 25 Dahlias of a variety in this catalogue will be priced at the 50 rate. Not less than 1000 of a kind will be supplied at the 100 rate, quoted in this catalogue. 75 will be priced at the pro rata rate for 50.

\section{Dahlia and Vegetable Exhibit}

On September 24, 25, 26 and 27, I9I4, we will hold our Sixth Annual Exhibition. This is an interesting
event in Philadelphia. 


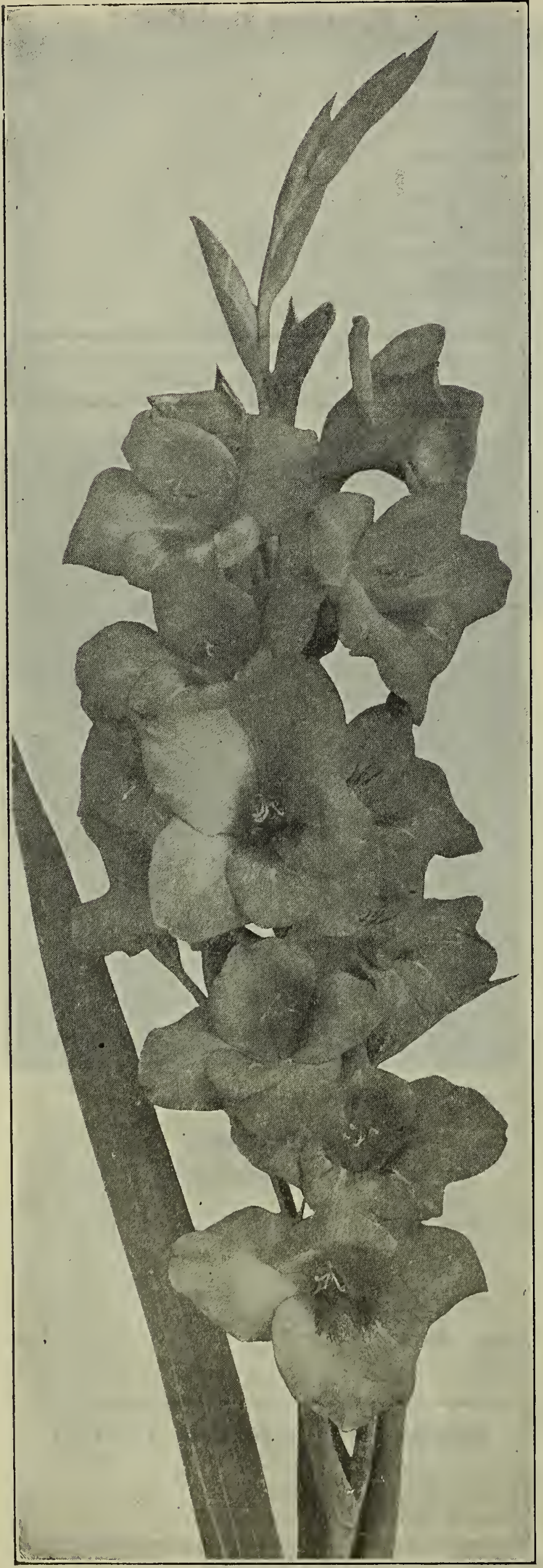

Gladiolus Mrs. Francis Kitug

\section{MICHELL'S GLADIOLUS}

The gladiolus to-day occupies just as important a place among cut flowers to be grown by florists as the Chrysanthemum or Sweet Pea. Its constantly increasing popularity with the general public is productive of a greater demand for forced flowers in the early spring, and the progressive florist of to-day cannot afford to let sales slip by. When they are forced during the winter and early spring months blooming from April till June, $\$ 2.00$ a dozen spikes is often paid for them wholesale, and what can you grow that will earn you more net profit. Some of the largest growers plant them between carnations and thus get a double crop out of the house, the carnation temperature being just right for the gladiolus. Not all varieties are suitable for forcing, but what we offer on this page have been successfully forced and are especially recommended.

To grow them successfully under glass, the following should be observed: From January on they should be planted in successive batches; to extend the flowering season for a long period. For early forcing avoid high temperatures, $50^{\circ}$ at night and $60^{\circ}$ during the day will give good results. It requires at least 12 weeks to bring them into bloom. After April Ist start some bulbs in the greenhouse in flats planted closely and cover them with sand. When roots are about an inch long, plant them in a cold-frame. This method will bring flowers fully one month ahead of outdoor planted stock. Keep gladioli bulbs near the surface; feed by mulching the ground with manure and water liberally when dry. Gladiolus should be staked to prevent them falling. They delight in moisture when well advanced in growth, but too much of it in the early stages may mean failure.

\section{SPECIAL FORCING VARIETIES ALSO SUITABLE FOR OUTDOOR PLANTING}

Pink Augusta (Novelty 1912.) Every grower knows that the White Augusta to-day is the ideal florist gladioli on account of its splendid habits. As a companion we have secured this very fine novelty, a lovely soft pink which we know will become, in a short time, as popular. We recommend it highly and want every florist to try it. Doz. 40c., \$2.75 per I00, per $1000 \$ 22.00$.

Rochester White. One of the finest white varieties, being absolutely pure without marking of any other shade. The spike is erect and completely covered by the gigantic open flowers. 6oc. each, doz. $\$ 6.00$.

Kunderdi Glory. Introduced by us in I9II. This variety received not less than Io distinct awards during the past season in Europe and America. The ruffled petals give this flower an original appearance and everyone who has seen it is delighted therewith. Color, cream pink with a faint blood-red stripe through the throat; splendid forcer; very healthy and robust. Doz. 80c., \$5.50 per I00, per I000 \$52.50.

America. The finest of all gladiolus; delicate pink, robust straight stem and giant flowers of delicate texture; forces readily and sells at sight; Extra Selected Bulbs. 30c. per doz., per I00 $\$ 2.00$, $\$ 17.00$ per 1000 . First Size Bulbs. 25c. per doz., per $100 \$ 1.80$, $\$ 16.00$ per 1000.

Augusta. A pure white flower, slightly pencilled in throat; all flowers open at one time. Straight spike, 3 feet, covered with flowers; one of the most popular sorts. 35c. doz., per $100 \$ 2.25$, \$20.00 per 1000.

May. White, pencilled crimson, one of the old standbys; compact, wellformed spikes, forces easily and always sells. 40c. doz., per Ioo $\$ 2.25$, $\$ 20.00$ per IO00.

Brenchleyensis. Bright, brilliant scarlet; straight stem, showing all flowers at one time; a showy glorious bright flower with all good qualities combined; easy forcer, 20c. doz., per I00 \$1.25, \$12.00 per I000.

Shakespeare. White flaked carmine, striped pink. For many years this has been the leading forcing gladiolus and is grown in enormous quantities to-day. 80c. doz., per I00 $\$ 5.50, \$ 50.00$ per I000.

Mrs. Francis King. Gigantic spikes often $4^{\mathrm{T}} / 2$ feet high, well arranged with enormous flowers of the most brilliant soft scarlet. A splendid forcer and a color that sells readily. Doz. 40c., \$2.25 per Ioo, per IOOO \$I7.50.

Wm. Falconer. The most pleasing shade of light pink, flowers are very cpen, extremely large with many of them showing at one time. Doz. 75c., $\$ 6.00$ per I00, $\$ 50.00$ per I000. 


\section{MICHELL'S GLADIOLUS, Ete. Large Heavy Blooming Size Bulbs}

Named Varieties (Continued)

Attraction. Enormous flower, deep rich crimson with which blotch in throat. Doz. 50c., $\$ 3.50$ per I00, $\$ 32.50$ per I000.

Baron Hulot. Rich deep indigo blue, the only true blue variety. Doz. 75c., $\$ 4.50$ per I00, \$38.00 per I000.

Canary Bird. Soft light yellow, giant flowers. Doz. 75c., $\$ 5.50$ per I00, $\$ 50.00$ per I000. Cardinal. Intense cardinal red; spike and flower perfect. Doz. $\$ 1.25, \$ 8.50$ per IOO, $\$ 82.50$ per I000.

Contrast. Color intense scarlet with distinct pure white centre. Doz. \$3.50, \$25.00 per 100.

Dawn (Groff's). Peachblow pink, gigantic flowers. Doz. $\$ 6.00, \$ 45.00$ per Ioo.

Eugene Scribe. Beautiful tender rose, shaded deeper. Doz. 6oc., $\$ 4.50$ per IOo, $\$ 42.50$ per Iooo.

Europe $(N e w)$. Gigantic flowers of purest white without a trace of any other color Spike averages 25 blossoms. It has received highest awards at every exhibition where shown. $\$ 6.00$ doz., per Ioo $\$ 45.00$.

Geo. Paul. Rich crimson, heavy bloomer. Doz. 70c., $\$ 4.50$ per Ioo, $\$ 42.50$ per I000.

I. S. Hendrickson. Mottling of pink and white. Doz. 70c., $\$ 5.00$ per I00, per I000 $\$ 45.00$.

Jean Dieulafoy. Cream white, red blotched. Doz. $\$ 1.25$, $\$ 8.00$ per I00, $\$ 75.00$ per I000.

Kate. Blush white, crimson throat. Doz. 50c., $\$ 3.75$ per Ioo, per Iooo $\$ 33.50$.

Klondyke. Primrose, blotched crimson in throat. Doz. 50c., $\$ 3.00$ per I00, $\$ 26.00$ per Iooo.

La Luna (Groff's). Primrose yellow, shaded cream white. Doz. \$4.50, \$35.00 per I00

Lemon Drop. Light yellow, with a bright yellow throat. 7oc. per doz., per Ioo $\$ 5.00$, $\$ 45.00$ per 1000

Mephistopheles. Bright red, marked yellow. Doz. $\$ 1.00, \$ 7.00$ per I00, per I000 $\$ 65.00$.

Mrs. Frank Pendleton, Jr. Without a doubt this is the finest of the bright colored gladiolus. The flower resembles a gigantic gloxinia and makes a show hard to describe. A rich, delicate salmon pink, blotched rich maroon. \$4.oo doz. per $100 \$ 27.50$.

Nezinscott. Bright blood red with velvety blotches, mottled white. $75 \mathrm{c}$. per doz., per I00 \$5.50, \$50.00 per I000.

Niagara (New). A shade of rich cream combined with canary yellow. The form and habit of this variety is exactly like America, except that the spike grows taller. Doz. \$2.00, \$1 5.00 per I00.

Panama $(N e w)$. Fully equal of America and superseding it in color, which is more on the order of salmon pink. 40c. each, doz. $\$ 3.75, \$ 27.50$ per Ioo.

Peace $(N e w)$. A grand pure white flower with just a slight marking of a lilac feather on the lower petal. The plant is very robust, 5 feet high and shows the enormous flowers well placed all along the stem. "Peace" flowers mid-season and late, when the best of other gladiolus are gone. Doz. \$1.50, $\$$ Io.00 per Ioo, \$90.00 per I000.

Primulinus. Canary yellow, very distinct. Doz. \$1.5o, \$10.00 per Ioo.

Primulinus Major Hybrids. Various shades of yellow. Doz. 85 c., $\$ 6.00$ per 100.

Princeps. A giant gladiolus, dazzling scarlet. Doz. 70c., $\$ 5.00$ per IO0, \$45.00 per I000.

Rosella. Delicate pink, white throat. Doz. 85c., $\$ 6.00$ per 100 $\$ 5 \% .50$ per I000.

Scarsdale. Lavender, very fine. 85c. per doz., $\$ 6.00$ per Ioo, $\$ 50.00$ per 1000 .

Scribe. Large spike, enormous flower, rose flaked carmine tinted white. 75c. per doz., per I00 $\$ 5.00, \$ 45.00$ per I 1000.

Sulphur King. Exquisite sulphur yellow. Doz. \$I.75, \$12.50 per Ioo.

Sunlight. Crimson with canary yellow throat. Doz. $60 \mathrm{c}$., $\$ 3.50$ per I00, \$32.50 per I000.

Taconic. Pink, flecked and striped crimson. Doz. 8oc., $\$ 6.00$ per I oo, $\$ 52.50$ per I000.

Victory. Sulphur yellow, blotched maroon. Doz. $80 c$., $\$ 5.00$ per I00, $\$ 47.50$ per I000.

Wild Rose. Delicate pink. Doz. \$1.00, $\$ 7.00$ per I00, $\$ 65.00$ per I000.

\section{UNNAMED GLADIOLUS (Separate CoIors)}

Pink and Rose.......................... $100 \quad 1000$

Pink and Rose..................... \$0.25 \$I.75 \$I4.00

Scarlet and Crimson....................20 I.35 I 2.50

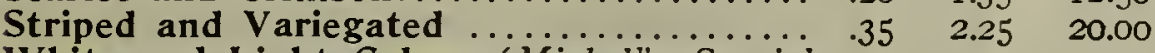

White and Light Colors "Michell's Special

Florists' Mixture). This mixture is blended

under our own supervision...............35 $2.50 \quad 20.00$

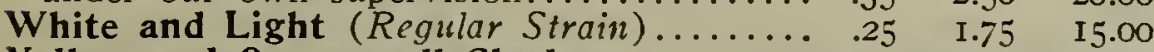

Yellow and Orange, all Shades............. 50 .50 $3.75 \quad 35.00$

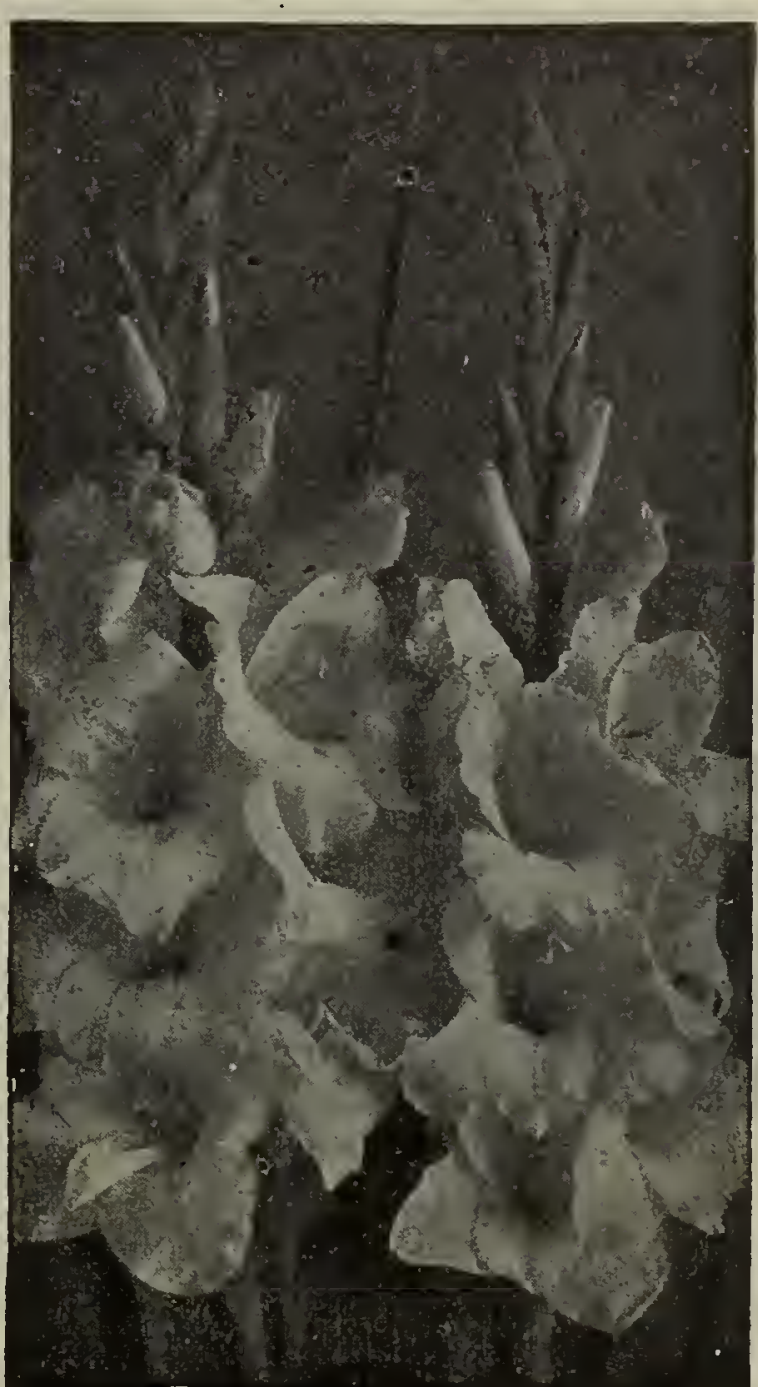

Gladiolus America (See opposite page) 


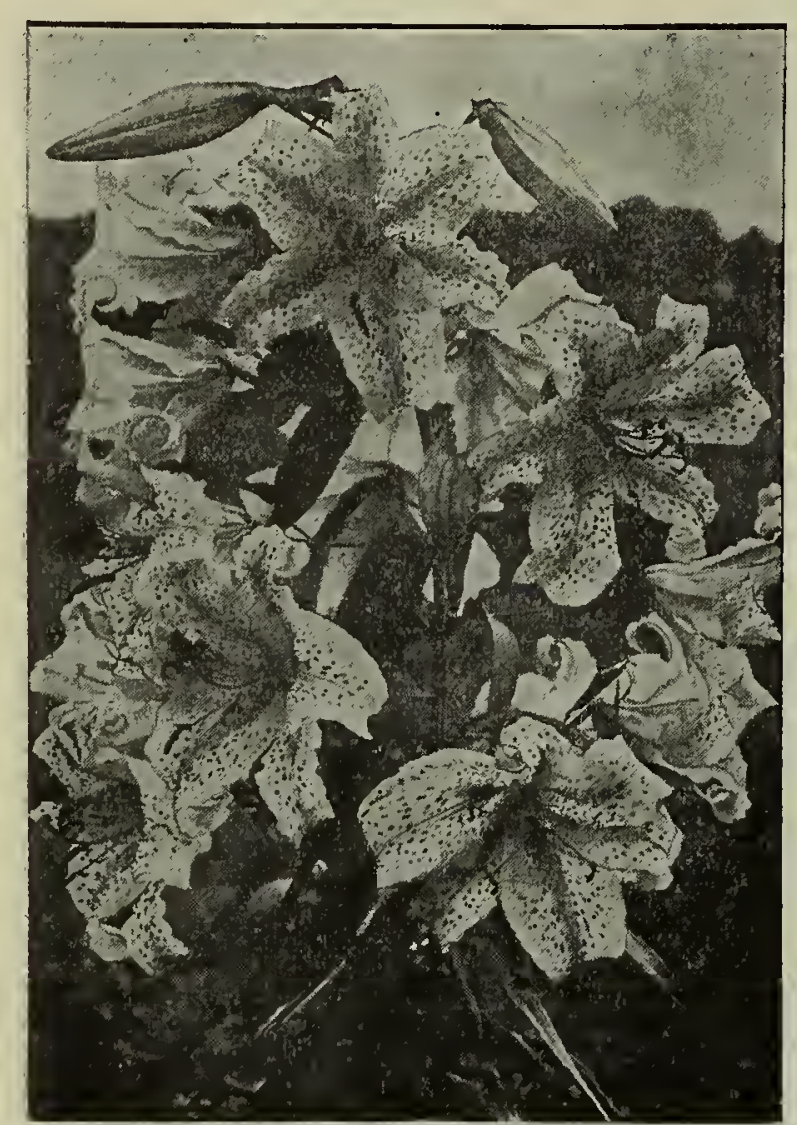

Lil. Auratum

\section{Hardy Lilies}

Hardy Lilies are now planted by many florists. They bloom outdoors in July and August and are extremely useful for decorative purposes. The Auratum, Album and Rubrum are excellent for forcing. JAPANESE VARIETIES

Auratum (Golden Banded Lily). Enormous flowers, pure white ground

brown with yellow striped petals. Bulbs
Per Case Doz. $100 \quad 1000$

8 to 9 inches..... $225 \$ 0.90 \$ 5.50 \$ 50.00$ 9 to II inches..... Album (Præcox). Pure white.

8 to 9 Doz. $100 \quad 1000$ 9 to II inches..... 125 I.75 12.50 I 20.00 Magnificum. Deep pink, spotted crimson. 8 to 9 inches.... $225 \begin{array}{rrrr}\text { Doz. } & 100 & 1000 \\ .80 & 5.50 & 50.00\end{array}$ 9 to I I inches..... I25 I.25 $8.25 \quad 77.50$ Melpomene. Deep pink, spotted dark red. $\begin{array}{lllllll}8 \text { to } 9 \text { inches..... } 225 & 225 & 5.50 & 50.00\end{array}$ 9 to II inches..... I25 $\quad$ I.35 $8.50 \quad 80.00$ Rubrum or Roseum. Beautiful pink, spotted crimson. Doz. $100 \quad 1000$ 8 to 9 inches..... $225 \quad .80 \quad 5.50 \quad 50.00$ 9 to 1 I inches..... I25 $\quad$ I.35 $\quad 8.25 \quad 77.50$ LILIUM TIGRINUM (Tiger Lily) Orange, spotted brown.

\begin{tabular}{cc} 
Doz. $100 \quad 1000$ \\
\hline
\end{tabular} Double (Imported bulbs) $1.00 \quad 6.00 \quad 55.00$ NATIVE LILIES Doz

Canadense. Bright yellow .....\$0.75 \$5.25 Canadense Rubrum. Crimson,

spotted black ............. I.35 I0.50 Elegans Painted Chief. Bright Elegans Leonard Joerg. Apricot pink ............... $1.25 \quad 9.00$ Hansoni. Reddish orange..... $3.75 \quad 30.00$ Variegated Le a v e d. Doz. $100 \quad 1000$ Henryi. Orange yellow...... $6.00 \quad 45.00$ Double white $\ldots . \ldots . \$ 0.25 \quad \$ 1.50 \quad \$ 12.00$ Superbum. Orange red..... $.85 \quad 5.50$ Albino. Single white....25 I.50 I 2.00 Tenuifolium. Brilliant scarlet. I.00 7.00 When ordering Tuberoses please state Umbellatum. Orange scarlet.. .856 .00 when shipment is desired. on long spikes, when properly grown.

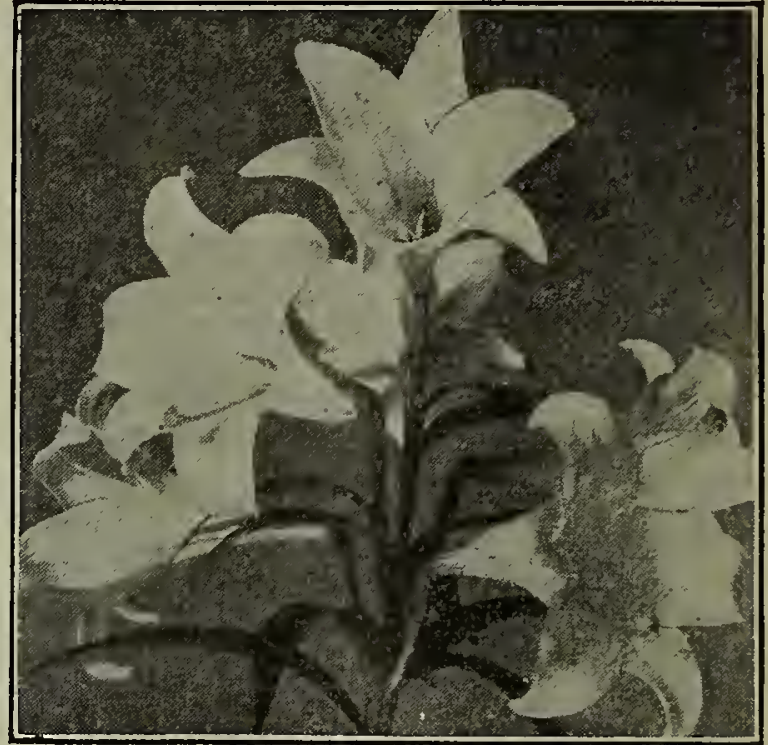

\section{Cold Storage Lilies}

For forcing in all seasons, they bloom in I 2 to 14 weeks. Every progressive florist should, from time to time, force a batch of these, as they are money-makers.

Important Note.-Always unpack immediately all cold storage Lilies on arrival. We forward these bulbs by express; if desired by freight, they travel at purchaser's risk.

invariably produces I 5 or more large bells

Delivery January to June 3oth

Per I00......\$2.50 | Per I000..... \$17.50 Per 250..... 4.75 Per 2000..... 34.00 Delivery July Ist to December 3Ist

Per I00......\$2.75 | Per 1000......\$18.00 Per 250.... 5.00 Per 2000..... 35.00

\section{LILY OF THE VALLEY CLUMPS}

For outside planting, stock is usually exhausted after May I5th. \$2.00 per doz., per I 00 \$15.00, \$140.00 per I000.

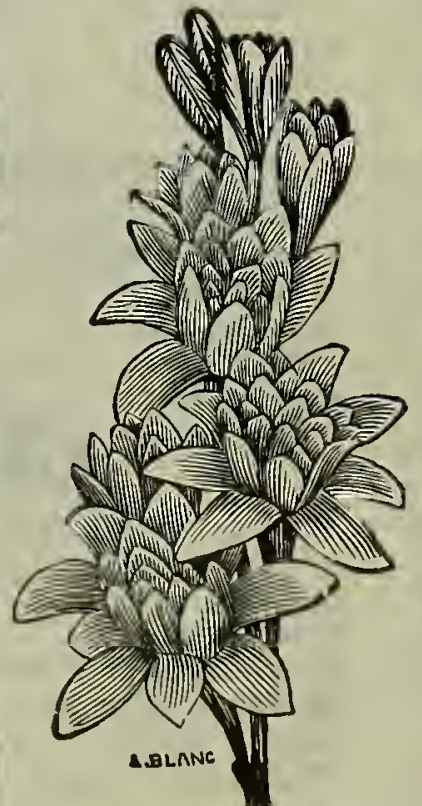

Tuberoses

Our $\mathrm{T}$ uberose bulbs are all hand selected and may be depended upon to bloom.

Mammoth Pearl. Double pure white. First size bulbs, doz. 20c., \$1.00 per I00, $\$ 9.00$ p e r IOOO.

$\mathrm{r}$

Strong Roots or Tubers $\$ 0.30 \$ 2.00 \$ I 7.50$

\section{Oxalis (Summer Flowering)}

Deppi. White .........\$O.I0 $\$ 0.75 \$ 6.00$ Lasiandra. Pink ...... . I0 $75 \quad 6.00$

ZEPHYRANTHES (See Amaryllis (Page 56) 


\section{New Carnations, Chrysanthemums and Roses}

A very large grower in Connecticut has undertaken to grow most all of the stock offered on this page. His reputation has no equal in the United States for quality. All shipments are made direct from his establishment under our name, so to insure receiving them promptly and in first-class condition. This class of stock is shipped by express only. It is all offered subject to being unsold when your order is received. 6 of a variety at dozen rate, 25 at 100 rate, 250 at 1000 rate.

\section{Carnations}

(Strong Rooted Cuttings, ready after January 1st)

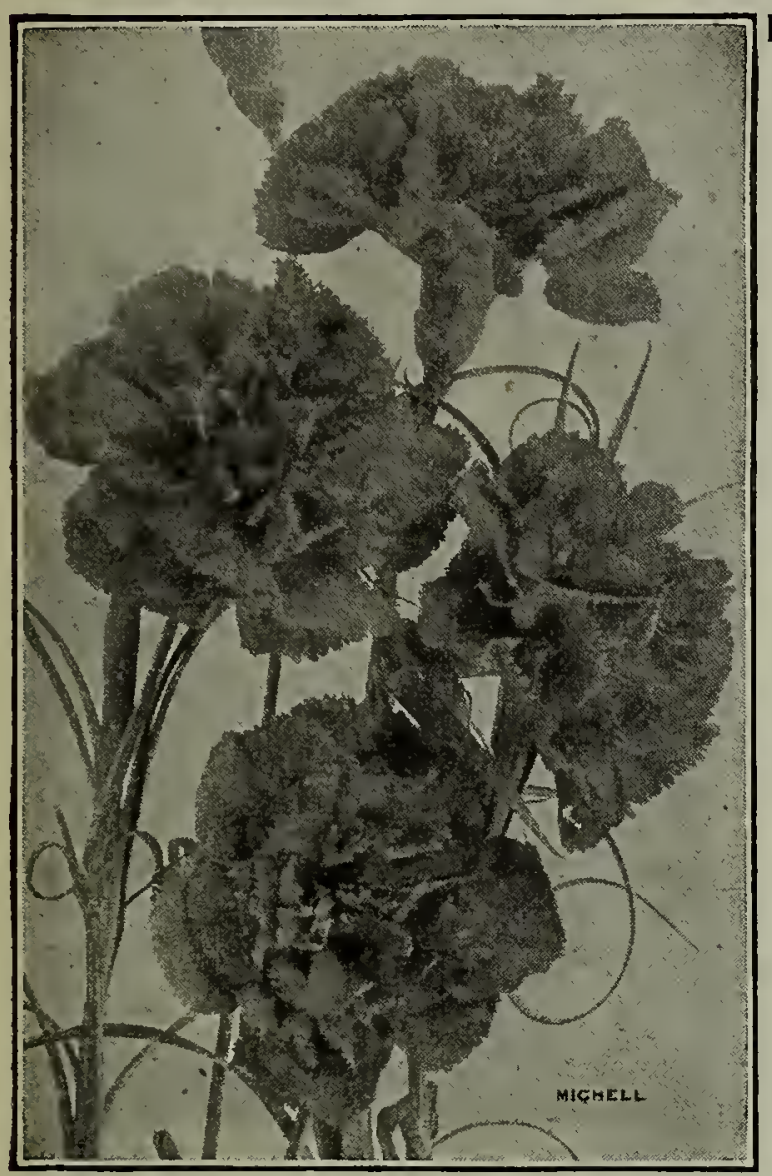

Carnation Gorgeous

Philadelphia. $T$ h is variety, named after our home city, originated in Detroit. It is a cross between Beacon and Winona, combining all the good qualities of both and yet excels each of them. The color is a true rose pink, a shade which shows up wonderfully well under artificial light. The flowers average $3^{1 / 2}$ to 4 inches in $\mathrm{di}$ ameter. It is the stiffest and longest stemmed variety in existence to-day. It is absolutely nonsplitting and of an exceptionally strong constitution, of wonderful root action, which means vigor and an ability to produce, and of continuous flowering habit. Our orders are filled by the originator, whose prices we quote, so in buying from us you are procuring your stock from first hands. Strong, vigorous-rooted cuttings, ready after January Ist. $\$ 2.00$ per doz., 25 for $\$ 3.50$, \$12.00 per Ioo, $\$ 100.00$ per 1000.250 at I000 rate. Doz.

Princess Dagmar. Rich dark crimson. $\$ 2.00$

Gloria. The brightest pink in existence. 2.00

Gorgeous. Brilliant crimson, suffused vermilion, shaded rose on the outer edge

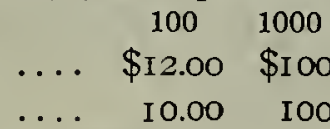

\section{0} $2.00 \$ 5.50$

10.00

\section{New Roses}

Killarney Brilliant. A sport from Killarney grown in the open ground in England. Killarney was introduced in 1898 and since then there have been so many sports that Killarney has developed into a type rather than a variety. Messrs. Alexander Dickson \& Sons, the original introducers, are to be congratulated, sixteen years after the advent of Killarney, in giving us now this distinct novelty which is undoubtedly the best of all varieties of this type. Killarney Brilliant has the same habit of growth and the same freedom of bloom as its parent, while the flower is twice as large, having 25 to 40 full-sized petals. It will be as useful for summer blooming as for winter forcing. The color is a very brilliant pink and varies like Killarney; in bright weather it is almost crimson, and in dull weather it is as bright as Killarney at its best. The sale of Killarney Brilliant a year before its introduction has been larger than any other Rose ever sent out in this country.

Mme. Edouard Herriot. This variety does not need a wide description. It is already known by having won at the International in May, I9I2, the Daily Mail Cup, also the Gold Medal at the National Rose. Society on May I, I9I3. It is a hardy plant with ample bronzy-green foliage, buds coral red, shaded yellow at the base, mid-sized flower, not too full. A superb coral red in color, shades of yellow and rose de carthame, passing to shrimp red.

Willowmere. Vigorous plant with strong branches, foliage clear green; long bud borne on a strong peduncle, coral-carmine red; very large flower, full, cup-shaped, of a rich shrimp red shaded yellow in the center, with extremity of the petals carmine rose. Said to represent an advance on Lyon Rose.

Prices of any of the above new Roses for 1914

Grafted, $21 / 4$ inch, $75 \mathrm{c}$ each, $\$ 6.00$ per doz., $\$ 35.00$ per I00, $\$ 300.00$ per IOOO.

No own root plants sold of the above named varieties.

Milady. The habit of growth is strong and sturdy and foliage excellent. The flower is large and double and opens perfectly at all seasons of the year. In color it is similar to Richmond, although richer in color in the bud. In form of flower and fragrance it resembles Gen. Jacqueminot and combines with this excellent color, strong growth, great productiveness and wonderful keeping qualities, which strongly recommend the variety as an excellent forcing Rose.

Grafted, 21/4 inch, $\$ 2.25$ per doz., \$I7.50 per I00, per I000 \$150.00. Own root, $2 \mathrm{~T} / 4$ inch, $\$ 1.75$ per doz., $\$ 12.00$ per IOO, per I000 $\$ 100.00$. Mrs. Chas. Russell. A strong-growing, free-flowering Rose. With one pinching makes stems four to five feet in length. The foliage is heavy and leathery, inclined to slightly curl on the older wood, is almost mildew proof and never drops the leaves. The bud is fully as large as American Beauty but longer and pointed, and opens into a flower of unusual beauty. The color is a bright rose pink, deeper toward the center. Is a remarkable keeper and shipper.

Grafted, $2 \mathrm{I} / 4$ inch, $\$ 2.25$ per doz., \$I7.50 per I00, per I000 \$150.00. Own root, $21 / 4$ inch, $\$ 1.75$ per doz., $\$ 12.00$ per I00, per I000 $\$ 100.00$. Mrs. George Shawyer. Brilliant rose pink in color. Flowers large, well formed, fairly full; petals of good substance. Growth is tall and stiff and carries heavy, leathery foliage. From the point of production and quality of bloom this Rose is recognized as one of our best forcing varieties.

Grafted, $2 \mathrm{I} / 4$ inch, $\$ 2.25$ per doz., \$I7.50 per I00, per I000 \$I50.00. Own root, $2 \mathrm{I} / 4$ inch, $\$$ I.75 per doz., $\$ 12.00$ per IO0, per 1000 \$100.00.

Sunburst. In color, orange-copper or golden yellow. Very intense shades and brilliant in coloring. It is a strong-growing variety and belongs in the class with big Roses. The foliage and stem are excellent. Owing to the fact that Sunburst has not been a general success grafted, we are offering the variety on its own roots only.

Own root, $2 \frac{1}{4} / \mathrm{inch}, \$ 1.75$ per doz., $\$ 12.00$ per 100 , per $1000 \$ 100.00$ 6 of any one variety at dozen rate, 25 at 100 rate, 250 of a variety at 1000 rate.

Note.-Unless so priced, no order for less than 6 of a kind will be filled at the prices quoted on this page. See our Retail Cata. logue for small quantities, from which we will allow a discount of $10 \%$ on varieties offered on this page. 
Most of the stock on this page is produced for us by an extensive grower in Connecticut, from whose place we make shipments direct to you. His reputation stands unequaled for quality stock.

\section{STANDARD CARNATIONS} (Strong Rooted Cuttings)

Enchantress Supreme. It is a light salmon pink, which endures exposure to the sun without bleaching. \$1.00 per doz., $\$ 6.00$ per $100, \$ 50.00$ per 1000

Beacon. The best scarlet variety........... $\begin{array}{ccc}\text { Doz. } & 100 & 1000 \\ \$ 3.50 & \$ 30.00\end{array}$

Benora. The best variegated ever introduced.

Color cream white, beautifully penciled with

bright red $\ldots \ldots \ldots \ldots \ldots \ldots \ldots \ldots \ldots \ldots$.6 .60 $3.50 \quad 30.00$

Eureka. Scarlet seedling from Beacon..... $60 \quad 60 \quad 3.50 \quad 30.00$

Octoroon. Bright crimson in color......... .60 $3.50 \quad 30.00$

White Wonder. Large pure white.......... $60 \quad 3.50 \quad 30.00$

Enchantress. Standard shell pink...........60 $\quad .60 \quad 3.00 \quad 25.00$

May Day. An excellent light pink........... $.60 \quad 3.00 \quad 25.00$

Mrs. C. W. Ward. Pleasing shade of pink,
slightly lighter than Mrs. Lawson........ .6o $3.00 \quad 25.00$

Rosette. A dark pink carnation.......... .60 $3.00 \quad 25.00$

White Enchantress. The pure white strain .60 $3.00 \quad 25.00$

White Perfection. Perfection of bloom.... $\quad .60 \quad 3.00 \quad 25.00$

White Winsor. A pure white sport of Win-

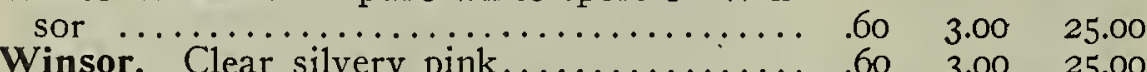

NoTE.-Plants of Carnations can be supplied at an advance over price of rooted cuttings, as follows: From $2 \frac{1}{4}$-inch pots, 50c. per doz.; \$2.00 per 100; 25 at the IOO rate; 250 of a variety at the 1000 rate; 6 of a variety at dozen rate.

NOTE.-No order for less than 6 of a kind will be filled at the prices quoted on this page. For smaller quantities see our Retail Catalogue, from which prices we will allow a discount of 10\%.

\section{CHRYSANTHEMUMS Exhibition Sorts}

Annie E. Angus. Pure

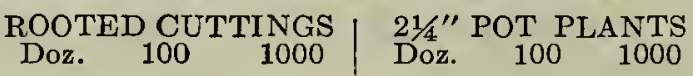

ch hite ................

\begin{tabular}{ll|llll} 
Pure white............. $\$ 0.60$ & $\$ 3.00$ & $\$ 25.00$ & .85 & 4.00 & $\$ 37.50$
\end{tabular}

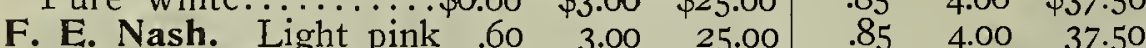

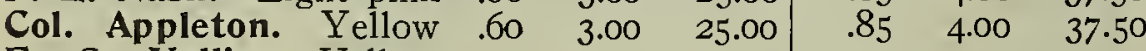

F. S. Vallis. Yellow

dwarf ..............

Glenview. Deep bronze

Harry E. Converse.

Lady Hopetoun. Light

pink .......................
Manhattan.

Mary Donellan. Golden

Mary Mason. R ơ s y

Mry Mason.
M. Louiseau Rousseau.

Pink Gilbert Drabble.

Pure white...........

Mrs. J. E. Dunne. Sal-

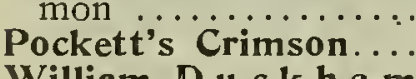

William $\mathrm{Du} \mathrm{ck}$ h a m.

Light pink............
William Turner. Pure

whils $\mathrm{L}$ a $\mathbf{t}$ e $\mathrm{p}$ in $\mathrm{k}$

Wells' Late Pink.

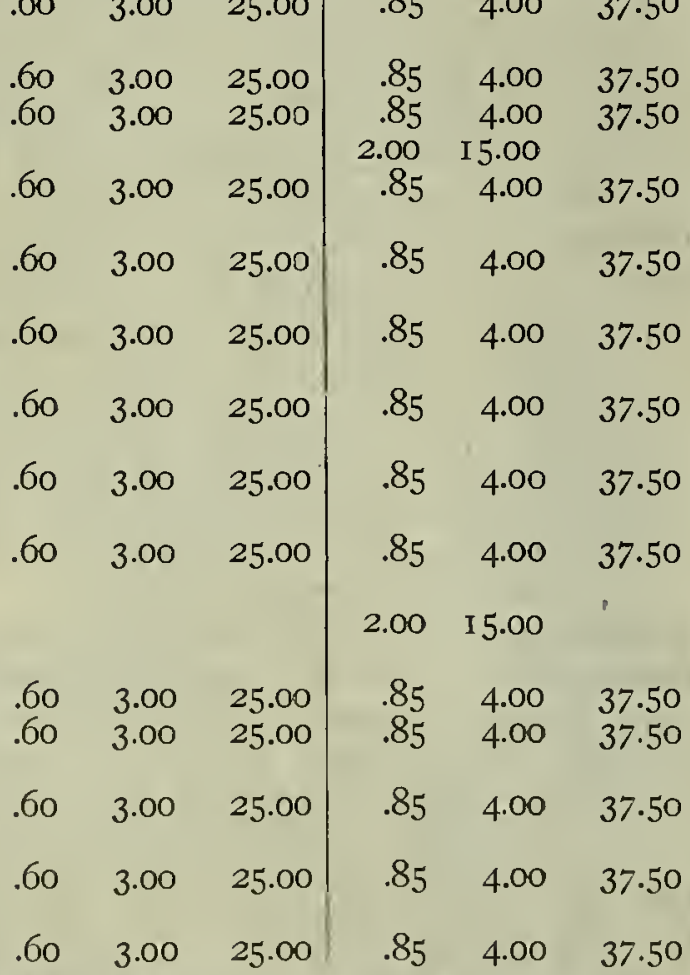

\section{CHRYSANTHEMUMS Commereial Sorts}

$$
\begin{array}{llllll}
\text { PINK ROOTED CUTTINGS } & \text { 21/4" POT PLANTS } \\
\text { Doz. } & 100 \quad 1000
\end{array}
$$

\begin{tabular}{llll|lll|} 
Chadwick Supreme.... $\$ 0.60$ & $\$ 3.00$ & $\$ 25.00$ & $\$ 0.85$ & $\$ 4.00$ & $\$ 30.00$
\end{tabular}

$\begin{array}{llllllll}\text { Dr. Enguehard.......... } & .60 & 2.00 & 17.50 & .75 & 3.00 & 25.00\end{array}$

\begin{tabular}{llll|rrr|} 
Helen Frick.............. & .60 & 3.00 & 20.00 & .85 & 4.00 & 30.00 \\
Pacific Supreme..... & 60 & 2.00 & 17.50 & .75 & 3.00 & 25.00
\end{tabular}

\begin{tabular}{llll|lll} 
Pacific Supreme........ & .60 & 2.00 & 17.50 & .75 & 3.00 & 25.00 \\
Unaka & .60 & 3.00 & 20.00 & .85 & 4.00 & 30.00
\end{tabular}

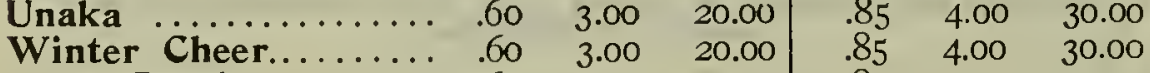

$\begin{array}{lllllll}\text { W. R. Brock............. } & .60 & 3.00 & 20.00 & .85 & 4.00 & 30.00\end{array}$

We can supply also all other pink varieties. and Bedding Plants

\section{Commercial Chrysanthemums (Continued) RED}

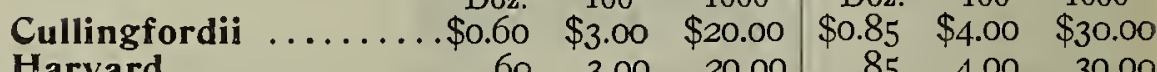

$\begin{array}{llllllll}\text { Harvard } \ldots \ldots \ldots \ldots \ldots \ldots & .60 & 3.00 & 20.00 & .85 & 4.00 & 30.00 \\ \text { Intensity } \ldots \ldots \ldots \ldots & .60 & 3.00 & 20.00 & .85 & 4.00 & 30.00\end{array}$

\begin{tabular}{lllll|lll} 
Chadwick Improved... & .60 & 3.00 & 25.00 & .85 & 4.00 & 30.00
\end{tabular}

$\begin{array}{llllllll}\text { Chas. Raser............ } & .60 & 3.00 & 20.00 & .85 & 4.00 & 30.00\end{array}$

$\begin{array}{lllllll}\text { Early Snow............ } & .60 & 3.00 & 20.00 & .85 & 4.00 & 30.00\end{array}$

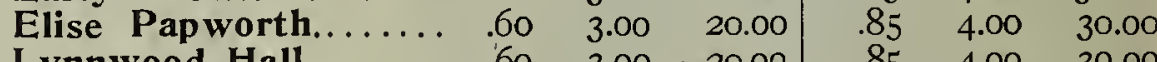

$\begin{array}{lllllll}\text { Lynnwood Hall........ } 60 & .60 & 3.00 & 20.00 & .85 & 4.00 & 30.00\end{array}$

$\begin{array}{llllllll}\text { Smith's Advance...... } & .60 & 2.00 & 17.50 & .75 & 3.00 & 25.00\end{array}$

$\begin{array}{llllllll}\text { Timothy Eaton........ } & .60 & 3.00 & 20.00 & .85 & 4.00 & 30.00\end{array}$

$\begin{array}{llllllll}\text { W. H. Chadwick....... } & .60 & 3.00 & 25.00 & .85 & 4.00 & 30.00\end{array}$

$\begin{array}{lllllll}\text { White Bonnaffon....... } & .60 & 3.00 & 20.00 & .85 & 4.00 & 30.00\end{array}$

$\begin{array}{lllllll}\text { White Helen Frick.... } & .60 & 3.00 & 20.00 & .85 & 4.00 & 30.00\end{array}$

We also can do all other white varieties.

\section{YELLOW}

\begin{tabular}{|c|c|c|c|c|c|c|}
\hline August Dasse & .60 & 3.00 & 20.00 & .8 & 4.00 & 30.00 \\
\hline ysolora & .60 & 3.00 & 20.00 & & 4.00 & 30.00 \\
\hline Dimple & .60 & 3.00 & 20.00 & .85 & 4.00 & 30.00 \\
\hline n Chadwick & .60 & & & & 4.00 & 30.00 \\
\hline n Eas & .60 & $3 . c$ & & & 4.00 & 30.00 \\
\hline Iolden Rob & I.OO & 7.00 & 60.00 & & 10.00 & 90.00 \\
\hline maroud $G$ & & 15.00 & & & 20.00 & \\
\hline$M$ & .6 & 2.00 & 17.5 & & 3.00 & 25.00 \\
\hline $\mathrm{Val}$ & & 3.00 & & & 4.00 & 30.00 \\
\hline
\end{tabular}

We can supply also all other yellow varieties.

\section{ROSES (From 21/4" Pots)}

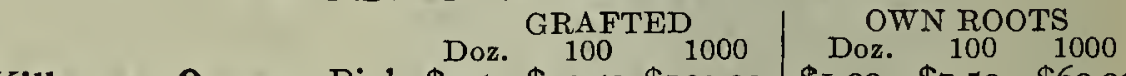

Killarney Queen. Pink. \$1.50 \$12.50 \$120.00 $\begin{array}{lllll}\text { \$1.00 } & \$ 7.50 & \$ 60.00\end{array}$

$\begin{array}{lllllll}\text { Double Wh. Killarney. I.50 } & 12.50 & 120.00 & \text { I.00 } & 7.50 & 60.00\end{array}$

Mrs. Taft (Antoine Ri-

\begin{tabular}{llll|lll} 
voire). Shell pink.... I.50 & I 2.50 & I 20.00 & I.00 & 7.50 & 60.00
\end{tabular}

Mrs. Aaron W a rd.

$\begin{array}{lllllll}\text { Yellow, shaded pink... I.50 } & \text { I2.50 } & \text { I } 20.00 & \text { I.00 } & 7.50 & 60.00\end{array}$

\begin{tabular}{llll|lll} 
Lady Hillington. Yellow & 1.50 & I 2.50 & I 20.00 & 1.00 & 7.50 & 60.00
\end{tabular}

$\begin{array}{llllllll}\text { Killarney. Pink........ } & 1.50 & 12.50 & \mathrm{I} 20.00 & \mathrm{I} .00 & 7.50 & 60.00\end{array}$

$\begin{array}{llllllll}\text { White Killarney........ I.50 } & \text { I } 2.50 & \text { I } 20.00 & \text { I.00 } & 7.50 & 60.00\end{array}$

\begin{tabular}{lllll|lll} 
Jonkheer J. L. Mock. . I.50 & I 2.50 & I 20.00 & 1.00 & 7.50 & 60.00
\end{tabular}

\begin{tabular}{lllll|lll} 
Richmond $\ldots \ldots \ldots \ldots$ & I.50 & I 2.50 & I 20.00 & I.00 & 7.50 & 60.00
\end{tabular}

\begin{tabular}{lllll|lll} 
Radiance $\ldots \ldots \ldots \ldots \ldots$ & I.50 & 12.50 & 120.00 & 1.00 & 7.50 & 60.00
\end{tabular}

$\begin{array}{lllllll}\text { My Maryland........... } & \mathrm{I} .50 & \mathrm{I} 2.50 & \mathrm{I} 20.00 & \mathbf{1} .50 & 10.00 & 90.00\end{array}$

American Beauty. 21/2-

in. pot stock...........

I.50 $12.00 \quad 100.00$

Sunburst .............

Six roses of a kind at dozen rate, 25 at 100 rate, 250 at 1000 rate.

If you are interested in Roses from 3 and 4 -inch pots write us for prices.

\section{MISCELLANEOUS PLANTS (21/4" Pots)}

$\begin{array}{llll}\text { Abutilon Savitzi ...................... } & \text { Doz, } & 100 & 1000\end{array}$

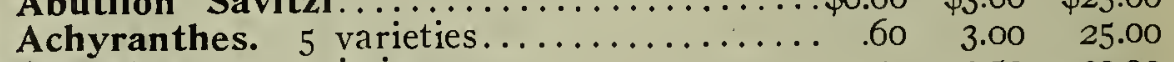

Ageratum. 3 varieties.................... $50 \quad 2.50 \quad 20.00$

Alternanthera. 5 varieties..................5 $50 \quad 2.50 \quad 20.00$

Antirrhinum. 3 varieties.................. . .70 $4.00 \quad 35.00$

Begonia Gloire de Lorraine..............2.00 I 5.00 I 35.00

Begonia Glory of Cincinnati............ $3.00 \quad 20.00 \quad$ I 75.00

Bouvardia. White....................... 60 . $4.00 \quad 35.00$

Coleus. I9 varieties.................... $.50 \quad 2.50 \quad 20.00$

Gardenia ........................... I.00 $7.00 \quad 60.00$

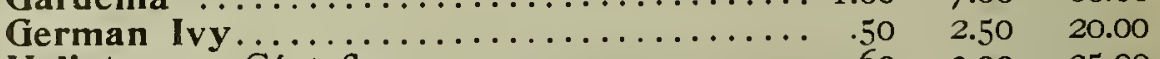

Heliotrope. Céntefleur.................... .60 $3.00 \quad 25.00$

Lantana. 6 varieties.................. $.70 \quad 4.00 \quad 35.00$

Poinsettia. Single...................... 1.00 $7.00 \quad 60.00$

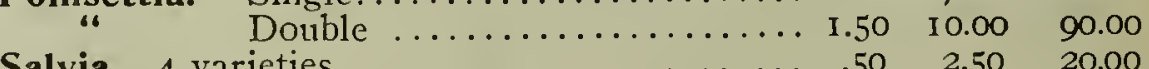

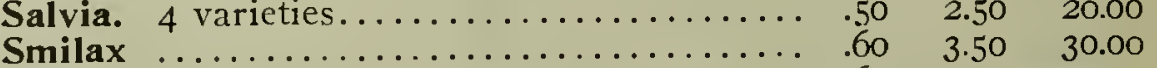

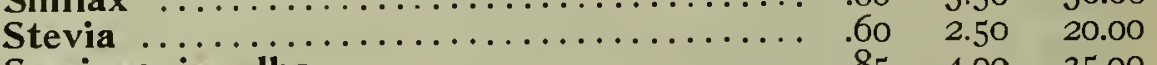

Swainsonia alba ................... $85 \quad 4.00 \quad 35.00$

Not less than 50 plants of a kind under this heading supplied at Ioo rate, not less than 250 of a kind supplied at 1000 rate, and not less than I doz. of any one kind supplied at the above prices. 


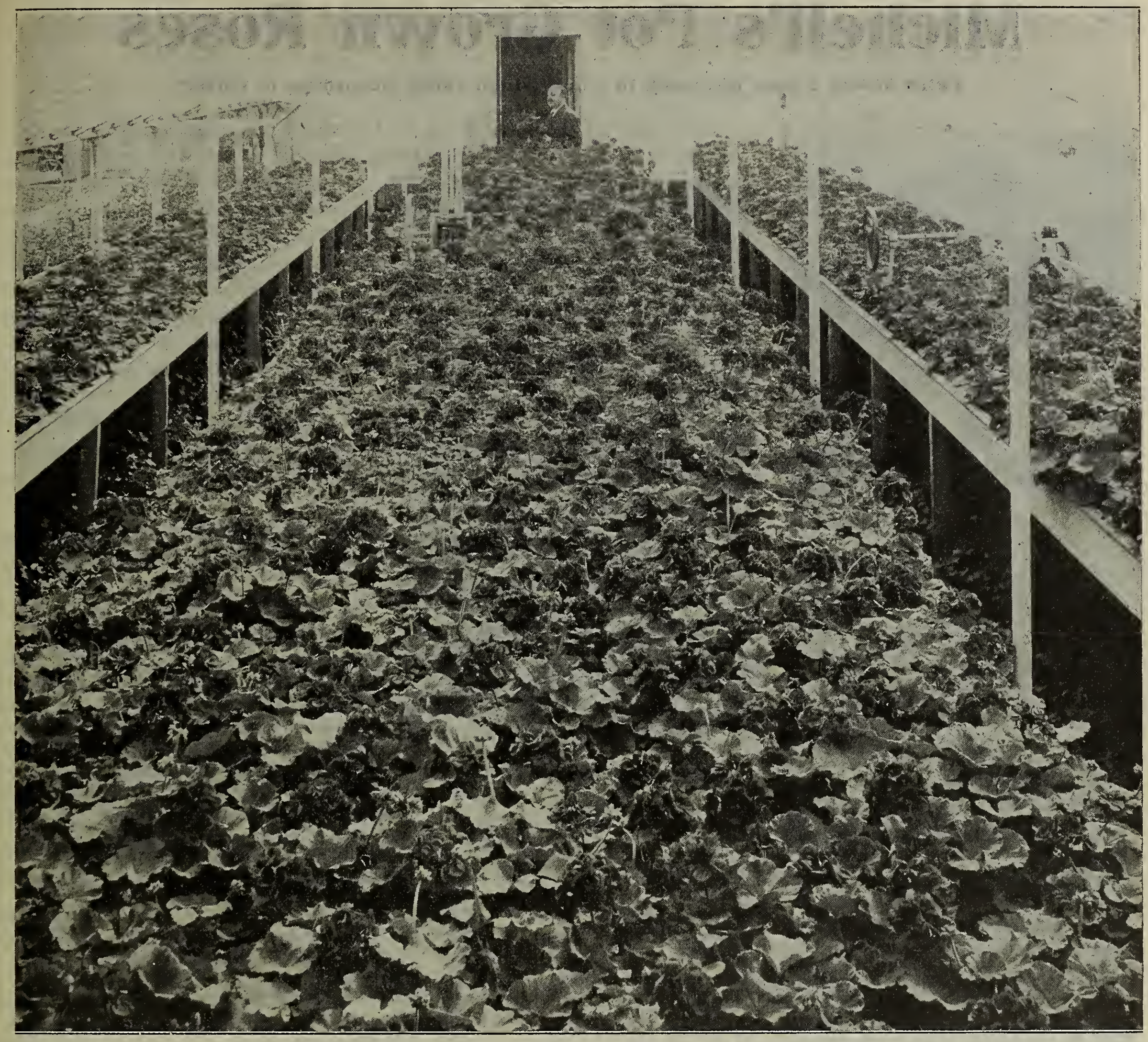

New Scarlet Bedding Geranium "Helen Michell"

This wonderful new Geranium is fully described on the second cover page of this catalogue, opposite which appears an illustration in color, drawn from nature of one plant, to show its habit. The photograph above shows a section of one of our greenhouses, where we produced a quantity of the stock. For the most part these plants are in 4-inch pots. This photograph was taken in March, 1913, which will convey some idea of the early and freeflowering characteristics of the "Helen Michell" Geranium. We have already booked a huge number of orders and predict that the demand will greatly increase. Book your order early. All orders will be filled in rotation, beginning in January, 1914.

PRICES TO THE FLORIST TRADE, FROM 2 $\frac{1}{4}-$ INCH POTS

Each, 25c.; Dozen $\$ 2.50 ; 100, \$ 15.00 ; 1000, \$ 125.00$

6 at dozen rates, 25 at 100 rate, 250 at 1000 rate 


\section{Extra strong 2-year old stock in 5 and 6 -inch stock, according to variety}

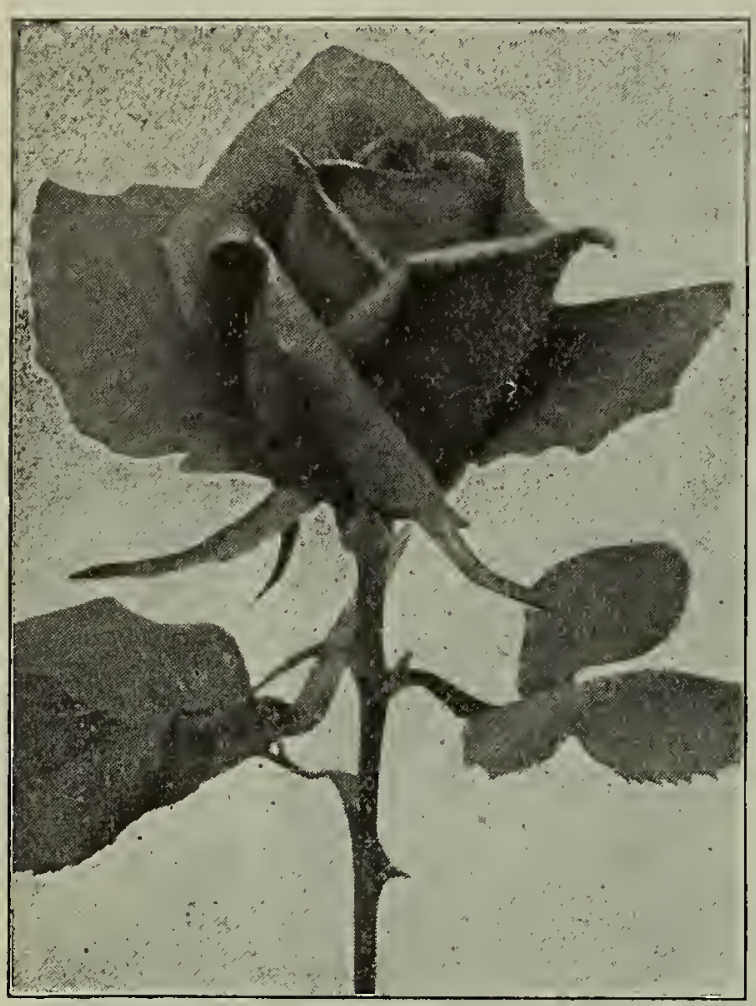

Rose Milady

\section{Climbing Varieties}

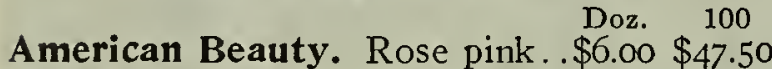
American Pillar. Single pink. $4.00 \quad 32.00$ Baltimore Belle. Blush...... 3.0022 .00 Christine Wright. Pink..... 6.0047 .50 Crimson Rambler. Red..... $3.50 \quad 27.00$ Dorothy Perkins. Pink...... $3.50 \quad 27.00$ Excelsa. Scarlet........... $4.00 \quad 32.00$ Flower of Fairfield. Crimson. $3.50 \quad 27.00$ Hiawatha. Single scarlet.... $3.50 \quad 27.00$ Lady Gay. Pink............ $3.50 \quad 27.00$ Tausendschoen. Soft pink... $3.50 \quad 27.00$

\section{Dwarf Ramblers}

Baby Rambler (N. Lavasseur). Doz. 100

Crimson $\ldots \ldots \ldots \ldots \ldots \ldots \ldots \ldots 3.25 \$ 25.00$

Catherine Zeimet. White.....3.25 25.00

Erna Terschendorff. Scarlet. $3.25 \quad 25.00$

Jessie. Red

Mrs. W. Cutbush. Pink...... $3.25 \quad 25.00$

Phyllis. Cerise pink........ $3.50 \quad 27.00$

$\begin{array}{lll}\text { White Dorothy Perkins. White } & 3.50 & 27.00 \\ \text { Yellow Rambler. Yellow.... } 3.50 & 27.00\end{array}$

\section{Hybrid Perpetual Varieties}

American Beauty. Deep Pink. $\$ 3.75$ \$30.00 Baroness Rothschild. Pink... 3.50 27.00

Clio. Flcsh Pink.

Capt. Christy. Pink

Fisher Holmes. Red.

Frau Karl Druschki. White.

Gen. Jacqueminot. Crimson.

La France. Rosc pink.

Magna Charta. Pink.

M. Dickson. Whitc

Mme. Gab. Luizet. Pink

Mrs. Jno. Laing. Pink.

Mrs. R. G. Sharman Crawford. T'ink

Paul Néyron. Decp pink..... Crimson

Soleil d'Or. Yellow.

Ulrich Brunner. Deep pink..

Our stock of pot grown Roses is of unusual quality. Many varieties we have grown ourselves in our nursery at Andalusia, where the soil is particularly adapted to their prime development. Others have been produced for us on contract and are equal to our own growing. The stock is lifted late in the fall as possible and ripened, potted and plunged in sand beds in cold glass houses, where they winter over under natural conditions. Towards spring the leaf buds break forth, just as they do on the stock growing outdoors, except a few weeks earlier. Our plants will be in prime shipping condition after April Ist. In forwarding, the plants are taken out of the earthen pots (unless we are instructed to the contrary) and placed with the original ball of earth intact in paper pots, which process saves considerably in transportation charges and enables the plants to reach you in prime condition, as the earthen pots are invariably broken in transit. The past autumn we have completed the erection of three cold rose houses; modern in every respect, they are built of concrete, iron and removable glass sash. These houses are each 23 feet wide and 125 feet long. We can promise extra fine quality in rose plants.

Note.-For the quality of stock we supply, our prices are very low. Less than $1 / 2$ dozen Roses will be priced at our retail catalogue rates, as quoted on pages 139 to 145 , inclusive, less 20 per cent.

\section{Hybrid Tea Varieties}

$\begin{array}{ccc}\text { Antoine Rivoire. Pink ........ } \$ 3.75 & \$ 30.00\end{array}$ Bessie Brown. Cream white.. $3.75 \quad 30.00$ Betty. Pink .............. $3.75 \quad 30.00$ British Queen (New). White. Each, $\$$ I.25; 14.00

Chateau de Clos Vougeot.

Scarlet .................. $5.00 \quad 40.00$

Dean Hole. Pink........... 3.7530 .00

Duchesse of Westminster.

Clear rose .............. $7.00 \quad 55.00$

Earl of Gosford (New).

Crimson.........Each, $\$ 1.25 ; 14.00$

Edward Mawley. Crimson... 7.00

Etoile de France. Red...... 5.00

Etoile de Lyon. Yellow...... 3.50

Farbenkonigin. Pink...... 3.7530 .00

Florence Pemberton. Cream

white .................. $3.75 \quad 30.00$

Franz Deegen. Yellow....... 3.7530 .00

Gen. MacArthur. Red..... 3.7530 .00

Geo. Dickson (New). Crim-

son ..........Each, \$I.25; I 4.00

George C. Waud. Vermilion. 4.50

Gruss aus Teplitz. Red..... 3.50

Harry Kirk. Yellow........ .4.50

Hermosa. Pink............ 3.2525 .00

3.5027 .00 Jonkheer J. L. Mock. Rose

$\begin{array}{ll}3.50 & 27.00 \\ 3.50 & 27.00\end{array}$

$\begin{array}{ll}3.50 & 27.00 \\ 3.50 & 27.00\end{array}$

\begin{tabular}{ll|l}
3.50 & 27.00 & Juliet. Orangc ................... \\
3.75 & 30.00 & Kaiserin A. Victoria. White.
\end{tabular}

$3.50 \quad 27.00$ Killarney. Pink...........................

. 3.50 27.00 Kady Ashtown. Pink .................

27.00 Lady Hillingdon. Yellow..... $6.00 \quad 45.00$

3.5027 .00 La Hollande. White....... $6.00 \quad 45.00$

$\begin{array}{llllll}3.50 & 27.00 & \text { Laurente Carle. Red........ } 3.75 \quad 30.00\end{array}$

$\begin{array}{ll}3.50 & 27.00 \\ 3.50 & 27.00\end{array}$ Le Progres. Deep Yellow .... 3.75 30.00 $\begin{array}{llll}\text { Leuchtfeuer. Fiery crimson. } & 5.00 & 40.00 \\ \text { Lyon. Yellow ............. } & 3.75 & 30.00\end{array}$ \begin{tabular}{ll|lllll}
3.50 & 27.00 & Lyon. Yellow .............. 3.75 & 30.00 \\
3.50 & 27.00 & Mad. Abel Chantenay. Pink. & 3.75 & 30.00
\end{tabular} \begin{tabular}{ll|lll}
3.50 & 27.00 & Mad. Caroline Testout. Rose. 3.75 & 30.00
\end{tabular}
Mad. Jenny Gillemot. Doz. 100 mot. Pink. $\$ 3.75 \$ 30.00$ Mad. Jules Grolez. Pink..... $3.75 \quad 30.00$ Mad. Ravary. Yellow........ $3.75 \quad 30.00$ Maman Cochet Pink........ $3.50 \quad 27.00$ Maman Cochet White...... $3.50 \quad 27.00$ Marg. Guillot. White....... $4.00 \quad 30.00$ Marquise de Sinety. Yellow. 5.00 40.00 Milady. Dazzling red....... $6.00 \quad 45.00$ Mildred Grant. Blush white.. $3.75 \quad 30.00$ Molly Sharma n Crawford.

White ................. 5.0040 .00 Mrs. Aaron Ward. Yellow... 3.7530 .00 Mrs. C. C. Harrison. Deep pink ................. $6.00 \quad 45.00$ Mrs. David Jardine. Pink... $4.50 \quad 35.00$ Mrs. Geo. Shawyer (New).

Deep pink....... Each, \$I.25; I 4.00

Mrs. Peter Blair. Yellow.... $4.50 \quad 35.00$ My Maryland. Pink....... $4.50 \quad 35.00$ Neervelt. Red .......... 5.00 40.00 Perle des Jardins. Yellow ... $3.75 \quad 30.00$ Prince de Bulgarie. Pink.... $3.75 \quad 30.00$ Richmond. Red ........... 3.7530 .00 Souv. de P. Notting. Yellow.. 3.7530 .00 White Killarney. White.... $3.75 \quad 30.00$ Wm. Shean. Delicate pink... $4.50 \quad 35.00$ Souvenir de Pres. Carnot.

Delicate pink ............. $3.75 \quad 30.00$ Souvenir de la Malmaison. Flesh .................. $3.50 \quad 27.00$

\section{Miscellaneous Roses}

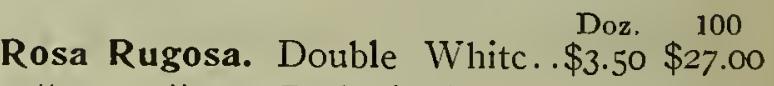
" " " Red single.... 2.75 22.00 " " " White single... 2.75 22.00 " Con. F. Meyer, double pink... $3.50 \quad 27.00$

Wichuriana. Single white... $3.25 \quad 25.00$ Alba Rubifolia.. $3.50 \quad 27.00$ Gardenia ...... $3.25 \quad 25.00$ Persian yellow. 3.50 27.00 


\section{MICHELL'S HARDY PERENNIAL PLANTS AND ROOTS ${ }^{69}$}

The past year we have greatly improved our facilities for handling orders for hardy plants, having added to our equipment 4 large modern greenhouses and 250 additional frames. We therefore want your order for perennials and such other goods in our line which we handle extensively. Special Notice: On account of the small profit in plants at wholesale, no order for plants that aggregates less than $\$ 1.00$ will be filled at these wholesale rates; such orders will be filled at retail catalog prices for plants, less $10 \%$. Complete description of all plants offered here will be found in our retail catalog, a copy of which can be had on request.

\section{ACHILLEA (Sneezewort)}

Cerise Queen. Red.......... \$1.00 Ptarmica FI. PI. (The Pearl).

White ................... .90

Boule de Neige (Snowball).... I. ACONITUM (Monkshood)

Fischeri. Pale blue........... I.35 Napellus. Dark blue.......... Napellus Bicolor. Blue and

white..$\ldots \ldots \ldots \ldots \ldots \ldots$ I.35 Wilsoni. Violet blue.......... I.50

Autumnale. Deep purple..... I. I5

Stroekianum. Rich deep blue.. I.50 I0.00 ACTAEA (Baneberry)

Spicata Alba. Pure white ber-

ries ................... I.50 I0.00

Spicata Rubra. Bright scarlet

berries ............... I.50 10.00 AETHEOPAPPUS (New)

Pulcherrimus. Brilliant rose.. I.50 I0.00 AGROSTEMMA (Campion)

Coronaria. Crimson.......... .90

AKEBIA Each Doz

Quinata. ...............\$ \$0.20 \$2.00 ALYSSUM (Gold Dust)

$\begin{array}{ccc}\text { Saxatile Comp. Yellow....... } \$ 0.90 & \$ 100 \\ \$ 6.50\end{array}$ AMPELOPSIS

Veitchii. Extra strong; 4 in

pots .................. $2.00 \quad 15.00$ Quinquefolia. ................ $2.00 \quad 12.50$ ANCHUSA (Italica)

Dropmore. Blue............ I.50 I0.00

Myosotidaeflora $(N e w)$. Rich

blue $\ldots \ldots \ldots \ldots \ldots \ldots \ldots \ldots$
Opal. Pale blue.............. ANEMONE (Windflower)

Alba. Pure white........... I.Io

Alice. Shell pink............... I.50

Kriemhilde. Rose pink........ I.5O

Pr. Henry. Rich pink......... I.IO

Rubra. Rosy red............. I.Io

Whirlwind. Pure white...... I.Io

kord Ardilaun. Pure white.... I.50

Geante Blanche. Giant white.. I.50

Queen Charlotte. Semi-double;

pink ................. I.IO

Purpurine. Semi-double; deep

rose $\ldots \ldots \ldots \ldots \ldots \ldots \ldots$ I.50 AQUILEGIA (Columbine)

Canadensis. Red and yellow.. .90

Chrysantha Alba. Pure white .90

Chrysantha. Yellow......... .90

Coerulea. Blue and white..... .90

Erskine Park Hybrids. Mixed. .90

Flabellata Nana. White..... .90

Rose Queen. Delicate pink.... .90

Helenae. Blue, white spurs.... .90 ARABIS (Rock Cress)

Alpina. Pure white........ .90

Alpina FI. PI. Double white.. I.IO

ARISTOLOCHIA (Dutchman's Pipe)

Sipho. Each 40c.; $\$ 4.00$ doz. ARMERIA (Sea Pink)

Maritima. Pink............ .90 ARTEMISIA

Lactiflora. Cream white..... I.50 I0.00 ASCLEPIAS (Butterfly Weed)

Tuberosa. Orange red....... .90

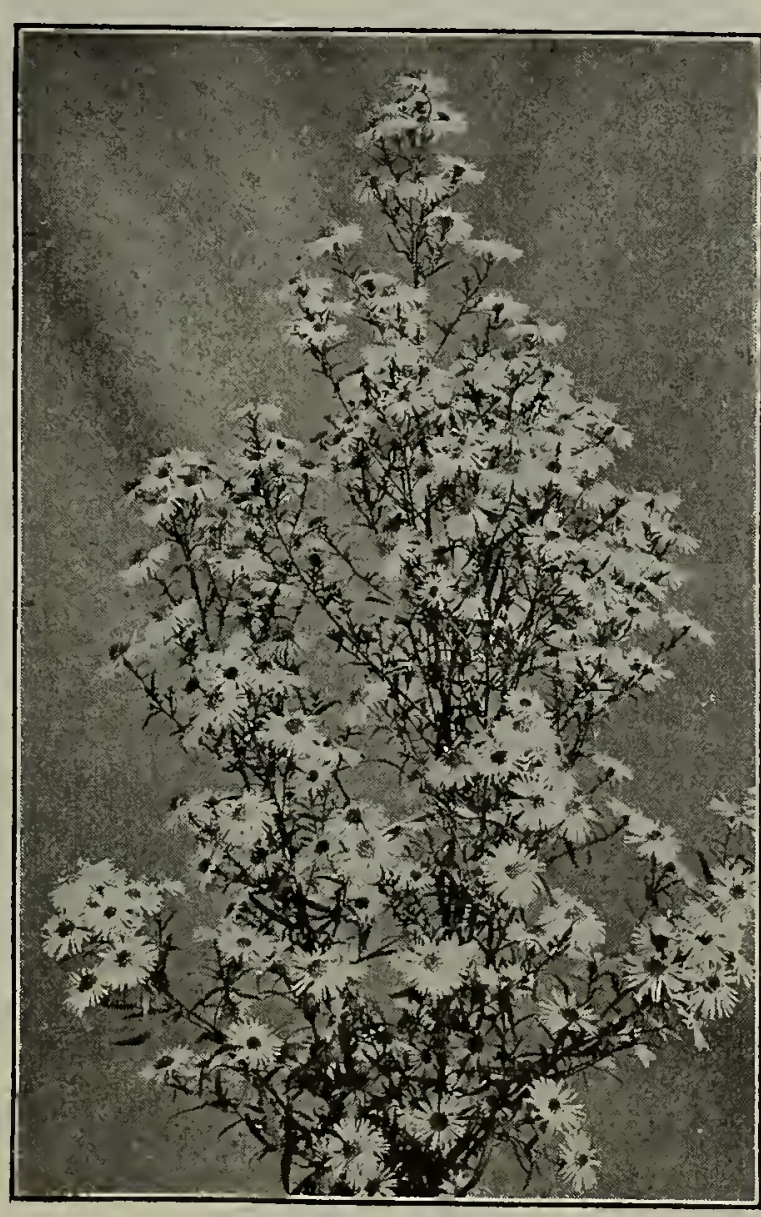

Hardy Aster

ASTERS (Hardy) Doz. 100 Beaute Parfait. Violet......... I.50 I0.00

Nov. Ang. Rubra. Red....... I.IO

Amellus Perry's. Pink....... I.5O

Ptarmac. Maj. Pure white... I.Io

Robt. Parker. Lavender...... I.Io

7.50 St. Egwin. Pink............. I.50

7.50 White Queen. Pure white.... I.Io

7.50 Wm. Marshall. Clear blue.... I.Io

I0.00 Subcoeruleus. Deep blue...... I. Io

I0.00 Fairfield. Pure white........ I.Io

Beatrice. Pure white......... I.Io

7.50 Beauty of Colwall. Lavender. I.75

Thompsoni Nana. Sky-blue.... I.50

BIGNONIA (Trumpet Vine)

Grandiflora. 40c. each; doz. \$4.00.

6.50 Radicans. 20c. each; doz. $\$ 2.00$.

6.50 BoCCONIA (Plume Poppy)

6.50 Cordata. Cream white....... I.Io

6.50 BOLTONIA (False Chamomile)

6.50 Asteroides. Pure white...... .90

6.50 Latisquama. Pink...........
6.50 .90

6.50 Latisquama Nana. Pink. Dwf. .90 BUDDLEYA (Butterfly Bush)

6.50 Var. Magnifica. Lavender.... 2.00 I5.00

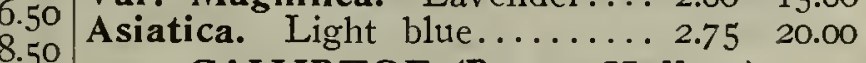
CALLIRHOE (Poppy Mallow) Involucrata. Crimson......... I.IO CAMPANULA (Bell Flower)

Calycanthema. Pink.......... I.50

Calycanthema. Blue......... I.50

Calycanthema. White......... I.50

Glomerata. Violet blue....... I.Io

Lactiflora. Bluish white...... I.IO

6.50 Media. Pink............... I.Io
CAMPANULA (Continued) Doz. 100

Media. Blue ............. \$1.Io $\$ 7.50$

Media. White............. I.Io 7.50

Moerheimi. Pure white....... I.50 I 2.00

Pers. Grand Coerulea. Blue.. I.35 8.50

Pers. Grand Alba. White.... I. I5 8.50

Trachelium. Purple.......... I.IO 7.50

Alliariaefolia. White.......... I.IO 7.50

Carpatica. Blue............ I.IO 7.50

Carpatica. White........... I.Io 7.50

Pyramidalis. Blue............ I.35 8.50

Pyramidalis. White.......... I.IO 7.50

Humosa. Light blue......... I.50 I2.00

White Star. Pure white...... I.IO 8.50 CASSIA (American Senna)

Marilandica. Yellow......... .90 6.50

CENTAUREA (Perennial Cornflower)

Montana. Blue............. I.35 8.50

Montana Alba. White....... I.35 8.50

Pulcherrima. .............. I. 35 s 8.50

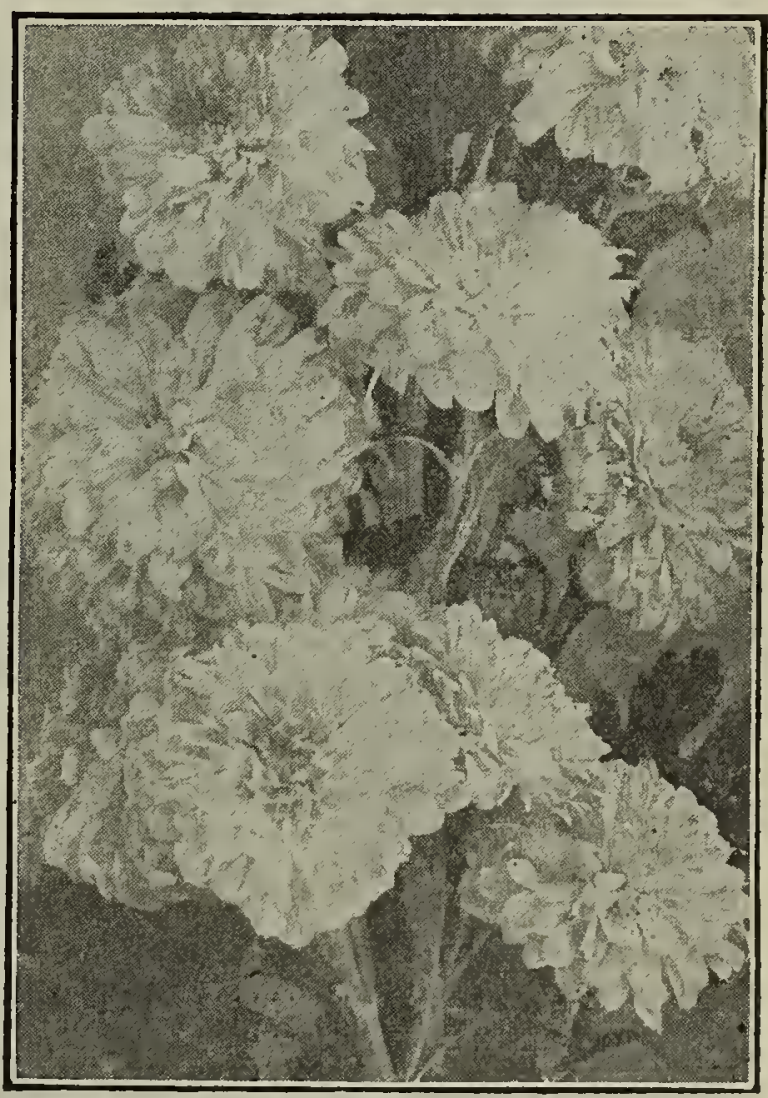

Hardy Chrysanthemum

CHRYSANTHEMUMS (Hardy)

Pompon Varieties

7.50 Agalia. Orange. Irene. White.

Aaron. Scarlet. Julia Lagravere.

6.50 Anna Marie. Cream Maroon.

6.50 white. Jeanette. Bronze.

Ashbury, Yellow. Jas. Boone. White

Baby. Yellow. Lady Naylor. White

Dawn. Pink. White.

Dundee. Red.

Excelsior. Yellow.

Ermine. Scarlet.

Findon. Rose.

I0.00 Furnessia. White.

I0.00 Globe d'or. Yellow. White.

7.50 Gladys. Pearl. St. Elmo. White.

7.50 Ida. Yellow. St. Illoria. Rose

7.50 See page 70 for other Hardy 'Mums.

Miss Julia. Yellow.

Q

Crieen of Bulgaria. Crimson

Queen of Whites. 
HARDY CHRYSANTHEMUMS

Sylvia. Bronze. Triomphe d'Or.

Susquehanna. Yel.- yellow.

low. Viola. Red

Scarlet Beauty. Urith. Bronze. Red.

Price of any of the Hardy Pompon

Chrysanthemums offered, 65c. doz.; per IOO $\$ 4.50$.

\section{Large, Early Flowering}

ENGLISH CHRYSANTHEMUMS

Primavere. Prim- Le Pactole. Yellow.

Wells Crimson.

Mad. Marie Masse.

Red.

Saumon Rouge.

Salmon.

Border Beauty. Orange.

Champagne. Red.

Countess. White.

let.

Mrs. A. Beech.

Bronze.

Mabel Roberts.

Pink.

Normandie. Pink.

October Gold. Yellow.

Queen of the

Golden Queen of Earlies. Yellow.

Price of English Hardy Chrysanthemums,

$\$ \mathrm{I} .25$ doz., per I00 $\$ 8.00$.

\section{CHRYSANTHEMUM}

Arcticum. Pure white....... $\$ 2.00$ DI 100 Maximum Vermorense. Pure

white $\ldots \ldots \ldots \ldots \ldots \ldots \ldots .2 .00 \quad$ I2.50

CLEMATIS (Extra Strong Plants)

Henryi. White........ \$0.35 \$3.50

Jackmanii. Purple.......... $35 \quad 3.50$

Jackmanii Alba. White.. $.35 \quad 3.50$

Mad. E. Andre. Red..... $.35 \quad 3.50$

Integrifolia Durandi. Blue .40 4.00

Montana Rubens. Red... $.50 \quad 5.00$

Flamula. White......... $.35 \quad 3.50$

Coccinea. Red............... . . I5 $\begin{array}{lll}3.50 & \\ \text { I.50 } \$ 9.00\end{array}$

Crispa. Lavender........... .I5 I.50 9.00

Tanguticus. Yellow........... 50 .50 5.00

Paniculata. White........

Lanc. Grand. Yellow....... .90 DAISY (Bellis perennis)

Monstrosa. White...........60

Monstrosa. Pink............. .60

Monstrosa. Red...

.60

DELPHINIUM (Larkspur)

Amos Perry. Mauve.......2. 2.50

Belladonna. Blue............. 1.50

Belladonna Semi PI. Blue.... 2.50

Chinense Azureum. Blue.... . .90

Chinense Album. White..... .90

Formosum. Deep blue....... .90

Formosum Coelestinum. Blue. .90

Kelway's Hybrids. Mixed.... I.25

King of Delphiniums. Blue... 3.50

Moerheimi. Pure white..... 3.50

DIANTHUS (Garden Pink)

Deltioides. Pink............ .90

Latif. Atroc. FI. PI. Crimson.. . .90

Mixed Colors

DICTAMNUS (Gas Plant)

Fraxinella. Pink............ I.35

Fraxinella. White............ I.35

DIELYTRA (Bleeding Heart)

Spectabilis. Pink and white..: .90

DIGITALIS (Fox Glove)

Gloxiniaflora. White........ .90

Gloxiniaflora. Pink............

Gloxiniaflora. Blue........ . .90

Gloxiniaflora. Yellow......... .90

6.50

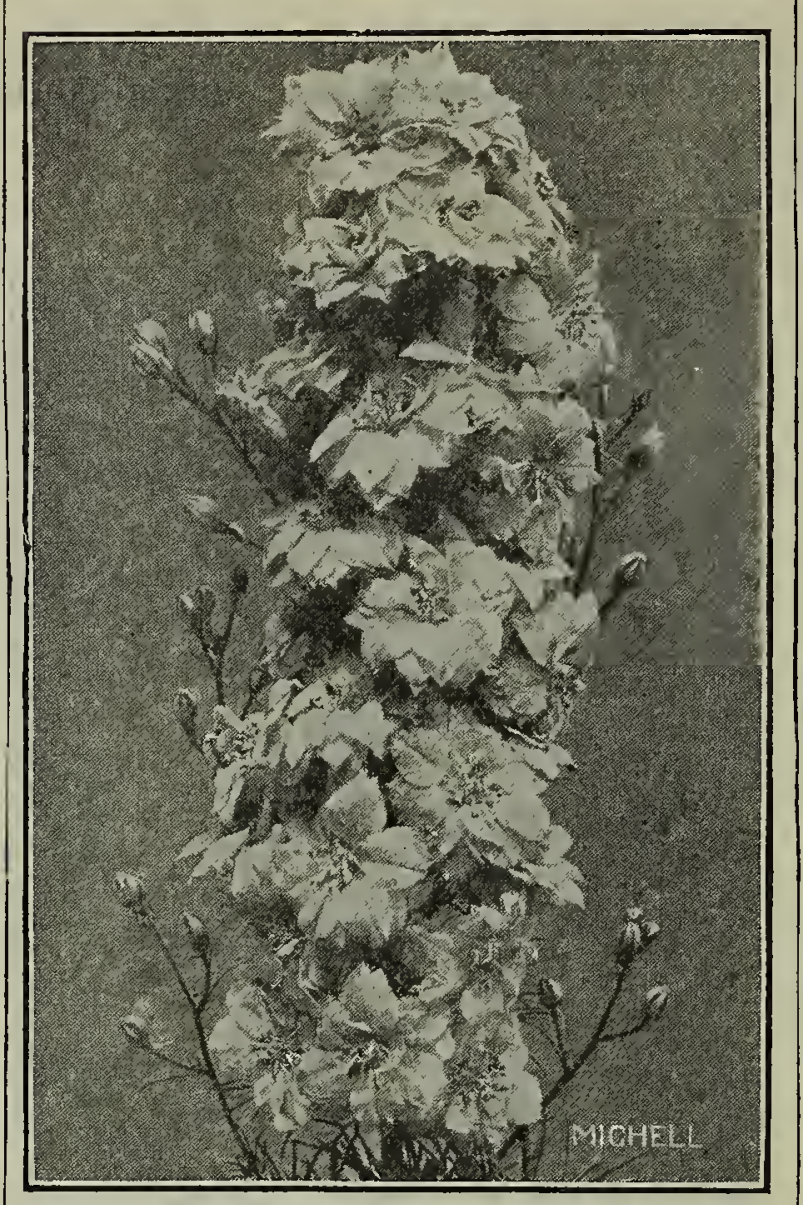

Delphinium Belladonna (See left-hand column)

DORONICUM Doz. 100

Excelsum. Yellow.........\$I.35 \$8.50 ECHINOPS (Globe Thistle)

Ritro. Deep blue........... I.35 EDELWEISS (Alpine Plant)

White $\ldots \ldots \ldots \ldots \ldots \ldots \ldots$. I.25 ERYNGIUM (Sea Holly)

Planum. Blue............. I.35 EUPATORIUM

Ageratoides
Coelestinum. Light biue........

Coelestinum. Light blue....
FERNS (Hardy)

Adiantum Pedatum........... I.75

4.50 Dicksonia Punctilobula......... I.00

4.50 Osmunda Regalis............ I.75

4.50 Aspidium Acrostichoides........ I.00

Aspidium Marginale........... I.25

20.00 Aspidium Thelypteris.......... I.25

I2.00 Asplenium Felix=foemina..... I.25

I7.50 Osmundi Claytonia............ I.75

6.50 Lastrea Dilitata.............. 1.75

6.50 Onoclea Sensibilis............. I.00

6.50 Onoclea Struthiopteris.........

6.50 Osmunda Gracilis.............. I.75

8.00 Osmunda Cinnamonae.......... I.75

25.00 Scolopendrium Vulgaris..... 2.00

FUNKIA (Day Lily)

Coerulea. Blue .............8

6.50 Subcordata Grand. White.... I.35

6.50 Undulata Med. Pict. Varie-

6.50 gated foliage, purple........ I.35 GAILLARDIA (Blanket Flower)

Grandiflora. Red and orange.. .90

9.00 GERANIUM (Crane's Bill)

9.00 Grandiflora. Violet blue...... I.IO

Endressi. Light rose........ I.IO

6.00 GALEGA (Goats' Rue)

Hartlandii. Blue and white... I.OO

6.50 Coccineum. Scarlet.......... I.Io

6.50 Mrs. Bradshaw (Neiv).

8.00

8.00
I 1.00

I I.00

7.00

II .00

II .00

I 5.00

8.50

8.50

6.50

6.50
7.50

7.50

7.00

7.50
GENTIANA

Andrewsii. Blue ........... Doz. 100 GRASSES (Extra Strong)

Arundo Donax .............. I.50 I0.00

Pennisetum Japonicum ....... I.25 $\quad 8.00$

Erianthus Ravennae .......... I.00 8.00

Eulalia Grac. Univit. ............ I.00 $\quad$ I.00 8.00

“J Jap. Variegata ......

Zebrina ............... $1.00 \quad 8.00$

Gynerium Argent ......... 2.00 I 5.00

Phalaris Arund. Variegata... $\quad .85 \quad 6.00$

GYPSOPHILA

Paniculata. White.......... .90 6.50 FI. PI.

Double white.. 2.00 I 5.00 HELENIUM (Sneezewort)

Autumnale Sup. Yellow...... I.IO 7.50

Grand. Striatum. Orange.... I.IO 7.50

Riverton Beauty. Lemon yel-

low ................. I.60 II.00

Pumilum Magnificum. Golden

yellow ................. I.Io 7.50 HELIANTHUS

Miss Mellish. Yellow....... .90 6.50

Mult. FI. PI. Double yellow.. I.00 7.00

Rigidus. Yellow ............ .90 6.50

Wolly Dod. Yellow.............. $.90 \quad 6.50$

Orygalis.. Golden yellow..... $.90 \quad 6.50$ HELIANTHEMUM (Rock Rose)

Mixed colors .............. I.IO 7.50 HELIOPSIS (Orange Sunflower)

Pitcheriana. Yellow......... .906 .50 HELLEBORUS (Christmas Rose)

Niger. Pure white......... 2.7522 .00 HEMEROCALLIS (Yellow Day Lily)

Aur. Major. Orange........ 2.00 I 5.00

8.50 Flava. Yellow................ $90 \quad 6.50$

Fulva. Deep orange..........90 6.50

Kwanso FI. PI. Coppery red.. I.00 7.50

7.00 Dumortieri. Rich yellow...... $\quad .90 \quad 6.50$

Dr. Regal. Apricot........... I.50 II.00

8.50 Sovereign. Chrome yellow.... 2.00 15.00 HEUCHERA (Alum Root)

6.50 Sanguinea. Scarlet ......... I. IO 7.50

6.50 Flambeau. Light rose.......... I. IO 7.50

Pink Beauty. Clear pink..... I.Io 7.50

I .00 HIBISCUS

7.00 Meehani. Mixed colors....... $2.00 \quad$ I2.50

I I.00 Moscheutos Roseus. Pink.... $.90 \quad 6.50$

7.00 Crimson Eye. White, crimson

8.00 eye $\ldots \ldots \ldots \ldots \ldots \ldots \ldots .96 \ldots .90 .50$

I.50 10.00

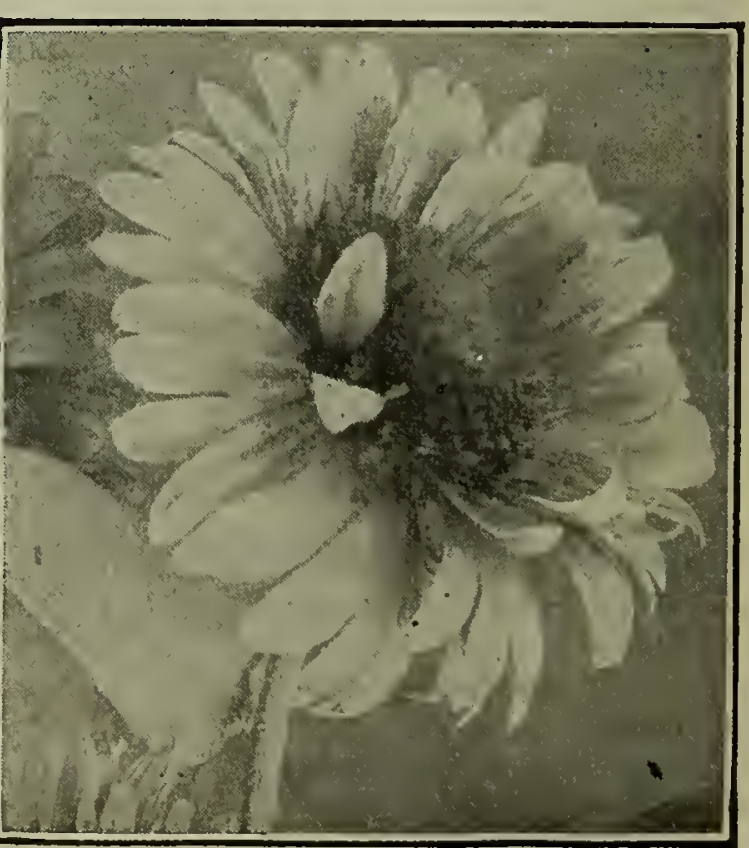

Gaillardia 


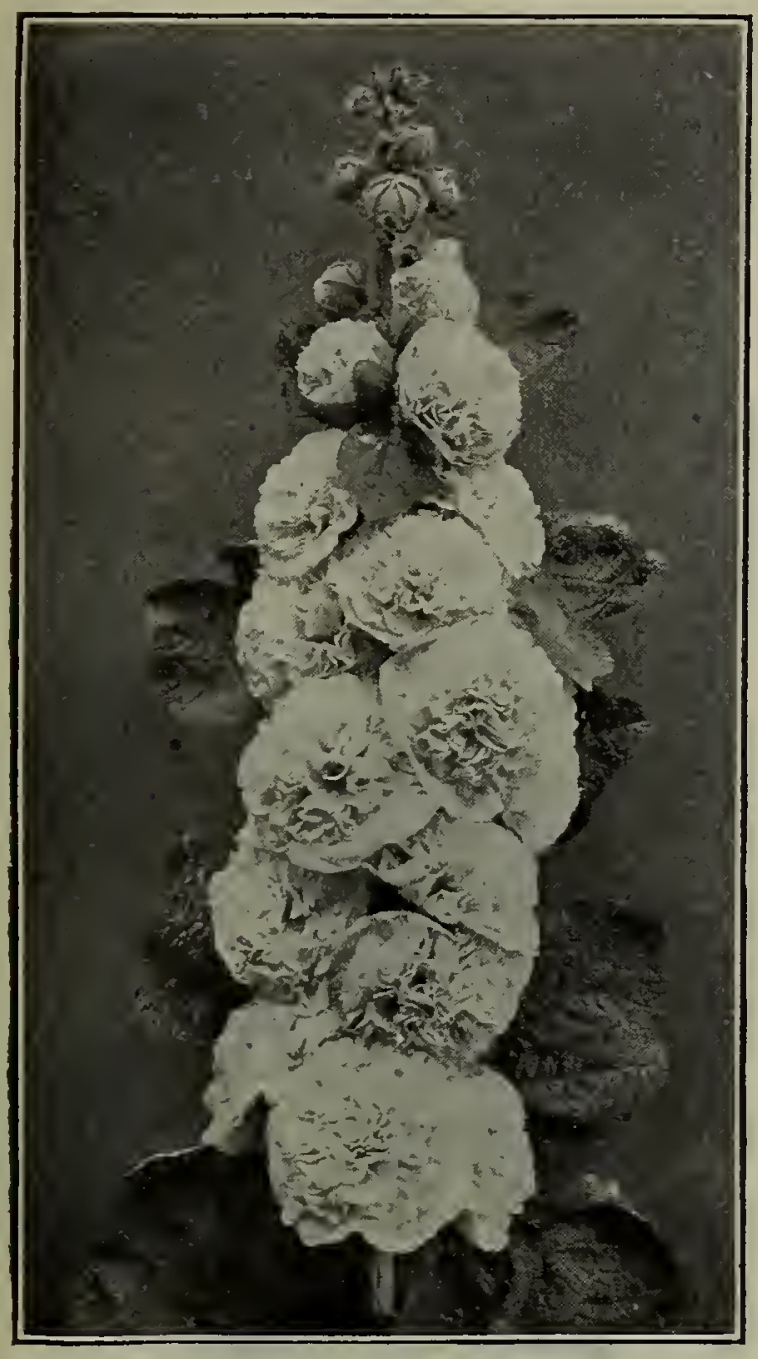

HOLLYHOCKS Doz. 100

Double. White .......... \$1.50 \$10.00 Crimson $\ldots \ldots \ldots \ldots$. I.50 I0.00 Salmon $\ldots \ldots \ldots \ldots \ldots$. $1.50 \quad 10.00$ Canary yellow ......... Pink ............... 1.50 I0.00 Maroon ............ I.50 10.00

Newport Pink ......... I.50 10.00 Mixed colors .......... I. 1.25

Single. Mixed colors ....... I.25

Allegheny. Se mi - doubi e,

fringed, mixed colors....... I.25 8.00

HONEYSUCKLE (Pot Grown)

Chinese Evergreen ......... 2.00 I 5.00

Halleana $\ldots \ldots \ldots \ldots \ldots \ldots \ldots 2.00$ I 15.00

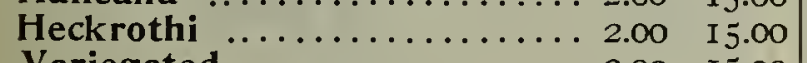

Variegated .............. $2.00 \quad$ I5.00

Red Coral ............... 2.00 I 5.00 HOP VINES $\begin{array}{llrl}\text { Japanese } \ldots \ldots \ldots \ldots \ldots \ldots \ldots & .75 & 6.00 \\ \text { Golden Leaved } \ldots \ldots \ldots \ldots \ldots & \text {..25 } & 8.00\end{array}$

INCARVILLEA (Hardy Gloxinia)

Delavayi ................ I.35 8.50

Grandiflora ............. I.35 IPOMEA (Moon Vine)

Pandurata ................ I.10 IRIS GERMANICA (German)

Eugene Sue. White and spotted.

Gypsie Queen. Lavender.

Leonidas. Mauve.

Glorie de Hillegom. Light blue.

Gracchus. Crimson and white.

Honorabilis. Yellow and bronze.

Innocenza. Pure white.

Kharput. Deep blue.

Mad. Chereau. White edged blue.

Maori King. Golden yellow.

Pallida Dalmatica. Lavender. \$I.jo per doz., per I00 \$10.00.

Queen of May. Light pink.

Price at top of next column.
Price of any German Iris (except where noted), 90c. doz., per Ioo $\$ 6.50$.

Mixed, all colors, 50c. doz., per I00, \$3.50. IRIS KAEMPFERI (Japanese)

\section{Double varieties.}

Geishoi. Crimson purple.

Hodai. Lavender, veined purple.

$\mathbf{H o}=\mathbf{0}=\mathbf{J} \mathbf{0}$. Deep purple.

Kan Ran. White, veined violet.

Koki=No=lro. Purple, veined white.

Kuma Funjiu. Lilac, veined white.

Mana Dsura. Pure white.

Renjo=No=Toma. Violet and white.

Uchu. Purple, shaded crimson.

Wakamurasaki. Purplish crimson.

Yomo=No=Umi. Double white.

Single varieties.

Komanyo. Violet blue, veined white.

Osakazuki. Mauve, shaded lilac.

Tora=0dori. Lavender, white ground.

Yomo Zakuru. Purnlish red.

Price of separate named varieties Japanese Iris, $\$ 1.35$ doz., per I0o $\$ 8.50$.

Mixed, all colors, doz. 85 c., $\$ 5.00$ per 100 .

IRIS PUMILA Doz. 100

Azurea. Light blue......... \$0.85 $\$ 6.00$

$\begin{array}{lll}\text { Lutea. Yellow } \ldots \ldots \ldots \ldots \ldots \ldots & .85 & 6.00 \\ \text { Violacea. Dark blue.......... } & .85 & 6.00\end{array}$

\section{IRIS SIBIRICA}

Orientalis Blue King. Deep

Orientalis .................

white $\ldots \ldots \ldots \ldots \ldots \ldots \ldots$. I.IO IVY

English. $2 \frac{\mathrm{T}}{2} \mathrm{2}$-inch pots....... 1.25 4-inch pots.......... 2.00 KUDZU VINE

Pueraria Thunbergiana....... I.75 LATHYRUS LATIFOLIUS

Albus $\ldots \ldots \ldots \ldots \ldots \ldots \ldots \ldots$ I.I5

Phite Pearl $\ldots \ldots \ldots \ldots \ldots \ldots \ldots \ldots \ldots$. 2.50 LIATRIS (Blazing Star)

Pycnostachia. Purple......... .90
LLY OF THE VALLEY

Large clumps ............ 2.00 I5.00 LOBELIA

Cardinalis. Vivid crimson.... .90 LUPINUS

Moerheimi. Pink.......... 2.25 I6.00

Polyphyllus. Blue............ White $\ldots \ldots \ldots \ldots$...... LYCHNIS

Chalcedonica. Scarlet ...... .90

Dioscea Rosea. Pink.......... I.I 5

Haag. Hybrida. Orange scar-

let .......................

Semperflorens PI. Pink........ 35

Viscaria. Red............. I.35 LYTHRUM (Loosestrife)

Roseum Superbum. Pink.... .90

Virgatum. Bright pink........ I.50 MONARDA (Bergamot)

Didyma. Scarlet $\ldots \ldots \ldots \ldots .90$

Fistulosa Alba. White....... .90 MONTBRETIA (Bulbs)

Aurantiaca. Golden yellow... .25

Crocosmiaeflora. Scarlet and yellow

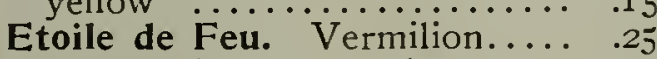

Pottsii. Orange scarlet...... .20

Rayon d'Or. Yellow.......... .25

Speciosa. Yellow ............
OENOTHERA (Evening Primros

OENOTHERA (Evening Primrose)

Missouriensis. Yellow........ 1.10 7.50

Youngii. Lemon yellow........ I.IO 7.50

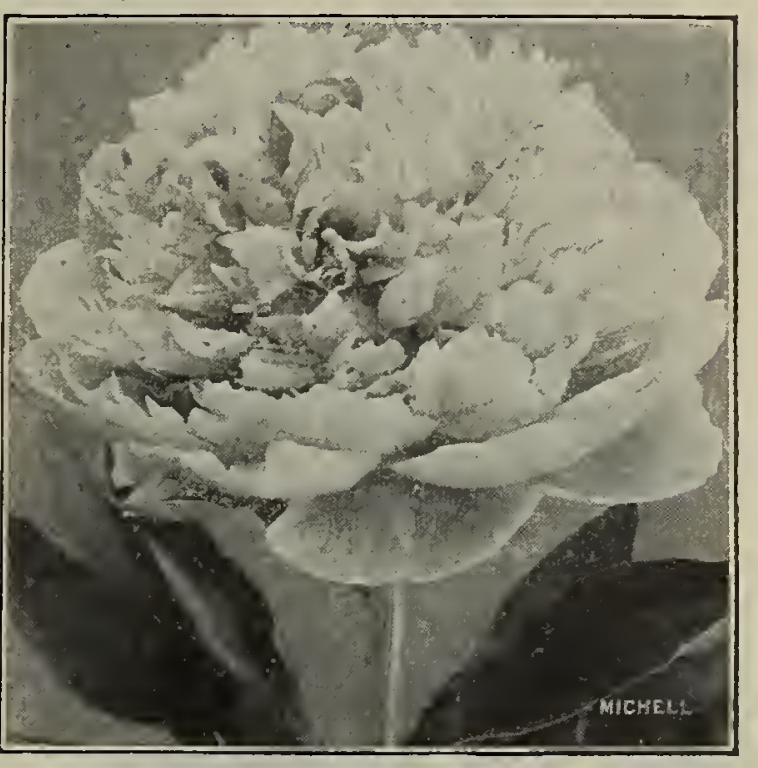

Paeony-Achille

PAEONIES (Double)

Named Varieties

Sorts marked * are especially suited for

florists' cut flowers.
Achille. Shell pink.......... \$i.50 100
$\$ 10.00$

Agnes M. Kelway. Cream... I.50 I0.00

*A nem. Flor. Rubra. Crimson. $2.00 \quad 15.00$

Charlemagne. Pink........ $3.00 \quad 20.00$

Clarisse. Rose pink.......... I.75 14.00

Couronne d'Or. White...... $3.25 \quad 22.00$

Duc de Wellington. White.. 3.00 20.00

Edulis Superba. Pink....... I.75 I2.50

*Festiva Maxima. White.... 2.50 I8.00

Marie Lemoine. Cream..... 4.00 30.00

Tenuifolia FI. Pl. Red...... 2.50 I 8.00

Beaute Francaise. Lilac rose 2.50 18.00

Berlioz. Magenta rose...... 2.50 18.00

Dr. Brettonneau. Lilac rose. I.75 I2.50

* Carnea elegans. Flesh color. 2.50 I8.00

Delicatissima. Lilac rose... $3.50 \quad 25.00$

Eugene Verdier. Soft pink... 3.50 25.00

Faust. Delicate pink......... I.75 12.50

*Grandiflora Rosea. Solferino I.75 12.50

L'Indispensable. Delicate

cream ................ $3.50 \quad 25.00$

Mme. Forel. Light pink........ $3.50 \quad 25.00$

Mons. Krelage. Dark pink... $3.50 \quad 25.00$

* Mlle. Leonie Calot. Rosy

white ................ $3.00 \quad 22.50$

*Alba Plena. Purest white... I.75 12.50

Duchesse de Nemours. White 2.00 I 6.00

La Rosiere. Yellowish white. 2.00 I6.00

Delachi. Purple...........2.00 16.00

6.50 *Felix Crousse. Bright red... 3.50 25.00

8.00 General McMahon. Deep vio-

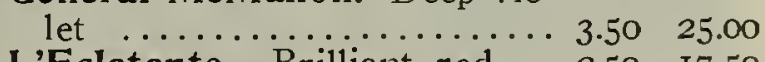

L'Eclatante. Brilliant red... 2.50 17.50

8.50 Meissonier. Purplish red..... 2.25 I6.50

8.500 *Victor Hugo. Brilliant red... $5.00 \quad 35.00$

Tree Paeonies

In Io choice named varieties, 80 . each, $\$ 8.75 \mathrm{doz}$.

Unnamed Paeonies Doz. 100

Chinensis Alba. White....... $1.00 \quad 7.00$ $\begin{array}{llll}\text { Rosea. } & \text { Pink...... } & \text { 1.00 } & 7.00 \\ \text { Rubra. } & \text { Red..... I.00 } & 7.00\end{array}$

*Officinalis Rosea. Pink, early 1.50 I0.00 I.50* "6 Rubra. Red, early I.00 7.00 * “ Alba. White, early 1.50 I0.00 I.50 Single Roots of Paeonies (not priced) I.25 of the dozen rate, thus: If $\$ 1.75$ per doz., I.50 price will be I7 cents each, etc.

PACHYSANDRA Doz. 100 Terminalis. $\begin{gathered}\text { Green foliage.....\$I.Io } \$ 7.50 \\ \text { Variegated. Varie- }\end{gathered}$ gated foliage. 


\section{Michell's Hardy Perennial Plants and Roots (Continued) \\ PENTSTEMON (Beard Tongue) \\ POPPY}

Doz. 100 Fiancée. Pure white....... \$o.90 $\$ 6.50$ Iceland.

Barb. Torreyi. Scarlet....... \$1.10 \$7.50 Hanny Pfleiderer. White and Digitalis. Pure white......... I.IO 7.50 PHYSOSTEGIA (False Dragon Head) Virginica. Soft pink ......... \$0.90 $\$ 6.50$ Manky Pfleiderer. White and Richard Wallace. White and Alba. White........ $90 \quad 6.50$ Frau Anton Buchner. Pure

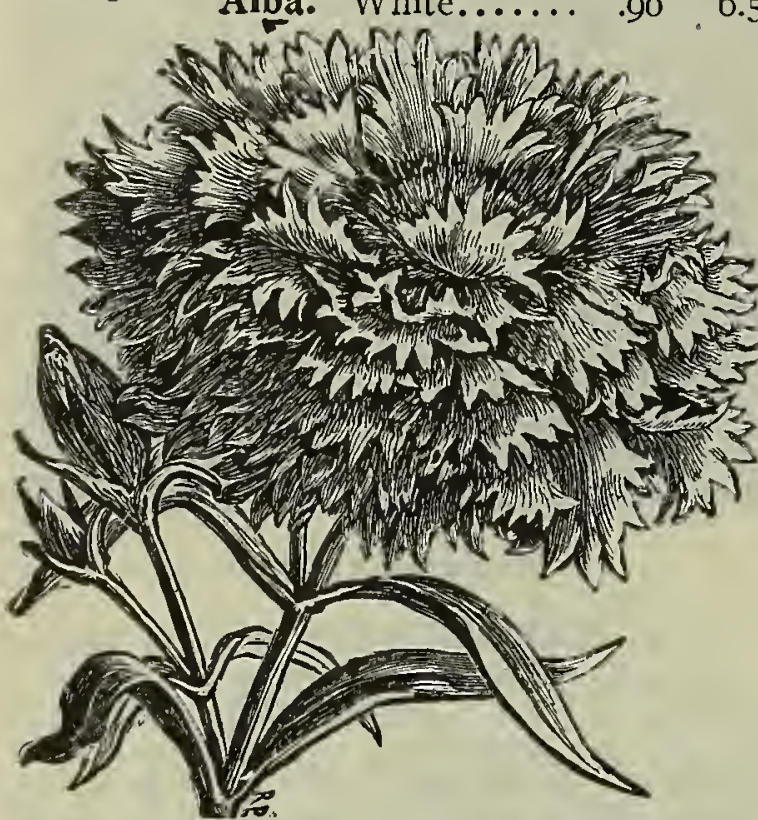

Hardy Pinks

PINKS-DOUBLE (Hardy Garden)

Carmen. Pink

Delicata. Pink

Her Majesty. White.

Lord Lyon. Pink.

White Reserve. White.

Plumarius FI. PI. Mixed..... I.00 6.50

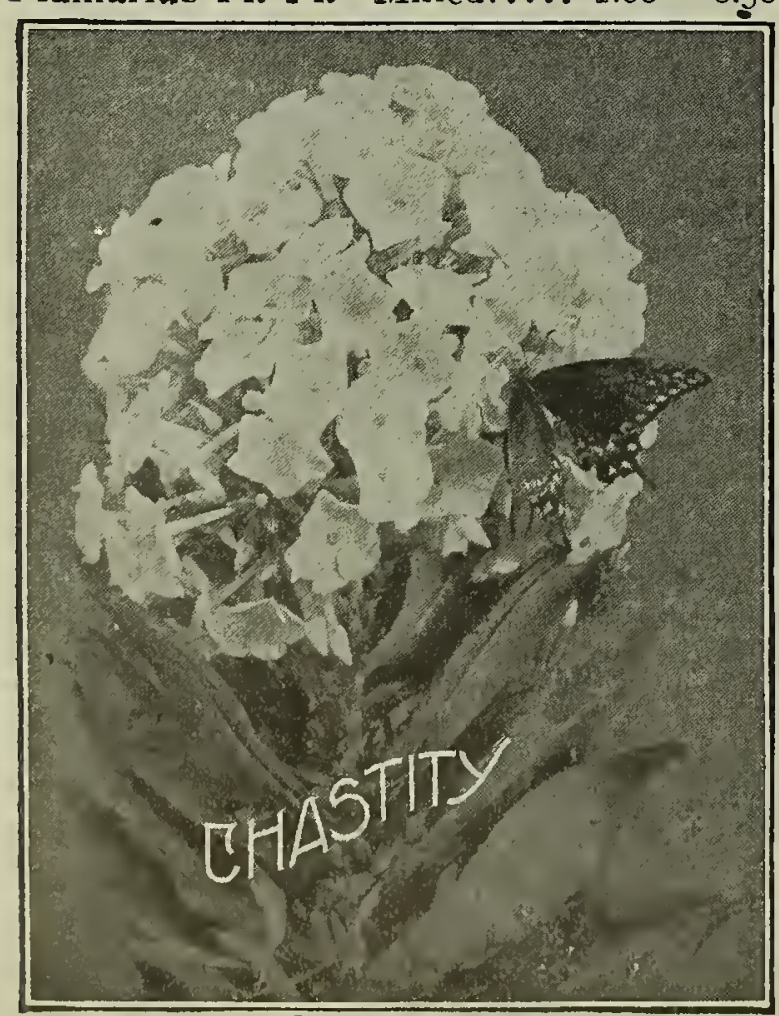

Ph́lox Chastity

PHLOX (Hardy)

Strong plants.

Doz. 100

Chastity $(N e w)$. Pure white. \$r.50 \$I 0.00

Coquelicot. Scarlet.

Dr. Konigshofer. Red.

Elizabeth Campbell. Pink.

Matador. Red.

Miss Lingard.

Mrs. Jenkins. White.

Pink Beauty

Rheinstrom. Pink.

Europa (New). Blush whit

pink eye

\section{J
V
G
R
L
$M$
$M$
V
A
A
T
W
B
E
F
G
G
G
E}

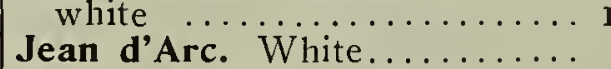

$\begin{array}{ll}\text { Von Lassburg. Pure white.... } & .85 \\ \text { Mad. Paul Dutrie. Soft pink. } & .85\end{array}$

Gruppen Konigin. Rose Pink. I.25

R. P. Struthers. Deep salmon .85

Le Mahdi. Deep purple.

Montagnard. Purple.

Mad. P. Langier. Red.

Von Hochberg. Crimson...... I.

Asia. Purple................ I.25

Africa. Rich purple......... I.25

Tower of Eiffel. Light salmon .85

Wm. Robinson. Carmine.

Baron V. Dedem. Deep pink.

Embrazement. Pink.

Fernand Cortez. Cerise pink.

General von Heutsz. Salmon.

Goliath. Cerise.

Gen. Chanczy. Orange.

Eugene Danzanvilliers. Lav-

ender .................. $85 \quad 5.50$

PHLOX (Miscellaneous Varieties)

Divaricata Canadensis. Lav-

ender .................. I.00 6.50

Subulata Rosea. Moss pink... $85 \quad 5.50$

Alba. White....... $.85 \quad 5.50$

For full description of Hardy
page 138 of our Retail Catalogue.

PLATYCODON (Bell Flower)

Grand. Blue.............. 90

White $\ldots \ldots \ldots \ldots \cdots \cdots$
PLUMBA GO (Leadwort)

Larpentae. Blue............ I.IO PRIMULA (Hardy Primrose) Veris (Cowslip). Mixed...... .85 Polyanthus. Red, edged yellow r.00

Auricula. Mixed...

$\mathrm{r} .50$

Vulgaris. Yellow.............
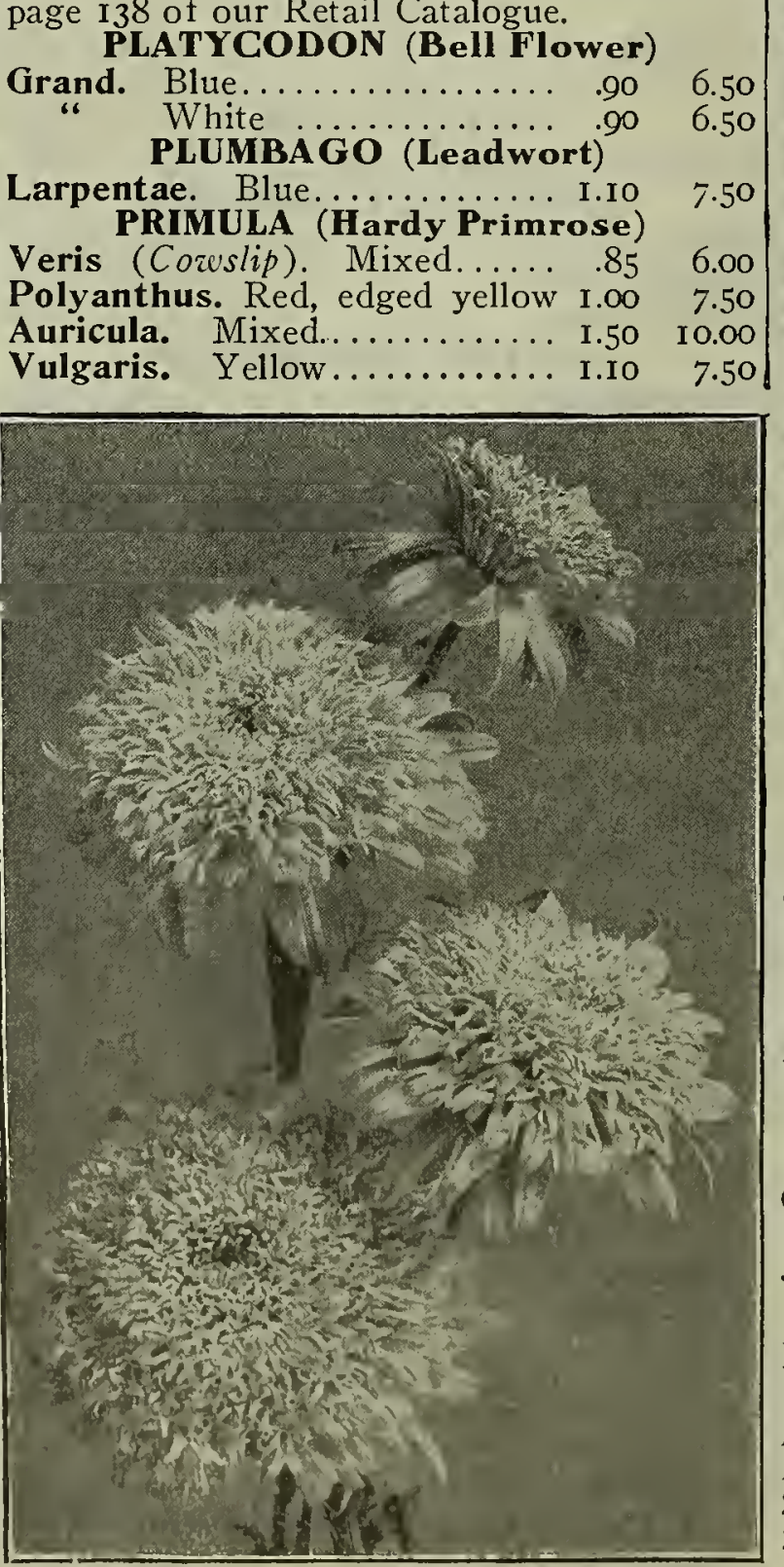

Pyrethrum Ne Plus Ultra

5.50

$5 \cdot 50$

$5 \cdot 50$

5.50

$5 \cdot 50$
$5 \cdot 50$
Doz.

Yellow

$\begin{array}{crr}\ldots .35 & 8.50\end{array}$

6.50 Orientalk

“

8.00 " " Fürsten Kind. Scarlet I.IO 8.50

“50 “ Parkmanni. Crimson I.IO 8.50

5.50 “ Goliath. Scarlet..... 1.50 I0.00

Hybridum. Single mixed...... I.IO 7.50

5.50 Uliginosum. Single white.... $.90 \quad 6.50$

5.50 Ne plus ultra. Soft lilac, double 2.50 r 8.00

5.50 Roi de Rouges. Double, red... $2.50 \quad$ I 8.00

7.50 Princess Metternich. Double

8.00 white $\ldots \ldots \ldots \ldots \ldots \ldots \ldots 2.50$ I 8.00

8.00 ROSES (Pot Grown) See page 68.

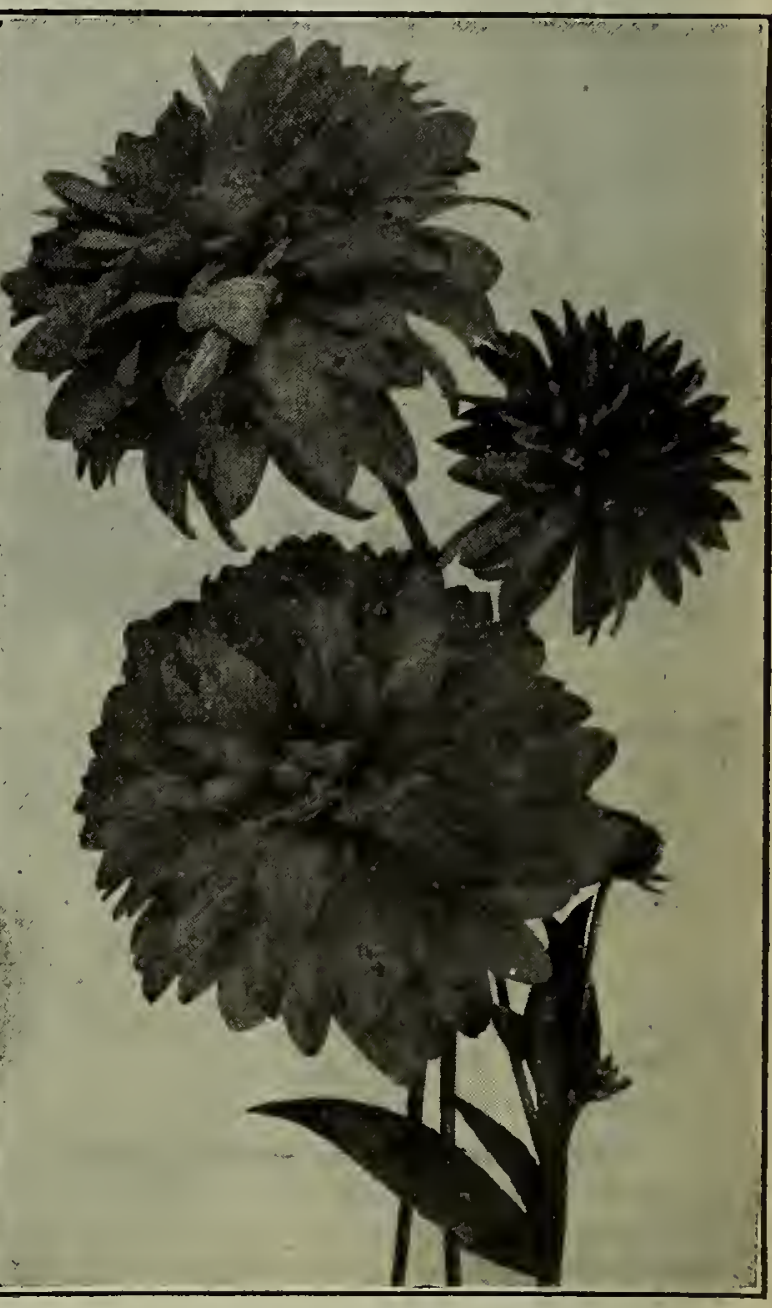

Rudbeckia Golden Glow

RUDBECKIA (See cut above)

Golden Glow. Double yellow. . $\$ 0.90 \quad \$ 6.50$ Newmani. Single yellow...... I.IO 7.50 Purpurea. Single purple...... I.Io 7.50

Azurea. Blue........... Io 7.50 Virgata Nemorosa (Neiv).

Dark blue ............... 2.00 I 5.00 SCABIOSA

Caucasica Alba. White....... r.50 10.00 Blue $\ldots \ldots \ldots \ldots \ldots$ I.50 10.00

Japonica. Rich bilie............ I.35 9.00

SCHIZOPHRAGMA (Climbing Hydrangea)

Hydrangeoides, each 6oc., doz. $\$ 6.00$. SEDUM (Stone Crop)

Acre. Yellow............... $85 \quad 6.00$

Album. White $\ldots \ldots \ldots \ldots \ldots, 85 \quad 6.00$

Sieboldi. Pink.............. I.00 7.00

Spectabilis. Pink.............. $1.00 \quad 7.00$

Brilliant. Amaranth

red $\ldots \ldots \ldots \ldots \ldots$ r.50 10.00 


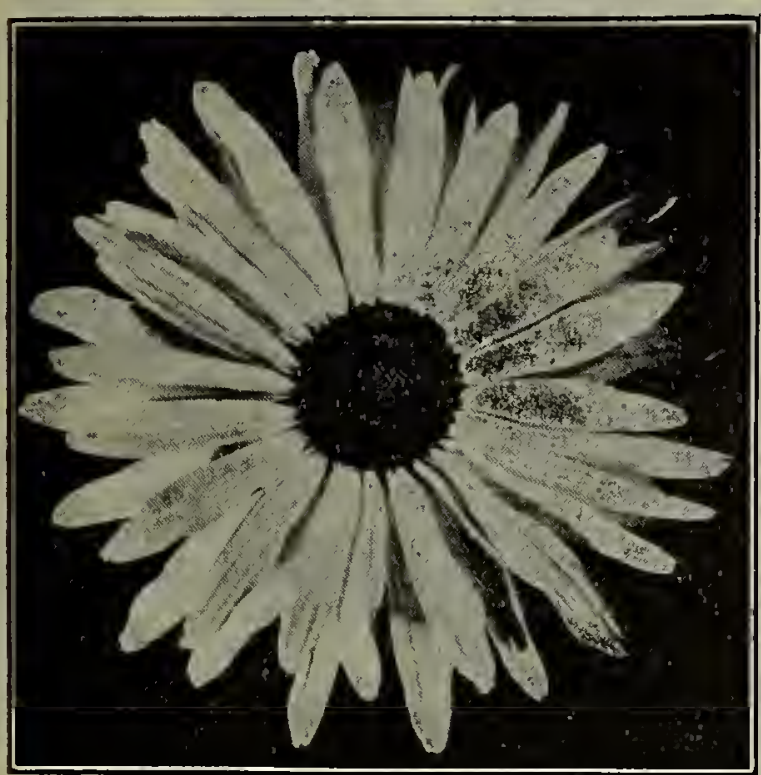

Shasta Daisy

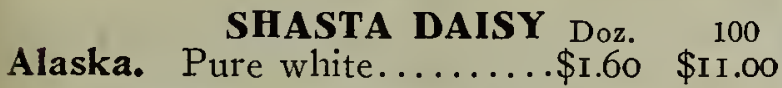
STACHYS (Woundwort)

Betonica Rosea. Rich pink.... I.35 SPIRAEA (Drop Wort)

Filipendula FI. PI. White.... I.35 STATICE (Sea Lavender)

Latifolia. Dark blue........ I.Io

Eximia. Lilac ............... 1.ro STOKESIA (Cornflower Aster) Cyanea Alba. White...$\ldots \ldots$. . 90 Blue ............... .90

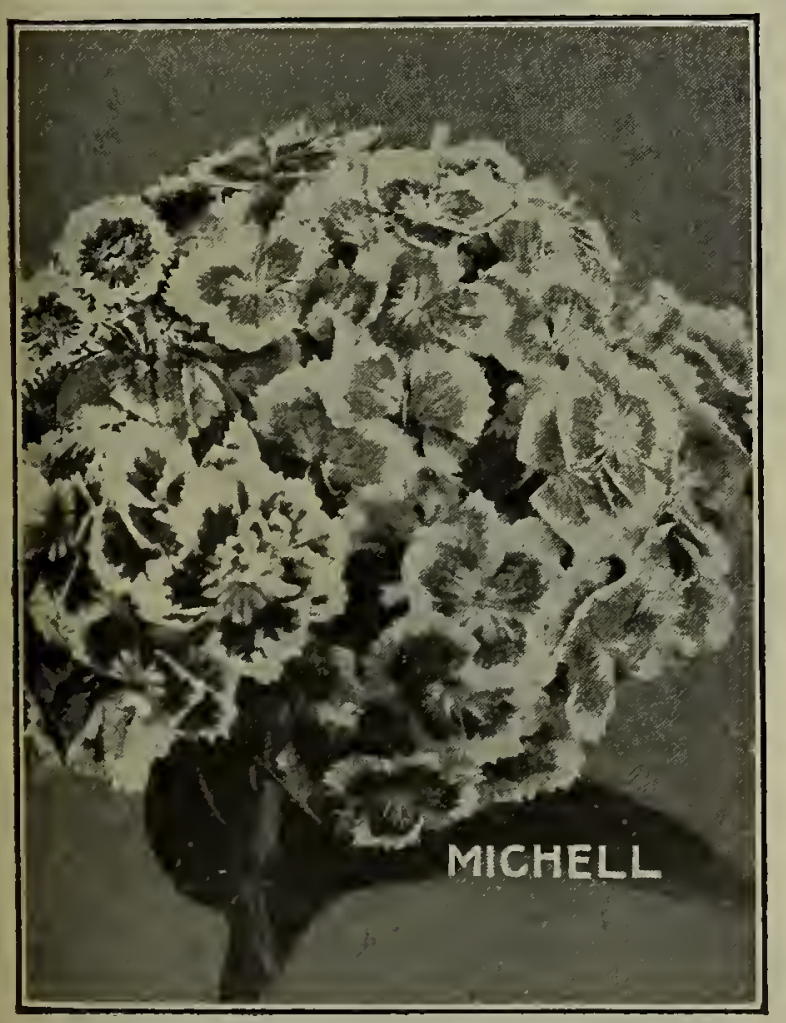

Fabacea. Yellow.......... \$1.50 \$10.00 TRILLIUM (Wood Lily)

Erectum. Purple................ $85 \quad 5.50$ Grandiflor. White.. 85

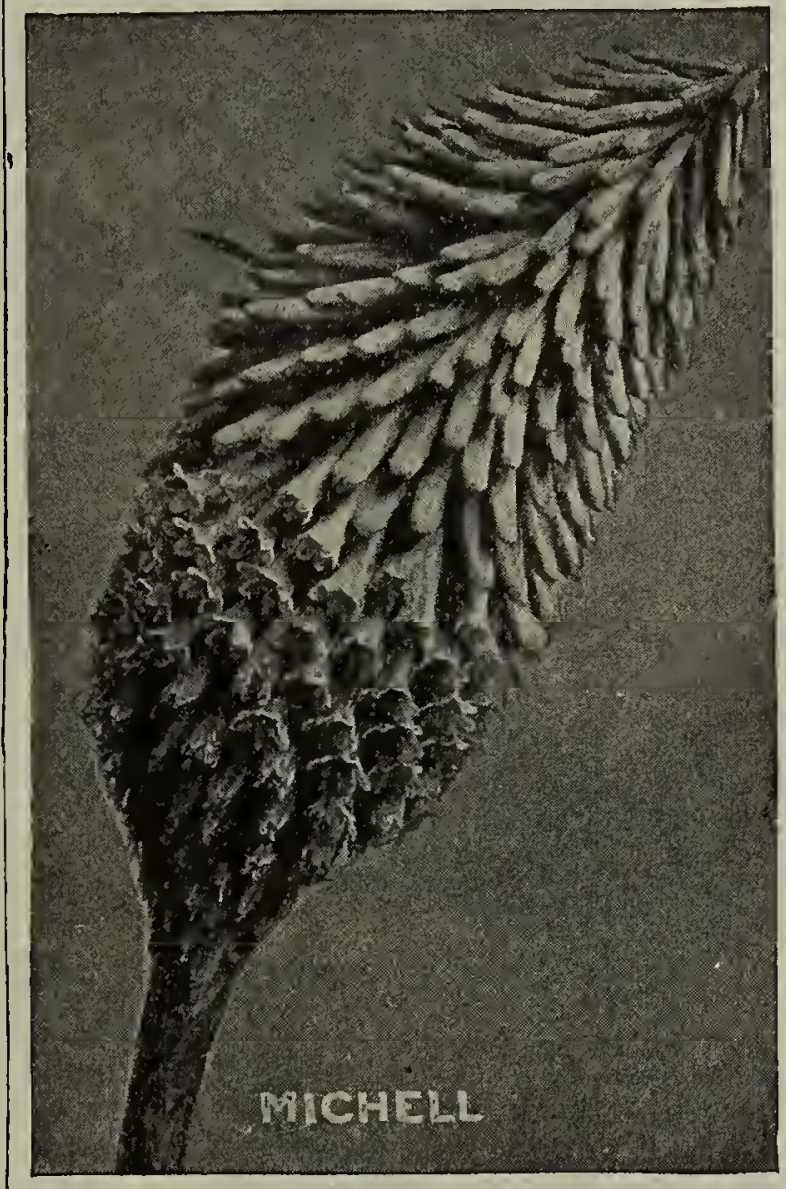

\section{Tritoma}

TRITOMA (Flame Flower)

$\begin{array}{lll}\text { Pfitzeri. Orange scarlet...... } \$ \text { Doz. } .25 & \$ 8.00\end{array}$ TROLLIUS (Globe Flower)

Europaeus. Yellow.......... I.50 I0.00 Cauc. "Orange Globe." " Deep

$\begin{array}{ccc}\text { orange .................... } & \text { I.50 } & \text { 10.00 } \\ \text { Japonicus "Excelsior." Orange } & \text { I.50 } & \text { 10.00 }\end{array}$ VALERIANA (Spurred Flower) Coccinea. Rich red.......... I.35 Alba. White....... I.35

Officinalis. Pink............ I. 35

VERONICA (Speedwell)

Amethystina. Blue.......... I.Io Incana. Blue .............. I. Io

Long. Subsess. Blue ........ I.50

Virginica Alba. White....... I.Io

Spicata. Blue .............. I.Io

Virginica. Pale blue.......... I.Io VINCA (Periwinkle)

Aurea. Variegated foliage, lav-

ender blue ............... I.50 I0.00 Minor. Lavender blue....... $90 \quad 600$

VIOLA CORNUTA (Tufted Pansies)

Blue and Purple............ .70 4.50 SWEET WILLIAM

Crimson $\ldots \ldots \ldots \ldots \ldots \ldots \ldots . \$ 0.90 \quad \$ 6.50$

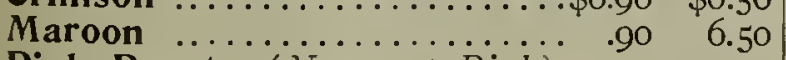

Pink Beauty (Ncwport Pink).

Pink $\ldots \ldots \ldots \ldots \ldots \ldots \ldots \ldots .6 .90 \quad 6.50$

$\begin{array}{llll}\text { Pure White..................... } & .90 & 6.50 \\ \text { Red White Eye............ } & .90 & 6.50\end{array}$

Prize Mixture. Ail colors..... . .80

THALICTRUM (Meadow Rue) Aquileg. Atrop. Purple...... I.35 Album. IVhite....... I.35 8.50
8.50
Gustav Wermig. Blue....... I.35 8.50

White and Yellow........... 40 .70 4.50

Mixed WALFLOWER

8.50

YUCCA (Adam's Needle)

8.50 Filamentosa. White........ I.60

Chinensis Alba. Each 40c., \$4.00 doz. Blue. Each 40c., \$4.00 doz.
6.00

Miscellaneous Plants, Vines and Shrubs

Boxwood. For edging....... Do.75. $\begin{array}{cc} & 100 \\ \$ 5.00\end{array}$

Berberis. Thunbergii, 18 to 24

inches $\ldots \ldots \ldots \ldots \ldots \ldots \ldots 2.00 \quad 12.50$

Cobaea Scandens. 4 in......... I.50 I 2.00

Moon Vine Learii. Blue...... 1.20 9.00

Moon Vine Noctiflora. White

4 in ................... I.50 I2.00

Moon Vine Paniculata. Pink... 2.00 15.00

Passion Vines. 4 in.......... I.50 10.00

Viburnum Carlesi...Each, 65c. 7.00

Opulus .......... 2.00 15.00

Plicatum .........2.2.00 15.00

Weigelia E. Rathke......... 2.50 I7.50

Rosea ............ 2.50 17.50

Abel Carriere......... 2.50 17.50

Amabilis ........ 2.00 I 5.00

Tamarix Hispida Aestivalis.... 2.50 I 7.50

Euonymus Radicans........... I.IO 8.50

Azalea Amoena, I2 to I 8 in... $\$ 0.60$ Doz. A. Koster …........ $\quad .75 \quad 7.50$ Mollis, I5 to 18 in........ 60 5.50

Doz. $\quad 100$

Calycanthus Floridus........\$2.50 \$17.50

Deutzia Gracilis ............. 2.00 I5.00

Forsythia Fortunei............ 2.00 I 5.00

Hydrangea Paniculata Grand.. 2.00 I5.00

Hydrangea Arborescens $\because \ldots \ldots{ }^{2.50}$ I 7.50

page I46, Retail Catalogue.)

Hypericum Moserianum......2.00 I 3.00

Kalmia Latifolia, I8 to 24 in... $\$ 0.65 \$ 7.00$

Lilac. Charles X............ .40 4.00

“ Marie Le Gray......... $.40 \quad 4.00$

“ Persian Purple........ .40 4.00

" " White ........ .40 4.00

$\begin{array}{lllll}\text { “ Common Purple } \ldots \ldots . & .20 & 2.00 \\ & & \text { White } \ldots . . . & .20 & 2.00\end{array}$

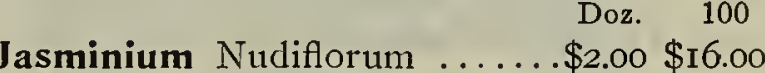
Officinalis $\ldots \ldots 2.00 \quad \mathrm{I} 6.00$

Each Doz.

Rhododendrons in 8 distinct
named sorts, I 2 to I5 buds...\$1.00 \$IO.00

Spirea. A. Waterer......... \$I.75\$12.50

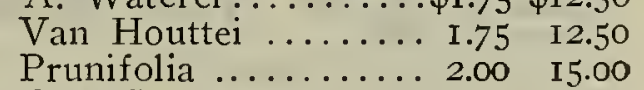
7.50 Philadelphus Coronarius....... 2.00 I 5.00 PRIVET (California)

We grow large quantities of this, which is extra fine.

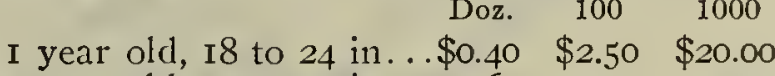
2 year old, 24 to $30 \mathrm{in}$... $.60 \quad 3.50 \quad 32.00$ 2 year old, 30 to $36 \mathrm{in} \ldots . .75 \quad 4.50 \quad 42.00$

\section{GOLDEN LEAVED PRIVET}

I 8 to 24 in., 2 year old, \$I.25 per doz., per I00 $\$ 9.00$.

Testimonial on Michell's Hardy Plants

FAIRMONT, W. VA.

WISTARIA

6 Plants of a Variety at Dozen Rate, 25 at 100 Rate

(hc) 


\section{Planet Jr. and Iron Age Farm and Garden Tools, Etc.}

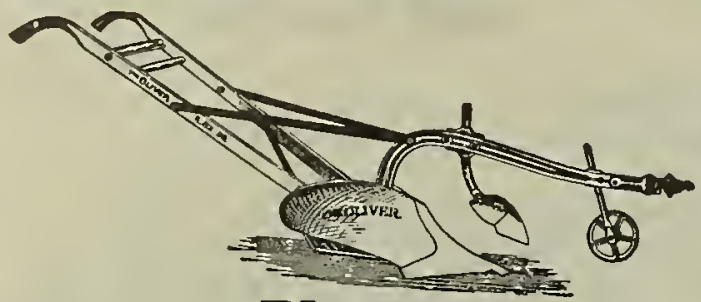

Plows

SOUTH BEND PLOWS

This plow has been one of the favorites in the section of Philadelphia for many years. It is substantially made, neat, and gives splendid satisfaction.

No. IB. For one horse, wood beam...\$5.00

No. 2. For one heavy horse or two

light horses, wood beam... 7.25

No. 3A. 2-horse, wood beam....... 9.00

No. 4. 2-horse, heavy, wood beam... 9.50 OLIVER PLOWS

A 2. I-horse, plain, wood beam.

ro. 2-horse, medium, wood beam.

$\$ 4.50$

The prices above are for plain plows with clevis only. Jointers and wheels can be supplied for Nos. 2, 3, 4 and IO.

If wheel only is wanted, add $\$ 1.00$, or if jointer only is wanted, add $\$ 2.00$. We can also supply Gale and Syracuse Plows.

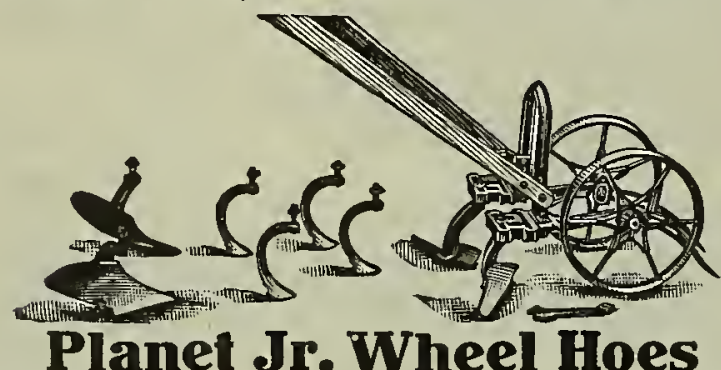

No. I2 Double wheel (see cut) $\ldots . \$ 6.50$

No. I 3 Double wheel.

No. II Double wheel.

No. I4 Double wheel.

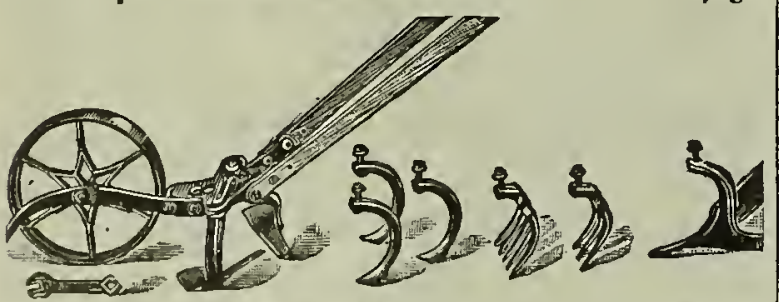

No. I6 Single wheel.

No. I7 Single wheel

No. I8 Single wheel.

No. 38 Single wheel.

No. 30 Single wheel.

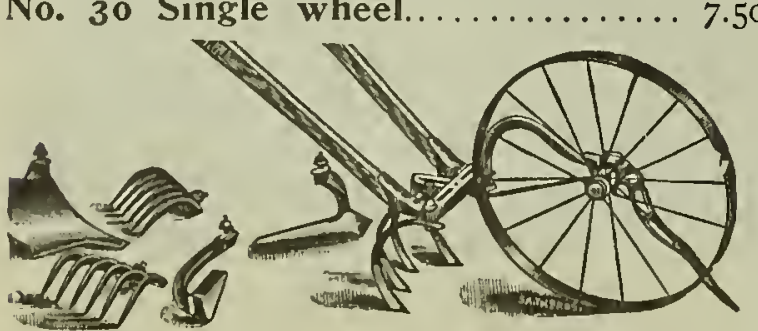

\section{Iron Age Wheel Hoes}

No. 9 Single wheel (see cut).... \$5.25

No. Io Single wheel.

No. I I Single wheel.

No. I2 Single wheel.

3.25

Planet Jr. Wheel Hoe Parts

Sicle Hoes, per pair, 4\%/2-inch, 8oc.; 6 -

inch, 90c.; 7 -inch

Side Plows, per pair.

Cultivator Teeth, each

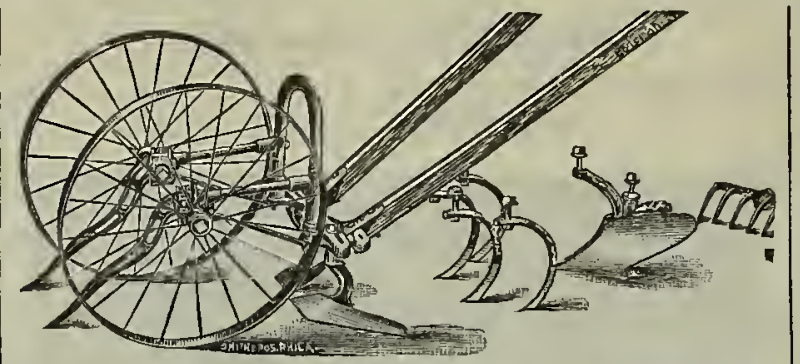

\section{Iron Age Double Wheel Hoes}

No. I Double Wheel Hoe (see cut) $\ldots$ \$7.00

No. 3 Double Wheel Hoe......... 4.25

Iron Age Hand Plow (no wheel) ..... I.35

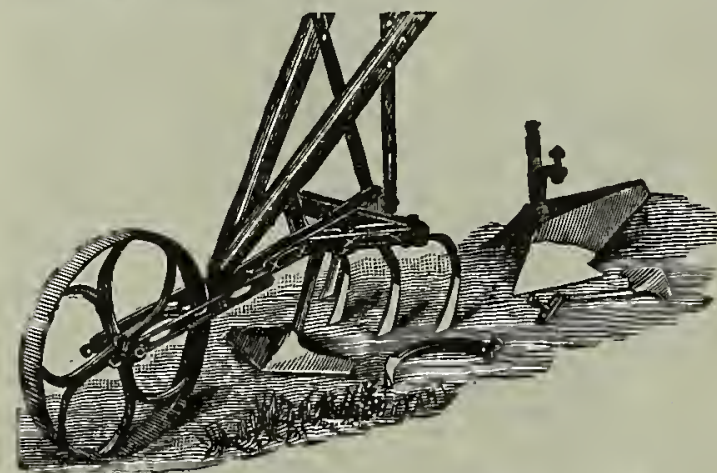

GEM SINGLE WHEEL HOE

Of garden tools this is the most popular being low in price and complete in detail suited for most any work in a garden. It weeds, hoes, hills and harrows. Price, $\$ 4.75$ Gem Double $=$ Wheel Hoe

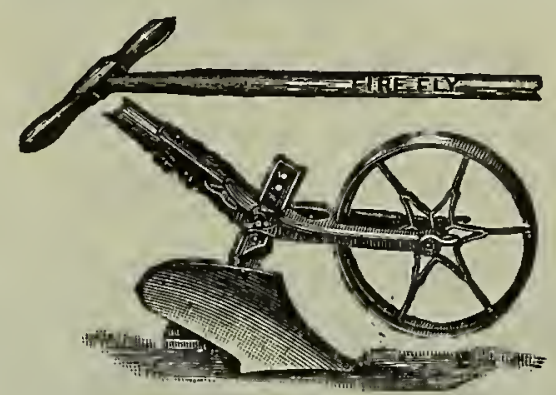

FIRE-FLY GARDEN PLOW

Exceedingly useful to every owner of a garden. It throws furrows various widths very desirable for plowing up gardens for new crops (after general plowing in spring). Price, $\$ 2.25$

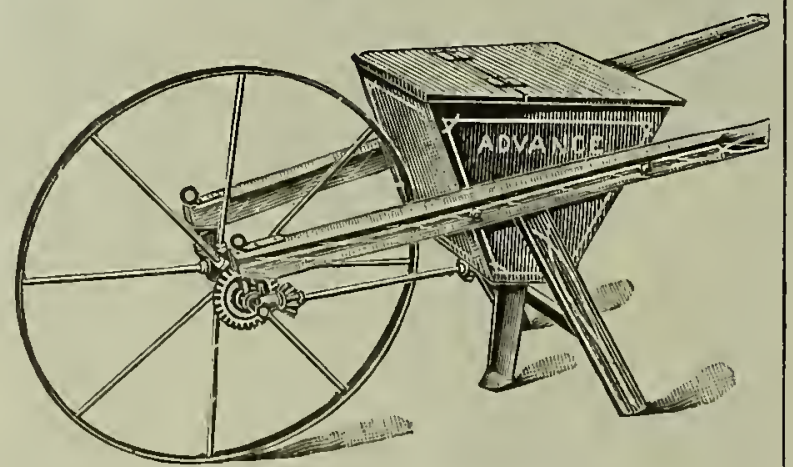

\section{“ADVANCE" FERTILIZER DRILL}

Best low-priced distributor on the market. A shut-off to prevent the escape of fertilizer when wheeling around end of row, is little things which go far, however, in making a tool valuable. A first-class machine for the drilling of peas and corn. Price, 35 each, \$6.50.

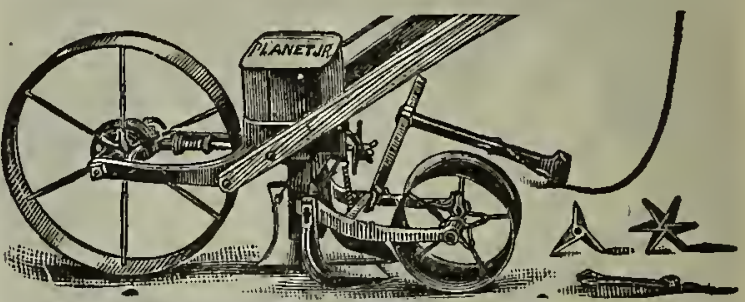

No. 4 Planet Jr. Combined Hill and Drill Seeder, Wheel Hoe Cultivator, Plow, Ete.

This is the most popular combined tool made. It combines in a single implement a first-class hill-dropping seeder, a singlewheel hoe or weeder, a cultivator and a plow. The hopper holds $2 \frac{1}{2} 2$ quarts of seed, which can be sown in rows, or dropped in hills at $4,6,8$, I 2 or 24 inches apart.

The drill is detached and the tool frame substituted by removing but one bolt. It then becomes a single-wheel hoe.

Price, complete as described above, \$10.50. As a seeder only, $\$ 8.50$.

No. 3 PLANET JR. SEEDER

This seeder is the latest and most perfect development of the hand seed drill. It sows evenly in drills, and also drops in hills at $4,6,8$, 12 or 24 inches apart. It is thrown out of gear instantly by moving a convenient lever, or the flow of seed is stopped by pushing down the feed rod. No time is lost, no seed is wasted. It is quickly set to sow the different kinds of seed in the exact thickness required. Hopper holds 3 quarts. No. 3 Planet Jr. cannot be equipped as a wheel hoe. Price, \$10.00.

Prices of Planet Jr. Drills (Not lllustrated)

No. I ....... \$9.00 No. 2 ...... \$7.00

No. 25. Combined................ I 3.00

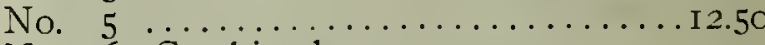

No. 6. Combined.................. 13.00

No. 6. Plain, as a drill.............. I0.50

No. 28. Combined................ I 4.50

No. 29. Plain, as drill............... II.00

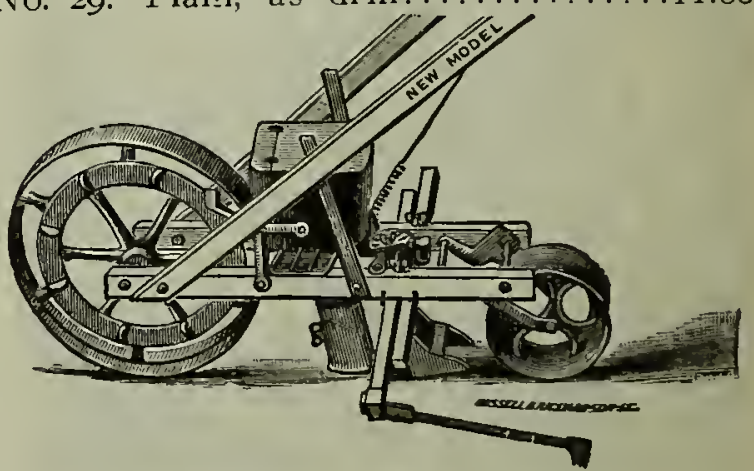

THE MODEL SEED DRILL

It is designed as a drill seeder only; the depth of sowing can be regulated to any desired distance. It is well named the market gardeners' drill, having a large capacity for seeds, and is a wonderfully efficient machine. Price, $\$ 7.50$.

IRON AGE SEED DRILLS

No. 6 Double and Single $=$ Wheel Hoe, Hill and Drill Seeder combined, complete, \$12.00. No, 7 Hill and Drill Seeder only, $\$ 9.00$.

No. 4 Double and Single=Wheel Hoe, and Drill Seeder combined, complete, \$II.00. No. 5 Drill Seeder only, $\$ 8.00$.

No. 22 COMBINED FERTILIZER DISTRIBUTOR, HILL AND DRILL SEEDER

The two operations-seeding and fertilizing-are done in one. Price, \$17.00. 
Iron Age and Planet Jr. Farm and Garden Tools, Etc.

Write for a complete catalog on either IRON AGE or PLANET JR. TOOLS-Mailed Free.

No. 607-E.L.

7-TOOTH IRON AGE CULTIVATOR

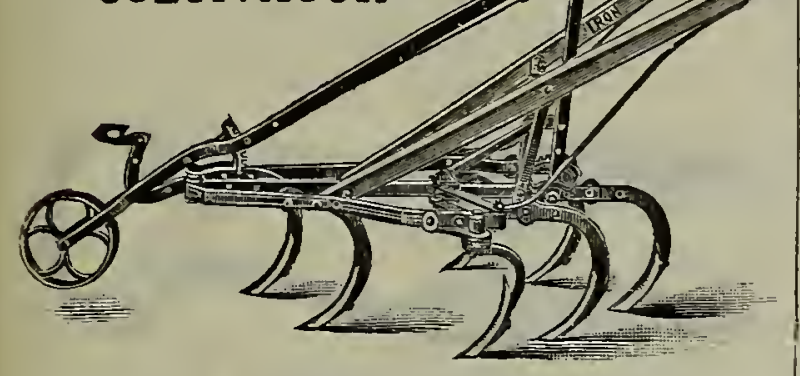

By means of the lever wheel the depth may be regulated with a single stroke of the arm; the expanding lever renders it able to go through very narrow rows successfully. The cultivator may also be used as a five-tooth machine by merely unbolting two teeth and arms. Price. \$6.50.

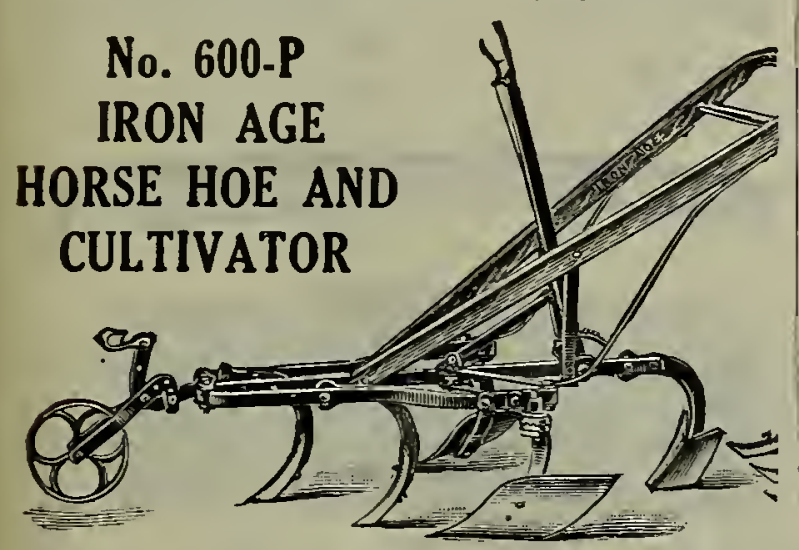

Equipped with side steels or coverers, which can easily be detached, and the regular cultivator teeth, which accompany each implement, attached. Price, \$5.50.

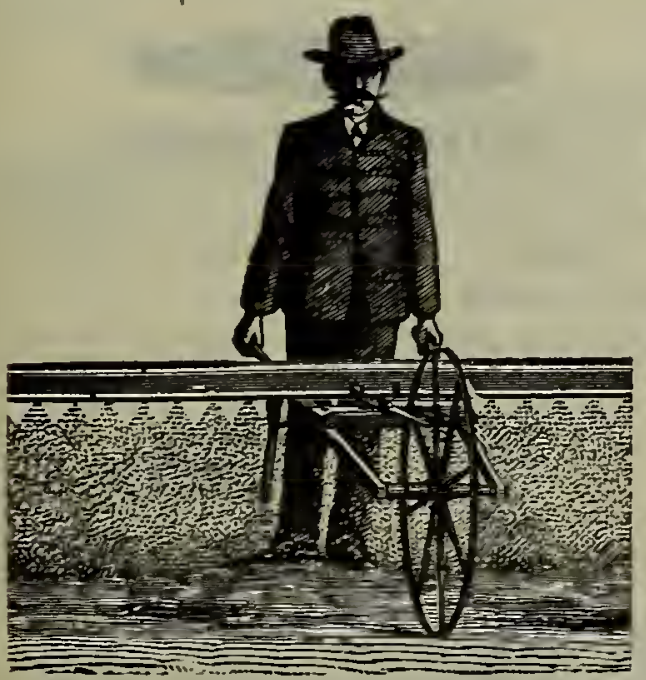

GRASS SEEDERS

These machines are now largely used for distributing grass and other seeds over large areas. The distributing box is very near the ground, which is an important feature, preventing the seed from blowing away and thus coming up unevenly.

సo. 5 ( 14 feet sowing area), $\$ 6.75$.

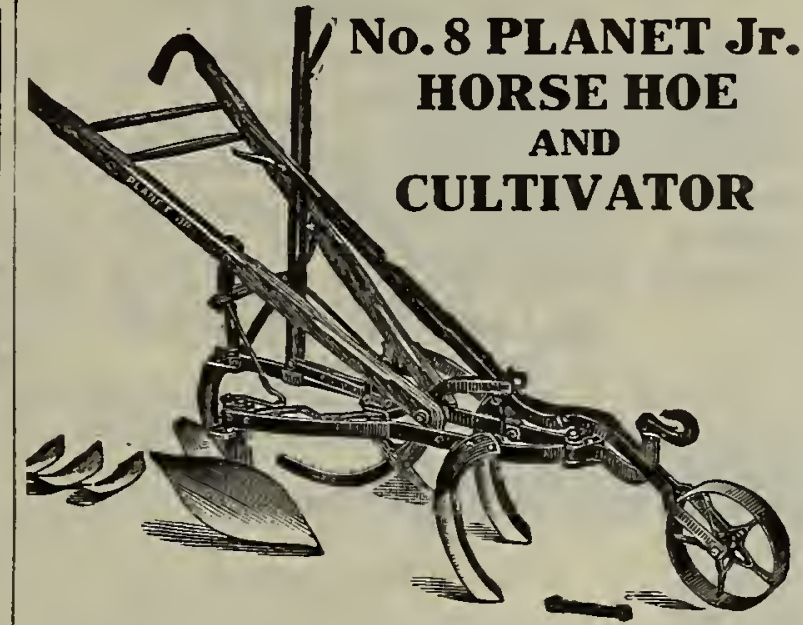

Made of steel throughout. The lever wheel and depth regulator enable the operator to increase or lessen the depth of tilling by the mere stroke of the arm. The side or covering steels and shovel which is in the rear may be taken off and the arms so turned that when the extra teeth, which accompany the machine, are attached, it presents a perfect five-toothed cultivator. Price, with cast wheel as above, \$8.50.

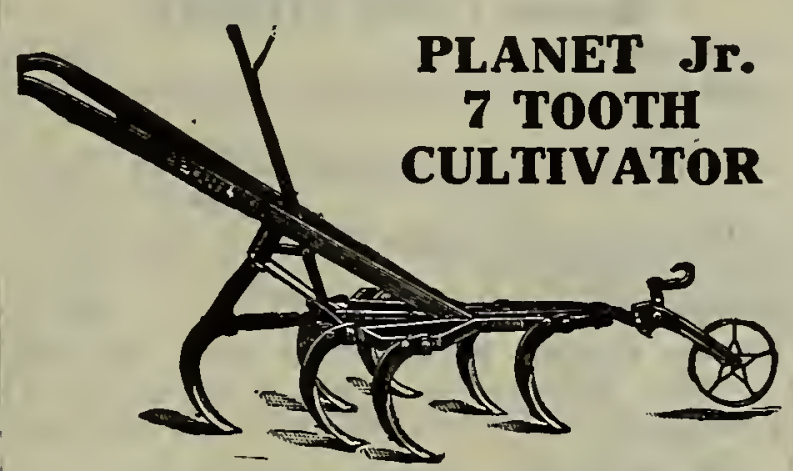

Many gardeners like the 7 -tooth cultivator because it prepares the soil better than does the 5-tooth machine. The expanding lever makes possible to cultivate a row of greater width than is possible with a smaller size. Price, complete as in cut, \$7.50. IVithout wheel, $\$ 6.75$.

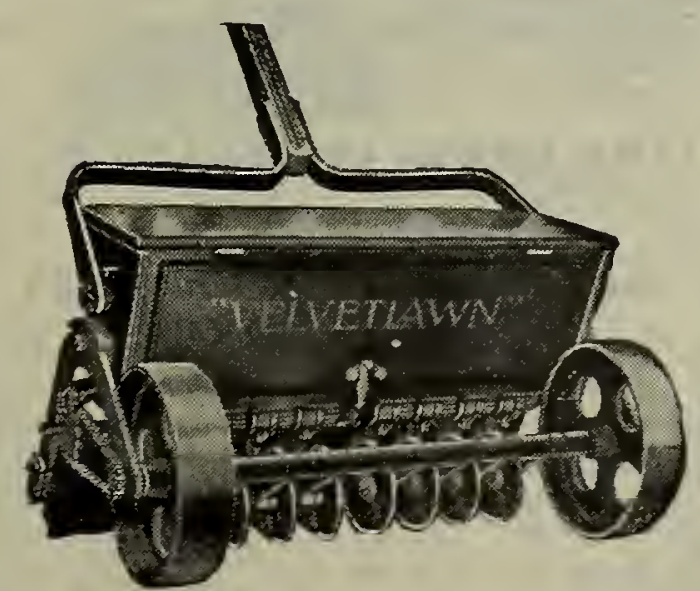

\section{"VELVETLAWN" SEEDER}

An excellent machine for properly sowing grass seed. It places it in the ground in close furrows, covers and rolls it at one operation. The result is an even, quick growth of grass. Fine for resowing in established lawns. Price, \$I4.00.

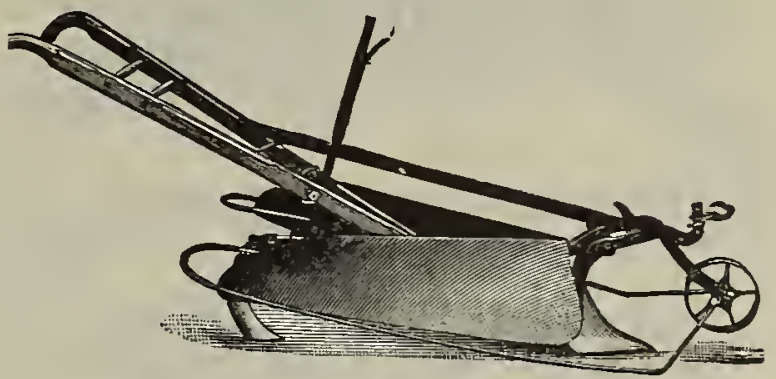

Planet Jr. Double Celery Hiller

\section{PLANET Jr.CELERY HILLER}

For throwing earth against celery plants prior to blanching, nothing equals this machine. Made in two styles. Single, for hilling one side of the row. Double, for hilling one side of two rows. Price, double style, \$15.50; single style, \$12.50.

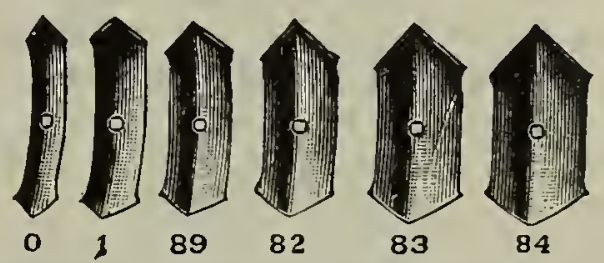

\section{IRON AGE CULTIVATOR TEETH}

\begin{tabular}{|c|c|c|c|}
\hline Width & Each & Width & Each \\
\hline$-\mathrm{I} / \mathrm{d}$ in &.$\$ 0.10$ & $82-3$ & . \$o.II \\
\hline$-\mathrm{I} / 2 \mathrm{in}$ & . . .IO & $83-3^{T / 2}$ & in.... .I \\
\hline $\mathrm{I}-2$ in & . Io & $84-4$ & in. . \\
\hline$-21 / 2$ in & .10 & $68-4$ & in. \\
\hline
\end{tabular}

Bolts for Teeth, 3c. each: per doz., $30 c$.

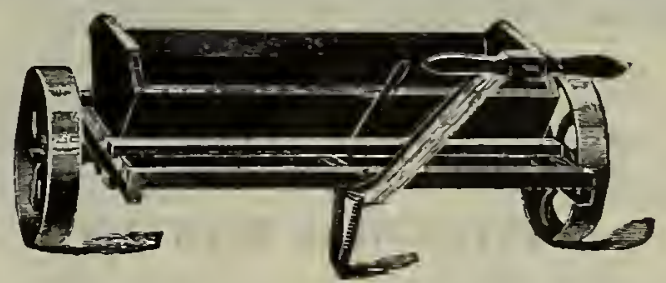

\section{The Stevens Fertilizer Distributor}

For distributing bone meal, wood ashes and other commercial fertilizers on fields, lawns, etc. Insures perfect and even distribution, requiring less time than by the hand process. Machine holds about I $3 / 4$ bu., nicely finished, covering area 3 feet wide. Price, \$I 1.00.

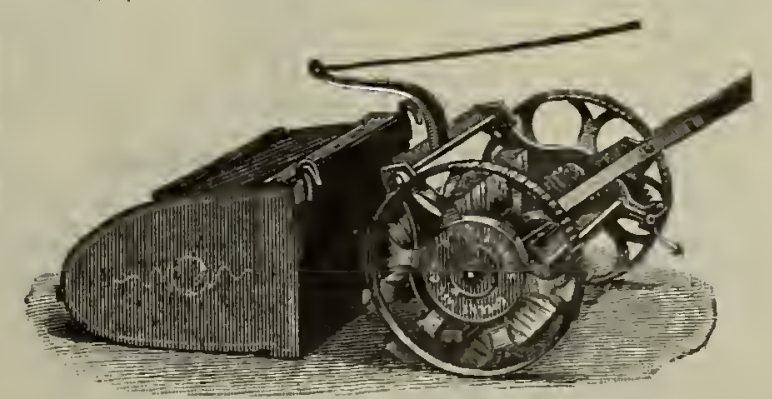

\section{APOLLO LAWN CLEANERS}

For sweeping lawns, paths, golf greens tennis courts, etc. 28 inches wide, with rubber tires. Price, \$I6.25. 


\section{Michell's Lawn Mowers, Rollers, Etc.}

\section{PENNA. LAWN MOWER}

Low wheel, 8-inch diameter. ro-inch..... \$6.65 $\mid$ I6-inch...... I 4 -inch . . . . . 8.55

High wheel, I0 $1 / 2$-inch diameter I5-inch......\$1 I.85 I9-inch. . I7-inch...... I 3.30

PENNA. JR. BALL BEARING

8 -inch or low whieel, 5 -blade cylinder, $5^{\mathrm{T} / 2}$ inch diameter.

I 2 -inch......\$8.05 $\mid$ I6-inch......\$10.45 I4-inch.......9.00 I8-inch....... II.40 ro-inch or high wheel, 5-blade cylinder, 6-inch diameter.

I5-inch......\$12.80 | I9-inch..... \$15.80 \begin{tabular}{l|l}
17 -inch....... I4.25 & 2I-inch....... I7.10
\end{tabular}

\begin{tabular}{|c|c|c|c|c|c|}
\hline \multicolumn{6}{|c|}{ VANIA GOLF } \\
\hline & $\begin{array}{c}\text { Ball } \\
\text { Bearing }\end{array}$ & $\begin{array}{l}\text { Plain } \\
\text { Bearing }\end{array}$ & $\begin{array}{c}7 \text { Blades } \\
9 \frac{1}{2} \text { in. Wheel }\end{array}$ & Bear & \\
\hline & & $\$ \mathrm{II} .40$ & & $\$ 19$. & \\
\hline & & & & 20.90 & \\
\hline & & & $2 I-1$ & & \\
\hline
\end{tabular}

\section{PENNA. PUTTING GREENS}

For cutting undulating greens.

io-inch.....\$10.45 | I6-inch......\$I6.15 I 2 -inch....... I2.35 I8-inch...... I8.05

\section{COLDWELL'S GREENS MOWER}

COLDWLLL'S GRELNS MOWER Price is for either Chat
without Grass Catcher.

I 4 -inch.

16-inch

\$IO.95

4-blade cylinder.

18-inch....... I3.75 18 I8-inch......... II.I0

\section{TOWNSEND'S GOLF WONDER} Without Catcher

I4-inch......\$16.35 | I6-inch. I8-inch I9.95

REGAL HIGH WHEEL

Ball-bearing, 5-blade cylinder. I 4 -inch......\$8.55 $\mid$ I8-inch..... \$10.45 I6-inch.......99.50 20 -inch....... II .40 CONTINENTAL MOWERS

\begin{tabular}{|c|c|}
\hline High wheel. & Low wheel. \\
\hline I5-inch.....\$II.85 & Io-inch.......\$6.6 \\
\hline I7-inch...... I3.30 & I 2 -inch... \\
\hline 19-inch........ 44.70 & I4-inch. \\
\hline $2 \mathrm{I}$-inch.......I6.I5 & $\begin{array}{l}\text { I6-inch } \ldots \ldots \ldots .9 .50 \\
\text { I } 8 \text {-inch } \ldots \ldots \ldots\end{array}$ \\
\hline
\end{tabular}

GREAT AMERICAN BALL BEARING High wheel.

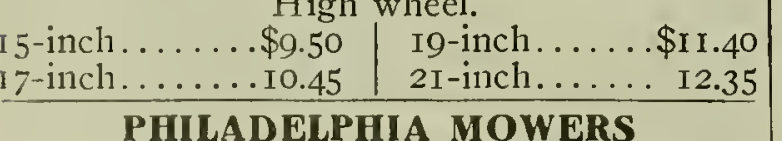

High whcel, style A.| High wheel, style $\mathrm{K}$. I5-inch.....\$10.00 I4-inch......\$6.20

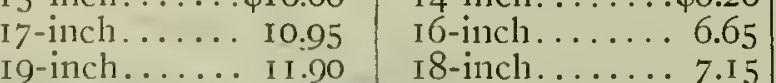

2 I-inch..... I 2.85 20-inch ...... 7.60

\section{NEW DEPARTURE MOWERS}

High whccl, 4-blacle. Low whecl, 3-blade. I5-inch..... $\$ 6.90$ I 2 -inch.....\$4.25

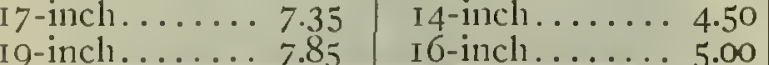
ELECTRA LAWN MOWERS 14-inch H. IV . \$4.50 $\mid$ I2-inch L. W 16-inch II. W. 4.75 14-inch L. W 18-inch T. IV.. 5.00 16-inch $\mathrm{I}_{\text {. }}$ WV Io-inch L. W.: 3.I0 I 8-inch L. W

GRAHAM (PHILA.) MOWERS flower beds and borders.

Coldwell

Penna. Regular style; Ball-bearing...\$4.75 40

Penna. Undercut style; Ball-bearing.. 7.0042 Capitol ....................... 5045 Coldwell Gem. 8-inch cut.......... 4.75 63

American B. B. and New Departure \begin{tabular}{l|l} 
Mowers. & IO-inch...... \$1.35 \\
I5-inch.......\$I.70
\end{tabular} I2-inch....... I.45 I7-inch....... I.80 14-inch........ 1.60 I9-inch........ 1.90

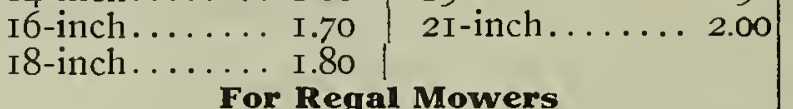
I 4 -inch.......\$I.50 $\mid$ I 8 -inch....... \$r.70 I6-inch........ I.6o $20-i n c h . . . . . .1 .80$ I 4 -inch....... $\$$ I.90 $\mid$ I 8 -inch....... \$2.20 I6-inch...... 2.05 20 -inch.......2.30 sides. Price, 12- to I6-inch size, \$I.I5 each; I8- to 22-inch size, \$I.30.

Coldwell, 25 -in. ............ \$36.00 Coldwell, 30-in. $\$ 52.50$, with seat and shafts $\$ 57.00$.

Coldwell, 35 -in. $\$ 66.50$, with seat and shaft $\$ 71.25$.

Coldwell, 40-in. \$80.00, with seat and shafts

Penna. Pony, 25 -in., .......... \$28.50 Penna. Horse, 30-in., $\$ 57.00$, with seat and

Penna. Horse, 38-in., \$74.I0, with seat and

30-inch cut, with draft irons........\$6 I.75 30 -inch with seat and shafts........ 73.15 38-inch cut, with draft irons....... 80.75 with 4-blade cylinders. Price for 6-blade cylinders on application.

Phila. Eagle, with seat and shafts.

30-inch. $\$ 67.50 \mid 35$-inch. $\$ 82.50 \mid$ 40-inch. $\$ 100$ Philadelphia, with draft irons only. 30 -inch. $\$ 60.00 \mid 35$-inch. $\$ 72.00 \mid$ $\$ 2.50$ for 5 gallons.

\begin{tabular}{|c|c|c|c|}
\hline "BOSS" & HAND & LAWI & ROLLERS \\
\hline Diam. & Long & Sec. & Lbs. \\
\hline To. I-I 5 in. & I 5 in. & 2 & $150 \ldots \ldots \$ 7.25$ \\
\hline Jo. $2-15$ in. & 22 in. & 3 & $200 \ldots$ \\
\hline To. $3-20$ in. & I6 in. & 2 & . . I0.50 \\
\hline To. $4-20 \mathrm{in}$ & $20 \mathrm{in.}$ & 2 & $250 \ldots \ldots$ II. 75 \\
\hline To. $6-20$ in. & $24 \mathrm{in.}$ & 3 & $300 \ldots \ldots 14.00$ \\
\hline To. $7-20$ in. & $24 \mathrm{in}$. & 2 & $\ldots 14.00$ \\
\hline To. $8-20$ in. & $30 \mathrm{in}$. & 3 & $350 \ldots \ldots$ I6.25 \\
\hline o. $9-2+$ in. & $20 \mathrm{in}$. & 2 & $400 \ldots \ldots 18.25$ \\
\hline
\end{tabular}

\$3.35 Sec. Dlam. Widh Welght filled with 3.55 H.IV. $6 \begin{array}{ccccc}\text { I } & 24 & 24 & \text { I } 85 & 560\end{array}$ 3.80 H.IV. 8 I $24 \quad 32 \quad 200 \cdot 710$ 4.00 H.IV.IO 2 I 18 24 $160 \quad 360$

H.W.I2 $2 \quad 24 \quad 32 \quad 230 \quad 710 \quad 19.25$
I5-in. H. IV . \$12.35 I9-in. H. W . \$1 5.20 15-in. H W . \$12.35 I9-111. H. W ..\$15.20

\section{LAWN TRIMMERS}

Grand for cutting around walks, drives,

\begin{tabular}{c|c} 
GRASS CATCHERS & 66 \\
Braun's Make & 67 \\
For the Pennsylvania, Continental, Great &
\end{tabular}

\section{K. C. GRASS CATCHER}

Made of sheet iron bottom and canvas

\section{HORSE LAWN MOWERS} $\$ 85.50$ shafts, $\$ 68.40$ shafts, $\$ 85.50$.

\section{Penna. Grand Horse Mower}

8-inch with seat and shafts........ 95.00 The above prices are for horse mowers

LAWN MOWER OIL (Best Quality)

Quart 20c., 35c. per $1 / 2$-gallon, gallon $65 \mathrm{c}$

\section{BOSS HORSE ROLLERS}

Diam. Length Weight

24 in. $\quad 40$ in. $800 \mathrm{lbs}$. $\$ 38.50$

24 in. $\quad 50$ in. $\quad 950$ lbs. $\quad 52.00$

28 in. 50 in. 1200 lbs. 65.00

24 in. 60 in. $1450 \mathrm{lbs} .57 .00$

28 in. 48 in. $\quad 1350$ lbs. 55.00

28 in. $60 \mathrm{in.}$ I650 lbs. 65.00

$28 \mathrm{in.} \quad 72 \mathrm{in.}$ I950 lbs. 75.00

Also all other sizes.

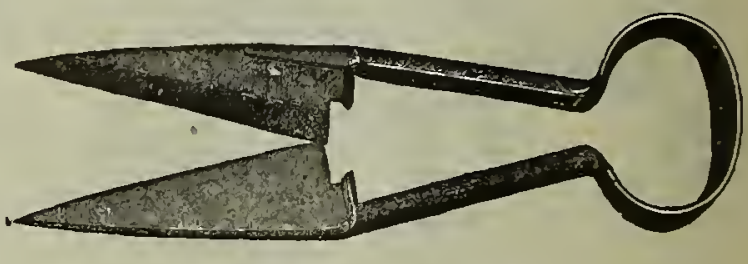

\section{GRASS SHEARS}

No75. 6-inch, English ...........\$0.90 3075. 7-inch, English ............. I.IO I I9. $7 / 2$-inch, Saynor (inside spring) I.35 I20. $7^{1 / 2}$-inch, Saynor............. I.50 360. 6 -inch, English ............ .65 361. $5 \mathrm{I} / 2$-inch $\ldots \ldots \ldots \ldots \ldots \ldots \ldots \ldots . .55$ 263. $51 / 2$-inch, Trowel Shank......... .45 268. $5^{1 / 2}$-inch, Extra Heavy.......... .55 273. American $. . \ldots \ldots \ldots \ldots \ldots \ldots . .30$

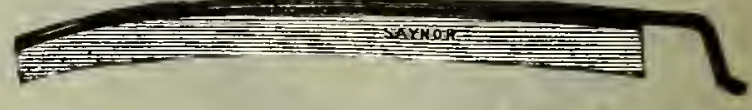

\section{SCYTHES}

English, 32-inch, rivet back........\$1.IO English, 34 -inch, rivet back......... r.Io English, 36-inch, rivet back........ r.20 English, 38-inch, rivet back......... 1.20 English, 38-inch, solid back......... I.35 American, Little Giant, 32 -inch..... .80 American, Little Giant, 34-inch...... .90 American, Little Giant, 36-inch...... I.00 Bush $\ldots \ldots \ldots \ldots \ldots \ldots \ldots \ldots \ldots \ldots . .85$ SNATHES for Scythes $\ldots \ldots \ldots \ldots \ldots$.70 $\begin{array}{lllllll}\text { IV.I2 } & 2 & 24 & 32 & 230 & 710 & 10.25\end{array}$ ballast rollers.

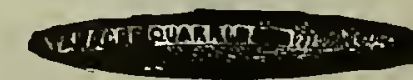

\section{SHARPENING STONES}

Each Doz. Talacre ................ \$0.15 \$1.50 Darby Creek ................ IO I.IO $\begin{array}{llll}\text { Carborundum } \ldots \ldots \ldots \ldots \ldots \ldots & .20 & -2.25\end{array}$

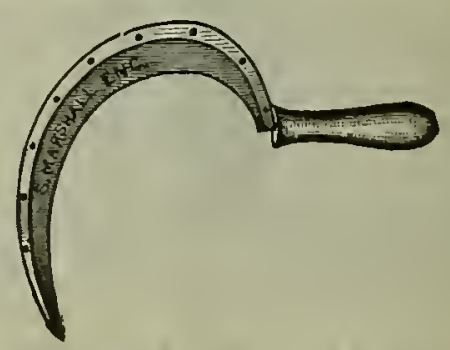

SICKLES OR GRASS HOOKS

English Soldier, No. 3, cach, 55c.; $\$ 5.75$ doz. English Soldier, No. 2, each, 45c.; 5.25 doz. \$1 4.00 English Soldier, No. I, each, 45c.; 5.25 doz. I 5.50 Dutch, small, No. I, each, 25c.; 2.75 doz. 4.75 Dutch, large, No. 2, each, 30c.; 3.25 doz. Little Giant, $\quad$ each, 45c.; $5.00 \mathrm{doz}$. Solid Back, No. 2. each, $40 \mathrm{Oc}$; $4.50 \mathrm{doz}$. Village Smithy, each, $40 \mathrm{c} . ; 4.50 \mathrm{doz}$. 


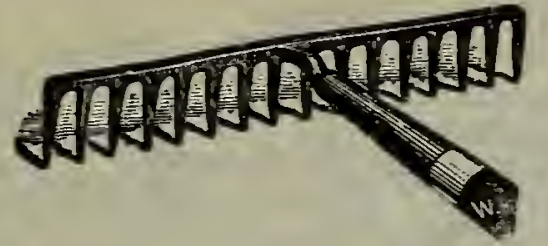

\section{STEEL GARDEN RAKES}

Made of best cast steel, with long teetl for penetrating the ground.

5 tooth......\$0.30 I2 tooth......\$0.50

6 tooth.........40 I4 tooth.......

8 tooth....... .40 I6 tooth...

to tooth........45 48 tooth

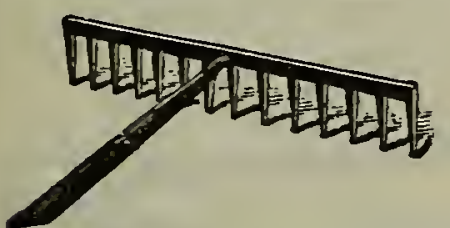

STEEL GRAVEL RAKES

These rakes are used for road-raking and for paths. Having very short teeth they do not gather up stones or gravel.

I2 tooth......\$ \$0.50| I6 tooth.......\$0.60 I4 tooth....... 55 is tooth... 20 tooth. .\$o.70

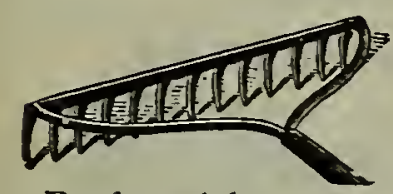

STEEL
BOW
RAKES

Preferred by many to the regular garden rake. The teeth are slightly bent toward the operator.

II tooth.......\$0.55 | I3 tooth......\$0.60

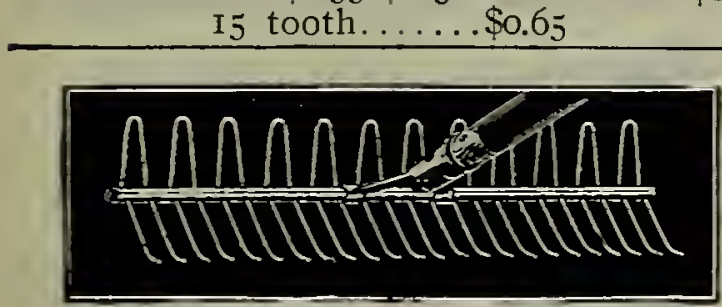

GIBBS OR LAWN QUBEN RAKE

Made of heavy tinned steel wire. These are excellent for lawn or walk work. The rake is reversible and will answer several purposes.

$2+$ tooth

$\$ 0.45 \mid 36$ tooth.

$\$ 0.65$

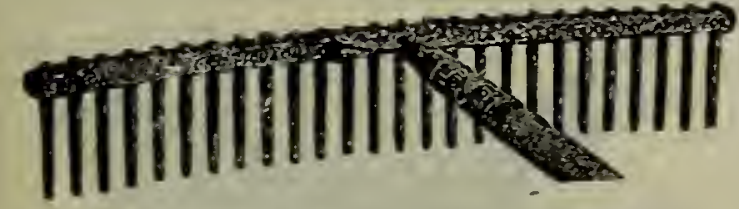

\section{OLE OLSEN LAWN RAKES}

This rake head is slightly curved from the centre to each end which does not allow any material that has been caught by the teeth to slip around the edges.

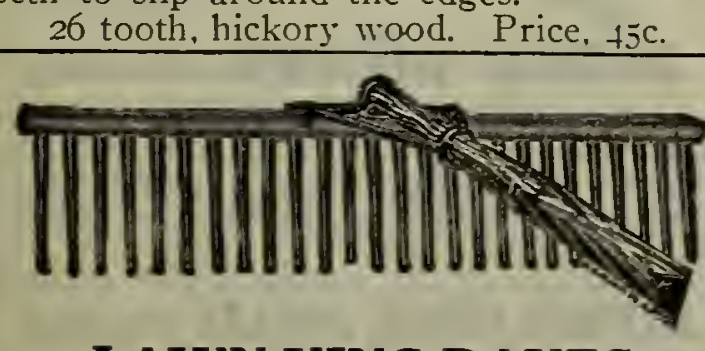

\section{LAWN KING RAKES}

Made of best hard wood, thoroughly braced with iron. The most excellent wooden lawn rake in the market.

22 tooth.......\$0.25|38 tooth.......\$0.65 26 tooth....... .45 5o tooth...

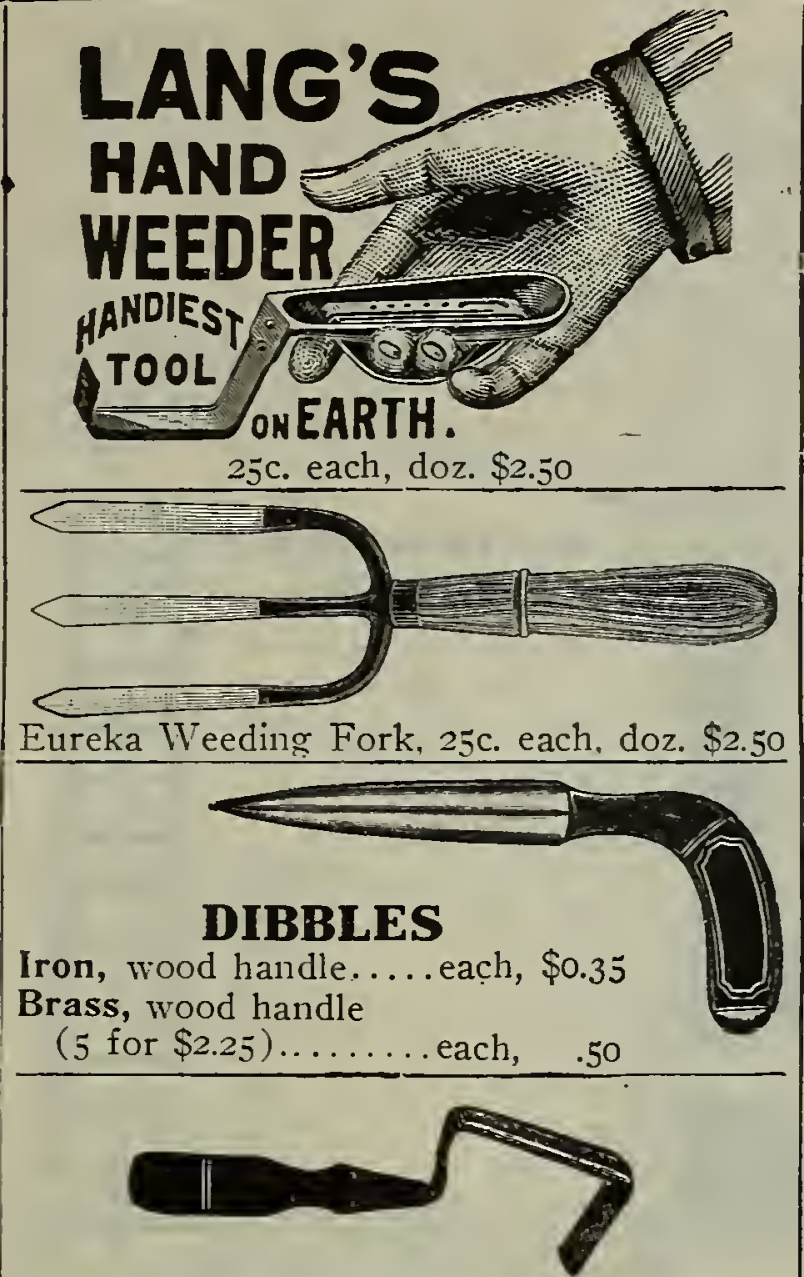

Hazeltine Weeder, 25c. each, doz. \$2.50

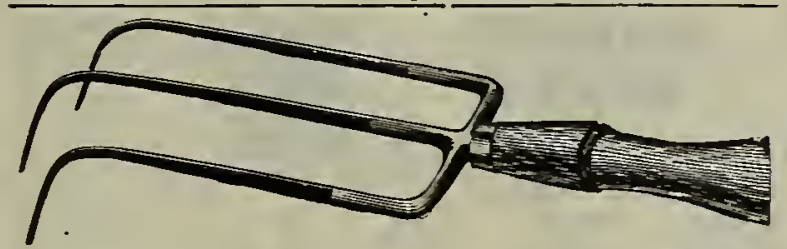

Eureka Weeder, 25c. each. doz. \$2.50

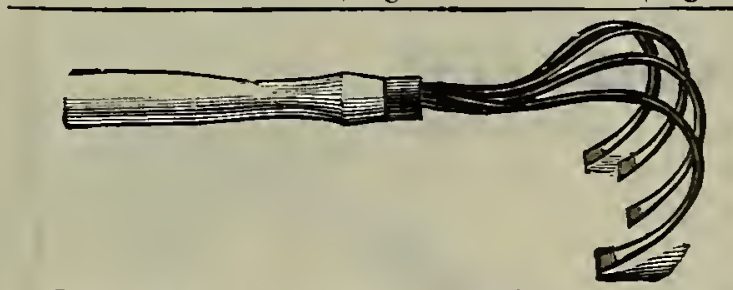

Yoder Weeder, 25c. each, \$2.50 per doz.

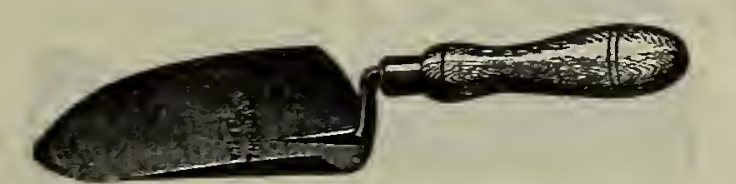

JOHNSON'S STEEL TROWELS

These are made of one piece steel blade and shank, equal to the imported trowels.

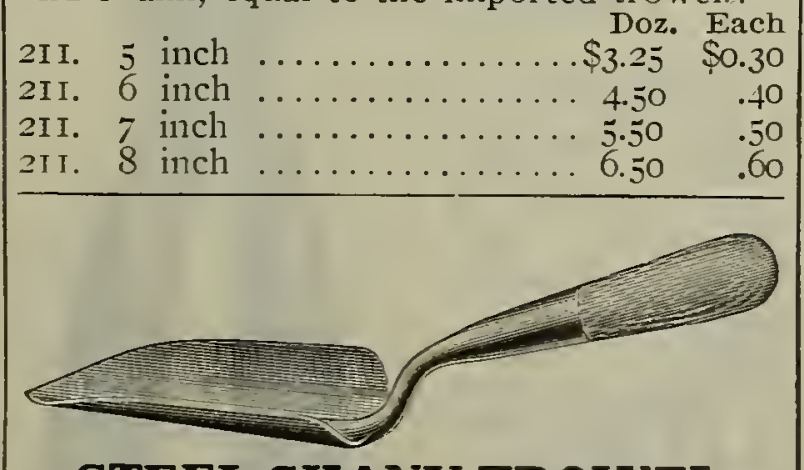

\section{STEEL SHANK TROWEL}

Wany prefer these as they are somewhat longer in blade and handle, making a very practical tool. 6 in. blade. One of them .90 will last a lifetime. 50c. each, doz. \$5.50.

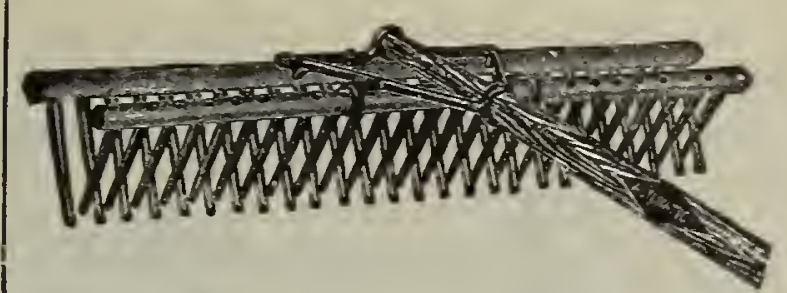

\section{AUTOMATIC LAWN RAKE}

This rake is fitted with an unloading head. While raking, this head lies forward, and lipon pressing the rake forward, the unloading head moves backward cleaning out the raking head entirely.

22 tooth......\$0.45 38 tooth ......\$0.90 26 tooth....... 55 50 tooth.......

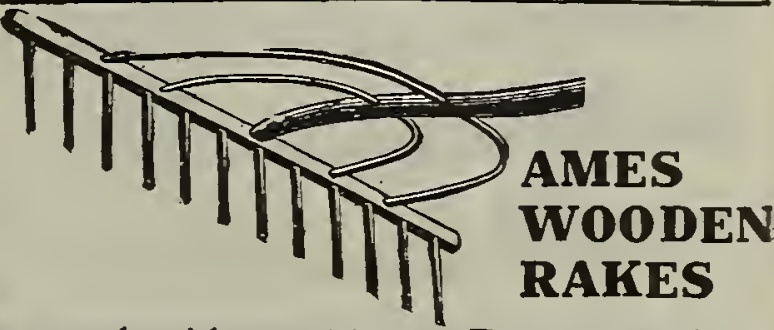

I4 tooth with wood bows. For hay, etc. $\$ 0.50$ 24
24

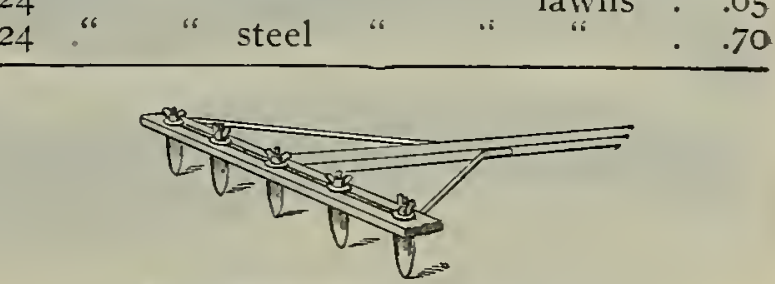

\section{MARKING RAKES}

These are for marking out garden rows; adjustable brass teeth, which are set for any width row desired up to $4 \frac{1}{2} \mathrm{ft}$. Price, 5.00. (Extra teeth, 50c. each.)
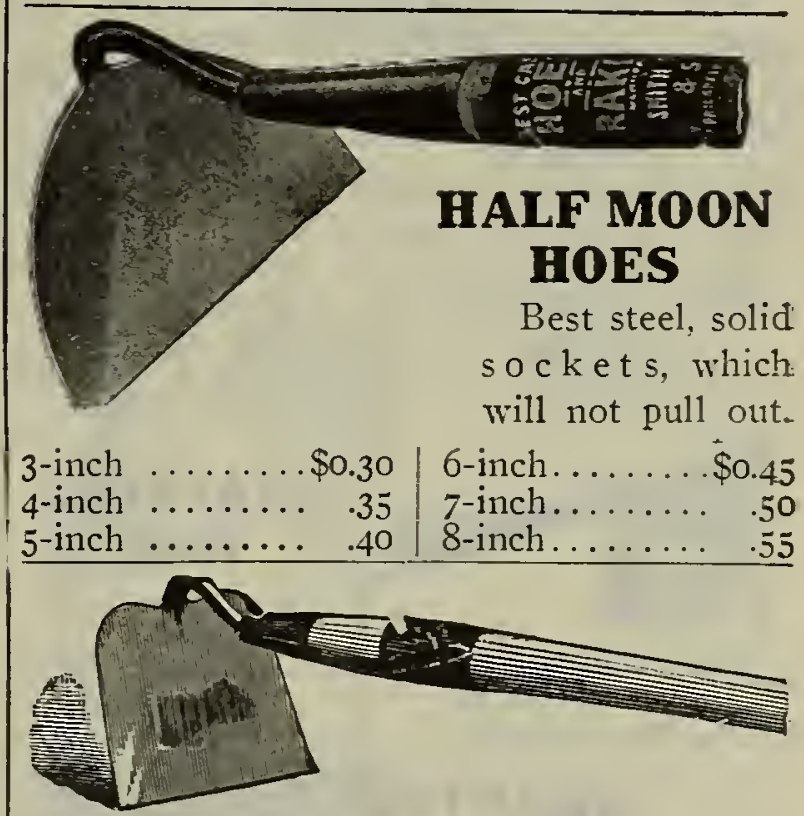

SQUARE HOES

6-inch, solid shank.

7 -inch, solid shank.

8-inch, solid shank.

SQUARE CELERY HOES Io-inch .......\$0.75 | I4-inch.......\$1.15 CLEVE'S ANGLE TROWEL

For getting dandelion, plantain and other weeds out of the lawn,

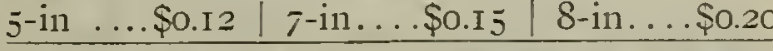
MISCELLANEOUS TROWELS No. 213-5-in., Thin Steel, \$0.08 \$0.80 No. 213-6-in., Thin Steel, .Io jo. 21 3-6-in., Heary Steel ( Jeverbreak). 


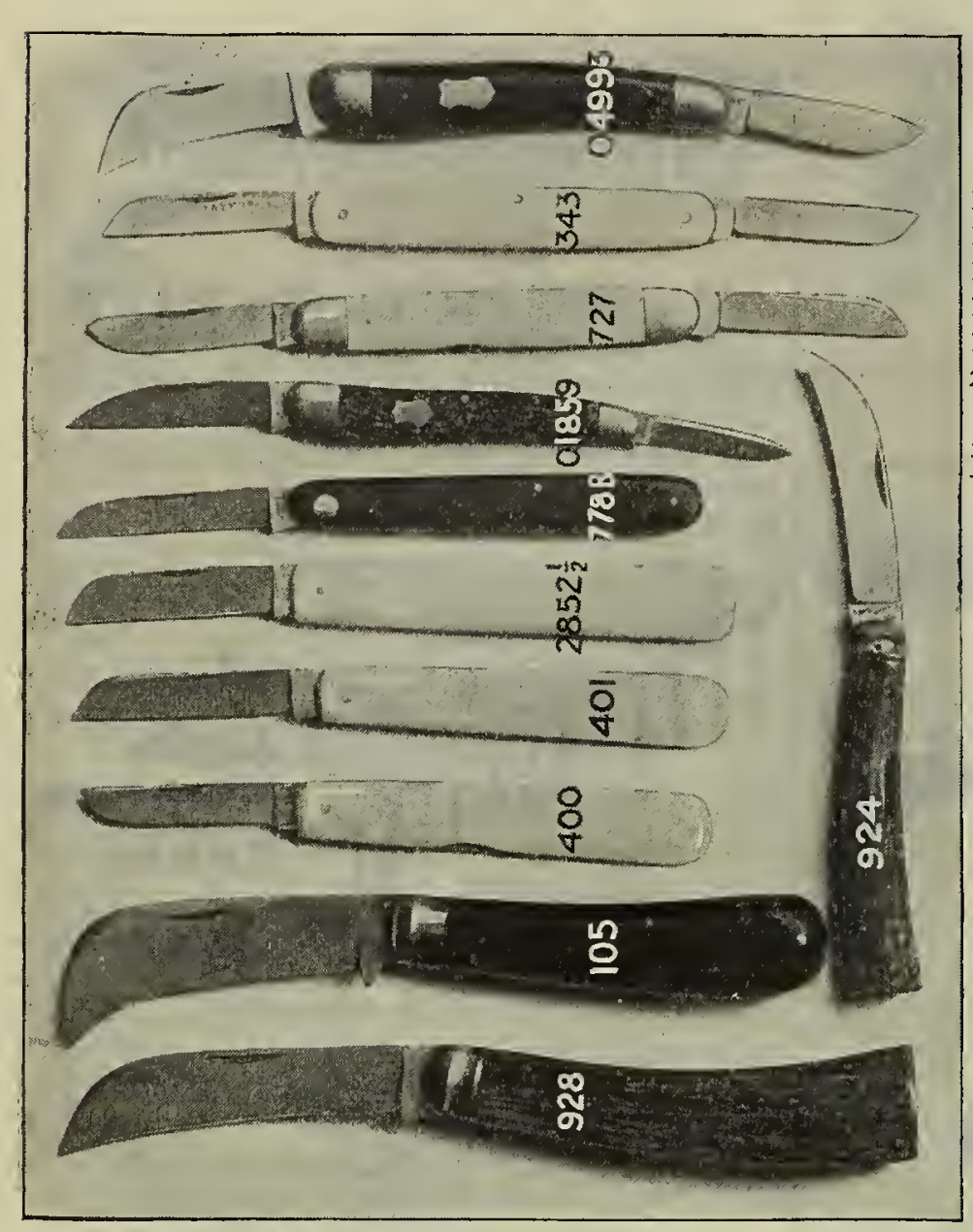

\section{SINGLE PLANK LADDERS}

Made of good hard wood, free from faulty knots; with perfect rounds.

Io-foot $\ldots \ldots \ldots \ldots \ldots \ldots \ldots 2.20$

I2-foot $\ldots \ldots \ldots \ldots \ldots \ldots \ldots \ldots \ldots \ldots \ldots, 2.64$

I 4 -foot $\cdots \cdots \cdots \cdots \cdots \cdots \cdots \cdots \cdots \cdots+3.08$

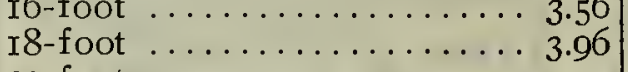

20 -foot $\ldots \ldots \ldots \ldots \ldots \ldots \ldots \ldots+4.40$

Longer sizes up to and including 24-foot, 22c. per foot.

\section{EXTENSION LADDERS}

These are made in the best manner pos-
sible, a r.e complete. being equipped with the necessary rope and pulleys.

I6-foot

i8-foot

20 -foot

24-foot

26-foot

30-foot

32 -foot

34 -foot $\ldots . . . .8 .6 .8$

36 to 44 -foot

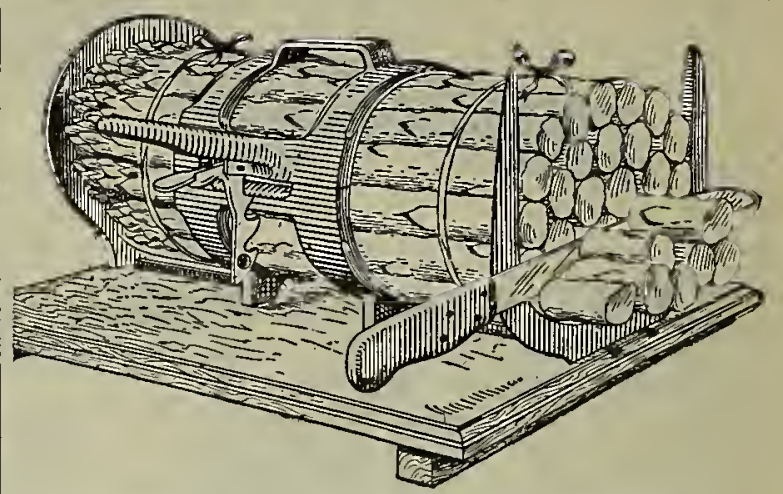

ASPARAGUS BUNCHERS

Even where one has a limited amount of asparagus to market it pays to use a buncher. It is quickly tied and looks uniform. Buncher, with Knife Guard, \$1.50.

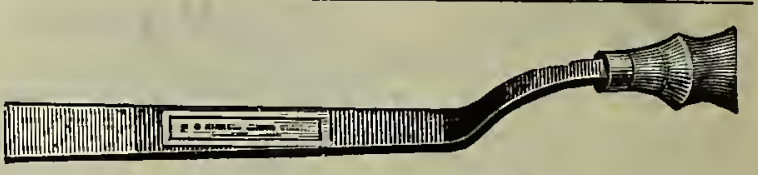

\section{ASPARAGUS KNIVES}

Bateman's (see cut) ............\$0.25

American. V-shaped blade........ .40

\section{ASPARAGUS TAPE}

A beautiful shade of cherry red in Ioooyard spools, waterproof. When tied with this material asparagus will bring fully 20 per cent. more. $\$ 2.00$ per spool; 5 spools,

\section{HORTICULTURAL KNIVES}

400. Saynor Budding, I bladc.....\$I.35 40I. Saynor Budding, I blade.

343. Saynor Budding, 2 blades ...

778B. German Budding, I blade.

or859. German Budding and Pruning,

04993. German Budding and Pruning,

2852 $1 / 2$. German Budding, I blade..... .90

924. English Pruner, $x$ blade....... r.oo

928. English Pruner, I blade, large. r.35

105. German Pruner, I blade, steel band, cocoa handle.

727 W. German Budding, 2 blades....

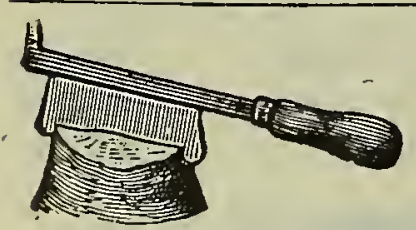

\section{GRAFTING} TOOL

Best English steel for grafting trees, etc. With Wood Handle.

With Steel Handle...

\section{GRAFTING WAX}

T/4 1b., 8c.; I 2c. $1 / 2$ lb.; I 1b., 20c.; $90 \mathrm{c}$. per 5 lbs.

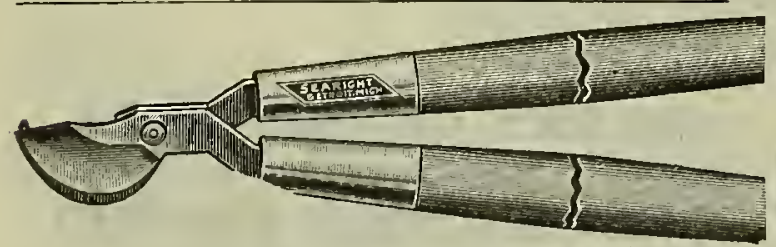

\section{LOPPING SHEARS}

These are used in trimming trees and for cutting heavy hedge that the regular hedge shear will not cut.

Rockdale Style

Searight Style (see cut). Has a tremendous leverage, which means easy cutting; made of the finest American steel

\section{GARDEN REELS}

Small, Single...\$0.45

Medium, Single. .70

Large, Single... T.25

Large, Double. . I.80

\section{GARDEN LINE}

\section{Best Italian hemp.}

60 feet........\$0.35

90 feet............55

120 feet............. .70

300 feet......... 40 (10

roo feet, braided. .70 Single Garden Reel

Plow Line Cotton, 45-foot hanks, 35c

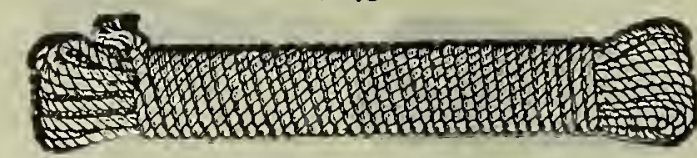

\section{RHODES LOPPING SHEAR}

For trimming trees, bushes, heavy shrubbery, Makes an absolutely clean, perfect cut, the blades a r e concaved at the cutting edge producing with the handles an enormous leverage. They are the easiest operating Lopping Shears ever made or sold. 24 inch handles. Price, $\$ 2.35$

Clipper Lopping Shear.............\$1.80 I.75 English Lopping Shear.

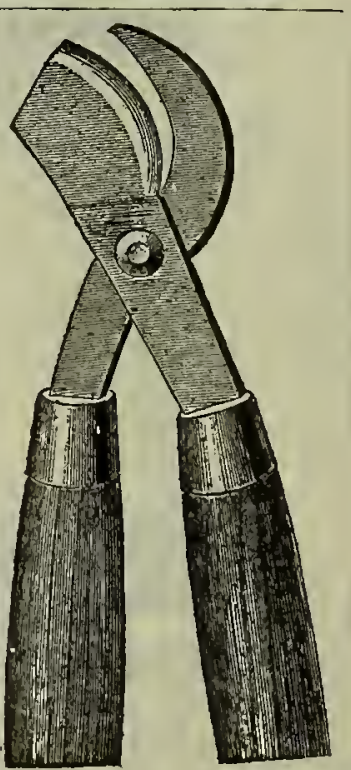
9.75 .

\section{ENGLISH HEDGE SHEARS}

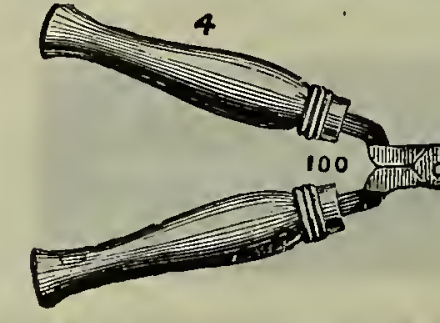

I07-5 $5^{\mathrm{T} / 2 \text {-inch, }}$ Ladies'......... \$0.90

IOI-8-inch $\ldots \ldots \ldots \ldots \ldots \ldots$ I. 35 \$I.80

IOI -9 -inch $\ldots \ldots \ldots \ldots \ldots \ldots \ldots$ I. $58 \quad 2.03$

IOI-IO-inch $\ldots \ldots \ldots \ldots \ldots \ldots \ldots$ I.75 2.25

roI-I2-inch $\ldots \ldots \ldots \ldots \ldots \ldots .2 .25$

Fly Nuts for Hedge Shears, 30c.

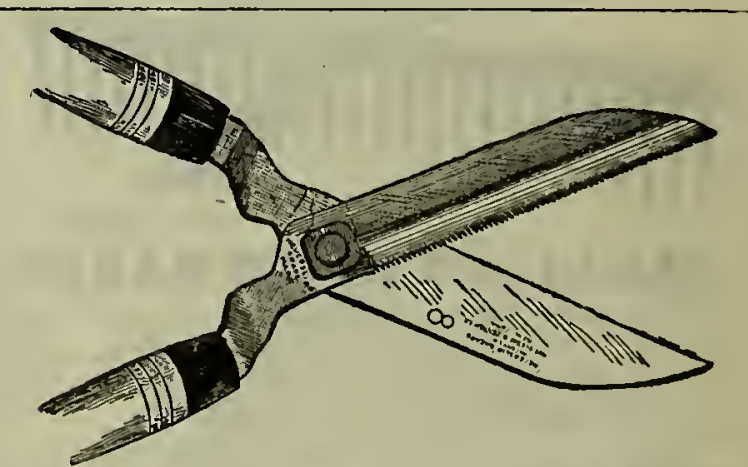

HEDGE SHEARS (Neverslip)

As may be seen by the illustration, these shears have a saw edge on one blade which prevents them from slipping when cutting, made of the best quality English steel.

8-in....\$1.60|9-in...\$2.00| Io-in...\$2.25

\section{SAYNOR HEDGE SHEARS (FIy Nut)}

For very heavy hedges.

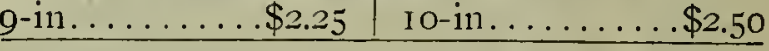

UNIQUE HEDGE TRIMMER

A practical tool for trimming the summer growth of hedge. r6-inch cut, $\$ 5.00$. 


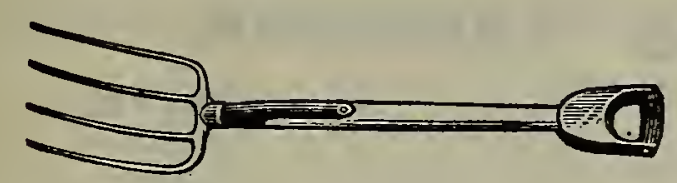

SPADING FORKS

Strapped shanks, short or D-wood handle. Made of best quality steel.

Men's, 4 tine..................\$0.90 " 5 " $\ldots \ldots \ldots \ldots \ldots \ldots \ldots \ldots$. I.05 Boys' or Ladies', 4 tine............ .50

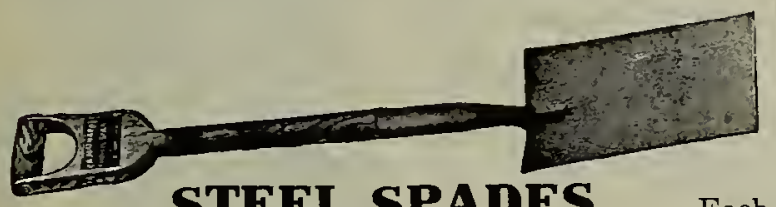

\section{STEEL SPADES}

\section{Ames, Short Handle.}

Maynard, Short Handle.....

Nursery (Ames), Short Handle...... I.6o

Imperial, Short Handle.

Long Handled Imperial.

Boy's

English Turf.

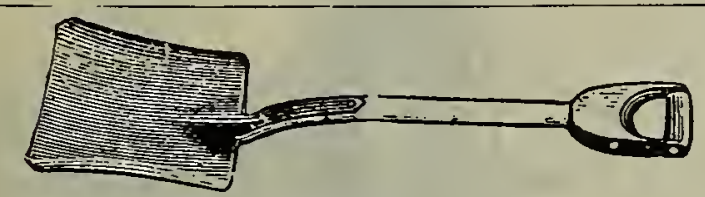

\section{SHOVELS}

We handle only the very best makes of steel shovels. Every one is guaranteed to give entire satisfaction. Short Handle

Ames, round point..............

Maynard, solid socket, square point.... I.25

Maynard, solid socket, round point.... I.25

Imperial, round point............. . .90

Imperial, square point.....

$$
\text { Long Handle }
$$

Ames, round point.............. \$1.25 Imperial, round point............ .90

Imperial, square point............ .90

Featherweight, round point, $4^{1 / 4}$ lbs. . I.IO Maynard, round point...............

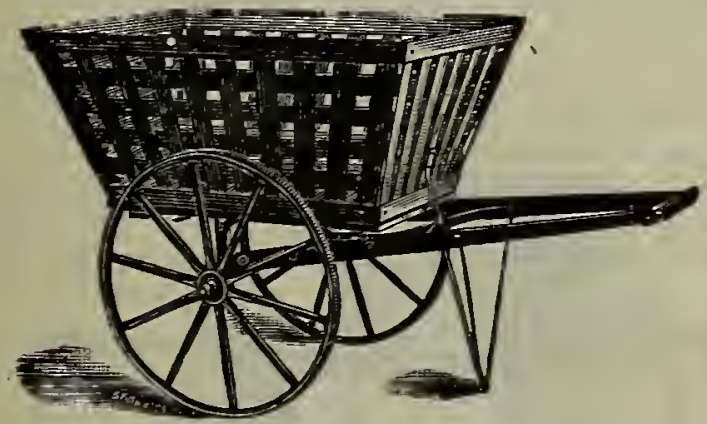

\section{LEAF RACKS, WATER BARRELS, ETC.}

The truck is constructed so that the barrel may be attached quickly and the leaf rack or stone box may be detached.

Leaf Rack only, no truck.

“ " " with $I / 2$ inch truck....... $\$$ II.00

“ “ " " $21 / 2$ "

Water Barrel $3^{1 / 2}$ " " $"$ " $\ldots \ldots \ldots$ I 2.50

Water Barrel with $\mathrm{I} 1 / 2$ inch truck... 9.75

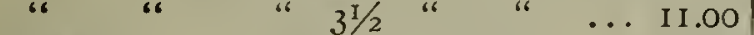

\begin{tabular}{l} 
Extra Barrels with trunnions...... \\
Keystone Leaf Rack............. 3.25 \\
\hline
\end{tabular}

\section{PRUNING SHEARS, ETC.}

Our pruning shears are procured from the most reliable makers in America and Europe and but 03 are fully guaranteed in every particular.

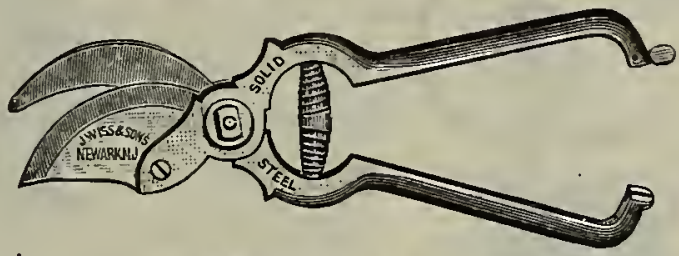

No. Wiss Pruning Shears

Iog Wiss, 8 in. ............... \$1.75 rgo Henckle Pattern, $7^{1 / 2}$ in ......... I.00 200 2 IO

Searight (Compound), $8 \mathrm{i} / 2$ in ...... The Henckle patterns are equipped with a ratchet nut which takes up all wear and allows the shear to make a perfect cut.

Rhodes' Double Cut, 9 in......... $\$ 1.60$

88 Hessenbruch, 8 in........... .90

537 German, 8 in

03 American, 8 in

23 Ladies' nickeled, $4 \frac{1}{2}$ in . . . . . . . . . 65

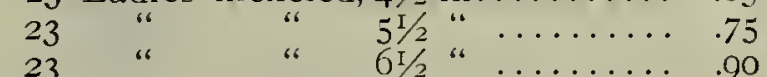

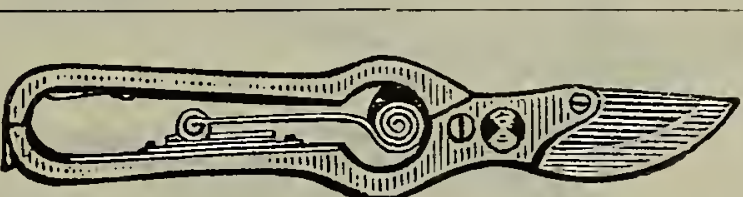

FRENCH PRUNING SHEARS

These have a distinct, very easy working, spring and are especially desirable for one whose hand is liable to fatigue when pruning.

French, sma11, 7 inch............ \$r.io

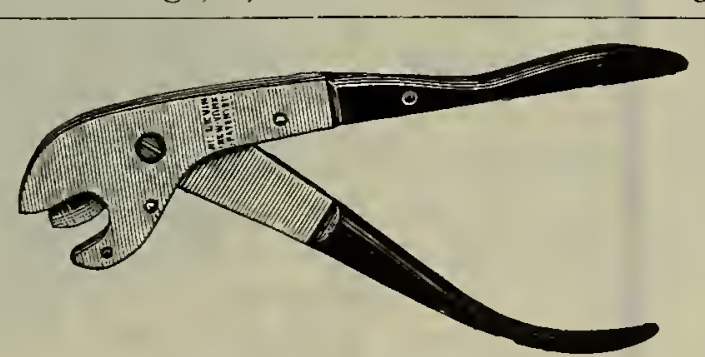

\section{LEVIN PRUNER}

On account of its peculiar construction, the handle of this shear affords a great deal of leverage. Ideal for cutting stakes. Price, 6oc.

Spiral Springs for Pruning Shears, 8c. each; per doz. 85c

Springs for French Pruning Shear, $20 c$.

\section{PRUNING SAWS}

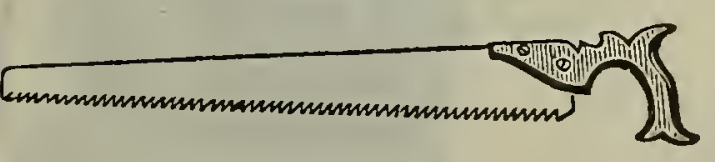

6 inch, single edge............\$0.60

I8

20 22

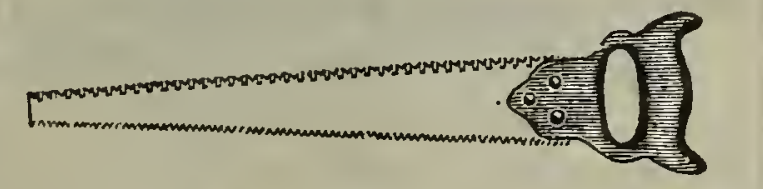

I8 inch Duplex (double edge) ......\$0.75

20 Searight Adjustable Tree Saw. Can

be worked from any angle..........

\section{TREE PRUNERS}

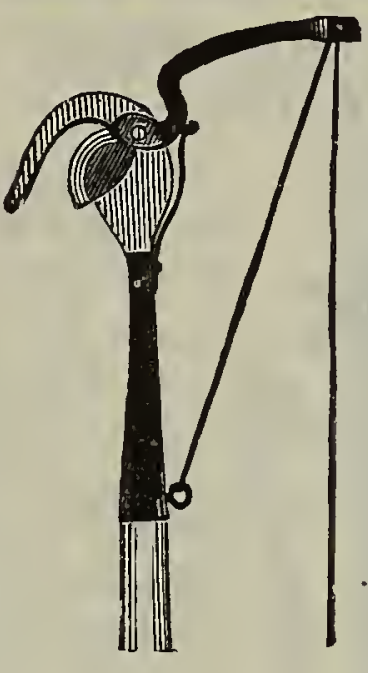

Disston's Pole Pruner

Disston's Little Giant. (See cut)....\$1.00 Disston's Little Giant. With saw at-

tachment. (See cut)............ I.35

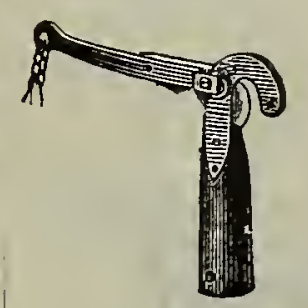

TELEGRAPH TREE PRUNER

Price, \$o.85.

\section{HESSENBRUCH TREE PRUNER}
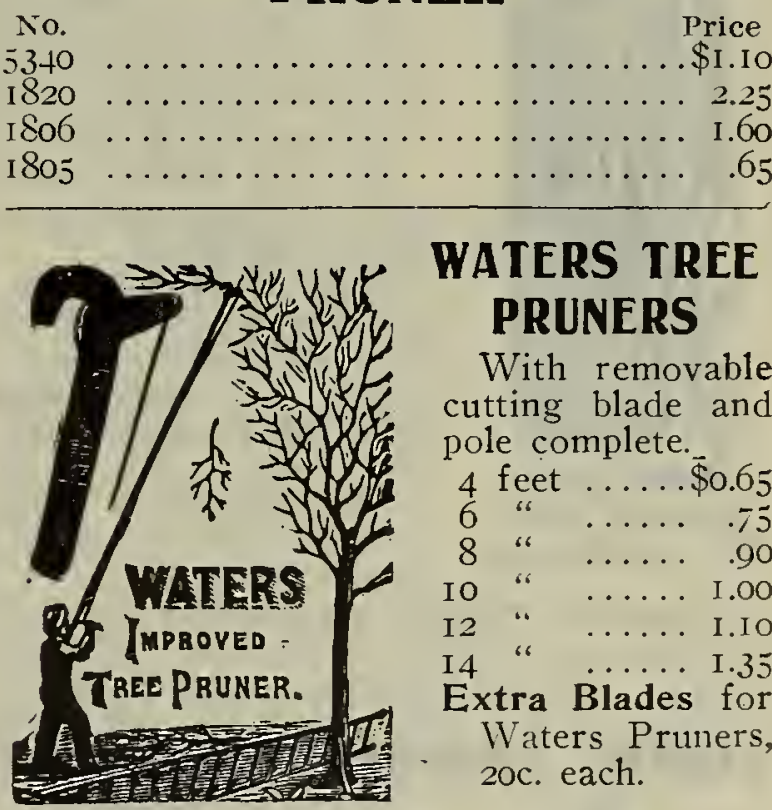

WATERS TREE PRUNERS

With removable cutting blade and pole complete. 4 feet $\ldots \ldots . \$ 0.65$ 8 “ $6 \cdots \cdots \cdot .75$ 10 " I2 I4 " Extra Blades for Waters Pruners 20c. each.

None of the above Tree Pruners except the Waters are equipped with poles or rope Searight Compound Lever Tree Pruners $8 \mathrm{ft}$. Pole.... \$I.25| Io ft. Pole. I $2 \mathrm{ft}$. Pole..... i.6o I4 ft. Pole.

POLES for Tree Pruners.

I 2 feet long, $\mathrm{I} 1 / 4$ inches diameter.....\$0.40 I4

I6

\section{LEATHER PRUNING GLOVES}

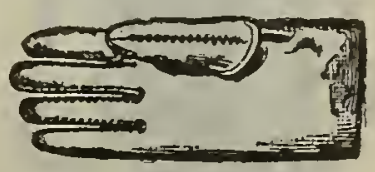

Buckskin, pair .$\$ 1.35$ Ordinary, pair $\ldots \ldots \ldots \ldots \ldots \ldots \ldots$
Buckskin, with gauntlets, pair........ 


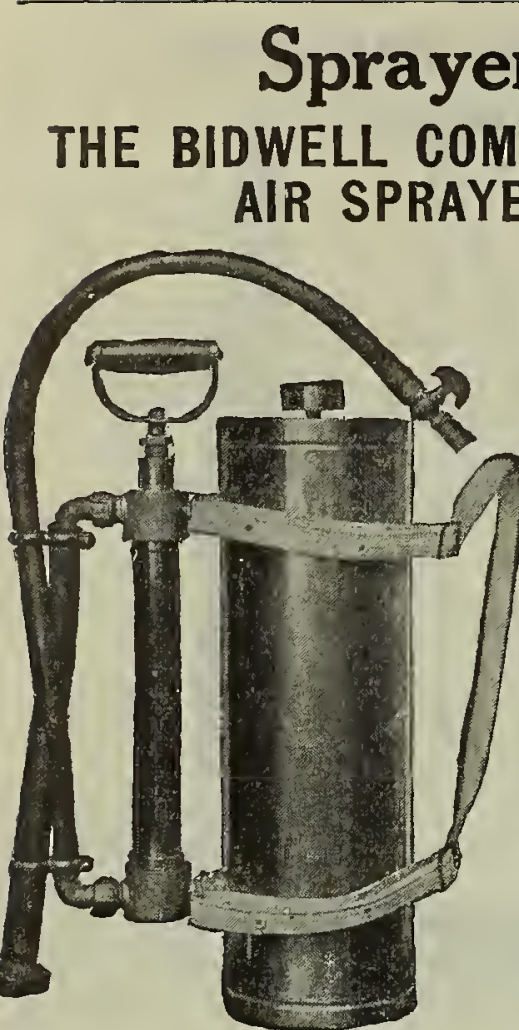

\section{Sprayers and} WELL COMPRESSED

Absolutely the best of all the compressed air spraysh e et-copper $\mathrm{t}$ a $\mathrm{nk}$ has a capacity of 5 gallons; the pressure capacity is 45 like mostother s p r a y e r s this one will tents of the reservoir with o ne charge; the pump is indepen d e $\mathrm{nt}$

of the tank and every part can be gotten at. Every piece is brass and copper except the hose and washers. The liquid is pumped into the reservoir through the same hose which takes in the air. Fitted with a famous Winkle-Mist nozzle; full directions with each one, together with our full guarantee. Price, \$I 4.25 each.

\section{THE AUTO SPRAY}

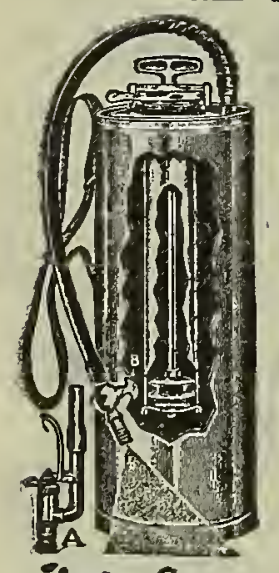

Auto Spray showing Auto

Pop Attachment
Now used by all leading florists and fruit growers. It operates with compressed air; safe and efficient; liquid capacity, 4 gallons; pressure capacity, 40 lbs.

No. I-A Brass, equipped with hose and regular nozzle, \$6.00.

No. I-B Brass, equipped with hose and AutoPop Attachment, \$6.50.

No. I-C Galvanized Iron, equipped with hose and regular nozzle, \$4.00. I-D Galvanized Iron, equipped with hose and Auto-Pop, \$4.50.

Auto=Pop Nozzle Attachment controls the flow instantly by a pressure of the hand. - When purchased separately, \$I.35 each.

\section{DEMING KNAPSACK SPRAYERS}

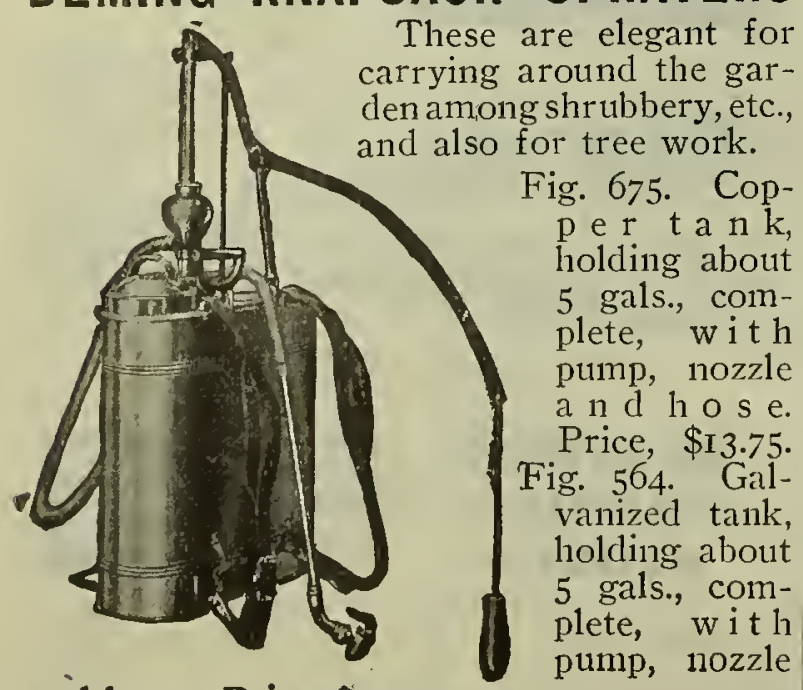

and hose. Price, \$9.00.

\section{Insecticide Distributing Apparatus}

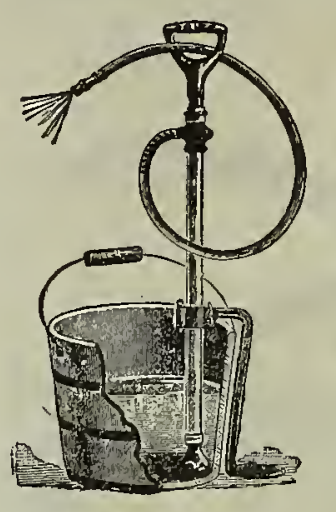

SPRAY BUCKET PUMPS

These are made entirely of brass except the foot rest, bucket fastener and hand grip. For years we have sold them with entire satisfaction. The prices below do not include bucket, but include nozzle and $3 \frac{1}{2}$ feet of $3 / 8$-in. hose.

Success (without bucket fastener) ...\$370

Perfect Success (with bucket fastener) 4.I 5

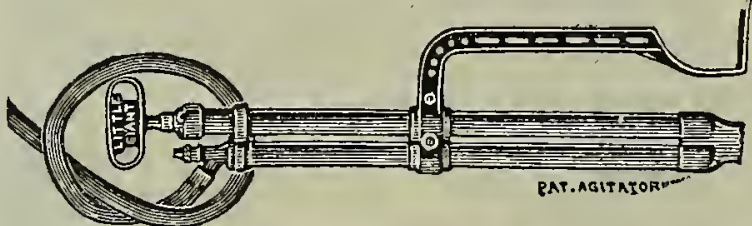

MYER'S BUCKET PUMP

This is a double brass chamber arrangement, and fills the want of those desiring a medium-priced sprayer.

Price, $\$ 2.85$, including hose and nozzle.

\section{JUNIOR SPRAY PUMP}

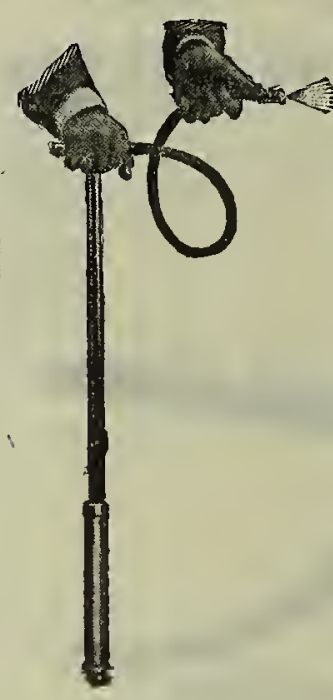

No. 5-F or bucket use; the pump works on a spring device, making compression which discharges the liquid. The most practical bucket pump for one person to use. All brass and excellent value. Just the thing for the man with small fruit garden, few greenhouses, or a hen house that needs spraying. Com plet e with hose and nozzle.

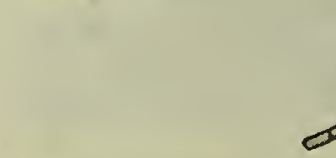
Price, \$2.75.

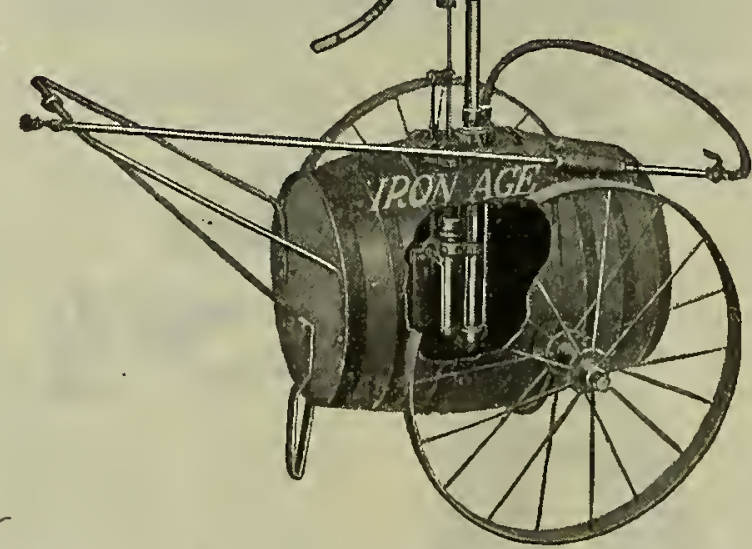

IRON AGE SPRAYER, No. 197

A perfect outfit for gardens, small farms, poultry, plants, etc.; capacity, 20 gals. Pump all brass with a 6 -inch stroke, large air chamber with a Ioo-1b. pressure capacity; bronze brass ball valves of easy access. Equipped with a perfect agitator, 4 feet of extension rod with hand grip and 4 feet of $1 / 2$-in. hose, stop cock and nozzle. \$15.75.
OTHER IRON AGE SPRAYERS, not

shown here; send for descriptive list.

No. I90I-Capacity 50 gals., equipped with I $5 \mathrm{ft}$. I/2-in. hose, I nozzle, $\$ 22.00$.

Equipped with two I5-ft. lengths of $1 / 2$-in. hose and 2 nozzles, $\$ 25.50$.

No. I94. Equipped with a 50-gal. barrel, $15 \mathrm{ft}$. of $1 / 2-i n$. hose and nozzle, $\$ 17.25$.

No. I94. Equipped with hose and nozzle only, $\$$ I 3.85 .

Plain pump, without hose or nozzle, \$9.50. No. I94 T-This is the same as the above pump equipped with a $2^{\mathrm{T}} / 2$-in. truck, barrel, I5 ft. of $1 / 2$-in. hose and nozzle, $\$ 25.00$.

No. $194 \mathrm{~T}-W$ ithout hose or nozzle, $\$ 21.75$

No. I95-Really a duplicate of No. I97, except that it is equipped with a I6-qt. bucket and a 2 -ft. extension rod, \$7.50.

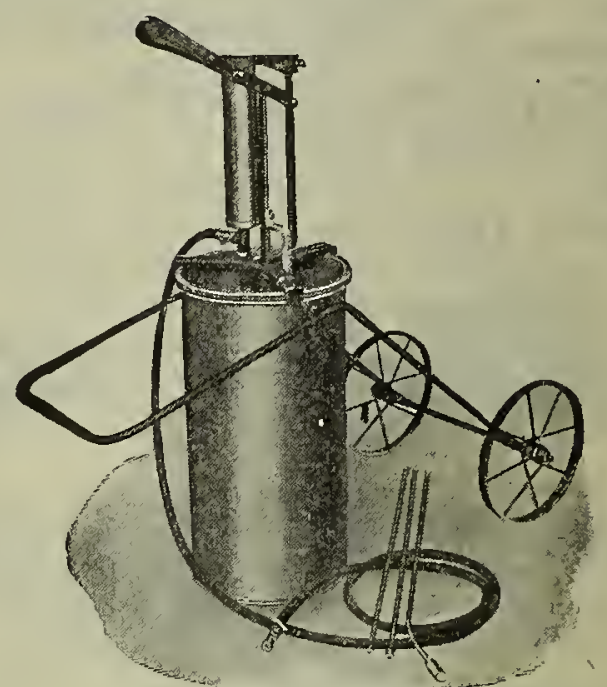

No. 3 Paragon Sprayer

\section{THE PARAGON SPRAYER}

Especially desirable for the reason that it is not necessary to strain the material before pouring it into the reservoir; although we recommend that this be done; guaranteed to give absolute satisfaction. Excellent for applying whitewash or cold water paint.

No. o-With a 3-gal. reservoir, $4 \mathrm{ft}$. of hose, nozzle and extension pipes. Price, $\$ 7.15$. No. I-With a 5-gal. reservoir, $5 \mathrm{ft}$. of hose and 2 extension pipes, \$9.50.

No. 3-Equipped with a I2-gal, tank mounted on a truck, three $2 \frac{1}{2}-\mathrm{ft}$. extension pipes, 2 nozzles and Io ft. of hose, \$I4.25.

No. 4-Mounted on a two-wheel truck; equipped with Io ft. of extension pipe, 20 $\mathrm{ft}$. of hose, and 2 nozzles. Complete, \$2I.00.

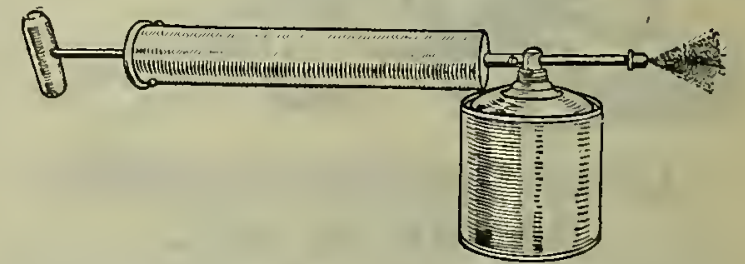

\section{AUTOMATIC COMPRESSED} AIR SPRAYER

This is the grandest hand sprayer ever offered, very easily operated.

Tin...... each, \$0.90 | Brass.....each, \$1.75

CYCLONE HAND SPRAYERS

Similar to the above except they do not have the automatic air reservoir attachment.

Tin...... each, \$0.40 | Brass.....each, \$o.8o 


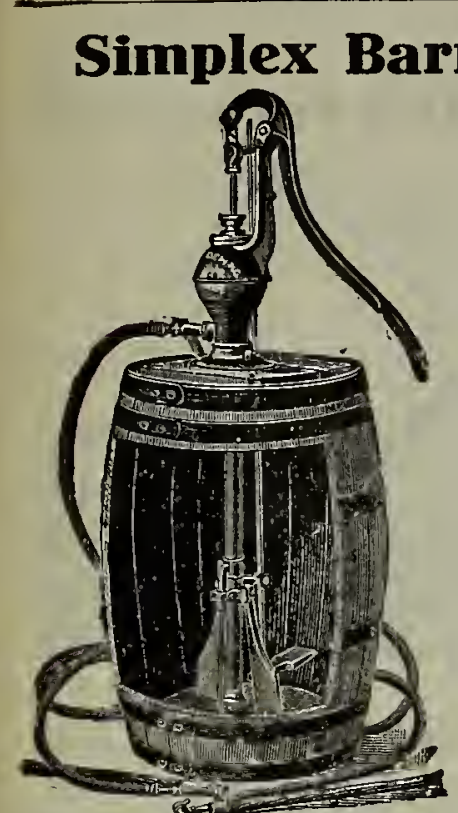
Out fit B-Pump, with two I2 $1 / 2$-foot sections of $1 / 2$-in. hose, two Bordeaux or Vermorel nozzles, pole connection, no barrel. Price, \$13.00.

\section{Century Pump}

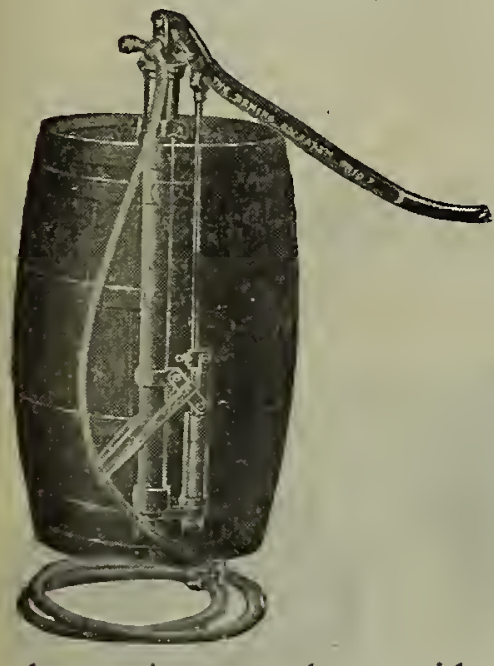

obstructions on the outside

A very powerful pump ; working parts are entirely of brass; has large air chamber; also a perfect agitator and a long fulc r u m link, which enables the operator to work the pump with little effort. The pump is largely submerged, which places it out of the way of all

Price for plain pump, no barrel or hose, $\$ 10.00$

Price, complete, with $121 / 2 \mathrm{ft} .1 / 2$-in. hose and nozzle, no barrel, \$r3.0o. Price, with two $\mathrm{I} 2 \mathrm{I} / 2-\mathrm{ft}$. leads, hose and nozzles, no barrel, \$I6.00.

Barrels, with trunnions ready to mount on truck, with cut head, $\$ 3.25$.

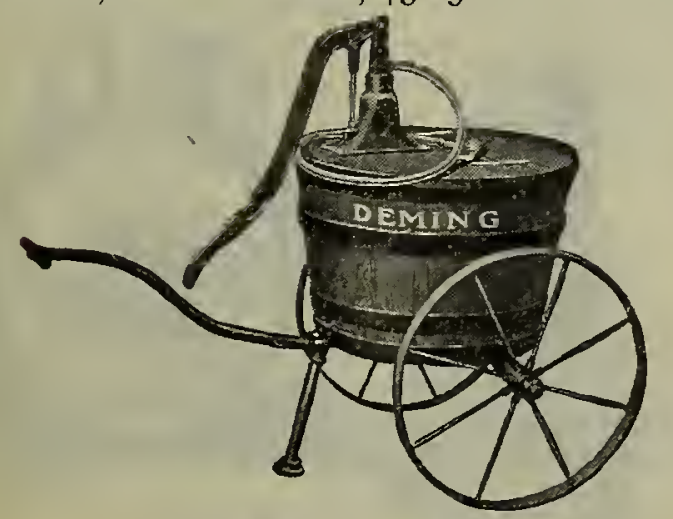

Gardener's

Choice Spray Outfit

Here is an equipment that is easily worth $\$ 5.00$ more than we ask for it; truly it is the greatest value in spray pumps we have; the reservoir holds 25 gals.; the pump has brass cylinder, and it is a complete equipment with hose and nozzle. Just the proper thing for use in greenhouses with wide aisles or without benches. Price, \$I 5.00 .

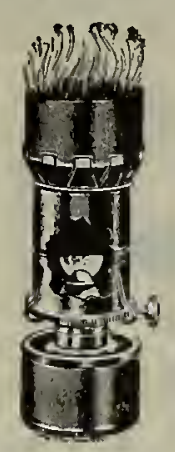

\section{Paris Green Shakers}

Tin. For dusting vegetables, potatoes, sma 11 fruit and shrubbery, $45 \mathrm{c}$. each.

Farmer's Favorite. (See cut.) Large doubleaction affair, \$I.I5 each.

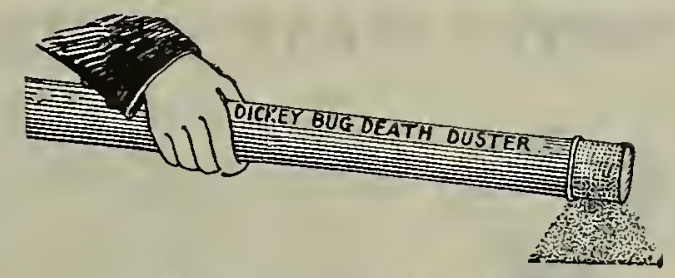

Dickey Duster

Excellent for distributing Bug Death, Slug Shot, etc. Price, 25c.; by mail, 35c.

"Acre an Hour" Sifter. 7oc. each.

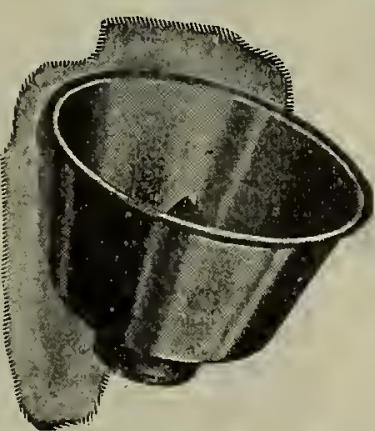

\section{Copper} Strainer

For straining whitewash, spraying material, etc. 9oc. each.

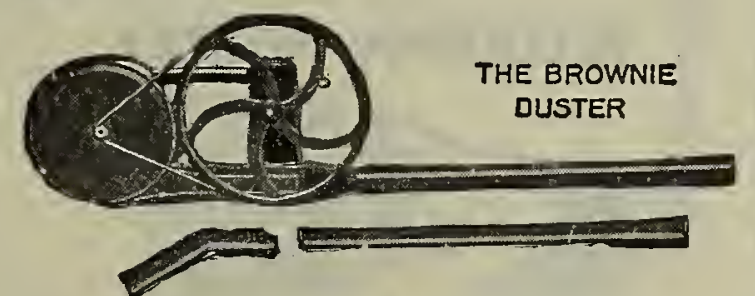

Brownie Gun

For distributing all Insect Powders for indoor or outdoor use. Price, $\$ 3.75$.

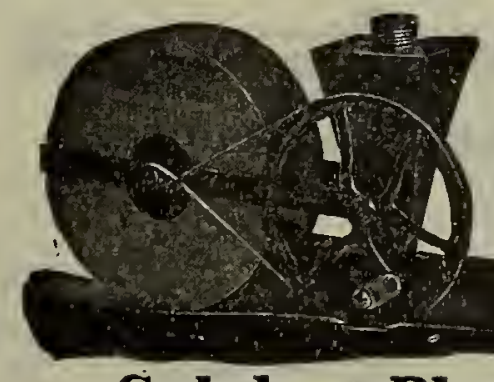

Sulphur Blower

For distributing sulphur and insecticides of various kinds. Made of heavy metal with no wearout to them. A man can dust a very large house in a few minutes, using

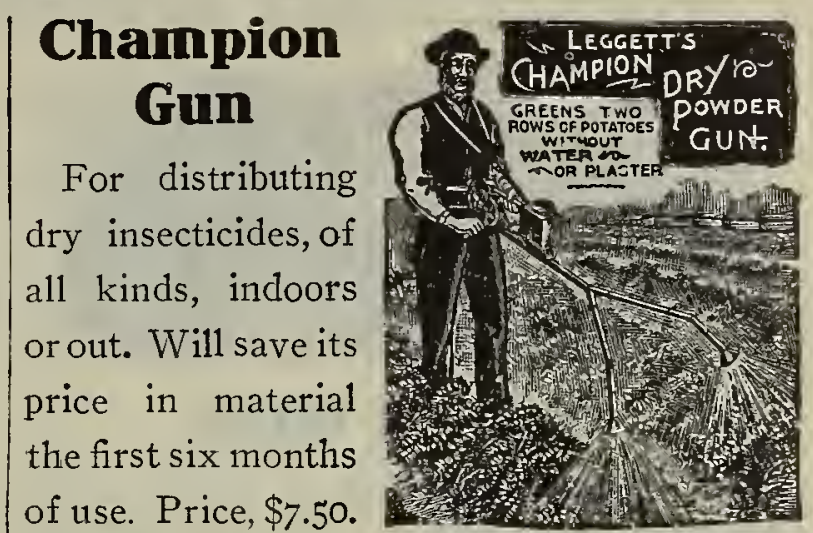

\section{Fumigators}

Perfection Make

Fitted with a Water Tank to prevent burning out. No.

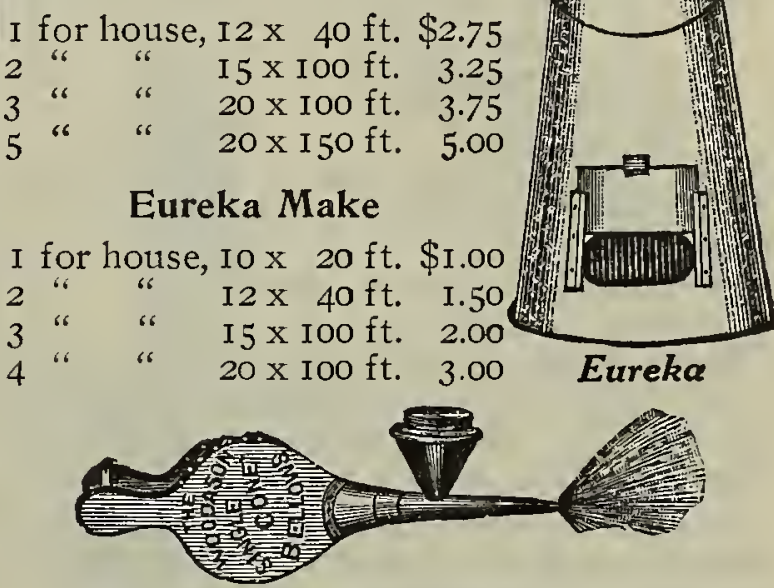

\section{Bellows}

Large Double Cone. $\$ 2.70$ Large Single Cone.................. I.80 Small Single Cone................ т.00 Liquid Spraying. Sulphur Bellows.

$\$ 1.35$ and I.80

\section{Copper Strainer}

For straining whitewash, spraying material, etc. 90c. each.

\section{Spray Nozzles $3 / 8$ in. thread}

Bordeaux and Vermorel......... each, \$o.7o Mistry, Jr.................. .85 Winkle Mist.................... .70 Paragon style...................... .35 Duplex Vermorel (2 nozzles)........ I.40 Triple Vermorel (3 nozzles).......... 2.I5 Quadruple Vermorel (4 nozzles)..... 2.I5 Duplex Mistry (2 nozzles).......... 2.75 For $3 / 4$-in. connections, add $25 \mathrm{c}$.

\section{Extension Pipes, Etc.}

For reaching into trees ( $3 / 8$-in. threads). Bamboo, with brass tube, $8 \mathrm{ft} \ldots \ldots \ldots$. $\$$ I.90 Galv. Iron, 2 ft., for Auto Sprays.... $\begin{array}{rr} & .25 \\ \end{array}$ Brass, 2 ft., for Auto Sprays........ . .40 Pet Cock, for extension pipes........ .35 Iron Age. Fig. 419-Steel pipe io $\mathrm{ft}$. long, with an angle connection, stop cock, 2 hand grips and drip guard, for $1 / 2-i n$. thread. Price, \$2.55.

Iron Age. Fig. 420-Bamboo casing witl brass pipe inside, with angle connection, stop cock, 2 hand grips and drip guard, Io ft. long. Price, $\$ 3.60$.

Extensions for Paragon Sprayers, $2 \frac{1}{2}$ ft. $45 \mathrm{c}$. each. 


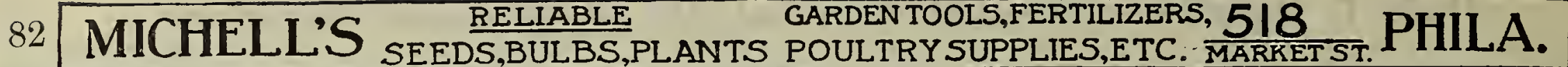

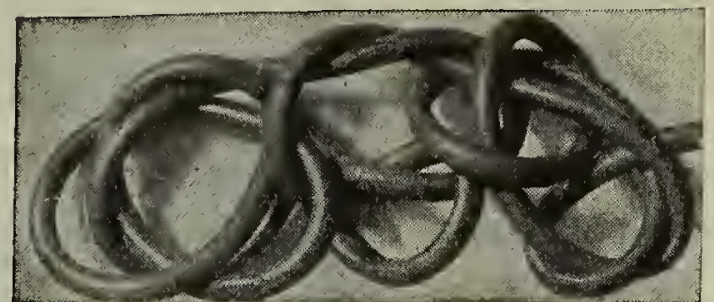

\section{RUBBER HOSE}

Michell's Rubber Hose is noted for its reliability in every way. We buy from the manufacturer in enormous quantities.

Bull Dog, 3/4-in., 7-ply...........\$o.15

Standard, $3 / 4$-in., 4 -ply........... .I I

Reliable, $3 / 4$-in., 3-ply............. .I $2^{1} / 2$

$$
\begin{aligned}
& \text { “ I-in., 3-ply } \\
& \text { 3/4-in., 4-ply } \\
& \text { I-in., 4-ply } \\
& \text { I/2-in., 4-ply }
\end{aligned}
$$

I-in 4 -ply $\ldots \ldots \ldots \ldots \ldots . .26$

*Any Length, $3 / 4$-in. (500 ft., $\$ 67.50$ ) .I $4 / 2$ *Electric, $3 / 4$-in. $(500$ ft., $\$ 78.00) \ldots$... . 6

*Electric, $1 / 2$-in................ $14 \%$

*Revero, $3 / 4$-in. $(500 \mathrm{ft} ., \$ 78.75) \ldots \ldots$.I6

*Revero, $1 / 2$-in $\ldots \ldots \ldots \ldots \ldots \ldots \ldots \ldots .$. .I 4

Spray Hose, $3 / 8$-in............ .I I

P. S.-Brands marked * come in reels of 500 feet and sections in any length to that number of feet may be had.

Longer sections of hose coupled free. Smaller sections coupled at the rate of $\mathrm{I}_{5} \mathrm{c}$. per pair for couplings.

Hose Washers. For inside and outside of couplings. 5c. doz.; $1 / 4$ lb., 20c. ; 70c. 1b.

Hose Protectors. For fastening to greenhouse bench legs. Keeps hose from wearing out. 25c. each; doz., $\$ 2.50$.

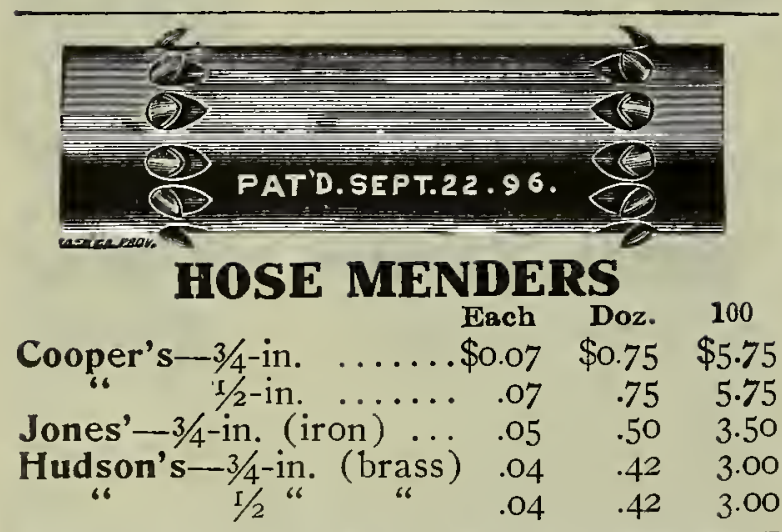

PERFECT HOSE MENDER

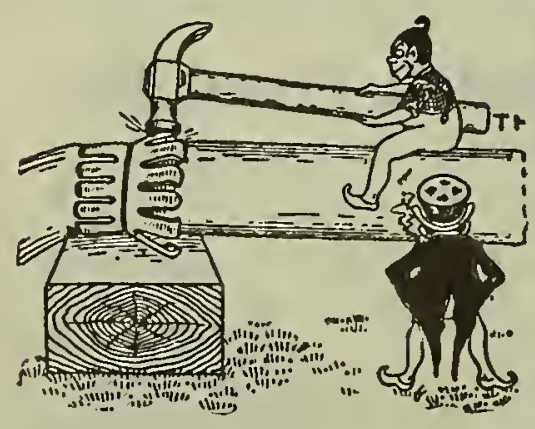

Made

entirely of

brass, with

swivel mo-

$\mathrm{t}$ i 0 n- no
band re-

quired.

For $3 / 4$ inch

hose, $8 c$.

8oc. ; $\$ 6.25$

per Ioo.

\section{RUBBER PLANT SPRINKLERS}

Straight Neck.

No. I..........\$0.85

No. $2 \ldots \ldots \ldots \ldots \cdot 75$

No. $4 \ldots \ldots \ldots \ldots . .50$

Angle Neck.

Large.............\$o.85

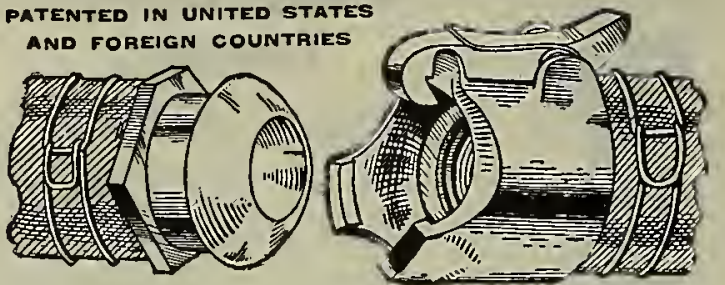

SNAP HOSE COUPLING

Snap Couplings are entirely new and novel. They couple hose instantly, work on a spring, and are water-tight. 25c. per pair; doz. pairs, $\$ 2.75 ; \$ 20.00$ per IOO.

\section{SNAP COUPLING PARTS}

No. 2-Male (see left hand illustration above). 8c. each; doz., 85c.; $\$ 6.50$ per IOO.

No. I-Female (see right hand illustration above). I7c. ea.; doz., \$I.90; \$I3.50 per Ioo. Washers for Snap couplings, 20c. doz.

\section{BOSTON SPRAY NOZZLE}

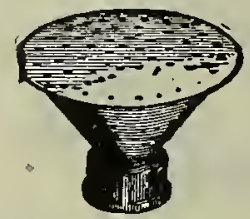

These render the same service as does the rose of a watering can. They are screwed on the end of the hose like any other nozzle. Coarse and fine screen, $3 / 4$-inch, All Brass, 6oc.; by mail,

75c. Copper (Sheet), soc.; by mail, 6oc.

\section{BOSS HOSE NOZZLES}

For 3/4-inch hose.

Price, 40c. each.
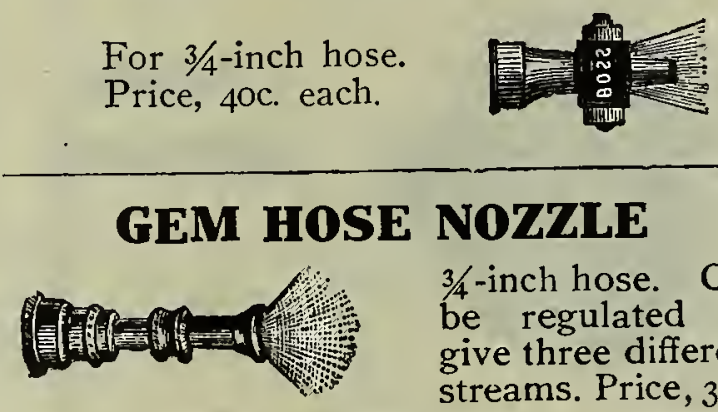

NOZRLE

$3 / 4$-inch hose. Can be regulated to give three different streams. Price, $30 \mathrm{c}$.

\section{RAINBOW NOZZLE}

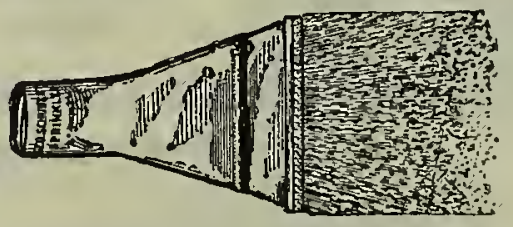

This nozzle gives the same result as when the thumb is placed over the hose, $\$ 1.50$.

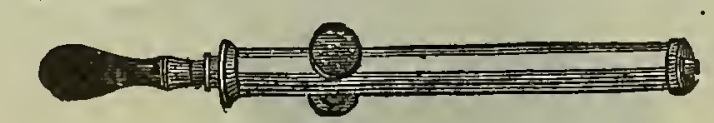

\section{BRASS SYRINGES}

No. Diam. Lenkth

99 -I I/2" I 8" Spray rose only......\$2.25 IOI -I I/4" I4" Spray rose and stream I.75 IOI - I I $1 / 2$ " I6" " " " " " 3.00

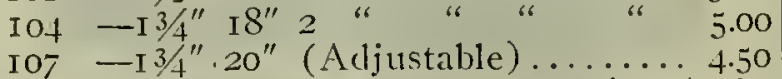
Lcwis (Sheet Brass), I qt. capacity, \$1.6o.

\section{RUBBER APRONS}

For protecting the clothing while watering or doing any work in the garden where your clothes could become soiled. Price, $\$ 1.50$.

WATER CANS Wotherspoon's Make

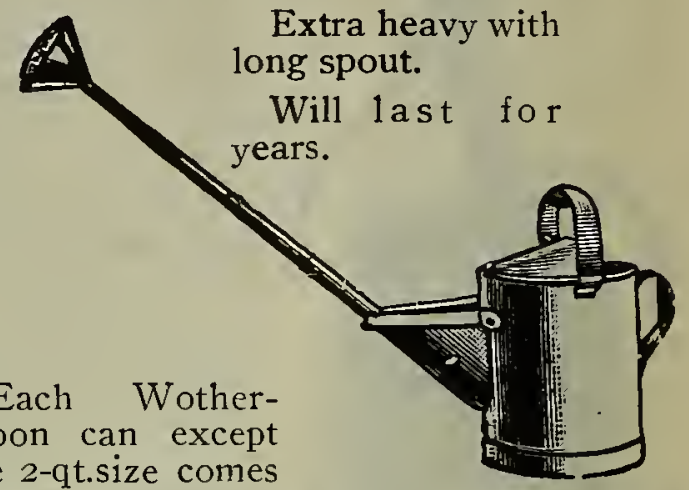

the 2-qt.size comes equipped with two roses, one coarse and one fine.

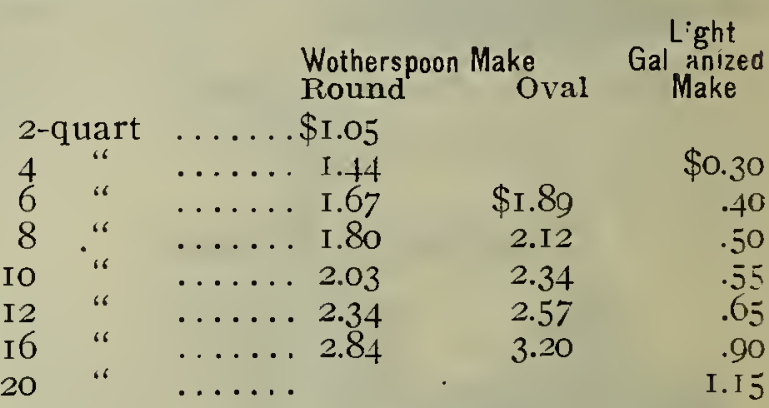

I2-qt. Manure Watering Can......\$2.50 4-qt. Fern or Low Watering Can... I.35 Extra Roses for Wotherspoon Watering Can, either coarse or fine, 3oc. each.

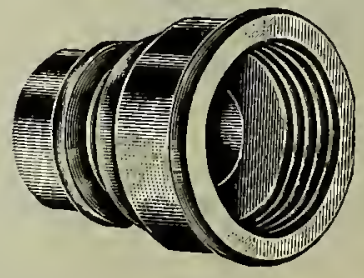

No. 3 ACME COUPLINGS

No. 3, for spigot. I5c. each, doz. \$1.40.

No. 4 part, for attaching to hose. $25 \mathrm{c}$. each, doz. \$2.40.

Couplings complete, consisting of one No. 3 and one No. 4 part, 35c. each; doz. \$3.6o.

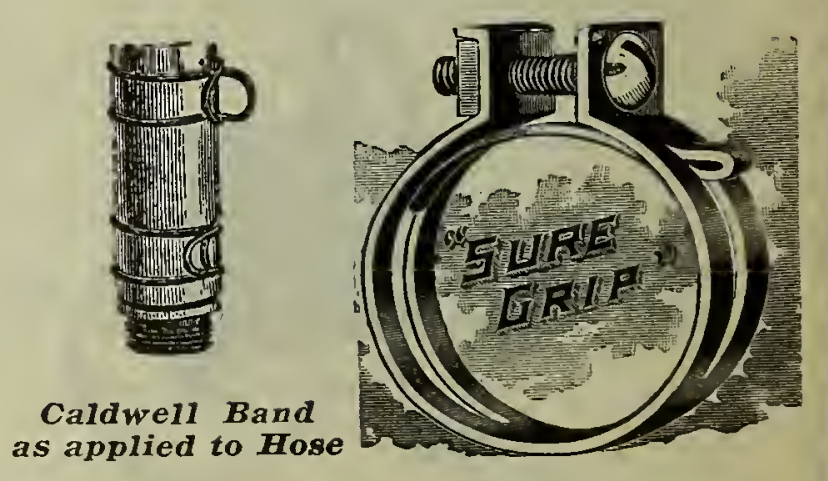

\section{HOSE BANDS}

For fastening couplings and menders in hose.

No. CALDWELL'S noz. 100 8-For 3-ply hose .......... \$0.I5 \$0.9o 6-For 4-ply hose ........... I5 90 HUDSON'S

$1 / 2$-inch $\ldots \ldots \ldots \ldots \ldots \ldots \ldots . \$ 0.15 \$ 0.90$ $3 / 4$-inch .................. I8 1.00 SURE GRIP

3/4-inch, 4c. each: doz.. 40c.; $\$ 2.75$ per 100 . 


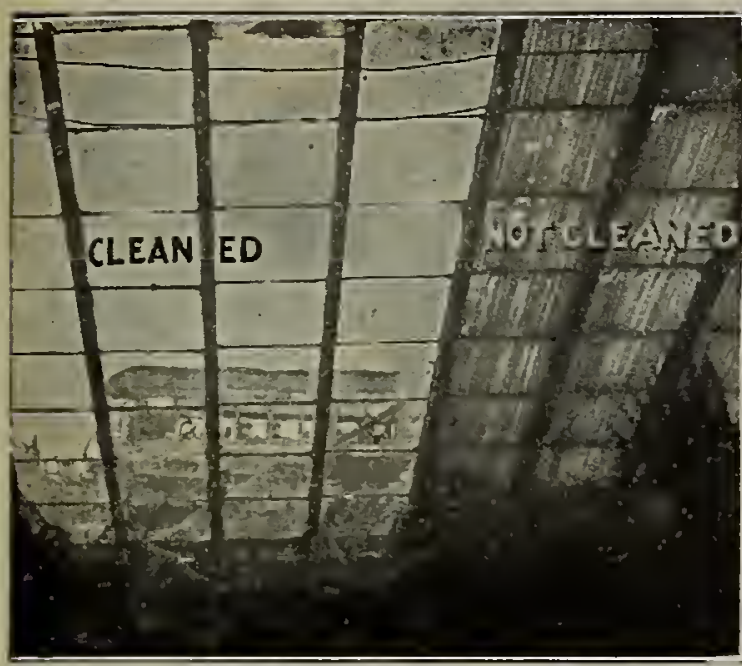

The effects of using Daylite Glass Cleaner DAYLITE GLASS CLEANER

For taking off whitewash shading, etc. Daylite Cleaner

Is the most powerful cleaner on the market. It is self-acting-the minute it is put on the glass, it commences to work for you. All you need to do is to apply it with a brush, leave it on a few minutes and rinse off with cold water.

Will not injure paint or putty.

Will always leave the glass clean and free from grease.

The cost of cleaning greenhouse glass is about one-fifth cent per square foot. One gallon will clean about 400 to 600 square feet of glass. Price, I gal., \$I.00; 5 gals. for $\$ 4.50$.

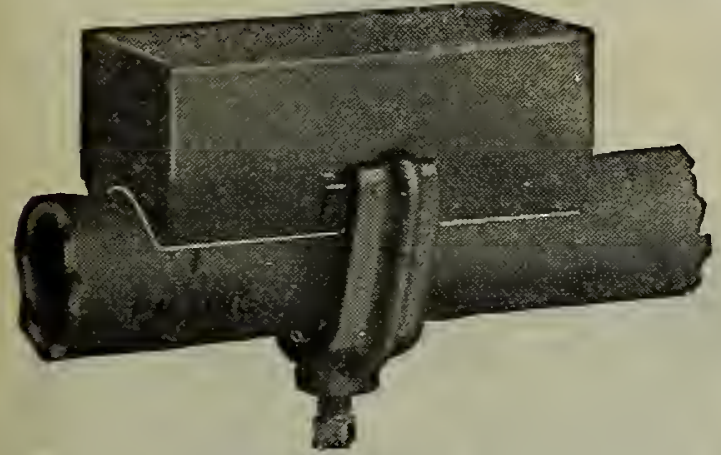

THE BATE EVAPORATOR

This consists of a bottomless pan, which fits directly over your steam or hot water pipes, the latter making the bottom of the pan. Made for $\mathrm{I}$-inch, $\mathrm{I} / 2$-inch and 2 -inch pipe. Always state for which size it is wanted when ordering. Price. f. o. b. factory: Each, 6oc., per dozen, $\$ 6.60$. Larger quantities at 50c. per pan.

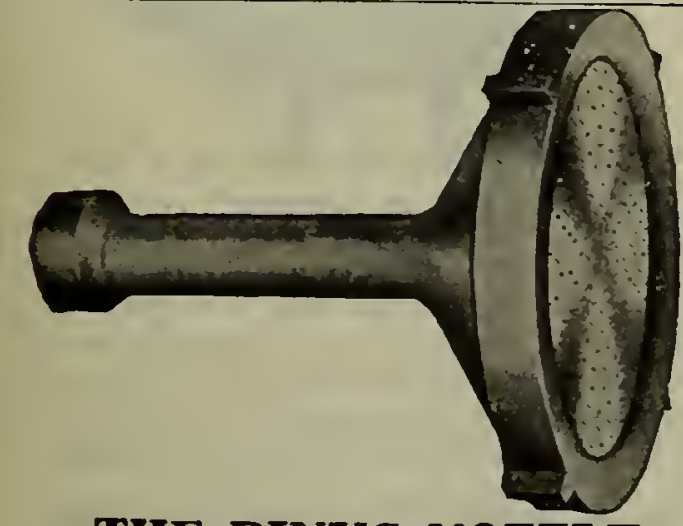

THE BINKS NOZZLE

Made of aluminum, with brass face, equipped with interchangeable sprays, coarse and fine. It makes watering possible without wetting the hands. Positively the best and most indestructible nozzle made. \$2.50 each; worth twice the orice.

\section{HOT BED SASH \\ Made of best quality cypress, I $3 / 4$ in. thick; 3 ft. $I^{T / 2}$ in. wide, $6 \mathrm{ft}$. long. Glazed with $8 \times$ Io in. glass, 4 lights wide, laid in putty. \\ Plain, reg-} ular style not glazed or painted.

Each \$1.35; $\$ 15.00$ p e r

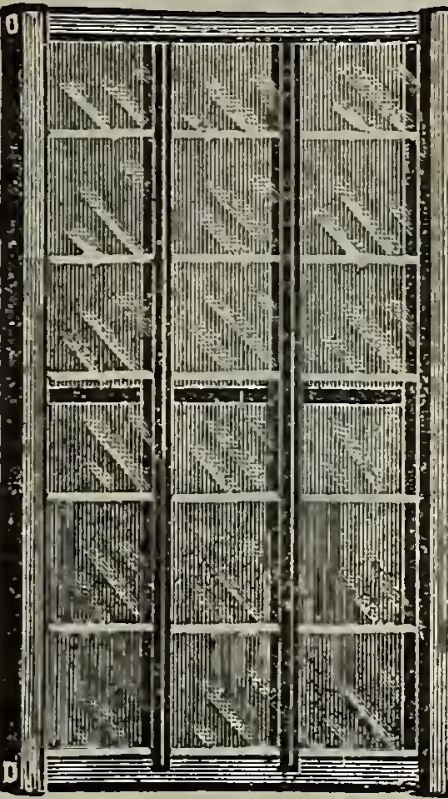

Glazed, regular style, including painting and puttying. Each $\$ 3.00 ; \$ 35.00$ per doz.

All glazed sash are shipped at purchaser's risk, although we pack very carefully to insure safe arrival.

Packing Charges on regular style Glazed sash only, Ioc. each; doz., \$I.20. Note: The above sash are 4 lights wide SUNLIGHT SASH (Double Glass) Plain Unglazed..... each, \$2.I5; doz., \$24.50 Glazed and Painted.each, 4.25; doz., 50.00 Crating Glazed Sunlight, Ijc. extra.

Special Prices quoted on sash in large quantities or special sizes.

\section{MARATHON GRINDERS}

Every floris needs a good grinding machine. By a combination of cut spur gears and steel cut pinions arranged in the "Marathon," we obtain a very high speed. This insures the quickest cutting results from the corundum stone witl minimum wear.

In. $3 / 4 \times 5, \$ 4.25$ " IX5, 5.25 3 " If $\mathrm{IX7}, 7.00$ warted, add \$I.40 to the above prices

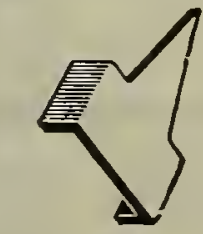

\section{(}

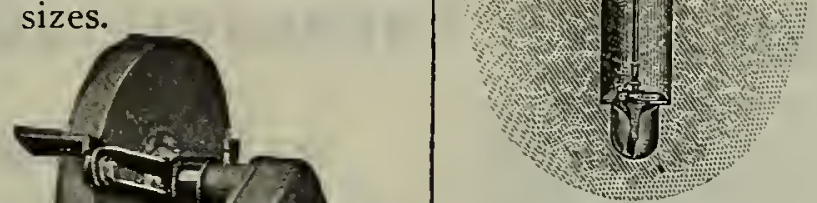
ment for burning rubetc., without endanlast a life's time.

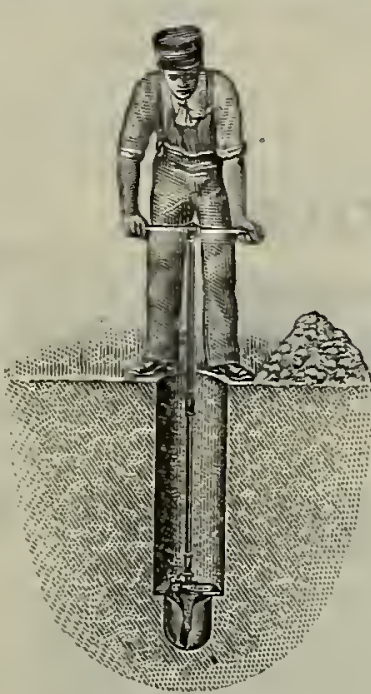

BRASS GLAZING POINT

\section{MICHELL'S \\ RUBBISH \\ CONSUMERS}

Made of heary galvanized wire, an indispensable arrangebish, paper, leaves, gering property. Will

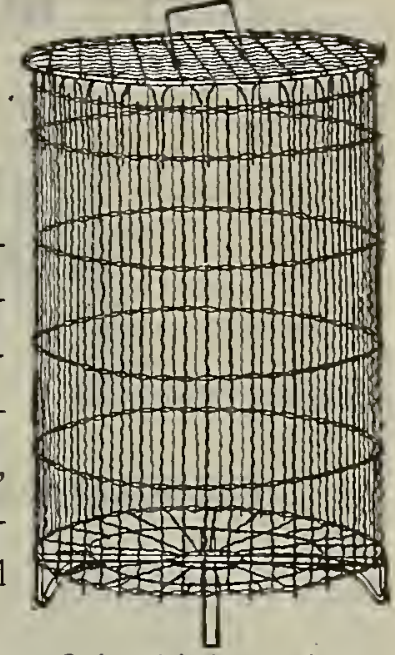

Letter A-I 2 in. diam,, I 8 in. high....\$1.10 Letter $\mathrm{B}-\mathrm{I} 5$ in diam, 22 in high.... I.35 Letter C-I8 in. diam., 26 in. high.... I.60 Letter D-2I in. diam.. 3I in. high... 2.25

\section{No. 8 \\ POST HOLE DIGGER}

This is really an earth auger, as will be seen by the illustration; will bore a hole $3 \frac{\mathrm{T}}{2} \mathrm{ft}$. deep and can be adjusted in diameter from 8 to 14 inches. It can be emptied instantly; it is made of the finest steel and a man with one of these can do 3 times as much work as with an ordinary digger. Price, $\$ 3.25$ each. No. I5 Eureka Posthole Diggers 9oc.ea.

\section{MEHLER HANDY GARDENER}
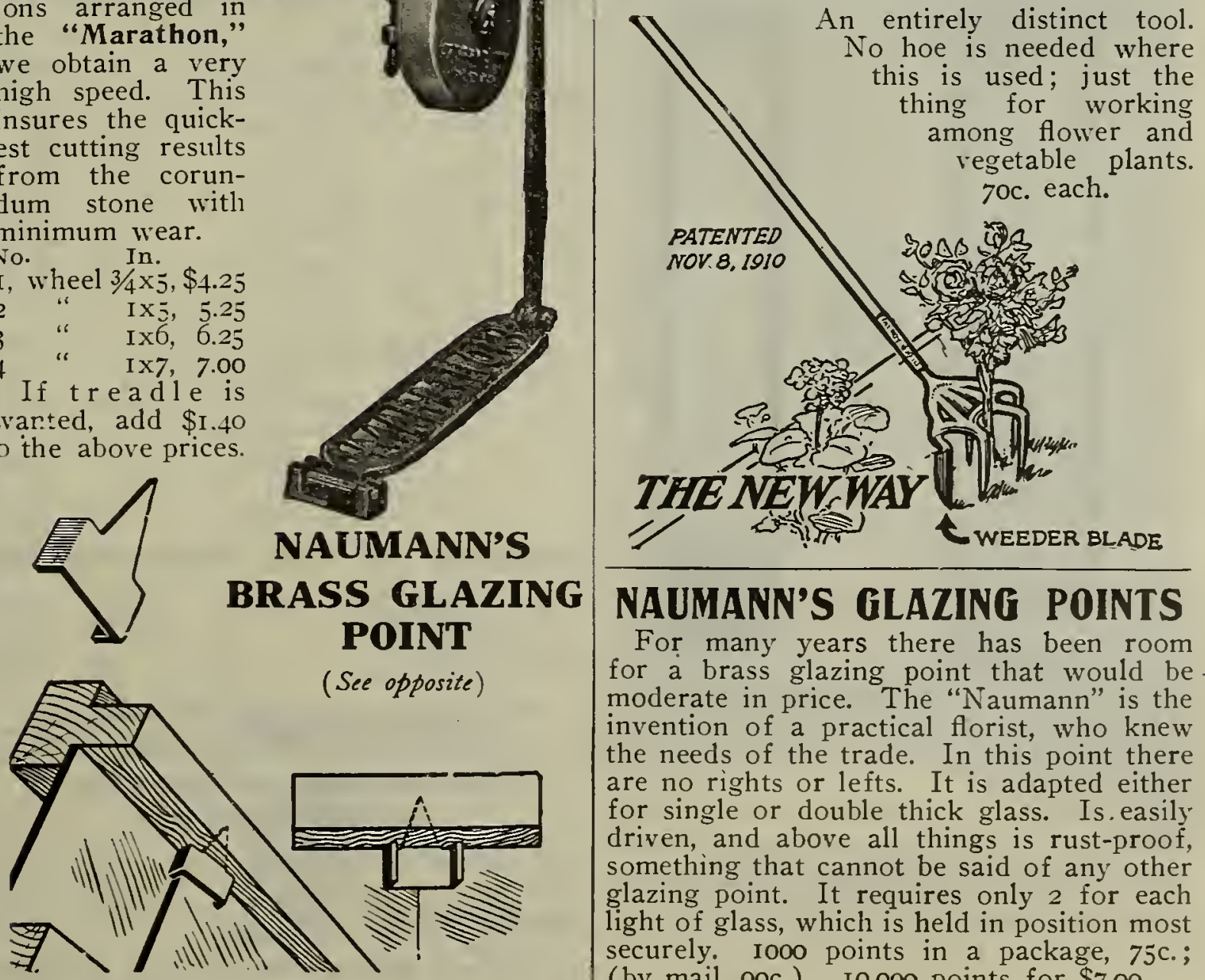

NAUMANN'S GLAZING POINTS

For many years there has been room for a brass glazing point that would be moderate in price. The "Naumann" is the invention of a practical florist, who knew the needs of the trade. In this point there are no rights or lefts. It is adapted either for single or double thick glass. Is easily driven, and above all things is rust-proof, something that cannot be said of any other glazing point. It requires only 2 for each light of glass, which is held in position most securely. I000 points in a package, $75 \mathrm{c}$. (by mail, 90c.). I0,000 points for $\$ 7.00$. 


\section{PUTTY BULBS (See Cut)}

The best appliance for distributing putty. One day's work by the old method of glazing can easily be done in four hours by the use of the distributor. Each, 90c.; by mail, \$1.00.

\section{MASTICA}

\begin{tabular}{ll|l}
$1 / 2$ & gallon $\ldots . . \$ 0.70$ & 5 gallons $\ldots . \$ 6.25$
\end{tabular}

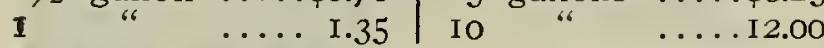
Mastica Machine each, $\$ 1.25$

\section{TWEMLOW'S PUTTY}

I6-lb. can ( I gallon), \$I.45; 50-1b. kit (3 gallons) 8o-lb. kit ( 5 gallons)

I6o-lb. kit (I o gallons)

$\mathrm{r} / 2$ barrel (25 gallons)

Per barrel (50 gallons)

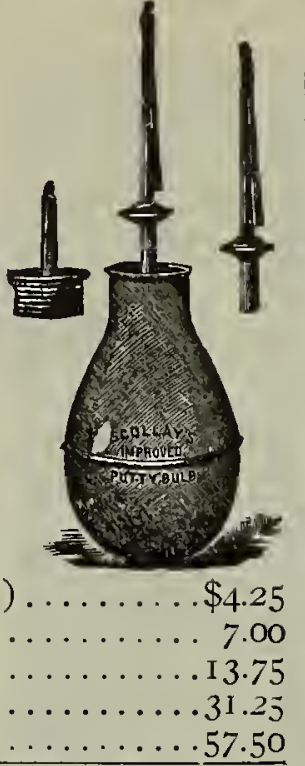

\section{HAMMOND'S GREENHOUSE WHITE PAINT}

The nuanufacturer claims this paint is superior in quality and lower in price than any other material of the same character. It is largely used now in place of the ordinary grade of white lead.

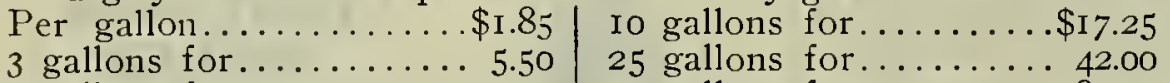

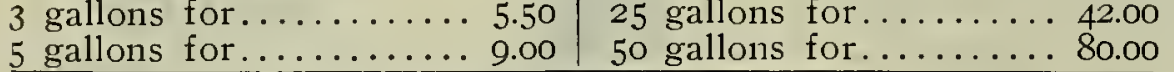

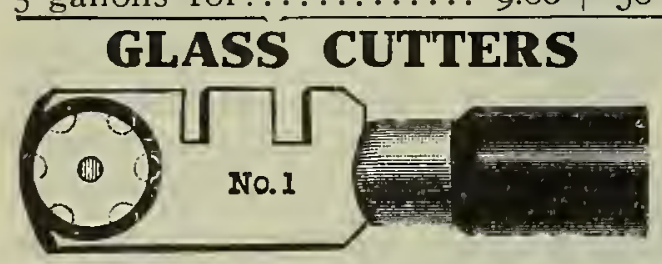

Small Diamond $\ldots \ldots \$ 2.53$ Large Diamond ....... 3.75 Single Wheel, SteeI. . .15 (Doz., \$1.50) 6=Wheel Adiustable.

\section{PEERLESS GLAZING POINTS}

Nos. I, 2, 21/2 Tinned. Nos. I and 2 are for single thick glass. No. $2 \frac{1}{2}$ for double thick glass. 6oc. per I000; 5000 for $\$ 2.75$. By mail, 76c. per IOOO.

PINCERS, for driving Peerless Points, '50c. per pair.

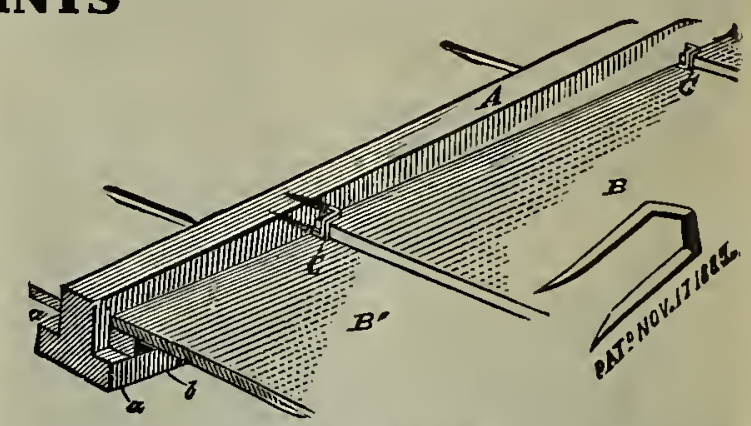

Peerless Glazing roints

Siebert's Style Points. (See opposite cut.) $5 / 8$ inch, $6 / 8$ inch and $7 / 8$ inch, 35c. per lb.; Io lbs., $\$ 3.00$. By mail, 50c. $1 \mathrm{~b}$.

ZINC NAILS, $5 / 8,3 / 4$ and $7 / 8$ inch, 20c. per lb.; 5 lbs., $90 c$. By mail, 36c. per lb.

Nauman's G la $z$ ing Points. (Brass.) 75c. per 1,000. By mail, 90c.

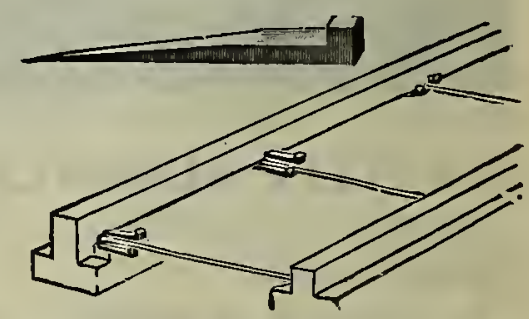

Siebert's Glazing Points

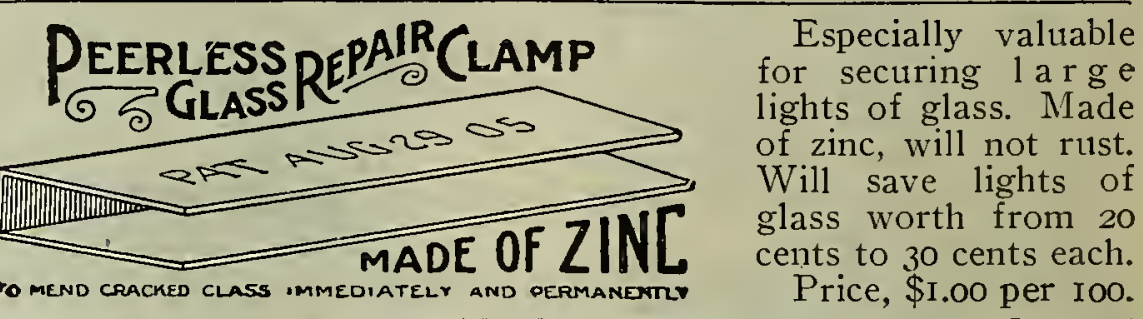

\section{RELIABLE THERMOMETERS AND THERMOSTATS}

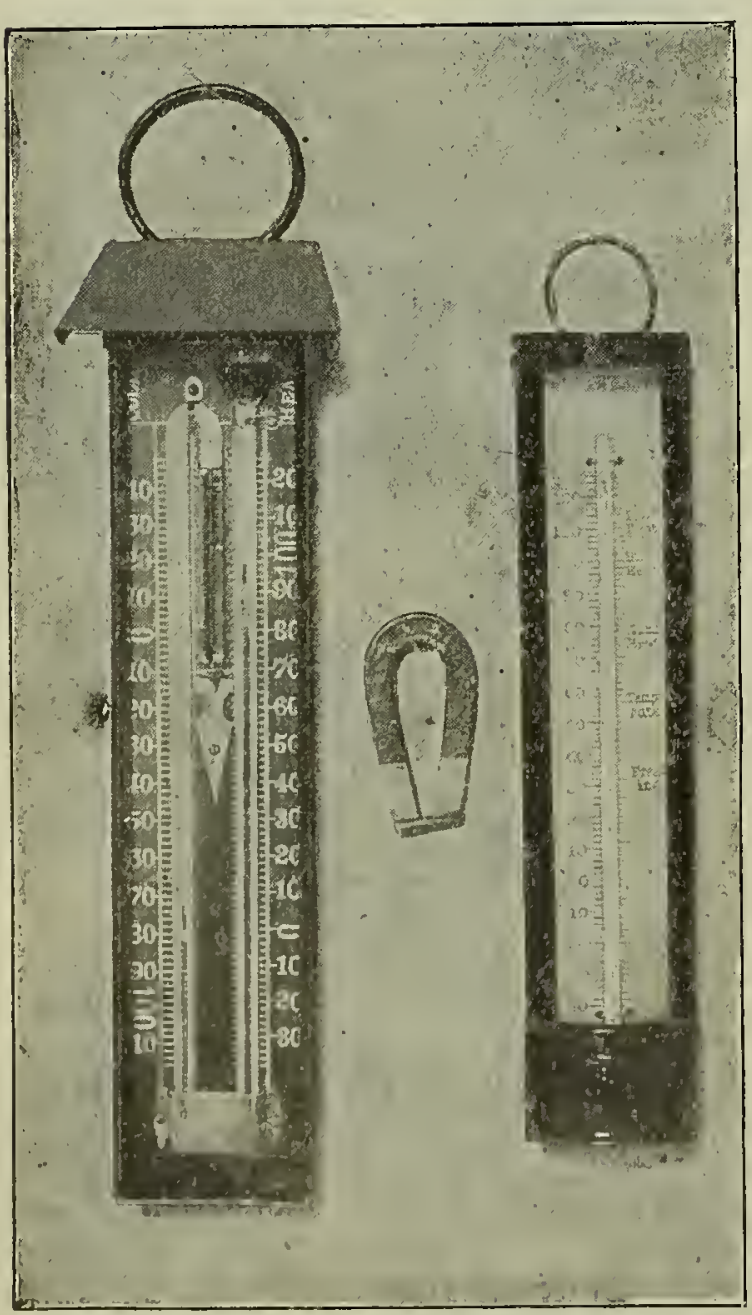

A reliable thermometer is a very necessary thing in a greenhouse establishment. Ours are selected with great care and we especially recommend the "Three Point Test."
MAXIMUM AND MINIMUM

Registering the coldest and the warmest point during previous night.

8-inch, each, \$2.50; per $1 / 4$ doz., $\$ 6.75$; Io-inch, each, $\$ 2.75$; per $1 / 4$ doz., $\$ 7.50$.

\section{THREE POINT TEST THERMOMETER}

This thermometer is positively accurate and may be depended upon at all times. We can supply these in Mercury or Spirit Glass; state which is wanted in ordering.

5420B. 8-inch, Tin Case....... \$0.40 \$4.00 5420B. ro-inch, Tin Case....... $.55 \quad 5.50$ 5420 B. I2-inch, Tin Case....... $85 \quad 9.00$ 5154. 8-inch, Copper Case.... $65 \quad 6.50$ 5I 54. Io-inch, Copper Case.... .85 5I 80. 8-inch Wood B a ck, Black Scale I.Io I 2.00 Io-inch Wood B a ck, Black Scale 8-inch, W o od B a ck, Porcelain Scale ..... .8o 9.00 ro-inch, W ood B a ck,

Porcelain Scale ..... I.00 II.00 Standard Tin Case Thermometers

White scale, very reliable. Each Doz. $5420 \mathrm{~W} .8$-inch $\ldots \ldots \ldots \ldots \ldots \ldots \ldots .25 \$ 2.75$ $5+20 \mathrm{VV}$. Io-inch ............... $35 \quad 3.75$

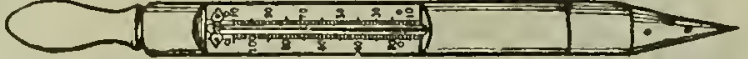 \\ MUSHROOM OR HOT BED} THERMOMETERS

Galvanized Iron Point (can't rust), Each, \$0.90

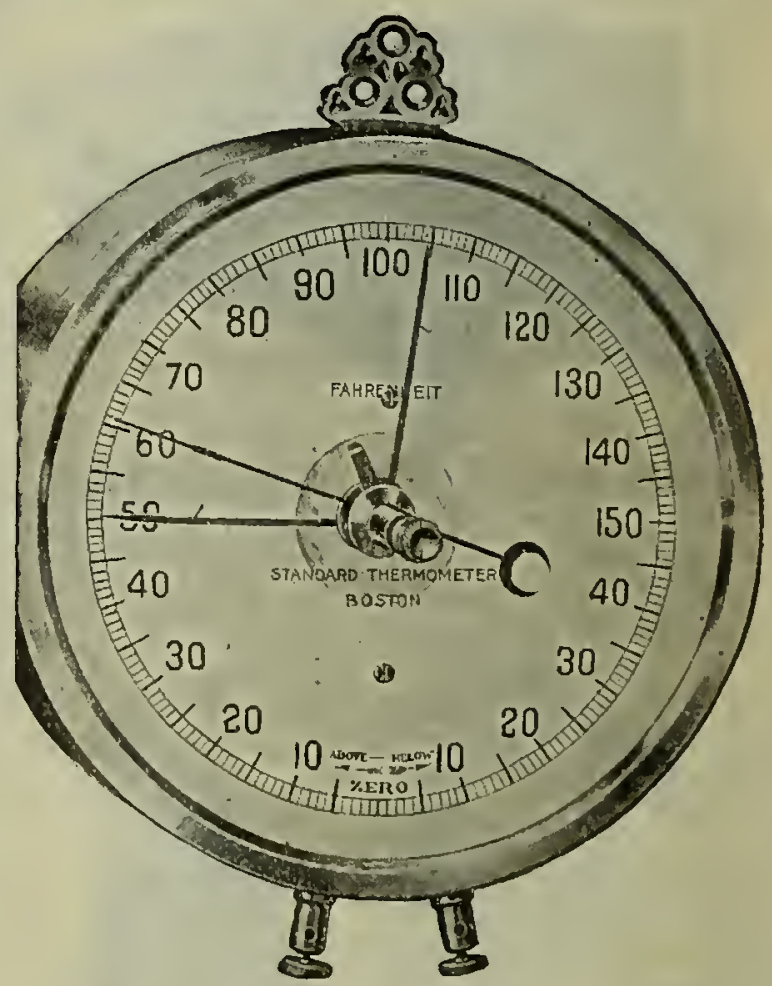

Style 1-THERMOSTAT (See Cut) This will he found far more reliable than the old method of having a thermometer attached to an ordinary thermostat and bell. Furnished complete with the exception of wire, battery and bell. All brass, Not a'aterproof style, \$5.00; Waterproof Stylc. \$IO.00.

\section{RECORDING THERMOMETERS}

Show accurately the temperature during every hour of the night. We can furnish them with 30 daily or I 2 weelily charts. I.35 ity). \$25.00; No. 100, \$20.00. 


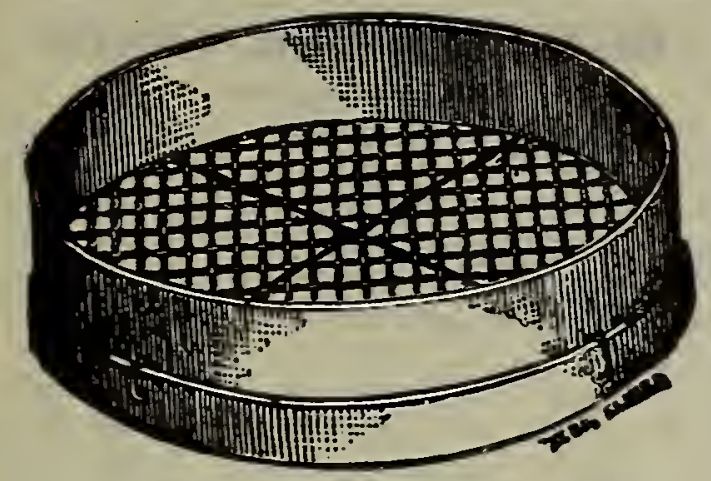

SIEVES (ANY SIZE MESH)

Made extra well, of galvanized wire an hard wood. 20 inch Foundry (extra heavy) .....\$0.75 20 inch Regular wire ............... .65 8 inch Regular wire $\ldots . . . \ldots \ldots \ldots . . .55$

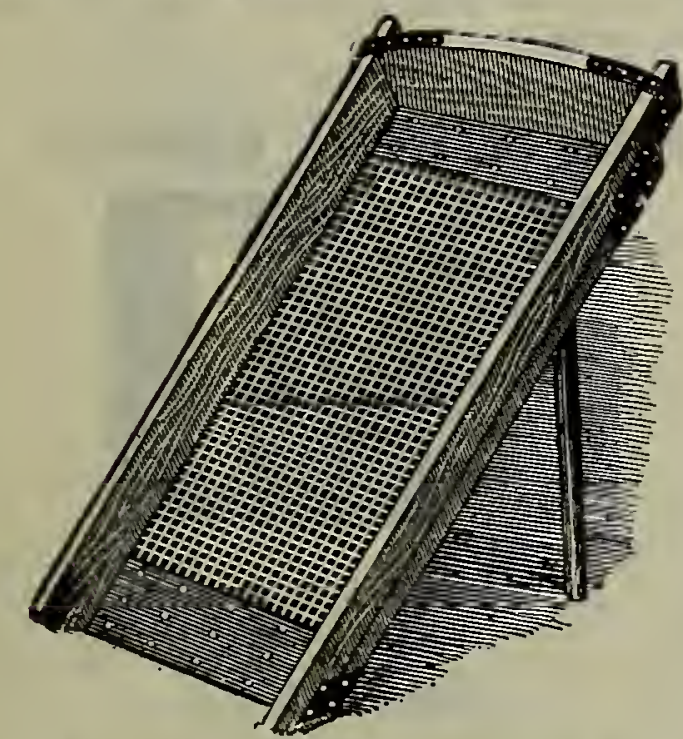

Large Upright Sieve for soil, gravel, sand, etc. Made in any size mesh, of extra heavy foundry wire, $\$ 7.25$ each

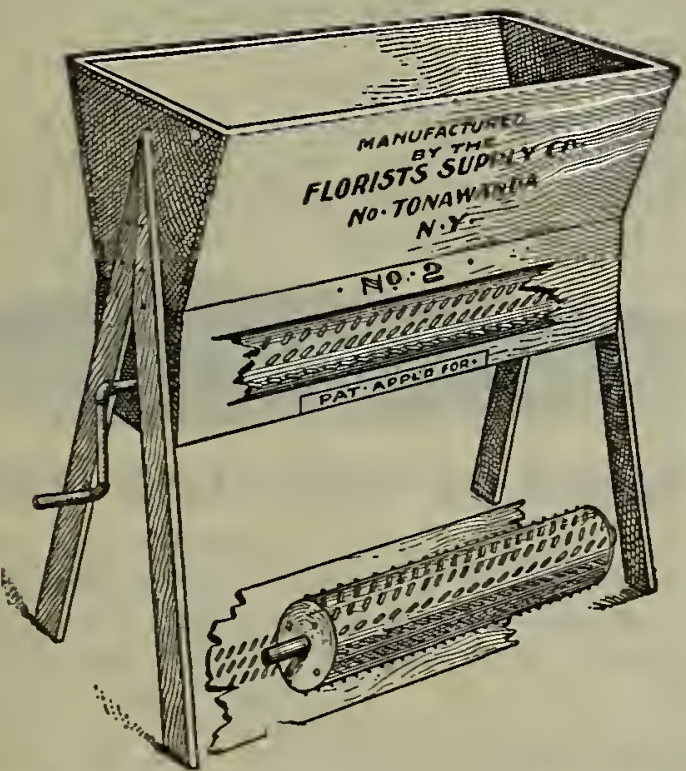

Sod Crusher and Soil Pulverizer

These machines are equipped with hopper, and a roller, the latter being spiked. It is turned by means of a handle and crushes the soil perfectly, aroiding the necessity to sift.

No. I, \$15.00| No. 2, \$20.00| No. 3, \$30.00 We can also supply Wolff's Automatic Soil Sifters. Write for prices.

Liquid Manure Distributor (See Opposite)

This can be attached to hose with which you are watering and, connected with a barrel of liquid manure, the suction of water will draw a quantity of manure with it, All brass.

Price, \$I.50 each. (By mail, postpaid,
WAGON AND AUTOMOBILE HEATERS

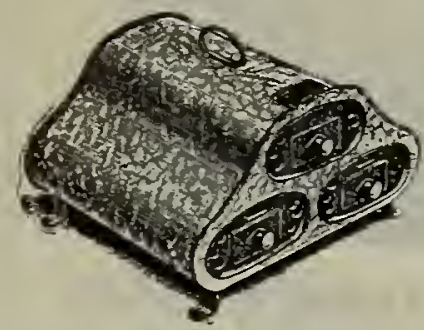

These heaters wil

keep the tempera-

ture above freez-

ing in most any ordinary close vehicle during the severest weather.

No.

5. Single drawer, I4 in. long....... \$I.75 ${ }_{5} \mathrm{~B}$. Single drawer, I4 in. long covered with Brussels carpet

2.00 9B. Single Drawer, I 2 in. long, covered I.25 9B. I2 in., Brussels carpet cover...... I.jo

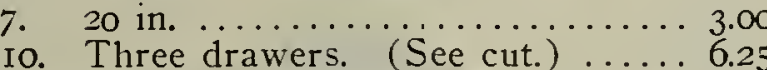
Coal for Wagon Heaters. 7oc. per doz. bricks; per IOO, $\$ 5.00$.

Tongs for Handling Hot Coals. 25c. Illustrated circular on request.

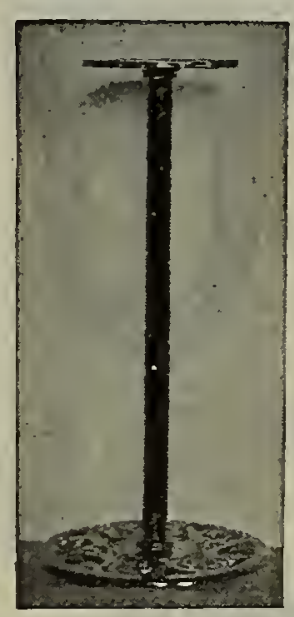

\section{IRON PLANT} STANDS

STAR STYLE

Somewhat similar to the "Superior," excepting with the tilting device, and are finished in black varnish.

Height Each Doz I2 inches ...\$0.60 \$6.75 $\begin{array}{lllll}\text { I8 } & . & \ldots & .70 & 8.00 \\ 24 & . & \ldots & .85 & 9.50\end{array}$ $\begin{array}{lllll}24 & \cdots & \cdots & .85 & 9.50 \\ 30 & & \cdots & .100 & 11.25\end{array}$ $\begin{array}{lllll}30 & . & \ldots & \text { I.00 } & \text { II } .25 \\ 36 & . & \ldots & \text { I.25 } & \text { I } 4.00\end{array}$ SUPERIOR STYLE

Can be tilted to set your plants at any angle desired to produce the proper decorative effect. Enameled green.

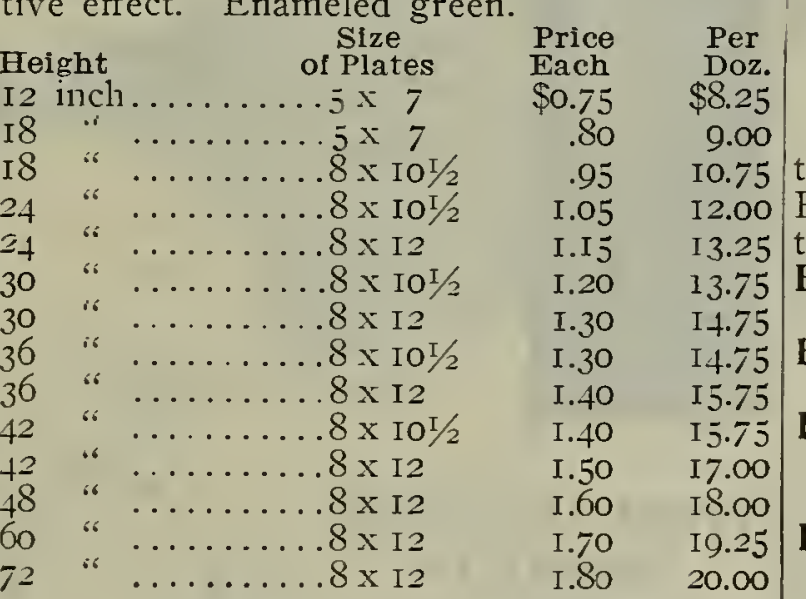

EXTRA PLATES FOR IRON STANDS For Superior For Star Stands

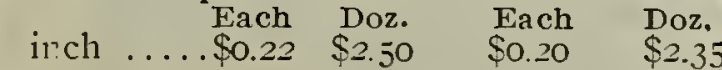

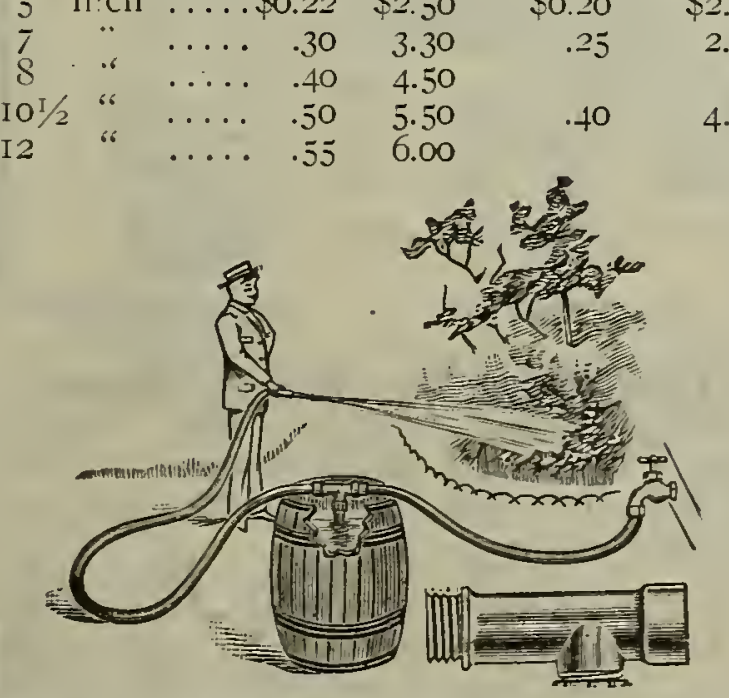

WHEELBARROWS MICHELL'S SPECIAL GREENHOUSE

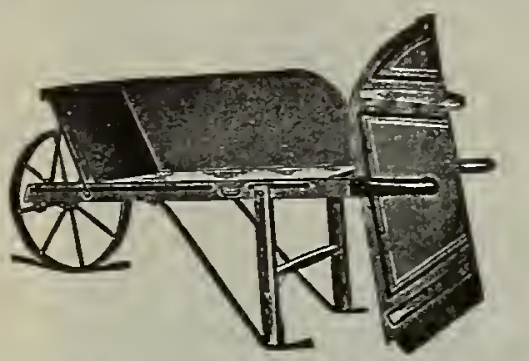

This a very narrow barrow, designed for us in aisles of greenho use ures inside It inches in front, I7 ins. Special Greenhouse Barrow in back, and I2 inches deep. Handles, 4 feet, 8 inches long. Spread of handles at hand hold 20 inches, which is extreme width of barrow. Furnished in r8-inch diameter wheel. Nicely painted and striped. Price, each, \$4.25. OTHER WHEELBARROWS No. Tire In. Length It. Depth In. Hidth It. Price

$\begin{array}{llllll}\mathrm{Nu}=W a y & \text { I } 1 / 2 & 26^{\mathrm{T}} / 2 & \text { I I } & 25 & \$ 5.00\end{array}$ O I d Gov=

$\begin{array}{llllll}\text { ernment } & \mathrm{I} / \mathrm{L} & 3 \mathrm{I} & 9 & 26 & 3.50\end{array}$ $\begin{array}{lllllll}\text { Eastern } & .4 & 3 & 261 / 4 & \text { I I } 1 / 2 & 27 & 4.25\end{array}$ $\begin{array}{lllllll}\text { Jacobs } & .5 & 3 & 281 / 4 & \text { I I } 3 / 4 & 27 & 4.50 \\ \text { I } 1 / 4 & 241 / 2 & \text { I I } & 23 & 3.50\end{array}$

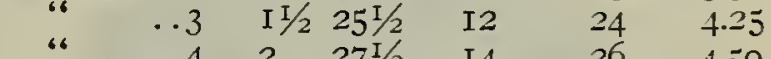
$\begin{array}{llllll}\text { Boys } \ldots .2 & \text { I } & 2 \mathrm{I} 3 / 4 & 91 / 4 & 20 & 2.75\end{array}$ Canal-Side dump (bolted) ....... 2.25

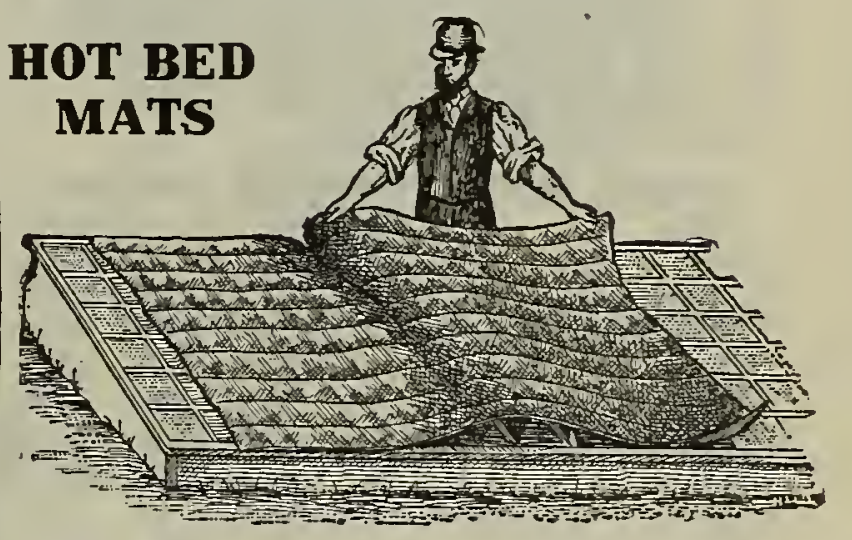

The Burlap, and Duck and Burlap are the best mats that it is possible to procure. they are otherwise practically indestructible.

Burlap. $76 \times 76$ inches. covering two regular size sash. Each, \$I.40; doz., \$16.00.

Burlap. $40 \times 76$ inches, for one sash. Each,

9oc.; doz., \$9.90.

Duck and Burlap. This style is water proofed on one side. $40 \times 76$ inches.

Duck and Burlap. $76 \times 76$ inches. Each, \$I.55; doz., \$18.00.

length desired:

Duck and Burlap Mats. 76 inches wide

2.75 Plain Burlap Mats. 76 inches wide at $23 \mathrm{c}$ per running foot. Fach Doz. Straw Mats. $3 \times 6$ feet.....\$0.90 \$10.50

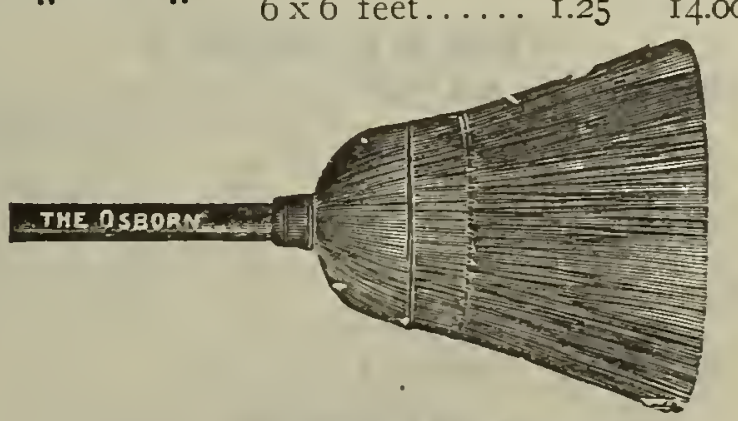

GREENHOUSE BROOM

Made of Japanese Fibre No wear to it. Price, 55c. each; 2 for \$1.00. 


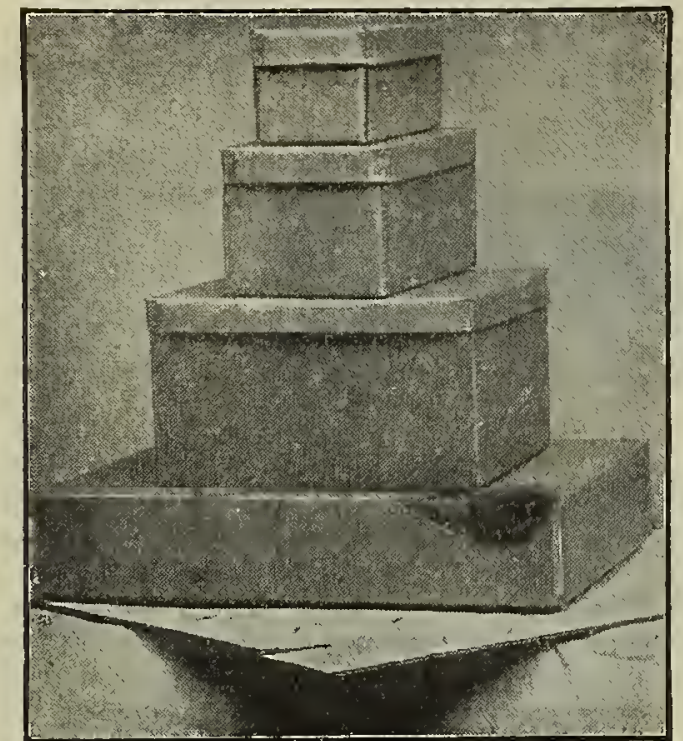

CUT FLOWER BOXES

Used almost exclusively for carrying and shipping cut flowers; they are lighter than wooden ones, carry the contents as safely, will stand numerous trips, and when needed to be replaced involve small expense.

Special sizes to order in lots not less than roo of a kind. Price on application.

\section{CORRUGATED PAPER}

$60 \times 20 \times 12$. inch $\ldots \ldots \ldots \$ 0.50 \quad \$ 5.00 \quad \$ 37.50$ $42 \times 14 \times 8$ inch $\ldots \ldots . .30 \quad 3.00 \quad 21.00$

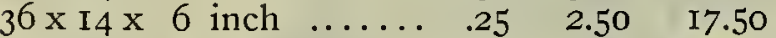
$24 \times 8 \times 5$ inch $\ldots \ldots . . .15$. I5 1.50 I0.00

Fifty of any one size at Ioo rate.

\section{LIGHT WEIGHT PAPER BOXES}

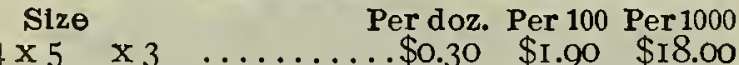
$\begin{array}{rrrrrr}20 \times 4 & \times 3 & \ldots \ldots \ldots \ldots & .35 & 2.10 & 20.00\end{array}$ $\begin{array}{llllll}16 \times 5 & \times 3 & \ldots \ldots \ldots \ldots & .35 & 2.10 & 20.00\end{array}$ $\begin{array}{llllll}18 \times 5 & \times 3 & \ldots \ldots \ldots \ldots & .35 & 2.20 & 21.00\end{array}$

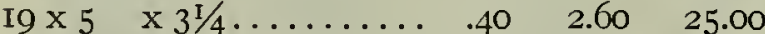
$18 \times 7^{\mathrm{T} / 2} \times 3^{\mathrm{T} / 2} \ldots \ldots \ldots \ldots . .45 \quad 3.10 \quad 30.00$ 2I $\times 5 \quad \times 31 / 4 \ldots \ldots \ldots \ldots, 45 \quad 3.10 \quad 30.00$

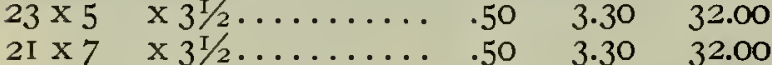
$2 \mathrm{I} \times 8 \quad \times 4 \quad \ldots \ldots \ldots \ldots . .55 \quad 3.60 \quad 35.00$ $23 \times 7 \quad \times 3 \frac{1}{1} 2 \ldots \ldots \ldots \ldots, \quad .55 \quad 3.60 \quad 35.00$ $\begin{array}{rrrrr}30 \times 5 & \times 31 / 2 \ldots \ldots \ldots \ldots & .55 & 3.60 & 35.00 \\ 24 \times 8 & \times 4 & \ldots & \end{array}$ $24 \times 8 \times 5 \quad \ldots \ldots \ldots \ldots \ldots, 65 \quad 4.35 \quad 42.50$ $\begin{array}{lllll}36 \times 5 & \times 33^{\mathrm{T}} / 2 \ldots \ldots \ldots \ldots & .70 & 4.85 & 47.50\end{array}$

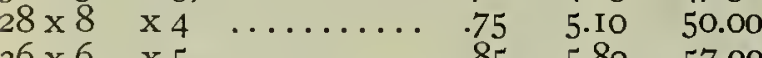
EXTRA HEAVY WEIGHT PAPER BOXES Size Per doz. Per 100 Per 1000 $23 \times 12 \times 4 \ldots \ldots \ldots \ldots . \$ 0.85 \quad \$ 6.10 \quad \$ 60.00$ $28 \times 8 \times 5 \ldots \ldots \ldots \ldots \ldots, 85 \quad 6.10 \quad 60.00$ $30 \times 9 \times 4 \ldots \ldots \ldots \ldots \ldots \ldots, \quad 85 \quad 6.10 \quad 60.00$

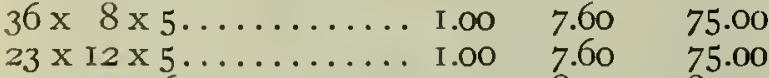
$30 \times 9 \times 6 \ldots \ldots \ldots \ldots$ I.IO $8.10 \quad 80.00$ $30 \times 12 \times 6 \ldots \ldots \ldots \ldots \ldots \ldots$ I. $50 \quad 10.25$ 100.00

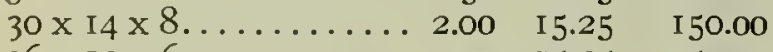

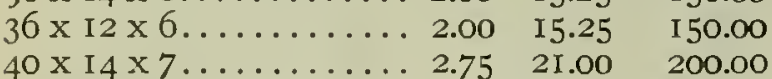

\section{VIOLET BOXES}

Made of violet and white color line glazed board

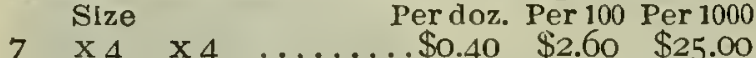
$8 \times 5 \times 5$

$9 \times 7 \times 5 \frac{1}{2} \ldots \ldots \ldots .70 \quad 5.10$ I3 $\times 9 \times 6 \quad \ldots \ldots \ldots$. I.I $8.10 \quad 80.00$ 500 boxes printed free with one size or style card. Smaller lots at cost.

\section{STRAPS}

For carrying large cut flower boxes. Eight feet long, of best leather, \$1.75 each. Canvas Straps, 5oc. each.

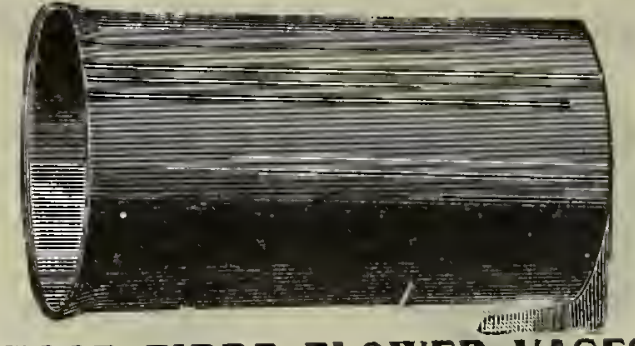

\section{WOOD FIBRE FLOWER VASES}

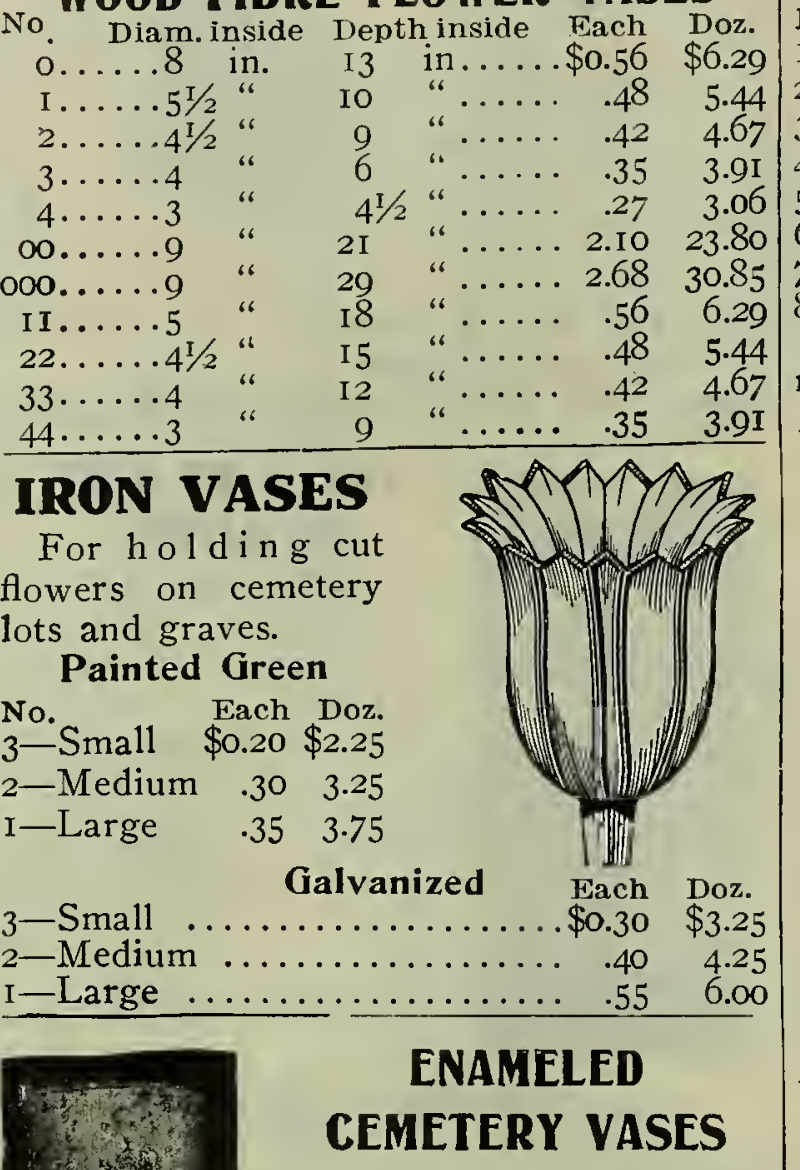

\section{IRON VASES}

flowers on cemetery

Painted green; made of tin and carefully enameled; will not burst in cold weather.

I-Large, each 2oc., doz.

$\$ 2.25$, $100 \$ 16.00$.

2-Small, each i5c., doz.

\$1.75, 100 \$13.00.

\section{WIRE HANGING}

\section{BASKETS}

Complete with Hanger.

$$
\begin{array}{rrrc}
\multicolumn{5}{c}{\text { Light }} & \text { style. } \\
& \text { Each } & \text { Doz. } & 100 \\
8 \text { in. } & \$ 0.09 & \$ 0.90 & \$ 6.75 \\
\text { I0 in. } & .14 & \text { I. } 40 & 10.50 \\
\text { I } 2 \text { in. } & .20 & 2.00 & 15.00 \\
\text { I4 in. } & .30 & 3.00 & 22.00 \\
\text { I6 in. } & .40 & 4.25 & .32 .50
\end{array}
$$

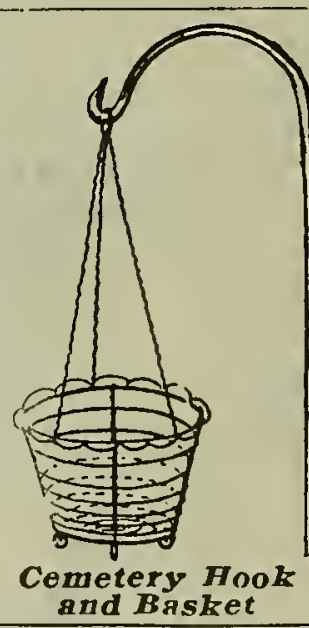

Extra Heary Wire Hanging Baskets

The most substantial wire langing basket made, and we recommend it where baskets are wanted for refilling each year, as these last.

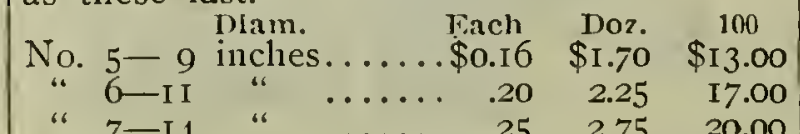

IDEAL FLOWER VASES

(Galvanized Iron)

Absolutely indestructible and unbreakable, made of heavy galvanized iron riveted and soldered so they cannot leak or come apart. The top and bottom are overturned, which serves as a reinforcement against wear. Fine for use in the greenhouse store or icebox.

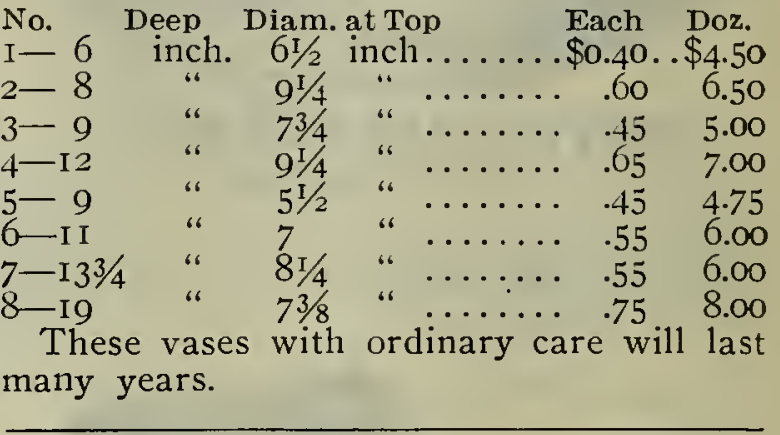

PAINTED POT LABELS
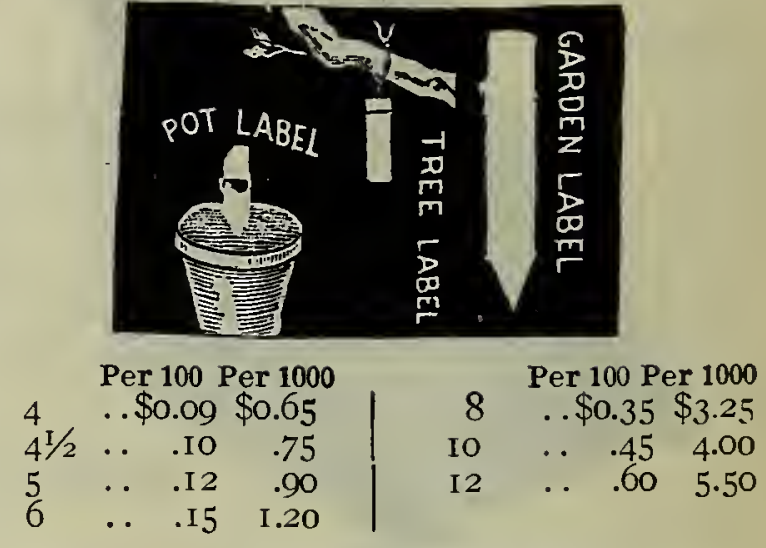

\section{TREE LABELS, Etc.}

Iron Wired. Plain wood...\$0.IO $\begin{array}{cc}\text { Per } 100 & \text { Per } 1000 \\ \$ 0.80 & 100\end{array}$ Copper " " " " Copper Sheer. Wired, doz., I 5c.; \$I per IOO. Zinc Sheet. Wired, doz., I5c.; \$I per roo. Indelible Marking Pencils, 5c. ea., doz. 5oc.

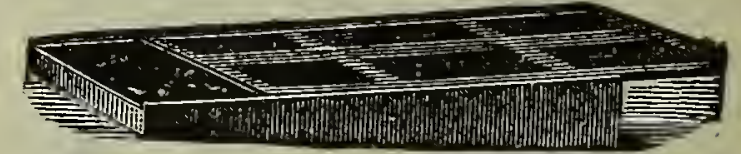

\section{SHADING OR PROTECTING CLOTH}

Largely used as a substitute for glass where protection is desired. It is admirable for summer use, protecting plants, etc., from sun and at the same time allowing ventilation. Yds. Per Price Price

Light. Brown cloth. .60 $60.05 \quad \begin{array}{r}\$ 2.60 \\ \text { \$0. }\end{array}$ Medium. " “" $60 \quad 09 \quad 4.80$ $\begin{array}{llll} & \text { " Green “ } 60 & .091 / 2 & 5.40\end{array}$ $\begin{array}{ccccc}\text { Heavy. Brown “" } & 40 & .12^{1 / 2} & 4.80 \\ \text { Green “ } & 40 & .14 & 5.20\end{array}$

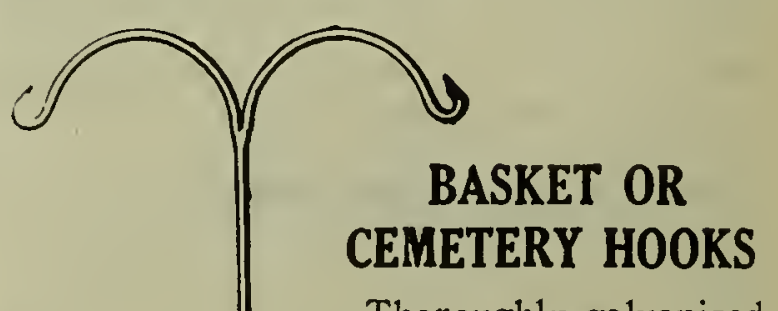

Thoroughly galvanized Single, ${ }^{5}$ inch thick........ \$ach $\$$ Do.35 Double (see cut), ${ }^{\frac{7}{16}}$ inch thick $.70 \quad 8.00$ 
Henry F. Michell Co., Wholesale Price-List, 518 Market Street, Philadelphia. 87

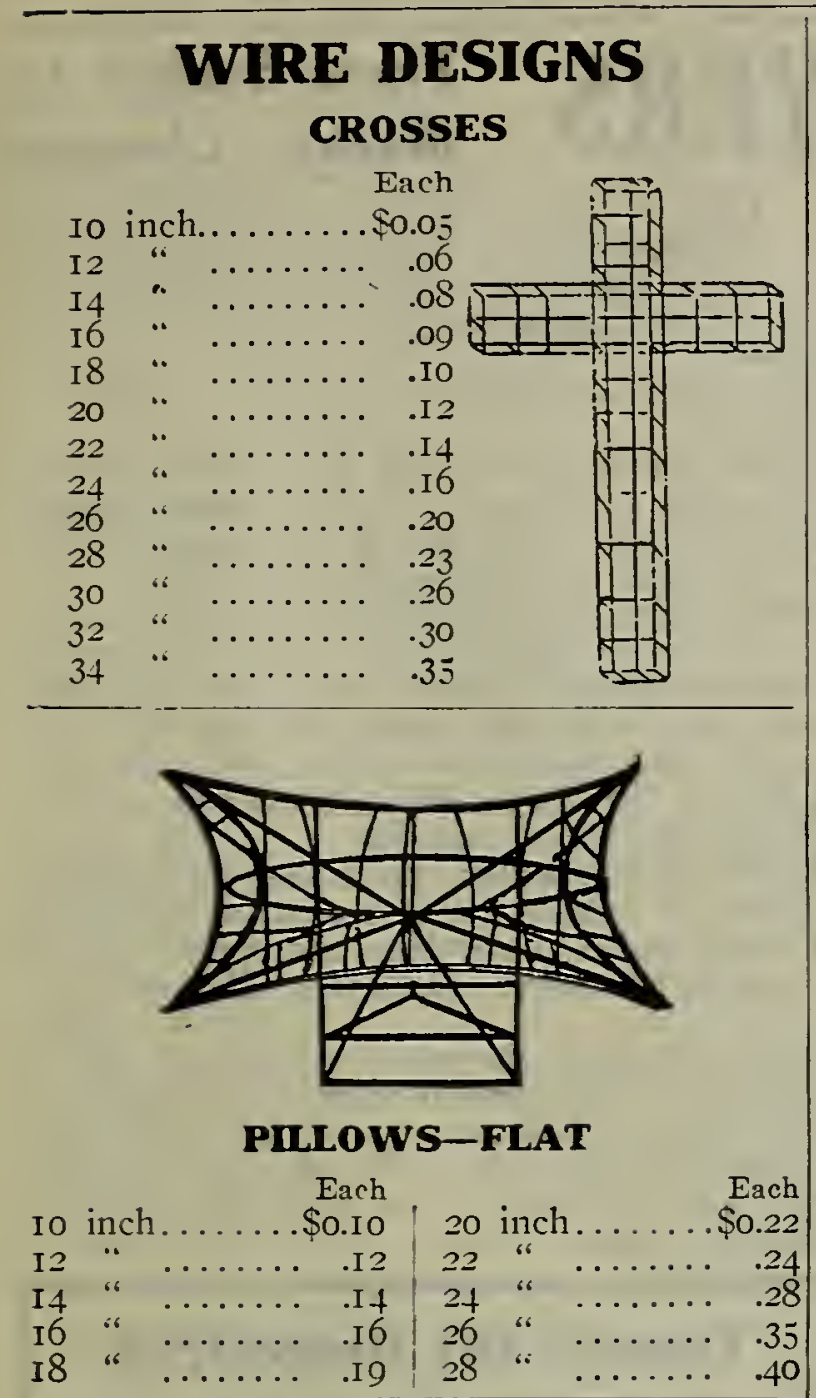

HORSE SHOES

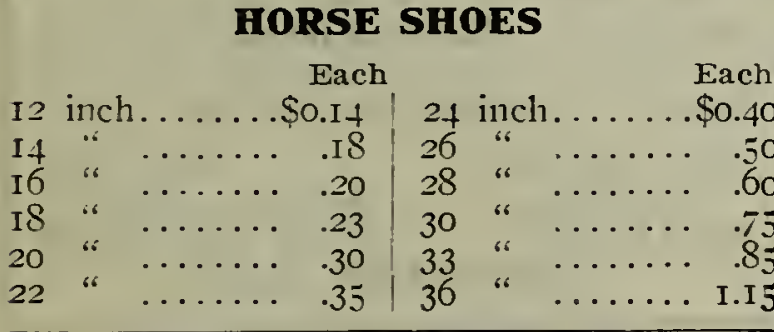

GATES AJAR

Measurements Include Entire Height Each I8 inches high. . . . . . . . . . . . \$ \$ 70
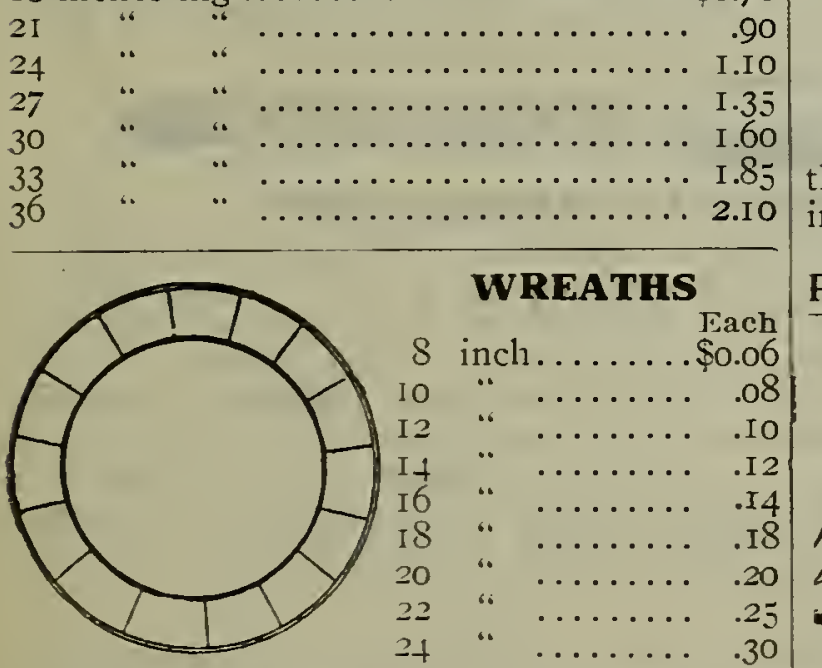

WREATHS

\section{ANCHORS}

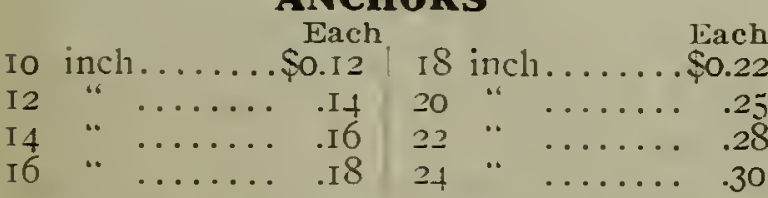

STAR AND CRESCENT 18
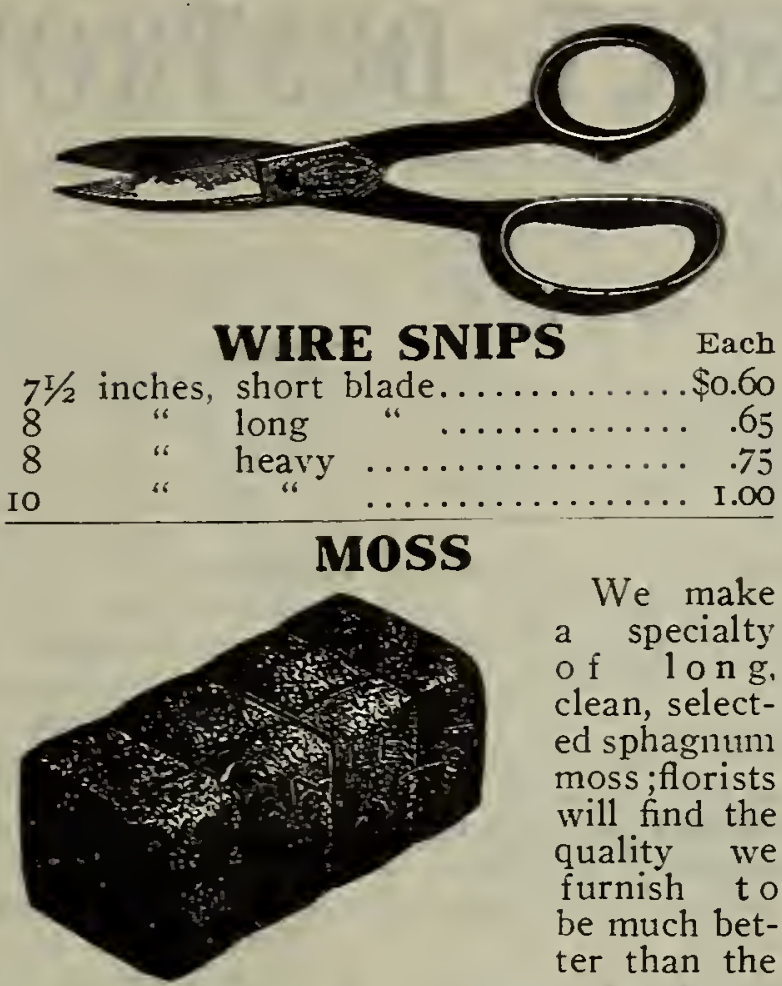

We make a specialty clean, selected sphagnum moss; florists will find the quality we be much better than the

Sphagnum, Live or Green. Peck 20c., 6oc. per bush. ............ per bbl., \$1.40 Sphagnum, Dry. Barrel bales 5oc. if called for; (if shipped 6oc.)....... Sphagnum, Dry. 5 barrel bales $\$ 1.75$ ( 3 bales for $\$ 5.00)$, $\$ 9.25$ for 6 bales. Green Lump. Peck 25c., 70c. bush. bbl bag $\$ 1.35$.

Green Sheet. Peck 30c., \$I.Io bush., bbl. bag $\$ 2.50$

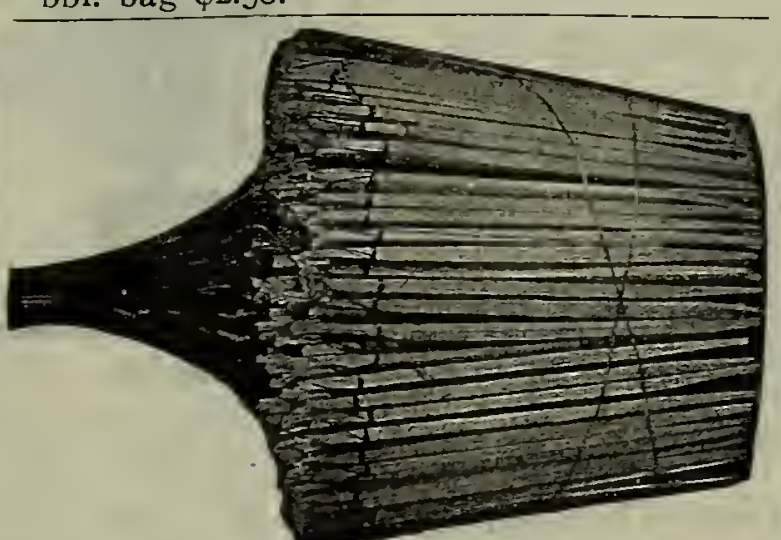

\section{WIRED TOOTH PICKS}

As a labor saver have no equal. Furthermore they are always ready; no looking for wire or shears.

Per box of $10,000 \$ 1.75,50,000$ for $\$ 7.50$. Plain Tooth Picks. $5 \mathrm{c}$. box, doz. boxes $50 \mathrm{c}$

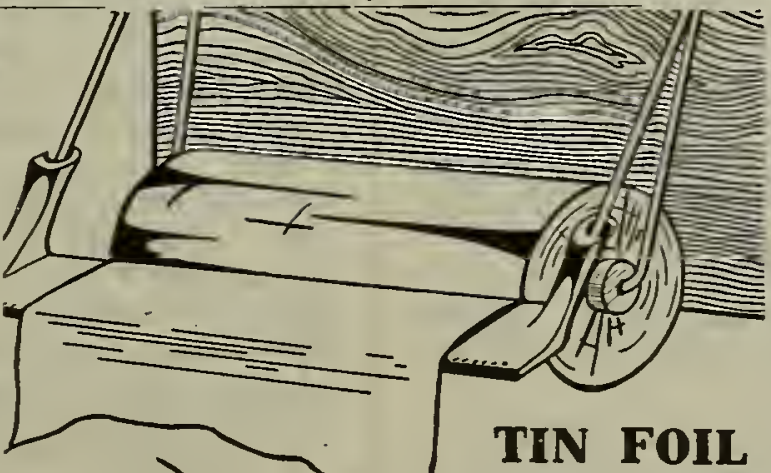

TIN FOIL

Plain. Put up in wide, 65c. Preve nts waste, saves time. Patent Cutter (see cut) extra, 25c. each,; I lb. pkgs., 5 in wide, IIc $1 \mathrm{~b}, 2 \mathrm{lbs}, 20 \mathrm{c}$., $50 \mathrm{c}$ for 5 lbs., 25 lbs. \$2.40, \$9.5o per Ioo lbs. Violet Foil. 30c. per 1b., 5 lbs. \$1.25.

Green Foil. 30c. per lb., 5 lbs. \$1.25.

\section{PAPER FOR FLOWERS}

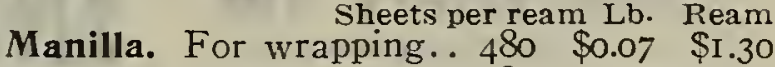
“ Tissue ...... $480 \quad .09$.70

Wax. White. Best qual-

ity, $24 \times 36$ inches.... 480 .I5 I.50 Wax. Green. Best qual-

ity, $24 \times 36$ inches..... $480 \quad .20 \quad 1.80$

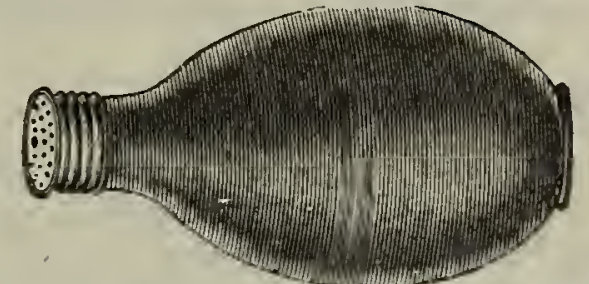

\section{RUBBER SPRINKLERS}

No. I, Large, straight neck.........\$0.8

No. 2, Medium

No. 4. Small

Crook Neck, large.......................

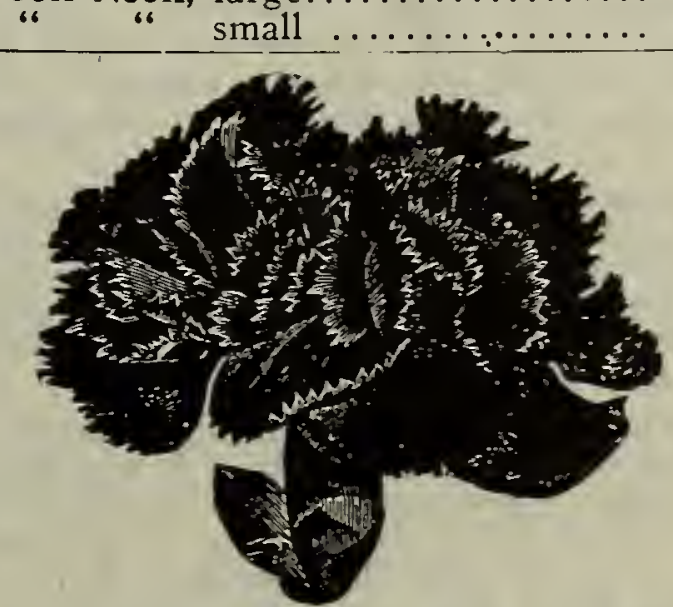

CARNATION MENDERS

Carnation Staples

For calyx mending, 50c. per I000, 5000 for $\$ 2.25, \$ 4.00$ for $10,000,25,000$ for $\$ 8.75$, $\$ 15.00$ for 50,000

Rubber Bands

Ounce $25 \mathrm{c} ., \mathrm{I} / 4 \mathrm{lb} .85 \mathrm{c}$., I/2 lb. $\$ \mathrm{I} .60, \mathrm{I} 1 \mathrm{~b}$ \$3.00. Add I6c. per lb. for postage. Bauer Carnation Outfits Pliers and I000 clips, \$2.50.

Pliers, each \$2.00.

Clips, 80c. per I00o, postpaid; 2000 for $\$ 1.50 ; \$ 3.25$ per 5000 .

\section{FLORISTS' SUNDRIES}

Charcoal (Lump) Peck Bu. Bbl. sacks Cocoanut Fibre ....... $30 \quad .75 \quad 2.00$ Leaf Mould. ............ Pebbles ................. .20 .80 I.80

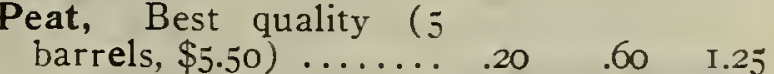

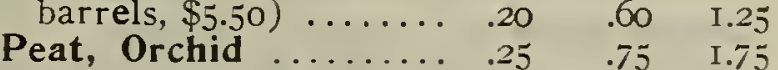
Sand. For propagating $.20 \quad .60$ I.50 Soil. Prepared potting.. $\quad .20 \quad .60 \quad$ I.50 Celery Brushes. Large, $40 \mathrm{c}$; small, $25 \mathrm{c}$. Celery Tape. I000 yds., $\$ 2.00$.

Carnation Dye. (Green.) \$I.oo per bott

Daylite Glass Cleaner. For greenlou glass. I gal., \$1.00; $\$ 4.50$ per 5 gals
Grafting Wax. $1 / 4$ lb., 8c.; I 2 c. $1 / 2$ lb. Grafting Wax. $1 / 4$

Shaderine. For shading greenhouse glass, 30 lbs., \$3.60; $\$ 6.00$ per 60 lbs.; I00 lbs. $\$ 8.00 ; \$ 1.00$ per 200 lbs.

Weed Killer. (Herbicide.) Per at., $48 \mathrm{c}$ 75 c. per $1 / 2$ gal; per gal., \$1.40; \$5.25 per 5 gals.

Weed Killer. Michell's, \$1.00 gal.; 5 gals, \$4.50: \$8.50 Io gals. : jo gals., \$35.00.

Zementine. For whitewashing and shadin glass, 2 lbs.. I 5 c.: $70 \mathrm{co}$. for to lbs. $\$ 6.50$; barrels (325 lbs.), 6c. per 
Antipest (Carman's). For destroying red spider scale and green fly. Qt., 45c; 65c. per I/2 gal.; gal., $\$ 1.25 ; \$ 5.00$ per 5 gals.

Ant Exterminator. A powder that is used for distributing around buildings, on the greenhouse benches, on lawns, gardens, and any other places infested by ants. Per 1/4 1b., I5c.; per $1 / 2$ lb., 30c.; per lb., 55c.

Aphine. For destroying aphis, green fly, thrip, red spider and other greenhouse and outdoor insects. It dilutes readily in water about I part to 40 of the latter. $1 / 4$ pt., $25 \mathrm{c}$; $40 \mathrm{c}$. per $1 / 2$ pt.; per pt., 65c.; \$1.00 per qt.; gal., $\$ 2.50$.

Aphis Punk. A paper that has been thoroughly saturated with nicotine. Used for fumigating, giving off dense fumes of nicotine. Excellent for aphis, thrip, white and green fly, also red spider. (For use in greenhouses only.) Per pkg., 6oc.; $\$ 6.50$ per 12 pkgs.

Arsenate of Lead (Bowker's Disparene). (See Disparene.)

Arsenate of Lead (Powdered). This is used the same as the paste form. It is more economical to ship and goes farther in use, dissolves instantly in water; $\mathbf{I} 1 \mathrm{~b}$. dilutes to 50 gallons. I lb., 30c.; \$I.40 for 5 lbs.; Io lbs., \$2.60; 25 lbs., \$5.50; \$I0.50 for 50 lbs.; Ioo lbs., \$19.00.

Arsenate of Lead (Paste). For spraying trees and shrubs against the attacks of leaf-biting insects of all kinds, especially valuable for spraying to prevent the codling moth. It comes in paste form, and dilutes I 1b. to 25 gals. water. Per lb., 20c.; 8oc. per 5 lbs.: per Io lbs. \$1.40; \$3.IO per 25 lbs.; per 50 lbs., $\$ 5.25$; per 100 lbs., $\$ 9.50$.

Black Leaf 40. A concentrated solution of nicotine sulphate, an excellent spray for black aphis and sucking insects of all kinds; dilutes I part from Ioo to I,O0o parts of water, according to treatment; f 111 lirections on each package. $1 / 2$ ib., $85 \mathrm{c}$.; $\$ 3.25$ for $2 \mathrm{~T} / 2 \mathrm{lbs}$; $1 \mathrm{O}^{\mathrm{T} / 2} \mathrm{lbs}$., $\$ \mathrm{I} 2.5 \mathrm{O}$.

Boro=Wax. For painting trees to destroy and keep away borers. 33c. qt.; 1/2 gal., 55c.; I gal., 95c.

Bordeaux Mixture. Used principally for mildew, blight and fungous diseases that affect potatoes and fruit trees, etc.

Paste or Pulp Bordeaut. One part dilutes to 50 parts of water. Per qt., 35c.; 90c. per gal.; 5 gals., \$4.00.

Quick Bordeaux (in dry form). This is a combination of the proper materials put up in burlap sacks with full directions for using on each. Suspend the sack in a barrel of water or other receptacle and let the contents dissolve. I 1b., I8c.; 6-lb. sack makes 30 gals. liquid, price, 60c.; I0-1b. sack makes 50 gals. liquid, price, 9oc.

Bug Death. Largely used instead of Paris Green. It is claimed to have the same effect. The manufacturers say that it acts as a fertilizer as well as an insecticide. It comes in powder form, and is applied pure. Not poisonous to persons. Per $1 \mathrm{~b}$., I5c.; 35c. per 3 lbs.; per 5 lbs., 50c.; per I2I/2 lbs., \$1.00; $\$ 7.50$ per Ioo lbs. (Special Shaker for Bug Death, 25c.)

Carbolineum (Arvcnarius). A germicide and disinfectant for purifying poultry houses, stables, cow barns, etc., also an excellent wood preserver when used as a paint. \$1.20 per gal. can.

Copper Solution. Made of sulphate of copper and other materials. Excellent spray for carnation rust annd diseases of the grape, pear, apple and other fruits. A good thing to use for leaf blight and mildew. It is diluted in water. Per qt., 50c.; Cow Ease. factory, who claim similar merits for it. Applied 5 gals., $\$ 4.00$

Cyanide Potassium. (For fumigating.) I/4 lb., 20c.; 45c. lb.

Dalmatian, or Persian Powder. For ridding buildings of all kinds of various insect pests, particularly for the smaller and creeping kinds, as it is not strong enough to destroy large or more hardy insects. 12c. per $1 / 4$ lb.; per 1b., 40c.; $\$ 1.75$ per 5 lbs.

Disparene (Bowker's). A trade name for a brand of Arsenate of Lead, which it resembles in every way. Dilute I lb. to 25 gals. water. Price, 25c. per lb.; 5 lbs., 90c.; \$1.60 per ro lbs.; 25 lbs., $\$ 3.75 ; \$ 6.50$ per 50 lbs.; \$1 2.00 per Ioo lbs.
Fir Tree Oil Soap. This is very much like the Fir Tree Oil except that it is in the shape of soft soap, and many prefer to use it in that way. It is dissolved according to directions in warm or hot water and used as a spray or wash. Per $1 / 2 \mathrm{lb}$, 20c.; 65c. per $2-1 \mathrm{~b}$. can.

Fungine. An excellent article for fungous diseases of all kinds. Qt., 75 c. ; $\$ 2.00$ per gal.

Grape Dust. A powder preparation used for mildew, aphis, black fly, and other insects and fungous diseases, principally in greenhouses. Per 5 lbs., 35c.; 65c. per Io lbs.: per 25 lbs., $\$ 1.50 ; \$ 5.25$ per I00 lbs.; bbls. of 200 lbs. (bulk), \$IO.00.

Hellebore. The ideal material for destroying rose bugs, currant worms and other soft-shelled insects that infest the garden. It can be applied dry or in liquid form. Per $1 / 4$ lb., 8c.; I2c. per $1 / 2 \mathrm{lb}$.; per lb., 20c.; per 5 lbs., 85 c.; per Io lbs., $\$ 1.60$.

Getz=There Soap. For washing palms. 2 lbs., 30c.; 8oc. for 8 lbs.; $\$ 1.90$ per 25 lbs.; 50 lbs., $\$ 3.50$; bbl., 5 I 2 c. per $1 \mathrm{~b}$.

Hydrocyanic Acid. (See bottom of page 89.)

Kerosene Emulsion. Diluted in water this makes an excellent spray for all mild forms of scale, and soft lice of any kind such as infect rose and fruit bushes, vegetables and trees. Liquid dilutes I part to 20 parts of water. (LiQuin.) Per qt., 35c.; per gal., goc.

Kil $=\mathbf{0}=\mathbf{S}$ Scale. Destroys and prevents the spread of scale insects of all kinds. Its chief use is the destruction of the San Jose Scale, which prevails in all parts of this country. It is diluted, one part Kil-o-Scale to twenty parts water. Per pt., 30c.; 50c. per qt.; per $1 / 2$ gal., $75 \mathrm{c}$; per gal., $\$ 1.25 ; \$ 5.00$ per 5 gals.; per 25 gals., $\$ 21.25$; per 50 gals., $\$ 42.50$.

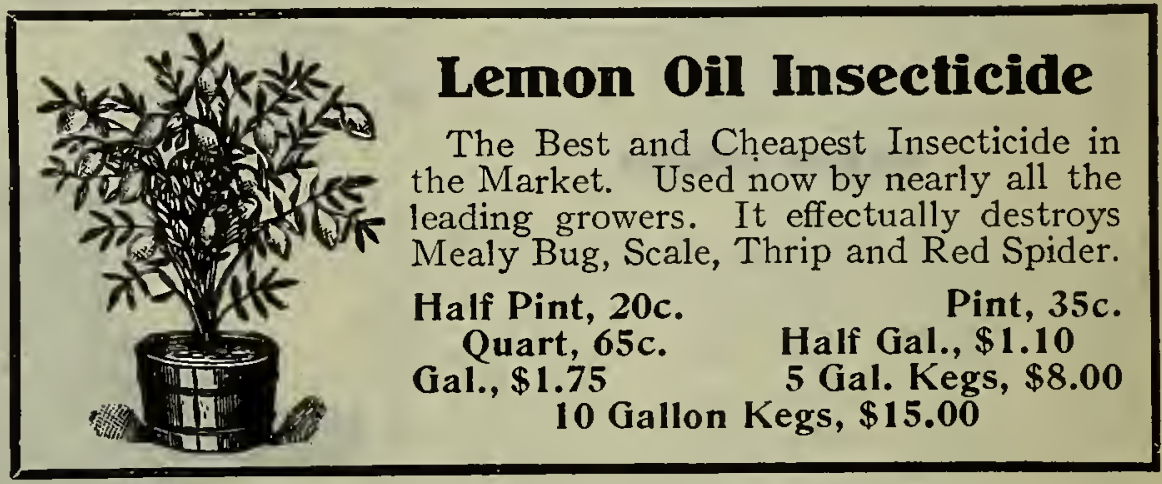

Lime Sulphur. For destroying San Jose Scale. This is in concentrated form which is diluted I gal. to I 2 or I5 gals. water, either hot or cold. May be used as a summer or winter spray, excellent to use as a fungicide. I gal., 60c.; $\$ 1.50$ per 5 gals.; IO gals., $\$ 2.60 ; \$ 4.75$ per 25 gals.; 50 gals., $\$ 7.25$.

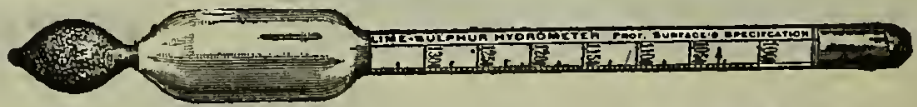

\section{CARBONDALE HYDROMETERS}

These are highly recommended by the Pennsylvania State Department of Agriculture for testing the gravity of Lime Sulphur solution; one should be in the hands of every man who uses this material. Price, 90c. (Postpaid, \$1.05.) With directions.

Lime Sulphur $(D r y)$. This form of Lime Sulphur is becoming very popular on account of the ease with which it can be handled. It is quite an economy in shipping, as you do not have to pay freight on water. It dilutes at the rate of $\mathrm{I} \mathrm{lb}$. to 6 gals. of water, and is soluble instantly in cold water. I lb., 22c. $\$$ I.IO for 5 lbs.; Io lbs., $\$ \mathrm{I} .40 ; \$ 3.00$ for $25 \mathrm{lbs}$; 50 lbs., $\$ 4.75$; $\$ 7.50$ per Ioo lbs.

Nicoticide. Used as a spray or as a vapor, principally in the latter way, it is placed in a tin saucer with lamp underneath, and the nicotine fumes are thus distributed. It is very effective in destroying thrip, aphis, white fly and red spider. etc. Per $1 / 4$ pt., 70c.; per 1/2 pt., \$I.25: per pt., \$2.50; per qt., \$4.50; \$8.25 per $1 / 2$ gal.; I gal., \$I 5.0o. (Special price in larger quantities.) LA Mips for Nicoticide, 50c. each.

Nikotiana. For spraying and fumigating. \$1.25 per qt., per gal., $\$ 4.00$

Nikoteen. One of the milder forms of tobacco or nicotine preparations, usually diluted in water. makes a most satisfactory spray as well as vapor, excellent for Pea lice in the garden. $\$ 1.50$ per pt.; 5 pts., \$7.00; per Io pts., \$13.00. 


\section{INSECT DESTROYERS-Continued}

Nico=Fume (Liquid). This is used in very much the same way as Nicoticide. Per $\mathrm{T} / 4$ lb., $60 \mathrm{c}$.; $\$ 2.00$ per lb.; 4 lbs., $\$ 7.00 ; \$ 13.50$ per 8 lbs.; 5-8-1b. cans for $\$ 64.10 ; \$ 124.90$ for I0-8-1b. cans; $20-8$-1b. cans, $\$ 243.00$.

Nico=Fume. This is a paper treated with nicotine, giving off dense fumes of strong nicotine when ignited. Preferred by many who do not wish to spray or vaporize. Per box, 24 sheets, $\$$ I.00; per I 44 sheets, $\$ 4.50$; per 288 sheets, $\$ 8.50 ; \$ 48.45$ for 6 cans, 288 sheets each; I2 cans, $\$ 94.35 ; \$ 183.60$ for 24 cans.

Paris Green. The chief merit of this article is the destruction of the potato bug. It may be used in liquid form, I pound in 50 gallons of water, or with Land Plaster at the rate of I pound Paris Green to Ioo pounds Land Plaster. Ioc. per $1 / 4 \mathrm{lb}$; per $1 / 2$ lb., I5c.; 30c. per lb.; $\$ 1.25$ per 5 lbs.; per I4 lbs., $\$ 3.00$.

Pyrox (Bowker's). A pasty substance used for all leaf-biting insects. It is really a Bordeaux and Arsenate of Lead combined and is excellent. Dilute I lb. to 5 gals. water. 25c. per lb.; 5 lbs., $\$$ I.00; $\$$ I. 75 per Io lbs.; 25 lbs., $\$ 4.00 ; \$ 7.50$ per 50 lbs.; \$13.50 per I00 lbs.; 200 lbs., $\$ 26.50$; $\$ 62.50$ per 500 lbs.

Readeana Rose Bug Exterminator. A poisonous preparation which dilutes in water. Used for destroying green fly, mealy bug, blight, mildew, etc. Will not injure flowers. Trial bottle, 23c., Io oz., 45c., 9oc. per 24 oz., $\$ 3.75$ per gal.

Scalecide (Soluble Crude Oil). Used for the destruction of the San Jose Scale. Dilute at the rate of one gallon Scalecide to 20 gallons of water. Scalecide does not clog nozzles or pump. 45c. per qt.; per gal., $\$ 1.00 ; \$ 3.25$ per 5 gals.; to gals., $\$ 6.00$; $\$ 16.00$ per 30 -gal. hbl.; per 30 gal. jacketed tin, \$I5.00; \$25.00 per 50-gal. bbl.

Scale Destroyer (Soluble Oil). A combination of mineral and vegetable oils, and has many excellent scale destroying properties. Dilute at various strengths according to season. Per qt., 35c.; 65c. per 1/2 gal.; per gal., \$1.00; $\$ 3.75$ per 5 gals.; Io gals., $\$ 7.50 ; 25$ gals., $\$ 12.50$; per 50 gals., $\$ 23.00$.

Shoo Fly. For keeping flies off cattle and horses, used with a sprayer or a sponge, the cattle and horses are either sprayed or rubbed with the preparation in the morning before being put in the field or out to their day's work. Per qt., 35c.; \$1.00 per gal.

Slug Shot. The standard remedy for currant worms, rose slugs, cabbage worms, and almost any soft-shelled insects that infest the vegetable or flower garden. I5c. per canister; per $5 \mathrm{lbs}$., 3oc.: 6oc. per to lbs.; 25 lbs., $\$ 1.50 ; \$ 2.50$ per 50 lbs.; I00 lbs., \$5.0o. Full bbl. lots (about 250 1bs.), 4\%2c. per 1b., f. o. b. Factory; $43 / 1$ c. per lb., f. o. b. Phila.

Sulphate of Copper. For destroying fungous diseases of all kinds, also used in making Bordeaux mixture, ar,d for spraying potato vines in connection with Paris Green. Where used as a Bordeaux mixture it requires four pounds Sulphate of Copper to 6 pounds Lime, which is diluted in 50 gallons of water. Per lb., IOc.; 9oc. per Io lbs.; 50 lbs., $\$ 4.00 ; \$ 7.50$ per Ioo lbs.

Sulphur (Flowers). Used principally in greenhouses for checking mildew. It is also used as a preventive and cure for San Jose Scale when it is used in connection with lime and salt. Per 1b., 6c.; 25c. per 5 lbs.; 25 lbs., \$I.Io; $\$ 3.50$ per Ioo lbs.; I75-lb. barrel, $\$ 5.90$.

Sulphur Candles. For fumigating in sick-rooms, also in conservatories and greenhouses. Large, I5c. each; per doz., \$1.75; small, 8c. each; per doz., 85c.

Sulpho Tobacco Soap. An excellent article for the person with a few plants. Especially good for destroying scale on palms and other plants. Soluble in warm water. Per 3-oz. package, 8c.; I5c. per 8-oz. package; in Io-lb. cakes, $\$ 2.00$ per cake; 25 lbs., $\$ 4.50$.

Sulphocide. An excellent summer spray for fungous diseases, combining Bordeaux Mixture and Lime Sulphur. 5oc. pt.; qt., $75 \mathrm{c}$; $\$ 2.00$ per gal.; 5 gals., $\$ 7.50$.

Thymo Cresol (Sheep Dip). This preparation is used for disinfecting, etc. Per 4-oz. bottle, 25c.; 40c. per 8-oz. bottle; per qt., 7oc.; \$1.Io per 1/2 gal.; per gal., \$2.00.
Tobacco Dust. Excellent for dusting on Lettuce and other plants to destroy soft, creeping insects. Per 1b., 5c.; 20c. per 5 lbs.; per Io lbs., 35c.; 75c. per 25 lbs.; IOO lbs., \$2.50; \$II.75 per 500 !hs

Tobacco Dust (Special Dusting). A specially prepared, finely ground article. 5 lbs., 25c.; 25 lbs., $85 \mathrm{c}$.; $\$$ I.50 per 50 lbs.; 100 lbs., $\$ 2.50 ;$ \$II.25 for 500 lbs.

Tobacco Dust (Special Fumigating). A specially prepared article for fumigating. 5 lbs., $25 \mathrm{c}$.; 25 lbs., 85c.; $\$$ I.50 per 50 lbs.; 100 lbs., $\$ 2.50 ; \$$ II.25 for 500 lbs.

Tobacco Soap (Sulpho). This is excellent for washing off palms and plants such as Oleanders, Camellias, etc. Soluble in water, making an excellent preparation for washing animals. 3 oz., 8c.; I5c. for 8 oz.; io lbs., $\$ 2.00 ; \$ 4.50$ for 25 lbs.

Tobacco Stems (Fresh). Used principally for fumigating and under benches in greenhouses. They may also be steeped in hot water and used as a spray. Per lb., 5c.; 40c. per bu.; per bbl. bag, 75c.; per large bale, \$I.50; $\$ 5.50$ per half-ton; per ton, $\$$ Io.0o.

To=bak=ine Fumigating Paper. Very much like Aphis Punk, which it resembles. It is used in exactly the same way as Aphis Punk. Per package of 24 sheets, \$1.00; \$4.50 per I44 sheets ; $\$ 8.00$ per box of 288 sheets.

To=bak=ine Liquid. Similar to Nicoticide; it is used in the same manner, and is practically the same, excepting that it is made by a different factory, and they claim for it everything that goes to make up a first-class insecticide; two grades, fumigating and spraying, state which is wanted when ordering. Per $1 / 8$ pt., 50c.; 1/4 pt., 75c.; $\$ 1.35$ per $1 / 2$ pt.; per pt., $\$ 2.50 ; \$ 9.00$ per $1 / 2$ gal.; per gal., $\$ 17.50 ; \$ 85.00$ per 5 -gal can.

Tree Tanglefoot. A paste preparation for painting around the trunks of trees, in the form of a band, and insects and other crawling pests cannot get over it. Per lb., 28c.; 3-1b. cans, 8oc.; Io-lb. cans, $\$ 2.50 ; 20-1 b$. cans, $\$ 4.50 ; \$ 8.50$ for $40-1 b$. cans.

Vaporite. Vaporite is a gray non-poisonous powder which, when it comes into contact with soil, gives off a vapor. This vapor kills all underground insects such as Wireworms, etc. Vaporite is for soil application-not for the leaves of the plant. Vaporite should be uniformly distributed on the surface or in the soil among the insects, so that the gas evolved may destroy them. $I$ to $I / 2 \mathrm{lbs}$. is enough for a cubic yard of soil (about I cart load). 5oc. per 5 lbs.; 25 lbs., $\$$ I.75; $\$ 3.25$ per 50 lbs.; per I 12 lbs., $\$ 6.25$.

Vermine. For sterilizing soil to destroy worms, maggots, etc. $1 / 2$ pt., 40c.; 65c. pt.; qt., $\$ 1.00 ; \$ 3.00$ per gal.

Whale or Fish Oil Soap. For mild forms of Scale, also an excellent summer spray. Dissolved in water according to various purposes. Per $1 / 2 \mathrm{lb}$., $8 \mathrm{c}$.; I5c. per lb.; per $5 \mathrm{lbs}$., $55 \mathrm{c}$.; $\$$ I.00 per Io lbs.; per 25 lbs., $\$ 1.60 ; \$ 6.00$ per Ioo $1 \mathrm{bs}$.

Whale Oil Soap (Goods Caustic). Used extensively as a tree spray and as a summer remedy for San Jose Scale, it comes in a soft soap form and is easily dissolved, I lb. to Io gals. water. I8c. per I-1b. can; 5-1b. can, 7oc.; \$1.65 per 25-1b. can; 50 lbs., $\$ 2.90$; $\$ 4.75$ per IOo lbs. ; 425-lb. bbl., \$16.75.

Worm Killer (Reade's). Extensivèly employed on putting greens, lawns and grass plots, destroying all worms, grubs, etc., and produces a luxuriant growth of grass. In Ioo-lb. bags only, $\$ 5.00$ per IOo lbs.; 500 lbs., $\$ 24.00$; I,000 lbs. for $\$ 45.00$; $\$ 90.00$ per ton.

Worm Eradicator (Reade's Electric). Used indoors as well as outdoors, for destroying worms in pots, tubs, benches; in tennis courts and putting greens. Apply with a sprinkling can or other wise. Small size, 23c.; Io oz., 45c.; 9oc. for 24 ozs.; gal., \$3.75.

Worm Eradicating Fertilizer (Carter's). Used extensively, being applied to grass plots, putting greens, etc. It causes the worms to come to the surface, where they may be scooped up readily and further destroyed. Price, f. o. b. Philadelphia: In IOo-lb. bags only, $\$ 4.00 ; \$ 36.00$ per I,000 lbs:; 2,000 lbs., $\$ 69.00$ Apply at the rate of $1 / 2 \mathrm{lb}$. per square yard. (Special price, f. o. b. Boston.)

HYOROCYANIC-ACID GAS-CYANIDE POTASSIUM-FUMIGATION as given to us by a practical gardener. Very Poisonous to liuman beings and animals. Put four ounces of water in a galvanized iron pail. add to this two ounces of sulphuric $\Lambda$ cid, wrap an ounco Cyanide of Potassium in paper and place it in the bucket which should be placed near the door of the greenhouse to afford quick exit: the moment the Cranide strikes the liquid it generates a poisonous gas which must not be inhalcd. The above charge is sufficient for 1000 cubic fcet of space. Don't open the greenhouse for at least 12 hours. One of the ventilating be the only and best remcdy to absolutcly kill the white fly. It is claimed that it will not injure the most delicate plant, but the uscr should take great care of himself. Cyanide, $1 / 4$ lb. 20 c.. $45 \mathrm{c}$. 1b.; Sulphuric Acid, $25 \mathrm{c}$. 1b. 
Animal Bone and Potash. An ideal fertilizer for most all farm and garden crops. Apply 400 to 600 per acre. 200 lbs., $\$ 3.00$; $\$ 24.00$ per ton.

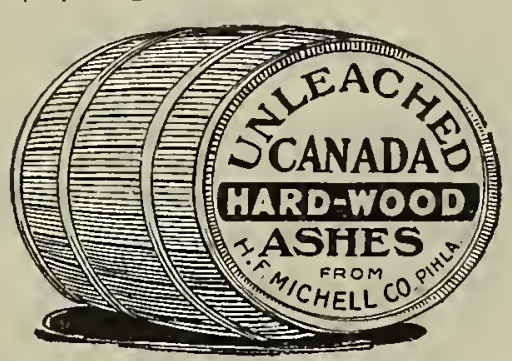

Ashes. Canadian Hard Wood. Apply Iooo lbs. per acre. For top dressing lawn and grass fields it is applied to best advantage either in very early spring or late fall. 25c. per Io lbs.; 25 lbs., 40c.; 75c. per 50 lbs.; IOO lbs., \$I.35; $\$ 2.50$ per 200-lb. barrel; per ton, $\$ 2$ I.oo.

Acid or Rock Phosphate. Apply Ioo lbs. per acre. Used for mixing with other fertilizers to increase the phosphoric acid analysis. In 200-1b. sacks only, $\$ 1.75 ; \$ 13.50$ per ton.

Asparagus Fertilizer (Purc Bone and Potash). A mixture that promotes the root and top growth. Apply 600 lbs. per acre. 75c. per 25 lbs., 50 lbs. \$1.I5, $\$ 2.00$ per IOo lbs., 200 lbs. $\$ 4.00$, $\$ 35.00$ per ton.

Basic Slag. (See Phosphate.)

Bon Arbor. A concentrated chemical fertilizer similar to Bonora, but less expensive; used in liquid form according to directions. LIQUID: \$I.80 per gal.; 5 gals., \$8.50. POWDER, dilutes I $1 \mathrm{~b}$. to 30 gals. water: 5 lbs., $\$ 1.60 ; \$ 11.00$ per $50 \mathrm{lbs}$; I00 1bs., \$18.00.

Blood (Dried). Apply 300 lbs. per acre. For indoor culture of flowering plants, like roses, carnations, etc., its chief element being nitrogen. 5 lbs., 25c.; 45c. per Io lbs.; 25 lbs., \$1.00; $\$ 1.85$ per 50 lbs.; I00 lbs., $\$ 3.50 ; \$ 6.25$ per 200 lbs.; per ton, $\$ 60.00$.

Blood, Bone and Potash (Potash and Truck Special). The best fertilizer for the truck patch or garden, combines every element of plant food valuable for all vegetable crops. Note the high analysis, $7 \%$ avail. Phosp. Acid, 31/2\% Ammonia, $7 \%$ Potash. Ioo lbs. $\$ 2.25, \$ 4.00$ per $200 \mathrm{lbs}$., $1 / 2$ ton $\$ 17.50, \$ 34.00$ per ton.

Blood Flour. Apply 200 lbs. per acre. Much like dried blood except that it is finer and acts almost instantly. (Price, f. o. b. Chicago, $\$ 4.00$ per Ioo lbs.; 200 lbs., $\$ 7.75 ; \$ 35.50$ per $1 / 2$ ton per ton, $\$ 70.00$.) Price, f. o. b. Philadelphia, 5 1bs., 35c.; 60c. per Io lbs.; 25 lbs., \$1.25; $\$ 2.25$ per 50 lbs.; IOo 1bs., $\$ 4.50$ $\$ 8.50$ per 200 lbs. ; I000 lbs., \$40.00; $\$ 78.00$ per ton.

Bone, Pure Fine Ground. For top dressing, potting soil, etc., not quite so high in analysis as the "Special Florists' Brand." 200 lbs., $\$ 3.25 ; \$ 30.00$ per ton.

Bone Meal (Pcirson's). The best on the market for rose growers; supply limited. 200 lbs., $\$ 3.75 ; \$ 18.00$ per $1 / 2$ ton
ton, $\$ 35.00$.

MONELLS
MEAL
HENRY F.MICHELI
PHILADELPHIA

Bone Meal (Michell's Special Florists'Brand) Apply 600 to 800 lbs. per acre. Made from pure raw bone, without any addition of materials. The ideal bone for rose beds and greenhouse use. 3 lbs., I2c.; 20c. for 5 lbs.; Io $1 \mathrm{bs} ., 35 \mathrm{c}$; $65 \mathrm{c}$. per 25 lbs.; 50 lbs., \$I.I5; $\$ 2.00$ per I00 lbs.; 200 lbs., $\$ 3.50 ; \$ 33.00$ per ton.

Bone Flour (Pure). Apply 600 lbs. per acre. Very fine, like dust, effective almost immediately, can be used for indoor or outdoor
purposes. 5 lbs., 25c.; 35 c. per Io $1 \mathrm{bs} .: 25$ lbs., 75c.; \$1.25 per 50 lbs.; I00 lbs., $\$ 2.25 ; \$ 4.00$ per 200 ibs. ton, \$35.00.

Bone (Coarse Cracked). For use in making up compost or soil heaps. 200 lbs., $\$ 4.50 ; \$ 40.00$ per ton.

Bone (Coarse Ground). Apply 600 to 800 lbs. per acre. Prepared from raw bones, exactly like bone meal except that it is not so fine, or quick in action, is used for the same purposes. 5 lbs., 20c.; 30c. per Io lbs.; 25 lbs., 70c.; \$1.25 per 50 lbs.; Ioo lbs., \$2.00; \$3.50 per 200 lbs.; per ton, \$33.00.

Bonora. Directions for use are on each package. It may bc used in either dry or liquid form; excellent for greenhouse and pot plants or vegetable forcing. 25c. per trial pkg. (by mail, 3oc.) ; 5oc. per $1 \mathrm{~b}$. (by mail, 66c.) ; $\$ 2.50$ per $5 \mathrm{lbs}$.

Button Bone. Very desirable for rose growing; in 200-lb. bags only. $\$ 3.75$ per bag; per ton, $\$ 35.00$.
Chrysanthemum Manure (Thomson's Special). Especially recommended and used by the leading gardeners of England and America. Very highly concentrated. Can be used in liquid and in dry form. Per $28-1 b$. sack, $\$ 4.00$; per $56-1 b$. sack, $\$ 6.75$.

Climax Lawn Sand. (See Lawn Sand.)

Clay's Fertilizer. An English chemical fertilizer, for forcing greenhouse plants and vegetables. It can be used in either dry or liquid form. 5 lbs., 50c.; 95c. per Io lbs.; 28 lbs., \$1.75; $\$ 3.25$ per 56 lbs.; i 22 lbs., \$6.00.

Copperas (Sulphate of Iron). For destroying lawn and farm weeds as well as acting as a gentle fertilizing stimulant; it dilutes $100 \mathrm{lbs}$. to 50 gals. of water, which is sufficient to spray

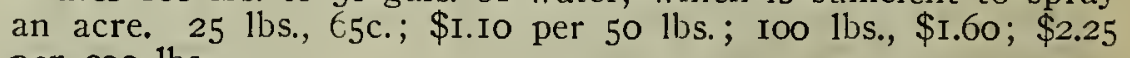
per 200 lbs.

Cotton Seed Meal. Apply 600 lbs. per acre. Exceedingly rich in potash and ammonia, making it excellent for use as a grass and grain fertilizer; for putting greens it is invaluable. 5 lbs.. 20c.; 35c. per Io lbs.; 25 lbs., 75c.; \$I.25 per 50 lbs.; Ioo lbs., $\$ 2.25$ : $\$ 4.00$ per 200 lbs.: ton, \$38.00.

Corn Phosphate. (See Phosphal

Cow or Cattle Manure (Pulverizcd). This we do not carry in stock, but can procure to order from Chicago in numerous cars we have coming forward constantly; some growers prefer this to the shredded kind. Price $f$. o. b. Chicago: Ioo lbs., $\$ 1.35 ; \$ 5.50$ for 500 lbs.; I000 1bs., $\$ 9.00 ; \$ 17.00$ per ton. Price f. o. b. Phila.: \$1.65 per I00 1bs.; 500 lbs., $\$ 7.50 ; \$ 13.00$ per $1 / 2$ ton; ton, $\$ 24.00$.

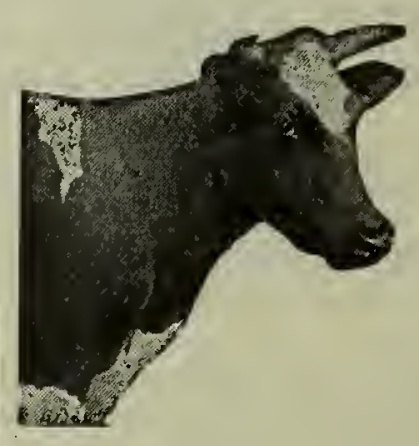

Cow or Cattle Manure (Shredded) One sack of this is equal to one cartload of cow manure, it is convenient to handle, making it possible for everyone to get this ustrally scarce article at all times. It takes up very little space and is indispensable for any fertilizing purpose. F. o. b. Philadelphia. 25 lbs., 50c.; 85c. per 50 lbs. : I00 lbs., $\$ 1.50$; $\$ 6.50$ per 500 lbs.; 1000 lbs., \$II.50; $\$ 22.00$ per ton. F. o. b. Chicago: I00 1bs., $\$$ I.25; $\$ 5.00$ per 500 lbs.; 1000 lbs., $\$ 8.50 ; \$ 16.00$ per ton.

Dissolved Bone. Apply 600 to 800 ths. per acre. Used principally for indoor culture, although it is highly recommended for a grass top dres. ing. 200-lb. sacks only, \$3.25; \$30.00 per ton.

Fish Guano or Dried Fish. Apply 300 to 400 lbs. per acre. For truck and plant forcing this is recommended. Also used to mix with other fertilizers to increase the ammonia analysis. In $200-1 \mathrm{~b}$. sacks only. $\$ 5.50 ; \$ 50.00$ per ton.

Farmo=Germ. A nitrogen gathering bacteria to be used when planting or sowing seeds of leguminous plants sucl as clover, peas, beans, etc. I makes possible to grow Alfalfa where it of ten can otherwise not be grown it increases the yield and makes it possible for plants to gather free nitrogen from the air equal in value to 150 lbs. nitrate per acre. Crops treatel
with Farmo-Germ leave the ground rich in nitrogen for the next sucwith Farmo-Germ leave the ground rich in nitrogen for the next suc-
ceeding one. Ask for special pamphlet on Farmo-Germ. Garden (1/4-acre) ceeding one. Ask for special pamphlet on Farmo-Germ. Garden (1/4-acre)
bottles, 50c.; $\$ 2.00$ per acre bottle. Always specify in order for what crop Farmo-Germ is desired.

Guano (Pcruvian Substitute). Of very high analysis in all necessary plant food elements and is now extensively used in place of Peruvian guano, which has become extremely scarce. 25 lbs., $75 \mathrm{c}$.; $\$ 1.35$ per 50 lbs. $100 \mathrm{lbs}$., $\$ 2.40 ; \$ 3.75$ per $200 \mathrm{lbs}$; ton, $\$ 35.00$.

Horse Manure (See Manure.)

Hog Manure (Pulvcrizcd). Some growers prefer this to either sheep or cow manure. We can supply it to order. bringing it forward in n.merous cars which we have coming from $\$$. Phicago at intervals. f. o. b. Phila.: $\$ 1.50$ per 100 lbs. 500 lbs., $\$ 7.00 ; \$ 12.00$ per $1 / 2$ ton; ton,
$\$ 23.00$. Price f. o. b. Chicago: $\$ 1.35$ per $100 \mathrm{lbs}$; $500 \mathrm{lbs}, \quad \$ 5.00 ; \$ 8.50$ per 1000 lbs.; ton, $\$ 16.00$.

Humus (Alphano). This material is a natural deposit of decomposed vegetable matter, taken from the bottom of a drained lake. We had it rcported on by several experiment stations. who report it worthy of its
extensive use. It is rich in ammonia, potash and phosphoric acid, and is ideal for mixing either with poor or even rich soil, and as a top dressing ideal for ming either with poor or event rich soil, and as a top dressing
on lawns or golf courses. Flowers, vegetables, grass and other crops thrive luxuriantly where Alphano is used. For entire renovating poor ground luxuriantly where Alphano is used. For entire renovating poor ground
it is spread about six incles deep. For a top dressing one incli of deptl

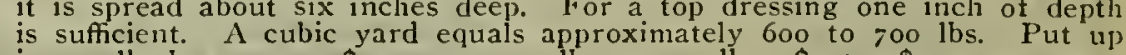
in too-1b. bags, 90c.; $\$ 4.25$ per 500 lbs.; 1000 lbs., $\$ 7.50 ; \$ 14.00$ per ton. Special price f. o. b. factory and in car lots. 


\section{FERTULIZERS-CONTLNUED（ ALL PRICES SLBJECT}

Horn Shavings. Used principally for mixing in potting soil, is rich in ammonia; especially valuable in chrysanthemum growing. 5 lbs., 30c.; \$1.15 per 25 lbs.; 50 lbs., \$2.20; \$4.00 per IoO lbs.

Kainit (Potash Salts). Apply about 800 to 1000 lbs. per acre. Excellent for potatoes, corn and other grains. 5 lbs., I5c. 25c. per Io 1bs.; 25 lbs., 40c.; \$1.00 per I00 lbs.; 200 lbs., \$I.75; $\$$ I 4.00 per ton.

Land Plaster. Apply about 1000 to Ijoo lbs. per acre. For top dressing, sour and wornout soils, also for mixing with Paris Greell, 25c. per 25 lbs.; jo lbs., 35c.; 60c. per Ioo lbs.; 200 lbs., \$1.I0; \$9.00 per ton.

MICHELL'S
ODORLESS
LAWN
DRESSLNG
MENRY F.MICHELU

Lawn Dressing (Michell's Odorless). Apply 500 to 600 lbs. per acre. A quick stimulant for lawns and grass lands. 5 lbs., 25c.; 40c per Io lbs.; 25 lbs., 85c.; \$I.50 per 50 lbs.; I00 lbs., \$2.50; $\$ 4.00$ per 200 lbs.; per ton, $\$ 37.50$.

Lawn Sand (Climax). A weed destroyer as well as a fertilizer, containing a large percentage of nitrogen. IVill be found very valuable for lawn use. For best results follow the directions on the packages. $33^{\mathrm{I} / 2}-1 \mathrm{~b}$ tin, 30c.; 60c. for 7 lbs. : \$I.00 per I $4-1 \mathrm{lb}$. tin 28 lbs., \$1 6o: 56 lbs., \$2.80; \$4.80 per II $2-1 b$. keg; 560 lbs., $\$ 20.00$.

Limestone (Pulverized). For applying on sour and worn-out soils at the rate of $\mathrm{I}$ ton per acre. Put up in Ioo-lb. bags: no less quantity sold. $7 ฐ c$. per bag; 1000 lbs. $\$ 5.50 ; \$ 9.00$ per ton.

Lime (Hydrated or Powdercd). For mixing with earth or other purposes where a soil sweetener is needed. Ioo-lb. sack, \$1.00; 500 lbs. for \$4.00: \$1 I.00 per ton.

Manure. At short notice we can usually supply first-class horse. cow and stock yard manure in carload lots only. Prices quoted on request.

Manure (Dried Pulverized Horse). Richer in analysis than sheep manure, excellent for flower growing: a sack is almost equal in bulk to a cartload. Price $f .0 . b$. Phila.: 100 lbs. \$I.75; \$7.75 per 500 lbs.; I000 lbs., \$15.00; \$27.00 per ton. Price f. o. b. Factory: 100 lbs., \$1.50; $\$ 7.00$ per 500 lbs.; $10001 \mathrm{bs}$. \$1 $3.00 ; \$ 25.00$ per ton.

$$
\text { MAPES FERTILIZERS F.o.b. Phila, F.o.b. Factory }
$$

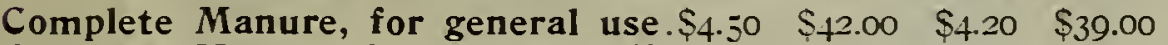
$\begin{array}{lllll}\text { Complete Manure, for average soils } & 4.50 & +2.00 & 4.20 & 39.00\end{array}$ Complete Manure, for light soils... 4.85 $47.00 \quad 4.55 \quad+4.00$ Corn Manure ................ 4.50 $43.00 \quad 4.25 \quad 40.00$ Early Vegetable and Truck Manure. $4.85 \quad 47.00 \quad 4.55 \quad 4+.00$ Potato Manure ................. $4.75 \quad 45.00 \quad 4.50 \quad+3.00$ Vegetable Manure, for all soils..... 4.85 $47.00 \quad 4.55 \quad 4400$

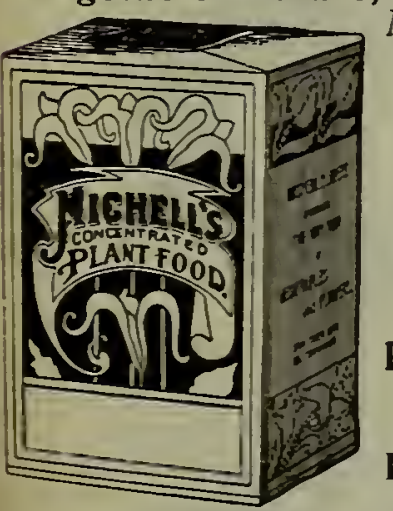
Muriate of Potash. Apply 100 to I jo jbs. per acre, usually wih other fertilizers. This must be used with great care, as it is very powerfül. Excellent for potatoes, corn, grains, etc. Analysis, equal to $50 \%$ actual potash. 30c. per 5 lbs.; Io lbs., 45 c.; \$1.00 per 25 lbs.; 50 1bs., \$1.65 $\$ 2.75$ per I0o 1bs.; 200 lbs., $\$ 5.25$. $\$ 26.50$ per $1 / 2$ ton; ton, $\$ 52.00$.

Plant Food (Boziker's). 4-oz. pkgs.. I3c. each; doz.. \$1.35: \$10.50 per IOO: I 2-Oz. pkgs., 20c.; \$2.25 per doz.: per I00, \$16.00.

Plant Food (Michell's). Ioc. per 6-oz. pkg. (by mail, I8c.): \$I.00 per doz.; $100 \$ 8.00$

Nitrate of Soda. Apply 100 to 150 lbs. per acre, mixing with land plaster or other fertilizers to render application more easy. Use only after plants are above ground. If used in liquid form dilute two ozs. to I gal. of water and do not apply oftener than twice a week. 5 lbs., 25 c. ; 50c. per Io lbs.; 25 lbs., \$I. Io; $\$ 2.00$ per 50 lbs.; Ioo lbs. $\$ 3.50 ; \$ 6.75$ per 200 lbs.; $1 / 2$ ton, $\$ 32.50$ : $\$ 64.00$ per ton.

Phosphate (High Grade Ammoniated). For all vegetable crops, grain, grass, etc. Apply 500 to 600 lbs. per acre broadcast. 5 lbs., I5c.; 25c. per Io lbs.; 25 lbs., 50c.; 85c. per 50 lbs.; I00 lbs., \$1.50; \$2.75 per 200 lbs., ton, \$23.00.
Pig Manure. (See Hog Manure.)

Phosphate for Corn (Phosphate and Potash). Appiy 500 to 600 1bs. per acre. This contains the necessary ingredients to produce a bumper crop of either field or sugar corn. 200 lbs., $\$ 3.00 ; \$ 12.00$ per $1 / 2$ ton; ton, $\$ 23.00$.

Phosphate (Michell's Hi-Grade Potato). Apply 400 to $600 \mathrm{lbs}$. per acre. The best fertilizer for potatoes, being especially ricl in every ingredient on which potatoes thrive. $200 \mathrm{lbs} ., \$ 3.75$; $\$ 16.50$ per $1 / 2$ ton; ton, $\$ 32.00$.

\begin{tabular}{|c|c|}
\hline $\begin{array}{l}\text { MCHEL } \\
\text { SUPE } \\
\text { PHOSPH }\end{array}$ & $\begin{array}{l}\text { Phosphate (Basic Slag). Used extensively } \\
\text { for top dressing lawns, grass and grain } \\
\text { lands. Contains the proper elements to } \\
\text { produce a rich luxuriant growth. Apply } \\
600 \text { to } \$ 00 \text { lbs. per acre. } \$ 2.25 \text { per } 200 \text { lbs.; } \\
\text { per ton, \$18.00 } \\
\text { Potato Manure (Baugh's). Apply } 400 \text { lbs. per } \\
\text { acre. The principal fertilizer for potatoes in } \\
\text { this section, being especially compounded for } \\
\text { this purpose. } 251 \text { bs., } 60 c \text {; } \$ 1.00 \text { per 50 lbs.; } \\
\text { I00 lbs., \$1.75; } \$ 3.25 \text { per } 200 \text { lbs.; ton, } \$ 28.00 \text {. }\end{array}$ \\
\hline
\end{tabular}

Poudrette (Native Guano). Apply Iooo lbs. per acre. Extensively used for gardens, lawns, in making compost and in fact wherever a good, quick acting fertilizer is wanted. It is odorless and easily handled. 5 lbs., I5c.; 25c. per Io $1 \mathrm{bs}$.; $25 \mathrm{lbs}$., 50c.; 100 lbs., \$1.25; $\$ 2.25$ per 200 lbs.; 600 lbs., $\$ 6.00 ; \$ 8.50$ per 1000 lbs.; per ton, \$16.00.

Salt. For agricultural purposes, asparagus beds and putting on walks and roads to kill weeds. Apply 600 to 800 lbs. per acre in early spring. 25c. for 25 lbs.; 75c. per I00 lbs.; 200 lbs., $\$ 1.35 ; \$ 9.00$ per ton.

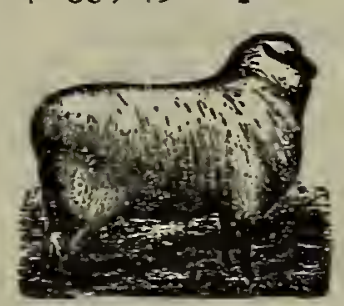

Sheep Manure (Wizard Brand). Apply I000 lbs. per acre. For garden, lawn or greenhouse use nothing surpasses sheep manure; it is clean and easily handled, besides giving immediate results. Prices. f. o. b. Philadelphia, 20r. per 5 lbs.; Io lbs., 30c.; 50c. per 25 lbs.; per 100 lbs. \$1.50; 500 lbs., \$7.00; \$13.50 per 1000 lbs per ton, \$25.00.

Sheep Manure (Wizard Brand). F. o. b. Chicago: I00 1bs., \$I.25; $\$ 6.00$ per 500 lbs.; I000 lbs., \$10.00; \$18.00 per ton.

Soot (Imported Scotch). This is used principally for bringing a good, healthy color into the foliage of chrysanthemum and other greenhouse plants. Also destroys insects and grubs that work on top of and underneath the surface. 5 lbs., $25 \mathrm{c}$.; $40 \mathrm{Oc}$.
for Io lbs.; 75 c. per $25 \mathrm{lbs}$; i I 2 lbs., $\$ 2.75$; \$ 2.50 for $560 \mathrm{lbs}$.

Sulphate of Ammonia. Apply 75 to 100 lbs. per acre only with other fertilizers deficient in nitrogen. This material will stimulate growth almost immediately: Analysis, equal to $25 \%$ of ammonia. 30c. per 5 lbs.; Io lbs., 55 c.; \$1.25 per 25 lbs.; 50 lbs., \$2.50; \$4.75 per Ioo lbs.; $200 \mathrm{lbs}_{\text {. }} \$ 9.00$ : $\$ 42.50$ per $1 / 2$ ton.

Sulphate of Potash. Apply Ioo to I $25 \mathrm{lbs}$. per acre. usually with other fertilizers. On account of its great strength it must be used judiciously. Valuable for root and grain crops. Analysis, equal to $50 \%$ of actual potash. 5 lbs., $35 \mathrm{c}$.; \$1.00 per $25 \mathrm{lbs}$. $\$ 1.75$ per 50 lbs.; I00 1bs., \$3.25; $\$ 6.00$ per 200 lbs.;

$\$ 28.50 ; \$ 55.00$ ton.

Tankage. This is usually applied to plant under glass. It is similar to dried blood. $5 \mathrm{lbs}, 25 \mathrm{c}: 40 \mathrm{c}$. per 10 lbs.; 25 lbs., 75c.; \$1.25 per 50 lbs.; 100 lbs., \$2.00; \$3.50 per 200 lbs.: ton, $\$ 30.00$

Thomson's Special Flower, Vegetable and Vine Manure. Imported from England, this excellent chemical fertilizer is extensively used wherever it is desired to force flower regetables. 28 lbs., \$1.60; \$3.10 per 56 lbs.: i I 2 lbs., \$6.00.

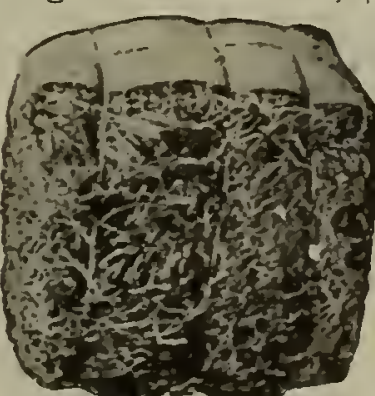

Wheat Fertilizer. For grass and crops. Apply 5 to 600 lbs. per acre. 200 lbs., \$3.00: \$12.00 per

ton. $\$ 23.00$

Tobacco Stems. For fumigating. mulching and fertilizing. Lb., 5 c.: per bushel, 40c.; $75 \mathrm{c}$. per barrel sack: large bales, \$I.50; $1 / 2$ ton, \$5.50; ton, \$IO.00.

Wood Ashes. opposite page. 


\section{MICHELL'S SEEDS,BULBS,PLANTS PORDENTOOLS,FERTILIZERS, 518 PHPLIES,ETC. MARKET ST. PHILA.}

CARNATION SUPPORTS P̉er doz. Per 100 Per 1000 Model, 2 ring $\ldots . \ldots .60 \%$

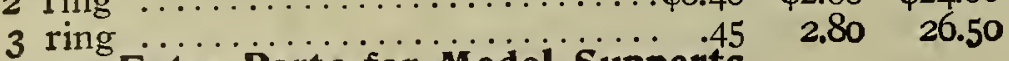

Rings, 6oc. per roo, per $1000 \$ 4.00$.

Tops, \$I.35 per IO0, per I000, \$I I.00.

2 Ring Bottoms, \$1.50 per I00, per I000 \$13.75.

3 Ring Bottoms. \$1.80 per 100, per I000, \$16.50.

RICHMOND SUPPORTS Perdoz. Per 100 Per 1000 No. II. 29 in., 3 ring, single $\ldots . . . \ldots \ldots \ldots . . \$ 0.35 \quad \$ 2.50 \quad \$ 23.50$ No. II. 29 in., 3 ring, double $\ldots \ldots \ldots \ldots \ldots . .45 \quad 3.25 \quad 30.00$

\section{MÜLLERS DOUBLE SUPPORT}

One of the best on the market, easily put together. After the rings are detached it folds flat, thereby requiring very little storage room when putting away.

Per doz., 65c.; \$4.50 per I00; per I000, \$40.00.

\section{PLANT STAKES}

No. Io Steel Wire, Galvanized

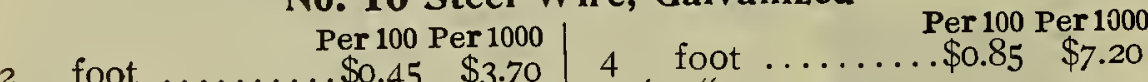
\begin{tabular}{rr|rrrrr}
.55 & 4.45 & $41 / 2$ & “ & $\ldots \ldots \ldots \ldots$ & $\ldots .00$ & 8.00
\end{tabular} \begin{tabular}{rr|lllll}
.55 & 4.45 & 5 & “ & $\ldots \ldots \ldots$ & 1. 10 & 9.00 \\
65 & 5.40 & 6 & “ & $\cdots$ & $\ldots$ &
\end{tabular}

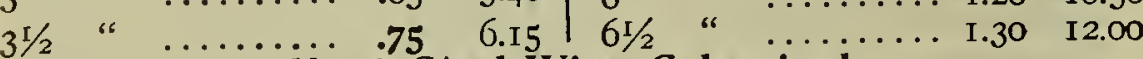
$31 / 2 \ldots$ No. 8 Steel Wire, Galvanized

For staking American Beauty and other strong Roses

Per 100 Per $1000 \mid$ Per 100 Per 1000 2 foot $\ldots \ldots \ldots \ldots . \$ 0.60 \$ 5.50 \quad 41 / 2$ foot $\ldots \ldots \ldots . \$ 1.25 \$ 11.00$

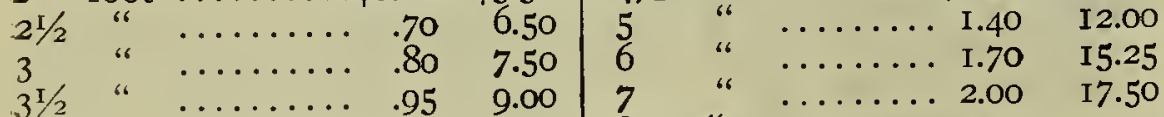

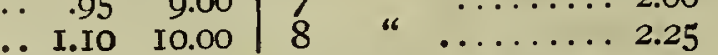

IREEN PAINTED TAPERING PLANT STAKES

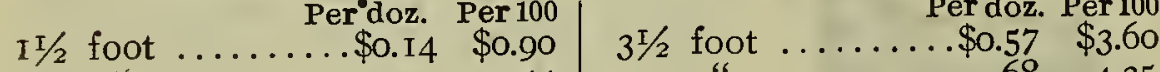

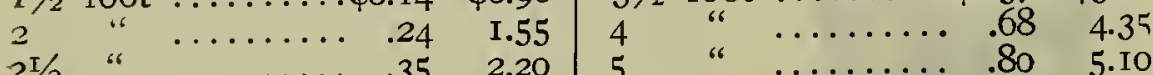
$\begin{array}{lllll}21 / 2 & \cdots & \cdots \cdots \cdots \cdots & .35 & 2.20 \\ 3 & \cdots & \cdots \cdots \cdots & .46 & 2.90\end{array}$

\section{GREEN PAINTED HEAVY OR DAHLIA STAKES}

3 foot $\ldots \ldots \ldots \ldots \$ 0.68$ Per doz. Per 100 $\$ 4.40 \mid 5$ foot $\ldots \ldots \ldots \ldots . \$ 1.15$ Per doz. Per 100

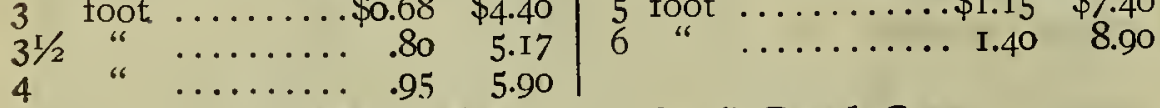

HYACINTH STAKES (Wood) Dyed Green

Per 100 Per 1000 Per 5000

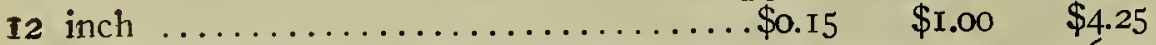
18

HEADQUARTERS FOR CANE STAKES

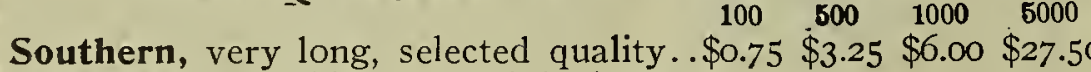
$\begin{array}{lllll}\text { Japanese, very thin, about } 6 \mathrm{ft} \text {. long.. } & .75 & 2.75 & 5.00 & 22.50\end{array}$ Japanese, dyed green, 3 feet lengths only

UNPAINTED STAKES OR DOWELS Per 100 Per 1000 24 in. long, $3 / 8$ in. diameter................. $\$ 0.50 \quad \$ 4.00$

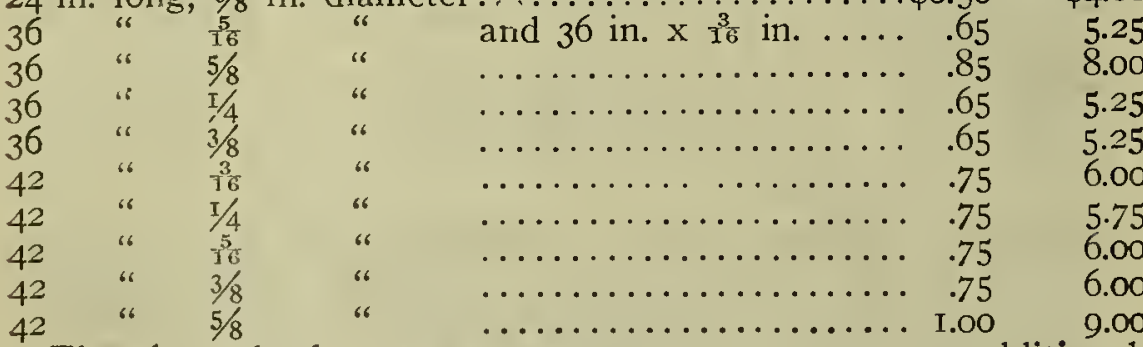
The above dyed green, IOc. per IOo or 50c. per IOoo additional.

\section{SQUARE PAINTEd PLANT STAKES}

\begin{tabular}{|c|c|c|c|c|c|c|c|}
\hline & & Doz & 100 & & & Doz. & \\
\hline & & $\$ 0.12$ & $\$ 0.90$ & $3^{1 / 2}$ & t &.$\$ 0.54$ & $\$ 3.80$ \\
\hline & & & 1.40 & & f & .02 & \\
\hline & $\mathrm{ft}$. & .28 & 2.00 & 5 & $\mathrm{ft}$ & .85 & \\
\hline & ft.... & .45 & 3.20 & 6 & $\mathrm{ft}$. & I.07 & \\
\hline
\end{tabular}

\section{STAKE FASTENERS}

Corts Everlasting. Heavy, $\$ 1.60$ for 500 ; $1000, \$ 3.00$.

Corts Eureka. Light, 85c. for 500; 1000, $\$$ T. 50 .

Qlakes, 8oc. for 500,1000 \$.50.

\section{FLORISTS' STECIAL TWINE}

(See Cut)

For making bouquets, funeral work, stemming, etc. Color, Nile green; in I-1b. spools. 45c. 1b.; 5 lbs., \$2.10

\section{RAFFIATAPE}

This article is made of a composition of paper and linen, and is tremendously strong. It is about $1 / 8$ in. broad, and is put up in $250-y d$. spools or reels. There is no waste, as the reel permits it to be hung from a buttonhole, and it can be used as needed. Color, Nile green. Per bolt of 250 yards, 50c.; 6 reels, $\$ 2.75 ; \$ 5.25$ for 12 reels.

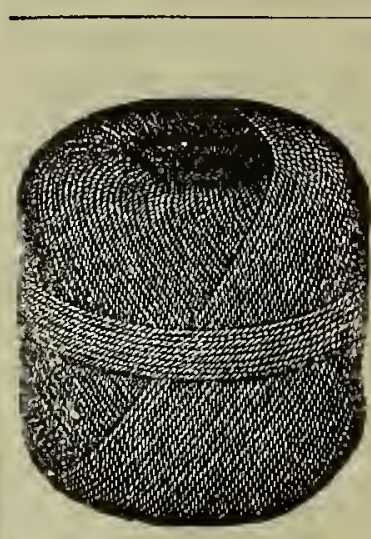

\section{TWINES, Etc.}

Per ball Per lb.

No. 12. Light Italian Twine....\$0.16 \$0.30

No. I8. Medium Italian Twine. .I6 .30

No. 24. Heavy Italian Twine... . . 5 .28

No. 36. Heavy Italian Twine... .15 .I .28

2-Ply, 3-Ply, 5-Ply Jute....... . . I0 .I

Linen Bouquet, 3 lbs., \$I.10.... . .06 $\quad .40$

Boston Linen, 2 and 3 -Ply..... . . 8 . $\quad .32$

Green Sea Island............ .08 $\quad .40$

Jefferson, 3-Ply, White Cotton.. $.07 \quad .30$

2-Ply Texas White Cotton.... $.05 \quad .25$

Tarred, for Mat Making....... .I

Tarred Sisal for Fodder....... . I

Binder (5-1b. ball) ........... .60

Green Silkaline. For stringing Smilax and Asparagus. Fast color and will not fade; very strong and will not break.

Price, per lb. ( 8 spools), F, fine; FF, medium; FFF, coarse

\$1.25. Price, per spool ........................20 Green Linen (substitute for Silkaline). Very similar to the above; fast color. Per lb., 75c.; $\$ 3.50$ for $5 \mathrm{lbs}$.

\section{HEADQUARTERS FOR RAFFEA}

We import this direct from Madagascar representatives who make a careful selection of long, broad strands for our trade. Natural Color, Ijc. 1b., Io lbs. \$1.25, \$II.00 per Ioo lbs.

Colored or Dyed. Submit sample of shade desired. 35c. 1b., 5 lbs. $\$$ I. $60, \$ 3.00$ per 1o $\mathrm{lb}$.

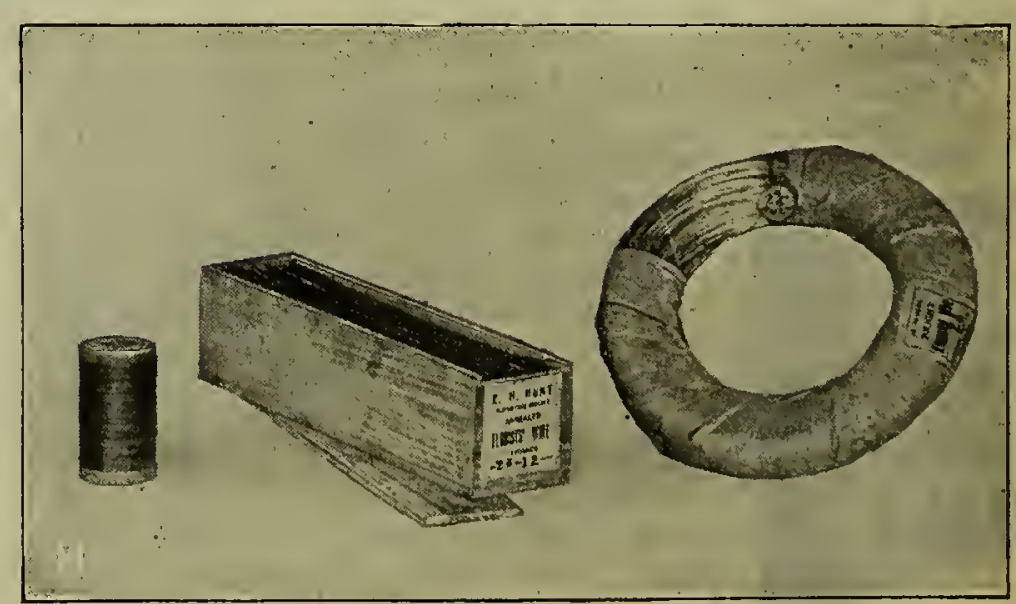

WIRE (Price subject to change) ANNEALED

OALVANIZED

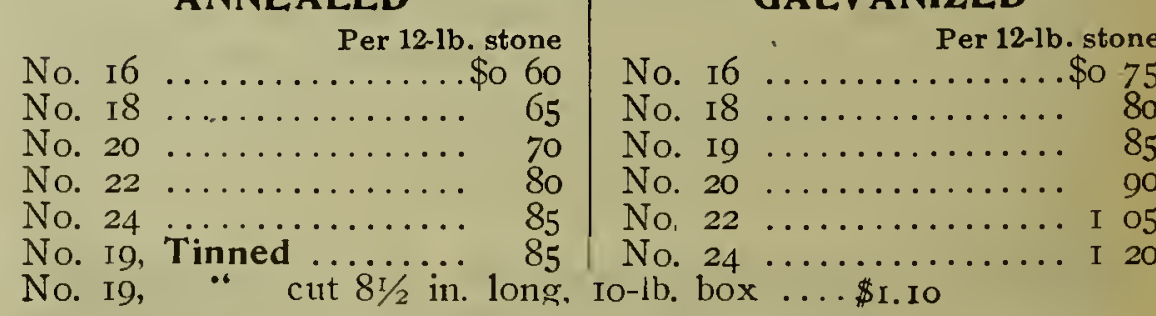

\section{CUT BOUQUET WIRE}

For Stemming Flowers, Etc.

No. 20. 9, I2 or I8 in., IOc. per 1 b., per box I2 lb., \$I.Io

No. 22. 9, I2 or I8 in., IIc. per 1b., per box I2 1b., \$I.20.

No. 24. 9, I2 or 18 in., I4c. per 1 b., per box 12 lb., $\$$ I. 40 . 


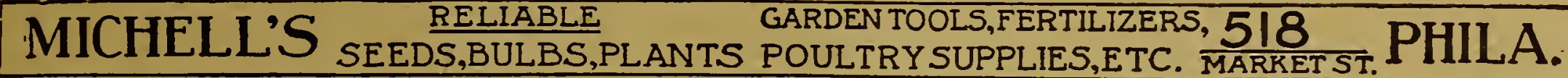

PLANT TUBS, POTS, ETC.

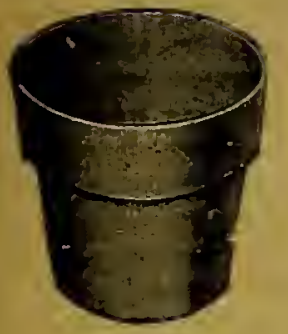

P. S.-The prices on clay flower pots, bulb pans and saucers are subject to a discount of 5 per cent. for cash with order, or if paid within so days.

\section{STANDARD FLOWER POTS}

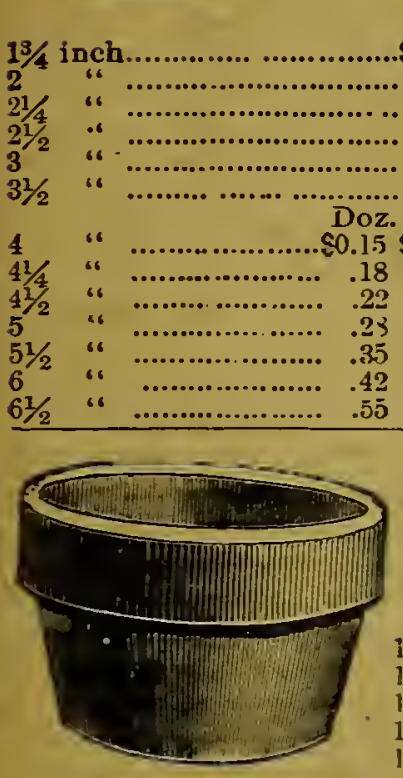

$\begin{array}{rr}100 & 1000 \\ \$ 0.31 & \$ 2.80\end{array}$ $\begin{array}{rr}\$ 0.31 & \$ 2.80 \\ .35 & 3.20\end{array}$

$\begin{array}{ll}.40 & 360 \\ .48 & 4.40 \\ .02 & 5.60\end{array}$

$.62 \quad 5.60$

$15 \$ 097 \$ 8.80$

$18 \quad 110 \quad 1000$

$\begin{array}{llll}23 & 132 & 12.00 \\ 1.76 & 1600\end{array}$

2.2020 .10

52.16021 .10

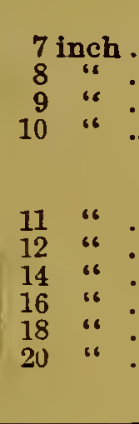

3.36 3.10

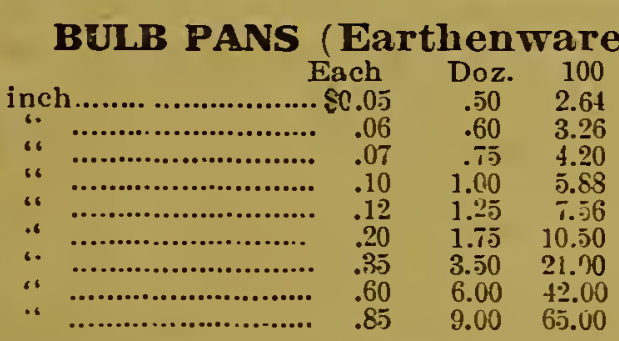

\section{ORCHID RECEPTACLES}

(Earthenware)

Square Baskets Round Pans

Each Doz.

Round Pans
Each Doz

4 in .... $\$ 0.12 \$ 120 \quad 4$ in........\$0.49 $\$ 0.90$

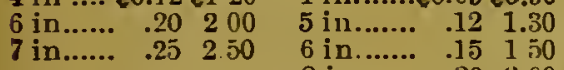
$\begin{array}{rrrr}8 \text { in .......... } & .20 & 2 & 00 \\ 10 \text { in ...... } & .30 & 3 & 01\end{array}$

\section{FERN DISH LINERS}

$\begin{array}{lrrrrr}\text { Width } & \text { Height } & \text { Each } & \text { Doz. } & 100 & 1000 \\ 7 \text { inch..........17\% inch................... } \$ 1.06 & \$ 0.60 & \$ 2.94 & 28.00\end{array}$

7 inch..........17/8 inch................. \$n.06 $\quad \$ 0.60 \quad \$ 2.94 \quad 28.00$

\section{FERN PANS}

(Earthenware)

Width Height Each Doz. 100

4 in. $17 / 8$ in.............\$ \$0.03 $\$ 027 \quad \$ 1.32$

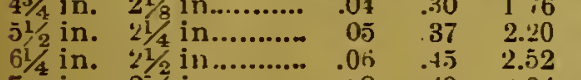

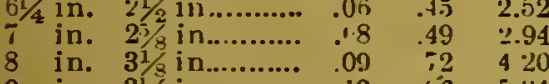

9 in. $31 / 4$ in .............. 13

The device for lifting plants in and out of Jardinieres; also for suspending plants, such as Asparagus Sprengerii, No. 1 - for 3

3 to 5-inch Pots

SQUARE SEED PANS

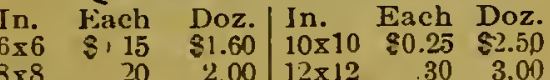

ro. 3 - for 8 to 10 -inch Fots

?0.20 \$1.50

PERFECIIU SUYGLE WIRE POT HANGERS 50c. doz

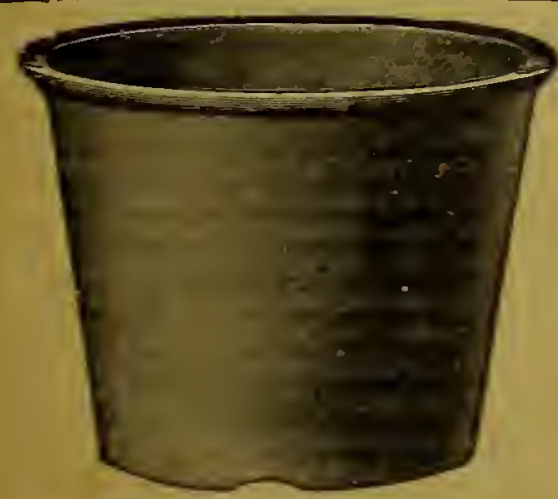

Wood Fibre Plant Tub

10 inch aiameter

12
18
18

\begin{tabular}{ll|ll|}
.653 & 7.655 & $1 .(14$ & 11.73 \\
1.35 & 15.30 & 1.80 & 20.40
\end{tabular}
Doz. $100 \quad 1000$ $\begin{array}{lll}D & 0.68\end{array} \$ 4.20 \quad \$ 4000$ $1350.40 \quad 80.00$ Fach Perdoz Per 100 .... \$0.25 $\$ 2.40 \quad \$ 15.12$ $\begin{array}{llll}.35 & 3.40 & 21 & 00 \\ .50 & 5.50 & 4200\end{array}$ $\begin{array}{lrr}.10 & 1.100 & 42.100\end{array}$ $150 \quad 1650012600$

\section{"NEPONSET" PAPER FLOWER POTS}

They are the cheapest flower pots on the market. Made from the well-k.nown Neponset Water=Proof Fabric, and for lightness, cleanliness and cheapnes hare no equal. Especially valuable for shipping plants by express.

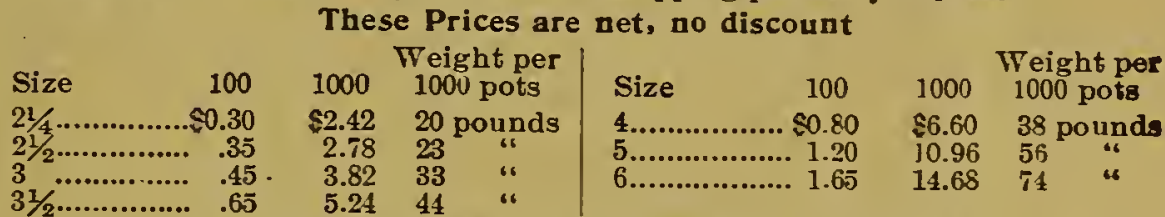

500 of any of the above in one size at 1000 rate

FLOWER POT SAUCERS (Earthenware)
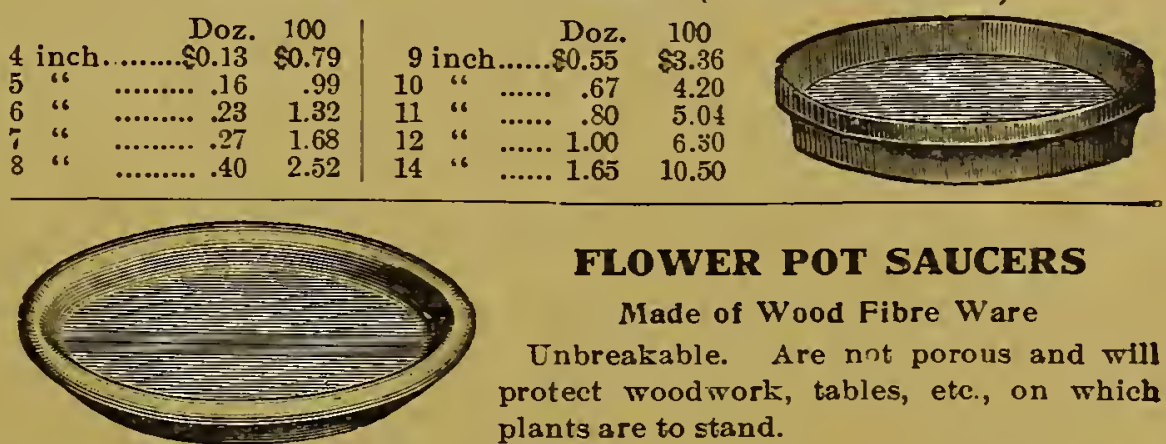

FLOWER POT SAUCERS

Made of Wood Fibre Ware

Unbreakable. Are not porous and will protect woodwork, tables, etc., on which plants are to stand.

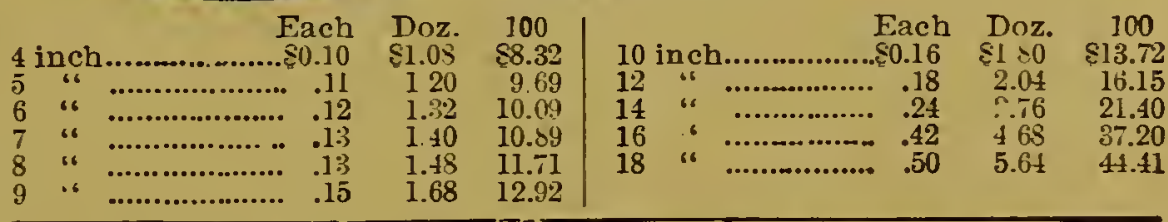

\section{ROLEING STANDS}

Made of Indurated Fibre Ware

Water cannot soak through.

Every heary plant sold needs one

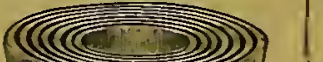

\section{(1)}

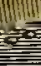

\section{4}

Th

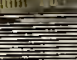

$+\frac{1}{10}$

20

in

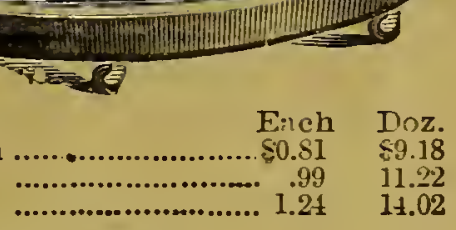

to save carpets and floors. Can be

moved about with ease.

Size

12 inch

14

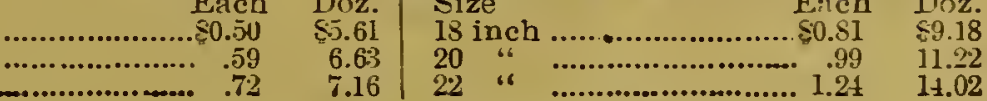

WHITE CEDAR PLANT TUBS

With black iron hoops. Our cedar tubs are all made of extra quality wood by hana, and will be found far superior in every way to the regular machine made tub. Measurements are outside.

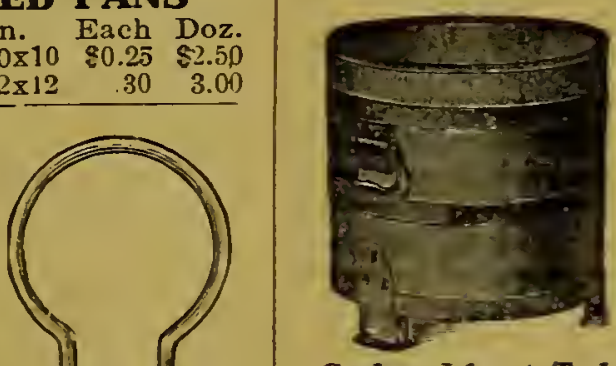

\begin{tabular}{|c|c|c|}
\hline & Diam. & $\begin{array}{l}\text { Length of } \\
\text { Stave }\end{array}$ \\
\hline No. o & 27 in. & 24 in. \\
\hline . I & & $22 " 6$ \\
\hline ). 2 & $23 \quad 16$ & $2 I " 1$ \\
\hline 3 & 2 I $\quad "$ & I8 " \\
\hline 4 & $191 / 2 " “$ & I6" \\
\hline .5 & I8" " & $14 "$ \\
\hline .6 & $161 / 2 " 0$ & I3" \\
\hline .7 & I5 " & II " \\
\hline
\end{tabular}

Price

No. 8

12 $\$ 3.00$ Per 100

WHITE CEDAR PLAN'T GUBS

With Extra Heavy Galvanized Hoops

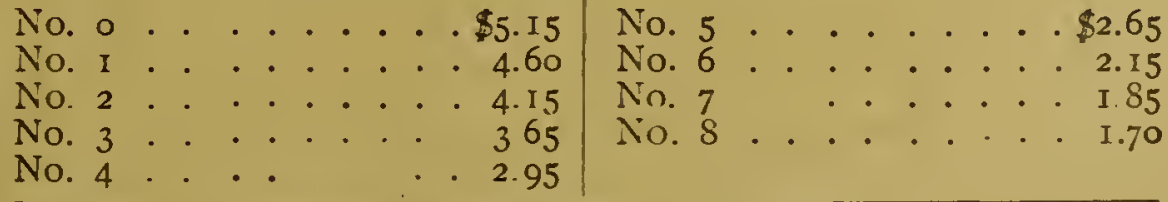

\section{ORCHID RECEPTACLES}

WOOD FIBRE PLANT TUBS

Complete with.saucer

Plain Enameled Green

Each Doz. Fach Dcz.

\begin{tabular}{ll|ll}
80.59 & 56.63 & $\$ 0.86$ & $\$ 0.69$
\end{tabular}

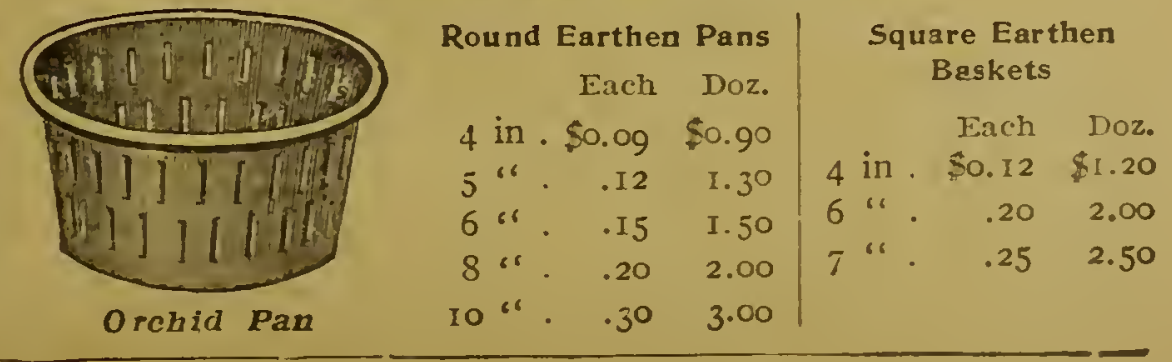




\section{MICHELL'S}

\section{Keystone Plant Tub}

THE MOST ECONOMICAL TUB FOR THE FLORIST

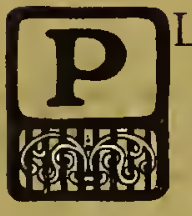

LANTS, large or small, appear always to better advantage when planted in tubs instead of pots. They are easier handled because they are much lighter in weight; they are more attractive, and bring a higher price. Tubs have welded hoops, except bottom hoop, which is flat, (and neat handles, when desired, at extra prices as mentioned below). Unlike pots, they do not break, nor do they require special packing when used in shipping. Made of white cedar, they are by far the cheapest, neatest, lightest, and best florist tub put on the market.

Please note the full assortment of sizes, all of them being painted inside and out and their tops finished round bevel.

\section{PRICES}

\begin{tabular}{|c|c|c|c|c|c|c|c|}
\hline \multirow{3}{*}{$\begin{array}{c}\text { Size No. } \\
\text { I }\end{array}$} & \multirow{3}{*}{$\begin{array}{c}\text { Inside } \\
\text { Top Diam } \\
6.6\end{array}$} & \multirow{2}{*}{$\begin{array}{c}\text { Inside } \\
\text { Bottom Diam }\end{array}$} & \multirow{2}{*}{$\begin{array}{l}\text { Inside } \\
\text { Depth }\end{array}$} & \multirow{2}{*}{$\begin{array}{c}\text { Thickness } \\
\text { of Stave }\end{array}$} & \\
\hline & & & & & Price Each & Dozen & Per 100 \\
\hline & & & & . . $3 / 8$ & $\$ 0.25$ & $\$ 2.50$ & . $\$ 20.00$ \\
\hline $2 \ldots$ & $\ldots 7 \ldots$ & 5 & 7 & $3 / 8$ & $\begin{array}{ll}. .28 \\
.\end{array}$ & 3.00 & . 24.00 \\
\hline 3 & . & 6 & 8 & $3 / 8$ & .30 . & 3.25 & 25.00 \\
\hline 4 & 9 & 7 & 9 & $3 / 8$ & .35 & 3.50 & 26.00 \\
\hline 5 & . . то . & $7^{1 / 2}$ & . 9 & $I^{7} 6$ & .40 . & 3.75 . & 30.00 \\
\hline 6 & . II & $8^{1 / 2}$ & . 10 & & .45 . & 4.75 & 37.50 \\
\hline 7 & . . I2. & 9 & . II & $1 / 2$ & .50 & 5.75 & 47.50 \\
\hline 8 & $\ldots 13$. & .10 & .12 & $1 / 2$ & .65 . & 7.00 & 57.50 \\
\hline 9 & . . I4. & . III & .13 & $5 / 8$ & .70 & 7.75 & 62.50 \\
\hline Io & . I5. & . III $1 / 2$ &. $\mathrm{I} 4$ & $5 / 8$ & .80 & 8.75 & 71.00 \\
\hline Ir. & . I6. & . $121 / 2$ & .15 & $5 / 8$ & .95 . & 9.75 & 77.50 \\
\hline I2. &.$\quad I 7$ & . . I31/2 & .16 & $5 / 8$ & . I.00. & . Ir.25 & 92.00 \\
\hline I3. & . . I8. & . . I $4^{1} / 2$ & . 17 . & $5 / 8$ & . I.30. & . $\mathrm{I}_{4} \mathrm{co}$ & . II 5.00 \\
\hline 14. & .. I9. & $.151 / 2$ & .18 . & $5 / 8$ & I. 45. & .17 .00 & . I 35.00 \\
\hline
\end{tabular}

None of these Tubs are equipped with handles at the above prices.

If stamped steel side handles are wanted, add 7 cents to the price of each Tub in single or dozen lots ; 6 cents each in roo lots. These handles are not sold attached to the tub.

\section{Michell's “Anylength" Greenhouse Hose}

\section{AT A SPECIAL PRICE}

Every florist knows how difficult it is to get hose that will stand all the rackets of the greenhouse It's just six years since we began selling this one ("Michell's Anylength"), and we can't help recommending it

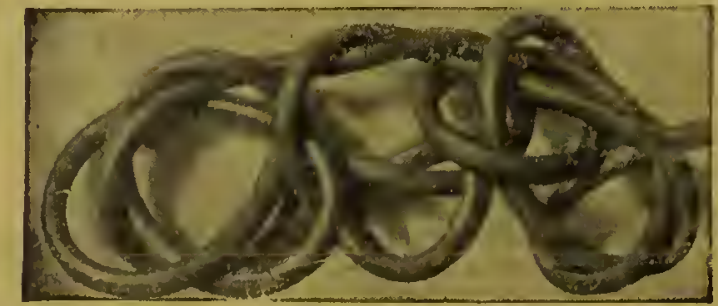

"YOU CAN'T KINK IT" in the highest terms. It's mighty tough, very flexible, and best of all it's a wearer with a record behind it; can be had any length up to 500 feet; made by the inventors of continuous length hose. (Write for a free sample.)

\section{SPECIAL LOW PRICES FOR 1914} $14 \frac{1}{2}$ c. PER FOOT 